UNIVERSIDADE DE SÃO PAULO

INSTITUTO DE GEOCIÊNCIAS

\title{
AVALIAÇÃO DE MÉTODOS PARA CÁLCULO E INFERÊNCIA DE CONDIÇÕES P-T EM ROCHAS DA FÁCIES GRANULITO: INVESTIGAÇÃO DAS ROCHAS DAS NAPPES TRÊS PONTAS- VARGINHA E SOCORRO-GUAXUPÉ
}

Renato Bezner Martinez

Orientador: Prof. Dr. Renato de Moraes

DISSERTAÇÃO DE MESTRADO

VERSÃO CORRIGIDA

Programa de Pós-Graduação em Mineralogia e Petrologia

SÃO PAULO

2015 
Renato Bezner Martinez

\begin{abstract}
AVALIAÇÃO DE MÉTODOS PARA CÁLCULO E INFERÊNCIA DE CONDIÇÕES $P$-T EM ROCHAS DA FÁCIES GRANULITO: INVESTIGAÇÃO DAS ROCHAS DAS NAPPES TRÊS PONTAS-VARGINHA E SOCORRO-GUAXUPÉ
\end{abstract}

Dissertação apresentada ao Instituto de Geociências da Universidade de São Paulo para obtenção do título de Mestre em Geologia

Orientador: Prof. Dr. Renato de Moraes

Programa de Pós-Graduação em Mineralogia e Petrologia

SÃO PAULO

2015 
Ficha catalográfica preparada pelo Serviço de Biblioteca e Documentação do Instituto de Geociências da Universidade de São Paulo

Martinez, Renato Bezner

Avaliação de métodos para cálculo e inferência de condições $\mathrm{P}-\mathrm{T}$ em rochas da fácies granulito: investigação das rochas das nappes Três PontasVarginha e Socorro-Guaxupé. / Renato Martinez. -São Paulo, 2015.

163 p. : il. + anexos

Dissertação (Mestrado) : IGc/USP

Orient.: Moraes, Renato de 


\section{AGRADECIMENTOS}

Um trabalho de mais de dois anos não poderia ser realizado sem a ajuda de muita gente, portanto, gostaria de agradecer em primeiro lugar minha família, principalmente meus pais, Ricardo de Aragão Martinez e Marilda Bezner Martinez, e meu irmão, Mauricio Bezner Martinez, por todo apoio em tudo na minha vida.

Agradeço à FAPESP pela bolsa processo 2012/23665-5 e pelo auxílio do projeto temático de processo 2013/04007-0.

A todo o pessoal dos laboratórios do IGc-USP: Paulinho e Renato da laminação, Marcos e Leandro da microssonda eletrônica, Samuca na preparação de amostras, Angélica da microscopia óptica. Agradeço a todos da biblioteca e da gráfica, sempre muito atenciosos.

Ao Professor Thomas Zack da Universidade de Gotemburgo e seus orientados, Firat Sengun e Andreas Karlsson, por todo o apoio durante as análises de laser ablation e pela convivência sempre muito acolhedora e respeitosa.

A todos que me auxiliaram nas viagens de campo: Professor Edward William Sawyer da Universidade de Quebec à Chicoutimi por todo ensinamento e incrível visão não só sobre migmatitos, mas sobre geologia geral, Rafael Gonçalves Motta (Vivi) e Caio Arthur Santos (Fofona). Ao Mauricio Pavan (Pavão) pelas discussões e auxílio com as pseudosseções.

Ao Professor David Kelsey da Universidade de Adelaide pela ajuda com as pseudosseções. Sem esse auxílio provavelmente jamais teria terminado como planejado.

Ao pessoal do Laboratório de microssonda eletrônica da UnB, Professor Nilson Botelho, técnicos e estudantes de pós graduação que me ajudaram enquanto estive lá. Mesmo com todos os problemas sou muito grato a vocês.

A todos os professores do IGc-USP com quem convivi principalmente nesses anos de mestrado: Professores Ulbrich, Rogério, Adriana, Gaston, Excelso e Gergely.

Ao professor, mestre, doutor, conhecedor de músicas loucas, orientador e amigo Renato de Moraes, sempre muito atencioso durante todos esses anos de convívio. Muito obrigado por todo aprendizado que você me proporcionou. É nóis!

À Carolina Cavanha (Cacá) pelo companheirismo e apoio no que escolho e faço em tudo da minha vida.

Por fim, mas não menos importantes, agradeço aos meus amigos de longa data Fabinho e Gabriel, e meus colegas de geologia: Marcelo (Bucetauro), Sérgio (Craca), Clóvis (Funério), Paulo (Kuprólito), Caio (Mocinha), Guilherme (Piriguete), Giuseppe (Peluda), Camila (Planária), Víctor (Sheila), Guilherme (Sífilis), Renato (Tassolto) e Daílson (Vaselina). Sempre muito presentes em minha vida. 

"A pergunta que constantemente nos faziam na civilização era e ainda é: "De que serve todo esse esforço? Há ouro? Ou há carvão?". O espírito comercial dos dias atuais não vê vantagens na ciência pura. $O$ fabricante inglês não está interessado em pesquisa que não Ihe dê um retorno financeiro em um ano. O habitante das cidades vê na ciência pura apenas muita energia gasta em trabalho improdutivo. Na verdade, estão presos à roda da vida convencional."

Apsley Cherry-Garrard, "A Pior Viagem do Mundo" 



\section{RESUMO}

O presente trabalho teve como objetivo investigar e determinar condições $P$ - $T$ de rochas metamórficas da fácies granulito em altas pressões, usando diversos métodos geotermobarométricos. Foram usados termobarometria convencional, com os geotermômetros: granada-clinopiroxênio e granada-ortopiroxênio; e os geobarômetros: granada-clinopiroxênio-plagioclásio, granada-clinopiroxênio-ortopiroxênio-plagioclásio e granada-ortopiroxênio-plagioclásio; métodos otimizados como o THERMOCALC, e método que, por meio de correções nas composições de ortopiroxênio e granada, tenta calcular condições $P$ - $T$ de pico metamórfico; pseudosseções e métodos que usam elementos traço na composição dos minerais, tais como Zr-rutilo e Ti-quartzo.

Para o estudo foram escolhidas rochas da Nappe Três Pontas-Varginha e da Nappe Socorro-Guaxupé, que constituem a porção meridional do Orógeno Brasília. Na primeira ocorrem granulitos de alta pressão de composição pelítica, máfica e calciossilicática. Dois conjuntos de granulitos de alta pressão foram analisados, um representado por amostras de rutilo-cianita-granada granulito, com quartzo e feldspato potássico abundantes, e o outro de rocha calciossilicática com clinopiroxênio, granada, quartzo, raro plagioclásio e hornblenda retrometamórfica. O granulito félsico da Nappe Socorro-Guaxupé é constituído de granada, dois feldspatos, quartzo, orto- e clinopiroxênio e ilmenita, com hornblenda e biotita retrometamórficas. Em todas as rochas é comum a presença de leucossoma, indicando que todas as rochas sofreram maior ou menor grau de fusão parcial.

Para o rutilo-cianita-granada granulito da Nappe Três Pontas-Varginha, condições $P-T$ do pico metamórfico foram calculadas com o par Zr-rutilo e Ti-quartzo e com pseudosseções e condições de $\sim 850{ }^{\circ} \mathrm{C}$ a 15 kbar foram determinadas, com geração de pelo menos $25 \%$ de fundido. Os diversos geotermobarômetros usados, baseados em granada, clinopiroxênio e plagioclásio, apresentam resultados compatíveis, da ordem de $850^{\circ} \mathrm{C}$ e pressões entre $14 \mathrm{e}$ $16 \mathrm{kbar}$

Para o granulito félsico, termobarometria convencional e THERMOCALC forneceram condições de temperatura ultra-alta para o pico metamórfico, em $950^{\circ} \mathrm{C}$ e 11 - $13 \mathrm{kbar}$. Um método baseado no recálculo das composições dos minerais não gerou bons resultados, diminuindo as condições $P-T$.

Os resultados indicam que as rochas da Nappe Três Pontas-Varginha foram metamorfizadas em condições da fácies eclogito e cavalgadas pelo granulito basal da Nappe Socorro-Guaxupé, que foi metamorfizado em regime de temperaturas mais elevadas.

PALAVRAS-CHAVE: geotermobarometria; granulito; métodos; Três Pontas-Varginha; Socorro-Guaxupé; 



\section{ABSTRACT}

The aim of the present work is to investigate and determine $P-T$ conditions of high pressures metamorphic rocks at granulite facies, using a variety of geothermobarometric methods. There were used conventional thermobarometry with thermometers: garnetclinopyroxene and garnet-orthopyroxene; and barometers: garnet-clinopyroxene-plagioclase, garnet-clinopyroxene-orthopyroxene-plagioclase and garnet-orthopyroxene-plagioclase; optimized methods as THERMOCALC, and a method that with corrections in orthopyroxene and garnet compositions try to re-calculate $P-T$ conditions of metamorphic peak; pseudosections; and methods that use trace elements in mineral compositions, such as Zr in rutile and $\mathrm{Ti}$ in quartz.

For this study rocks of Três Pontas-Varginha and Socorro-Guaxupé nappes were chosen, which are part of southern portion of the Brasília Orogen. In the first unit, there are high-pressure granulites of pelitic composition, mafic and calc-silicate rocks. Two sets of highpressure granulites were analyzed, one is represented by rutile-kyanite-garnet granulite samples, with abundant quartz and potassium feldspar, and the other is a calc-silicate rock with clinopyroxene, garnet, sphene, quartz, rare plagioclase and retrograde hornblende. The Socorro-Guaxupé nappe felsic granulite consists of garnet, two feldspars, quartz, ortho- and clinopyroxene and ilmenite, with retrograde hornblende and biotite. Leucosome is present in all rocks, indicating that those underwent some degree of partial melting.

For the rutile-kyanite-garnet granulite of Três Pontas-Varginha nappe, metamorphic peak conditions were calculated with $\mathrm{Zr}$-rutile and Ti-quartz pair and pseudosections, resulting in $~ 850{ }^{\circ} \mathrm{C}$ at $15 \mathrm{kbar}$ with genaration of at least $25 \%$ of melt. Conventional geothermobarometers based on garnet, clinopyroxene and plagioclase, present compatible results of $850^{\circ} \mathrm{C}$ and pressures between 14 and $16 \mathrm{kbar}$.

For the felsic granulite of the Socorro-Guaxupé nappe, conventional geothermobarometry and THERMOCALC provide ultra-high temperature conditions for the metamorphic peak, with $950^{\circ} \mathrm{C}$ and $11-13 \mathrm{kbar}$. A method based on mineral compositions recalculation did not produced good results, with lower final $P-T$ conditions.

The results of this work indicate that Três Pontas-Varginha nappe was metamorphosed under eclogite facies conditions and was thrusted by hotter basal granulites of the SocorroGuaxupé nappe.

KEYWORDS: geothermobarometry; granulite; methods; Três Pontas-Varginha; SocorroGuaxupé; 



\section{ÍNDICE DE TABELAS}

Tabela 1 - Parâmetros e padrões utilizados nas análises de química mineral por microssonda eletrônica.

Tabela 2 - Fórmulas estruturais aproximadas e proporções moleculares (médias) de granada para cada amostra analisada 100

Tabela 3 - Valores médios dos membros finais de granada das três amostras da Nappe Três Pontas-Varginha. Número subscrito entre parênteses $=$ número de análises. Maiores proporções médias em negrito. 101

Tabela 4 - Valores médios dos membros-finais de granada da Nappe Socorro-Guaxupé e das três amostras da Nappe Três Pontas-Varginha. Número subscrito entre parênteses = número de análises. Maiores proporções médias em negrito. 106

Tabela 5 - Fórmulas estruturais aproximadas (médias) de piroxênio para cada amostra analisada. 110

Tabela 6 - Valores médios dos elementos (em a.p.f.u.) analisados em clinopiroxênio e ortopiroxênio de cada amostra de ambas as unidades; Número subscrito entre parênteses = número de análises. Maiores proporções médias entre amostras de clinopiroxênio da Nappe Três Pontas-Varginha em negrito.

Tabela 7 - Valores médios dos elementos (em a.p.f.u.) analisados em clinopiroxênio e ortopiroxênio de cada amostra de ambas as unidades; Número subscrito entre parênteses = número de análises. Maiores proporções médias em negrito.

Tabela 8 - Fórmulas estruturais aproximadas (médias) de plagioclásio para cada amostra analisada.

Tabela 9 - Valores médios dos elementos (em a.p.f.u.) analisados em plagioclásio de cada amostra de ambas as unidades; Número subscrito entre parênteses = número de análises. Maiores proporções médias em negrito (apenas para as amostras da Nappe Três PontasVarginha).

Tabela 10 - Valores médios dos elementos (em a.p.f.u.) analisados em plagioclásio de cada amostra de ambas as unidades; Número subscrito entre parênteses = número de análises. Maiores proporções médias em negrito (apenas para as amostras da Nappe SocorroGuaxupé)

Tabela 11 - Padrões de ablação utilizados para cada mineral durante as análises de Laser Ablation

Tabela 12 - Temperaturas em ${ }^{\circ} \mathrm{C}$ calculadas pelo geotermômetro de Ellis \& Green (1979) para pressões de 10, 15 e 20 kbar. Número entre parênteses indica a análise do grão.....134

Tabela 13 - Pressões em kbar calculadas pelo geobarômetro de Eckert et al. (1991) utilizando as temperaturas calculadas a 15 kbar. Número entre parênteses indica a análise do grão.

Tabela 14 - Temperaturas em ${ }^{\circ} \mathrm{C}$ calculadas pelo geotermômetro de Ellis \& Green (1979) para pressões de 12, 15 e 20 kbar. Número entre parênteses indica a análise do grão.....136

Tabela 15 - Temperaturas em ${ }^{\circ} \mathrm{C}$ calculadas pelo geotermômetro de Harley (1984) para pressão de 12 kbar. Número entre parênteses indica a análise do grão. 
Tabela 16 - Pressões em kbar calculadas pelo geobarômetro de Eckert et al. (1991) utilizando as respectivas temperaturas à $12 \mathrm{kbar}$ calculadas para cada par mineral pelo geotermômetro de Ellis \& Green (1979) encontradas na Tabela $14 .$.

Tabela 17 - Pressões calculadas com os geobarômetros de Newton \& Perkins (1982), Perkins \& Chipera (1985), Paria et al. (1988) e Eckert et al. (1991). Valores em kbar. 138

Tabela 18 - Valores $P$-T para o granulito félsico da Nappe Socorro-Guaxupé determinados por THERMOCALC. Correl. = Correlação entre os valores de pressão e temperatura calculados conjuntamente. 139

Tabela 19 - Valores P-T iniciais e ajustados para o granulito félsico da Nappe SocorroGuaxupé determinados por RCLC. 140

Tabela 20 - Composições químicas utilizadas nos cálculos das pseudosseções, e do filito original (SC-07) de Pavan (2010). Valores em proporções molares. 


\section{ÍNDICE DE FIGURAS}

Figura 1 - Localização da área de estudo. Estrela azul indica a localização da pedreira abandonada "Niemeyer" estudada em detalhe e a estrela preta a pedreira "Grupo Santo Antônio" em Varginha

Figura 2 - Mapa simplificado de Gondwana. Áreas cratônicas em coloração cinza e faixas móveis como tracejados. Imagem retirada de Reno et al. 2009 30

Figura 3 - Província Tocantins com suas principais estruturas e domínios tectônicos (Delgado et al. 2003)

Figura 4 - Mapa esquemático da porção meridional da Faixa Brasília com as pedreiras estudadas assinaladas (modificado de Campos Neto \& Caby 1999, 2000).

Figura 5 - Exemplo de pseudosseção P-T com contornos de \% de liquido. A intensidade da cor indica a variância do campo, com maior variância e menor número de fases nos campos escuros e menor variância e maior número de fases nos campos claros. Retirado de Powell et al. (2005).

Figura 6 - Diferentes amostras utilizadas por Zack et al. (2004) nos diferentes campos de pressão e temperatura, sugerindo a não dependência da pressão na assimilação de Zr pelo rutilo. Retirado de Zack et al. (2004)

Figura 7 - Fórmulas para cálculo de temperatura de Zack et al. (2004). Em (a) são utilizados valores médios de $\mathrm{Zr}$ para cada amostra e em (b) apenas os máximos. Retirado de Zack et al. (2004)

Figura 8 - a) Termômetro Zr em rutilo de Watson et al. (2006); círculos abertos e quadrados pretos representam respectivamente cristais de rutilo sintéticos e naturais. b) Comparação entre as calibrações de Zack et al. (2004a), Watson et al. (2006) e Degeling (2003). Retirado de Watson et al. (2006).

Figura 9 - Termômetro Zr em rutilo de Tomkins et al. (2007). Retirado de Tomkins et al. (2007).

Figura 10 - Termômetro Ti em zircão de Watson et al. (2006); quadrados e reta de regressão fina, e triângulos e linha tracejada representam respectivamente cristais de zircão sintéticos e naturais. Reta de regressão grossa é a global. Retirado de Watson et al. (2006).

Figura 11 - Concentrações de Ti em quartzo x 1/T. Símbolos fechados na reta de $10 \mathrm{kbar}$ são de Wark \& Watson (2006). Incertezas são menores que os símbolos a não ser quando há barra de erro.

Figura 12 - Isopletas de a) Ti-quartzo e Zr-rutilo e b) Ti-quartzo e Zr-titanita com aproximação das fácies a partir de Spear (1993) e Philpotts (1990). A curva WSS é a sólidus saturada em água (water-saturated solidus) para composições "mínimas" de referências listadas em Holtz \& Johannes (1994). Retirado de Thomas et al (2010).

Figura 13 - Diagramas P-T produzidos pelo software TWQ (Berman 1991) e retirados de Pattison et al. (2003) para análise de granulito ilustrando as reações de equilíbrio na associação mineral granada - ortopiroxênio - plagioclásio - quartzo. Figura 13a indica curvas e resultados não corrigidos pelo método; Figura 13b apresenta a distribuição das curvas e resultado P-T após correção Fe-Mg-Al. 
Figura 14 - Afloramento TPR-31. Metatexíto estromático apresentando grande estiramento com indicadores cinemáticos indicando movimentação de topo para Leste. Bolsões centimétricos de fundido demarcados.

Figura 15 - Afloramento TPR-26. Metatexíto estromático com leucossoma de espessura centimétrica (1-3 cm), quartzo-feldspático, em granulação média, e resíduo finamente bandado com leitos félsicos e máficos, composto por quartzo, feldspato, biotita e granada. 64

Figura 16 - Afloramento TPR-27. Metatexito estromático com dobras intrafoliais centimétricas e finos leitos de biotita nas bordas de leucossoma. 65

Figura 17 - Afloramento TPR-28. Metatexito estromático com leucossoma de granulação grossa em aspecto pegmatoide. Estrutura schollen, demarcada na porção inferior da foto, com bloco angular centimétrico de resíduo em meio ao leucossoma.

Figura 18 - Afloramento TPR-20. Quartzito típico da área de cor cinza a tons amarronzados, acamadado, de granulação fina. 66

Figura 19 - TPR-19B. Biotita gnaisse milonítico com alternância de leitos escuros e sinuosos ricos em biotita e outros claros quartzo-feldspáticos.

Figura 20 - Visão geral da pedreira de Três Pontas (TPR-01). Intrusão de rocha metabásica metatexítica (MB), representada predominantemente por "resíduo" rico em hornblenda, em metapelito migmatítico/ cianita granulito migmatíticos (MP). Orientação ENE-WSW.....

Figura 21 - TPR-01. Detalhe do contato abrupto entre rocha residual máfica e metapelítica. Metapelito: leucossoma (L) em leitos contínuos, melanossoma (M) maciço, por vezes como leitos centimétricos, contínuos e boudinados; Leucossoma (LB) tonalítico paralelo à foliação, in-situ e in-source, resíduo $(R)$ melanocrático, rico em hornblenda e leucossoma rosado (LI) grosso, rico em feldspato potássico. Notar dobramentos recumbentes com topo para ENE. Orientação ENE-WSW. 69

Figura 22 - Fotomicrografias. a) TPR-01-O. Granada com aspecto esqueletal repleta de inclusões de quartzo e plagioclásio no resíduo do rt-ky-grt granulito (Polarizador inferior; largura 12,0 mm); b) TPR-01-Z. Granada com inclusões arredondadas de quartzo e muito finas de rutilo, monazita e zircão, no resíduo do rt-ky-grt granulito (Polarizador inferior; largura $1,5 \mathrm{~mm}$ ); c) TPR-01-U. Associação retrometamórfica de biotita, plagioclásio e granada (granada = biotita + plagioclásio) no resíduo do rt-ky-grt granulito (Polarizadores cruzados; largura 1,5 mm); d) TPR-01-Z. Cianita prismática orientada junto à granada do resíduo do rtky-grt granulito (Polarizador inferior; largura 3,5 mm); e) TPR-01-X1. Biotita retrometamórfica alterando bordas e fraturas de granada do resíduo do rt-ky-grt granulito (Polarizador inferior; largura 3,5 mm); f) TPR-01-K. Biotita e plagioclásio retrometamórficos substituindo granada. $\mathrm{Na}$ área inferior da imagem, biotita e cianita como cristais subidioblásticos orientados na foliação do resíduo do rt-ky-grt granulito (Polarizador inferior; largura 3,5 mm). 71

Figura 23 - TPR-01. Cianita-granada granulito migmatítico com veios de leucossoma, o que gera estrutura estromática (L1), dobras assimétricas vergentes para ENE e selvedge (S) de biotita. Leucossoma grosso (L2) em porção entre camadas mais competentes ricas em biotita. Orientação ENE-WSW. 72

Figura 24 - Fotomicrografias. a) TPR-01-Q. Indicador cinemático quartzo-feldspático tipo fish amoldado por biotita no resíduo do rt-ky-grt granulito (Polarizador inferior; largura 3,5 mm); b) TPR-01-I. Ribbon de quartzo em leucossoma do rt-ky-grt granulito deformado. Notar os contatos arredondados e suturados com os demais minerais (Polarizadores cruzados; largura $3,5 \mathrm{~mm}$ ); c) TPR-01-I. Exsoluções de microclínio em megacristais de plagioclásio de 
leucossoma do rt-ky-grt granulito (Polarizadores cruzados; largura 3,5 mm); d) TPR-01-U. Inclusões de rutilo prismático em granada do leucossoma (Polarizador inferior; largura 3,5 $\mathrm{mm}$ ); e) TPR-01-X2. Cristais prismáticos de cianita orientados e inclusos em granada no leucossoma do rt-ky-grt granulito (Polarizadores cruzados; largura 3,5 mm); f) TPR-01-A. Rocha protomilonítica: porção de granulação fina rica em biotita com quartzo e plagioclásio e porfiroclastos médios de apatita (Polarizador inferior; largura 3,5 mm).

Figura 25 - TPR-01. Cianita-granada granulito migmatítico apresentando contato difuso entre melanossoma (M) e leucossoma (L); leito contínuo de espessura centimétrica composto por biotita retrometamórfica/ selvedge $(S)$ entre leucossoma (L) e melanossoma (M). O melanossoma é formado por aglomerado de granada, cianita rutilo e feldspato potássico. $\mathrm{Na}$ porção central da foto é possível perceber o contato transicional entre o melanossoma e leucossoma, o que permite inferir a segregação do último a partir do primeiro. Orientação ENE-WSW.

Figura 26 - TPR-01. Boudin em melanossoma no interior de leucossoma. Notar contato superior retilíneo e inferior difuso, indicando diferença nas reologias do melanossoma, com o topo mais competente que a base. Orientação ENE-WSW. .76

Figura 27 - Fotomicrografias. a) TPR-01-D. Rocha protomilonítica: porção de granulação fina rica em biotita com quartzo e plagioclásio e porfiroclastos médios de escapolita e hornblenda (Polarizadores cruzados; largura 3,5 mm); b) TPR-01-A. Rocha protomilonítica: porção de granulação fina com menor proporção de biotita comparada a de menor granulação. No centro da foto, sigmoide policristalino composto por plagioclásio $(70 \%)$ e quartzo (30\%). No canto inferior esquerdo, porfiroclasto médio de plagioclásio manteado por porção policristalina do mesmo mineral em menor granulação (Polarizadores cruzados; largura 12,0 mm); c) TPR-01D. Visível bimodalidade de bandas, ambas lepidogranoblásticas, com a inferior de granulação muito fina a fina, rica em biotita com porfiroclastos de apatita, granada e escapolita, e a superior de granulação fina e menor proporção de biotita (Polarizadores cruzados; largura $12,0 \mathrm{~mm}$ ); d) TPR-01-A. Porfiroblasto de granada com inclusões de cianita e biotita (metamorfismo progressivo) (Polarizador inferior; largura 3,5 mm); e) TPR-01-T. Foliação (biotita) oblíqua à principal (Polarizador inferior; largura 3,5 mm);f) TPR-01-E2. Rocha residual máfica: cristal de ortopiroxênio com inclusões de minerais opacos envoltos por honblenda. Esta também ocorre alterando clivagem de ortopiroxênio (Polarizador inferior; largura 3,5 $\mathrm{mm})$. 78

Figura 28 - Fotomicrografias. a) TPR-01-E1. Rocha residual máfica com filmes de quartzo de terminações em cúspide (Polarizador inferior; largura 1,5 mm); b) TPR-01-N. Rocha residual máfica: Em cor rosa na porção central superior ocorrem filmes de quartzo com continuidade ótica entre cristais de hornblenda (fusão parcial in-situ) (Polarizadores cruzados + acessório; largura 1,5 mm); c) TPR-01-G2. Retrometamorfismo na rocha residual máfica com geração de biotita (marrom), plagioclásio (rosa), carbonato (lilás) e opacos (preto) a partir de hornblenda (cristal verde desmembrado) + fluido rico em $\mathrm{CO}_{2}$ (presença de carbonato, e escapolita no leucossoma) (Polarizadores cruzados + acessório; largura 1,5 mm); d) TPR-01S1. Biotita e opaco xenoblástico coroado por titanita em porção de resíduo próxima a leucossoma (Polarizador inferior; largura 3,5 mm); e) TPR-01-L. Inclusões de opacos e rutilo coroados por titanita em ortopiroxênio com hornblenda associada (opaco+hblıopx=titanita) (Polarizador inferior; largura 1,5 mm); f) TPR-01-M. Intercrescimento de hornblenda e plagioclásio próximo a leucossomas in-situ no resíduo máfico (Polarizador inferior; largura 1,5 $\mathrm{mm})$.

Figura 29 - TPR-01. Rocha residual máfica composta essencialmente pelo resíduo melanocrático (hornblenda) e diferentes veios de leucossoma: in-situ (L1), in-source (L2) e em 
veios (L3). O desenvolvimento de L1 leva à geração de L2, e com o aumento da fusão parcial, L3 em regiões de alívio de pressão. Notar orientação do veio L3 concordante à das dobras do ri-ky-grt granulito migmatítico. Orientação ENE-WSW.

Figura 30 - TPR-01. Contato interdigitado/ penetrativo entre leucossoma (L) e resíduo máfico. Banda de espessura centimétrica de resíduo menos alterado portador de plagioclásio (R2). Notar contatos também interdigitados entre resíduo com e sem plagioclásio, com plagioclásio concentrado em pequenos veios de leucossoma in-situ (L2). 82

Figura 31 - TPR-01. Boudins centimétricos na rocha residual básfica com zonas surreíticas preenchidas por leucossoma tonalítico. Veios de leucossoma in-situ e in-source. Orientação ENE-WSW. 83

Figura 32 - TPR-01. Bloco rotacionado de rocha máfica residual com movimento indicando topo para leste. A evolução da fusão parcial aumenta a quantidade de leucossoma, que envolve e movimenta pedaços maiores de resíduo. A evolução desse quadro leva a estruturas do tipo schollen. Notar penetrações de material fundido no bloco em direção perpendicular à foliação. Orientação ENE-WSW. 83

Figura 33 - TPR-01. Leucossoma com porfiroblasto centimétrico de clinopiroxênio envolto por coroa de hornblenda retrometamórfica.

Figura 34 - TPR-01. Bandamento centimétrico que alterna leitos de resíduo (M), leucossoma com porfiroblastos de clinopiroxênio (L) e de hornblenda retrometamórfica/ selvedge (S)... 84

Figura 35 - TPR-01. Fotomicrografias. a) TPR-01-E1. Rocha residual máfica bem preservada com clinopiroxênio abundante e alterado a partir das bordas por hornblenda. Minerais opacos granulares a alongados e intersticiais são associados (Polarizador inferior; largura 3,5 $\mathrm{mm}$ ); b) TPR-01-E2. Clinopiroxênio alterado nas bordas por hornblenda em leucossoma de rocha residual máfica (Polarizador inferior; largura 3,5 mm); c) TPR-01-M. Cristais subidioblásticos a xenoblásticos de hornblenda acompanhados por opacos em leucossoma de rocha residual máfica (Polarizador inferior; largura 3,5 mm); d) TPR-01-N. Veio fino de leucossoma composto por plagioclásio e quartzo em textura ígnea (Polarizadores cruzados); e) TPR-01-P. Porção rica em escapolita em leucossoma de rocha residual máfica. Notar junções triplas de $120^{\circ}$ (Polarizadores cruzados; largura 3,5 mm); f) TPR-01-P. No contato leucossoma-resíduo máfico ocorre biotita xenoblástica (Polarizador inferior; largura 3,5 mm).

Figura 36 - TPR-01. Leucossoma intrusivo (LI) grosso em rocha residual, rico em feldspato potássico. Em contato abrupto há rocha metamáfica (B2) distinta, característica por grande quantidade de leucossoma in-situ e in-source, e ainda portar quantidade considerável de plagioclásio. Notar dobras assimétricas no leucossoma intrusivo com movimentação de topo para ENE. Orientação ENE-WSW.

Figura 37 - TPR-01. Diferentes veios de leucossoma em rocha residual máfica: (L1) leucossoma tonalítico gerado a partir da rocha máfica original; (L2) material fundido portador de feldspato potássico, resultante da interação de L1 com material de fusão parcial de metapelito. Notar orientação dos veios de leucossoma que indicação movimentação com topo para ENE. Orientação ENE-WSW..

Figura 38 - TPR-01. Rocha máfica distinta (B2 na Figura 36) com menor mobilização do material fundido. Leucossoma in-situ (L1) e in-source (L2). 89

Figura 39 - TPR-01. Fotomicrografias. a) TPR-01-F1. Banda cinza claro de rocha calciossilicática composta por granada, quartzo intersticial e titanita orientada paralelamente ao bandamento (Polarizador inferior; largura 3,5 mm); b) TPR-01-C. Inclusões muito finas de 
monazita/ zircão em granada de banda cinza escura em rocha calciossilicática. Notar fino filme de quartzo abaixo da granada (Polarizadores cruzados; largura 1,5 mm); c) TPR-01-F1. Banda cinza escura de rocha calciossilicática diferenciada da anterior pela presença de hornblenda e clinopiroxênio e quase total ausência de quartzo e baixa de titanita. Os contatos entre os minerais são retos com raros exemplos arredondados quando quartzo está envolvido (Polarizador inferior; largura 3,5 mm); d) TPR-01-R. Visão geral do resíduo internamente bandado em rocha calciossilicática. Extremo inferior esquerdo ocorre banda com as maiores proporções de hornblenda e granada. A banda central, mais espessa, apresenta menores proporções de granada e hornblenda e maiores de quartzo, plagioclásio e biotita, em maior granulação relativa (ainda fina). A passagem de resíduo para leucossoma ocorre de maneira abrupta por meio de leito fino lepidogranoblástico, com espessura de 1-2mm na porção superior da foto, composto por biotita muito fina a fina e quartzo (Polarizador inferior; largura 12,0 mm); e) TPR-01-R. Granada xenoblástica com aspecto esqueletal na banda rica em hornblenda de rocha calciossilicática. Sua textura sugere consumo durante o metamorfismo (Polarizador inferior; largura 3,5 mm); f) TPR-01-R. Cianita inclusa parcial e totalmente em granada no leucossoma de rocha calciossilicática (Polarizadores cruzados; largura 3,5 mm).

Figura 40 - IC-06-R. Granulito félsico da Nappe Socorro-Guaxupé bandado, característico por apresentar resíduo mesocrático alternado por leucossoma tonalítico de espessura milimétrica (leitos de coloração clara). .94

Figura 41 - IC-06-R. Diferentes gerações de leucossoma no granulito félsico. Leucossoma em leito de espessura milimétrica paralelo à foliação (L1; mais abundante); Leucossoma em finos bolsões estirados ricos em plagioclásio (L2); Leucossoma in-situ, oblíquo à foliação (L3).

Figura 42 - Fotomicrografias. a) IC-06-R. Ortopiroxênio, clinopiroxênio e hornblenda no leucossoma do granulito félsico. Notar cristal de clinopiroxênio substituido na borda por hornblenda na porção inferior central da imagem (Polarizador inferior; largura 3,5 mm); b) IC06-R. Inclusão de fundido composto por plagioclásio, quartzo e biotita em granada de resíduo do granulito félsico (Polarizadores cruzados; largura 3,5 mm).

Figura 43 - Dados estruturais do granulito metapelítico. A. Atitudes de foliação (polares) indicando mergulhos de baixo ângulo com rumo S-SW. $n=34 ; B$. Atitudes de lineações mostram predominância de caimento para W-SW. $n=12$.

Figura 44 - Perfis composicionais de granada das amostras TPR-01-C, -B e -F1 (eixo X representa as análises pontuais plotadas na imagem de elétrons retro-espalhados). 102

Figura 45 - Mapas composicionais da granada 3 da amostra TPR-01-C para Fe, Mn, Ca e Mg. 103

Figura 46 - Mapas composicionais da granada 3 da amostra TPR-01-B para Fe, Mn, Ca e Mg.

Figura 47 - Mapas composicionais da granada 3 da amostra TPR-01-F1 para Fe, Mn, Ca e Mg. 105

Figura 48 - Perfis composicionais de granada da amostra IC-06-R (eixo X representa as análises pontuais plotadas na imagem de elétrons retroespalhados).

Figura 49 - Mapas composicionais da granada 2 da amostra IC-06-R para Fe, Mn, Ca e Mg 
Figura 50 - Perfis composicionais de clinopiroxênio das amostras TPR-01-C e -B (eixo X representa as análises pontuais plotadas na imagem de elétrons retroespalhados.

Figura 51 - Perfis composicionais de clinopiroxênio das amostras TPR-01-C e -F1 (eixo X representa as análises pontuais plotadas na imagem de elétrons retroespalhados. 113

Figura 52 - Mapas composicionais dos clinopiroxênios 2 e 3 da amostra TPR-01-C para Fe, $\mathrm{Al}, \mathrm{Ca}$ e Mg. Cristais 2 e 3 são os analisados nos perfis composicionais da Figura $51 \ldots . . .114$ Figura 53 - Mapas composicionais do clinopiroxênio 7 da amostra TPR-01-B para $\mathrm{Fe}, \mathrm{Al}, \mathrm{Ca}$ e Mg. 115

Figura 54 - Mapas composicionais do clinopiroxênio 5 da amostra TPR-01-F1 para Fe, Al, Ca e Mg. 116

Figura 55 - Perfis composicionais de clinopiroxênio e ortopiroxênio da amostra IC-06-R (eixo $\mathrm{X}$ representa as análises pontuais plotadas na imagem de elétrons retroespalhados........118

Figura 56 - Mapas composicionais do ortopiroxênio 4 da amostra IC-06-R para $\mathrm{Fe}, \mathrm{Al}, \mathrm{Ca}$ e $\mathrm{Mg}$.

Figura 57 - Perfis composicionais de plagioclásio das amostras TPR-01-F1 e TPR-01-C (eixo $X$ representa as análises pontuais plotadas na imagem de elétrons retroespalhados....... 122

Figura 58 - Mapas composicionais de plagioclásio 5 e 6 da amostra TPR-01-F1 para Ca e Na 123

Figura 59 - Mapas composicionais de plagioclásio 3 e 4 da amostra TPR-01-C para Ca e Na. 123

Figura 60 - Perfis composicionais de plagioclásio da amostra IC-06-R (eixo X representa as análises pontuais plotadas na imagem de elétrons retroespalhados). 125

Figura 61 - Mapas composicionais de plagioclásio 6 da amostra IC-06-R para Ca e Na... 126 Figura 62 - Diagrama PT modificado de Thomas et al. (2010) que relaciona os geotermômetros Zr-rutilo e Ti-quartzo. 128

Figura 63 - a) Teores de $\mathrm{Zr}$ em rutilo com campo delimitando faixa com os maiores valores; b) Respectivas temperaturas Zr-rutilo através do termômetro quartzo $\beta$, a 15 kbar, de Tomkins et. al. (2007). 129

Figura 64 -a) Teores de Ti em quartzo com campo delimitando faixa com os maiores valores; b) Respectivas temperaturas Ti-quartzo através do termômetro de Thomas et. al. (2010) a 15 kbar. 130

Figura 65 - Diagrama modificado de Thomas et al. (2010) com os resultados obtidos a partir do cálculo pareado utilizando os termômetros Zr-rutilo (Tomkins et al. 2007) e Ti-quartzo (Thomas et al. 2010) para os 37 pares minerais. 131

Figura 66 - Pseudosseção 1 P-T no sistema química NCKFMASHTO com ilmenita e quartzo em excesso. Paragênese do rt-ky-grt granulito demarcada pelo retângulo preto. Curvas em vermelho indicam proporção de fusão parcial produzida na rocha. Composição química calculada a partir da proporção molar normalizada. 142

Figura 67 - Pseudosseção 2 P-T no sistema química NCKFMASHTO com ilmenita e quartzo em excesso. Paragênese do rt-ky-grt granulito demarcada pelo retângulo preto. Curvas em 
amarelo indicam proporção de fundido na rocha. Composição química calculada a partir da proporção molar normalizada.

Figura 68 - Sobreposição das pseudosseções 1 e 2 com apenas as curvas univariantes e as isopletas de fusão parcial indicadas. Curvas grossas e isopletas vermelhas são do diagrama 1 , e curvas finas e isopletas amarelas do 2 . Índices nos minerais indicam a respectiva pseudosseção.

Figura 69. Fotomicrografia. Amostra TPR-01-ZF3. Porfiroblasto de granada rico em inclusões de quartzo e rutilo. Notação utilizada: Q7 = identificação da análise de quartzo; (23) = teor de Ti. O mesmo padrão de notação foi utilizado nas análises de rutilo. Feições arredondadas nas áreas sinalizadas são os locais analisados por laser. Polarizador inferior. 



\section{SUMÁRIO}

1. INTRODUÇÃO

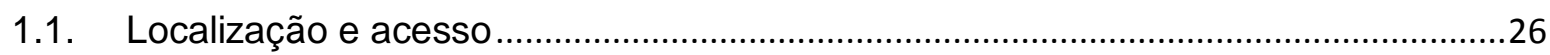

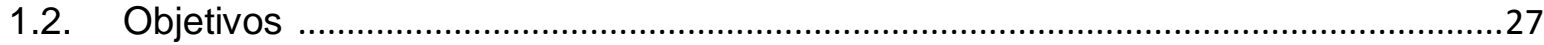

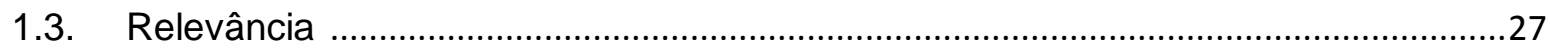

2. MATERIAIS E MÉTODOS

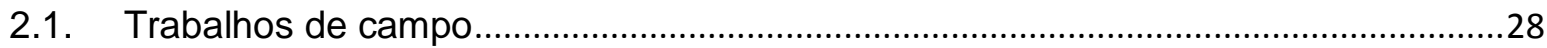

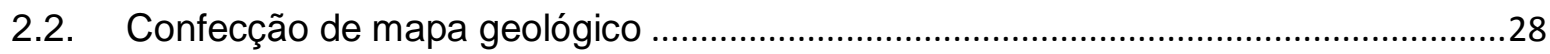

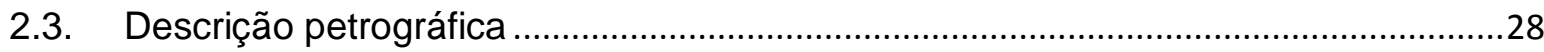

2.4. Química mineral (microssonda eletrônica e LA-ICP-MS).............................................28

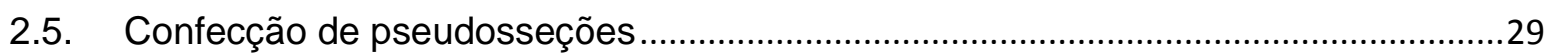

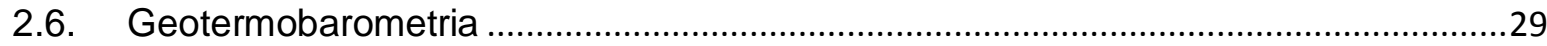

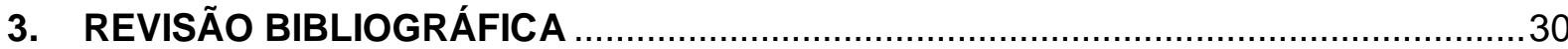

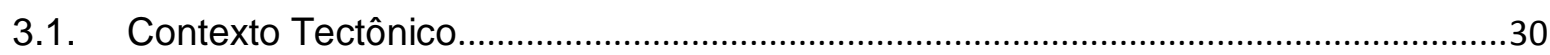

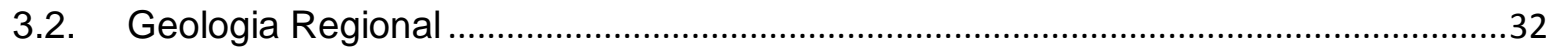

3.3. Breve conceituação sobre granulitos .....................................................................36

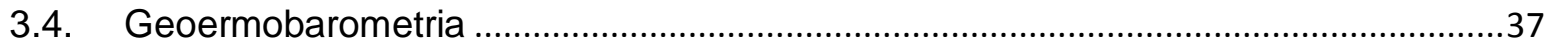

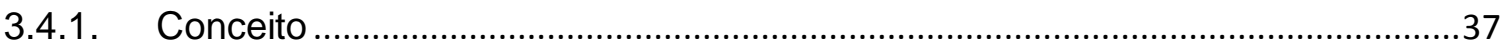

3.4.2. Geotermômetros convencionais .......................................................................41

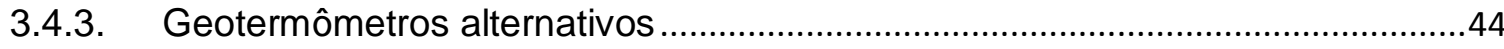

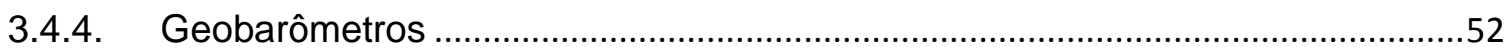

3.4.5. Fatores Controladores...................................................................................57

3.4.6. Estimativas de temperatura ...........................................................................5

3.4.7. Importância de um meio intergranular ……………………..................................60

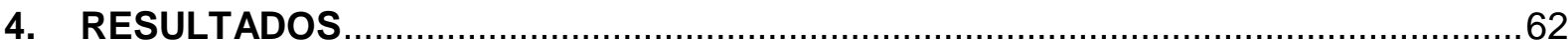

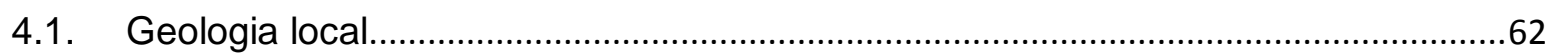

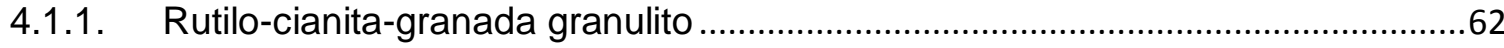

4.1.2. Metatexito estromático …………………………………………………….....63

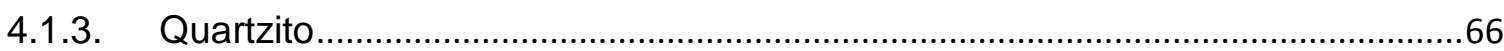

4.1.4. Biotita gnaisse milonítico …………………………………………………….....66

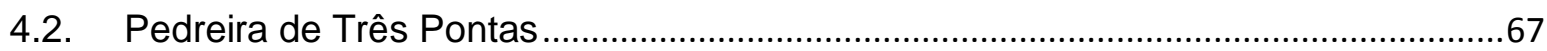

4.2.1. Rutilo-cianita-granada granulito ....................................................................68

4.2.2. Rocha residual máfica........................................................................................79 


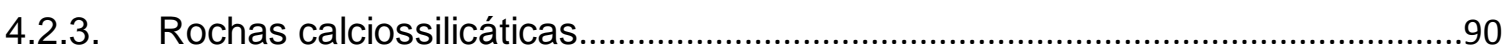

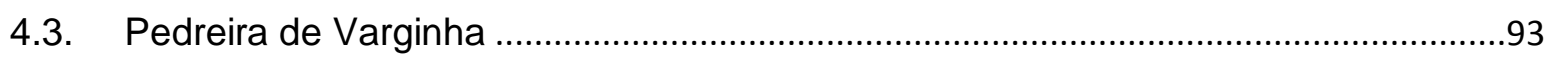

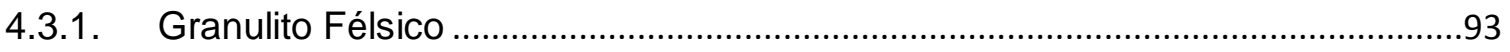

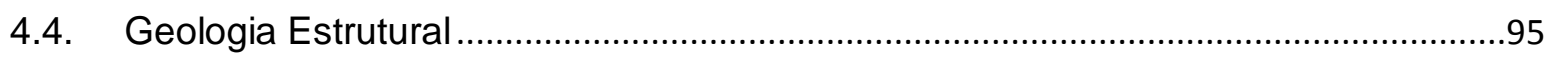

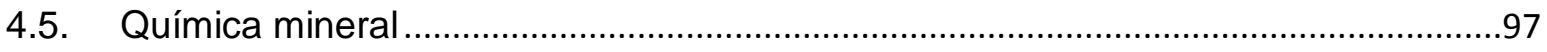

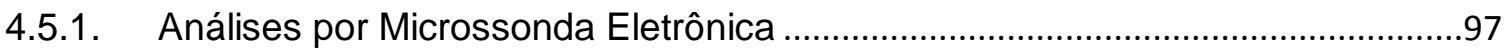

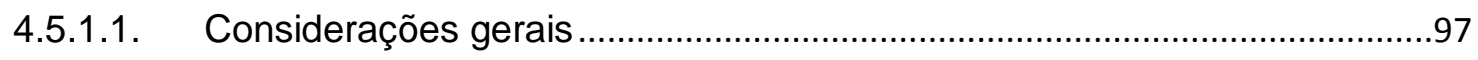

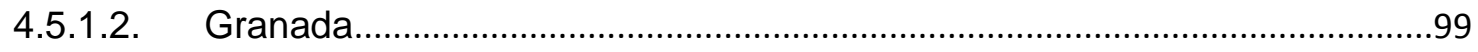

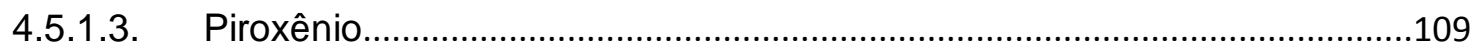

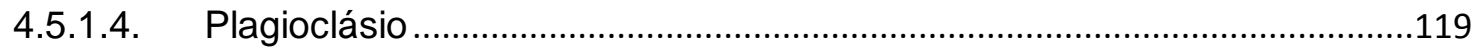

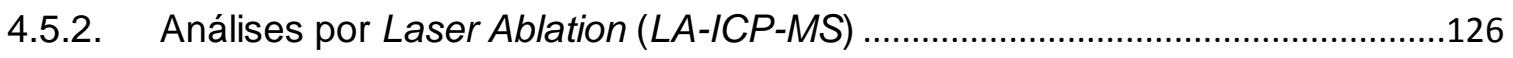

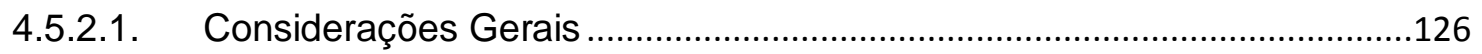

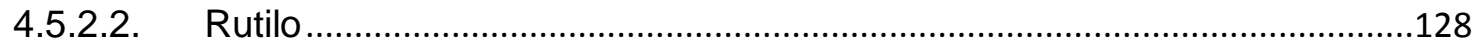

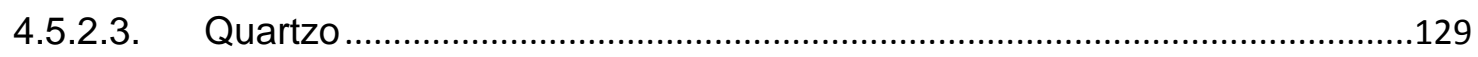

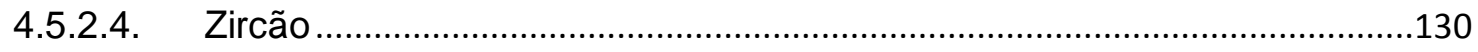

4.5.2.5. Cálculo pareado Zr-rutilo - Ti-quartzo....................................................130

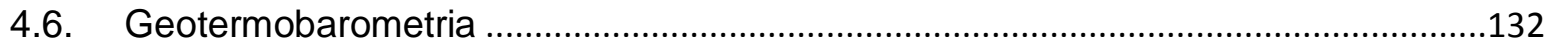

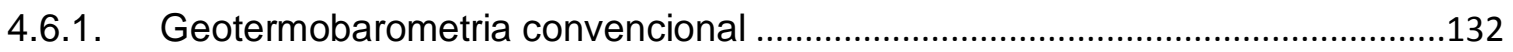

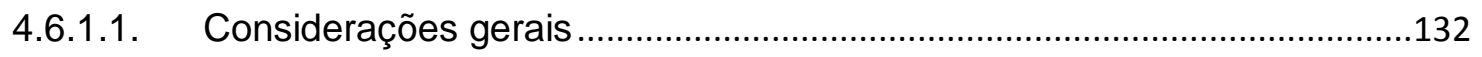

4.6.1.2. Nappe Três Pontas-Varginha ....................................................................132

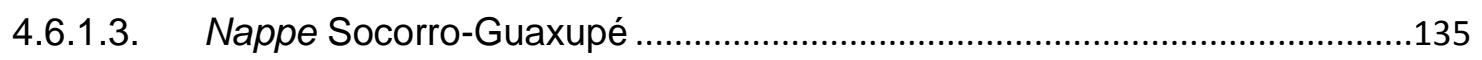

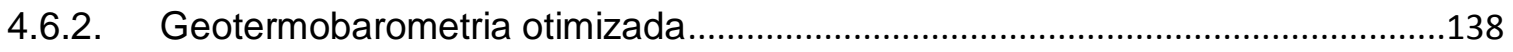

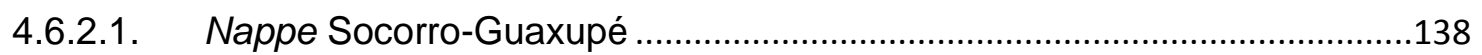

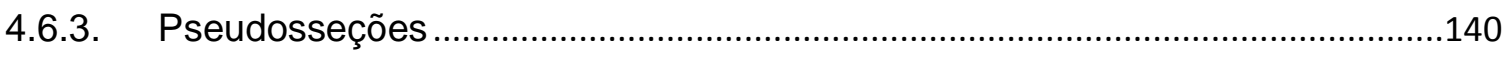

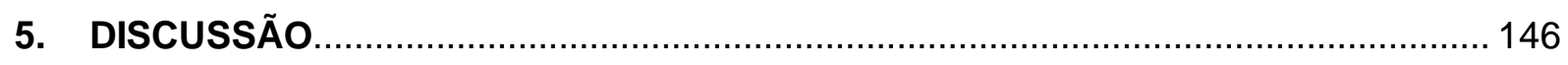

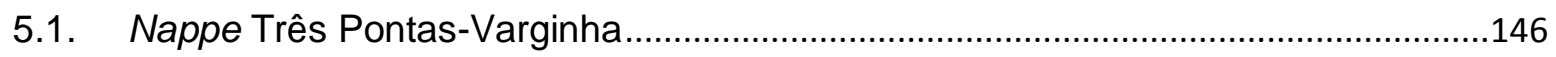

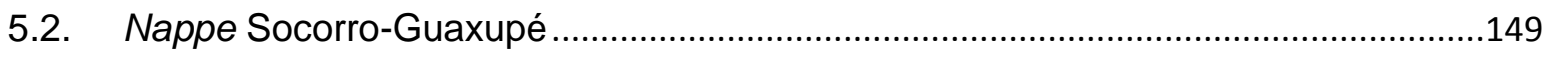

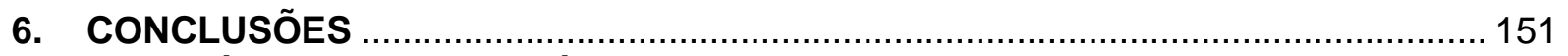

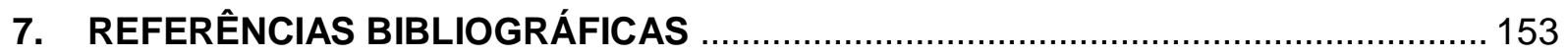

8. APÊNDICES

Apêndice 1 - Mapa e perfil geológico e mapa de pontos ....................................................163

Apêndice 2 - Tabelas de análises químicas e fórmulas estruturais de granada, clinopiroxênio, ortopiroxênio e plagioclásio, e Geotermometria Zr-rutilo e Ti-quartzo.......163 


\section{INTRODUÇÃO}

A geotermobarometria é a ferramenta dentro da petrologia que investiga as condições $P-T$ nas quais determinada associação mineral foi formada/ esteve em equilíbrio. Muitos minerais que possuem variação composicional, isto é, são soluções-sólidas, têm suas composições químicas relacionadas e dependentes das variações de temperatura e pressão, e quando em equilíbrio com outras fases que oferecem potencial troca iônica, como $\mathrm{Fe} \mathrm{e} \mathrm{Mg}$ entre granada e clinopiroxênio, e ao utilizar modelos apropriados de atividade e consequentemente determinar a constante de equilíbrio da reação entre seus membros finais, é possível indicar as condições $P-T$ nas quais essa associação mineral foi formada/ era estável. Esse tipo de método é considerado convencional e utiliza apenas uma reação mineral. Métodos mais recentes, como o utilizado pelo software THERMOCALC, calcula o equilíbrio químico das fases minerais desejadas utilizando um conjunto de reações linearmente independentes de seus membros finais. Valores de entalpia, entropia e volume, necessários nos cálculos, são retirados de um banco de dados internamente consistente. Assim, calculadas as reações, uma barra de erro é ajustada no sentido de se obter seu menor valor considerando o maior número de reações.

Métodos mais recentes utilizam elementos traços em apenas uma fase mineral, como é o caso de Zr-rutilo (Zack et al. 2004a, Watson et al. 2006, Tomkins et al. 2007) e Ti-quartzo (Wark \& Watson 2006, Thomas et al. 2010). Nesses trabalhos foram realizadas calibrações experimentais e empíricas onde foi determinada forte dependência em relação à temperatura, e menor com a pressão, nas concentrações desses elementos nos respectivos minerais. Outro método preciso e moderno é o cálculo de pseudosseções, que são diagramas $P-T$ calculados para determinado sistema químico e composição química de rocha total em que ocorrem campos de associações minerais, separados por curvas univariantes, que indicam quais fases minerais estariam estáveis nos intervalos desejados.

A aplicação desses métodos em rochas de fácies granulito teoricamente deve ser ideal, pois essas rochas são formadas nas mesmas janelas $P-T$ em que a maior parte dos experimentos das calibrações experimentais de termômetros e barômetros é feita. Deste modo, as correções de inferências fora da janela $P$ - $T$ deveriam ser menores ou inexistentes e os erros deveriam estar apenas relacionados com os modelos e cálculos de atividade. Entretanto, vários fatores petrológicos, geológicos e tectônicos inerentes à formação e evolução dos granulitos fazem com que a tarefa do cálculo $P$-T para a sua formação seja no mínimo desafiadora. Fatores como a comum relação entre granulitos e material silicático resultante de fusão parcial que oblitera a composição inicial da rocha dificulta sobremaneira a aplicação da maioria dos métodos. 
No sul de Minas Gerais estão expostos granulitos associados a várias unidades, sendo que na Nappe Três Pontas-Varginha, na região entre Três Pontas e Carmo da Cachoeira, ocorrem granulitos de alta pressão (Trouw \& Castro 1996; Campos Neto \& Caby 1999, 2000; Garcia \& Campos Neto 2003), representados por granulito migmatítico de composição pelítica, com paragênese residual de cianita + ortoclásio + granada + rutilo + quartzo, e por rocha residual máfica, com paragênese residual com camadas de hornblenda + diopsídio + rutilo \pm granada \pm ortopiroxênio. Leucossoma granítico e tonalítico são observados, respectivamente, associados a cada tipo de granulito. Ambas rochas apresentam associações típicas de alta temperatura e pressão, mas os cálculos para a determinação desses parâmetros são dificultados, pois em ambas rochas o plagioclásio foi em grande parte exaurido durante a fusão, dificultando a aplicação dos barômetros clássicos. Na mesma região ocorre granulito basal da Nappe Socorro-Guaxupé com paragênese granada-ortopiroxênioclinopiroxênio-plagioclásio-ortoclásio-quartzo-ilmenita. O objetivo da presente dissertação é a determinação das condições $P$ - $T$ dos granulitos das nappes Três Pontas-Varginha e SocorroGuaxupé com a aplicação de métodos termobarométricos convencionais, otimizados e alternativos.

\subsection{Localização e acesso}

A área estudada encontra-se no Município de Três Pontas, região sul do Estado de Minas Gerais. Foi mapeada área de aproximadamente $156 \mathrm{~km}^{2}$, situada a sul de Três Pontas, que engloba o município de Boa Vista, e está contida nas cartas topográficas de Três Pontas e Ribeirão da Espera (coordenadas UTM: 23K 7634000/435000; 7628000/435000; 7634000/461000; 7628000/461000). O acesso a Três Pontas a partir da cidade de São Paulo se dá pela rodovia Fernão Dias (BR-381) até o Município de Três Corações, e de lá, pela rodovia Claudionor Vasconcelos (MG-167) até Três Pontas. Dentro dessa área foi estudada em detalhe a pedreira abandonada "Niemeyer" (coordenadas UTM: 7632035/450716). O acesso à pedreira se dá, a partir da região sudeste do Município de Três Pontas, pela Rodovia Claudionor Vasconcelos (MG-167). Em outra pedreira, "Grupo Santo Antônio", a noroeste de Varginha (UTM: 7619887/451711), acessada pela mesma rovovia anterior, foram coletadas e estudadas algumas amostras. A Figura 1 ilustra a localização da área mapeada e das pedreiras estudadas. 


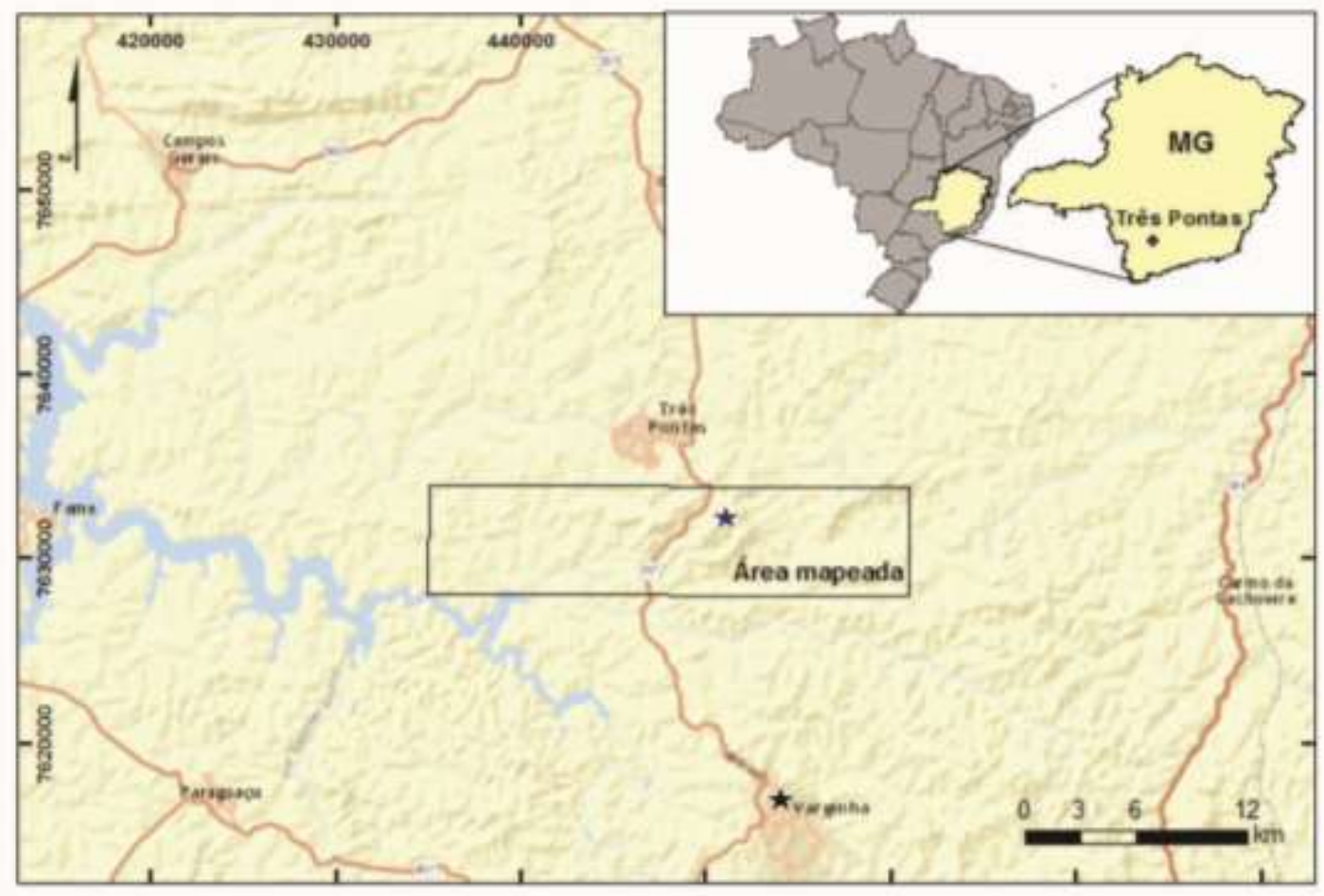

Figura 1 - Localização da área de estudo. Estrela azul indica a localização da pedreira abandonada "Niemeyer" estudada em detalhe e a estrela preta a pedreira "Grupo Santo Antônio" em Varginha.

\subsection{Objetivos}

A presente dissertação teve por objetivo testar e comparar a aplicação de métodos convencionais e não convencionais de termobarometria em rochas da fácies granulito das nappes Três Pontas - Varginha e Socorro - Guaxupé. A presença de rochas félsicas, pelíticas e máficas metamorfizadas nas condições da fácies granulito em altas pressões em pedreiras nas regiões entre Três Pontas e Varginha, MG, é ideal para a aplicação de vários métodos termobarométricos, para avaliação e comparação dos resultados obtidos e discussão da confiabilidade dos métodos.

\subsection{Relevância}

Frente à dificuldade recorrente encontrada no estudo de geotermobarometria de rochas de fácies granulito, este trabalho tentou por meio da mais ampla variedade de métodos, convencionais ou não, avaliar e estabelecer qual ou quais aqueles são mais confiáveis e precisos. Além do caráter analítico, com novos dados tanto de geologia de campo, como de condições $P-T$, auxilia no refinamento e entendimento da geologia de uma região bastante estudada, mas para a qual os dados disponíveis são conflitantes. 


\section{MATERIAIS E MÉTODOS}

2.1. Trabalhos de campo

Foram realizadas duas etapas de trabalhos de campo durante o período do projeto. A primeira ocorreu entre os dias 3 e 7 de setembro de 2013, na região entre Três Pontas e Varginha, MG. O objetivo do trabalho foi visitar a pedreira abandonada "Niemeyer" em Três Pontas, a fim de descrever os litotipos presentes, mineralogia, estruturas e relações de contato, e a pedreira Grupo Santo Antônio, a leste de Varginha, para descrição e amostragem. Já a segunda, entre os dias 12 e 16 de abril de 2014, teve como objetivo a confecção de um mapa geológico na escala 1:50.000 de uma área de aproximadamente $156 \mathrm{~km}^{2}$, situada a sul da cidade de Três Pontas, que engloba o município de Boa Vista, sul do Estado de Minas Gerais, e está contida nas cartas topográficas de Três Pontas e Ribeirão da Espera (coordenadas UTM: 7634000/435000; 7628000/435000; 7634000/461000; 7628000/461000). Esse mapeamento teve como objetivo obter maiores informações a respeito da geologia local nos arredores da pedreira Niemayer (tema central deste estudo).

\subsection{Confecção de mapa geológico}

Com base nas viagens de campos, descrições petrográficas, compilação de dados de Maciel (1986) e utilizando o software ArcGIS ${ }^{\circledR}$ (versão 10.1) foi confeccionado mapa geológico citado acima (Apêndice 1).

\subsection{Descrição petrográfica}

Após as etapas de campo foram produzidas, pelo Laboratório de Laminação do Instituto de Geociências, 32 lâminas petrográficas dos principais litotipos atentando para as diferentes texturas em cada um deles. Foi usado microscópio da marca Olympus, modelo BX40, nas descrições. A aquisição das fotomicrografias foi realizada com microscópio Olympus, modelo BX50, câmera "Infinity 1" e, software "analySIS starter". Toda aparelhagem utilizada é pertencente ao Laboratório de Microscopia Óptica do Instituto de Geociências da Universidade de São Paulo.

\subsection{Química mineral (microssonda eletrônica e $L A-I C P-M S$ )}

Com a descrição petrográfica feita, foram selecionadas amostras que contivessem fases essenciais em equilíbrio para a geotermobarometria. Para as análises de microssonda eletrônica foram confeccionadas (IGc - USP) e analisadas quatro seções polidas pelo equipamento JEOL, modelo JXA-FE-8530, Field Emission Electron Probe Microanalyser (FEEPMA) no Instituto de Geociências da USP. As análises pontuais foram feitas com corrente de $20 \mathrm{nA}$ e voltagem de $15 \mathrm{kV}$, enquanto que os mapas composicionais foram feitos com 
condições de 100 e 150 nA e 15 kv. Foram usados padrões de minerais naturais para a calibração da máquina. Entre os dias 28/07/2014 e 08/08/2014 foi realizada viagem para a cidade de Gotemburgo, Suécia, com o objetivo de trabalhar em conjunto com o Professor Thomas Zack, da Universidade de Gotemburgo, em análises de LA-ICP-MS em rutilo, quartzo e zircão. Para essas análises, outras quatro seções polidas de $80 \mu \mathrm{m}$ foram confeccionadas (IGc - USP) e analisadas pelo equipamento Laser-Ablation NWR213 (ESI) acoplado a ICPMS 8800 Triple Quadruple (Agilent Technologies) na Universidade de Gotemburgo, Suécia. Grãos de minerais ou materiais sintéticos foram usados como padrões para o levantamento da curva de calibração.

\subsection{Confecção de pseudosseções}

Com análise química de outros trabalhos (e.g. Pavan 2010) foram sugeridas composições químicas para as rochas desse trabalho e confeccionadas duas pseudosseções no sistema NCKFMASHTO, utilizando o software THERMOCALC, v.333 (Holland \& Powell 2011) e banco de dados termodinâmicos atualizados em 6 de fevereiro de 2012. Ambos diagramas foram calculados na janela de 2 a $20 \mathrm{kbar}$ e de 650 a $1000{ }^{\circ} \mathrm{C}$.

\subsection{Geotermobarometria}

Com as análises de química mineral em mãos, os dados de granada, clinopiroxênio, ortopiroxênio e plagioclásio obtidos por microssonda eletrônica foram tratados pelo software "AX", de Tim Holland (http://www.esc.cam.ac.uk/research/research-groups/researchprojects/tim-hollands-software-pages/ax) e, utilizados na geotermobarometria convencional pelos geotermômetros de Ellis \& Green (1979) e Harley (1984), e pelos barômetros de Newton \& Perkins (1982), Perkins \& Chipera (1985), Paria et al. (1988) e Eckert et al. (1991). Os métodos otimizados utilizados foram os de Pattison et al. (2003) com o software RCLC e de Holland \& Powell (2011) com THERMOCALC. Já os dados de rutilo, quartzo e zircão obtidos por LA-ICP-MS foram tratados pelo software GLITTER, versão 4.4 .4 (http://www.glittergemoc.com) e, utilizados para a geotermobarometria não convencional com os geotermômetros de Watson et al. (2006), Tomkins et al. (2007) e Thomas et al. (2010). 


\section{REVISÃO BIBLIOGRÁFICA}

\subsection{Contexto Tectônico}

$\mathrm{Na}$ região sudeste brasileira ocorrem rochas arqueanas a paleoproterozóicas pertencentes ao Cráton São Francisco e bordejadas por outras neoproterozóicas, relacionadas ao Evento Brasiliano - Pan Africano, que levou à formação do supercontinente Gondwana, representadas por faixas móveis (Figura 2). A Faixa Brasília (Marini et al. 1981; Fuck 1994; Dardenne 2000), situada na Província Tocantins (Figura 3) entre os Crátons São Francisco e Amazônico e que ainda engloba as Faixas Araguaia e Paraguai (Almeida et al. 1981), é composta de leste para oeste por metassedimentos parautóctones do Grupo Bambuí na zona de antepaís, metassedimentos alóctones da margem passiva neoproterozóica e rochas de seu embasamento, o Maciço Goiano e o Arco Magmático de Goiás. O orógeno pode ser dividido em Setentrional e Meridional devido à localização e orientação geográficas, deformação e metamorfismo distintos (Valeriano et al. 2000).

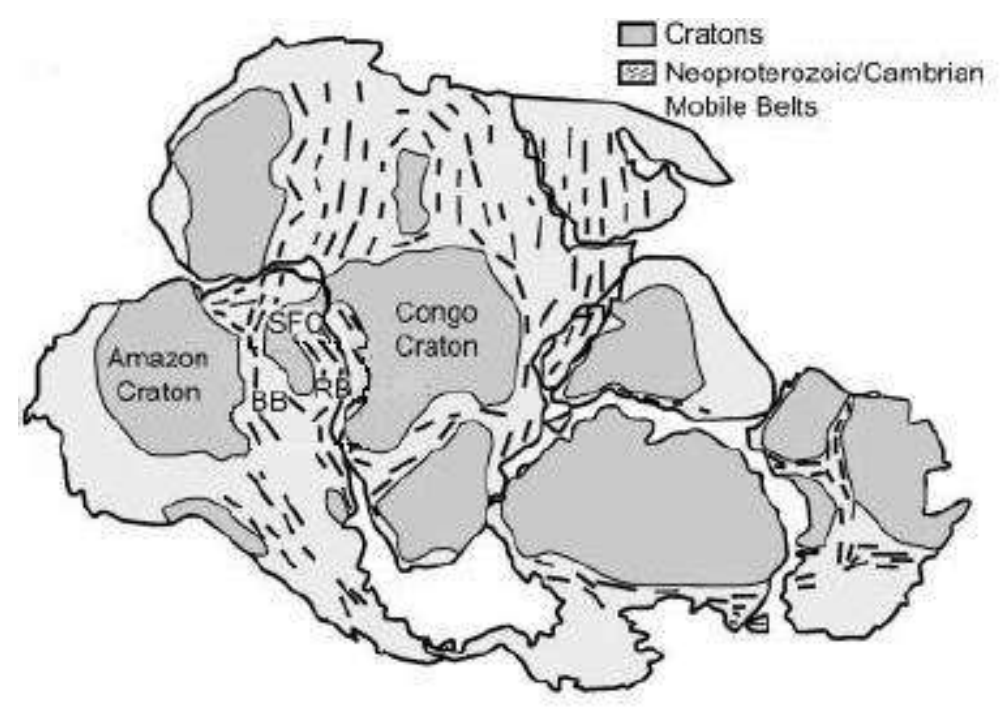

Figura 2 - Mapa simplificado de Gondwana. Áreas cratônicas em coloração cinza e faixas móveis como tracejados. Imagem retirada de Reno et al. 2009

A Faixa Brasília Setentrional apresenta orientação N-NE e é formada por diversos compartimentos com diferentes materiais (Figura 3), de diferentes idades, graus metamórficos e estilos estruturais. Os seguintes domínios tectônicos são reconhecidos: porção externa, em que ocorrem rochas de cobertura cratônica, não deformadas e sem metamorfismo, até leve deformação e metamorfismo, na sua porção oeste; domínio interno, o núcleo metamórfico em que rochas das fácies xisto verde até granulito são observadas, com migmatitos e eclogitos e grande volume de intrusões de corpos ígneos máficos a félsicos; domínio de Arco Magmático; em Goiás ocorre terreno com núcleo antigo, onde predominam rochas do Paleoproterozóico 
e do Arqueano (Fuck 1994; Seer 1999; Dardenne 2000; Pimentel et al. 2000; Valeriano et al. 2000;).

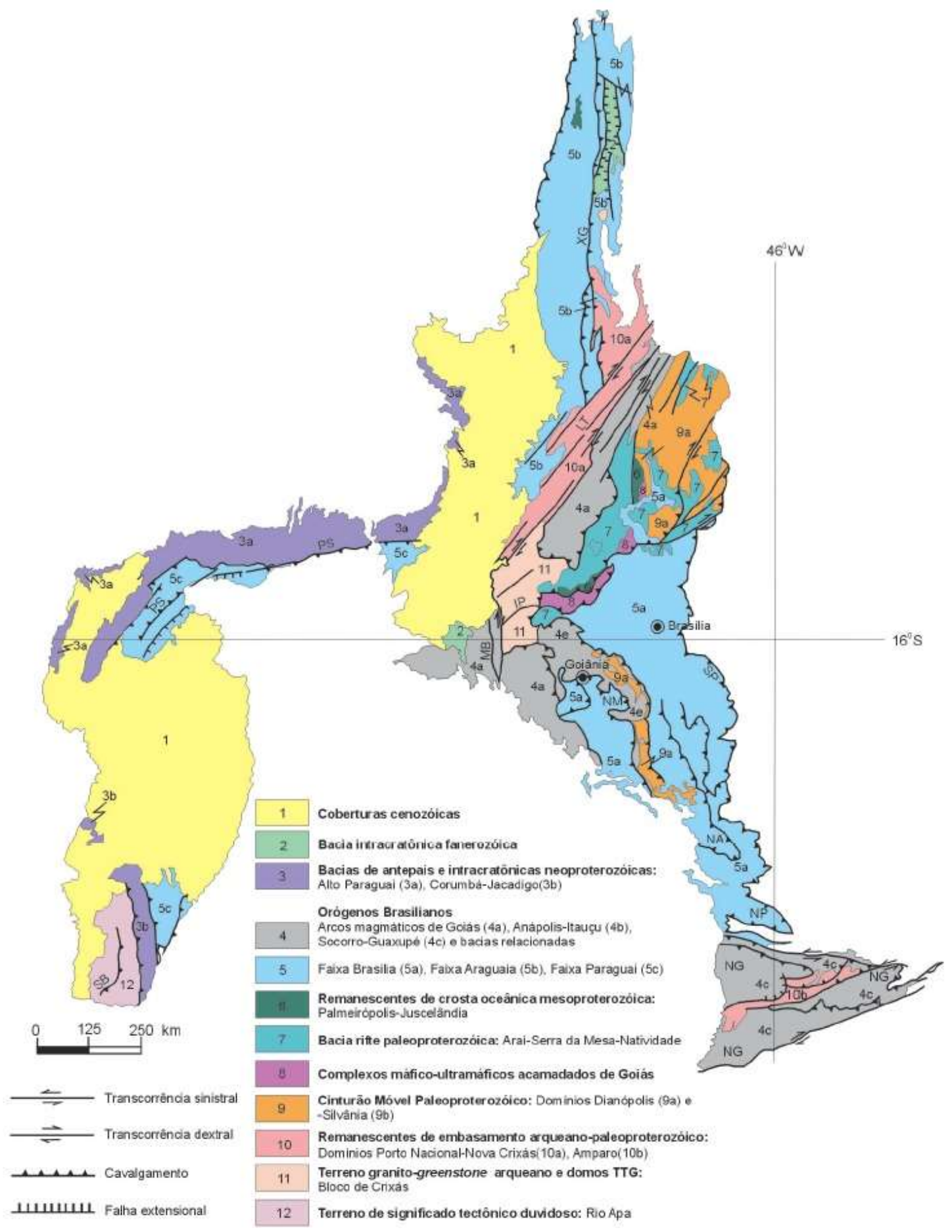

Figura 3 - Província Tocantins com suas principais estruturas e domínios tectônicos (Delgado et al. 2003)

A Faixa Brasília Meridional apresenta orientação EW e diferencia-se da Setentrional por apresentar outro estilo tectônico, determinado por empilhamento de nappes formadas por rochas da margem passiva (conforme indicado por faciologia sedimentar e características geoquímicas/geocronológicas) sanfranciscana, empurradas contra o Cráton São Francisco em ca. $640 \mathrm{Ma}$. Cada terreno formador da pilha é limitado entre si por superfícies de 
cavalgamento sub-horizontais, sendo formado por unidades litoestratigráficas metassedimentares, como os grupos Canastra, Ibiá, Paranoá e Araxá-Andrelândia, ordenados em posição estratigráfica inferior a superior. Descontinuidades metamórficas ocorrem entre terrenos vizinhos e indicam que o empilhamento tectônico foi posterior aos respectivos picos metamórficos (Valeriano et al. 2004).

O metamorfismo da porção meridional é característico por ser de baixo grau em fácies xisto verde nas nappes inferiores e de médio a alto grau, fácies anfibolito a granulito, nas superiores (e.g. nappes Três Pontas - Varginha e Socorro-Guaxupé). Rochas de alta pressão nas porções superiores são relacionadas à subducção parcial de margem continental distal sanfranciscana sob a placa e/ou terrenos vindos de oeste, posteriormente extrudida sobre as nappes nas proximidades do antepaís, e conferindo ao pacote um padrão metamórfico invertido (Campos Neto \& Caby 1999, 2000, Pavan 2010). A maior parte do padrão invertido se dá pela sobreposição das nappes, mas algumas delas apresentam sequência normal de metamorfismo dentro (Motta 2009).

O encontro das porções setentrional e meridional do orógeno, na altura do paralelo de Brasília, forma a chamada Flexura dos Pirineus (Costa \& Angeiras 1971), caracterizada por lineamentos de direção E-W. Nessa região, estruturas da Faixa Brasília Meridional são superpostas por feições deformacionais da Setentrional, conferindo ao orógeno como um todo um caráter diacrônico.

Além da Faixa Brasília, o Cráton São Francisco na região sudeste brasileira é bordejado pelas faixas móveis de Araçuaí, a nordeste, e Ribeira-Búzios, a sul, pertencentes à Província Mantiqueira, sendo relacionadas ao fechamento do paleoceano Adamastor, entre a margem leste do Cráton São Francisco e o Cráton do Congo, e que resultou em pelo menos um arco magmático (Arco Magmático do Rio Negro); (e.g. Machado et al. 1996, Schmitt et al. 1999, Heilbron \& Machado 2003, Schmitt et al. 2004, 2008, Alkmim et al. 2006; Heilbron et al. 2008).

\subsection{Geologia Regional}

No sul de Minas Gerais estão expostas rochas do Cráton São Francisco e da porção meridional do Orógeno Brasília. Na região esta unidade é representada por vários sistemas de nappes, que de oeste para leste estão empilhados do topo para a base: Socorro-Guaxupé, Três Pontas-Varginha e klippen relacionadas, Liberdade e Carmo da Cachoeira ou Andrelândia, que representam, respectivamente, rochas intermediárias a máficas em fácies granulito de alta pressão derivadas de arco magmático, cianita granulitos de alta pressão de 
prisma acrescionário subductado e metapelitos em fácies anfibolito relacionados a bacia de foreland (Campos Neto \& Caby 1999, 2000; Figura 4).

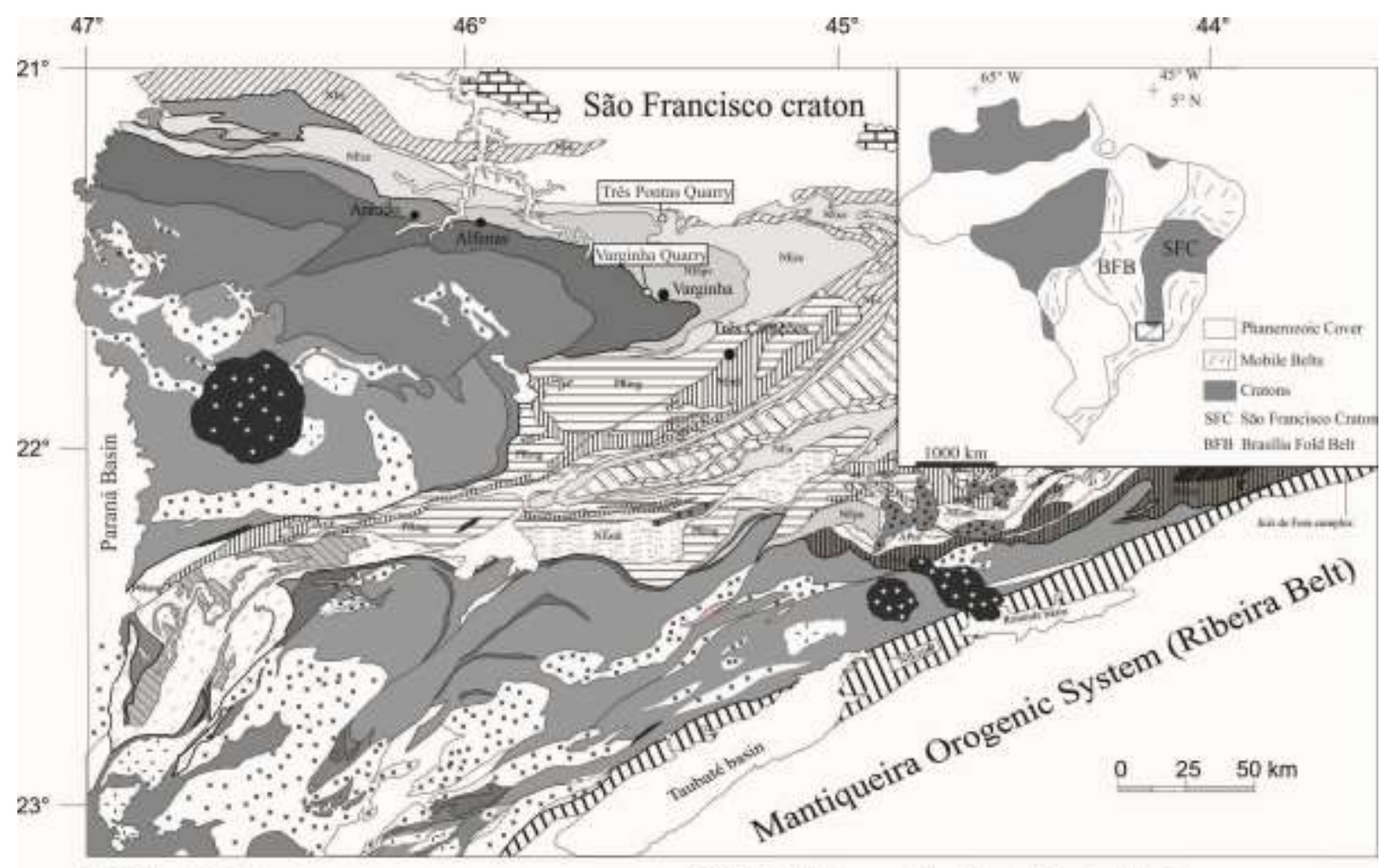

\begin{tabular}{|c|c|c|}
\hline \multicolumn{3}{|l|}{ Edacarm Canbrian remains of molassic bain } \\
\hline Sãe Francisce Plate and Andrelîndia Terrane & \multirow{3}{*}{ 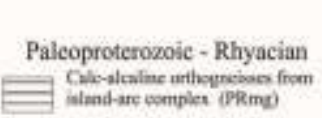 } & \multirow{3}{*}{$\begin{array}{c}\text { Paranapanema Plate } \\
\text { Neoproterozoic-Ediacaran } \\
\text { Socorro-Guaxupd nappe }\end{array}$} \\
\hline Ceranites & & \\
\hline roterogoic - Ediacaran & & \\
\hline Cimmar neppe system (NEe) & T.7. Migmatitic athogrowibses (PRgm) & 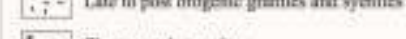 \\
\hline 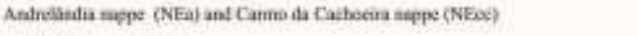 & & $\because \quad 5$ in-metenic granthen \\
\hline Libontade nappe (Nifinl) & Arquean - Palcoprotrozoic & Metwakritor \\
\hline Alapos mignatite & Mantoquein uncinses (Ahm) & Distexites \\
\hline \multirow{2}{*}{ 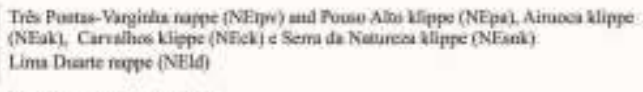 } & \multirow{2}{*}{ Ampan Campler } & \multirow[b]{2}{*}{ Mesoproteruzoic and Older } \\
\hline & & \\
\hline 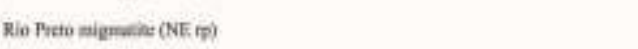 & & Scria do ltaberabe Group \\
\hline lispin Comples & & Sin Rapare Ginew \\
\hline
\end{tabular}

Figura 4 - Mapa esquemático da porção meridional da Faixa Brasília com as pedreiras estudadas assinaladas (modificado de Campos Neto \& Caby 1999, 2000).

A Nappe Socorro-Guaxupé apresenta em sua base, em camada com cerca de $3 \mathrm{~km}$ de espessura, granulito enderbítico bandado com granada, clinopiroxênio, ortopiroxênio, plagioclásio e quartzo, e leucossoma grosso charnoquítico interpretado como fusão anidra insitu. Acima dessa porção, em camada de $\sim 6 \mathrm{~km}$ de espessura, essa rocha grada para biotitahornblenda diatexito leucocrático, de granulação grossa na porção intermediária, e migmatitos semi-pelíticos a pelíticos, representados por granada-sillimanita-biotita metatexito com leucossoma portador de biotita e granada no topo (grau de anatexia diminui para as porções 
superiores), com lentes de quartzito, rochas calciossilicáticas, mármores e metabásicas intrusivas sin-metamórficas (Campos Neto \& Caby 1999; 2000).

Isócrona Sm-Nd feita com granada, biotita e rocha total produziu idade neoproterozóica de $629 \pm 14$ Ma para o metamorfismo de fácies granulito. Em relação ao protolito dos granulitos enderbíticos, idades modelo Sm-Nd $T_{d m}$ de $1290 \mathrm{Ma}$, com $\varepsilon_{\mathrm{Nd}}(0.640)$ $=-1,2$, são obtidos e relacionados ao Arco Mara Rosa localizado no interior da Faixa Brasília (Campos Neto \& Caby 1999), enquanto que, para a unidade migmatítica superior, dados U/Pb (intercepto superior) de zircões fornecem idades entre 1,9 e 2,1 Ga (Ebert et al. 1996), interpretadas como valores de grãos herdados no sedimento.

Trabalhos anteriores, como o de Del Lama et al. (1994), apontam altas pressões e temperaturas iniciais de metamorfismo, com $P$ de $12,5 \mathrm{kbar}$ e $T$ de $900{ }^{\circ} \mathrm{C}$. Reequilíbrio metamórfico parcial a $7,5 \mathrm{kbar}$ e $850^{\circ} \mathrm{C}$ é descrito por Oliveira \& Ruberti (1979).

Estruturalmente, a Nappe Socorro-Guaxupé é caracterizada por apresentar foliação subhorizontal com lineações ENE, e indicadores cinemáticos com sentidos de transporte para E. Fatores que sugerem seu transporte para leste por pelo menos $200 \mathrm{~km}$. Ao sul é limitada por zona de cisalhamento de direção NE (Campos Neto \& Caby 1999).

Na região de entre Três Pontas e Carmo da Cachoeira, MG, ocorrem rochas metassedimentares do Grupo Andrelândia (Ebert 1956, 1984, Trouw et al. 1986) formadas sob condições de altas temperaturas e pressões, provavelmente relacionadas a ambientes de margens ativas (Janasi 1999; Trouw et al. 2000, 2006; Campos Neto \& Caby 1999, 2000). Estruturalmente, a unidade é dividida na Nappe Três Pontas - Varginha, superior, formada por cianita e sillimanita granulitos, e Nappe Carmo da Cachoeira, inferior, constituída por xistos e gnaisses com granada e cianita (Campos Neto \& Caby 2000).

A Nappe Três Pontas - Varginha, com cerca de $5 \mathrm{~km}$ de espessura, é formada por rochas de fácies granulito com cianita na base e sillimanita no topo, com intercalações de leitos de rochas calciossilicáticos, cianita quartzitos, quartzitos impuros, quartzitos ricos em granada e rochas máficas. O rutilo-granada-cianita granulito é de granulação média a grossa, foliação interpretada como o acamamento sedimentar original, e apresenta-se comumente boudinado, com bandamento composicional que apresenta camadas centimétricas ricas em granada, outras milimétricas compostas por maior quantidade de cianita e, mais raramente, finos leitos micáceos (Campos Neto \& Caby 1999). É composto por quartzo, feldspato potássico, granada, cianita, biotita, plagioclásio, rutilo e ilmenita, com apatita, zircão, titanita, monazita e minerais opacos como acessórios. São comuns as feições de fusão parcial com geração de leucossoma com feldspato potássico, cianita e granada, minerais característicos de fusão por quebra da biotita, e melanossoma rico neste último mineral. Ainda há rochas com 
foliação milonítica, com aumento no grau de milonitização nas proximidades do contato basal da sequência (Garcia 2001).

No topo do pacote a rocha apresenta sillimanita. Como mineralogia principal ocorre sillimanita, quartzo, biotita, microclínio, plagioclásio e ilmenita, com rutilo, zircão, minerais opacos, epidoto, apatita, titanita e turmalina como acessórios. Assim como no cianita granulito, feições de fusão parcial por quebra de biotita e porções com foliação milonítica são comuns (Garcia, 2001). Esse metamorfismo invertido, com cianita na base e sillimanita no topo, tem sua gênese provavelmente relacionada ao calor advectivo derivado da colocação da nappe Socorro-Guaxupé, acima e mais quente (Campos Neto \& Caby 1999).

Rochas calciossilicáticas ocorrem na forma de leitos de espessuras milimétricas a decimétricas, comumente boudinados, concordantes com a foliação das encaixantes. São rochas bandadas de granulação média a grossa, textura granoblástica e composição variada, apresentando como tipos básicos metamargas aluminosas e mármores calciossilicáticos (Garcia, 2001).

Idades modelo Sm-Nd de rocha total para os protolitos dos granulitos com cianita e sillimanita são proterozóicas de cerca de 1,4 e 1,55 Ga, respectivamente, e $\varepsilon_{\mathrm{Nd}}(0.625)$ de 3,6 e -2,1 (Campos Neto \& Caby 1999). Tais valores diferem dos da cobertura terrígena do Cráton São Francisco, e possuem características de ambiente de margem continental ativa, como caracterizado em outras regiões (McLennan et al. 1990).

Campos Neto \& Caby (1999) realizaram trabalhos pioneiros com resultados termobarométricos na área. Estimativas de temperatura utilizando a partição de Fe e Mg entre biotita e granada, e levando em consideração a presença de $\mathrm{Al}^{\mathrm{VI}}$ e $\mathrm{Ti}$ em biotita de fácies granulito (Indares \& Martignole 1985), colocam a formação dos granulitos com cianita entre $690^{\circ} \mathrm{C}$ e $780^{\circ} \mathrm{C}$, e dos com sillimanita em aproximadamente $890^{\circ} \mathrm{C}$. A partir desses valores, Campo Neto \& Caby (1999) obtém valores de pressões de cerca de 12 kbar pela reação GRAIL usando a composição de granada rica em piropo (Alm48-Prp47). Já valores na ordem de 13 kbar são sugeridos pela coexistência de mesopertita e plagioclásio primário, através da reação GRIPS com a atividade de ilmenita na matriz $=0.93$ (Bohlen \& Liotta 1986). A partir disso foram gerados mais dados termobarométricos com os trabalhos de Campos Neto \& Caby (2000), Garcia \& Campos Neto (2003) e Reno et al. (2009), apontando temperaturas entre $700{ }^{\circ} \mathrm{C}$ e $900{ }^{\circ} \mathrm{C}$ (este próximo ao topo, mas ainda com cianita) e pressões entre $10 \mathrm{e}$ $16 \mathrm{kbar}$ para o cianita granulito, $800^{\circ} \mathrm{C}$ a $960^{\circ} \mathrm{C}$ e 11 a $15 \mathrm{kbar}$ para o sillimanita granulito de topo.

O padrão estrutural apresentado pelas rochas da Nappe Três Pontas-Varginha é comparável ao da Socorro-Guaxupé, com foliação subhorizontal, lineação mineral, e lineação 
de estiramento mineral de cianita, rutilo, muscovita e quartzo (ribbons), com direção ENE. Klippen de cianita granulito localizadas a sul da nappe indicam que seu transporte ocorreu por pelo menos $100 \mathrm{~km}$ para leste (Campos Neto \& Caby 1999).

A Nappe Carmo da Cachoeira é unidade composta por quartzito, xisto e gnaisse, com intercalações de anfibolito e gondito (Garcia 2001). As rochas paraderivadas são xisto, xisto feldspático e quartzito com cianita, granada e rutilo. A variação entre elas ocorre devido à ocorrência ou não de plagioclásio, biotita e cianita e à proporção de quartzo, com gradação entre os três tipos, normalmente apresentando bandamento sedimentar reliquiar. A granulação varia de fina a grossa, de textura lepidogranoblástica a granolepidoblástica e composição mineralógica quartzo, plagioclásio, cianita, granada, biotita, muscovita, e rutilo, zircão, apatita, turmalina e minerais opacos como acessórios (Garcia 2001). Ocorre ainda granada-biotita-plagioclásio gnaisse, de granulação fina e nem sempre apresentam bandamento composicional. A composição mineralógica é formada por quartzo, plagioclásio (oligoclásio), biotita, muscovita, granada, cianita, e apatita, zircão, turmalina e minerais opacos como acessórios. São comuns feições miloníticas nessas rochas (Garcia 2001). Lentes de anfibolito com ou sem granada ocorrem com espessuras variáveis junto ao xisto, quartzito e gnaisse, em geral com foliação concordante à das encaixantes. Como mineralogia apresentam hornblenda, plagioclásio, quartzo, granada e \pm clinopiroxênio ou \pm epidoto, e ainda com rutilo, zircão, biotita, apatita, actinolita, clorita, carbonato, clinozoizita, titanita, e minerais opacos como acessórios (Garcia 2001). Gondito ocorre localmente, sendo rocha maciça, de granulação fina, de textura granoblástica e composta por quartzo e granada, mas apresenta como mineralogia acessória rutilo, por vezes em grandes quantidades, biotita, apatita, zircão e turmalina (Garcia 2001).

\subsection{Breve conceituação sobre granulitos}

Granulitos são rochas formadas em altas temperaturas $\left(T>750-800^{\circ} \mathrm{C}\right)$ e em amplo intervalo de pressão, condições essas relacionadas à perturbação da geoterma nas porções médias e inferiores da crosta continental, em ambientes continentais colisionais (Harley 1989) ou extensionais (Sandiford \& Powell 1986). A exumação dessas rochas geradas em grandes profundidades só é possível através de um posterior evento tectônico como por um sistema de nappes, fatias em terrenos colisionais (Harley 1989), através de colisão oblíqua (Thompson et al. 1997) ou por tectônica de fluxo de canal (Jamieson et al. 2004).

$\mathrm{Na}$ composição mineralógica apresentam tipicamente feldspato e minerais anidros, como piroxênios, principalmente ortopiroxênio, granada e quartzo. Em rochas aluminosas é comum a presença de cordierita, sillimanita e espinélio. A textura predominante é a 
granoblástica, variando para tipos orientados e estirados (texturas flaser e milonítica), e estrutura maciça a bandada/ gnáissica (Harley 1989).

As altas temperaturas existentes durante esse metamorfismo podem levar a rocha à fusão parcial, a partir da quebra de minerais como biotita e hornblenda, o que implica coexistência com líquido silicático. A eficiência com que esse material fundido é mobilizado e segregado se torna um importante fator na preservação da paragênese de pico metamórfico da rocha residual, isto é, o granulito (White \& Powell 2002, 2010). A rápida retirada do líquido evita maiores reações de difusão fundido-rocha, caso contrário, se o material fundido não for segregado com eficiência, as altas taxas de difusão podem alterar desde teores de determinados elementos em minerais, como diminuição de Ca em granada para cristalização de plagioclásio (Moraes et al. 2002), até a paragênese de mais alto grau da rocha por completo (White \& Powell 2002), dificultando sobremaneira a obtenção das composições minerais de pico metamórfico e consequentemente dados termobarométricos precisos.

\subsection{Geoermobarometria}

\subsubsection{Conceito}

Muitos minerais apresentam variações composicionais caracterizadas como soluçõessólidas. Quando em coexistência em associação mineral, suas composições químicas são relacionadas e dependentes das variações de temperatura e pressão. Ao analisar, por exemplo, os teores de $\mathrm{Fe} \mathrm{e} \mathrm{Mg}$ de minerais em equilíbrio de uma mesma rocha, utilizar modelos apropriados de atividade e assim determinar a constante de equilíbrio de uma reação entre os membros finais desses minerais, é possível estabelecer valores de temperatura e pressão para as quais a associação mineral, ou paragênese, foi formada.

A reação de troca Fe-Mg entre minerais é exemplificada por Philpotts \& Ague (2009) através do par estaurolita-clorita, que podem ser relacionados por duas reações, 1 e 2:

Reação 1: para componentes de ferro: $41 \mathrm{Al}_{2} \mathrm{SiO}_{5}+4 \mathrm{Fe}_{5} \mathrm{Al}_{2} \mathrm{Si}_{3} \mathrm{O}_{10}(\mathrm{OH})_{8}=$ $10 \mathrm{Fe}_{2} \mathrm{Al}_{9} \mathrm{Si}_{4} \mathrm{O}_{23}(\mathrm{OH})+13 \mathrm{SiO}_{2}+11 \mathrm{H}_{2} \mathrm{O}$

Reação 2: para componentes de magnésio: $41 \mathrm{Al}_{2} \mathrm{SiO}_{5}+4 \mathrm{Mg}_{5} \mathrm{Al}_{2} \mathrm{Si}_{3} \mathrm{O}_{10}(\mathrm{OH})_{8}=$ $10 \mathrm{Mg}_{2} \mathrm{Al}_{9} \mathrm{Si}_{4} \mathrm{O}_{23}(\mathrm{OH})+13 \mathrm{SiO}_{2}+11 \mathrm{H}_{2} \mathrm{O}$

Pela subtração 2 - 1, é alcançada a reação de troca Fe-Mg entre estaurolita e clorita: $10 \mathrm{Mg}$-estaurolita $+4 \mathrm{Fe}$-clorita $=10 \mathrm{Fe}$-estaurolita $+4 \mathrm{Mg}$-clorita . 
A composição de ambos os minerais no equilíbrio é relacionada à constante de equilíbrio da reação, a qual pode ser recalculada em função da energia livre de Gibbs ( $G$ = $\left.\sum_{i} n_{i} \mu_{i}\right):$

$$
10 \mu_{\mathrm{MgSt}}+4 \mu_{\mathrm{FeChl}}=10 \mu_{\mathrm{FeSt}}+4 \mu_{\mathrm{MgChl}} \rightarrow 10\left(\mu_{\mathrm{FeSt}}+\mu_{\mathrm{MgSt}}\right)-4\left(\mu_{\mathrm{FeChl}}+\mu_{\mathrm{MgChl}}\right)=0
$$

Em termos de atividade $(a)$, por exemplo:

$\mu_{\mathrm{FeSt}}=\mu_{\mathrm{FeSt}}^{*}+R T \ln a_{\mathrm{FeSt}}$, em que $\mu^{*}{ }_{\mathrm{FeSt}}$ é o potencial químico de Fe-estaurolita em determinada pressão e temperatura, assim:

$$
10\left(\mu_{\mathrm{FeSt}}^{*}-\mu_{\mathrm{MgSt}}^{*}\right)-4\left(\mu_{\mathrm{FeChl}}^{*}-\mu_{\mathrm{MgChl}}^{*}\right)=-10 R T \ln \frac{a_{F e S t}}{a_{M g S t}}+4 R T \ln \frac{a_{F e C h l}}{a_{M g C h l}}
$$

Como $\mu^{*} \mathrm{FeSt}=G_{\mathrm{FeSt}}$, o lado esquerdo da reação é simplesmente a variação da energia livre de Gibbs $(\Delta G)$ da reação de troca Fe-Mg em determinada pressão e temperatura, assim:

$$
\Delta G=-R T \ln \frac{a_{F e S t}^{10} a_{M g C h l}^{4}}{a_{M g S t}^{10} a_{F e C h l}^{4}}
$$

Essa mudança de energia livre é chamada de potencial de troca Fe-Mg. Para relacionar o potencial com a composição dos minerais é preciso saber a relação entre as atividades em frações molares dos membros finais dos minerais $\left(a_{i}=X_{i}^{n}\right.$; onde $n$ é o número de sítios no mineral, com $n=2$ no caso da estaurolita e $n=5$ para a clorita):

$$
\Delta G=-R T \ln \frac{X_{F e S t}^{20} X_{M g C h l}^{20}}{X_{M g S t}^{20} X_{F e C h l}^{20}} \rightarrow-\Delta G=20 R T \ln \frac{X_{F e S t} X_{M g C h l}}{X_{M g S t} X_{F e C h l}}
$$

A razão entre as frações molares de $\mathrm{Fe}$ e $\mathrm{Mg}$ das fases coexistentes, nesse caso estaurolita e clorita, é conhecida como coeficiente de distribuição $\left(K_{D}\right)$, e pode ser determinada por análises químicas minerais com o uso de microssonda eletrônica.

Como a energia livre de Gibbs $(\Delta G)$ pode ser explicada em função de temperatura e pressão, o coeficiente de distribuição $\left(\mathrm{K}_{\mathrm{D}}\right)$ pode ser utilizado para a obtenção de valores das variáveis intensivas para as quais minerais coexistentes se formaram em determinada rocha. Dessa maneira:

$$
\Delta G=\Delta H-T \Delta S+\left(P-10^{5}\right) \Delta V
$$




$$
\Delta G=-m R T \ln K_{D}
$$

Então,

$$
\ln K_{D}=-\frac{\Delta H}{m R T}+\frac{\Delta S}{m R}-\left(P-10^{5}\right) \frac{\Delta V}{m R T}
$$

Onde:

$K_{D}$ - constante de equilíbrio de uma reação - determinada pela composição química dos minerais obtida na microssonda eletrônica;

$\Delta H$ - variação da entalpia da reação em relação a um estado padrão;

$\Delta S$ - variação da entropia da reação em relação a um estado padrão;

$\Delta V$ - variação do volume das fases em relação a um estado padrão;

$P$ - em pascal;

$T-\mathrm{em}^{\circ} \mathrm{C}$;

$m$ - baseado no modelo de atividade e nos coeficientes da reação (no caso, $m=20$ ).

A partir da última equação e dependendo da magnitude de cada um de seus termos é possível estimar temperaturas (geotermômetro) ou pressões (geobarômetro) metamórficas, e como pode ser visualizado, reações que envolvem pouca ou nenhuma variação de volume ( $\Delta V$ ) e grande variação de entropia ( $\Delta S$ ) são consideradas bons geotermômetros, reações entre minerais que trocam elementos de raios iônicos semelhantes, entre sítios cristalográficos de mesma coordenação; e.g. troca Fe-Mg, enquanto aquelas características por grande variação de volume ( $\Delta V$ ), bons geobarômetros, reações minerais que envolvem substituições acopladas entre elementos de raios iônicos diferentes e em sítios cristalográficos de coordenações diferentes; e.g. . Al $\mathrm{Al}_{1} \mathrm{VI}_{1} \mathrm{Al}_{1}{ }^{\mathrm{V}} \mathrm{Mg}_{-1} \mathrm{Si}_{-1}$ ou $\mathrm{Na}_{1} \mathrm{Al}_{1}{ }^{\mathrm{Vl}} \mathrm{Ca}_{-1} \mathrm{Mg}_{-1}$ (Carswell \& Harley 1990).

Para que a equação seja calibrada como um geotermômetro ou geobarômetro é necessário conhecer os valores das variações de entalpia $(\Delta H)$, entropia $(\Delta S)$ e volume ( $\Delta V)$ da reação em questão, que podem ser determinados através de calibrações experimentais, empíricas e termodinâmicas. As experimentais são feitas em laboratório, e através de experimentos com fases sintéticas ou naturais de composições conhecidas é feita a determinação da equação de equilíbrio. Nas empíricas, os dados termodinâmicos da reação a ser calibrada são obtidos de rochas cujas condições $P$ - $T$ são conhecidas através de algum método termobarométrico. E por fim, as termodinâmicas são montadas com dados termodinâmicos (volume molar - $V$, entropia de formação - $S$, entalpia de formação - $\mathrm{H}^{\circ}$, capacidade de calor - $\mathrm{Cp}$, etc) de membros finais puros disponíveis em tabelas de dados termodinâmicos e que foram determinados de modo experimental ou empírico. 
Além dos cálculos $P$-T utilizando os tipos de calibrações descritas acima, outras formas de se obter bons resultados são os programas que usam banco de dados termodinâmicos internamente consistentes, como os softwares THERMOCALC (Holland \& Powell, 2011) ou TWEEQU (Berman, 1988). O THERMOCALC usa um conjunto mínimo de reações linearmente independentes que combina a informação de todos os membros finais dos minerais presentes na rocha em determinado sistema químico modelo. Essas reações são deslocadas dentro de suas barras de erro até definirem uma elipse na região com o menor erro possível (Powell \& Holland, 1994).

Outra forma de se utilizar o banco de dados termodinâmicos internamente consistente é através do cálculo de pseudosseção (Figura 5), isto é, um diagrama de fases produzido em determinada janela $P-T$, para uma determinada composição de rocha (bulk composition). Pode-se considerar que a pseudosseção é o mapa das associações minerais no espaço $P$ - $T$, desenvolvidas para uma composição ou volume de equilíbrio. Assim, na pseudosseção são representados apenas os segmentos de reações univariantes em dado sistema químico modelo, ou faixa equivalente em sistema químico mais complexo, que a composição da rocha pode "ver" (Powell et al. 1998, 2005). A combinação da composição dos minerais da rocha investigada, com as variações composicionais calculadas na pseudosseção, fornece um dos modos mais precisos para a termobarometria, além de ser possível inferir trajetórias $P$-T pela comparação das texturas e os campos di-, tri-, tetra- ou de variância maior da pseudosseção (White et al. 2007; Pavan 2010). O maior problema no cálculo de pseudosseções quando rochas de alto grau metamórfico estão envolvidas, tais como migmatitos e granulitos, é que é fundamental se conhecer a composição da rocha a ser modelada. No caso dos migmatitos, a fusão com subsequente segregação, movimentação e perda de líquido impede o conhecimento da composição original da rocha e uma série de suposições deve ser feita. $O$ modelamento só pode ser realizado levando-se em conta uma composição estimada, sendo que as condições $P$-T inferidas serão dependentes do quanto a composição original da rocha pode ser recuperada, seja lá qual for o método usado para isso. 


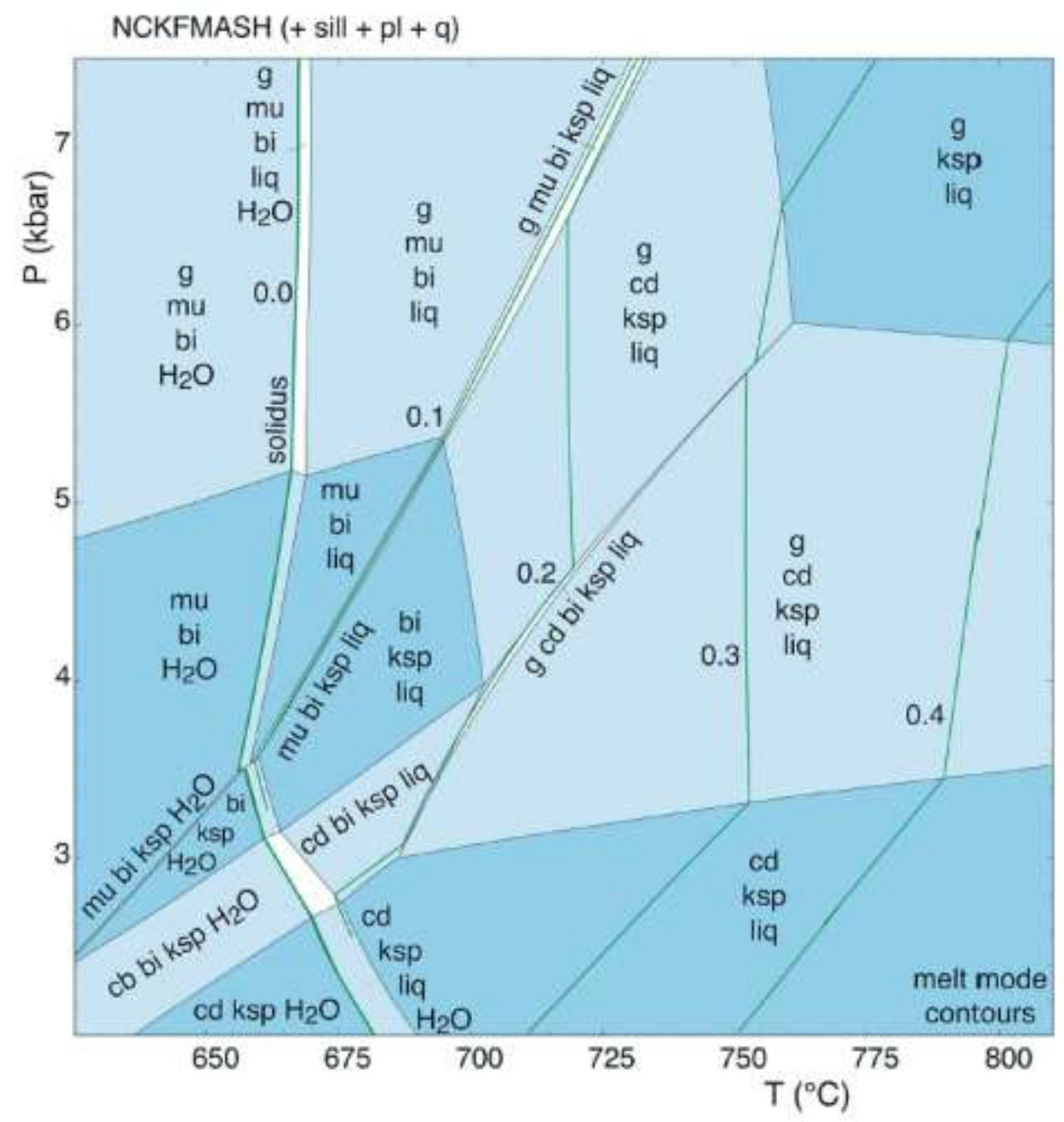

Figura 5 - Exemplo de pseudosseção P-T com contornos de \% de liquido. A intensidade da cor indica a variância do campo, com maior variância e menor número de fases nos campos escuros e menor variância e maior número de fases nos campos claros. Retirado de Powell et al. (2005).

\subsubsection{Geotermômetros convencionais}

\section{Granada-Clinopiroxênio}

Geotermômetro utilizado para rochas de alto grau como granulitos básicos e intermediários a eclogitos, de diferentes ambientes, portadores de clinopiroxênio e granada.

Os primeiros trabalhos a estudar a troca Fe-Mg entre esses minerais (e.g. Coleman et al. 1965, Lovering \& White 1969, Banno 1970, Mysen \& Heier 1972 e Raheim \& Green 1974) mostram que diferentes valores de $\mathrm{K}_{\mathrm{D}}\left[(\mathrm{Fe} / \mathrm{Mg})^{\mathrm{Grt}} /(\mathrm{Fe} / \mathrm{Mg})^{\mathrm{Cpx}}\right]$ em rochas geradas em diferentes ambientes, são relacionados a distintas condições $P$ - $T$ em suas gerações. O papel da pressão nessa relação não era bem explicada e quantificada, até que, Ellis \& Green (1979) resolveram essa questão e mostraram através de calibração experimental no sistema CMFAS ( $\mathrm{CaO}, \mathrm{MgO}, \mathrm{FeO}, \mathrm{Al}_{2} \mathrm{O}_{3}$ e $\mathrm{SiO}_{2}$ ), em associações com clinopiroxênio e granada, a pressões 
entre 24 e 30 kbar e temperaturas entre 750 e $1300^{\circ} \mathrm{C}$, que o $\mathrm{K}_{\mathrm{D}}$ é também dependente do conteúdo de Ca na granada, provavelmente relacionado à substituição Ca-Mg não ideal entre os dois minerais.

A partir da equação de troca Fe-Mg entre granada e piroxênio,

$$
\begin{aligned}
& \frac{1}{3} \mathrm{Mg}_{3} \mathrm{Al}_{2} \mathrm{Si}_{3} \mathrm{O}_{12}+\mathrm{CaFeSi}_{2} \mathrm{O}_{6}=\frac{1}{3} \mathrm{Fe}_{3} \mathrm{Al}_{2} \mathrm{Si}_{3} \mathrm{O}_{12}+\mathrm{CaMgSi}_{2} \mathrm{O}_{6} \\
& \text { (piropo) (hedenbergita) (almandina) (diopsídio) }
\end{aligned}
$$

foi desenvolvido o seguinte geotermômetro (Ellis \& Green 1979):

$$
T(K)=\frac{3104 X_{C a}^{G r t}+3030+10.86 P}{\ln K_{D}+1.9034}
$$

Onde, $K_{D}$ é o coeficiente de distribuição de $\mathrm{Fe}$ e $\mathrm{Mg}$ entre granada e clinopiroxênio $\left(\frac{\left(X_{F}^{G r t}\right)}{\left(X_{M g}^{G r}\right)} \times \frac{\left(X_{M g}^{C p x}\right)}{\left(X_{F e}^{C p x}\right)}\right), X_{C a}^{G r t}$ é a fração molar do Ca na granada e $P$ em kbar.

Como esse geotermômetro é dependente da pressão, é necessária uma boa estimativa dessa variável para obtenção de valores confiáveis de temperatura. Incertezas nos resultados podem ser geradas, por exemplo, pelas substituições de Ca e Mn em granada, pois alteram as atividades de Fe e Mg nos membros finais (e.g. Berman 1991).

Após o trabalho de Ellis \& Green (1979), o termômetro foi revisado com novas calibrações ou modelos de atividade (e.g. Powell 1985, Krogh 1988, Pattison \& Newton 1989, Ai 1994, Berman et al. 1995, Ravna 2000), porém a calibração de Ellis \& Green (1979) parece ainda ser a que produz resultados de maior confiabilidade.

\section{GARB}

A reação de troca catiônica $(\mathrm{Fe}-\mathrm{Mg}$ ) entre granada e biotita em paragênese é geotermômetro importante e amplamente utilizado, devido ao fato desses minerais ocorrerem em larga faixa de condições metamórficas, do baixo ao alto grau, e por não envolver significativa variação de volume molar durante a troca Fe-Mg desses minerais. A reação GARB pode ser escrita da seguinte maneira (Ferry \& Spear 1978):

$$
\underset{\text { (flogopita) }}{\mathrm{KMg}_{3} \mathrm{AlSi}_{3} \mathrm{O}_{10}(\mathrm{OH})_{2}}+\underset{\text { (almandina) }}{\mathrm{Fe}_{3} \mathrm{Al}_{2} \mathrm{Si}_{3} \mathrm{O}_{12}}=\underset{\text { (anita) }}{\mathrm{KFe}_{3} \mathrm{AlSi}_{3} \mathrm{O}_{10}(\mathrm{OH})_{2}}+\underset{\text { (piropo) }}{\mathrm{Mg}_{3} \mathrm{Al}_{2} \mathrm{Si}_{3} \mathrm{O}_{12}}
$$


Nela observa-se que as composições de biotita, com o aumento de temperatura, tornam-se cada vez mais enriquecidas em Fe (anita) enquanto que as de granada em $\mathrm{Mg}$ (piropo).

Ferry \& Spear (1978) calibraram experimentalmente essa reação e produziram o seguinte geotermômetro:

$$
\ln K_{D}=-\frac{52108}{3 R} \frac{1}{T}+\frac{19.51}{3 R}-\left(P-10^{5}\right) \frac{0.238 \times 10^{-5}}{3 R T}
$$

Onde, $K_{D}$ é o coeficiente de distribuição de Fe e Mg entre granada e biotita, $T$ em ${ }^{\circ} \mathrm{C}, P$ em kbar e $R$ é a constante de gás $0.0083144 \mathrm{~kJ} \mathrm{~K}^{-1}$.

Como a variação de volume na troca entre Fe e Mg é pequena $\left(0.238 \times 10^{-5}\right)$ e mesmo que os valores de pressão já obtidos não sejam tão bem definidos, as estimativas de temperatura com esse termômetro podem apresentar incerteza de $\pm 50^{\circ} \mathrm{C}$. Assim como no termômetro granada-clinopiroxênio, substituições de Ca e Mn em granada, e aqui de Ti em biotita, alteram as atividades de Fe e Mg nos membros finais (e.g. Berman 1991), e maiores concentrações de $\mathrm{Fe}^{3+}$, $\mathrm{Ti}, \mathrm{F}$ e Cl, comum em rochas de alto grau, também provocam erros significativos (Essene 1982). A aplicabilidade do termômetro é limitada em rochas da fácies granulito, pois dependendo dos mecanismos reacionais durante o retrometamorfismo, pode ocorrer a destruição da composição desses minerais por dissolução da granada ou difusão tardia nos dois minerais (Spear \& Florence, 1992).

\section{Granada-Ortopiroxênio}

Geotermômetro calibrado experimentalmente por Harley (1984) para granada peridotito e granulito que relaciona a troca $\mathrm{Fe}-\mathrm{Mg}$ entre granada e ortopiroxênio aluminoso, sob condições $P$ - $T$ de 5 a 30 kbar e 800 a $1200{ }^{\circ} \mathrm{C}$, nos sistemas $\mathrm{FeO}-\mathrm{MgO}-\mathrm{Al}_{2} \mathrm{O}_{3}-\mathrm{SiO}_{2}$ (FMAS) e $\mathrm{CaO}-\mathrm{FeO}-\mathrm{MgO}-\mathrm{Al}_{2} \mathrm{O}_{3}-\mathrm{SiO}_{2}$ (CFMAS). Assim como no geotermômetro de Ellis \& Green (1979), Ca efetua papel importante na partição Fe-Mg entre os minerais pareados, podendo ser atribuído à substituição $\mathrm{Ca}-\mathrm{Mg}$ não ideal na granada e descrita pelo fator de interação

$$
W_{\text {CaMg }}^{g r t}-W_{\text {CaFe }}^{g r t}=1400 \pm 500 \frac{\mathrm{cal}}{\mathrm{mol}}
$$

assim, por meio de redução dos dados experimentais, com os volumes molares dos membrosfinais das fases envolvidas, o geotermômetro pode ser escrito como: 


$$
T\left({ }^{\circ} \mathrm{C}\right)=\left[\frac{3740+1400 X_{\text {grs }}^{\text {grt }}+22,26 P(\text { kbar })}{R \ln K_{D}+1,96}\right]-273
$$

onde, $K_{D}=\frac{\left(\frac{F e}{M g}\right)^{g r t}}{\left(\frac{F e}{M g}\right)^{o p x}} \quad$ e $X_{g r s}^{g r t}=\left[\frac{C a}{C a+M g+F e}\right]^{g r t}$

Ao comparar resultados desse método com o de Ellis \& Green (1979) em suítes de granada Iherzolitos e granulitos de alta pressão, Harley (1984) obtém temperaturas inferiores, entre 50 e $130^{\circ} \mathrm{C}$ em rochas acima de $1000^{\circ} \mathrm{C}$, e entre 0 e $50^{\circ} \mathrm{C}$ nas de temperaturas mais baixas. Para essas discrepâncias, o autor apresenta quatro hipóteses: 1) Erros em um ou ambos termômetros; 2) Equilíbrio Fe-Mg é mais rápido entre granada e ortopiroxênio do que entre granada e clinopiroxênio; 3) Como $\mathrm{Fe}^{3+}$ não é considerado nesse método, as temperaturas encontradas são mínimas; 4) O termômetro de Ellis \& Green (1979) superestima as temperaturas de rochas de alto grau.

\subsubsection{Geotermômetros alternativos}

No final da década de 1990 e início da de 2000, o estudo da composição química de elementos traço de fases metamórficas essenciais e acessórias (Bea, 1996), com o uso de LA-ICP-MS permitiu a investigação de equilíbrio químico durante o metamorfismo envolvendo essas fases e elementos traço. Em trabalhos pioneiros, Pyle \& Spear (2000) e Pyle et al. (2001) calibraram termômetros envolvendo as fases monazita, xenotima e granada e a partição dos elementos $\mathrm{Y}, \mathrm{Gd}$ e Dy entre esses minerais, obtendo excelentes resultados.

Iniciando com calibração empírica (Zack et al. 2004a), sendo seguida por calibrações experimentais (Watson et al. 2006), com experimentos que envolvem reversibilidade e demonstrando a sua dependência com a pressão (Tomkins et al. 2007), o termômetro Zr em rutilo apresenta resultados confiáveis e é passível de ser aplicado em grande quantidade de rochas em todo o campo de estabilidade do rutilo. Em conjunto com esse termômetro, outro foi desenvolvido a partir da dependência da temperatura e a partição de Ti no zircão (Watson et al. 2006), e quando usados conjuntamente na mesma rocha pode produzir cálculo $P-T$ (Zack et al. 2006).

Um dos mais novos termômetros calibrados usa a partição de Ti no quartzo em altas temperaturas (Wark \& Watson 2006; Thomas et al. 2010), elemento que deve ser analisado com LA-ICP-MS. O maior problema para a aplicação desse termômetro em rochas de alto grau que sofreram resfriamento lento é a rápida exsolução do Ti formando agulhas de rutilo dificultando sobremaneira a sua aplicação. 


\section{$\underline{\text { Zr em rutilo }}$}

Estudos existentes sobre geoquímica de rutilo indicam que o mineral é um importante portador/carregador de elementos de alto potencial iônico (HFSE), tais como Zr, Nb, Mo, Sn, Sb, Hf, Ta, W (e.g. Saunders et al. 1980). O fato, aliado à dependência da temperatura na incorporação de Zr pelo rutilo, fazem do mineral uma poderosa ferramenta no estudo do metamorfismo de rochas portadoras de quartzo, zircão e rutilo em equilíbrio, formadas sob condições de fácies xisto verde a eclogito, mas em especial nas de mais altas temperaturas e pressões (e.g. Zack et al. 2004a; Watson et al. 2006; Ferry \& Watson 2007; Tomkins et al. 2007; Ewing et al. 2012).

Um dos primeiros trabalhos sobre a calibração do termômetro Zr em rutilo foi elaborado por Zack et al. (2004a), que realizaram calibrações empíricas utilizando a associação quartzorutilo-zircão de amostras já estudadas e que abrangem amplo intervalo de temperaturas (430 $-1100^{\circ} \mathrm{C}$ ) e de pressões. A partir dos resultados obtidos foram apresentadas duas fórmulas para cálculo de temperatura e foi considerado que os cálculos são independentes de influência de pressão (Figura 6 e Figura 7).

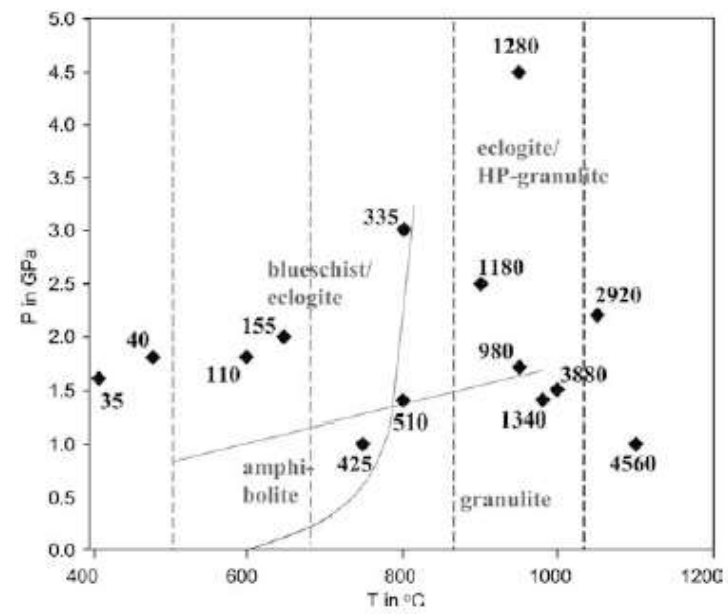

Figura 6 - Diferentes amostras utilizadas por Zack et al. (2004) nos diferentes campos de pressão e temperatura, sugerindo a não dependência da pressão na assimilação de Zr pelo rutilo. Retirado de Zack et al. (2004).
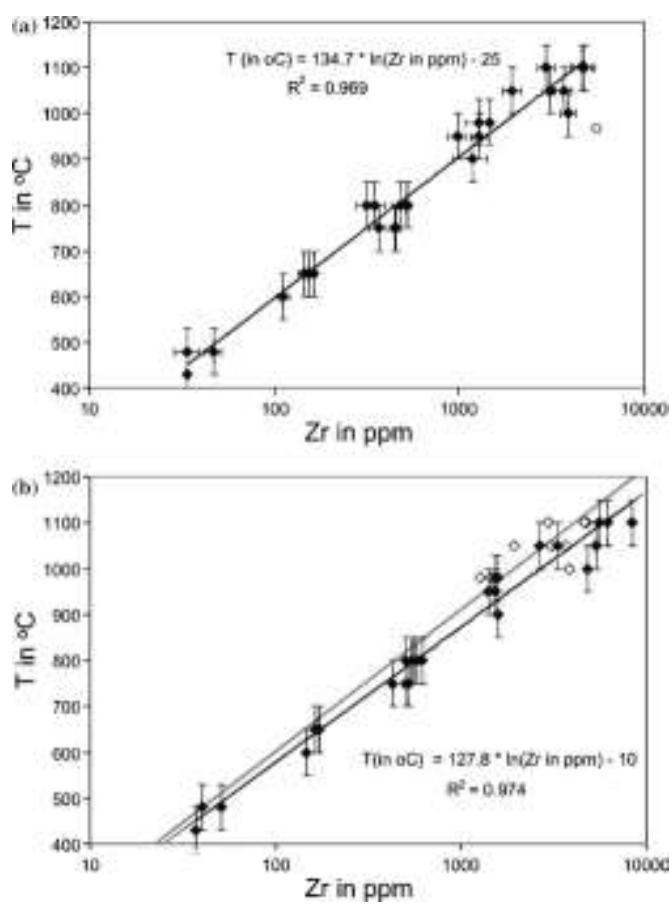

Figura 7 - Fórmulas para cálculo de temperatura de Zack et al. (2004). Em (a) são utilizados valores médios de Zr para cada amostra e em (b) apenas os máximos. Retirado de Zack et al. (2004).

Watson et al. (2006), utilizando calibrações experimentais e análises de cristais de amostras naturais de diversas origens $\left(0.35-30\right.$ kbar e $\left.470-1070{ }^{\circ} \mathrm{C}\right)$, sugerem a existência 
da dependência na assimilação de Zr por rutilo com a pressão. Ao comparar seus resultados aos apresentados por Zack et al. (2004a), é evidente a concordância de resultados apenas em aproximadamente $540^{\circ} \mathrm{C}$. Já em relação às curvas de Degeling (2003), produzidas por calibrações experimentais e onde a pressão foi levada em consideração, é possível observar boa adequação nos resultados apresentados com a curva para $1 \mathrm{GPa}$ (Figura 8).

As diferenças encontradas entre os termômetros de Zack et al. (2004a) e Watson et al. (2006) não são facilmente explicadas, mas provavelmente estão relacionadas ao modo de escolha dos cristais a serem analisados (apenas rutilo como inclusão no primeiro e aleatoriamente no segundo) e à influência da pressão desprezada por Zack et al. (2004a), como sugerido por Watson et al. (2006).
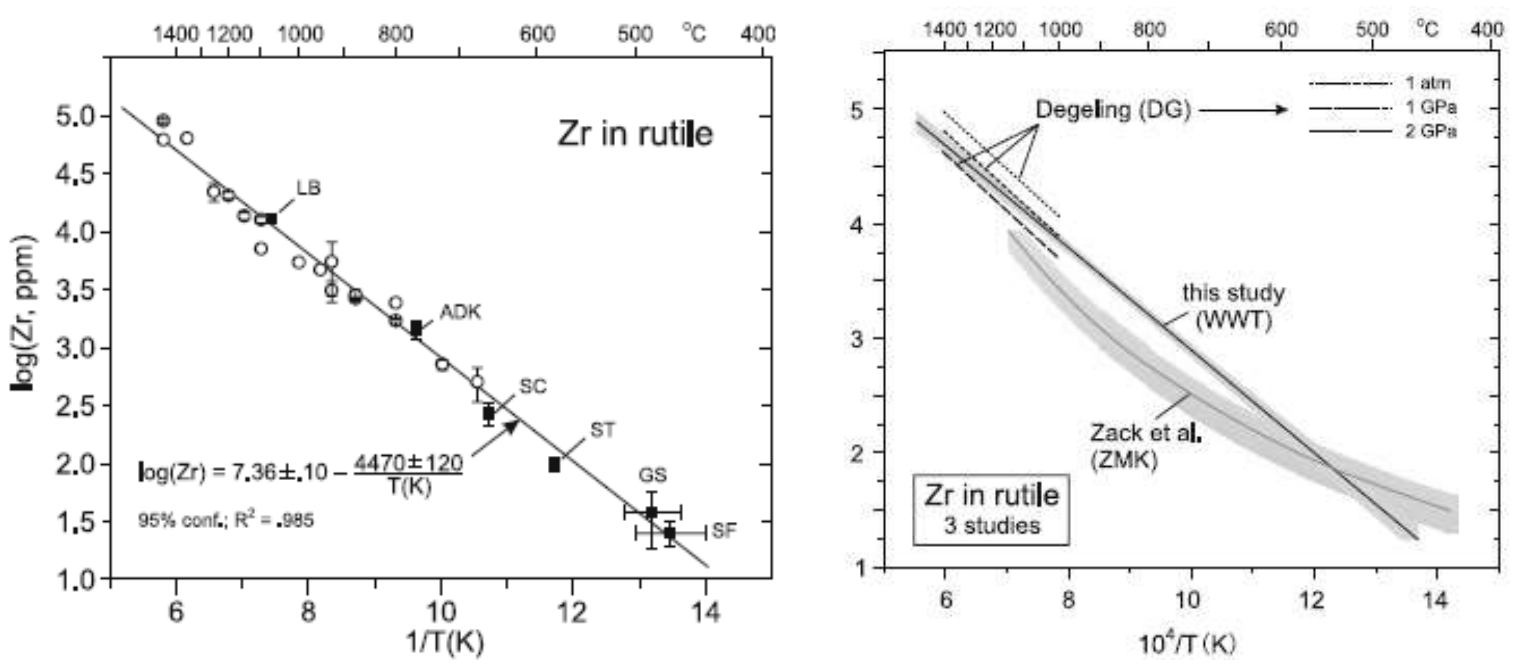

Figura 8 - a) Termômetro Zr em rutilo de Watson et al. (2006); círculos abertos e quadrados pretos representam respectivamente cristais de rutilo sintéticos e naturais. b) Comparação entre as calibrações de Zack et al. (2004a), Watson et al. (2006) e Degeling (2003). Retirado de Watson et al. (2006).

Tomkins et al. (2007) relacionam o fato de haver diferença significativa entre os raios iônicos do $\mathrm{Zr}^{4+}$ (0.72 A; Shannon 1976) e do íon substituído $\mathrm{Ti}^{4+}(0.61 \mathrm{~A})$, o que contraria a premissa de não haver variação de volume em geotermômetros. Assim, sob altas pressões, cátions de $\mathrm{Zr}^{4+}$ (maiores) são menos capazes de substituir $\mathrm{Ti}^{4+}$ na estrutura do rutilo.

Deste modo, de acordo com a pressão assumida para cada caso (campos do quartzo $\alpha$, quartzo $\beta$ ou da coesita; 10, 20 e $30 \mathrm{kbar}$, respectivamente), foram realizadas calibrações experimentais e desenvolvidos três diferentes geotermômetros com incertezas médias de \pm $30^{\circ} \mathrm{C}$ (Figura 9; Tomkins et al. 2007): 
- Campo do quartzo a (10 kbar):

$$
T\left({ }^{\circ} \mathrm{C}\right)=\frac{83.9+0.410 P}{0.1428-R \ln \phi}-273
$$

- Campo do quartzo $\beta$ (20 kbar):

$$
T\left({ }^{\circ} \mathrm{C}\right)=\frac{85.7+0.473 P}{0.1453-R \ln \phi}-273
$$

- Campo da coesita (30 kbar):

$$
T\left({ }^{\circ} \mathrm{C}\right)=\frac{88.1+0.206 P}{0.1412-R \ln \phi}-273
$$

Onde, $\phi$ é $\mathrm{Zr}$ em ppm, $P$ é em kbar e $R$ é a constante dos gazes $0.0083144 \mathrm{~kJ} \mathrm{~K}^{-1}$.
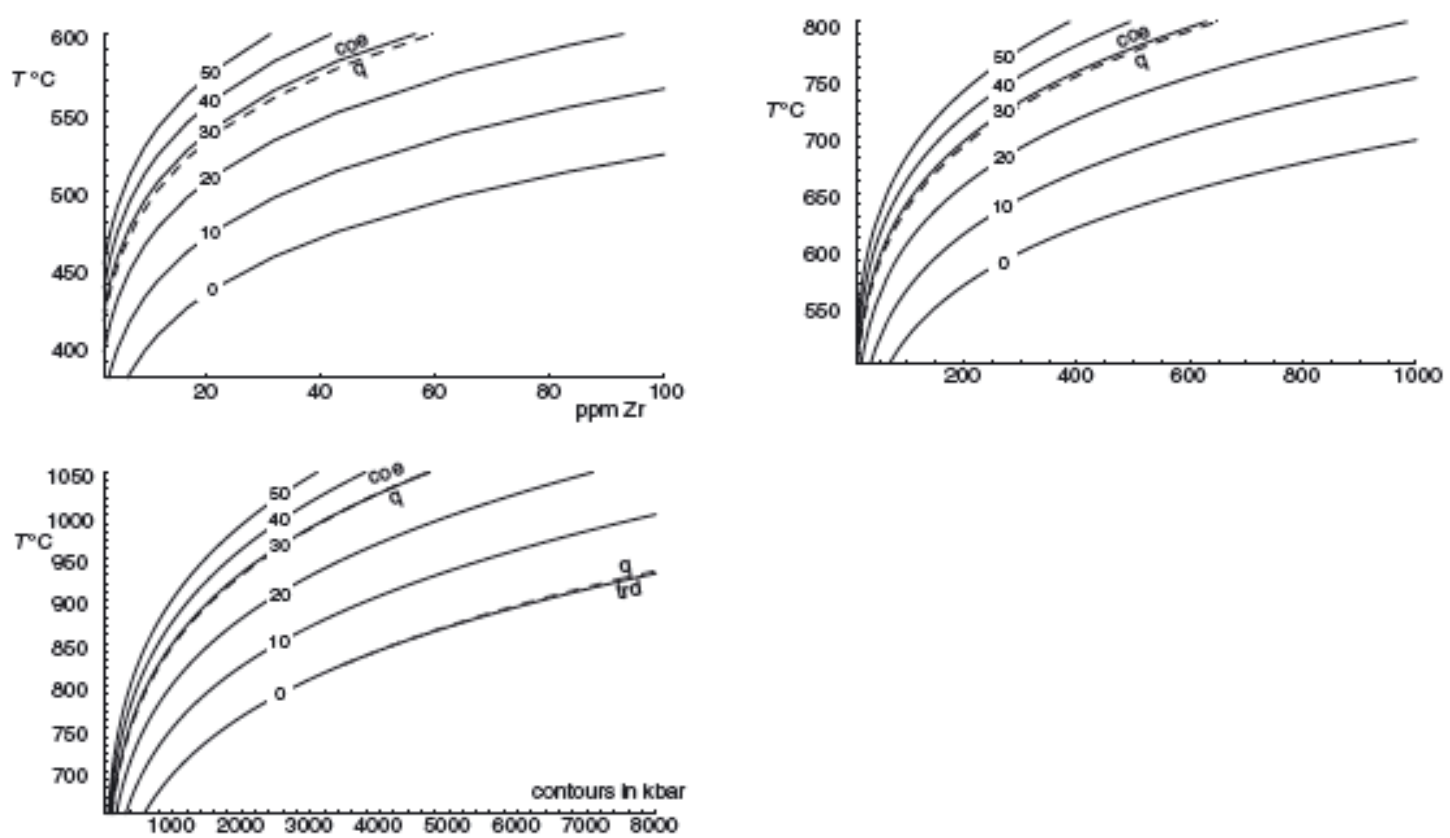

Figura 9 - Termômetro Zr em rutilo de Tomkins et al. (2007). Retirado de Tomkins et al. (2007).

Um fator que dificulta a utilização do método é a difusão do $Z r$ no rutilo, que é dependente, entre muitos fatores, da velocidade de resfriamento da rocha. Trabalhos pioneiros como o de Zack et al. (2004a) mostram que os maiores teores de Zr ocorrem em cristais de rutilo inclusos em porfiroblastos de granada e ortopiroxênio, comparados àqueles da matriz. Esse fato é explicado pelo isolamento criado entre rutilo e matriz, mantendo a inclusão longe da ação de fluidos, recristalização e pela lenta difusão de íons altamente carregados $\left(\mathrm{Zr}^{4+}\right)$ entre rutilo e granada (van Orman et al. 2002). Assim, estes cristais proveriam os valores de temperatura mais próximos aos vivenciados pela rocha durante 0 pico metamórfico, com pouca ou nenhuma influência de eventos retrometamórficos. 
Manchester et al. (2007) caracterizaram a difusão de $\mathrm{Zr}$ no rutilo e calcularam temperaturas de fechamento Tc (Dodson, 1973) para diferentes taxas de resfriamento. Para cristais com $500 \mu \mathrm{m}$, sua Tc é $\sim 670^{\circ} \mathrm{C}, 770^{\circ} \mathrm{C}$ e $890^{\circ} \mathrm{C}$ para taxas de resfriamento de $1^{\circ} \mathrm{C}$, $10^{\circ} \mathrm{C}$ e $100{ }^{\circ} \mathrm{C} / \mathrm{m}$.a., respectivamente. Já para grãos com $100 \mu \mathrm{m}, T c$ é $\sim 560^{\circ} \mathrm{C}, 635^{\circ} \mathrm{C}$ e $730^{\circ} \mathrm{C}$ para as mesmas taxas. Com esses dados é possível observar que a difusão do $\mathrm{Zr}$ é rápida o suficiente para alterar os valores de pico metamórfico em alguns casos, porém em outros, fatores como isolamento do cristal por fase pobre em $\mathrm{Zr}$ ou Ti e/ou baixa eficiência na capacidade de transporte iônico entre minerais adjacentes, podem preservar teores de $\mathrm{Zr}$ mesmo durante lento resfriamento.

A possibilidade de difusão com alteração no teor de Zr no rutilo sob condições de altas temperaturas pode complicar a interpretação das temperaturas obtidas. Portanto, na análise por microssonda eletrônica, recomenda-se evitar estudar cristais que sugiram qualquer tipo de possível difusão de $\mathrm{Zr}$, como por exemplo, inclusões em porfiroblastos de granada fraturados ou em minerais com estruturas cristalinas mais "abertas", como quartzo e cianita (Zack et al. 2004a), e quando houver exsolução de agulhas de zircão ou badeleíta (Ewing et al. 2012). Por uma maior acuracidade nos resultados, torna-se necessária análise do maior número possível de grãos.

\section{$\underline{\text { Ti em zircão }}$}

Zircão é mineral acessório comum em rocha de todos os tipos. Assim como o rutilo, tem facilidade em concentrar elementos traço, terras raras, isótopos radioativos, além de possuir grande resistência a fatores físicos e químicos e a reequilíbrio por difusão. Além de sua utilização nos campos da geocronologia e geoquímica, a partir de trabalhos realizados nos últimos anos (e.g. Watson et al. 2006; Ewing et al. 2012) vem sendo utilizado como importante ferramenta na geotermobarometria.

Entre os elementos presentes na estrutura do zircão, o titânio $\left(\mathrm{Ti}^{4+}\right)$ é bastante comum e ocorre principalmente por substituição do silício $\left(\mathrm{Si}^{4+}\right)$, em troca isovalente sem a necessidade de balanço de cargas. Seu conteúdo é fortemente controlado pela temperatura e, em relação ao rutilo, é relativamente imune a variações de pressão (Watson et al. 2006).

Para a calibração do termômetro, Watson et al. (2006) utilizaram condições em saturação de rutilo, situação bastante usual em exemplos reais vide a comum coexistência das fases rutilo e zircão, alta atividade de $\mathrm{TiO}_{2}$ em rochas crustais e a substituição de $\mathrm{Si}^{4+}$ por $\mathrm{Ti}^{4+}$ na estrutura do zircão. Quando o rutilo é ausente, é possível utilizar outras fases portadoras de Ti, como titanita e ilmenita, além de silicatos (em metapelitos $a_{\text {TiO2 é próxima }}$ 
de 1; em metabasitos $a_{\mathrm{TiO} 2} \sim 0.6$; Ghent \& Stout 1984). Desta maneira, foi calculado o seguinte termômetro Ti em zircão (Figura 10):

$$
T\left({ }^{\circ} \mathrm{C}\right)=\frac{5080 \pm 30}{(6.01 \pm 0.03)-\log (\mathrm{Ti})}-273
$$

Onde, Ti é em ppm.

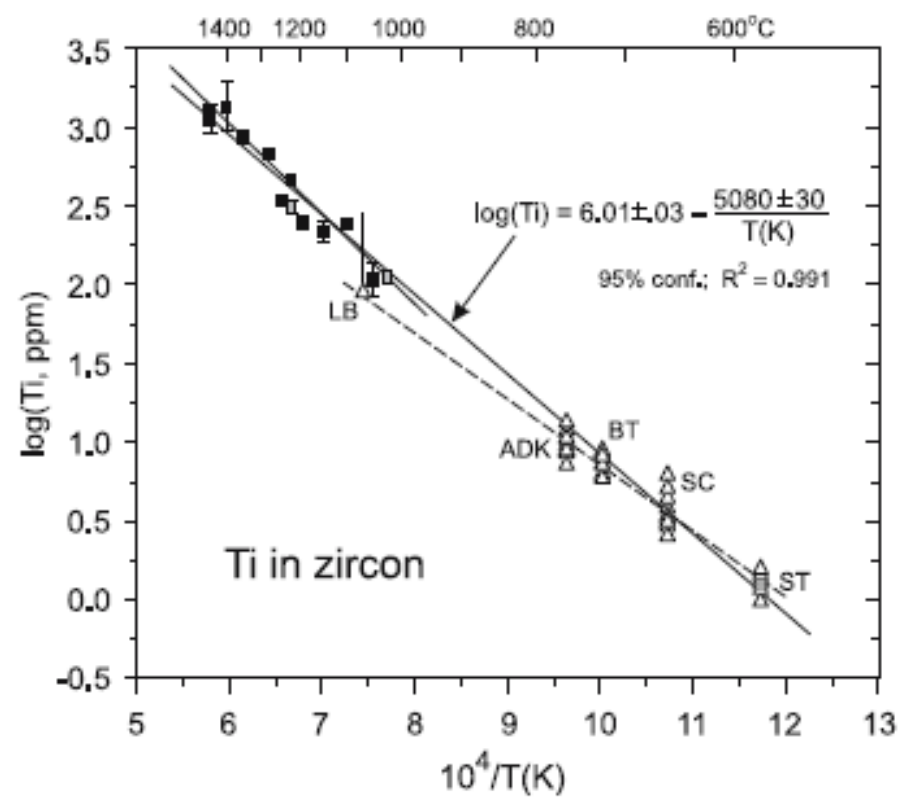

Figura 10 - Termômetro Ti em zircão de Watson et al. (2006); quadrados e reta de regressão fina, e triângulos e linha tracejada representam respectivamente cristais de zircão sintéticos e naturais. Reta de regressão grossa é a global. Retirado de Watson et al. (2006).

Assim como no termômetro $\mathrm{Zr}$ em rutilo, aqui se utiliza como instrumentação a microssonda eletrônica, mas a microssonda iônica pode ser utilizada em casos em que se quer obter melhor limite de detecção e/ou melhor precisão nos teores de Ti em grãos de zircão. A escolha dos locais a serem analisados em cada cristal deve ser criteriosa, vide o comum zoneamento núcleo-borda por sobrecrescimento e possíveis inclusões de fases relativamente ricas em Ti. Dúvidas em relação ao último problema podem ser sanadas através de imagens eletrônicas com elétrons retroespalhados (Watson et al. 2006).

\section{$\underline{\text { Ti em quartzo }}$}

Quartzo é um dos minerais mais abundantes na crosta da Terra. Está presente tanto em rochas ígneas como metamórficas, geradas em amplo intervalo de pressão e temperatura. Quando ocorre em coexistência com minerais portadores de titânio, como ilmenita, titanita, e em especial o rutilo, pode sofrer em sua estrutura formada por $\mathrm{SiO}_{2}$ a substituição de $\mathrm{Si}^{4+}$ por 
$\mathrm{Ti}^{4+}$, e se tratando de dois íons de valência 4+, nenhum balanço de cargas é necessário (Wark \& Watson 2006; Thomas et al. 2010). O trabalho pioneiro de Wark \& Watson (2006) desenvolveu o termômetro TitaniQ através de calibrações experimentais conduzidas sob pressão constante de $10 \mathrm{kbar}$ em amplo campo de temperatura. A partir de Ostapenko et al. (2007) é sugerida uma importante influência da pressão na solubilidade do titânio no quartzo. Sob pressões crustais a substituição de Si por Ti ocorre sem problemas, porém, com o aumento da pressão Ti tende a substituir o sítio maior do Zr na estrutura do zircão (Ferris et al. 2008). Essa dependência da pressão na solubilidade do Ti no quartzo ocorre devido à diferença do raio iônico entre os cátions, com o $\mathrm{Ti}^{4+}, \sim 38 \%$ maior que o sítio tetraédrico ocupado pelo $\mathrm{Si}^{4+}$ na estrutura do quartzo, além do fato de o quartzo ser anormalmente compressível (e.g. Levien et al. 1980). Assim, Thomas et al. (2010) através de calibrações experimentais realizadas a pressões entre 5 e $20 \mathrm{kbar}$ e sob as mesmas condições de temperatura utilizadas em Wark \& Watson (2006), apresentam a atualização do geotermômetro, com o anterior podendo ser usado com precisão para rochas formadas a pressões próximas a $10 \mathrm{kbar}$.

O rutilo é principal mineral necessário para a obtenção de bons dados geotermométricos nesse método, pois como se trata de uma fase praticamente pura em $\mathrm{TiO}_{2}$, sua atividade é fixa e próxima ao valor máximo ( $\left.a_{\mathrm{TiO} 2} \sim 1\right)$, assim, durante as calibrações, Thomas et al. (2010) fixaram esse valor em 1. A seguir, é apresentado o geotermômetro Tiquartzo nas diversas pressões (Thomas et al. 2010, Figura 11):

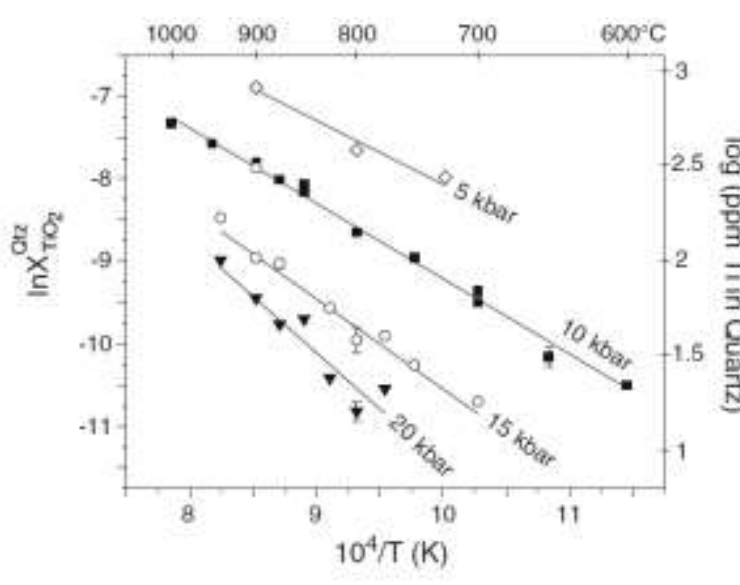

Figura 11 - Concentrações de Ti em quartzo x 1/T. Símbolos fechados na reta de 10 kbar são de Wark \& Watson (2006). Incertezas são menores que os símbolos a não ser quando há barra de erro.

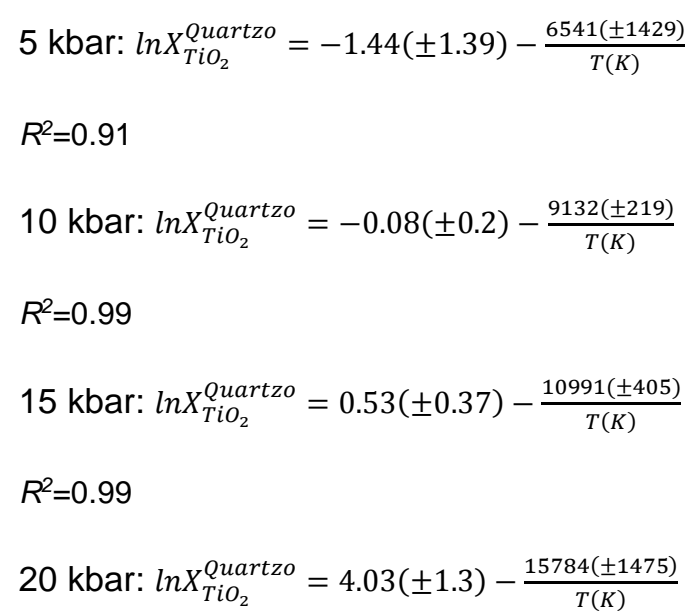

A partir das isóbaras apresentadas acima é visível uma maior inclinação na de 20 kbar. Isso provavelmente deve-se à diferença no comportamento da solubilidade do Ti no quartzo 
sob altas pressões devido a sua compressibilidade anômala anteriormente comentada (Levien et al. 1980).

O termômetro Ti em quartzo pode ser aplicado em vasta variedade de rochas crustais. Em termos de temperatura, o limite superior de análise corresponde a sistemas anidros, onde o quartzo ainda é estável em temperaturas acima de $1000^{\circ} \mathrm{C}$, já em sistemas com excesso de água sua estabilidade é reduzida a temperaturas de fusão de granito ( $\left.650{ }^{\circ} \mathrm{C}\right)$. $\mathrm{O}$ limite inferior para a aplicação do método é definido pelos métodos analíticos, pois em microssonda eletrônica são analisados teores de $\mathrm{Ti}$ a partir de aproximadamente 10 ppm, que correspondem a quartzo em equilíbrio sob temperaturas na ordem de $600{ }^{\circ} \mathrm{C}$ (com $a_{\mathrm{TiO} 2} \sim 1$ ). Já com o uso de microssonda iônica, esse limite inferior é reduzido em por volta de $400^{\circ} \mathrm{C}$ em razão da melhor capacidade de detecção do método. Em relação à pressão, o limite superior, como já mencionado, é de aproximadamente 20 kbar devido à mudança no comportamento da solubilidade do Ti no quartzo (Wark \& Watson 2006, Thomas et al. 2010).

Wark \& Watson (2006) calculam para o método a incerteza de $\pm 5{ }^{\circ} \mathrm{C}$. Esse valor é dependente da precisão e das incertezas de cada análise, sendo influenciado por erros de calibração, erros laboratoriais, condições analíticas, qualidade das amostras e dos padrões. Em relação às condições analíticas, a incerteza depende sobremaneira da escolha nos valores de corrente de feixe e tempo de contagem, tanto de pico como de background, podendo variar, por exemplo, nas mesmas condições em microssonda eletrônica ( $i=200$ nA e $\mathrm{t}=240 \mathrm{~s})$, entre $\pm 6^{\circ} \mathrm{C}\left(\sim 100 \mathrm{ppm}\right.$ de Ti) e $\pm 20^{\circ} \mathrm{C}(22 \mathrm{ppm})$. Utilizando microssonda iônica as incertezas são ainda menores, apresentando valores na ordem de $1-2{ }^{\circ} \mathrm{C}$ para quartzo cristalizado entre 450 e $800^{\circ} \mathrm{C}$.

As principais limitações do termômetro Ti em quartzo são devido à ausência do rutilo e à difusão do Ti no quartzo. Cherniak et al. (2007) calculam a difusão a diferentes temperaturas e obtém os valores relativos de distância característica de transporte. Para períodos de 0,001, 1,0 e 10,0 m.a., a $500{ }^{\circ} \mathrm{C}$ a difusão é de $\sim 0,05 \mu \mathrm{m}$, $\sim 2 \mu \mathrm{m}$ e $5 \mu \mathrm{m}$, respectivamente, já a $800{ }^{\circ} \mathrm{C}$, essa distância aumenta para $16 \mu \mathrm{m}, 500 \mu \mathrm{m}$ e $1600 \mu \mathrm{m}$ nos mesmos intervalos de tempo. Assim, a depender das dimensões do cristal analisado, apenas suas bordas apresentarão os teores de pico metamórfico, salvo exemplos onde condições de máxima temperatura perduraram por dezenas de milhões de anos e havendo consequente homogeneização de Ti. Para rochas de fácies granulito, com $T>900^{\circ} \mathrm{C}$, as distâncias chegam a $2 \mathrm{~mm}$ e aumentam a probabilidade de preservação de teores de pico metamórfico nos núcleos do cristal. Essa alta difusão em rochas de alto grau pode iniciar exsolução com cristalização de agulhas de rutilo, gerando outra dificuldade analítica. 
O uso deste método junto ao Zr-rutilo mostra-se eficiente para determinação conjunta de temperatura e pressão. Thomas et al. (2010) exploram essa relação onde $a_{\mathrm{TiO} 2} \sim 1 \mathrm{e}$ também quando $a_{\mathrm{TiO} 2}<1$ (nesse caso, $a_{\mathrm{TiO} 2}$ deve ser bem definida). Para isso, utilizam o geotermômetro Zr-rutilo de Tomkins et al. (2007). O cálculo pareado é ilustrado a seguir na Figura 12
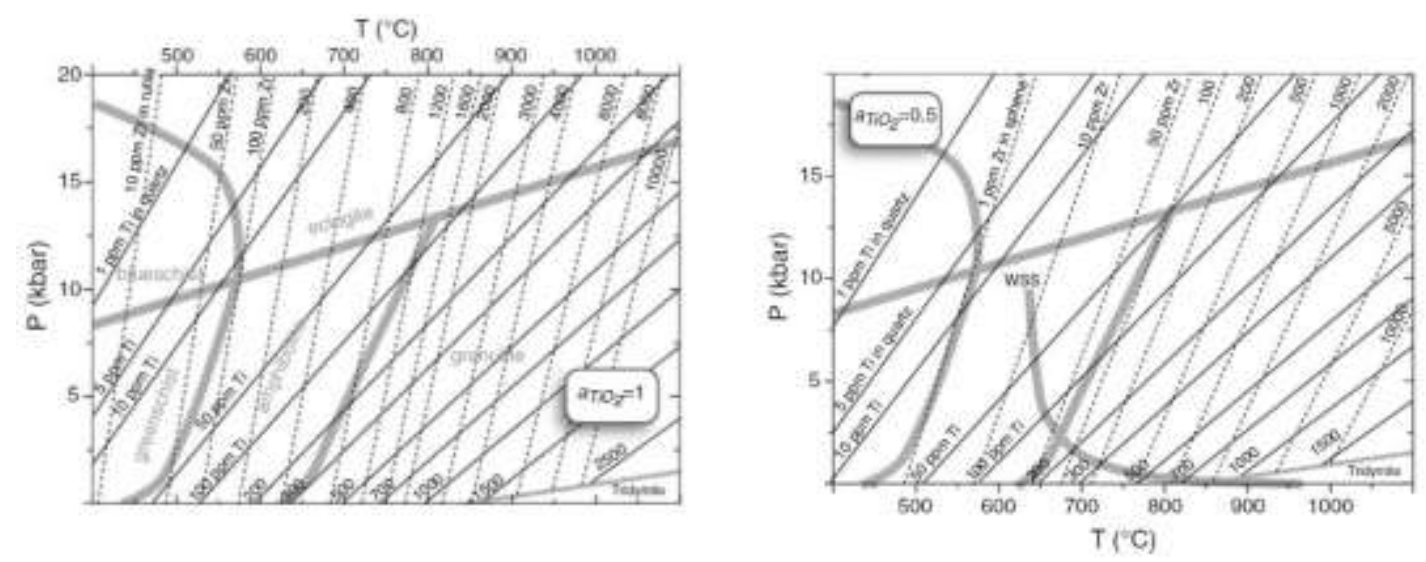

Figura 12 - Isopletas de a) Ti-quartzo e Zr-rutilo e b) Ti-quartzo e Zr-titanita com aproximação das fácies a partir de Spear (1993) e Philpotts (1990). A curva WSS é a sólidus saturada em água (water-saturated solidus) para composições "mínimas" de referências listadas em Holtz \& Johannes (1994). Retirado de Thomas et al (2010).

Para a utilização desse cálculo pareado é vital que seja confirmada, na medida do possível, a geração contemporânea do quartzo e da fase de Ti, assim, deve-se parear quartzo de matriz com rutilo de matriz e quartzo com rutilo da mesma inclusão, por exemplo (Thomas et al. 2010).

\subsubsection{Geobarômetros}

\section{$\underline{\text { GASP }}$}

Principal geobarômetro para rochas metapelíticas, desenvolvido por Ghent (1976), que utiliza a assembleia plagioclásio + granada $+\mathrm{Al}_{2} \mathrm{SiO}_{5}+$ quartzo e baseia-se na seguinte reação:

$$
\underset{\text { (anortita) }}{3 \mathrm{CaAl}_{2} \mathrm{Si}_{2} \mathrm{O}_{8}}=\underset{\text { (grossulária) }}{\mathrm{Ca}_{3} \mathrm{Al}_{2} \mathrm{Si}_{3} \mathrm{O}_{12}}+\underset{\text { (cianita) (quartzo) }}{2 \mathrm{Al}_{2} \mathrm{SiO}_{5}}+\mathrm{SiO}_{2}
$$

Através da reação acima é calculada a expressão de equilíbrio entre o componente grossulária na granada e anortita no plagioclásio, visto que, em um metamorfismo progressivo as composições de granada tornam-se mais ricas em $\mathrm{Ca}$ (grossulária) e as de plagioclásio mais pobres neste mesmo elemento e, consequentemente, enriquecidas em $\mathrm{Na}$ (albita). Essa expressão é definida através das atividades daqueles componentes, encontradas em bancos 
de dados termodinâmicos, em seus respectivos minerais, e considera $\mathrm{Al}_{2} \mathrm{SiO}_{5}$ e quartzo como fases puras:

$$
\ln \frac{a G_{g r o s s}}{\left(a P l_{a n}\right)^{3}}=-\left(\frac{-40770}{R}\right) \frac{1}{T}+\frac{(-136.5)}{R}-\left(P-10^{5}\right) \times \frac{\left(-6.605 \times 10^{-5}\right)}{R T}
$$

Onde $a$ é atividade, $R$ é a constante universal dos gases de gás $0.0083144 \mathrm{~kJ} \mathrm{~K}^{-1}$, $T$ é em ${ }^{\circ} \mathrm{C}$ e $P$ em kbar.

Como a variação de volume na troca catiônica é relativamente grande $\left(-6.605 \times 10^{-5}\right)$, tal expressão pode ser considerada um bom geobarômetro, porém dados de temperatura já devem ser conhecidos e precisos. Erros consideráveis também podem ocorrer em função das baixas proporções dos componentes nas respectivas fases, que dificultam a determinação de suas atividades, particularmente a de grossulária em granada (menos de $10 \mathrm{~mol} \%$ em granada de rocha pelítica típica).

\section{GRAIL}

Geobarômetro praticamente independente de temperatura que utiliza a assembleia granada + rutilo $+\mathrm{Al}_{2} \mathrm{SiO}_{5}+$ ilmenita + quartzo, sendo utilizado para fases puras geradas em pressões acima de $1 \mathrm{GPa}$. Abaixo a constante de equilíbrio da reação é descrita (Bohlen et al. 1983):

$$
K=\frac{\left(a_{I l m}^{I l m_{s s}}\right)^{3}\left(a_{\mathrm{Al}_{2} \mathrm{SiO}_{5}}^{K, S, S}\right)\left(a_{\mathrm{SiO}_{2}}^{Q}\right)^{2}}{\left(a_{\mathrm{Alm}}^{G_{\mathrm{si}}}\right)\left(a_{\mathrm{TiO}_{2}}^{R u}\right)^{3}}
$$

Onde $a$ é a atividade dos componentes em seu respectivo mineral.

Minerais como quartzo, rutilo e polimorfos de $\mathrm{Al}_{2} \mathrm{SiO}_{5}$ em rochas metapelíticas são característicos por normalmente serem fases puras, com atividades unitárias. Porém ilmenita e almandina formam soluções sólidas não ideais em hematita e granada, respectivamente, com grande solvus separando-as sob baixas temperaturas. Ilmenita, como na maioria dos metapelitos, está presente com menos de 15 mol\% em hematita e pode ser tratada como uma solução sólida ideal. Já no caso da almandina, podem ser encontradas na literatura (e.g. Bohlen et al. 1983) diversas curvas de $\log _{10} \mathrm{~K}$ em diagrama $P$-T que variam de acordo com sua dependência com a temperatura. 


\section{Plagioclásio-granada-piroxênio-quartzo}

Utilizam a assembleia plagioclásio + piroxênio + granada + quartzo, dois dos principais geobarômetros para metabasaltos e metapelitos em fáceis granulito a partir das seguintes reações:

$$
\begin{aligned}
& \mathrm{GAPES} \rightarrow \mathrm{CaAl}_{2} \mathrm{Si}_{2} \mathrm{O}_{8}+\mathrm{Mg}_{2} \mathrm{Si}_{2} \mathrm{O}_{6}=2 / 3 \mathrm{Mg}_{3} \mathrm{Al}_{2} \mathrm{Si}_{3} \mathrm{O}_{12}+1 / 3 \mathrm{Ca}_{3} \mathrm{Al}_{2} \mathrm{Si}_{3} \mathrm{O}_{12}+\mathrm{SiO}_{2} \\
& \text { (anortita) (enstatita) (piropo) (grossulária) (quartzo) } \\
& \mathrm{GADS} \rightarrow \mathrm{CaAl}_{2} \mathrm{Si}_{2} \mathrm{O}_{8}+\mathrm{CaMgSi}_{2} \mathrm{O}_{6}=2 / 3 \mathrm{Ca}_{3} \mathrm{Al}_{2} \mathrm{Si}_{3} \mathrm{O}_{12}+1 / 3 \mathrm{Mg}_{3} \mathrm{Al}_{2} \mathrm{Si}_{3} \mathrm{O}_{12}+\mathrm{SiO}_{2} \\
& \text { (anortita) (diopsidio) (grossulária) (piropo) (quartzo) }
\end{aligned}
$$

Newton \& Perkins (1982) calculam para GAPES a expressão (kbar): 3,94 + $0,01307 T(\mathrm{~K})+0,003504 \mathrm{nn} K_{\mathrm{A}}( \pm 1,5 \mathrm{kbar}) ;$ e para GADS (kbar): 0,675 + 0,01718T(K)+ $0,0035967 \mathrm{n} K_{B}( \pm 1,6 \mathrm{kbar})$.

$$
\text { Onde, } K_{\mathrm{A}}=\frac{\left(a_{C a} \times a_{M g}^{2}\right)^{g r t}}{\left(a_{C a}^{p l}\right) \times\left(a_{M g_{2}}^{p c x}\right)} \quad K_{B}=\frac{\left(a_{C a}^{2} \times a_{M g}\right)^{g r t}}{\left(a_{C a}^{p l}\right) \times\left(a_{C a M g}^{c p x}\right)}
$$

Os valores obtidos pelo primeiro geobarômetro são considerados mais precisos que os do segundo, e ajuste empíricos de $-0,6$ kbar e $+1,6$ kbar são sugeridos para os respectivos cálculos.

Perkins \& Chipera (1985) calculam geobarômetros GAPES para membros finais $-\mathrm{Fe}$ e -Mg nas associações minerais grossularia + almandina + quartzo $=$ anortita + ferrossilita $e$ grossulária + piropo + quartzo $=$ anortita + enstatita, respectivamente. Foram utilizados os modelos de atividades de anortita de Newton \& Perkins (1982), de enstatita e ferrossilita de Wood \& Banno (1973) e de granada de Ganguly \& Saxena (1984). A seguir são apresentados ambos geobarômetros:

$$
\begin{gathered}
P_{F e}(k b a r)=0,0630-0,3482 \ln K_{A}+0,0143 T\left({ }^{\circ} \mathrm{C}\right)-0,000997 T\left({ }^{\circ} \mathrm{C}\right) \ln K_{A} \\
P_{M g}(\mathrm{kbar})=6,1346-0,3471 \ln K_{B}+0,0136 T\left({ }^{\circ} \mathrm{C}\right)-0,001140 T\left({ }^{\circ} \mathrm{C}\right) \ln K_{B} \\
\text { Onde, } K_{A}=\frac{a_{F F}^{3} \times a_{A n}^{3}}{a_{G r} \times a_{A l m}^{2}} \\
K_{B}=\frac{a_{E n}^{3} \times a_{A n}^{3}}{a_{G r} \times a_{P i r}^{2}} \\
\text { É considerado erro de } \pm 1 \text { kbar. Para rochas com } \frac{F e^{2+}}{\left(F e^{2+}+M g\right)}>0,5 \text { são obtidos } \\
\text { resultados mais confiáveis com o geobarômetro de Fe como membro final, assim, para as } \\
\text { rochas do presente trabalho, apenas essa equação será utilizada. }
\end{gathered}
$$


Eckert et al. (1991) compilam dados anteriores de entropia e volume (Holland \& Powell 1985; Newton \& Perkins 1982), calculam os de entalpia para ambas reações e obtém as seguintes equações geobarométricas:

$$
\begin{aligned}
& \text { GAPES }( \pm 1,55 \mathrm{kbar}) \rightarrow P(\text { kbar })=3,47+0,01307 T(K)+0,003504 T(K) \ln K_{A} \\
& \text { GADS }( \pm 1,90 \mathrm{kbar}) \rightarrow P(\text { kbar })=2,60+0,01718 T(K)+0,003596 T(K) \ln K_{B} \\
& \text { Onde, } K_{A}=\frac{\alpha_{P y}^{2} \times \alpha_{G r} \times \alpha_{Q t z}}{\alpha_{A n} \times \alpha_{E n}} \\
& K_{B}=\frac{\alpha_{P y} \times \alpha_{G r}^{2} \times \alpha_{Q t z}}{\alpha_{A n} \times \alpha_{D i}}
\end{aligned}
$$

Paria et al. (1988) propuseram geobarômetros que envolvem clino- e ortopiroxênio, baseados na equação granada + clinopiroxênio +quartzo $=2$ ortopiroxênio + anortita, de acordo com os membros finais de ferro e de magnésio. Os valores dos membros finais foram tomados de Helgeson et al. (1978) e Saxena \& Erikson (1983). Os de atividade dos componentes de piroxênio, e de anortita em plagioclásio foram modelados segundo Wood \& Banno (1973) e Newton \& Perkins (1982), respectivamente. Já as atividades de piropo e almandina foram retiradas de Saxena \& Erikson (1983). Os geobarômetros para os membros finais de Fe e Mg são:

$$
\begin{aligned}
& P_{F e}(\text { bar })=32,097 T(K)-26385-22,79\left(T-848-T \ln \left(\frac{T}{848}\right)\right) \\
& -(3,655+0,0138 T)\left(\frac{(T-848)^{2}}{T}\right)-3,123 T \ln K_{A} \\
& P_{M g}(\text { bar })=9,270 T(K)+4006-0,9305\left(T-848-T \ln \left(\frac{T}{848}\right)\right) \\
& -\left(1,1963-6,0128 \times 10^{-3} T\right)\left(\frac{(T-848)^{2}}{T}\right)-3,489 T \ln K_{B}
\end{aligned}
$$

Onde, $K_{A}=\frac{\left(a_{a n}^{p l}\right)\left(a_{f s}^{o p x}\right)^{2}}{\left(a_{a l m}^{g r t}\right)\left(a_{h e d}^{c p x}\right)}$

$$
K_{B}=\frac{\left(a_{a n}^{p l}\right)\left(a_{e n}^{o p x}\right)^{2}}{\left(a_{p i r}^{g r t}\right)\left(a_{d i}^{c p x}\right)}
$$

Os cálculos de pressão realizados pelo geobarômetro de membro final-Fe aparentemente apresentam valores mais confiáveis quando comparados aos - Mg, e serão utilizados aqui. É provável que essas diferenças sejam resultado de misturas não ideias nas fases minerais, especialmente em granada (Paria et al. 1988).

Assim como em outros métodos geobarométricos, valores confiáveis de temperatura em todos os casos acima devem ser utilizados, e como as análises são pontuais, realizadas 
por microssonda eletrônica, critérios devem ser definidos na escolha dos locais para cada mineral. Desse modo, os resultados obtidos serão os mais precisos possíveis.

\section{RCLC ("Thermobarometry Corrected for Retrograde Exchange")}

Geotermobarômetro de Pattison et al. (2003) que utiliza a associação mineral granada - ortopiroxênio - plagioclásio - quartzo no sistema Ca-Fe-Mg-Al-Si (CFMAS), dados termodinâmicos do software "TWQ2.02b" baseados no conjunto de dados de Berman \& Aranovich (1996), além de modificações referentes à solubilidade de Al em ortopiroxênio em equilíbrio com granada em sistema de membro final -Fe de Aranovich \& Berman (1997). Esse método é baseado na solubilidade de Al no ortopiroxênio em equilíbrio com granada, corrigindo efeitos de troca $\mathrm{Fe}-\mathrm{Mg}$ tardia. Como o conteúdo de Al no ortopiroxênio é pouco alterado durante o retrometamorfismo devido à sua baixa velocidade de difusão, os efeitos da troca tardia de Fe-Mg entre os minerais são corrigidos pelo ajuste de razão Grt/ Opx, na tentativa de se chegar a um equilíbrio interno entre as duas fases. A Figura 13 apresenta dois diagramas produzidos pelo software TWQ (Berman 1991) para determinada amostra de granulito. As curvas 7, 8 e 9 são linearmente independentes, onde a primeira representa a reação de troca $\mathrm{Fe}-\mathrm{Mg}$ entre granada e ortopiroxênio em equilíbrio, a segunda indica o equilíbrio baseado na solubilidade de Al no ortopiroxênio num sistema de membros finais $-\mathrm{Fe}$ (Aranovich \& Berman 1997), e a terceira o barômetro granada - ortopiroxênio - plagioclásio - quartzo. Os vértices $\mathrm{A}$ e $\mathrm{B}$ representam o cálculo geotermobarométrico clássico de troca FeMg sem correções, e o cálculo Fe-Al levando em consideração a solubilidade do Al no opx porém sem correções tardias de Fe-Mg, respectivamente (Figura 13a). Na Figura 13b são ilustradas as curvas de equilíbrio corrigidas e o vértice $C$, com valores $\mathrm{P}$-T superiores aos anteriores e provavelmente representando condições mais próximas às do pico metamórfico. De modo geral, os valores corrigidos de 414 granulitos máficos, intermediários e aluminosos são em média $100^{\circ} \mathrm{C}$ maiores que os obtidos inicialmente, e colocam a maioria das amostras de granulito acima dos $850^{\circ} \mathrm{C}$, temperatura tida como início do fácies granulito pela entrada de ortopiroxênio. Em poucos exemplos o ajuste reduz as condições $P$ - $T$, e nesse caso, o os autores optaram por utilizar os não reequilibrados. 
Unadjusted equilibria

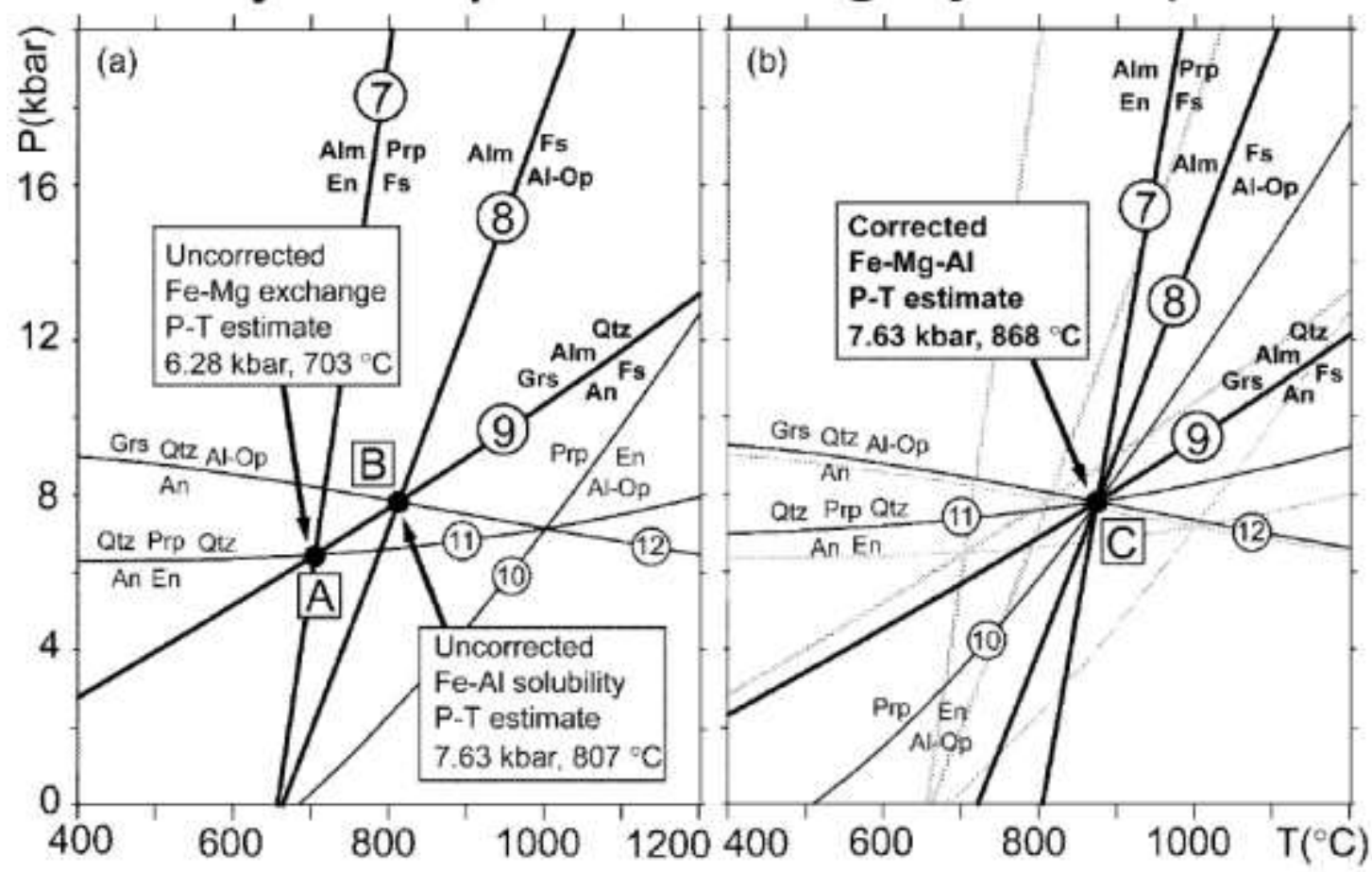

Figura 13 - Diagramas P-T produzidos pelo software TWQ (Berman 1991) e retirados de Pattison et al. (2003) para análise de granulito ilustrando as reações de equilíbrio na associação mineral granada - ortopiroxênio plagioclásio - quartzo. Figura 13a indica curvas e resultados não corrigidos pelo método; Figura 13b apresenta a distribuição das curvas e resultado $P$-T após correção Fe-Mg-Al.

\subsubsection{Fatores Controladores}

\section{$\underline{\text { Reações retrometamórficas }}$}

As reações retrometamórficas são aquelas que ocorrem entre os minerais durante o resfriamento, podendo ou não afetar suas proporções modais. De maneira geral, as principais reações retrometamórficas são as de troca de cátions como Fe, Mg e Mn entre duas fases minerais, onde não há variação expressiva nas proporções modais, e as por "transferência total" (net transfer reactions), que dissolvem e geram/ desenvolvem fases minerais (Kohn \& Spear 2000), basicamente envolvem a destruição do retículo cristalino de um mineral, ou seja seu consumo, para produção de outra fase.

As reações mais comuns na termometria são as de troca catiônica, como por exemplo, de Fe e Mg entre granada e biotita, com as composições de biotita tornando-se cada vez mais ricas em Mg, enquanto que as de granada, em Fe. Apenas ocorrendo esse tipo de reação retrometamórfica, as temperaturas obtidas serão inferiores às de pico. Já as reações por "transferência total", quando ocorrem, causam mudanças nas composições minerais na 
mesma direção, com granada e biotita se enriquecendo em ferro, por exemplo, e os dados termométricos gerados serão supervalorizados (Kohn \& Spear 2000).

\section{Minerais zonados}

Zoneamento químico mineral é um dos fatores que mais influenciam na metodologia empregada durante a análise e nos resultados obtidos. Entre os minerais utilizados na termobarometria granada, piroxênios e plagioclásio são aqueles que comumente apresentam esta característica. Deste modo, a escolha do local de análise em cada cristal deve ser realizada de maneira particular.

Kohn \& Spear (2000) estudando rochas de fácies anfibolito notaram, através de mapas composicionais de raio- $X$, um claro zoneamento composicional em granada, com os maiores teores de $\mathrm{Fe} /(\mathrm{Fe}+\mathrm{Mg})$ e $\mathrm{Mn}$ nos núcleos e fina auréola na borda enriquecida em $\mathrm{Mn}$, além de dois padrões de biotita, sendo as mais próximas aos cristais de granada, mais ricas em $\mathrm{Fe}$, e as mais distantes, menos ricas. Esses dados sugerem a ação de reações retrometamórficas do tipo net transfer, as quais promovem a dissolução de granada e liberação de Fe, Mg, Ca e Mn para a matriz. Embora a biotita e plagioclásio possam assimilar a maior parte dos elementos, o $\mathrm{Mn}$ permanece na granada criando bordas ricas nesse elemento, totalmente diferentes da composição do pico metamórfico. A utilização de cristais de granada e biotita para termometria, que tenham passado por essas mudanças químicas, gera resultados superestimados. Assim, a fim de evitar erros, mapas composicionais de raio$X$ são extremamente eficazes, e em qualquer sinal de reações desse tipo, deve-se utilizar os menores valores de Mn, próximos a borda enriquecida e cristais de biotita distantes.

Pattison \& Bégin (1994) discutem este assunto com foco em rochas de fácies granulito, onde pela confecção de mapas composicionais de vários minerais, incluindo granada, ortopiroxênio, plagioclásio e biotita, indicam clara evidência de troca de $\mathrm{Fe} e \mathrm{Mg}$, principalmente entre grãos de granada e ortopiroxênio em contato mútuo, o que não ocorre com grãos separados por quartzo e plagioclásio. As trocas dependem do tamanho dos grãos, dos minerais em contato físico, e até da presença de um meio intergranular.

\section{Granada}

O conteúdo de cálcio na granada apresenta aumento nas concentrações em direção às bordas, sendo que, no núcleo, ocorre ligeiro aumento com a diminuição do tamanho do cristal. Em relação ao $\mathrm{Fe} /(\mathrm{Fe}+\mathrm{Mg})$, as variações ocorrem principalmente devido aos minerais vizinhos e ao tamanho do cristal. Composições de bordas em contato com biotita e/ou ortopiroxênio não mostram quaisquer variações com o tamanho do cristal, já no núcleo, 
ocorrem padrões mais ricos em ferro quanto menor for o grão. A granulação para o reequilíbrio de $\mathrm{Fe} /(\mathrm{Fe}+\mathrm{Mg})$ é incerto, porém aparentemente, para cristais menores que $1 \mathrm{~mm}$, há claras evidência de reajuste, com casos extremos em cristais com menos de 0,3mm. Granada apenas em contato com plagioclásio e/ou quartzo apresenta evidências para reajuste mínimo.

\section{Ortopiroxênio}

O ortopiroxênio apresenta padrões complementares aos de granada. Seu conteúdo de alumínio é maior no núcleo que nas bordas. Nestas, ocorre pouca ou nenhuma variação com o tamanho do cristal e minerais adjacentes, enquanto que para o núcleo, há diminuição desse elemento quanto menor for o grão. Proporções de $\mathrm{Fe} /(\mathrm{Fe}+\mathrm{Mg})$ em bordas de ortopiroxênio em contato com granada mostram pouca relação com o tamanho do cristal, já no núcleo, ocorrem maiores concentrações de $\mathrm{Mg}$ (menor temperatura) quanto menor for o grão. reajuste de $\mathrm{Fe}$ - Mg em decorrência da granulação, assim como na granada, é incerto, porém cristais de 0,5mm já apresentam alteração significativa nos teores. Ortopiroxênio em contato com quartzo, plagioclásio e/ou biotita não demonstra variação nesses elementos, e quando em menor granulação, possui teores de núcleo semelhantes aos de cristais maiores sem necessariamente estarem em contato com essas fases. A falta de reajuste da razão $\mathrm{Fe} / \mathrm{Mg}$ entre ortopiroxênio e granada está relacionada ao fato que ambos minerais apresentam valores muito similares de $X_{\mathrm{Mg}}$.

\subsubsection{Estimativas de temperatura}

\section{Temperaturas de troca de $\mathrm{Fe}-\mathrm{Mg}$}

Como visto anteriormente, cristais de granada em contato com minerais como ortopiroxênio e/ou biotita apresentam significativa alteração nos teores de $\mathrm{Fe} \mathrm{e} \mathrm{Mg}$, sendo estes tão menores quanto menor for a granulação do grão analisado, enquanto que, quando em contato com quartzo e/ou plagioclásio, estes teores são pouco alterados (temperaturas de núcleo para granada pequena em contato com quartzo e/ou plagioclásio $\approx$ para granada grande em contato com biotita e/ou ortopiroxênio). Variações nas concentrações destes elementos também são evidentes quando comparadas as de núcleo e borda de um mesmo cristal. Pattison \& Bégin (1994) mostram, através de análises de granulitos, que temperaturas de bordas de granada, em contato com ortopiroxênio, são de 200 a $215^{\circ} \mathrm{C}$ mais baixas que as de núcleo. Assim, é possível afirmar que, de acordo com a assembleia de minerais em contato, as estimativas de temperatura serão controladas pela quantidade de possíveis trocas $\mathrm{Fe}$ - Mg durante o retrometamorfismo. 


\section{$\underline{\text { Temperaturas de solubilidade de Al }}$}

De maneira geral os teores de $\mathrm{Al}$ e as consequentes temperaturas encontradas são tão maiores quanto maior for o cristal, sendo que os resultados mais altos são encontrados nos núcleos de ortopiroxênio, sendo inclusive superiores aos valores encontrados através da troca $\mathrm{Fe}-\mathrm{Mg}$, tanto para as análises de borda como para as de núcleo.

Esses maiores resultados para estas análises são consistentes, visto que os gradientes de Al deixam de existir sob temperaturas onde ainda ocorrem trocas intracristalinas de $\mathrm{Fe}-\mathrm{Mg}$ (Al presente em sítios tetraédricos é menos móvel que Fe e Mg nos octaédricos).

\subsubsection{Importância de um meio intergranular}

A existência desse meio é importante principalmente sob altas temperaturas, pois facilita o equilíbrio intergranular de $\mathrm{Fe}-\mathrm{Mg}$ em granada e ortopiroxênio, de cálcio nas bordas de granada e de alumínio nas de ortopiroxênio. Quando removido, as trocas $\mathrm{Fe}-\mathrm{Mg}$ se restringem aos contatos entre minerais específicos, como granada, ortopiroxênio e biotita.

O meio intergranular pode ser um fluido supercrítico e/ou um fundido silicático. A presença do primeiro é menos comum principalmente em rochas de alto grau, visto que a maioria dos voláteis, como $\mathrm{H}_{2} \mathrm{O}$ e CO 2 , é absorvida pelo fundido (Burnham, 1979; Peterson \& Newton, 1990). Nessas rochas, mesmo na ausência de fases fluidas, líquidos silicáticos podem ser gerados pela desidratação de minerais hidratados como muscovita, biotita e hornblenda.

Um fator bastante importante para a obtenção de resultados confiáveis é o tempo de residência desse meio. Se o líquido silicático for expulso da rocha ainda sob altas temperaturas, é provável que os valores de temperatura encontrados sejam os mais próximos do pico metamórfico real, ao passo que, se esse meio permanecer nos interstícios da rocha durante o resfriamento, esses resultados provavelmente serão inferiores. Bégin \& Pattison (1994) indicam, através de minerais e texturas, a possível existência desses eventos distintos em rochas de fácies granulito: a ausência de biotita sugere que a rocha não foi reidratada durante o retrometamorfismo em decorrência da expulsão do fundido ou da liberação de fluidos apenas após a cristalização. Já a presença de biotita grossa e/ou poiquiloblástica indica reidratação, provavelmente devido à liberação de água de leucossoma quartzofeldspático na rocha.

No estudo de rochas de fácies granulito, comumente associadas a líquidos, as temperaturas de fechamento são provavelmente relacionadas às temperaturas nas quais 
esses líquidos foram extraídos ou cristalizados, inferiores as de pico metamórfico e as de quebras minerais (Pattison \& Bégin 1994).

A fim de reconhecer o local de composição mais refratária em cada cristal a ser analisado, é fundamental a produção de mapas composicionais, visto que núcleos nem sempre possuem os maiores valores de $\mathrm{Fe}$ e $\mathrm{Mg}$, e a relação entre borda e núcleo varia dependendo do elemento e do mineral ( $\mathrm{Ca}$ em granada e Al em ortopiroxênio). Quando a produção desses mapas não for possível, deve-se optar por analisar cristais de granada, ortopiroxênio e clinopiroxênio cercados por quartzo e/ou feldspato, ou quando em contato com minerais de possível troca Fe-Mg, os de maior granulação (Pattison \& Bégin 1994). 


\section{RESULTADOS}

\subsection{Geologia local}

A região setentrional da área mapeada apresenta as maiores altitudes, com morros que chegam próximo de $1200 \mathrm{~m}$, orientados, grosso modo, na direção leste-oeste e limitados comumente por drenagens afluentes da represa de Furnas e do Rio Verde. A região mais a sul, com altitudes inferiores a $900 \mathrm{~m}$, apresenta relevo menos acidentado com ocorrência comum de áreas alagadas e várzeas, e pequeno número de afloramentos. Outra razão para a baixa frequência de aforamentos no restante da área é o extenso cultivo de café. Por toda área ocorrem principalmente rochas metassedimentares de fácies granulito de alta pressão (rutilo-cianita-granada granulito; Nappe Três Pontas - Varginha; Orógeno Brasília Meridional), e quartzitos subordinados, os quais são atribuídos ao Grupo Carrancas (Trouw et al. 2000). Em contato tectônico com as rochas de alto grau, na forma de lentes, estão presentes rochas metatexíticas de provável protolito ígneo (Apêndice 1).

\subsubsection{Rutilo-cianita-granada granulito}

O litotipo representante da Nappe Três Pontas - Varginha aflora na maior parte da região, principalmente nas porções central e oeste, na forma de barrancos ou cortes de estrada bastante alterados, por vezes como saprolitos, ou como pavimento de estradas e blocos rolados. Trata-se de rocha bandada rica em quartzo, em que leitos escuros ricos em granada, com cianita e rutilo, estão alternados com leitos claros ,félsicos e quartzofeldspáticos, ambos com granulação que varia de fina a grossa. Granada e rutilo podem se apresentar como porfiroblastos milimétricos a centimétricos e bem formados. A rocha é rica em veios de quartzo de espessura milimétrica a centimétrica, dispostos paralelos à foliação, por vezes com bolsões ou lentes quartzo-feldspáticos associados, caracterizado como leucossoma. Biotita é alteração retrometamórfica comum de granada, ocorrendo na borda irregular de alguns cristais. Em porções mais deformadas pelo cisalhamento há maior proporção de veios de quartzo em granulação fina a média, ou grossa quando também apresentam feldspato, veios que são de leucossoma deformado; muscovita ocorre raramente, na foliação, mas principalmente disposta de maneira aleatória na rocha. Bandas ricas em biotita e porfiroblastos de granada estirados e rotacionados com sombras de pressão preenchidas por quartzo e feldspato, leucossoma, são comuns. Há variação para rocha xistosa quando a proporção de muscovita aumenta, com sillimanita associada, quando ocorre

diminuição na quantidade de feldspato, o que indica retrometamorfismo relacionado à deformação/ cisalhamento. É comum a intercalação de rocha máfica, como bandas centimétricas marrom avermelhadas a ocre, bastante alteradas. Em alguns locais há núcleos 
mais bem preservados onde é possível identificar cristais finos a médios de granada e clinopiroxênio.

\subsubsection{Metatexito estromático}

O metatexito estromático ocorre como corpos lenticulares orientados leste-oeste nos extremos leste e oeste da área mapeada. A forma de afloramento se dá através de barrancos de rocha bastante alterada, blocos rolados, em campos de matacões e em lajes em morros. A estrutura varia bastante, com tipos desde aparente granito deformado e orientado, biotita gnaisse protomilonítico, ao predominante metatexito estromático. Os exemplos deformados apresentam foliação protomilonítica e porfiroclastos centimétricos, tabulares e orientados de feldspato, indicadores cinemáticos, matriz fina a média quartzo-feldspática rica em biotita, com a característica presença de granada milimétrica entre cristais de biotita e feldspato alcalino. Em locais com maior deformação há leitos descontínuos, de coloração clara, formados por feldspato bastante estirado que por vezes indica cinemática (Figura 14). Mesmo nessas rochas bastante estiradas ocorrem porções aparentemente fundidas, com leitos quartzofeldspáticos mais espessos na forma de bolsões paralelos a foliação (Figura 14). Há interação com xenólito angular, cinza escuro, de granulação fina e com bordas de reação. Os tipos onde predomina a fusão parcial são bandados e alternam leucossoma de espessura centimétrica (1-3 cm), quartzo-feldspático com granada, em granulação média, de resíduo finamente bandado, com leitos félsicos e máficos, composto por quartzo, feldspato, biotita e granada (Figura 15). Biotita ocorre em finos leitos nas bordas de fundido (Figura 16). Em locais com maior desenvolvimento de fusão parcial, o leucossoma adquire aspecto pegmatoide, com granulação grossa, e apresenta estrutura schollen com blocos angulares centimétricos de resíduo (Figura 17). A alta porcentagem de fusão parcial em alguns locais é tamanha, que apenas devido a proeminente deformação associada com instalação de leitos paralelizados, não houve geração de diatexito. Dobras intrafoliais centimétricas são recorrentes (Figura 16). 


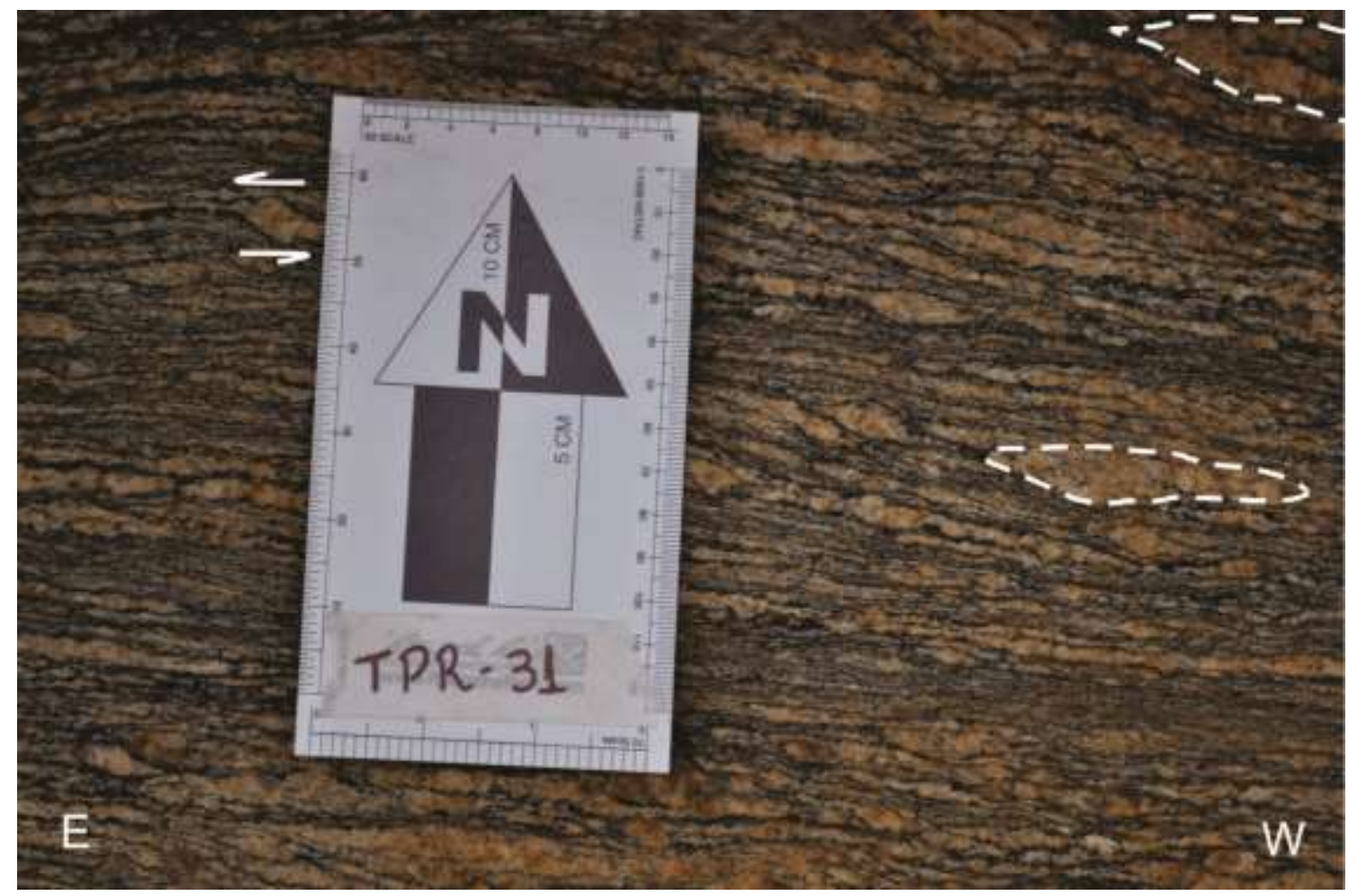

Figura 14 - Afloramento TPR-31. Metatexíto estromático apresentando grande estiramento com indicadores cinemáticos indicando movimentação de topo para Leste. Bolsões centimétricos de fundido demarcados.

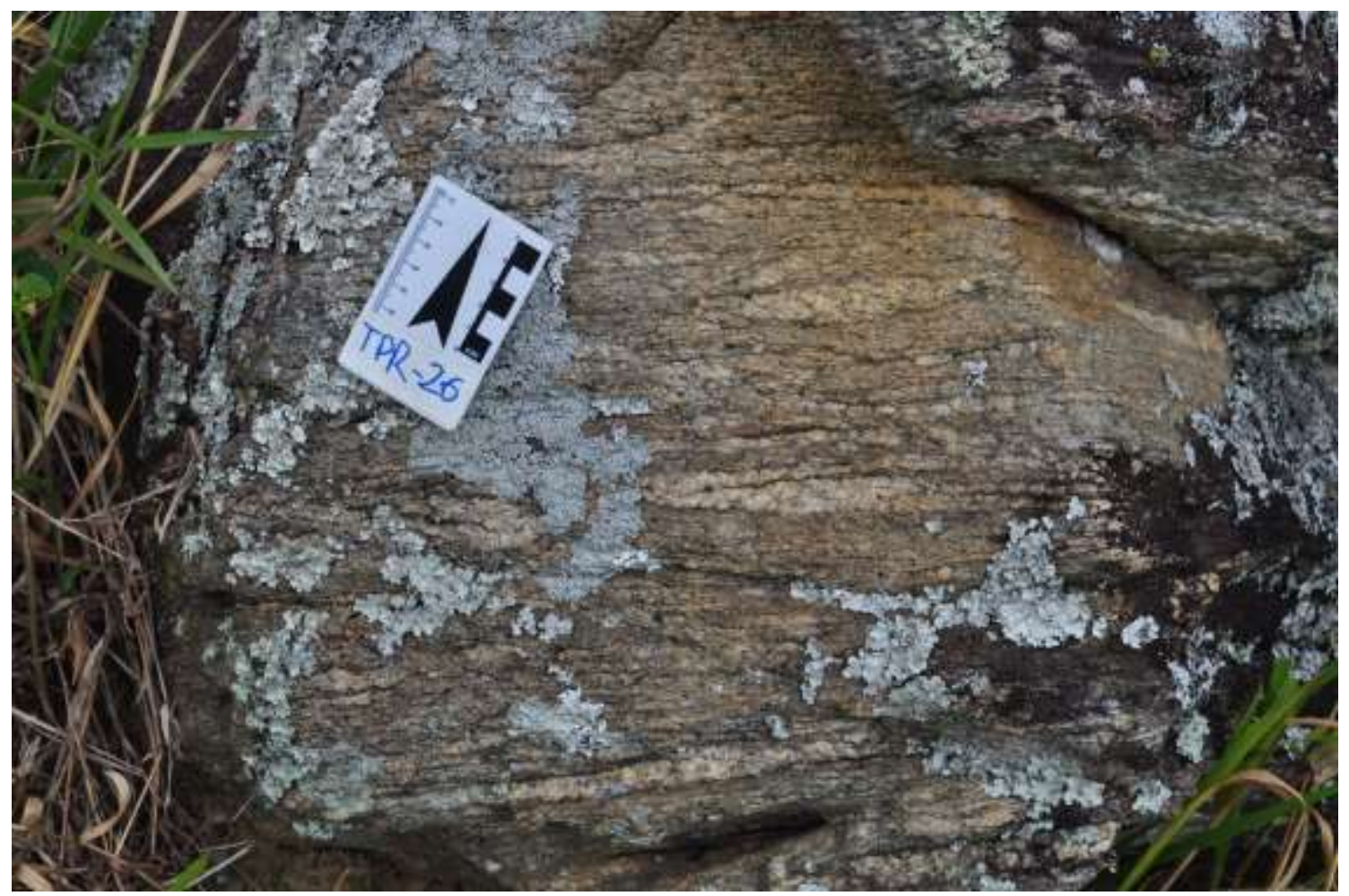

Figura 15 - Afloramento TPR-26. Metatexíto estromático com leucossoma de espessura centimétrica $(1-3 \mathrm{~cm})$, quartzo-feldspático, em granulação média, e resíduo finamente bandado com leitos félsicos e máficos, composto por quartzo, feldspato, biotita e granada. 


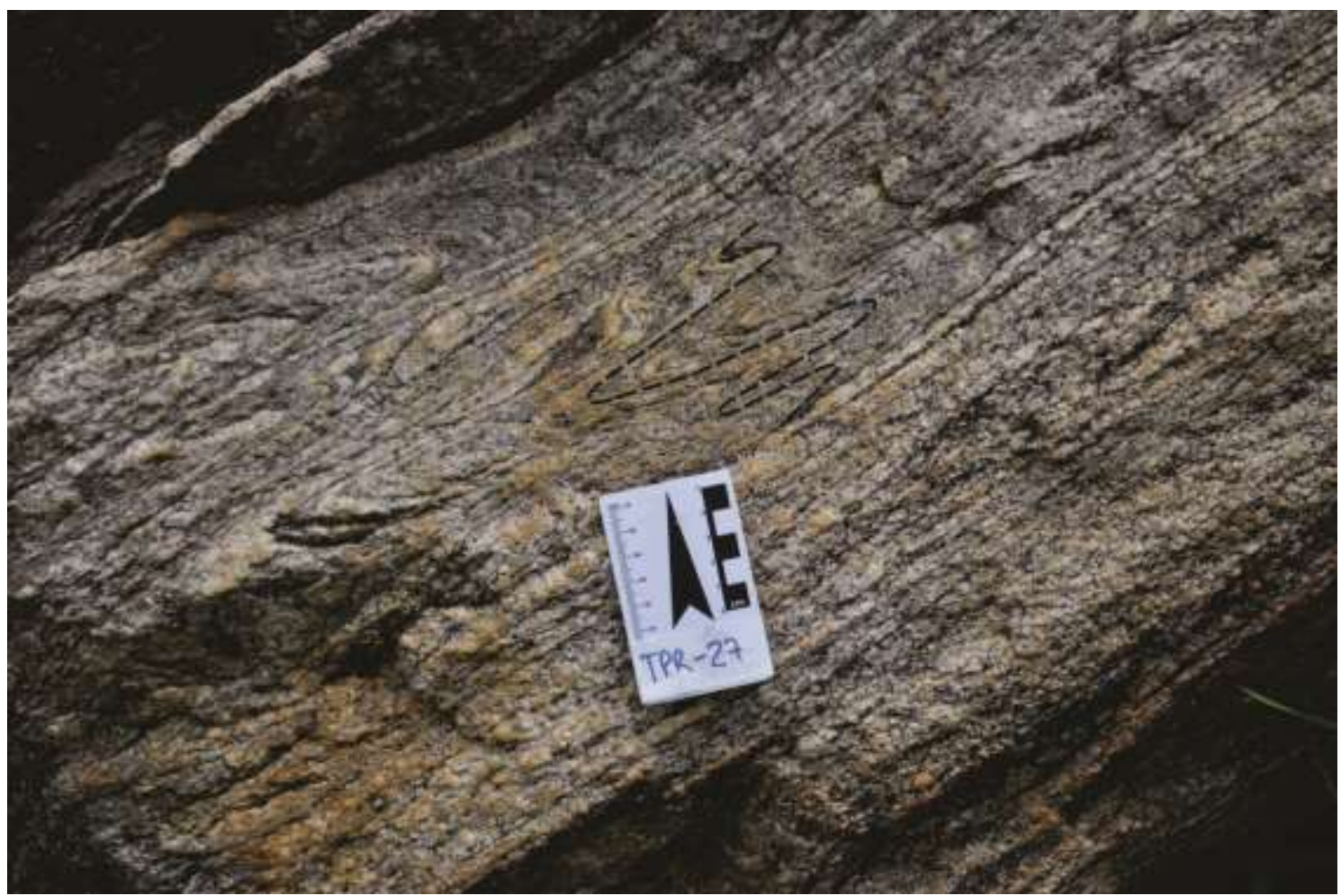

Figura 16 - Afloramento TPR-27. Metatexito estromático com dobras intrafoliais centimétricas e finos leitos de biotita nas bordas de leucossoma.

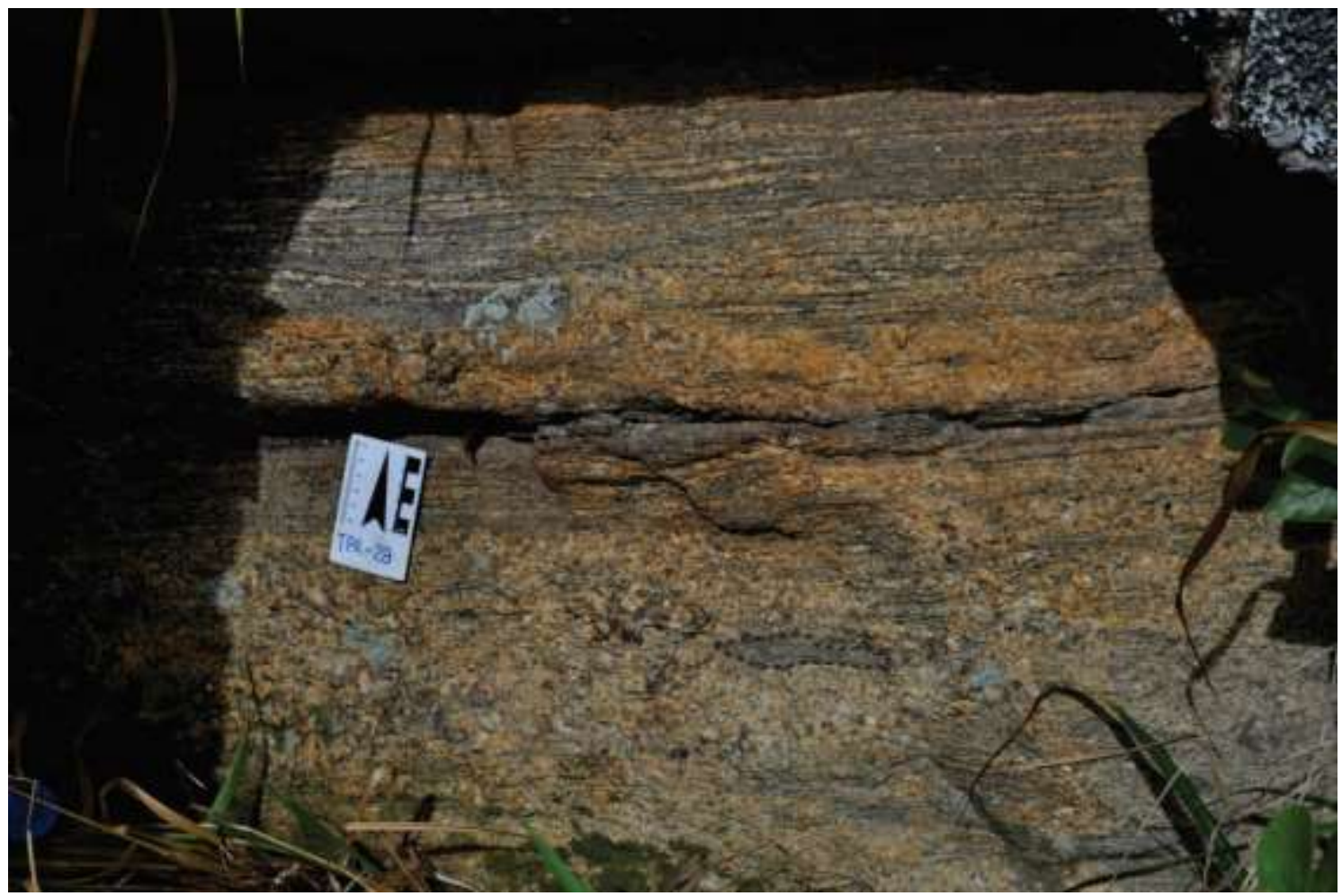

Figura 17 - Afloramento TPR-28. Metatexito estromático com leucossoma de granulação grossa em aspecto pegmatoide. Estrutura schollen, demarcada na porção inferior da foto, com bloco angular centimétrico de resíduo em meio ao leucossoma. 


\subsubsection{Quartzito}

Litotipo com pequeno número de afloramentos na área mapeada, o quartzito ocorre na porção nordeste como morro orientado NE-SW e limitado a sul pelo Córrego do Tabuão. Aflora nas encostas de morros como em perfis de erosão como ravinas. Trata-se de rocha bastante pura, cinza claro a tons amarronzados, com acamadamento milimétrico e de granulação fina (Figura 18). Turmalina fina prismática ocorre em pequena quantidade e dispersa e orientada na rocha. Lâminas com por volta de $1 \mathrm{~mm}$ de espessura de óxidos são comuns. Há porções em que o quartzito se encontra extremamente recristalizado, maciço, em granulação muito fina. Intercalações centimétricas a decimétricas de xisto cinza claro rico em muscovita são recorrentes, e comumente apresentam porções alteradas de coloração marrom avermelhado que sugerem presença de clorita.

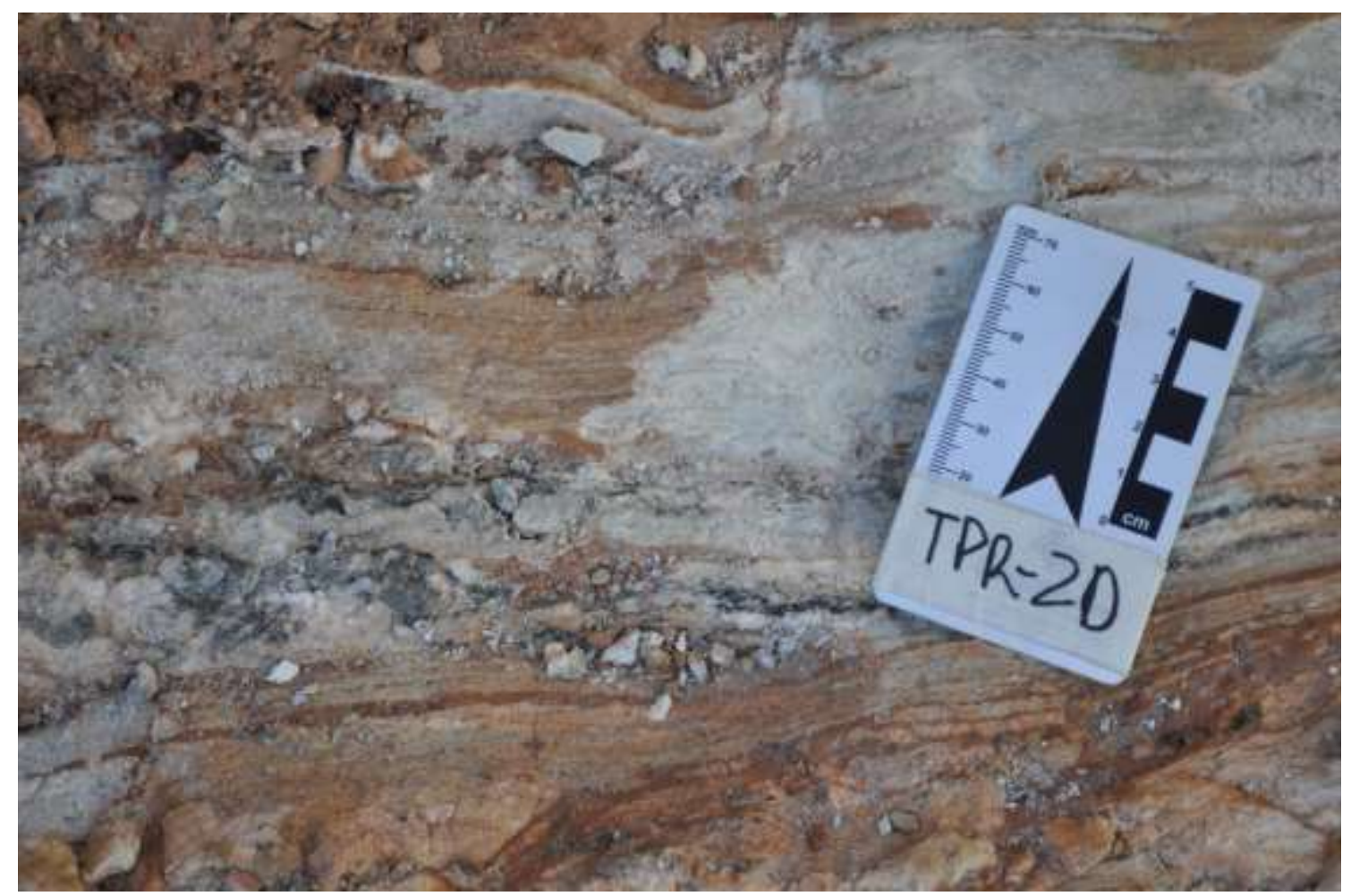

Figura 18 - Afloramento TPR-20. Quartzito típico da área de cor cinza a tons amarronzados, acamadado, de granulação fina.

\subsubsection{Biotita gnaisse milonítico}

Litotipo aflorante em apenas um ponto na região (TPR-19) na forma de pavimento de estrada bastante alterado e como blocos frescos rolados em drenagem. Trata-se de rocha cinza, com forte foliação milonítica, que alterna leitos milimétricos (1-2 mm) e sinuosos de biotita de outros quartzo-feldspáticos em maior proporção e de mesma espessura. Feldspato e granada ocorrem como porfiroclastos milimétricos. Características texturais e mineralógicas 
sugerem tal rocha tratar-se do Xisto Santo Antônio existente extensamente a norte da área mapeada, porém aqui, em maior grau de metamorfismo e estiramento (Figura 19).

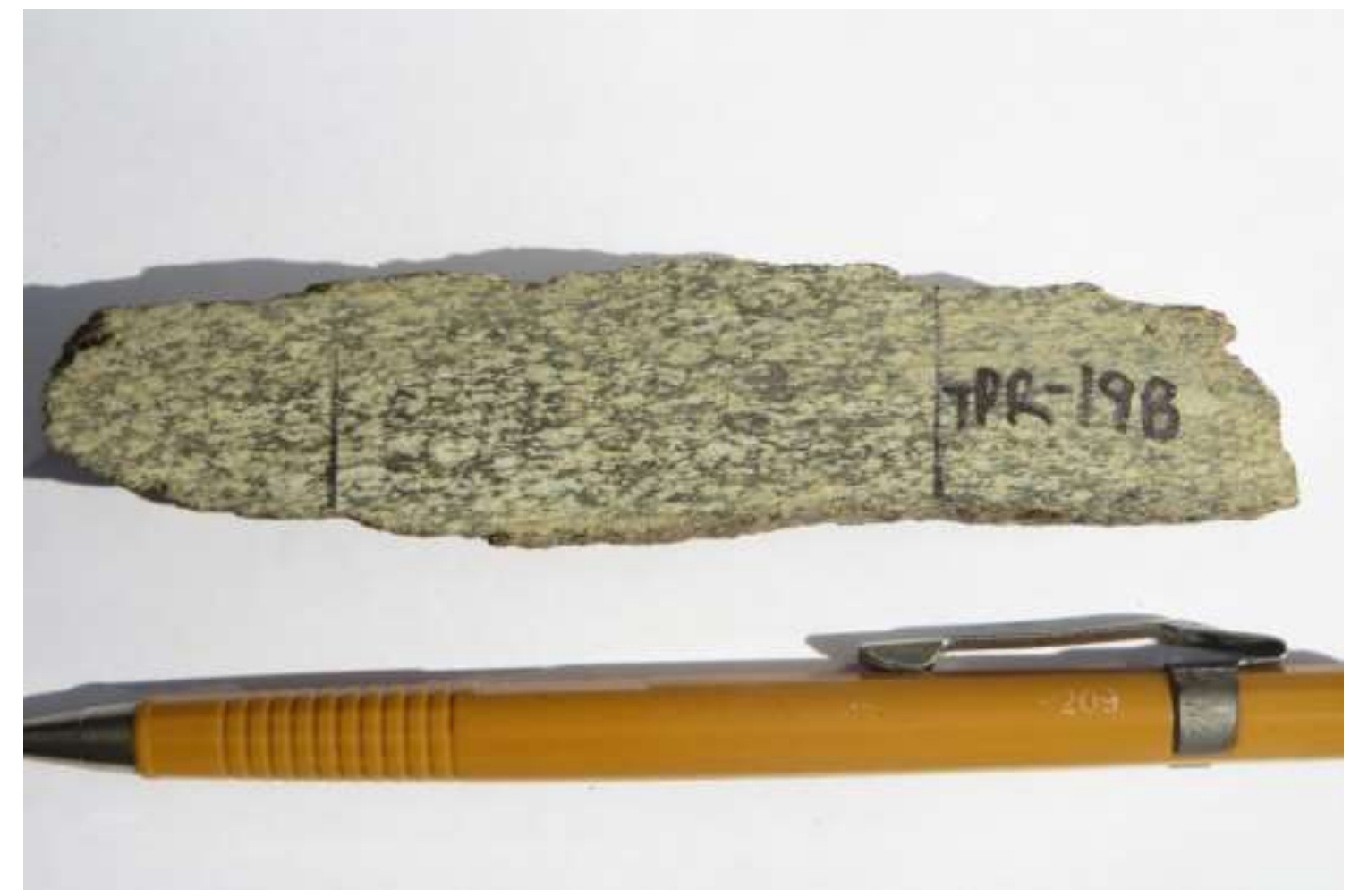

Figura 19 - TPR-19B. Biotita gnaisse milonítico com alternância de leitos escuros e sinuosos ricos em biotita e outros claros quartzo-feldspáticos.

\subsection{Pedreira de Três Pontas (TPR-01)}

No trabalho de campo realizado na pedreira abandonada "Niemeyer" em Três Pontas, teve como objetivo descrever os litotipos presentes, mineralogia, estruturas e relações de contato. O acesso à pedreira se dá, a partir da região sudeste do Município de Três Pontas, através da Rodovia - MG 167 - Claudionor Vasconcelos.

Além da descrição detalhada, foi realizada coleta de 24 amostras representativas dos principais litotipos e de feições texturais características, como leucossoma, melanossoma, resíduo e paleossoma. Foi visitada também a pedreira de Varginha onde foi amostrado granulito félsico da Nappe Socorro-Guaxupé. A nomenclatura para migmatitos segue a proposta de Sawyer (2008).

$\mathrm{Na}$ pedreira abandonada "Niemeyer" ocorrem três rochas distintas, com diferentes protolitos, reologia, mineralogia, estrutura e textura. A mais abundante em toda a pedreira, característica e representativa do cianita-granada granulito migmatítico da Nappe Três Pontas-Varginha. Quando não deformada, a rocha é diatexito nebulítico, com resíduo 
granulítico formado por cianita + granada + rutilo + quartzo + ortoclásio. Intercalado ao cianitagranada granulito migmatítico ocorre lente concordante de rocha residual máfica rica em hornblenda, com granada, clinopiroxênio e raro ortopiroxênio subordinados e com leucossoma de composição tonalítica. A distribuição dos litotipos na pedreira, da base para o topo, ocorre com o metapelito, em camada que varia de 2 a 3 metros, rocha residual máfica com espessura semelhante a anterior, e predominância metapelítica até o topo da pedreira, com aproximadamente $50 \mathrm{~m}$ (Figura 20). Em meio aos litotipos principais ocorrem rochas calciossilicáticas que apenas foram observadas e amostradas em exemplares soltos na pedreira de Três Pontas, nunca in-situ. O motivo talvez seja sua provável ocorrência em grandes alturas da frente de lavra.

\subsubsection{Rutilo-cianita-granada granulito}

O cianita-granada granulito migmatítico é produto de metamorfismo e fusão de rocha pelítica, é bastante heterogêneo, apresenta bandamento composicional centimétrico a decimétrico, onde leitos de leucossoma e resíduo se alternam, além de porção finamente bandada, mesocrática, com aspecto de gnaisse, rica em biotita. O melanossoma é maciço, forma leitos contínuos de espessuras centimétricas a decimétricas, descontínuos e até boudinados (Figura 21). Possui textura nematogranoblástica, granulação média a grossa, é formado por proporções variadas de microclínio, plagioclásio, quartzo, granada, cianita e rutilo. Minerais opacos, apatita, monazita e zircão são frequentes acessórios, e biotita, muscovita, clorita e calcita, secundários. 


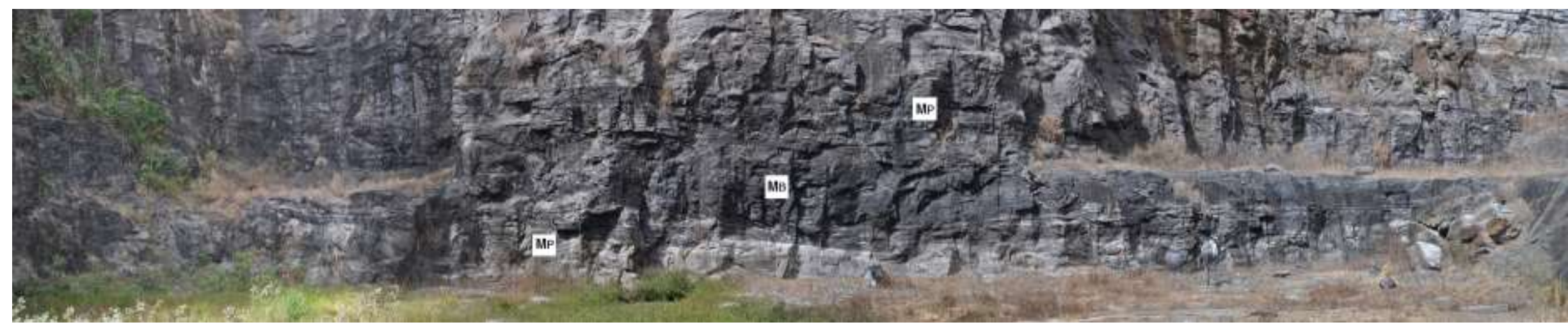

Figura 20 - Visão geral da pedreira de Três Pontas (TPR-01). Intrusão de rocha metabásica metatexítica (MB), representada predominantemente por "resíduo" rico em hornblenda, em metapelito migmatítico/ cianita granulito migmatíticos (MP). Orientação ENE-WSW.

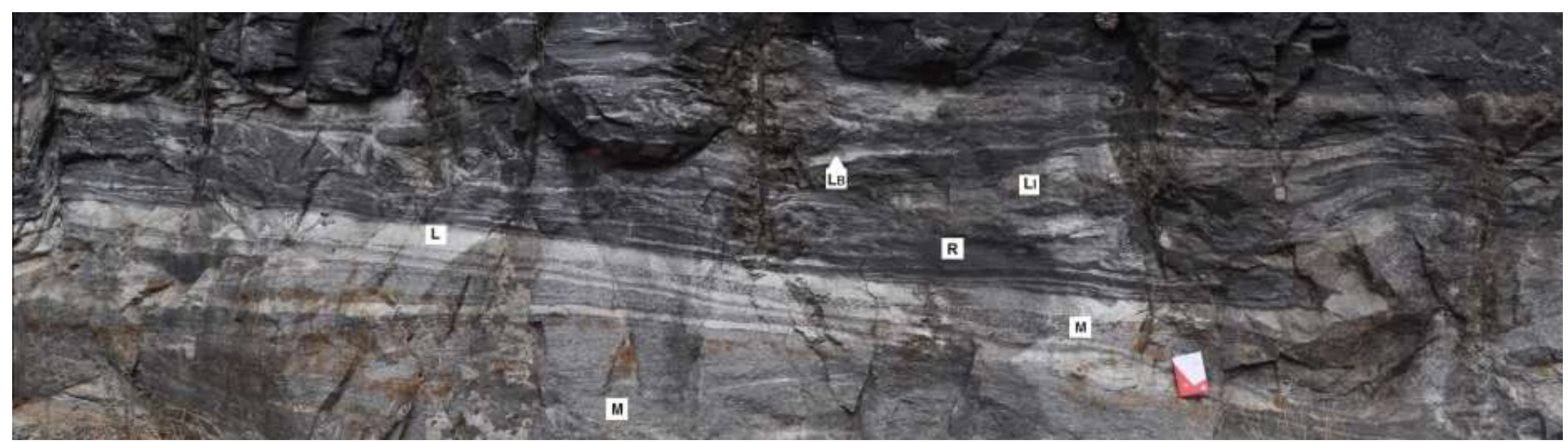

Figura 21 - TPR-01. Detalhe do contato abrupto entre rocha residual máfica e metapelítica. Metapelito: leucossoma (L) em leitos contínuos, melanossoma (M) maciço, por vezes como leitos centimétricos, contínuos e boudinados; Leucossoma (LB) tonalítico paralelo à foliação, in-situ e in-source, resíduo (R) melanocrático, rico em hornblenda e leucossoma rosado (LI) grosso, rico em feldspato potássico. Notar dobramentos recumbentes com topo para ENE. Orientação ENE-WSW. 
O feldspato potássico é subidioblástico a xenoblástico/ intersticial, possui bordas retas a arredondadas refletindo assim a variação dos contatos entre os minerais, forma junções tríplices de $120^{\circ}$, apresenta comumente exsoluções de plagioclásio chegando a exemplos mesopertíticos. Plagioclásio é bastante semelhante ao feldspato potássico em relação à textura, é subidioblástico e forma contatos retos com junções tríplices de $120^{\circ}$, a arredondados principalmente junto ao quartzo, ocorre também como cristais xenoblásticos/ intersticiais de terminações afinadas em cúspide. Em rochas mais deformadas se apresenta como porfiroclastos rodeados por porções policristalinas granoblásticas ou junto a quartzo em agregados sigmoidais de mesma textura. Quartzo forma cristais longos de bordas arredondadas e orientados paralelamente ao bandamento, pode apresentar bordas suturadas e subgrãos característicos de recristalização por migração de borda, e ocorre como finos filmes intersticiais de terminações afinadas em cúspide. Texturas em fitas ocorrem nos exemplares mais deformados. Granada é subidioblástica a xenoblástica, principalmente porfiroblástica, pode ser arredondada e alongada segundo o bandamento ou apresentar bordas bastantes irregulares com intenso fraturamento e reentrâncias exibindo um aspecto esqueletal (Figura 22a). Possui inclusões de quartzo arredondado (comumente em trilhas), plagioclásio, cianita, rutilo, biotita, estaurolita, monazita e zircão (Figura 22a e b), e por vezes de "micro granito" composto por quartzo, feldspato e biotita. É alterada em fraturas e bordas por biotita e carbonato. É recorrente associação com biotita e plagioclásio xenoblásticos que indica reação retrometamórfica (Figura 22c). Cianita ocorre como prismas subidioblásticos orientados concordantemente ao bandamento, próximos uns aos outros e junto a granada (Figura 22d) e biotita, pode estar inclusa parcial ou totalmente em granada, possuir inclusões de rutilo e feldspato potássico e ser substituída parcial a totalmente por muscovita. Rutilo é prismático subidioblástico a xenoblástico e granular, ocorre disperso pelo resíduo, mas principalmente junto à granada e incluso. Biotita é o principal mineral de alteração de granada em bordas e fraturas (Figura 22e), mas ocorre também subidioblástica a xenoblástica orientada na foliação ou aleatória (Figura 22f) e amoldando porfiroblastos de granada e indicadores cinemáticos tipo fish quartzo-feldspáticos (Figura 24a); apresenta inclusões de zircão com halo pleocróico. Em rochas com maior proporção de biotita (até $30 \%$ ) ela se concentra em bandas de granulação inferior à geral, é subidioblástica e orientada na foliação comumente amoldando porfiroblastos de granada. 

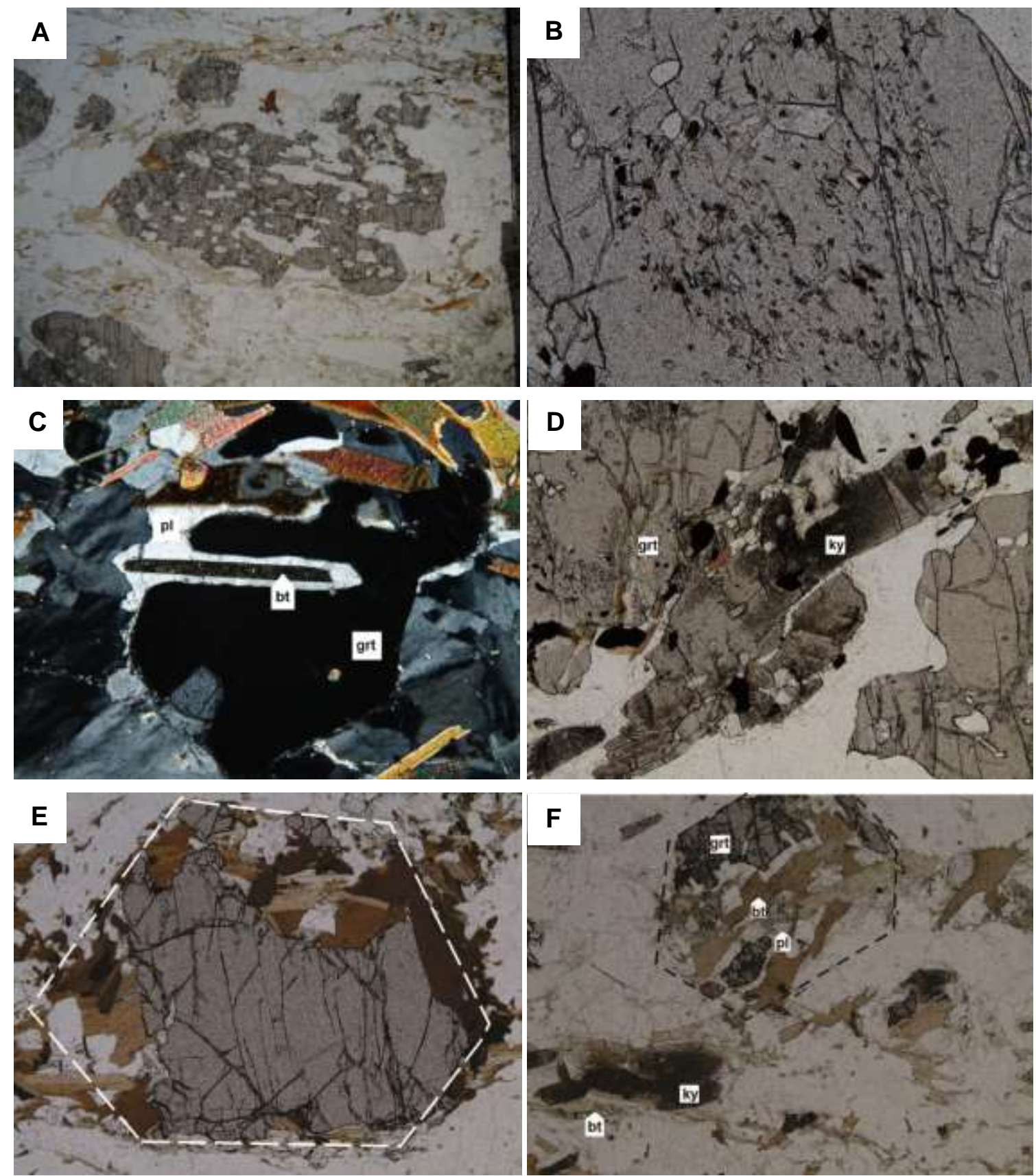

Figura 22 - Fotomicrografias. a) TPR-01-O. Granada com aspecto esqueletal repleta de inclusões de quartzo e plagioclásio no resíduo do rt-ky-grt granulito (Polarizador inferior; largura 12,0 mm); b) TPR-01-Z. Granada com inclusões arredondadas de quartzo e muito finas de rutilo, monazita e zircão, no resíduo do rt-ky-grt granulito (Polarizador inferior; largura 1,5 mm); c) TPR-01-U. Associação retrometamórfica de biotita, plagioclásio e granada (granada = biotita + plagioclásio) no resíduo do rt-ky-grt granulito (Polarizadores cruzados; largura 1,5 mm); d) TPR-01-Z. Cianita prismática orientada junto à granada do resíduo do rt-ky-grt granulito (Polarizador inferior; largura 3,5 mm); e) TPR-01-X1. Biotita retrometamórfica alterando bordas e fraturas de granada do resíduo do rtky-grt granulito (Polarizador inferior; largura 3,5 mm); f) TPR-01-K. Biotita e plagioclásio retrometamórficos substituindo granada. $\mathrm{Na}$ área inferior da imagem, biotita e cianita como cristais subidioblásticos orientados na foliação do resíduo do rt-ky-grt granulito (Polarizador inferior; largura 3,5 mm). 
O leucossoma, porção mais abundante do pacote, forma leitos contínuos ou, por vezes, discordantes do bandamento composicional, de espessura centimétrica a decimétrica, textura granoblástica e granulação fina à grossa, é composto por proporções variadas de feldspato potássico, plagioclásio, quartzo, granada porfiroblástica, rutilo e rara cianita (Figura 21). Apatita, monazita e zircão são minerais acessórios, enquanto muscovita/ sericita, clorita e biotita, secundários. Apresenta estrutura tanto maciça quanto orientada. São comuns dobras assimétricas que indicam vergência para leste (Figura 23). O leucossoma é branco, mas veios de granulação grossa (superior à sua granulação característica) são comuns entre camadas mais competentes compostas predominantemente por biotita. Esse tipo de textura pode ser explicado devido à relativa segregação do material fundido, conferindo-lhe maior período de cristalização (Figura 23).

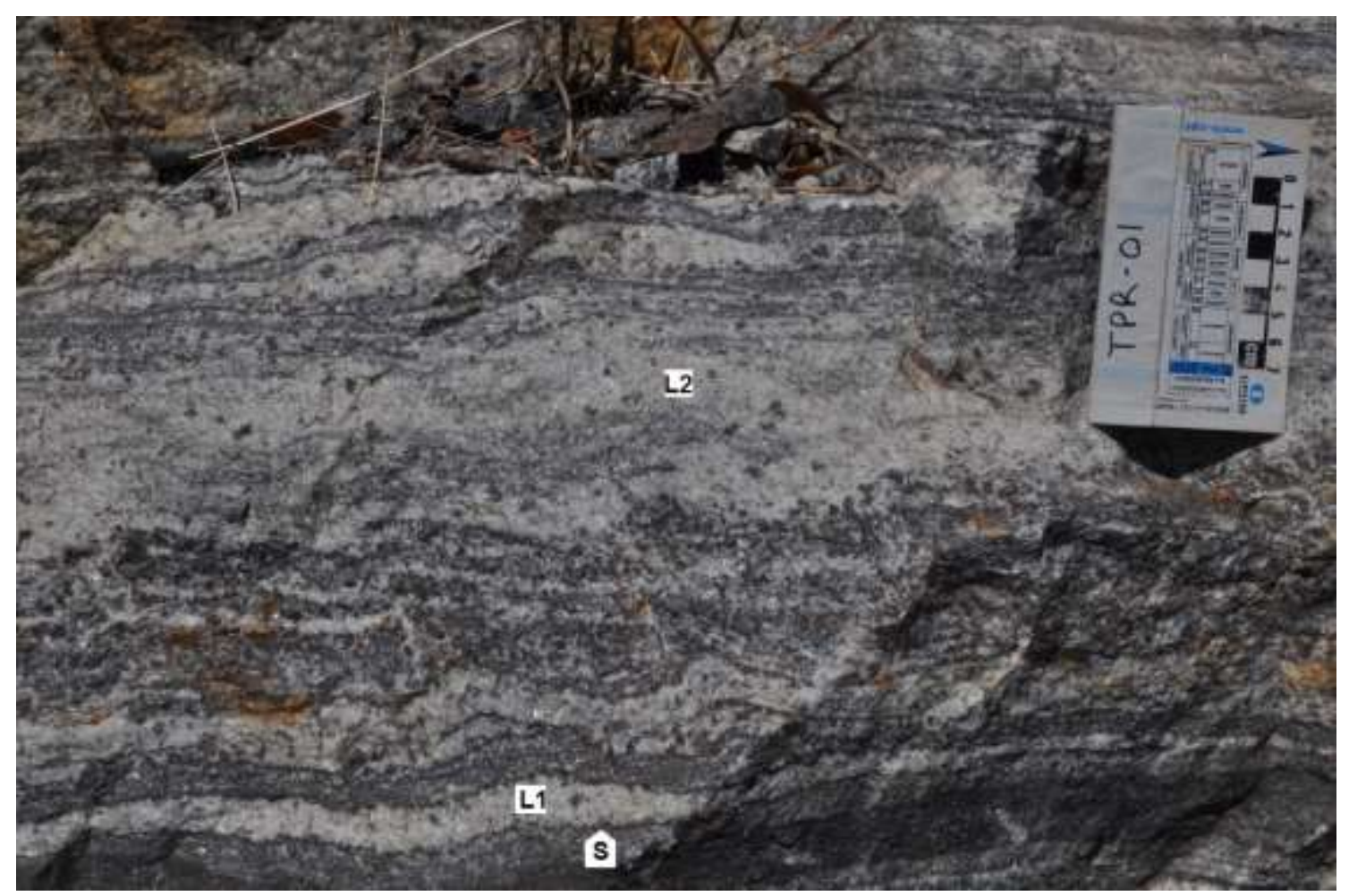

Figura 23 - TPR-01. Cianita-granada granulito migmatítico com veios de leucossoma, o que gera estrutura estromática (L1), dobras assimétricas vergentes para ENE e selvedge (S) de biotita. Leucossoma grosso (L2) em porção entre camadas mais competentes ricas em biotita. Orientação ENE-WSW. 
O microclínio é subidioblástico com bordas retas a irregulares que formam entre si contatos retos, por vezes junções tríplices de $120^{\circ}$, interlobados e/ou suturados, podendo também apresentar exsoluções de plagioclásio. Muitas vezes ocorre como mega cristais. Quartzo apresenta extinção ondulante, eventualmente bordas irregulares, e em amostras deformadas forma fitas (ribbons) alongadas paralelamente ao bandamento em contatos arredondados e irregulares/ suturados com os outros minerais (Figura 24b). Plagioclásio, nem sempre presente no leucossoma, se mostra semelhante ao microclínio, é subidioblástico, pode ocorrer como mega cristal, forma comuns junções triplas de $120^{\circ}$, e se concentra em pequenos agregados monominerálicos. Quando em cristais maiores são características as exsoluções de microclínio (Figura 24c). Granada é principalmente porfiroblástica com cristais que chegam a $1 \mathrm{~cm}$, porém às vezes é ausente, subidioblástica com bordas arredondadas, possui inclusões finas de quartzo (arredondadas e angulosas) que podem ser orientadas em trilhas ou formarem agregados poligonizados, de microclínio (angulosos), rutilo (Figura 24d), plagioclásio, monazita e zircão. O rutilo no leucossoma é mais bem formado quando comparado ao do resíduo, fino e subidioblástico a xenoblástico, apresenta comumente bordas retas e associa-se à granada em suas bordas ou incluso. Cianita é rara, porém quando presente é fina e tabular, e ocorre junto à granada (Figura 24e). Biotita altera granada em bordas e fraturas, e muscovita/ sericita (-\%) é alteração de microclínio e biotita. 

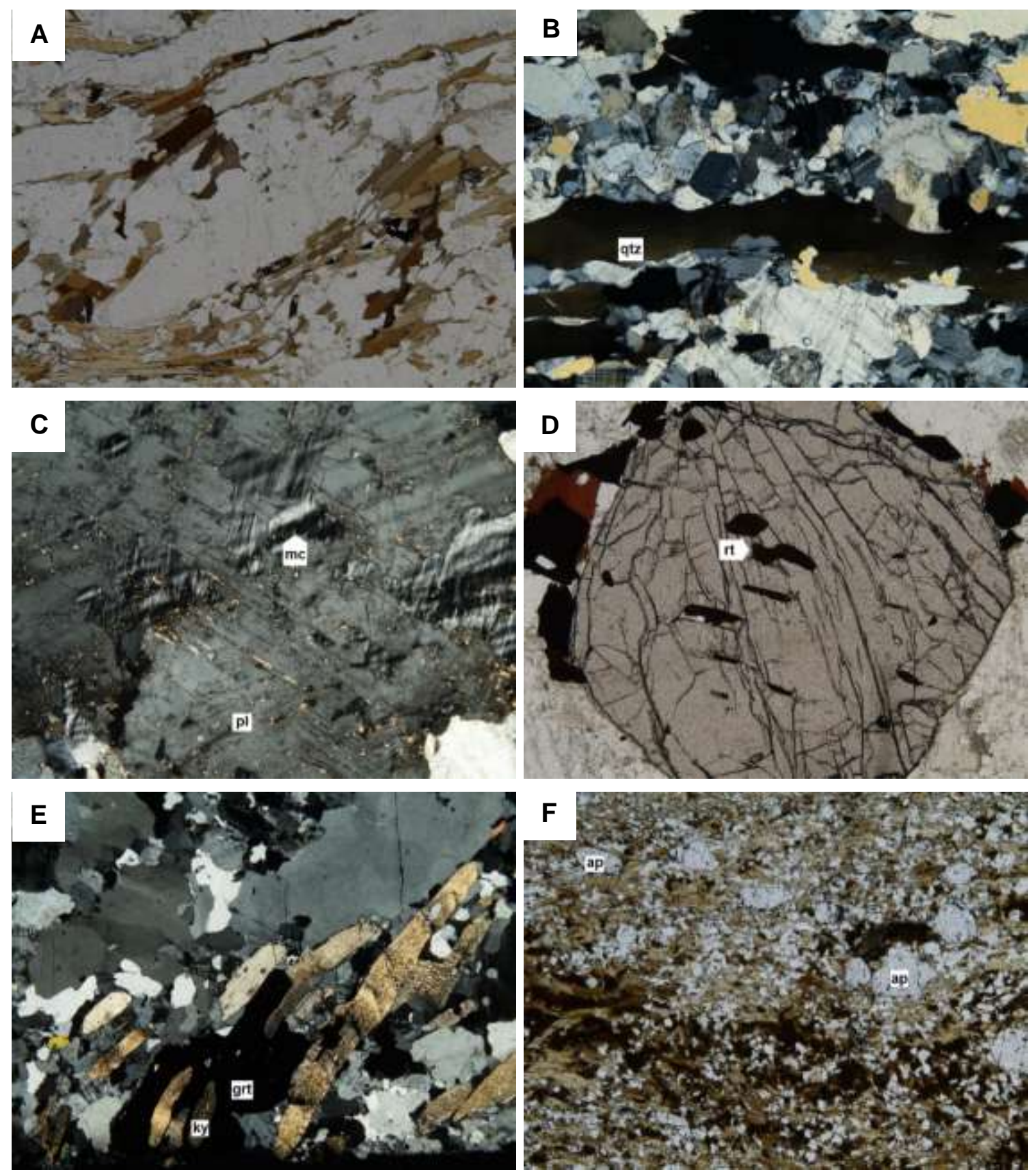

Figura 24 - Fotomicrografias. a) TPR-01-Q. Indicador cinemático quartzo-feldspático tipo fish amoldado por biotita no resíduo do rt-ky-grt granulito (Polarizador inferior; largura 3,5 mm); b) TPR-01-I. Ribbon de quartzo em leucossoma do rt-ky-grt granulito deformado. Notar os contatos arredondados e suturados com os demais minerais (Polarizadores cruzados; largura 3,5 mm); c) TPR-01-I. Exsoluções de microclínio em megacristais de plagioclásio de leucossoma do rt-ky-grt granulito (Polarizadores cruzados; largura 3,5 mm); d) TPR-01-U. Inclusões de rutilo prismático em granada do leucossoma (Polarizador inferior; largura 3,5 mm); e) TPR-01-X2. Cristais prismáticos de cianita orientados e inclusos em granada no leucossoma do rt-ky-grt granulito (Polarizadores cruzados; largura $3,5 \mathrm{~mm}$ ); f) TPR-01-A. Rocha protomilonítica: porção de granulação fina rica em biotita com quartzo e plagioclásio e porfiroclastos médios de apatita (Polarizador inferior; largura 3,5 mm). 
O contato entre leucossoma e melanossoma é retilíneo quando há leitos contínuos de espessura milimétrica de biotita retrometamórfica (selvedge) separando-os (Figura 23), ou gradual/ difuso quando é possível observar a segregação do material fundido (Figura 25). Estruturas boudinadas (Figura 21 e Figura 26) ocorrem em melanossoma dentro de leucossoma, possuem espessuras centimétricas, e se adelgaçam até desaparecer. O contato superior entre melanossoma e leucossoma é retilíneo, enquanto que o inferior, difuso, indicando uma diferença de reologia entre as diferentes porções do melanossoma, com o topo mais competente (local de maior atuação da deformação rúptil) e a base plástica (Figura 26). Esse contato também indica a segregação do leucossoma a partir do resíduo peritético rico em granada, ou aqui denominado de melanossoma.

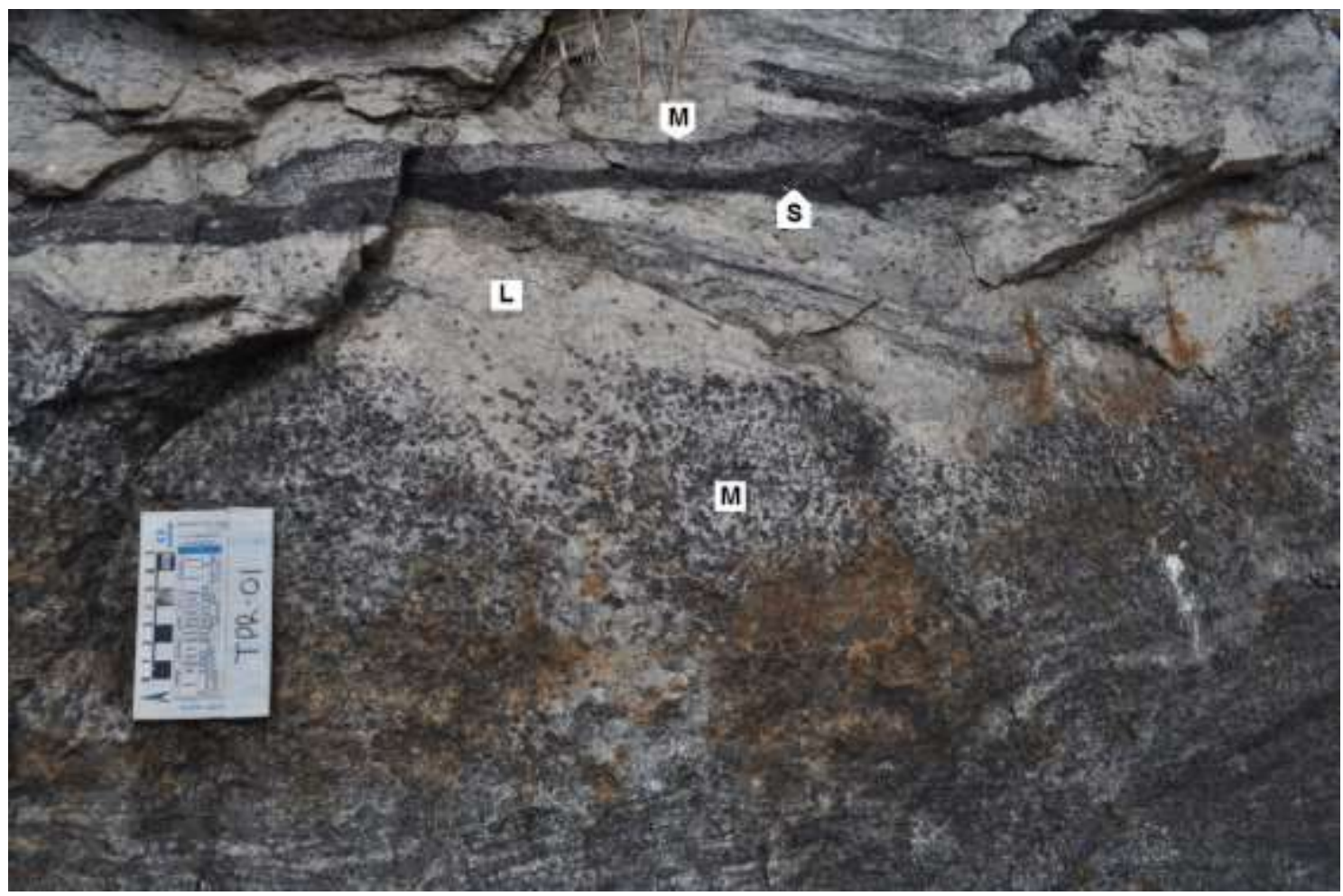

Figura 25 - TPR-01. Cianita-granada granulito migmatítico apresentando contato difuso entre melanossoma (M) e leucossoma (L); leito contínuo de espessura centimétrica composto por biotita retrometamórfica/ selvedge (S) entre leucossoma (L) e melanossoma (M). O melanossoma é formado por aglomerado de granada, cianita rutilo e feldspato potássico. Na porção central da foto é possível perceber o contato transicional entre o melanossoma e leucossoma, o que permite inferir a segregação do último a partir do primeiro. Orientação ENE-WSW. 


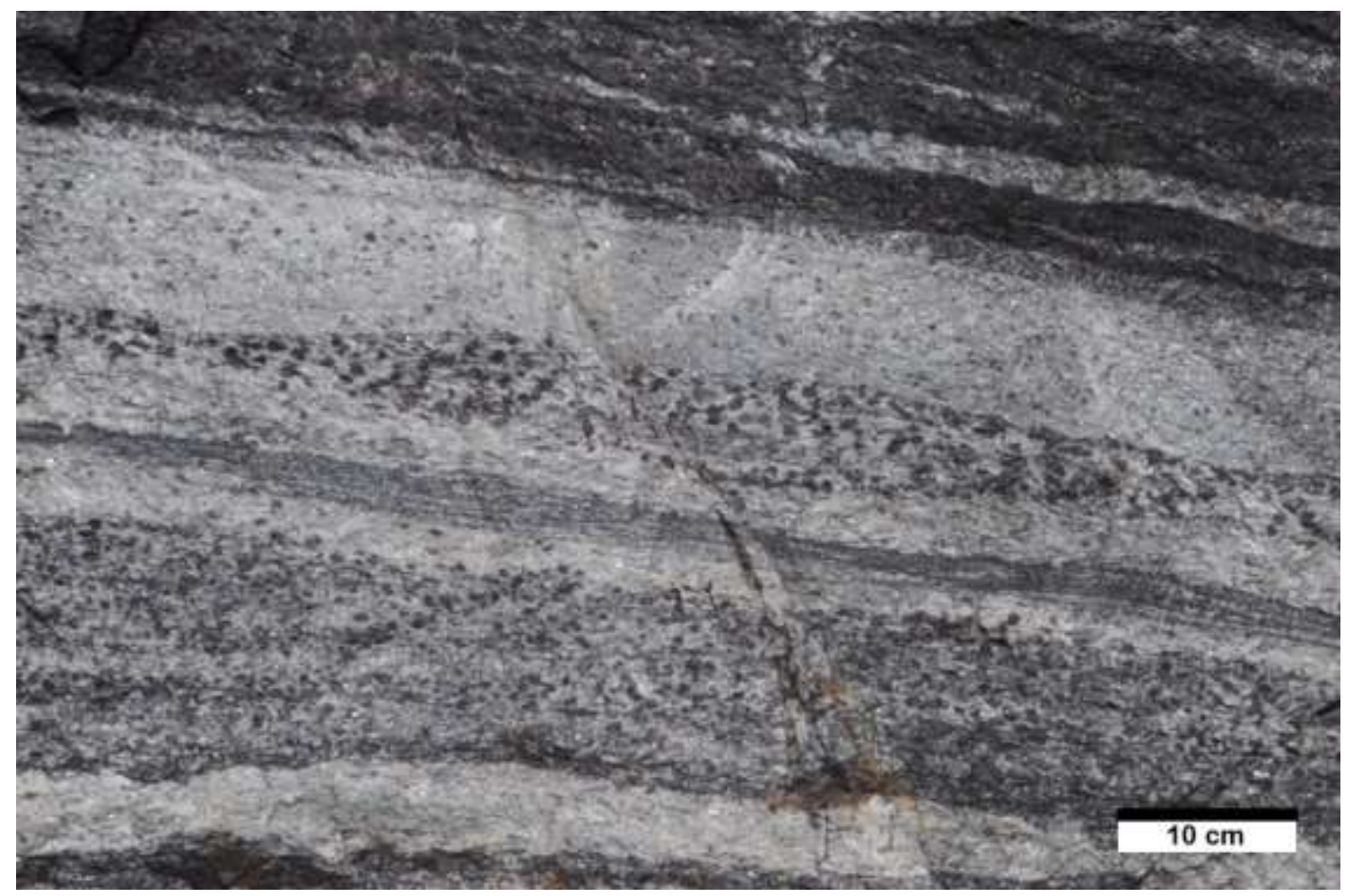

Figura 26 - TPR-01. Boudin em melanossoma no interior de leucossoma. Notar contato superior retilíneo e inferior difuso, indicando diferença nas reologias do melanossoma, com o topo mais competente que a base. Orientação ENE-WSW.

A princípio, toda a biotita existente na rocha metapelítica é interpretada como produto de retrometamorfismo. Além de substituir porfiroblastos de granada pode se concentrar em leitos de espessuras centimétricas a decimétricas, contínuos a descontínuos, podendo ser confundido com o paleossoma (Figura 25). Localmente ocorrem porções em que a biotita foi completamente exaurida pelas reações de fusão.

Em locais restritos essa rocha encontra-se em foliação protomilonítica, é rica em biotita (25-40\%) com matriz de quartzo e plagioclásio, apatita, e profiroclastos de escapolita, hornblenda e granada, rara cianita, com monazita e zircão de minerais acessórios. Varia de porções com granulação muito fina a fina, lepidogranoblásticas, ricas em biotita, com quartzo e plagioclásio, e porfiroclastos de apatita, escapolita, hornblenda e granada, subidioblásticos em granulação fina à média (Figura 24f e Figura 27a), a porções de mesma textura, porém de maior granulação geral (fina), que diminuem na proporção de biotita e aumentam nas de plagioclásio e quartzo, com porfiroclastos médios (1-3mm) subidioblásticos e alongados de granada, paralelos a orientação da rocha, de plagioclásio subidioblástico comumente manteado pelo mesmo mineral mas em porções policristalinas (Figura 27b), e fitas de quartzo (Figura 27c). Há leitos granoblásticos formados por plagioclásio (70\%) e quartzo (30\%), que comumente se afinam ou formam sigmoides policristalinos (Figura 27b). Cristais de plagioclásio são subidioblásticos a idioblásticos e formam entre si contatos retos com comuns junções triplas de $120^{\circ}$. Quartzo possui formas alongadas segundo a foliação, constitui fitas, 
apresenta bordas suturadas e ocorre como subgrãos arredondados gerados por recristalização por migração de borda. Há inclusões finas e orientadas em granada de prismas de rutilo, quartzo arredondado a alongado, biotita lamelar e raramente de cianita e plagioclásio (Figura 27d). Biotita além de fornecer a marcada foliação da rocha, amolda e cria sombras de pressão em porfiroclastos de granada, forma foliação oblíqua a principal com pares S-C (Figura 27e), e altera granada em bordas e fraturas. Monazita e zircão ocorrem distribuídos pela rocha e inclusos em granada. 

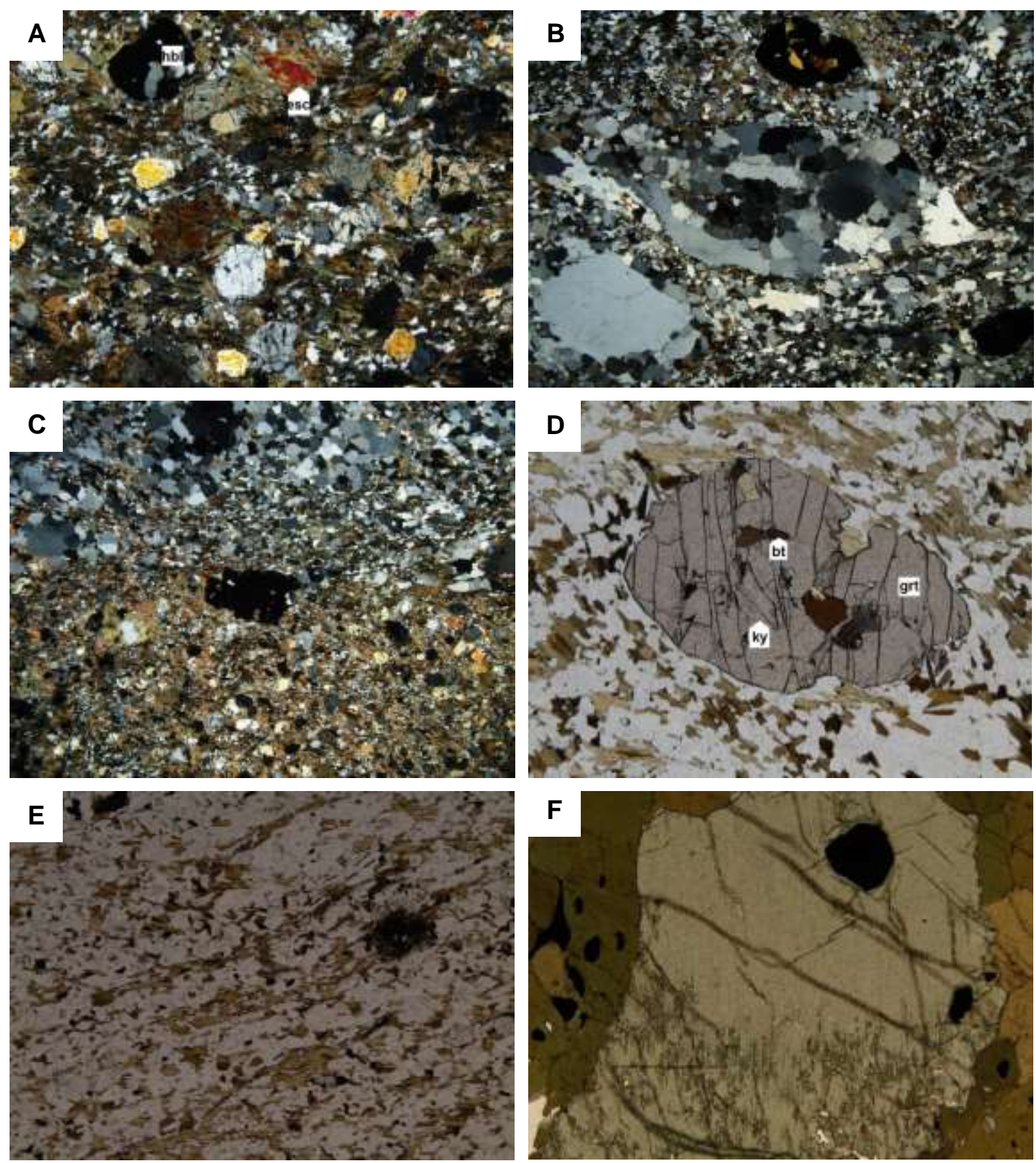

Figura 27 - Fotomicrografias. a) TPR-01-D. Rocha protomilonítica: porção de granulação fina rica em biotita com quartzo e plagioclásio e porfiroclastos médios de escapolita e hornblenda (Polarizadores cruzados; largura 3,5 $\mathrm{mm}$ ); b) TPR-01-A. Rocha protomilonítica: porção de granulação fina com menor proporção de biotita comparada a de menor granulação. No centro da foto, sigmoide policristalino composto por plagioclásio (70\%) e quartzo (30\%). No canto inferior esquerdo, porfiroclasto médio de plagioclásio manteado por porção policristalina do mesmo mineral em menor granulação (Polarizadores cruzados; largura 12,0 mm); c) TPR-01-D. Visível bimodalidade de bandas, ambas lepidogranoblásticas, com a inferior de granulação muito fina a fina, rica em biotita com porfiroclastos de apatita, granada e escapolita, e a superior de granulação fina e menor proporção de biotita (Polarizadores cruzados; largura 12,0 mm); d) TPR-01-A. Porfiroblasto de granada com inclusões de cianita e biotita (metamorfismo progressivo) (Polarizador inferior; largura 3,5 mm); e) TPR-01-T. Foliação (biotita) oblíqua à principal (Polarizador inferior; largura 3,5 mm); f) TPR-01-E2. Rocha residual máfica: cristal de ortopiroxênio com inclusões de minerais opacos envoltos por honblenda. Esta também ocorre alterando clivagem de ortopiroxênio (Polarizador inferior; largura 3,5 mm). 


\subsubsection{Rocha residual máfica}

Em contato abrupto ou interdigitado com o metapelito há rocha residual máfica. Tal rocha apresenta duas porções de diferentes cores e composições, uma melanocrática, classificada como rocha residual rica em hornblenda, com granada, clinopiroxênio e ortopiroxênio, e outra leucocrática, de composição tonalítica com fenocristais de hornblenda, clinopiroxênio e granada, como leucossoma. Uma terceira porção reconhecida em locais restritos como leitos de espessura de poucos centímetros, possui cor intermediária às duas principais (cinza) e trata-se de rocha residual relativamente preservada que ainda possui considerável proporção de clinopiroxênio e plagioclásio, além de hornblenda e quartzo.

O resíduo melanocrático é mais abundante em relação às outras rochas, possui estrutura orientada, é granonematoblástico, de granulação média a grossa. É rico em hornblenda (>80\%) subidioblástica a idioblástica que forma contatos retos, comumente junções típlices de $120^{\circ}$ ou terminações afinadas em cúspide, possui ainda clinopiroxênio e raro ortopiroxênio, ambos subidioblásticos e alterados por hornblenda nas bordas e em fraturas (no caso do ortopiroxênio essa alteração ocorre junto à clivagem e como "coroas" em inclusões de minerais opacos; opx+opaco=hbl - sistema aberto; Figura 27f), quartzo e plagioclásio intersticiais, como filmes estreitos e alongados com comuns terminações afinadas em cúspide (Figura 28a), e continuidade ótica (Figura 28b). Inclusões arredondadas de quartzo em hornblenda também são comuns. Como mineralogia acessória apresenta biotita subidioblástica a xenoblástica que substitui hornblenda ou se distribui de forma aleatória ou orientada em textura lepidoblástica incipiente, minerais opacos, que além de inclusos em hornblenda podem ser intersticiais, comumente associados à hornblenda (consumida no retrometamorfismo com preenchimento principalmente de plagioclásio em suas clivagens), plagioclásio, biotita e carbonato também xenoblásticos/ intersticiais (retrometamorfismo relacionado à fusão parcial; leucossoma com considerável proporção de $\mathrm{CO}_{2}$, o que explica escapolita e carbonato; Figura 28c), rutilo subidioblástico a prismático idioblástico, escapolita subidioblástica, apatita arredondada e titanita intersticial e/ou envolvendo rutilo e opacos da matriz próximos a leucossoma (opaco+plagioclásio=titanita; Figura 28d) ou inclusos em ortopiroxênio com hornblenda associada (opaco+hornblenda topx=titanita; Figura 28e). Em algumas porções, geralmente próximas a finos leucossomas, há intercrescimento de hornblenda e plagioclásio (Figura 28f). 

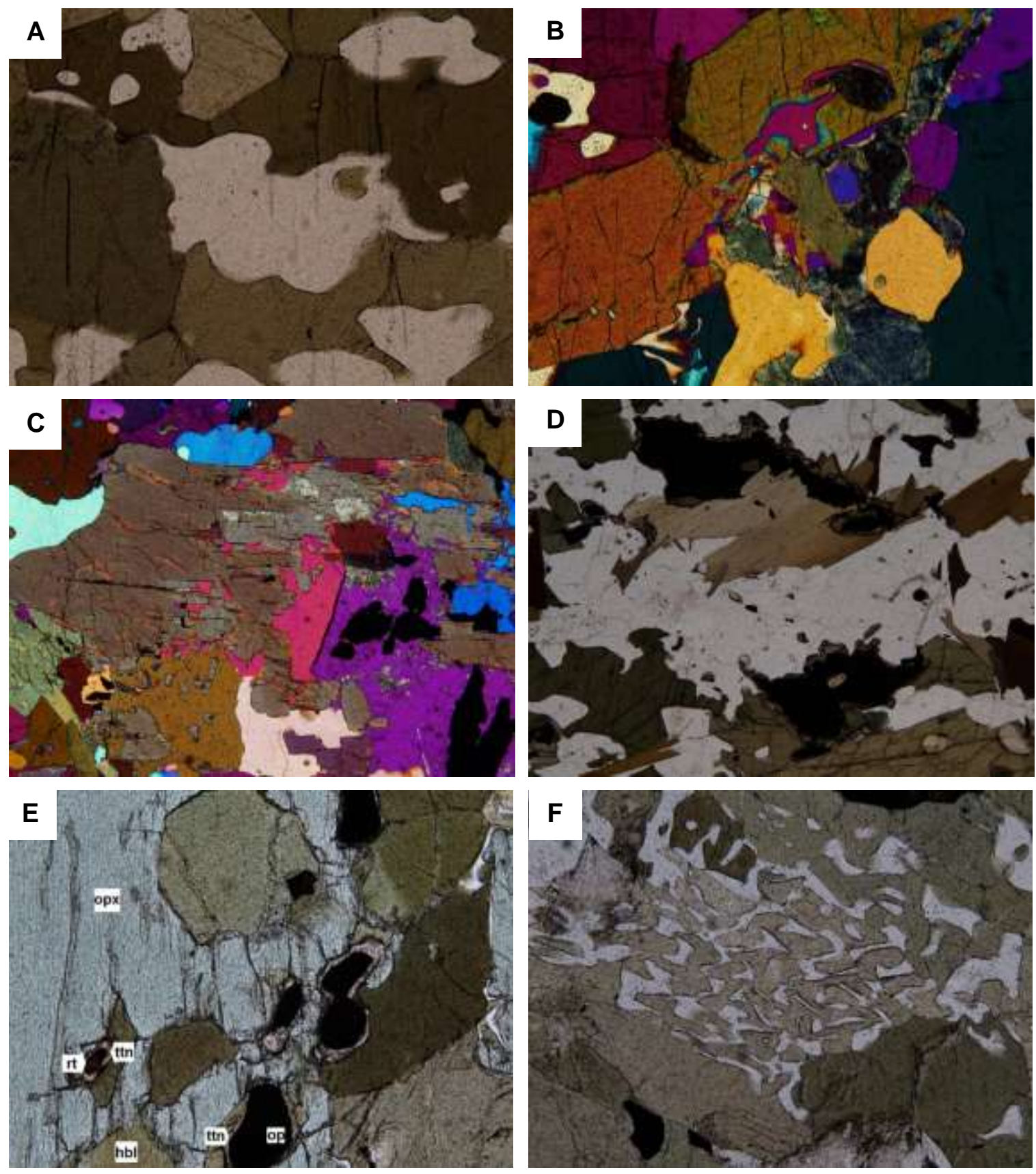

Figura 28 - Fotomicrografias. a) TPR-01-E1. Rocha residual máfica com filmes de quartzo de terminações em cúspide (Polarizador inferior; largura 1,5 mm); b) TPR-01-N. Rocha residual máfica: Em cor rosa na porção central superior ocorrem filmes de quartzo com continuidade ótica entre cristais de hornblenda (fusão parcial in-situ) (Polarizadores cruzados + acessório; largura 1,5 mm); c) TPR-01-G2. Retrometamorfismo na rocha residual máfica com geração de biotita (marrom), plagioclásio (rosa), carbonato (lilás) e opacos (preto) a partir de hornblenda (cristal verde desmembrado) + fluido rico em $\mathrm{CO}_{2}$ (presença de carbonato, e escapolita no leucossoma) (Polarizadores cruzados + acessório; largura 1,5 mm); d) TPR-01-S1. Biotita e opaco xenoblástico coroado por titanita em porção de resíduo próxima a leucossoma (Polarizador inferior; largura 3,5 mm); e) TPR-01-L. Inclusões de opacos e rutilo coroados por titanita em ortopiroxênio com hornblenda associada (opaco+hbl \pm opx=titanita) (Polarizador inferior; largura 1,5 mm); f) TPR-01-M. Intercrescimento de hornblenda e plagioclásio próximo a leucossomas in-situ no resíduo máfico (Polarizador inferior; largura 1,5 mm). 
A rocha residual, quando mais preservada, é cinza, de granulação geral fina com cristais de até $1 \mathrm{~mm}$. É composta principalmente por clinopiroxênio, plagioclásio e quartzo, com hornblenda, opacos, biotita e apatita em menores proporções. Clinopiroxênio é fino, subidioblástico, se distribui homogeneamente pela rocha e é alterado por hornblenda a partir das bordas e em fraturas (Figura 35a). Essa alteração é tão maior quanto mais próxima essa porção estiver do resíduo rico em hornblenda, sendo que este mineral raramente apresenta formas bem desenvolvidas de hábito prismático. Plagioclásio é subidioblástico a xenoblástico/ intersticial, forma contatos retos entre si com comuns junções triplas de $120^{\circ}$, a arredondados principalmente com o quartzo. Este em sua maioria é intersticial, arredondado, e apresentase também como subgrãos e inclusões arredondadas em clinopiroxênio e plagioclásio. Raramente com bordas bem definidas e contatos retos, ocorre também como filmes vermiformes junto a clinopiroxênio. Minerais opacos ocorrem principalmente junto aos máficos, com formas granulares a alongadas e intersticiais (Figura 35a). Biotita subidioblástica e apatita arredondada são raras e aleatórias. A transição entre os diferentes resíduos é representada por banda milimétrica de coloração pouco mais clara que a rocha rica em hornblenda (devido à maior proporção relativa de quartzo; 25\%), nematoblástica, formada principalmente por hornblenda subidioblástica a idioblástica em contatos retos entre si e quartzo intersticial de extinção ondulante, com bordas arredondadas e comuns terminações em cúspide, e como inclusões finas e arredondadas em hornblenda. A mineralogia acessória é composta por minerais opacos intersticiais e biotita subidioblástica a idioblástica, ambos em granulação fina e distribuídos aleatoriamente.

O leucossoma tonalítico se apresenta como leitos paralelos à foliação, de espessura milimétrica a centimétrica, como patches indicando fusão in-situ, ou orientados de maneira oblíqua à foliação (in-source), concordantes às dobras assimétricas presentes em ambas as rochas, em regiões de alívio de pressão, como região surreítica de boudins, e ainda alimentando os veios maiores (Figura 29). Em locais restritos o contato entre leucossoma e resíduo é interdigitado/penetrativo, indicando o evento de segregação do material fundido (Figura 30).

O material fundido ocorre em porções boudinadas (Figura 31) e envolve blocos do resíduo, rotacionados segundo a deformação vigente (movimentos de topo para leste; Figura 32). A evolução da fusão parcial em certos locais desmembra a rocha totalmente criando estruturas tipo schollen. É comum a presença de porfiroblastos de hornblenda e clinopiroxênio, sendo o último comumente apresentando coroas retrometamórficas do primeiro mineral (Figura 33). Leitos de espessuras milimétricas a centimétrica compostos por hornblenda retrometamórfica/ selvedge são comuns entre leucossoma e resíduo (Figura 34). 


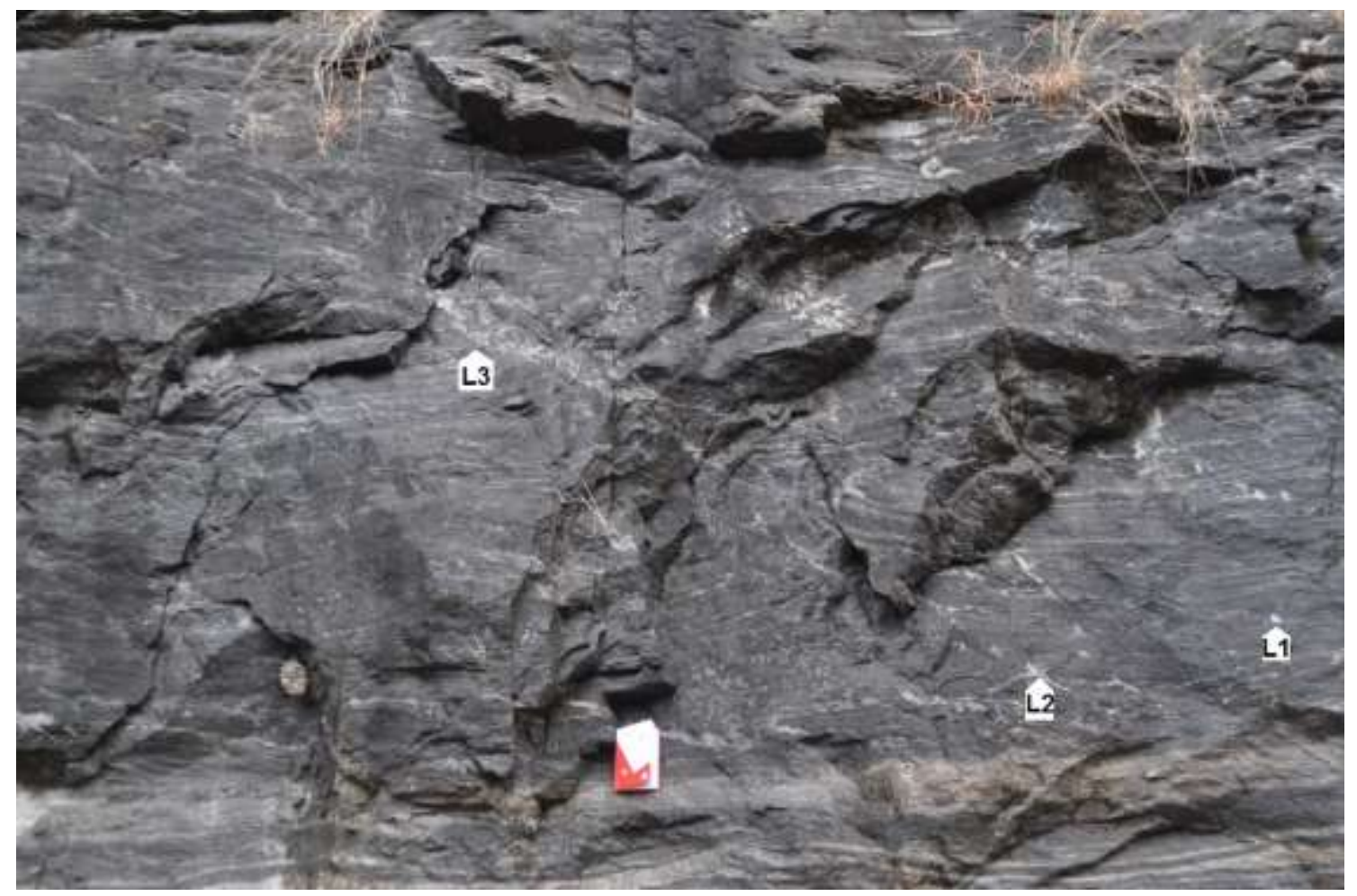

Figura 29 - TPR-01. Rocha residual máfica composta essencialmente pelo resíduo melanocrático (hornblenda) e diferentes veios de leucossoma: in-situ (L1), in-source (L2) e em veios (L3). O desenvolvimento de L1 leva à geração de L2, e com o aumento da fusão parcial, L3 em regiões de alívio de pressão. Notar orientação do veio L3 concordante à das dobras do ri-ky-grt granulito migmatítico. Orientação ENE-WSW.

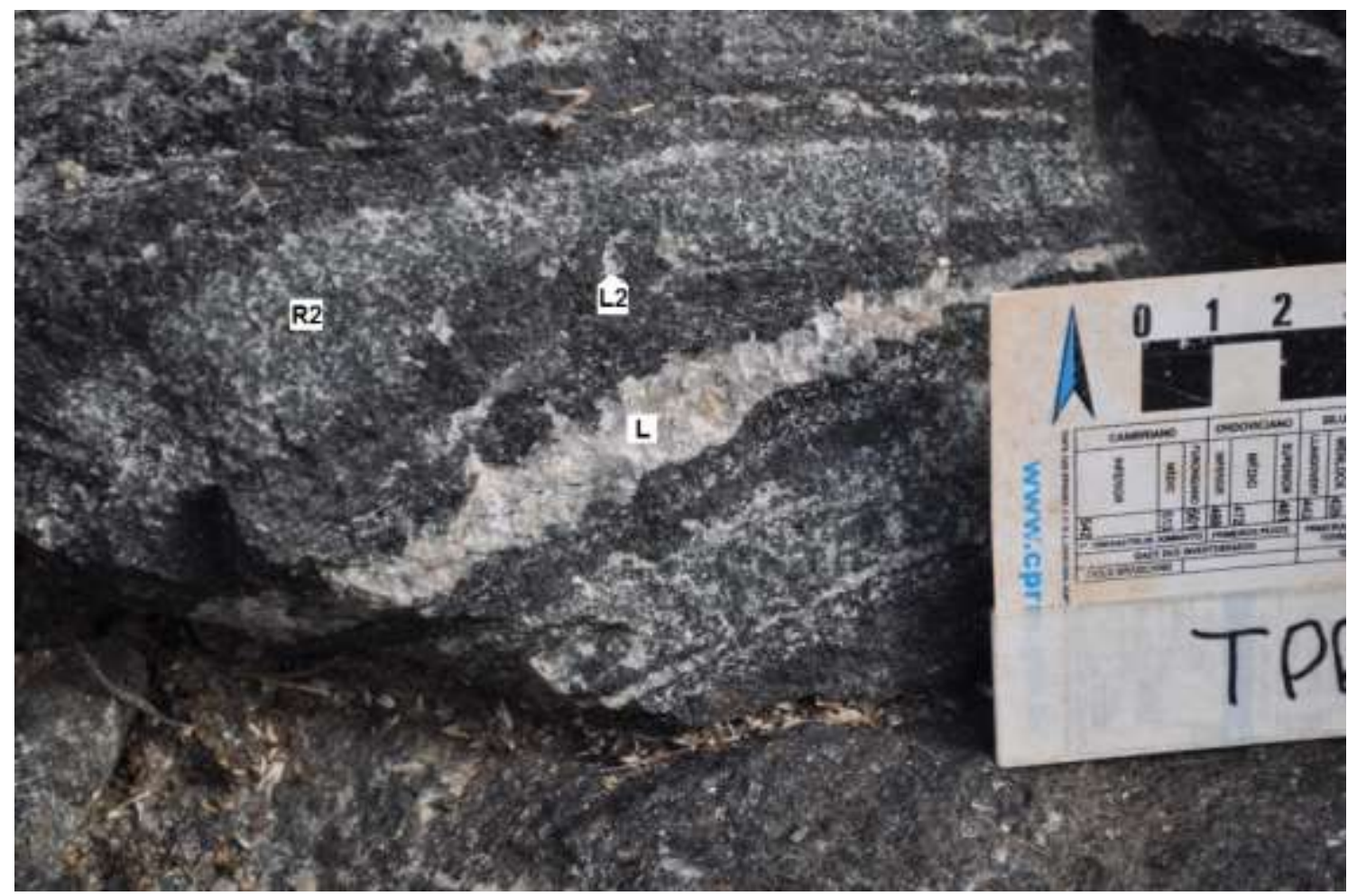

Figura 30 - TPR-01. Contato interdigitado/ penetrativo entre leucossoma (L) e resíduo máfico. Banda de espessura centimétrica de resíduo menos alterado portador de plagioclásio (R2). Notar contatos também interdigitados entre resíduo com e sem plagioclásio, com plagioclásio concentrado em pequenos veios de leucossoma in-situ (L2). 


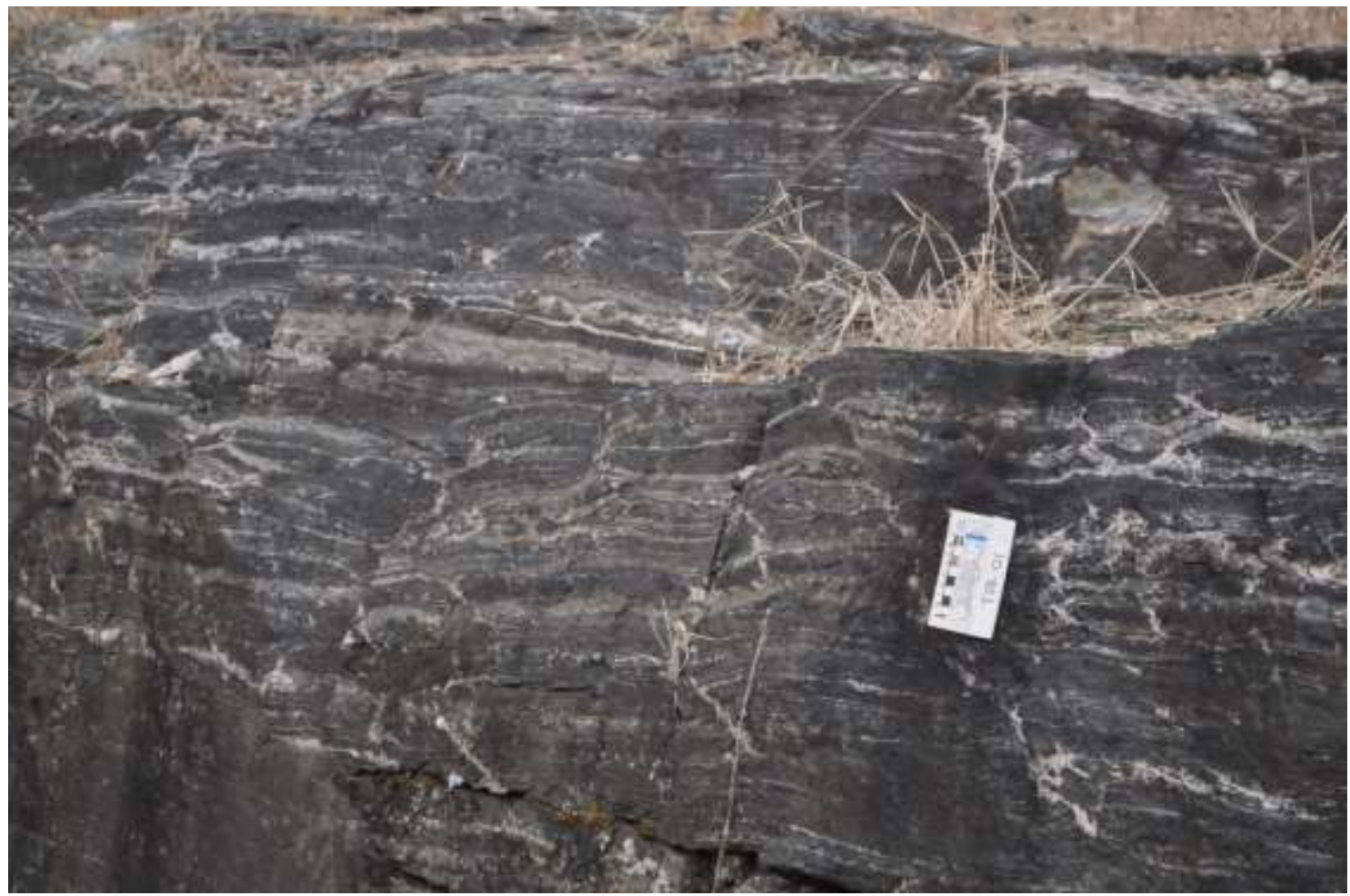

Figura 31 - TPR-01. Boudins centimétricos na rocha residual básfica com zonas surreíticas preenchidas por leucossoma tonalítico. Veios de leucossoma in-situ e in-source. Orientação ENE-WSW.

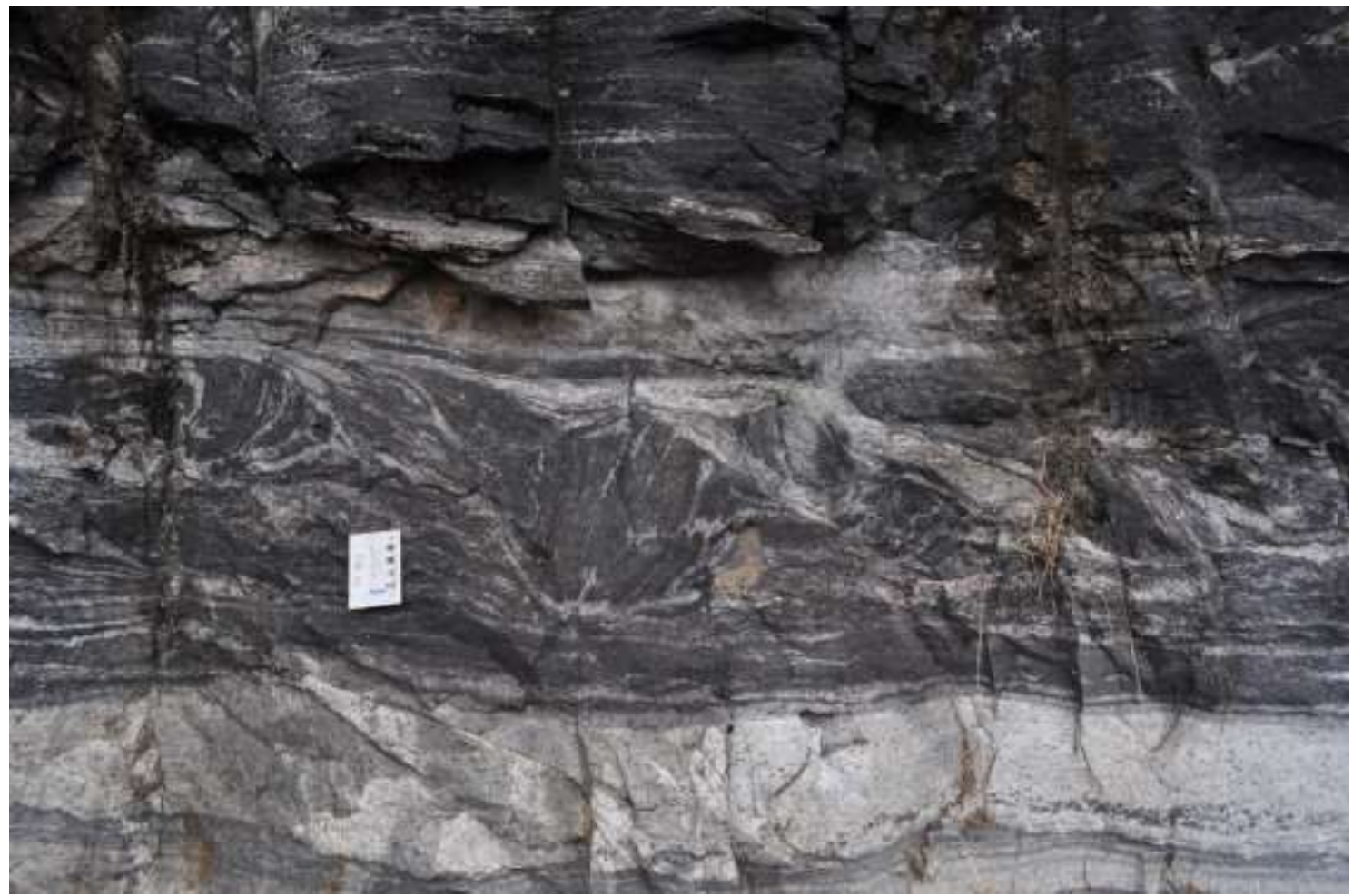

Figura 32 - TPR-01. Bloco rotacionado de rocha máfica residual com movimento indicando topo para leste. A evolução da fusão parcial aumenta a quantidade de leucossoma, que envolve e movimenta pedaços maiores de resíduo. A evolução desse quadro leva a estruturas do tipo schollen. Notar penetrações de material fundido no bloco em direção perpendicular à foliação. Orientação ENE-WSW. 


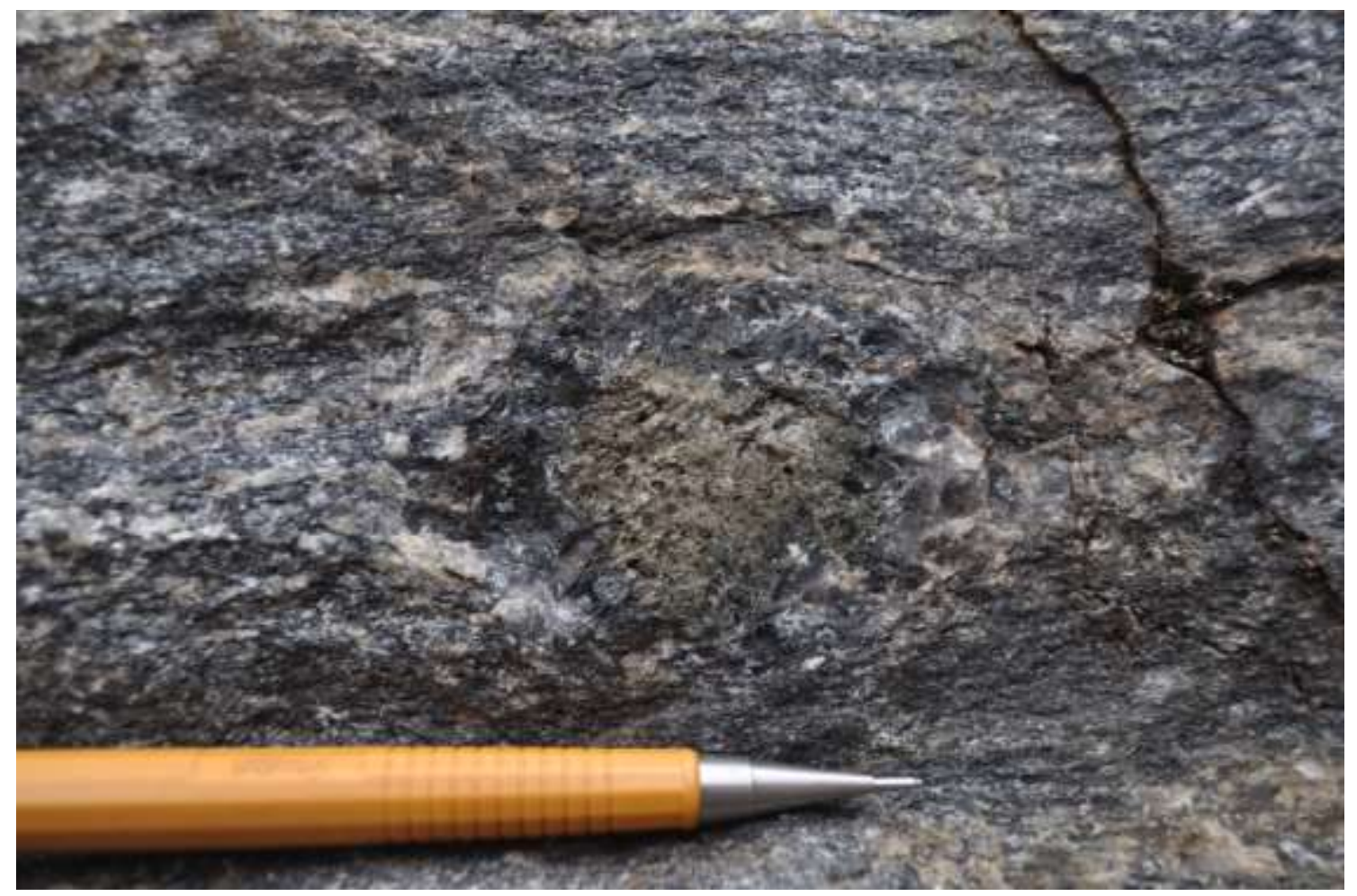

Figura 33 - TPR-01. Leucossoma com porfiroblasto centimétrico de clinopiroxênio envolto por coroa de hornblenda retrometamórfica.

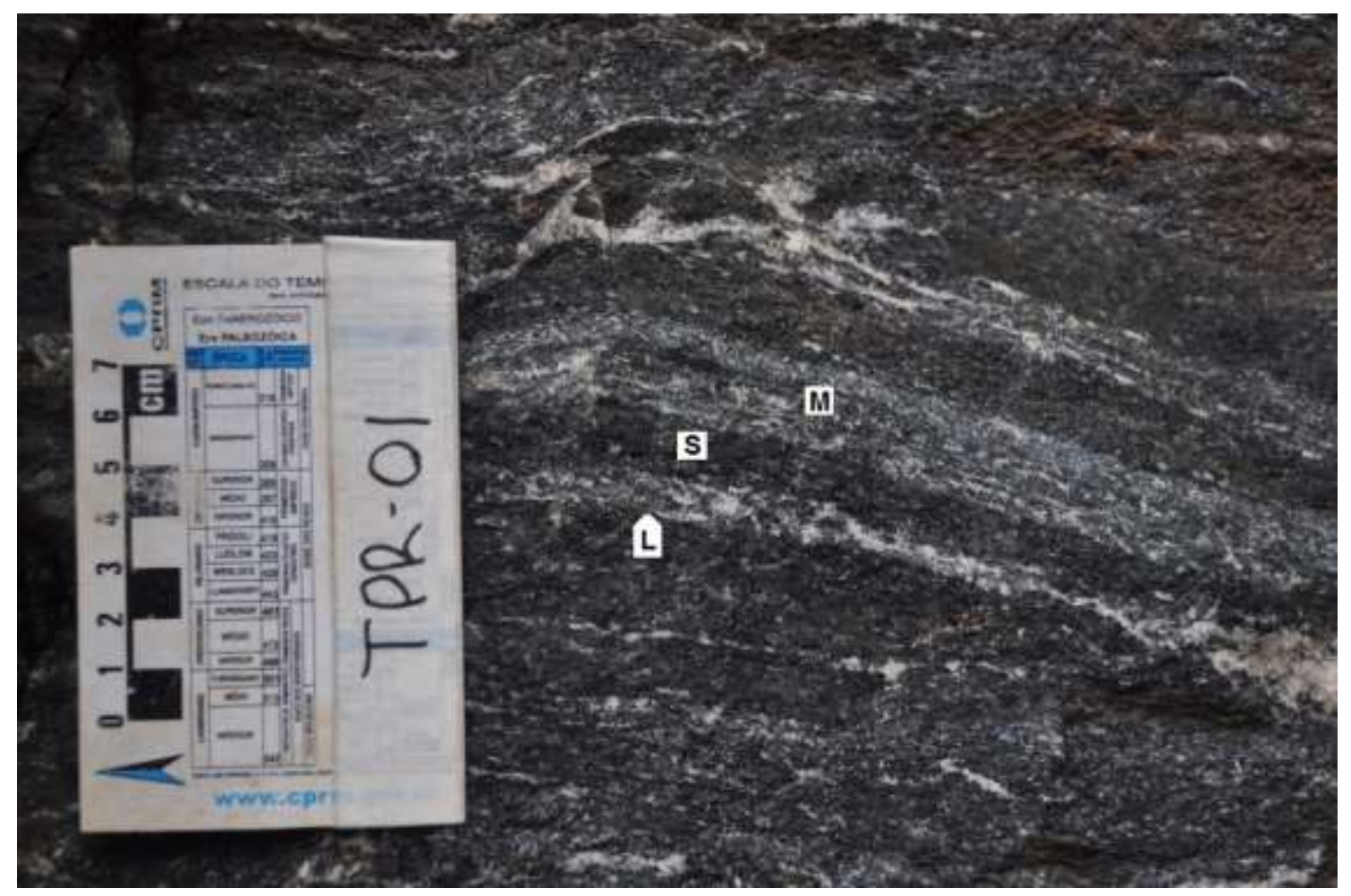

Figura 34 - TPR-01. Bandamento centimétrico que alterna leitos de resíduo (M), leucossoma com porfiroblastos de clinopiroxênio $(\mathrm{L})$ e de hornblenda retrometamórfica/ selvedge (S). 
Os minerais do resíduo no contato com o leucossoma têm bordas arredondadas e por vezes estão desagregados. O leucossoma é tonalítico, maciço ou orientado (fitas de quartzo), com textura granoblástica, composto predominantemente por plagioclásio (andesina An 3035) fino a médio, tabular em contatos retos entre si, por vezes em junções tríplices de $120^{\circ}$, e comumente alterado por sericita, com quartzo fino subidioblástico a xenoblástico/ intersticial com bordas arredondadas, e médio a grosso em formas alongadas, xenoblásticas, paralelo ao bandamento, com bordas suturadas e subgrãos gerados por migração de borda, clinopiroxênio subidioblástico a xenoblástico, comumente alterado por hornblenda a partir das bordas (Figura 35b), e cristais de hornblenda subidioblásticos a xenoblásticos de bordas arredondadas com opacos associados (Figura 35c). É comum o leucossoma se apresentar como veios finos (espessura entre 1 e $3 \mathrm{~mm}$ ) com plagioclásio e quartzo de granulação fina em textura granoblástica, formando contatos retos e junções triplas de $120^{\circ}$. Provavelmente devido a suas menores dimensões, ficou protegido da deformação e preservou texturas ígneas (Figura 35d). Outros leucossomas são característicos por apresentar cristais grossos $(0,4$ a $1,4 \mathrm{~cm})$ que raramente estão em contato, envoltos por porções granoblásticas de granulação fina a média de mesma composição, com hornblenda, biotita, apatita, escapolita, carbonato, feldspato potássico e titanita que juntos somam por volta de $1 \%$. Os cristais grossos são subidioblásticos com bordas irregulares que criam contatos desde suturados e arredondados a retos, estes raros quando o quartzo está envolvido. As porções intersticiais aos cristais maiores são formadas por plagioclásio subidioblástico a idioblástico e quartzo subidioblástico a xenoblástico/ intersticial. Entre cristais de plagioclásio os contatos são retos com comuns junções triplas de $120^{\circ}$, e quando há quartzo, prevalecem os contatos sinuosos a suturados com geração de subgrão por migração de borda. Ocorre hornblenda subidioblástica a idioblástica comumente alterada por biotita nas bordas (biotita também ocorre em pequenas porções de cristais subidioblásticos a xenoblásticos finos desorientados). Junto à hornblenda podem ocorrer minerais opacos, titanita comumente manteando-os e carbonato intersticial. Feldspato potássico é intersticial de granulação fina, por vezes parcialmente incluso em plagioclásio. É comum a presença de escapolita em proporções consideráveis (20-30\%), em leitos granoblásticos monominerálicos bem definidos em contato abrupto com o restante do leucossoma, com cristais subidioblásticos a idioblásticos, de granulação fina à média raramente grossa, bastante fraturados principalmente nas bordas, e formando contatos minerais retos a interlobados, por vezes com junções triplas de $120^{\circ}$ (Figura 35e).

Próximo ao contato com o resíduo há plagioclásio com terminações em cúspide, intersticial, sugerindo segregação de líquido silicático. Biotita xenoblástica fina à média aparentemente substitui o leucossoma e é acompanhada de carbonato intersticial no contato 
leucossoma-resíduo (retrometamorfismo; Figura 35f). Ainda nesse tipo de contato há exemplos com alta proporção $(\sim 50 \%)$ de clinopiroxênio (melanossoma) alterado por hornblenda e acompanhado por opaco intersticial. Alteração sericítica é comum em plagioclásio.

Ocorre intrusão de leucossoma rosado de espessura decimétrica, rico em feldspato potássico de granulação grossa, na rocha máfica (Figura 21 e Figura 36). Interação entre leucossoma do metapelito e da rocha máfica ocorre nas proximidades do contato entre os dois litotipos, na forma de veios centimétricos a decimétricos alimentados por outros menores, com presença característica de feldspato potássico (Figura 37). Acima da rocha máfica e abaixo da metapelítica, em contato abrupto, há camada de litotipo metabásico distinto dos demais (Figura 36 e Figura 38), de espessura decimétrica, mesocrático, foliado, de granulação fina a média, rico em hornblenda e biotita, com plagioclásio e granada. É caracterizado por apresentar leucossomas in situ, por vezes in source, além de poucos veios paralelizados, porém em menor proporção quando comparado aos dos litotipos principais. A principal diferença entre essa rocha e as outras é a presença considerável de plagioclásio. 

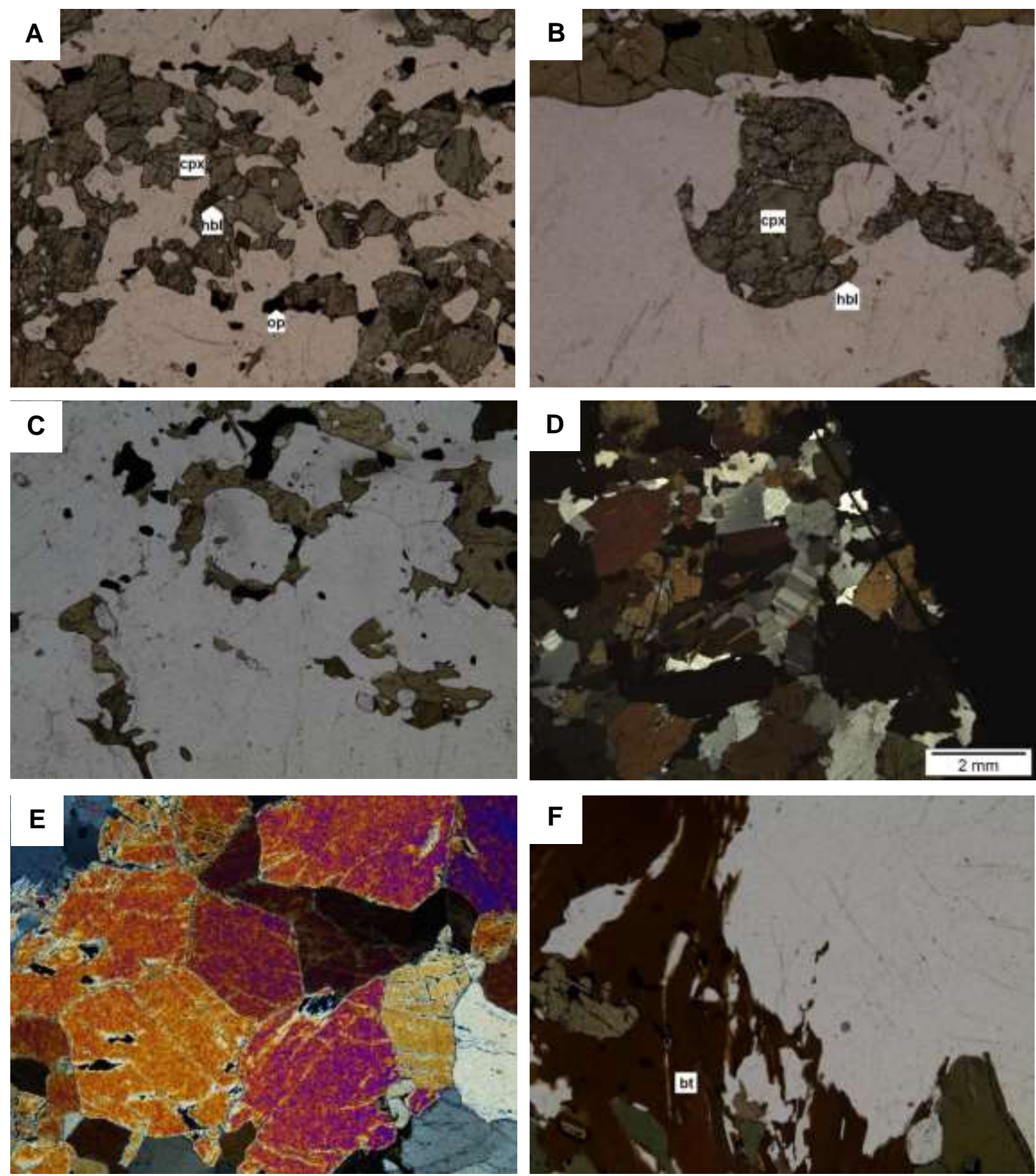

Figura 35 - TPR-01. Fotomicrografias. a) TPR-01-E1. Rocha residual máfica bem preservada com clinopiroxênio abundante e alterado a partir das bordas por hornblenda. Minerais opacos granulares a alongados e intersticiais são associados (Polarizador inferior; largura 3,5 mm); b) TPR-01-E2. Clinopiroxênio alterado nas bordas por hornblenda em leucossoma de rocha residual máfica (Polarizador inferior; largura 3,5 mm); c) TPR-01-M. Cristais subidioblásticos a xenoblásticos de hornblenda acompanhados por opacos em leucossoma de rocha residual máfica (Polarizador inferior; largura 3,5 mm); d) TPR-01-N. Veio fino de leucossoma composto por plagioclásio e quartzo em textura ígnea (Polarizadores cruzados); e) TPR-01-P. Porção rica em escapolita em leucossoma de rocha residual máfica. Notar junções triplas de $120^{\circ}$ (Polarizadores cruzados; largura 3,5 mm); f) TPR-01-P. No contato leucossoma-resíduo máfico ocorre biotita xenoblástica (Polarizador inferior; largura 3,5 mm). 


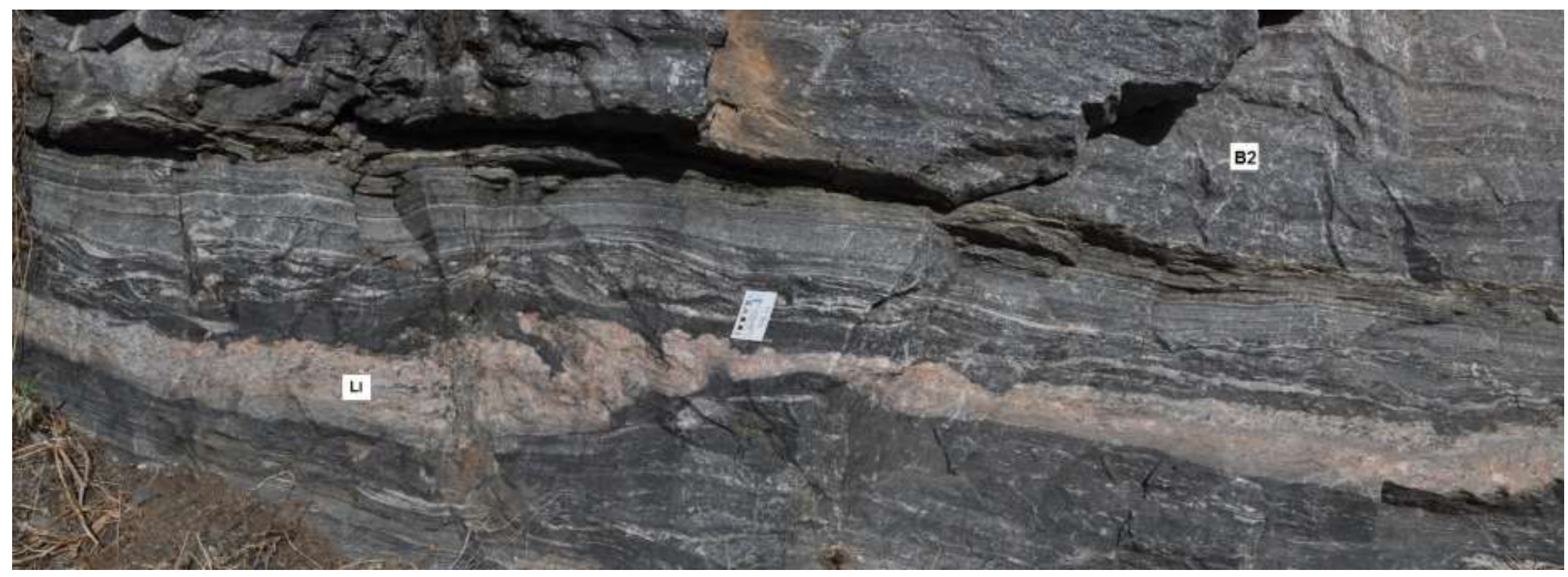

Figura 36 - TPR-01. Leucossoma intrusivo (LI) grosso em rocha residual, rico em feldspato potássico. Em contato abrupto há rocha metamáfica (B2) distinta, característica por grande quantidade de leucossoma in-situ e in-source, e ainda portar quantidade considerável de plagioclásio. Notar dobras assimétricas no leucossoma intrusivo com movimentação de topo para ENE. Orientação ENE-WSW. 


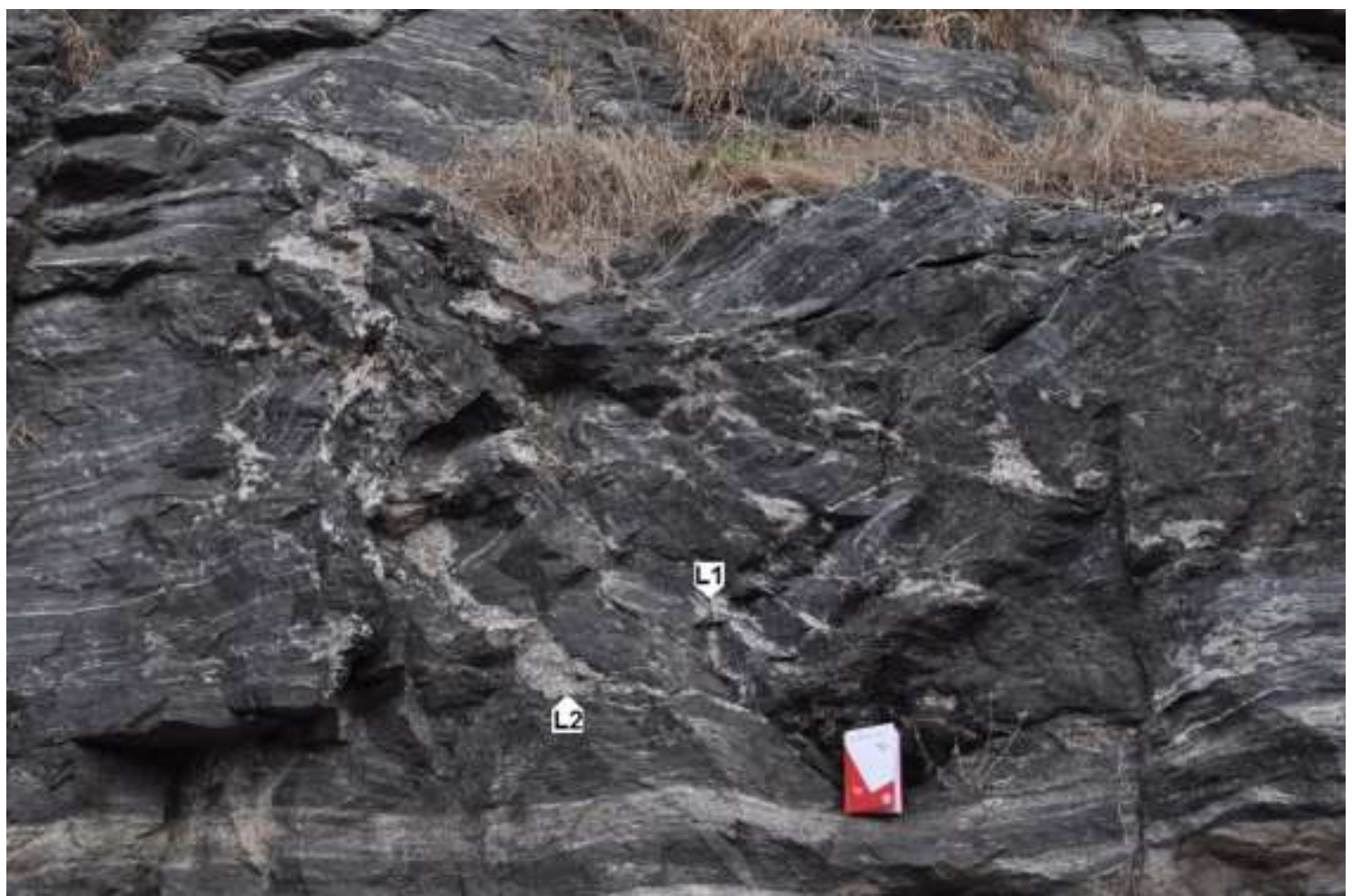

Figura 37 - TPR-01. Diferentes veios de leucossoma em rocha residual máfica: (L1) leucossoma tonalítico gerado a partir da rocha máfica original; (L2) material fundido portador de feldspato potássico, resultante da interação de L1 com material de fusão parcial de metapelito. Notar orientação dos veios de leucossoma que indicação movimentação com topo para ENE. Orientação ENE-WSW.

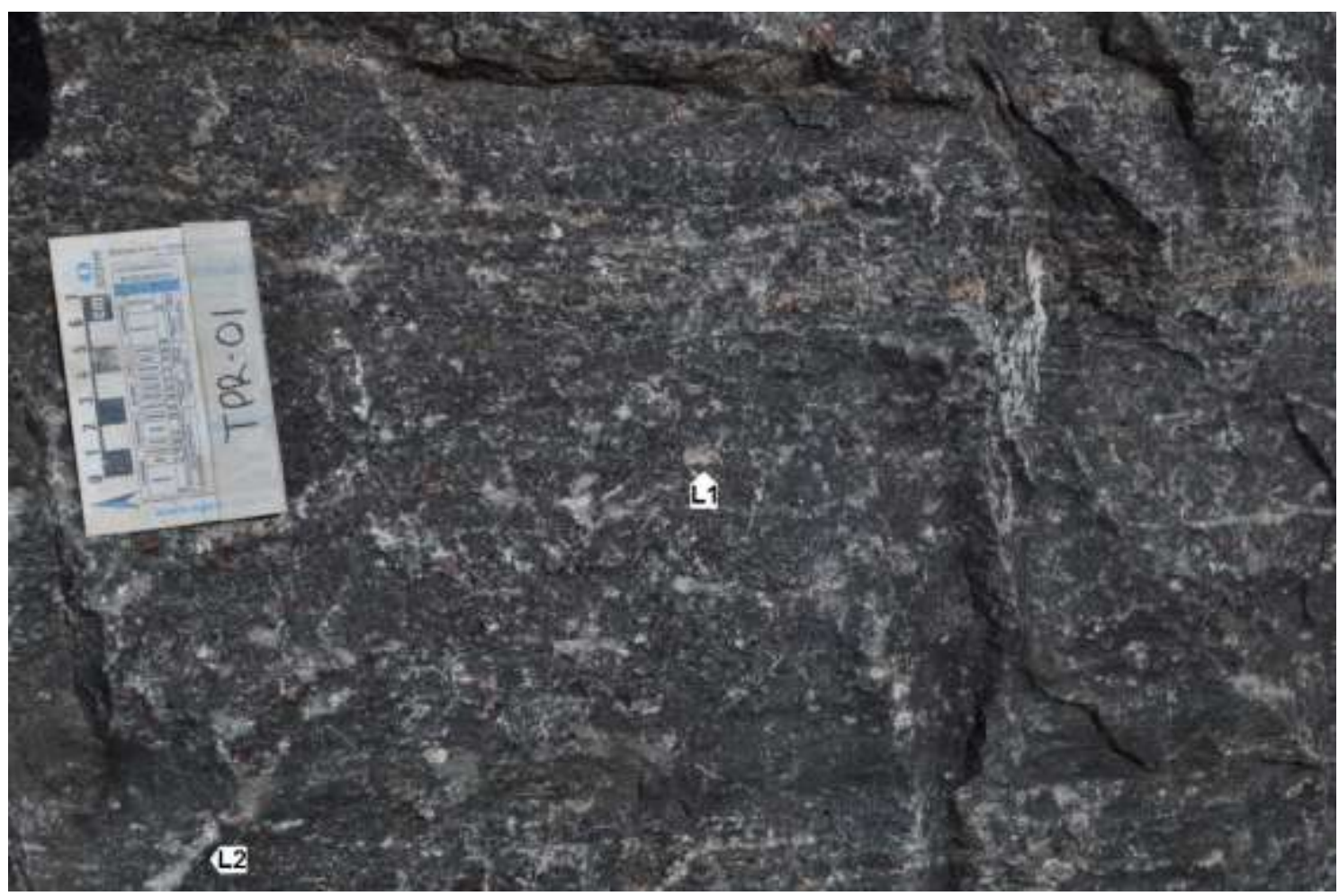

Figura 38 - TPR-01. Rocha máfica distinta (B2 na Figura 36) com menor mobilização do material fundido. Leucossoma in-situ (L1) e in-source (L2). 


\subsubsection{Rochas calciossilicáticas}

São rochas bandadas que alternam leitos centimétricos de cor cinza, granoblásticos, de granulação fina, compostos predominantemente por granada e quartzo com titanita, de leitos de mesma espessura com cor cinza escuro, em contato irregular/ difuso, granoblásticos, granulação fina, formados por principalmente por hornblenda, granada e clinopiroxênio, com titanita, quartzo e plagioclásio. Em contato abrupto com essa porção mais escura há leucossoma branco a cinza claro, granoblástico, fino a médio, composto por quartzo, plagioclásio e feldspato potássico (nem sempre presente), com granada e cianita. As bandas de cor cinza são orientadas (titanita paralela ao bandamento) e possuem granada idioblástica a subidioblástica rica em inclusões muito finas de monazita/ zircão em seu núcleo, quartzo intersticial com frequentes terminações afinadas em "cúspide" e titanita subidioblástica a prismática. Como mineralogia acessória ocorre biotita e opacos aleatórios, porém sempre em contato com granada, apatita e monazita dispersas (Figura 39a). O contato dessa banda com a de cor cinza escuro se dá pelo aparecimento de hornblenda e clinopiroxênio (juntos somam mais de $50 \%$ da moda) subidioblásticos a idioblásticos, com granada em ligeira menor proporção, porém nas mesmas texturas (Figura 39b). Quartzo e titanita têm suas proporções substancialmente reduzidas e possuem mesmas características da outra banda (quartzo ocorre também incluso em hornblenda e como finos filmes - fusão parcial; Figura 39b). Plagioclásio é raro e intersticial, e minerais opacos, também raros, se distribuem de maneira aleatória. Biotita é intersticial e se concentra em região próxima ao contato entre as bandas. Os contatos entre os minerais são retos com raros exemplos arredondados quando quartzo está envolvido (Figura 39c). Em contato abrupto ocorre leucossoma maciço, granoblástico com porfiroblastos de granada, granulação fina à média, composto principalmente por plagioclásio e quartzo, por vezes microclínio, granada, rutilo, cianita e muscovita/ sericita. Feldspatos são subidioblásticos e formam entre si contatos retos, por vezes junções tríplices de $120^{\circ}$, a arredondados, esses tipicamente junto ao quartzo, que é intersticial, forma fitas alongadas, subgrãos, inclusões finas e arredondadas em feldspato e granada, e possui bordas suturadas típicas de recristalização por migração de borda. Porfiroblastos de granada são médios a grossos, subidioblásticos, fraturados e com inclusões de quartzo, cianita e rutilo. Este último é fino, subidioblástico e também ocorre disperso. Biotita e muscovita/ sericita são alterações de feldspato e em bordas e fraturas de granada. A distribuição dos feldspatos é desigual. Há porções onde ocorre apenas plagioclásio e em outras, o feldspato predominante é o microclínio. Nessas últimas, rutilo é mais presente e granada é acompanhada de cianita prismática, fina a média, orientada paralelamente ao bandamento. 
Uma das amostras (TPR-01-R) é bandada e característica por apresentar resíduo internamente bandado (Figura 39d) formado por hornblenda, biotita e quartzo, com pouco plagioclásio e granada, e leucossoma composto por quartzo, plagiolásio e granada, com cianita. O resíduo é orientado, granonematolepidoblástico, de granulação fina à média com porfiroblastos médios a grossos de granada. O bandamento fino dentro do resíduo é característico por apresentar leitos contínuos de espessura milimétrica, de 5 a $6 \mathrm{~mm}$ (Figura 39d) granolepidonematoblásticos, formados por hornblenda fina à média, subidioblástica, orientada paralelamente ao bandamento, biotita fina, subidioblástica a xenoblástica, também orientada, por vezes forma leitos contínuos e sinuosos, e altera bordas de granada. Granada é fina à média, ocorre também porfiroblástica e xenoblástica, quando alongada é orientada na foliação, possui bordas arredondadas e aspectos esqueletais sugerindo consumo no metamorfismo (Figura 39e), inclusões alongadas e arredondadas de quartzo fino, biotita e hornblenda, orientadas e concordantes à foliação. Quartzo é fino, dificilmente forma contatos retos e junções tríplices de $120^{\circ}$ com os demais minerais, e ocorre também em finos veios policristalinos com cristais de bordas suturadas. Plagioclásio é fino, subidioblástico e forma contatos retos a arredondados. Rutilo é mineral acessório, possui granulação fina, é subidioblástico alongado a arredondado, e distribui-se pela rocha regularmente e ocorre como inclusões orientadas e paralelas a foliação da rocha em granada. Apatita, monazita, zircão, opacos xenoblásticos junto a minerais máficos e carbonato junto à biotita, completam os acessórios.

Na porção próxima ao leucossoma, leito com espessura entre 5 e 10mm (Figura 39d), as proporções de hornblenda e de granada são reduzidas, e as de quartzo, plagioclásio e biotita são aumentadas, assim como a granulação (porém ainda fina). A passagem de resíduo para o leucossoma ocorre de maneira abrupta por meio de leito fino, com espessura de 12mm (Figura 39d), lepidogranoblástico, composto por biotita muito fina a fina, subidioblástica a xenoblástica, que comumente forma leitos contínuos e sinuosos, quartzo subidioblástico a xenoblástico fino e plagioclásio subidioblástico fino. O leucossoma possui granulação fina à média com porfiroblastos médios a grossos, é orientado, granoblástico, composto por quartzo subidioblástico a xenoblástico, que forma contatos retos e por vezes arredondados e suturados, e ocorre também como agregados em veios de bordas suturadas. Plagioclásio é subidioblástico e forma contatos retos com comum junção tripla de $120^{\circ}$. Granada é fina à média ou porfiroblástica grossa, subidioblástica a xenoblástica, possui bordas arredondadas e aspecto "esqueletal", inclusões arredondadas de quartzo e de cianita. Essa é subidioblástica a xenoblástica com bordas arredondadas, ocorre inclusa parcial ou totalmente em granada (Figura 39f) e dispersa no leucossoma. Biotita associa-se à granada e cianita. 

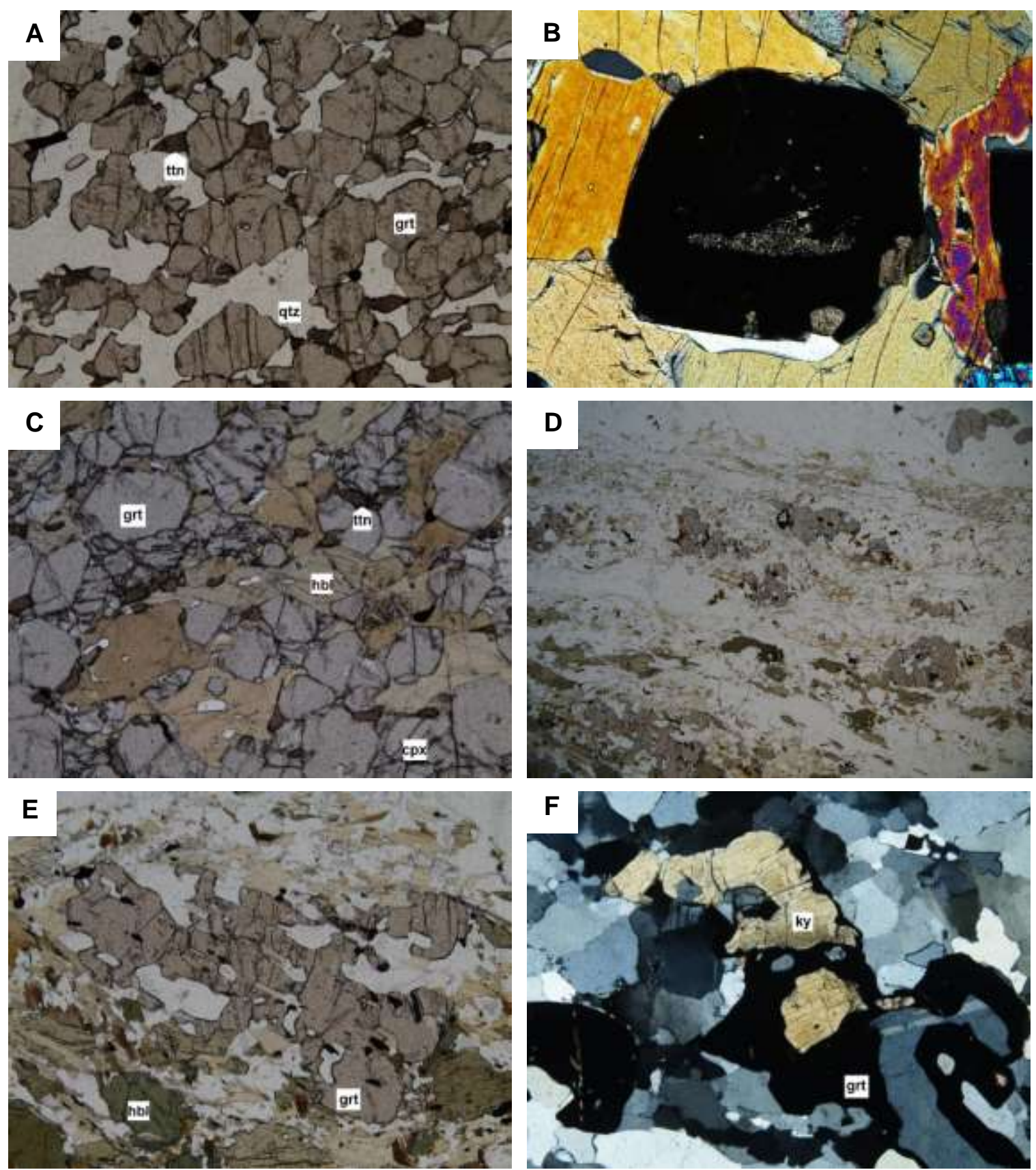

Figura 39 - TPR-01. Fotomicrografias. a) TPR-01-F1. Banda cinza claro de rocha calciossilicática composta por granada, quartzo intersticial e titanita orientada paralelamente ao bandamento (Polarizador inferior; largura 3,5 $\mathrm{mm}$ ); b) TPR-01-C. Inclusões muito finas de monazita/ zircão em granada de banda cinza escura em rocha calciossilicática. Notar fino filme de quartzo abaixo da granada (Polarizadores cruzados; largura 1,5 mm); c) TPR01-F1. Banda cinza escura de rocha calciossilicática diferenciada da anterior pela presença de hornblenda e clinopiroxênio e quase total ausência de quartzo e baixa de titanita. Os contatos entre os minerais são retos com raros exemplos arredondados quando quartzo está envolvido (Polarizador inferior; largura 3,5 mm); d) TPR-01-R. Visão geral do resíduo internamente bandado em rocha calciossilicática. Extremo inferior esquerdo ocorre banda com as maiores proporções de hornblenda e granada. A banda central, mais espessa, apresenta menores proporções de granada e hornblenda e maiores de quartzo, plagioclásio e biotita, em maior granulação relativa (ainda fina). A passagem de resíduo para leucossoma ocorre de maneira abrupta por meio de leito fino lepidogranoblástico, com espessura de 1-2mm na porção superior da foto, composto por biotita muito fina a fina e quartzo (Polarizador inferior; largura 12,0 mm); e) TPR-01-R. Granada xenoblástica com aspecto esqueletal na banda rica em hornblenda de rocha calciossilicática. Sua textura sugere consumo durante o metamorfismo (Polarizador inferior; largura 3,5 mm); f) TPR-01-R. Cianita inclusa parcial e totalmente em granada no leucossoma de rocha calciossilicática (Polarizadores cruzados; largura 3,5 mm). 


\subsection{Pedreira de Varginha (IC-06-R)}

Na pedreira Grupo Santo Antônio em Varginha ocorre contato entre granulito félsico basal da Nappe Socorro-Guaxupé e sillimanita granulito de topo da Nappe Três Pontas Varginha. No local foi amostrado apenas um exemplar do primeiro granulito citado.

\subsubsection{Granulito Félsico}

Rocha bandada formada por resíduo mesocrático composto por clinopiroxênio, hornblenda, plagioclásio e quartzo, alternado por milimétricos leitos de leucossoma tonalítico com clinopiroxênio, ortopiroxênio e hornblenda (Figura 40 e Figura 41), também ocorrendo como milimétricos bolsões estirados ricos em plagioclásio na foliação e in-situ oblíquo à foliação (Figura 41). O resíduo é granoblástico, por vezes nematogranoblástico, de granulação fina à média, composto por clinopiroxênio subidioblástico, substituido parcial a totalmente por hornblenda que chega a formar cristais prismáticos subidioblásticos a idioblásticos orientados segundo a foliação, e plagioclásio subidioblástico a intersticial com terminações afinadas. Os três minerais em proporções similares. Quartzo completa a mineralogia, é xenoblástico e intersticial com extinção ondulante. O leucossoma é paralelo à foliação, possui espessura milimétrica, textura granoblástica, e composição tonalítica com clinopiroxênio, ortopiroxênio e hornblenda. Plagioclásio é o principal mineral, subidioblástico a xenoblástico, forma contatos retos a arredondados entre si, raramente junções triplas de $120^{\circ}$, e apresenta alteração sericítica. Quartzo é xenoblástico com bordas comumente arredondadas e suturadas, ocorre como cristais alongados na foliação em textura flaser, e em porções granoblásticas junto a plagioclásio em granulação fina (inferior à geral). Clinopiroxênio e ortopiroxênio (Figura 42a) são subidioblásticos a xenoblásticos, comumente fraturados e desmembrados, alterados por hornblenda, e pinita no caso do ortopiroxênio. Ortopiroxênio apresenta pleocroísmo de cinza a rosa claro.

Uma terceira porção presente no litotipo (resíduo) é caracterizada por portar granada e biotita além dos demais minerais. É orientada, lepidogranoblástica com porfiroblastos médios a grossos de granada e granulação da matriz fina à média. Apresenta plagioclásio e quartzo como minerais principais. Plagioclásio é subidioblástico a xenoblástico, forma contatos retos entre si, por vezes junções tríplices de $120^{\circ}$, à arredondados com o quartzo. Quartzo forma textura flaser, bordas suturadas e subgrãos. Granada é subidioblástica a xenoblástica, fragmentada/ desmembrada e fraturada, rica em inclusões arredondadas de quartzo e outras xenoblásticas de plagioclásio + quartzo + biotita (fundido; Figura 42b). Clinopiroxênio e ortopiroxênio são subidioblásticos a xenoblásticos, comumente alterados nas bordas por hornblenda. Alguns cristais são fragmentados e orientados na foliação. 
Ortopiroxênio possui pleocroísmo cinza a rosa claro. Hornblenda alem de substituir piroxênio ocorre subidioblástica e orientada na foliação em textura nematoblástica. Biotita fina, subidioblástica a xenoblástica ocorre orientada na foliação, substituindo granada e associada à hornblenda. Minerais opacos são xenoblásticos e por vezes apresentam coroas de biotita e hornblenda. Há leitos granoblásticos de quartzo e plagioclásio em granulação fina (menor que a geral; 0,2mm) com subgrãos de quartzo. A maior presença desses leitos de menor granulação e de quartzo estirado (flaser), e ocorrência de biotita fina e orientada, sugerem uma maior deformação e retrometamorfismo para essa porção da rocha.

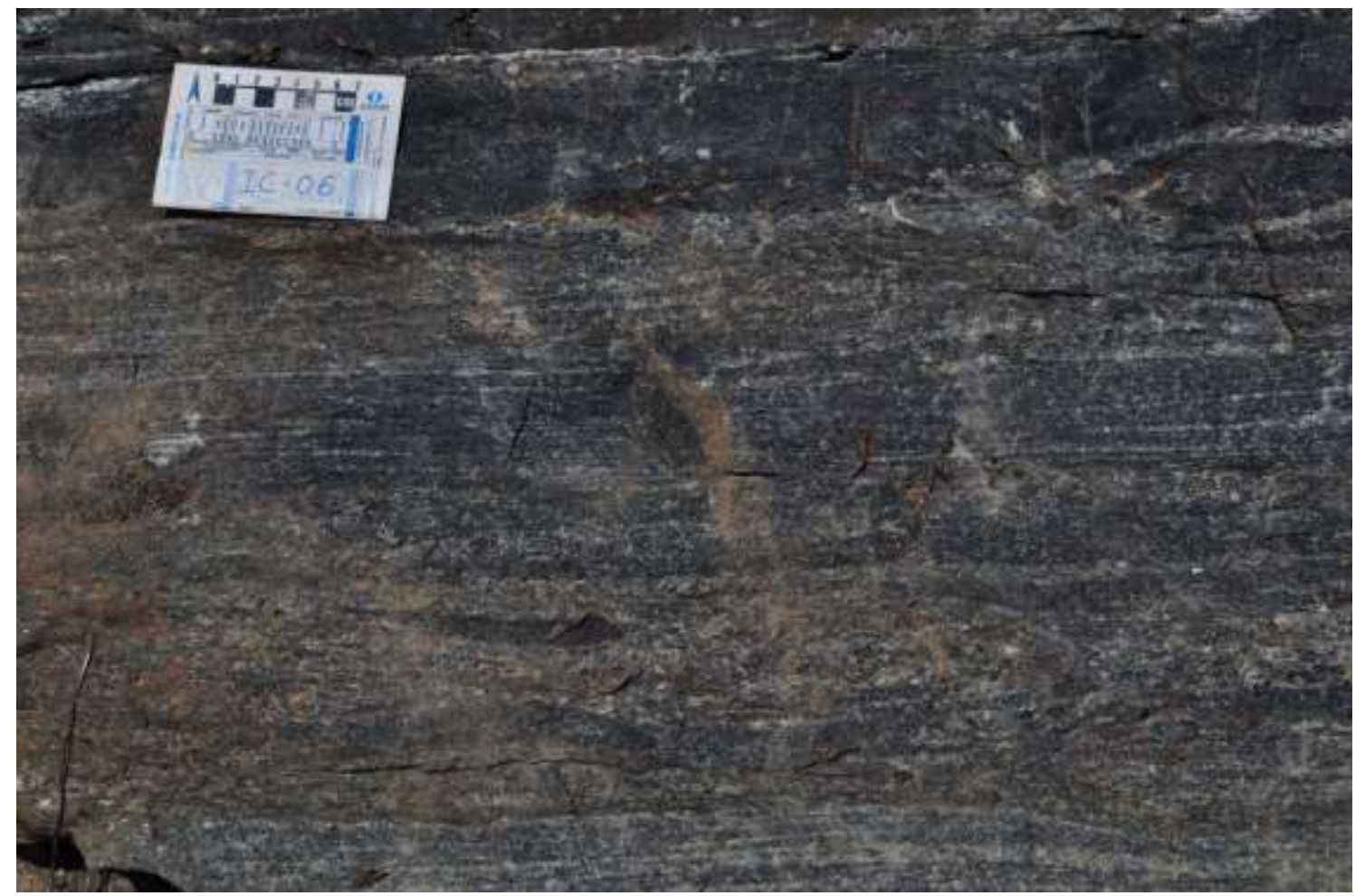

Figura 40 - IC-06-R. Granulito félsico da Nappe Socorro-Guaxupé bandado, característico por apresentar resíduo mesocrático alternado por leucossoma tonalítico de espessura milimétrica (leitos de coloração clara). 


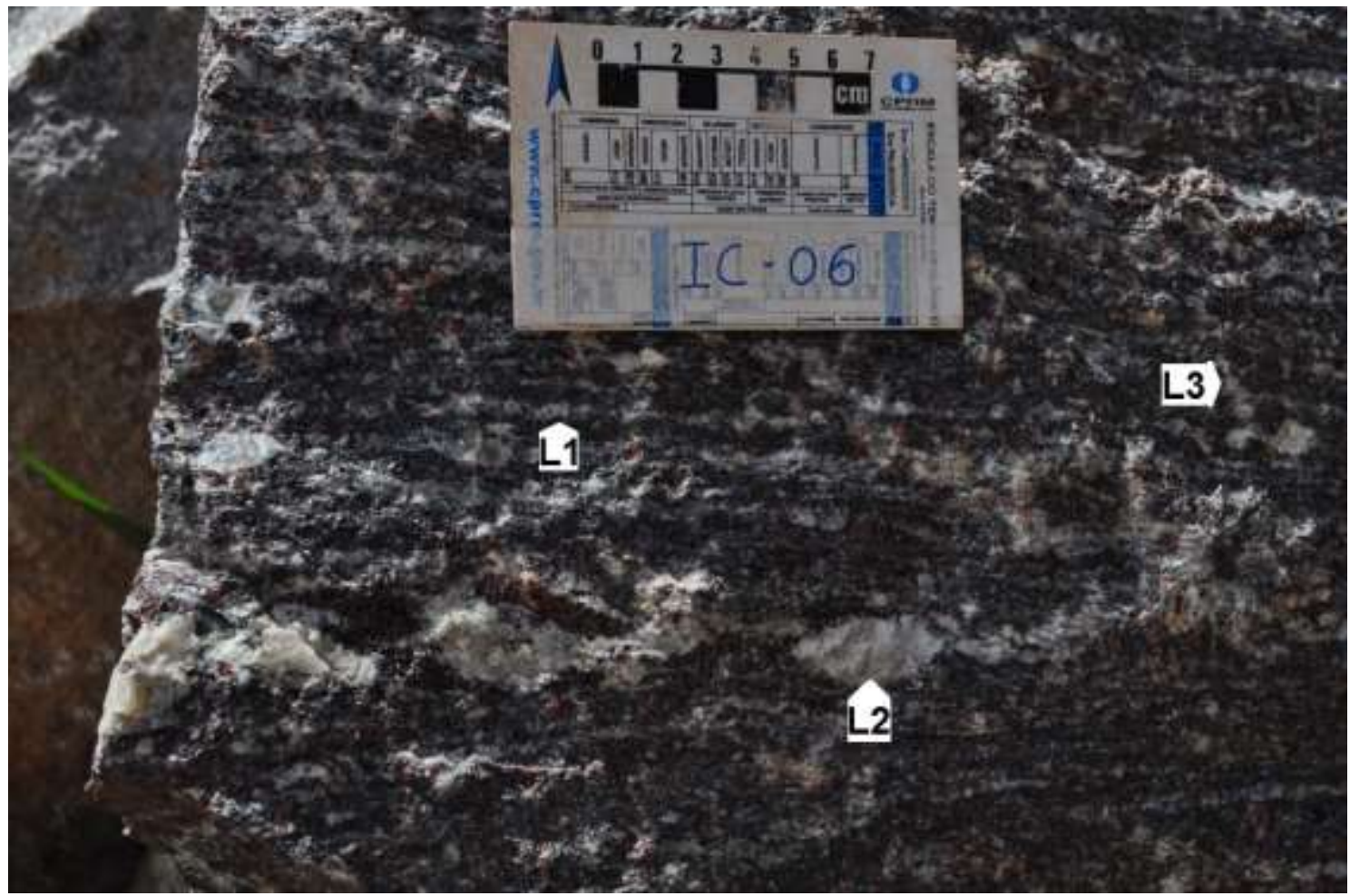

Figura 41 - IC-06-R. Diferentes gerações de leucossoma no granulito félsico. Leucossoma em leito de espessura milimétrica paralelo à foliação (L1; mais abundante); Leucossoma em finos bolsões estirados ricos em plagioclásio (L2); Leucossoma in-situ, oblíquo à foliação (L3).
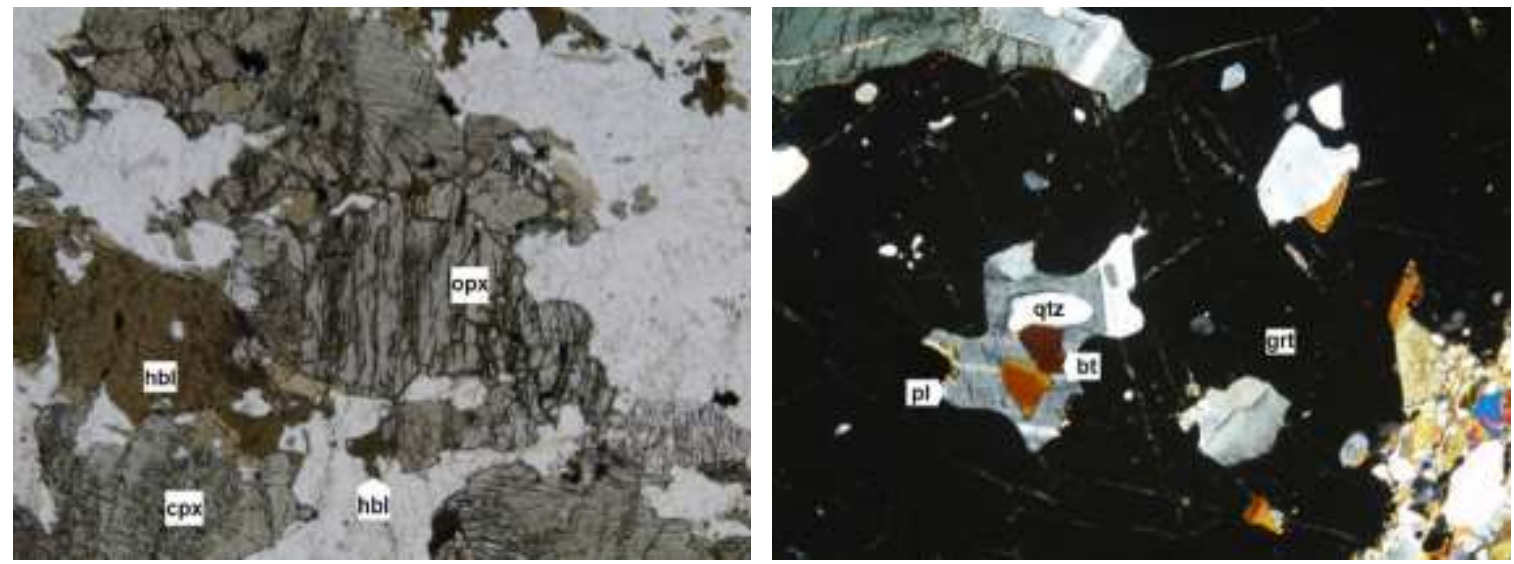

Figura 42 - Fotomicrografias. a) IC-06-R. Ortopiroxênio, clinopiroxênio e hornblenda no leucossoma do granulito félsico. Notar cristal de clinopiroxênio substituido na borda por hornblenda na porção inferior central da imagem (Polarizador inferior; largura 3,5 mm); b) IC-06-R. Inclusão de fundido composto por plagioclásio, quartzo e biotita em granada de resíduo do granulito félsico (Polarizadores cruzados; largura 3,5 mm).

\subsection{Geologia Estrutural}

O padrão apresentado pelas atitudes encontradas no granulito metapelítico da Nappe Três Pontas-Varginha corrobora os dados já publicados (e.g. Campos Neto \& Caby 1999, 2000), com foliação de baixo ângulo que mergulha para S-SW, atitude média de N104E/ 33SW (Figura 43A), e lineação mineral e de estiramento de mica branca, quartzo e turmalina com caimento para SW, atitude média de N47E/ 17SW (Figura 43B). 
A

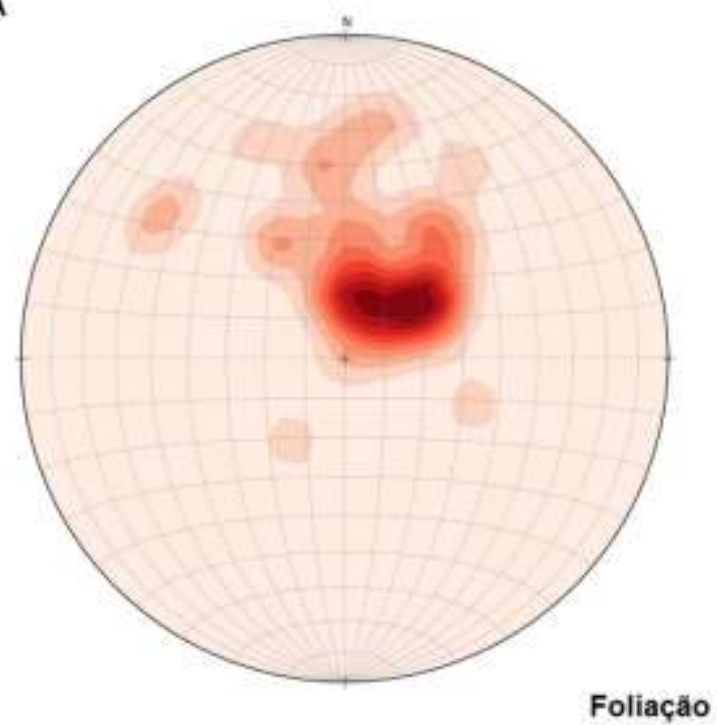

B

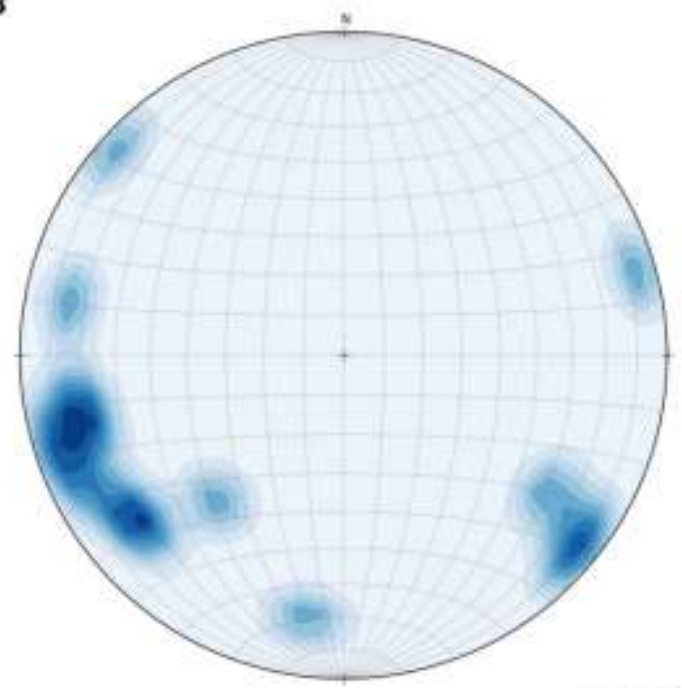

Lineaçăo

Figura 43 - Dados estruturais do granulito metapelítico. A. Atitudes de foliação (polares) indicando mergulhos de baixo ângulo com rumo S-SW. $n=34$; B. Atitudes de lineações mostram predominância de caimento para W-SW. $n=12$.

O metatexito estromático ocorre em porções isoladas dentro da área, com atitudes concordantes com os demais litotipos, foliação média N88E/ 56SE, que devido à orientação grosso modo leste oeste dos morros onde aflora foram interpretadas como lentes de mesma orientação colocadas em meio ao granulito de alta pressão. Estruturas comuns encontradas nesse litotipo são ribbons de quartzo, pares S-C, porfiroblastos de granada e porfiroclastos de feldspato como indicadores cinemáticos dos tipos phie delta indicando movimentação de topo para E-NE (Figura 14), e dobras intrafoliais.

A geometria do corpo de quartzito na região nordeste da área foi sugerida através de observações em campo, fotos aéreas/ carta topográfica e trabalhos regionais realizados anteriormente (e.g. Maciel 1986). Esse litotipo apresenta atitude média de foliação que mergulha para S-SE, N63E /39SE distinta da apresentada por sua encaixante, o que indica geração em nível crustal diferente.

$\mathrm{Na}$ região central da área mapeada ocorre zona de cisalhamento (afloramento TPR47; Ver mapa de pontos no Apêndice 1) onde a foliação passa de baixo ângulo para subvertical em padrão bastante conturbado. Provavelmente é a zona responsável por colocar a Nappe Três Pontas junto ao embasamento.

Dobras assimétricas em leucossoma do granulito metapelítico (Figura 23) e em leucossoma intrusivo na rocha residual máfica (Figura 36), veios de material fundido em regiões de alívio de pressão no útlimo litotipo (Figura 29 e Figura 37), e profiroclasto de feldspato no metatexíto estromático (Figura 14), funcionam como Indicadores cinemáticos e indicam movimentação para E-NE, o que corrobora a teoria de movimentação dessa unidade em direção ao Cráton São Francisco (e.g. Campos Neto \& Caby 1999, 2000). 
4.5. Química mineral

\subsubsection{Análises por Microssonda Eletrônica}

\subsubsection{Consideracõos gerais}

\section{Preparação das amostras}

Para as análises em microssonda eletrônica são necessárias amostras que possuam os minerais de interesse para o estudo geotermobarométrico - granada, clinopiroxênio, plagioclásio e ortopiroxênio, este último presente em apenas uma das amostras investigadas - assim, após petrografia detalhada, três exemplares de rochas calciossilicáticas pertencentes à Nappe Três Pontas - Varginha (TPR-01-B, TPR-01-C e TPR-01-F1), e um de granulito félsico da Nappe Socorro-Guaxupé (IC-06-R), foram selecionados e a partir deles, foram produzidas no Laboratório de Laminação do IGc, quatro seções delgadas polidas de $30 \mu \mathrm{m}$.

\section{Microssonda Eletrônica}

As análises de microssonda eletrônica foram realizadas no Laboratório de Microssonda Eletrônica do Instituto de Geociências da Universidade de São Paulo (IGc-USP), usando equipamento JEOL, modelo JXA-FE-8530, Field Emission Electron Probe Microanalyser (FE-EPMA). Todos procedimentos foram conduzidos sob voltagem de $15 \mathrm{kV}$ e corrente elétrica de $20 \mathrm{nA}$, com diâmetros dos pontos de $5 \mu \mathrm{m}$ para granada, clinopiroxênio e ortopiroxênio, e $10 \mu \mathrm{m}$ para plagioclásio. Os dados foram reduzidos pelos procedimentos de correção ZAF. A Tabela 1 apresenta para cada mineral analisado a distribuição dos elementos nos respectivos cristais utilizados, os tempos de análises dos picos, backgrounds, e os minerais utilizados como padrões em cada caso. 
Tabela 1 - Parâmetros e padrões utilizados nas análises de química mineral por microssonda eletrônica.

\begin{tabular}{|c|c|c|c|c|c|}
\hline \multicolumn{6}{|c|}{ Granada } \\
\hline Elemento & Linha & Cristal & Pico & Background & Padrão \\
\hline $\mathrm{Si}$ & $\mathrm{Ka}$ & TAP & $5,0 \mathrm{~s}$ & $2,5 \mathrm{~s}$ & grossulária \\
\hline $\mathrm{Al}$ & $\mathrm{Ka}$ & TAP & $10,0 \mathrm{~s}$ & $5,0 \mathrm{~s}$ & piropo \\
\hline $\mathrm{Fe}$ & $\mathrm{Ka}$ & LIFL & $20,0 \mathrm{~s}$ & $10,0 \mathrm{~s}$ & faialita \\
\hline $\mathrm{Mn}$ & $\mathrm{Ka}$ & LIFL & $40,0 \mathrm{~s}$ & $20,0 s$ & faialita \\
\hline $\mathrm{Ca}$ & $\mathrm{Ka}$ & PETJ & $10,0 \mathrm{~s}$ & $5,0 \mathrm{~s}$ & wollastonita \\
\hline $\mathrm{Ti}$ & $\mathrm{Ka}$ & LIFL & $20,0 \mathrm{~s}$ & $10,0 \mathrm{~s}$ & rutilo \\
\hline $\mathrm{Cr}$ & $\mathrm{Ka}$ & LIFL & $30,0 \mathrm{~s}$ & $15,0 \mathrm{~s}$ & cromita \\
\hline $\mathrm{Mg}$ & $\mathrm{Ka}$ & TAPH & $15,0 \mathrm{~s}$ & $7,5 \mathrm{~s}$ & diopsídio \\
\hline \multicolumn{6}{|c|}{ Piroxênio } \\
\hline $\mathrm{Si}$ & $\mathrm{Ka}$ & TAP & $20,0 s$ & $10,0 \mathrm{~s}$ & diopsídio \\
\hline $\mathrm{Al}$ & $\mathrm{Ka}$ & TAP & $10,0 \mathrm{~s}$ & $5,0 \mathrm{~s}$ & anortita \\
\hline $\mathrm{Fe}$ & $\mathrm{Ka}$ & LIFL & $10,0 \mathrm{~s}$ & $5,0 \mathrm{~s}$ & faialita \\
\hline $\mathrm{Mn}$ & $\mathrm{Ka}$ & LIFL & $40,0 \mathrm{~s}$ & $5,0 \mathrm{~s}$ & faialita \\
\hline $\mathrm{K}$ & $\mathrm{Ka}$ & PETJ & $10,0 \mathrm{~s}$ & $5,0 \mathrm{~s}$ & ortoclásio \\
\hline $\mathrm{Ca}$ & $\mathrm{Ka}$ & PETJ & $10,0 \mathrm{~s}$ & $5,0 \mathrm{~s}$ & wollastonita \\
\hline $\mathrm{Ti}$ & $\mathrm{Ka}$ & LIFL & $10,0 \mathrm{~s}$ & $5,0 \mathrm{~s}$ & rutilo \\
\hline $\mathrm{Cr}$ & $\mathrm{Ka}$ & LIFL & $10,0 \mathrm{~s}$ & $5,0 \mathrm{~s}$ & cromita \\
\hline $\mathrm{Na}$ & $\mathrm{Ka}$ & TAPH & $10,0 \mathrm{~s}$ & $5,0 \mathrm{~s}$ & $\mathrm{NaAISi}_{3} \mathrm{O}_{8}$ \\
\hline $\mathrm{Mg}$ & $\mathrm{Ka}$ & TAPH & $10,0 \mathrm{~s}$ & $5,0 \mathrm{~s}$ & diopsídio \\
\hline \multicolumn{6}{|c|}{ Plagioclásio } \\
\hline Si & $\mathrm{Ka}$ & TAP & $5,0 \mathrm{~s}$ & $2,5 s$ & anortoclásio \\
\hline $\mathrm{Al}$ & $\mathrm{Ka}$ & TAP & $10,0 \mathrm{~s}$ & $5,0 \mathrm{~s}$ & anortita \\
\hline $\mathrm{Fe}$ & $\mathrm{Ka}$ & LIFL & $20,0 \mathrm{~s}$ & $10,0 \mathrm{~s}$ & faialita \\
\hline Mn & $\mathrm{Ka}$ & LIFL & $40,0 \mathrm{~s}$ & $20,0 \mathrm{~s}$ & faialita \\
\hline $\mathrm{Ca}$ & $\mathrm{Ka}$ & PETJ & $10,0 \mathrm{~s}$ & $5,0 \mathrm{~s}$ & wollastonita \\
\hline $\mathrm{K}$ & $\mathrm{Ka}$ & PETJ & $20,0 \mathrm{~s}$ & $10,0 \mathrm{~s}$ & ortoclásio \\
\hline $\mathrm{Sr}$ & La & PETJ & $40,0 \mathrm{~s}$ & $20,0 \mathrm{~s}$ & estroncianita \\
\hline $\mathrm{Ti}$ & $\mathrm{Ka}$ & LIFL & $10,0 \mathrm{~s}$ & $5,0 \mathrm{~s}$ & rutilo \\
\hline $\mathrm{Ba}$ & La & LIFL & $30,0 \mathrm{~s}$ & $15,0 \mathrm{~s}$ & benitoíta \\
\hline $\mathrm{Na}$ & $\mathrm{Ka}$ & TAPH & $10,0 \mathrm{~s}$ & $5,0 \mathrm{~s}$ & albita \\
\hline $\mathrm{Mg}$ & $\mathrm{Ka}$ & TAPH & $10,0 \mathrm{~s}$ & $5,0 \mathrm{~s}$ & diopsídio \\
\hline
\end{tabular}


Os cristais escolhidos para análise foram aqueles sem sinais de alteração e com menor quantidade de inclusões e, no caso do plagioclásio, os que apresentam textura de equilíbrio com os outros minerais, que são considerados protegidos e preservados da fusão parcial, possivelmente preservando composições de pico metamórfico. A fim de se avaliar a variação dos teores dos elementos em cada cristal, as análises foram realizadas na forma de perfis tentando sempre cobrir o grão de uma borda à outra e passando pelo núcleo, evitando fraturas, alterações e inclusões com o auxílio de imagens de elétrons retroespalhados. Assim, do total de 73 cristais selecionados (25 cristais de clinopiroxênio, 24 de granada, 20 de plagioclásio e 4 de ortopiroxênio), foram realizados 791 pontos de análises (260 em clinopiroxênio, 359 em granada, 132 em plagioclásio e 40 em ortopiroxênio) com uma média de 10,83 análises por cristal. As análises foram tratadas com o software "A-X" para obtenção de fórmulas estruturais, proporções catiônicas e atividades dos membros finais.

Mapas composicionais de granada, clino- e ortopiroxênio foram confeccionados para $\mathrm{Fe}, \mathrm{Mg}, \mathrm{Ca}, \mathrm{Al}$ e $\mathrm{Mn}$, enquanto que para plagioclásio apenas $\mathrm{Ca}$ e $\mathrm{Na}$ foram feitos. A seleção dos cristais mapeados foi feita entre os já analisados através dos perfis previamente mencionados, assim, em cada amostra foi escolhido um cristal de cada fase mineral, salvo na amostra TPR-01-B em que plagioclásio é ausente, perfazendo um total de onze minerais analisados com 38 mapas produzidos. Todos procedimentos foram conduzidos sob voltagem de aceleração de $15 \mathrm{kV}$, corrente de $100 \mathrm{nA}$ para plagioclásio e $150 \mathrm{nA}$ para granada e piroxênio, e tempo de permanência (dwelltime) de 40s. O principal motivo de utilizar correntes altas e tempo de permanência elevado é a baixa proporção de Mn em granada.

\subsubsection{Granada}

A granada pertence à classe dos nesossilicatos, é característica de rochas metamórficas distribuindo-se em amplo campo $P$ - $T$, como também ocorre em rochas ígneas e sedimentares, nas últimas como grãos detríticos. Apresenta a fórmula química fundamental $\mathrm{X}_{3} \mathrm{Y}_{2} \mathrm{Si}_{3} \mathrm{O}_{12}$, na qual, tetraedros de $\mathrm{SiO}_{4}$ compartilham vértices com octaedros de $\mathrm{YO}_{6}$ (sítio $\mathrm{Y}$ ocupado pelos cátions trivalentes $\mathrm{Fe}$, $\mathrm{Al}$, Ti e/ou $\mathrm{Cr}$ ) e formam uma rede tridimensional. No interior dessa rede são geradas locais de coordenação 12 (sítio X, preenchidos pelos cátions divalentes $\mathrm{Fe}, \mathrm{Mg}, \mathrm{Mn}$ ou $\mathrm{Ca}$, com oito oxigênios compartilhados) descritas como cubos distorcidos. De acordo com o preenchimento do sítio $\mathrm{X}$, e com o $\mathrm{Y}$ ocupado por $\mathrm{Al}$, ocorrem quatro membros-finais: almandina $\left(\mathrm{Fe}_{3} \mathrm{Al}_{2} \mathrm{Si}_{3} \mathrm{O}_{12}\right)$, piropo $\left(\mathrm{Mg}_{3} \mathrm{Al}_{2} \mathrm{SiO}_{3} \mathrm{O}_{12}\right)$, espessartita $\left(\mathrm{Mn}_{3} \mathrm{Al}_{2} \mathrm{Si}_{3} \mathrm{O}_{12}\right)$ e grossulária $\left(\mathrm{Ca}_{3} \mathrm{Al}_{2} \mathrm{Si}_{3} \mathrm{O}_{12}\right)$. Já variando a ocupação do sítio $\mathrm{Y}$, com o $\mathrm{X}$ ocupado por $\mathrm{Ca}$ existem mais três membros-finais: andradita $\left(\mathrm{Ca}_{3}\left(\mathrm{Fe}, \mathrm{Ti}_{2}\right)_{2} \mathrm{Si}_{3} \mathrm{O}_{12}\right)$, uvarovita $\left(\mathrm{Ca}_{3} \mathrm{Cr}_{2} \mathrm{Si}_{3} \mathrm{O}_{12}\right)$ e ainda hidrogrossulária $\left(\mathrm{Ca}_{3} \mathrm{Al}_{2} \mathrm{Si}_{3} \mathrm{O}_{12}\left(\mathrm{SiO}_{4}\right)_{1-\mathrm{m}}(\mathrm{OH})_{4 \mathrm{~m}}\right)$, que é de ocorrência restrita (Deer et al., 1982). Devido a sua ampla distribuição dentro da janela $P-T$ no 
metamorfismo, com mudança composicional sistemática e, participar em reações dependentes de pressão e/ ou temperatura, a granada é o mineral mais importante para o cálculo dessas variáveis intensivas (Deer et al. 1982).

A granada das rochas calciossilicáticas ocorre tanto no resíduo como no leucossoma, principalmente como porfiroblastos. As analisadas são todas de cristais do resíduo, idioblásticos a subidioblásticos, em granulação fina, ricos em inclusões muito finas de monazita ou zircão, nos núcleos, finas de titanita e, por vezes, de quartzo e plagioclásio. Já a granada do granulito félsico da Nappe Socorro-Guaxupé forma porfiroblastos subidioblásticos, muitas vezes em aspecto esqueletal, com bordas arredondadas, ricos em inclusões de quartzo e/ou plagioclásio e até de intercrescimentos de quartzo, plagioclásio e biotita, interpretados como produto de cristalização de fundido aprisionado. Foram analisados 24 grãos, sendo 18 da Nappe Três Pontas-Varginha e 6 da Nappe Socosso-Guaxupé. A Tabela 2 apresenta as médias das fórmulas estruturais e proporções moleculares para da granada de cada amostra.

Tabela 2 - Fórmulas estruturais aproximadas e proporções moleculares (médias) de granada para cada amostra analisada

\begin{tabular}{|c|c|c|}
\hline Unidade & Amostra & Fórmula estrutural e proporções moleculares (médias) \\
\hline \multirow{6}{*}{ 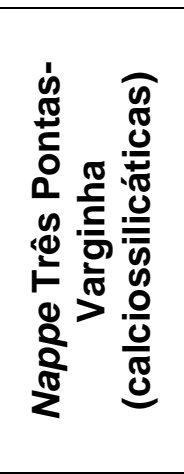 } & \multirow[t]{2}{*}{ TPR-01-C } & $\begin{array}{l}\left(\mathrm{Fe}^{2+}{ }_{1,40-1,53}, \mathrm{Mn}_{0,03-0,05}, \mathrm{Mg}_{0,62-0,79}, \mathrm{Ca}_{0,68-0,90}\right) \mathrm{Ti}_{0-0.01}, \mathrm{Fe}^{3+}{ }_{0-0,08}, \\
\mathrm{Al}_{1,92-2,00}\left(\mathrm{Al}_{0-0,04}, \mathrm{Si}_{2,96-3,00}\right) \mathrm{O}_{12}\end{array}$ \\
\hline & & $\operatorname{Alm}_{47,00-51,32} \operatorname{Prp}_{20,75-26,48} \operatorname{Sps}_{0,96-1,80} \operatorname{Grs}_{20,49-28,55} \operatorname{And}_{0,11-3,63} \mathrm{Uv}_{0-0,20}$ \\
\hline & \multirow[t]{2}{*}{ TPR-01-B } & $\begin{array}{l}\left(\mathrm{Fe}^{2+}{ }_{1,43-1,56}, \mathrm{Mn}_{0,03-0,04}, \mathrm{Mg}_{0,69-0,79}, \mathrm{Ca}_{0,68-0,78}\right) \mathrm{Ti}_{0-0.01}, \mathrm{Fe}^{3+}{ }_{0-0,04}, \\
\mathrm{Al}_{1,94-2,00}\left(\mathrm{Al}_{0-0,02}, \mathrm{Si}_{2,98-3,00}\right) \mathrm{O}_{12}\end{array}$ \\
\hline & & $\operatorname{Alm}_{47,94-51,99} \operatorname{Prp}_{23,03-26,42} \operatorname{Sps}_{1,01-1,27} \operatorname{Grs}_{21,13-25,42} \operatorname{And}_{0-2,03} U_{v_{0-0,17}}$ \\
\hline & \multirow[t]{2}{*}{ TPR-01-F1 } & $\begin{array}{l}\left(\mathrm{Fe}^{2+}{ }_{1,27-1,38}, \mathrm{Mn}_{0,03-0,04}, \mathrm{Mg}_{0,71-0,84}, \mathrm{Ca}_{0,82-0,87}\right) \mathrm{Ti}_{0-0.01}, \mathrm{Fe}^{3+}{ }_{0-0,05}, \\
\mathrm{Al}_{1,95-2,00}\left(\mathrm{Al}_{0-0,03}, \mathrm{Si}_{2,97-3,00}\right) \mathrm{O}_{12}\end{array}$ \\
\hline & & $\operatorname{Alm}_{42,44-46,20} \operatorname{Prp}_{23,86-28,20} \operatorname{Sps}_{0,97-1,28} \operatorname{Grs}_{25,62-28,54} \operatorname{And}_{0-2,59} U_{v_{0,04-0,35}}$ \\
\hline \multirow{2}{*}{$\begin{array}{l}\text { Nappe } \\
\text { Socorro- } \\
\text { Guaxupé }\end{array}$} & \multirow[t]{2}{*}{ IC-06-R } & $\begin{array}{l}\left(\mathrm{Fe}^{2+}{ }_{1,51-1,66}, \mathrm{Mn}_{0,08-0,10}, \mathrm{Mg}_{0,74-0,87}, \mathrm{Ca}_{0,47-0,57)} \mathrm{Ti}_{0-0.01}, \mathrm{Fe}^{3+}{ }_{0-0,07},\right. \\
\mathrm{Al}_{1,92-1,99}\left(\mathrm{Al}_{0-0,03}, \mathrm{Si}_{2,97-3,00}\right) \mathrm{O}_{12}\end{array}$ \\
\hline & & $\operatorname{Alm}_{50,48-55,29} \operatorname{Prp}_{24,68-29,24} \operatorname{Sps}_{2,77-3,43} \operatorname{Grs}_{13,19-17,56} A d_{0,16-3,54} U_{0-0,13}$ \\
\hline
\end{tabular}

Nappe Três Pontas-Varginha

A granada das rochas calciossilicáticas é rica na molécula almandina $(41,92 \%$ a $54,02 \%)$, com proporções intermediárias de grossulária (19,27\% a 31,93\%) e piropo $(16,71 \%$ a $28,50 \%)$, e baixas de espessartita ( $0,90 \%$ a $2,66 \%)$, andradita ( $0 \%$ a $4,05 \%)$ e uvarovita $(0 \%$ a 0,40\%). Entre as amostras analisadas, são os grãos de TPR-01-B com os maiores valores de almandina, com média de 49,38\%. Em relação às moléculas de piropo, grossulária e uvarovita, os grãos de TPR-01-F1 são os mais ricos, com 26,82\%, 27,41\% e 0,19\%, 
respectivamente. TPR-01-C apresenta os maiores valores médios de espessartita e andradita, com 1,33\% e 1,52\%. A Tabela 3 compara e resume os valores médios de todas análises de cada amostra.

Tabela 3 - Valores médios dos membros finais de granada das três amostras da Nappe Três Pontas-Varginha. Número subscrito entre parênteses = número de análises. Maiores proporções médias em negrito.

\begin{tabular}{c|ccc|c}
\hline \multirow{2}{*}{$\begin{array}{c}\text { Membro- } \\
\text { final }\end{array}$} & \multicolumn{3}{|c|}{ Nappe Três Pontas-Varginha } & Nappe S-G \\
\cline { 2 - 5 } & TPR-01-C $_{(96)}$ & TPR-01-B $_{(102)}$ & TPR-01-F1 $_{(66)}$ & IC-06-R $_{(95)}$ \\
\hline alm & $48,70 \%$ & $\mathbf{4 9 , 3 8 \%}$ & $43,72 \%$ & $52,08 \%$ \\
pir & $23,68 \%$ & $25,27 \%$ & $\mathbf{2 6 , 8 2} \%$ & $27,88 \%$ \\
sps & $\mathbf{1 , 3 3 \%}$ & $1,12 \%$ & $1,11 \%$ & $2,96 \%$ \\
grs & $24,69 \%$ & $23,57 \%$ & $\mathbf{2 7 , 4 1} \%$ & $15,16 \%$ \\
andr & $\mathbf{1 , 5 2} \%$ & $0,59 \%$ & $0,76 \%$ & $1,88 \%$ \\
uvr & $0,07 \%$ & $0,07 \%$ & $\mathbf{0 , 1 9 \%}$ & $0,04 \%$ \\
\hline \hline TOTAL & $100,00 \%$ & $100,00 \%$ & $100,00 \%$ & $100,00 \%$ \\
\hline
\end{tabular}

Pela análise dos perfis composicionais é típico o padrão plano de almandina com ligeiro enriquecimento nas bordas. Também plano, porém por vezes com núcleo relativamente mais rico (TPR-01-C) é o perfil de espessartita. Piropo e grossulária apresentam perfis de valores intermediários com padrões opostos, com aumento ligeiro de teores de grossulária nas bordas com respectiva diminuição de piropo. Contraste também observado em núcleo de granada de TPR-01-C, rico em grossulária e pobre em piropo (Figura 44). 


\section{TPR-01-C (granada 3)}

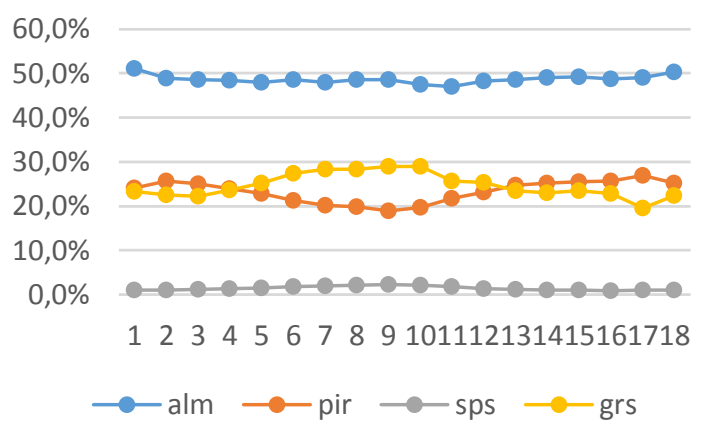

TPR-01-B (granada 3)

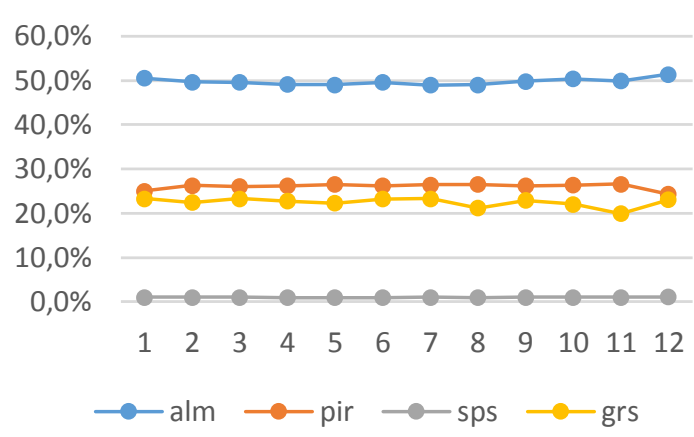

TPR-01-F1 (granada 3)

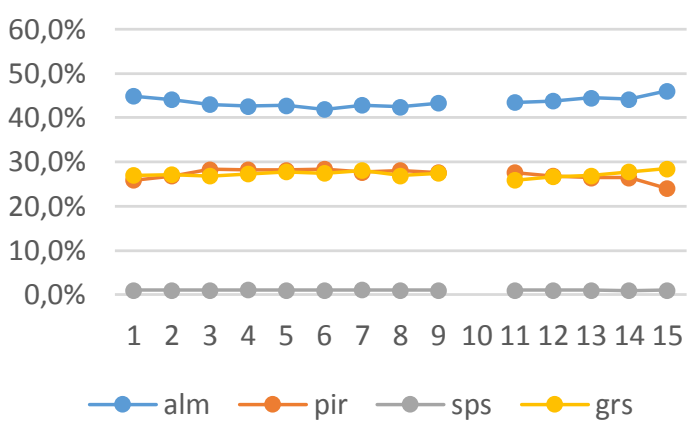

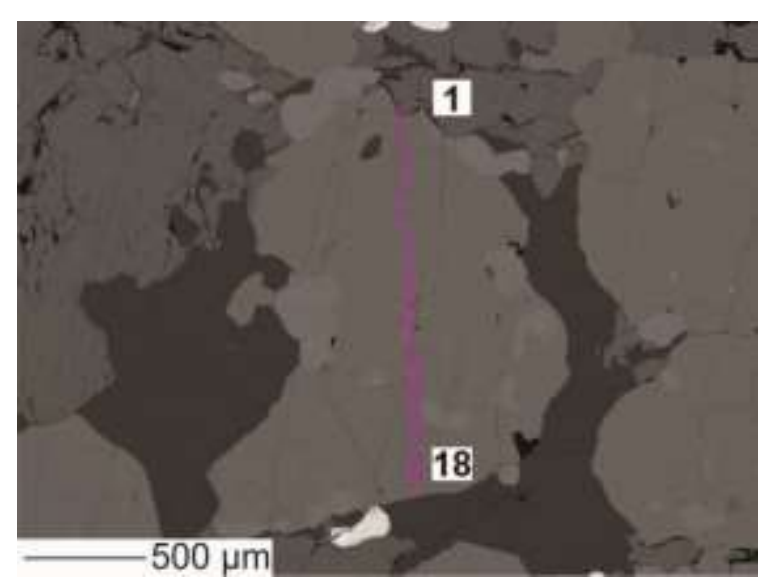
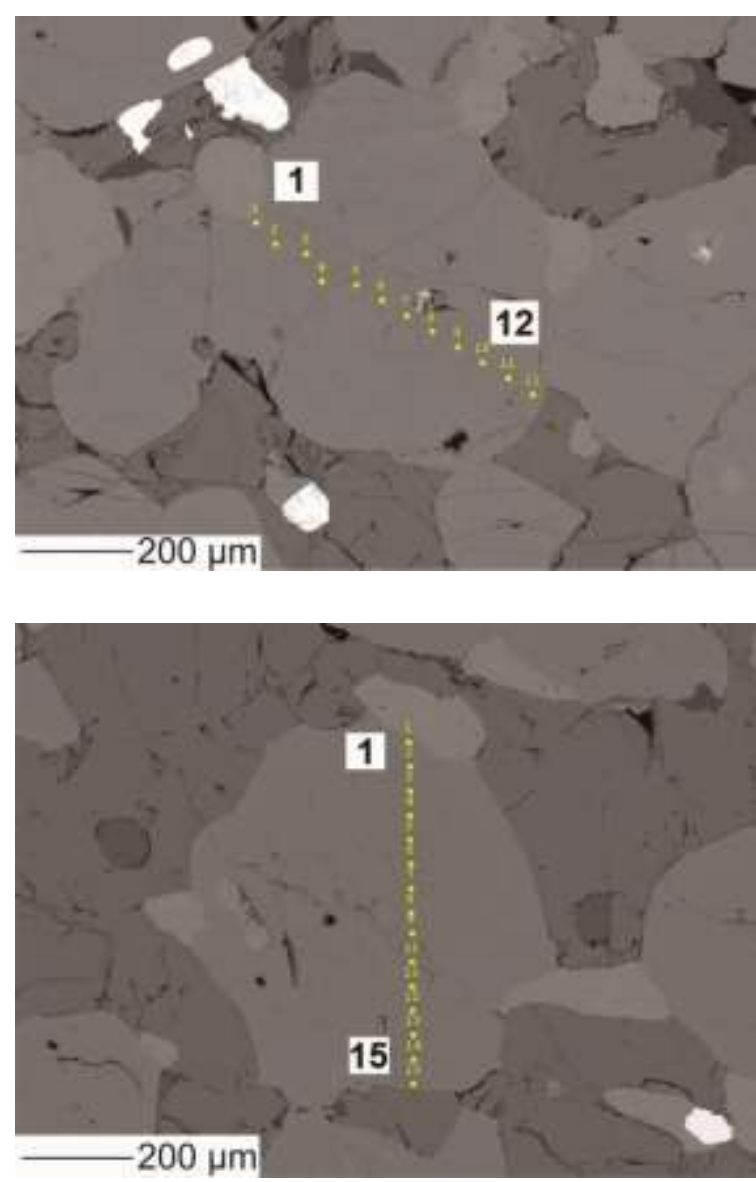

Figura 44 - Perfis composicionais de granada das amostras TPR-01-C, -B e -F1 (eixo X representa as análises pontuais plotadas na imagem de elétrons retro-espalhados).

As relações observadas da variação composicional núcleo-borda descritas nos perfis sugerem distribuição dos membros-finais de maneira concêntrica, o que é confirmado pelos mapas composicionais. A granada da amostra TPR-01-C tem claro enriquecimento de Fe em borda, de Mn em núcleo e discreto em borda em algumas porções superiores do grão, e padrões opostos de grossulária e piropo, com forte enriquecimento em núcleo e discreto em borda de $\mathrm{Ca}$ e forte empobrecimento em núcleo e borda de Mg (Figura 45). 

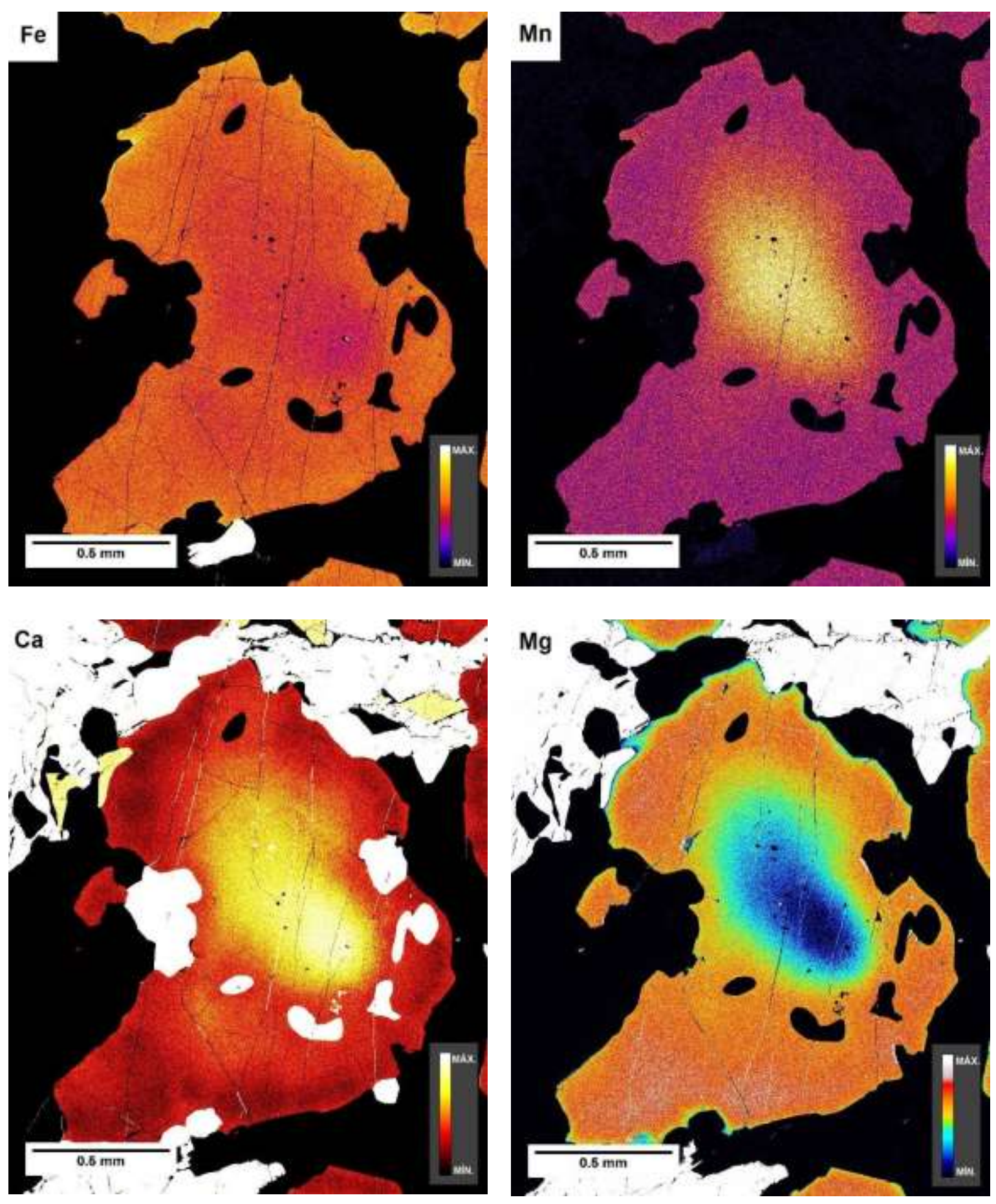

Figura 45 - Mapas composicionais da granada 3 da amostra TPR-01-C para Fe, Mn, Ca e Mg.

Como visto nos perfis composicionais, os mapas dos grãos das amostras TPR-01-B (Figura 46) e TPR-01-F1 (Figura 47) apresentam a mesma relação de enriquecimento de Fe nas bordas, homogeneidade de Mn da granada da amostra TPR-01-B e ligeiro aumento de teor apenas no extremo da borda esquerda do grão da amostra TPR-01-F1 (feição não observada no perfil composicional), e caráter de oposição entre $\mathrm{Mg}$ e $\mathrm{Ca}$, com suaves enriquecimento de Ca e empobrecimento de Mg nas bordas de ambos cristais. 

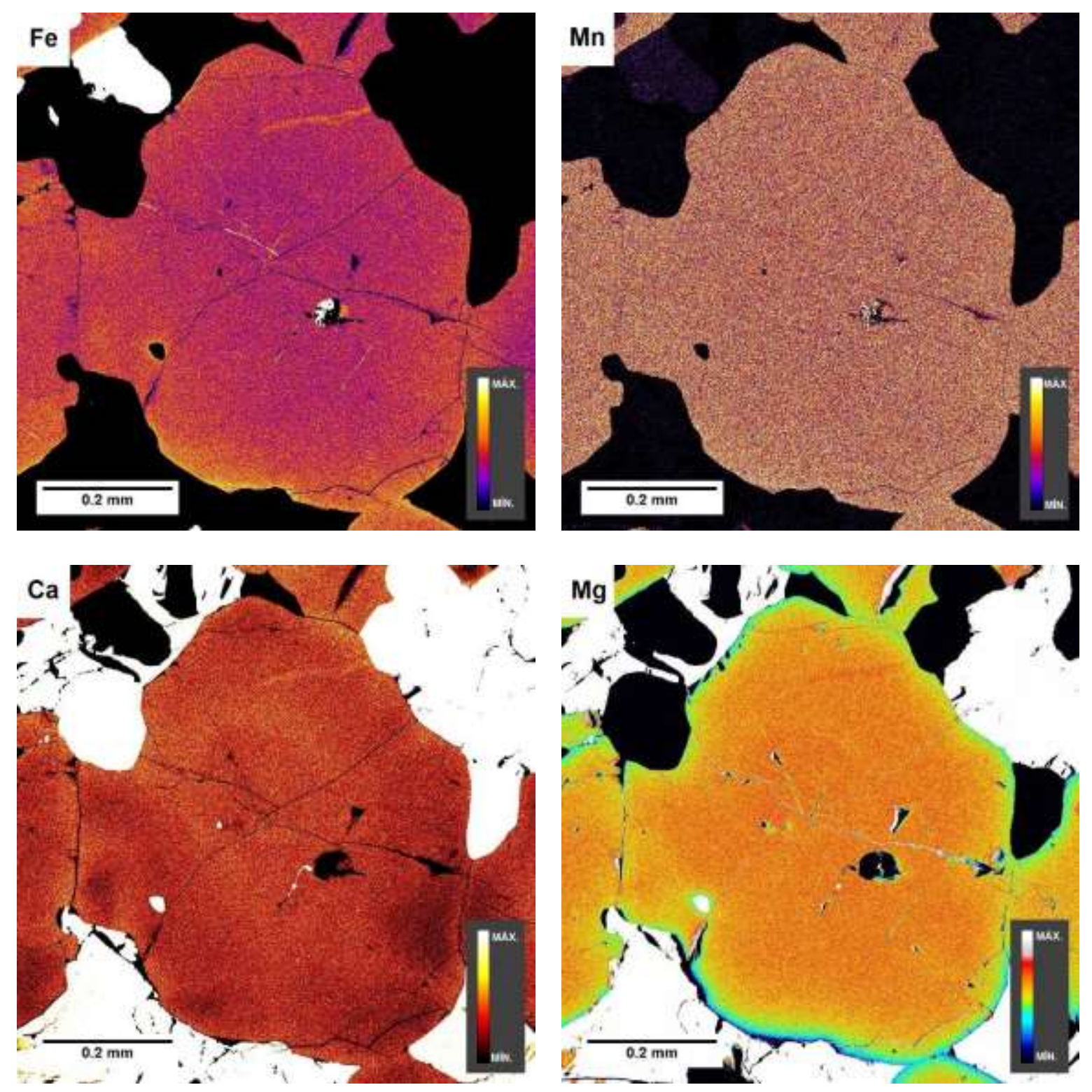

Figura 46 - Mapas composicionais da granada 3 da amostra TPR-01-B para Fe, Mn, Ca e Mg. 

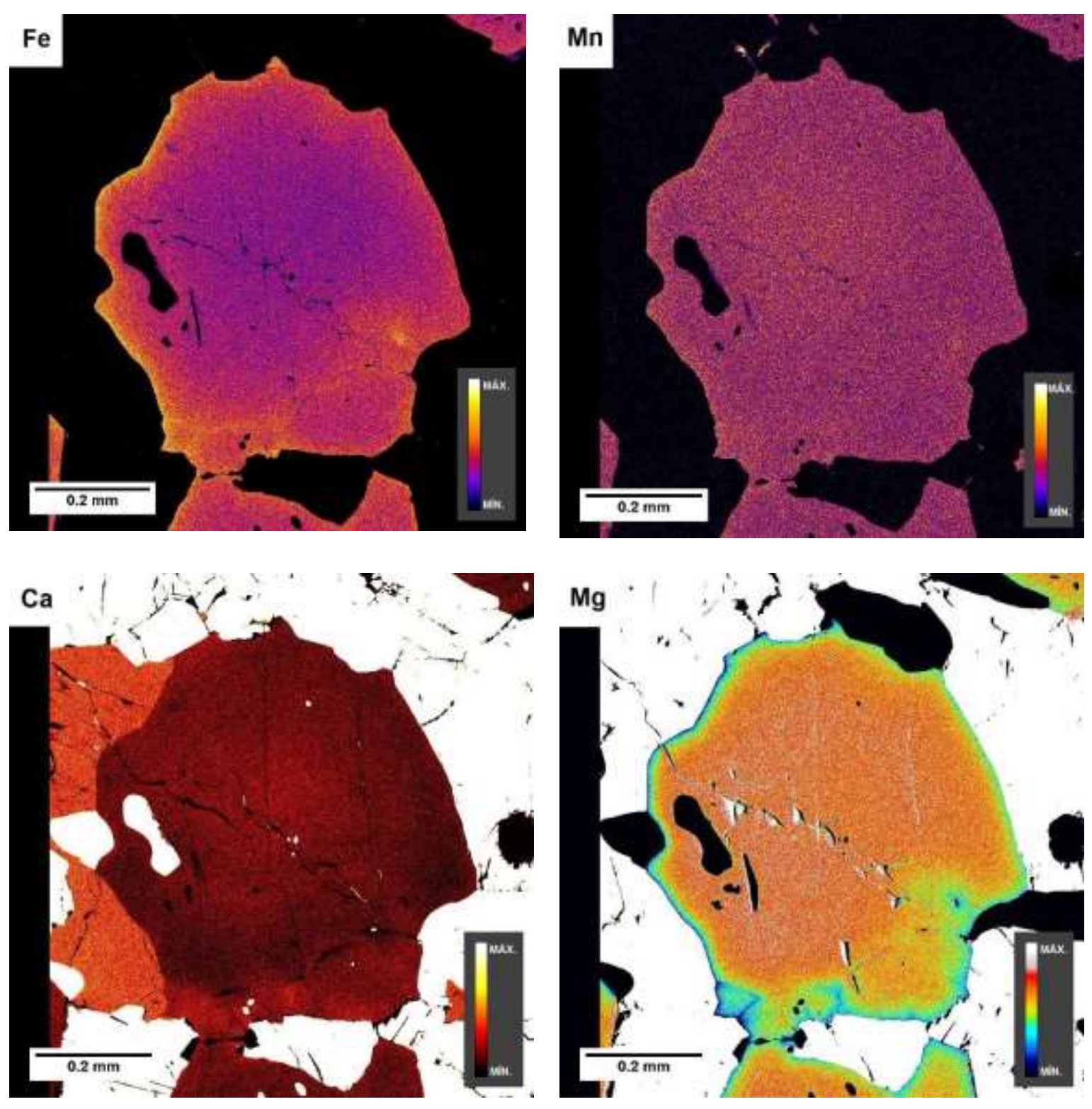

Figura 47 - Mapas composicionais da granada 3 da amostra TPR-01-F1 para Fe, Mn, Ca e Mg.

\section{Nappe Socorro-Guaxupé}

A granada do granulito félsico da Nappe Socorro-Guaxupé, amostra IC-06-R, é rica no membro almandina $(49,21 \%$ a $57,62 \%)$ apresenta proporções intermediárias de piropo $(22,33 \%$ a $31,17 \%)$ e grossulária $(12,28 \%$ a $20,05 \%)$ e baixas de espessartita $(2,34 \%$ a $3,71 \%)$, andradita ( $0 \%$ a $4,91 \%$ ) e uvarovita ( $0 \%$ a $0,15 \%)$. Quando comparada à granada das rochas calciossilicáticas da Nappe Três Pontas-Varginha apresenta valores médios superiores nos membros almandina $(52,08 \%)$, piropo $(27,88 \%)$, espessartita $(2,96 \%)$ e andradita $(1,88 \%)$. Proporções médias dos membros-finais de todos os grãos analisados são apresentadas na Tabela 4, assim como valores das amostras da Nappe Três Pontas-Varginha para efeito comparativo. 
Tabela 4 - Valores médios dos membros-finais de granada da Nappe Socorro-Guaxupé e das três amostras da Nappe Três Pontas-Varginha. Número subscrito entre parênteses = número de análises. Maiores proporções médias em negrito.

\begin{tabular}{c|c|lcc}
\hline \multirow{2}{*}{$\begin{array}{c}\text { Membro- } \\
\text { final }\end{array}$} & $\begin{array}{c}\text { Nappe } \\
\text { Socorro- } \\
\text { Guaxupé }\end{array}$ & \multicolumn{3}{|c}{ Nappe Três Pontas-Varginha } \\
\cline { 2 - 5 } & IC-06-R $_{(95)}$ & TPR-01-C $_{(96)}$ & TPR-01-B $_{(102)}$ & TPR-01-F $_{(66)}$ \\
\hline alm & $\mathbf{5 2 , 0 8 \%}$ & $48,70 \%$ & $49,38 \%$ & $43,72 \%$ \\
pir & $\mathbf{2 7 , 8 8 \%}$ & $23,68 \%$ & $25,27 \%$ & $26,82 \%$ \\
sps & $\mathbf{2 , 9 6 \%}$ & $1,33 \%$ & $1,12 \%$ & $1,11 \%$ \\
grs & $15,16 \%$ & $24,69 \%$ & $23,57 \%$ & $\mathbf{2 7 , 4 1 \%}$ \\
andr & $\mathbf{1 , 8 8 \%}$ & $1,52 \%$ & $0,59 \%$ & $0,76 \%$ \\
uvr & $0,04 \%$ & $0,07 \%$ & $0,07 \%$ & $\mathbf{0 , 1 9 \%}$ \\
\hline \hline TOTAL & $100,00 \%$ & $100,00 \%$ & $100,00 \%$ & $100,00 \%$ \\
\hline
\end{tabular}

Perfis composicionais realizados para cinco grãos da amostra apresentam padrões planos dos membros-finais ao longo dos mesmos. Almandina e espessartita, salvo as discrepantes concentrações locais, têm perfis uniformes e planos com leves enriquecimentos de borda e raramente de núcleo. Piropo, o segundo membro-final mais abundante, assim como para a granada das rochas da Nappe Três Pontas-Varginha, apresenta perfil com leve descréscimo para as bodas, o que é simétrico à da grossulária. Nos perfis composicionais da granada nos cristais 4 e 3 há enriquecimento diferenciado de borda nos membros almandina e grossulária, e inverso no piropo (análises 19 e 1, respectivamente) muito provavelmente relacionados ao contato com biotita (Figura 48). 
IC-06-R (granada 2)

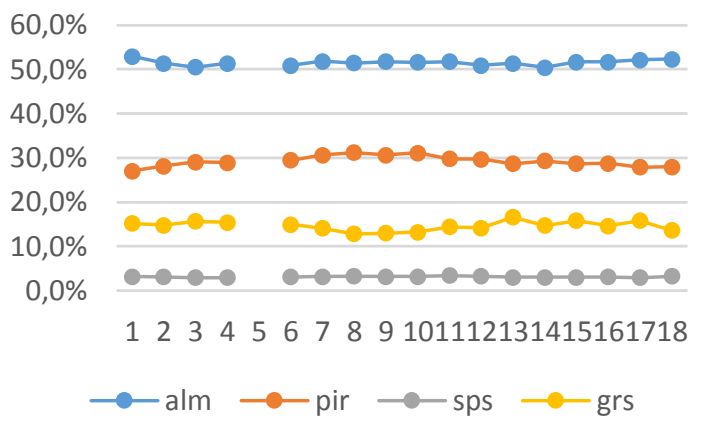

\section{IC-06-R (granada 4)}

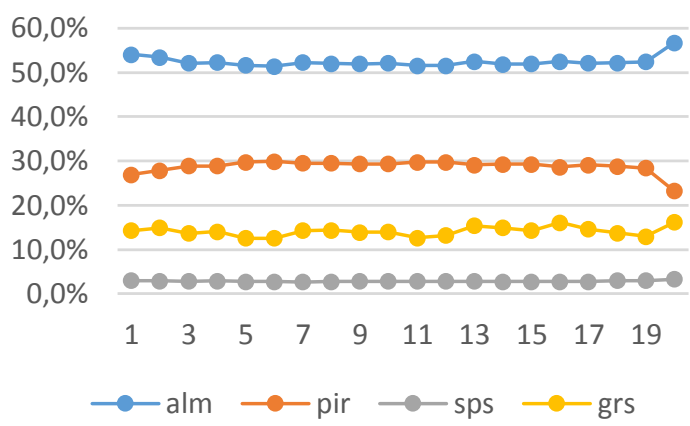

IC-06-R (granada 3)

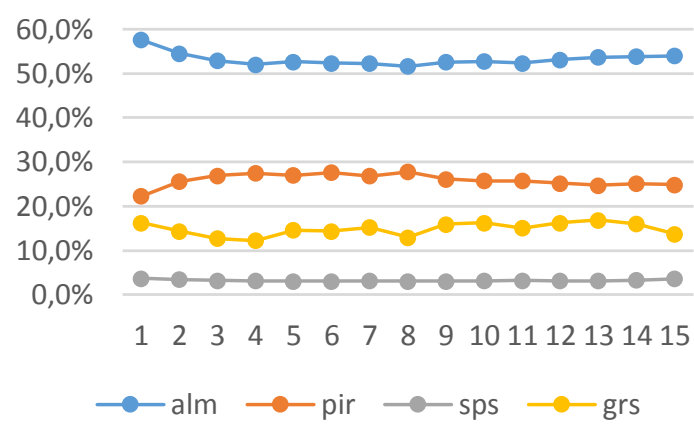

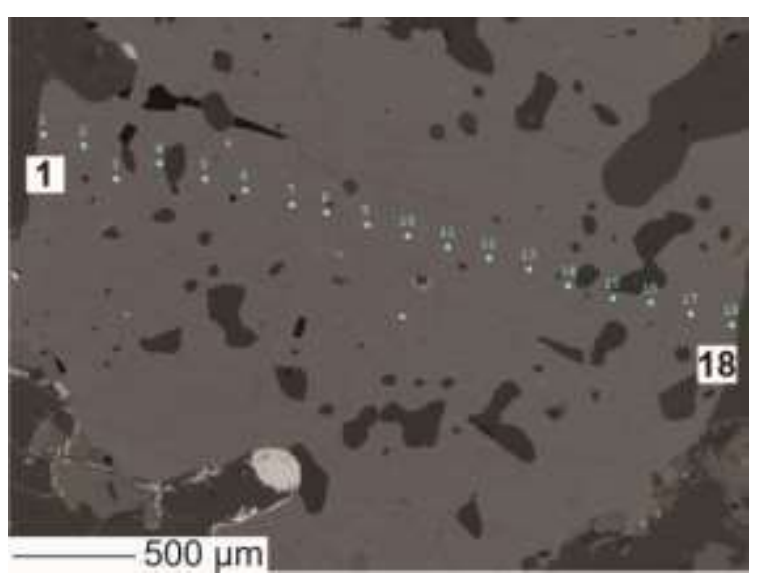
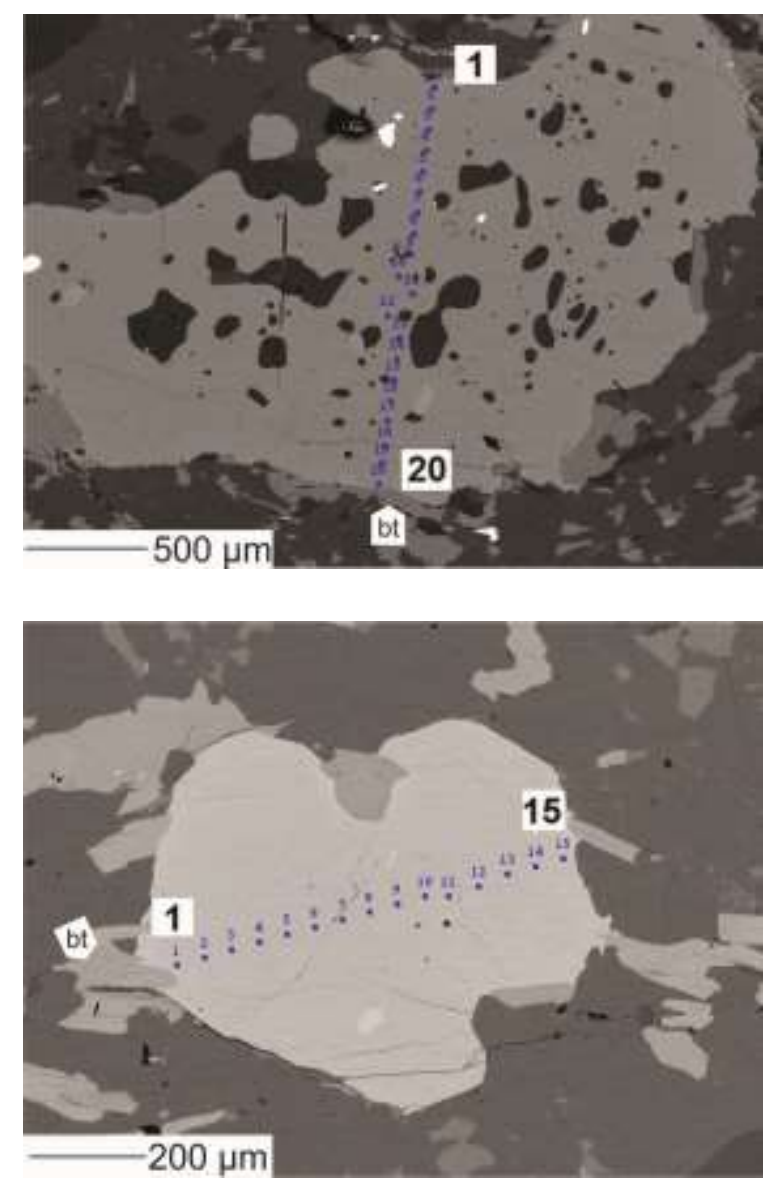

Figura 48 - Perfis composicionais de granada da amostra IC-06-R (eixo X representa as análises pontuais plotadas na imagem de elétrons retroespalhados).

Novamente o padrão de enriquecimento/ empobrecimento núcleo-borda sugere haver distribuição concêntrica dos membros-finais, o que é confirmado pelos mapas composicionais (Figura 49). 

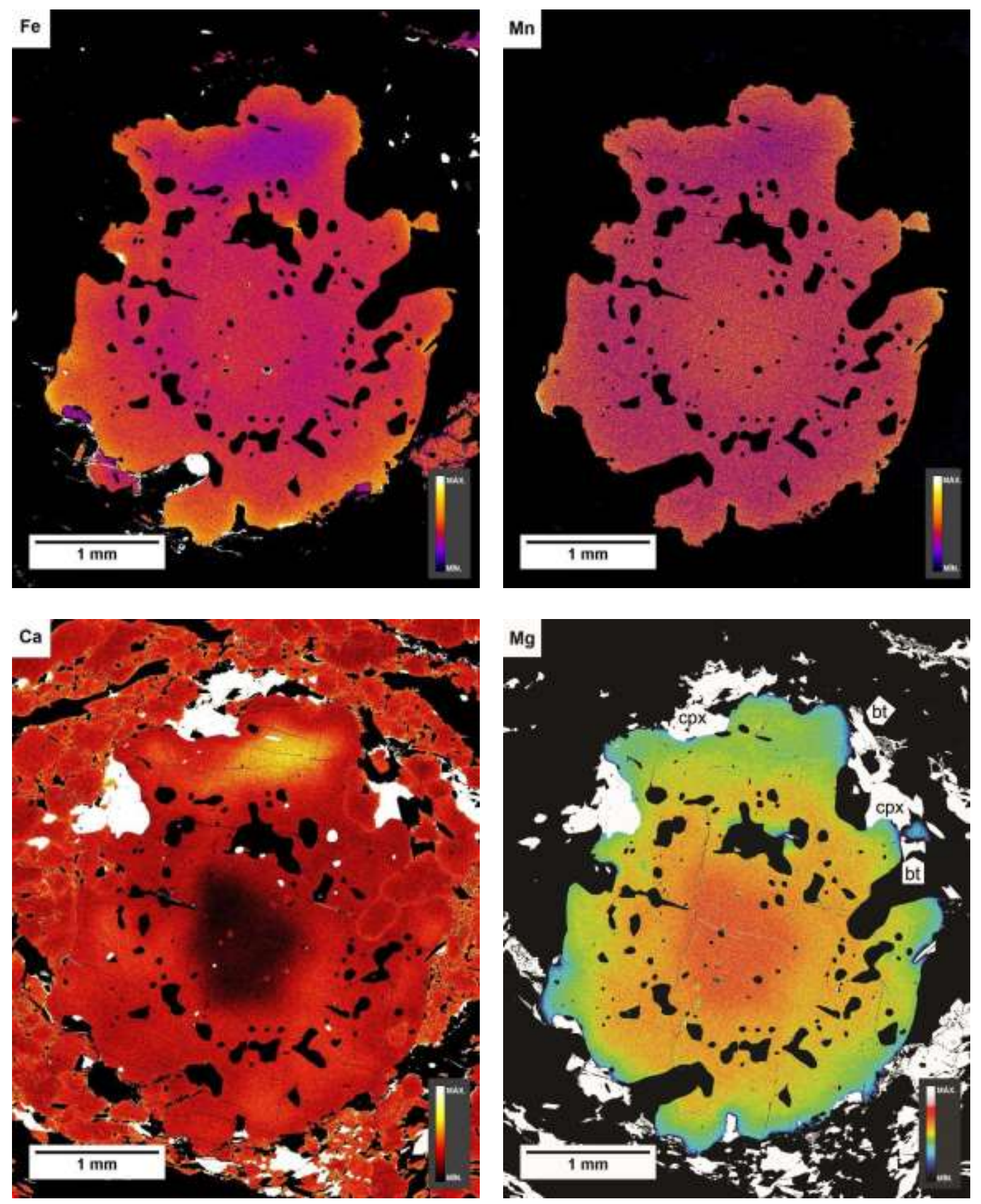

Figura 49 - Mapas composicionais da granada 2 da amostra IC-06-R para Fe, Mn, Ca e Mg

Como descrito no perfil composicional, a granada 2 da amostra IC-06-R apresenta núcleo relativamente rico em $\mathrm{Fe}$ e $\mathrm{Mn}$ com empobrecimento em direção às bordas e enriquecimento de borda externa, principalmente nos contatos com biotita. O mapa de $\mathrm{Ca}$ reforça enriquecimento núcleo-borda já mencionado, porém mostra decréscimos nos teores em regiões próximas às inclusões e em borda quando em contato com plagioclásio e clinopiroxênio externos. Os maiores valores são observados na área superior do mapa em 
local livre de inclusões. Já o mapa de Mg informa uma distribuição inversa a do Ca, também concêntrica, com decréscimo de teores em direção à borda, mostrando valores inferiores nos contatos com clinopiroxênio e ainda menores junto à biotita (Figura 49).

\subsubsection{3. $\quad$ Piroxênio}

O piroxênio pertence ao grupo dos inossilicatos de cadeia simples e é mineral ferromagnesiano importante constituinte de rochas ígneas e metamórficas. É dividido em minerais do sistema ortorrômbico, ortopiroxênio, com a simples série química ( $\mathrm{Mg}, \mathrm{Fe}) \mathrm{SiO}_{3}, \mathrm{e}$ minerais do sistema monoclínico, clinopiroxênios, com maior variação na composição química. Os membros-finais que descrevem as duas séries são $\mathrm{CaMgSi}_{2} \mathrm{O}_{6}-\mathrm{CaFeSi}_{2} \mathrm{O}_{6}-$ $\mathrm{Mg}_{2} \mathrm{Si}_{2} \mathrm{O}_{6}-\mathrm{Fe}_{2} \mathrm{Si}_{2} \mathrm{O}_{6}$, diopsídio - hedembergita - enstatita -ferrossilita. A fórmula geral é $\left[(\mathrm{M} 2)(\mathrm{M} 1)(\mathrm{Si}, \mathrm{Al})_{2} \mathrm{O}_{6}\right]$, em que $\mathrm{M} 1$ e $\mathrm{M} 2$ correspondem à sítios com coordenação octaédrica regular e distorcida, respectivamente e define três sub-grupos principais. Piroxênios de ferro e magnésio, onde outros cátions ocupam menos de 10\% M1 e M2: enstatita-ferrossilita $\left[(\mathrm{Mg}, \mathrm{Fe})_{2} \mathrm{Si}_{2} \mathrm{O}_{6}\right], \quad$ clinoenstatita-clinoferrossilita $\quad\left[(\mathrm{Mg}, \mathrm{Fe})_{2} \mathrm{Si}_{2} \mathrm{O}_{6}\right]$ e pigeonita $\left[\left(\mathrm{Mg}, \mathrm{Fe}^{2+}, \mathrm{Ca}\right)\left(\mathrm{Mg}, \mathrm{Fe}^{2+}\right) \mathrm{Si}_{2} \mathrm{O}_{6}\right.$. Piroxênios cálcicos, nos quais mais de dois terços de M2 é ocupado por $\mathrm{Ca}$ : diopsídio-hedembergita [ $\left.\mathrm{Ca}(\mathrm{Mg}, \mathrm{Fe}) \mathrm{Si}_{2} \mathrm{O}_{6}\right]$, e sódicos, onde $\mathrm{Na}$ ocupa quase que totalmente $\mathrm{M} 2$, e $\mathrm{Al}, \mathrm{Fe}^{3+}$ ou Cr ocorrem em $\mathrm{M} 1$ : jadeíta $\left(\mathrm{NaAlSi}_{2} \mathrm{O}_{6}\right)$, egirina $\left(\mathrm{NaFe}^{3+} \mathrm{Si}_{2} \mathrm{O}_{6}\right)$ e cosmocloro $\left(\mathrm{NaCrSi}_{2} \mathrm{O}_{6}\right)$, respectivamente. A substituição tschermak é importante em todas as séries (Deer et al. 1982).

Nas rochas calciossilicáticas da Nappe Três Pontas-Varginha ocorre apenas clinopiroxênio de granulação fina, subidioblástico a idioblástico, nas porções residuais da rocha. Possui fraturamento mais intenso que a granada, sendo parcialmente alterado por hornblenda em suas bordas ou substituído totalmente. Já o granulito félsico da Nappe Socorro-Guaxupé apresenta clino- e ortopiroxênio, ambos com as mesmas características texturais, granulação fina, subidioblásticos a idioblásticos, e fraturados. Ortopiroxênio apresenta por vezes lamelas de exsolução de clinopiroxênio (Figura 56) e alteração nas bordas para material marrom-avermelhado, e o clinopiroxênio ocorre principalmente junto à granada. Foram analisados 25 cristais de clinopiroxênio, sendo 22 de rocha calciossilicática da Nappe Três Pontas- Varginha e 3 do granulito félsico da Nappe Socorro-Guaxupé, e 4 de ortopiroxênio da última unidade. A Tabela 5 apresenta as médias das fórmulas estruturais para o piroxênio de cada amostra. 
Tabela 5 - Fórmulas estruturais aproximadas (médias) de piroxênio para cada amostra analisada.

\begin{tabular}{|c|c|c|}
\hline Unidade & Amostra & Fórmula estrutural(média) \\
\hline \multirow{3}{*}{ 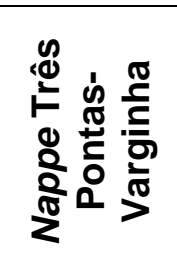 } & TPR-01-C & $\begin{array}{l}\mathrm{Na}_{0,05-0,07}, \mathrm{Ca}_{0,84-0,88}, \mathrm{Fe}^{2+}{ }_{0,22-0,26}, \mathrm{Mg}_{0,69-0,74}, \mathrm{Ti}_{0,01}, \mathrm{Al}_{0,09-0,12}\left(\mathrm{Al}_{0,05-}\right. \\
\left.0,07, \mathrm{Si}_{1,93-1,95}\right) \mathrm{O}_{6}\end{array}$ \\
\hline & TPR-01-B & $\begin{array}{l}\mathrm{Na}_{0,05-0,07}, \mathrm{Ca}_{0,84-0,87}, \mathrm{Fe}^{2+}{ }_{0,23-0,25}, \mathrm{Mg}_{0,69-0,73}, \mathrm{Ti}_{0,01}, \mathrm{Al}_{0,10-0,12}\left(\mathrm{Al}_{0,04-}\right. \\
\left.0,06, \mathrm{Si}_{1,94-1,96}\right) \mathrm{O}_{6}\end{array}$ \\
\hline & TPR-01-F1 & $\begin{array}{l}\mathrm{Na}_{0,04-0,07}, \mathrm{Ca}_{0,87-0,90}, \mathrm{Fe}^{2+}{ }_{0,19-0,20}, \mathrm{Mg}_{0,71-0,74}, \mathrm{Ti}_{0,01}, \mathrm{Al}_{0,11-0,14}\left(\mathrm{Al}_{0,06-}\right. \\
\left.0,09, \mathrm{Si}_{1,91-1,94}\right) \mathrm{O}_{6}\end{array}$ \\
\hline \multirow{2}{*}{$\begin{array}{l}\text { Nappe } \\
\text { Socorro- } \\
\text { Guaxupé }\end{array}$} & IC-06-R (cpx) & $\begin{array}{l}\mathrm{Na}_{0,06-0,07}, \mathrm{Ca}_{0,76-0,85}, \mathrm{Fe}^{2+}{ }_{0,28-0,36}, \mathrm{Mg}_{0,64-0,69}, \mathrm{Fe}^{3+}{ }_{0,01-0,04}, \mathrm{Ti}_{0,01}, \\
\mathrm{Al}_{0,09-0,10}\left(\mathrm{Al}_{0,06-0,09}, \mathrm{Si}_{1,91-1,94}\right) \mathrm{O}_{6}\end{array}$ \\
\hline & IC-06-R (opx) & $\begin{array}{l}\mathrm{Ca}_{0,02-0,04}, \mathrm{Fe}^{2+}{ }_{0,77-0,81}, \mathrm{Mg}_{1,08-1,13}, \mathrm{Fe}^{3+}{ }_{0-0,02}, \mathrm{Al}_{0,04-0,05}\left(\mathrm{Al}_{0,04-0,06},\right. \\
\left.\mathrm{Si}_{1,94-1,96}\right) \mathrm{O}_{6}\end{array}$ \\
\hline
\end{tabular}

Nappe Três Pontas-Varginha

O clinopiroxênio das rochas calciossilicáticas da Nappe Três Pontas-Varginha apresenta Ca na ordem de 0,83 a 0,91 a.p.f.u., Mg entre 0,68 e 0,78 a.p.f.u., $\mathrm{Fe}^{2+}$ entre 0,18 e 0,27 a.p.f.u, Al entre 0,11 e 0,24 a.p.f.u., e quantidades mais baixas de $\mathrm{Na}$, entre 0,04 e 0,09 a.p.f.u. e $\mathrm{Fe}^{3+}$ entre 0 e 0,04 a.p.f.u. Por apresentar diferença nas quantidades de $\mathrm{Mg}$ e $\mathrm{Fe}^{2+}$, o \#Mg é alto e encontra-se entre 71,5 e 81,7. Entre as três amostras analisadas, os cristais de TPR-01-C e TPR-01-B apresentam composições semelhantes (Tabela 5), até em relação a cada elemento, ambas apresentando 0,17 a.p.f.u. de Al, 0,24 a.p.f.u. de $\mathrm{Fe}^{2+}, 0,70$ a.p.f.u. de $\mathrm{Mg}$ e 0,86 e 0,85 a.p.f.u. de Ca, respectivamente. As análises de piroxênio da amostra TPR-01-F1 apresentam maiores valores médios de Al, Mg e Ca, com 0,20, 0,72 e 0,88 a.p.f.u., respectivamente, e de \#mg $(78,34)$. Todos esses valores médios são apresentados na Tabela 6. 
Tabela 6 - Valores médios dos elementos (em a.p.f.u.) analisados em clinopiroxênio e ortopiroxênio de cada amostra de ambas as unidades; Número subscrito entre parênteses = número de análises. Maiores proporções médias entre amostras de clinopiroxênio da Nappe Três Pontas-Varginha em negrito.

\begin{tabular}{c|ccc|cc}
\hline \multirow{2}{*}{ Elemento } & \multicolumn{3}{|c|}{ Nappe Três Pontas-Varginha } & \multicolumn{2}{c}{ Nappe Socorro- } \\
\cline { 2 - 6 } & $\mathrm{TPR}^{-01-\mathrm{C}_{(69)}}$ & $\mathrm{TPR}-01-\mathrm{B}_{(80)}$ & $\mathrm{TPR}-01-\mathrm{F} 1_{(78)}$ & \multicolumn{2}{|c}{${\mathrm{IC}-06-\mathrm{R}_{(69)}}$} \\
\cline { 2 - 6 } $\mathrm{cpx}$ & $\mathrm{cpx}$ & $\mathrm{cpx}$ & $\mathrm{cpx}(29)$ & $\mathrm{opx}_{(40)}$ \\
\hline $\mathrm{Si}$ & 1,94 & 1,95 & 1,92 & 1,92 & 1,95 \\
$\mathrm{Ti}$ & 0,01 & 0,01 & 0,01 & 0,01 & 0 \\
$\mathrm{Al}$ & 0,17 & 0,17 & $\mathbf{0 , 2}$ & 0,18 & 0,1 \\
$\mathrm{Cr}$ & 0 & 0 & 0 & 0 & 0 \\
$\mathrm{Fe}^{3+}$ & 0 & 0 & 0 & 0,04 & 0,01 \\
$\mathrm{Fe}^{2+}$ & $\mathbf{0 , 2 4}$ & $\mathbf{0 , 2 4}$ & 0,2 & 0,31 & 0,79 \\
$\mathrm{Mn}$ & 0 & 0 & 0 & 0,01 & 0,02 \\
$\mathrm{Mg}$ & 0,7 & 0,7 & $\mathbf{0 , 7 2}$ & 0,66 & 1,11 \\
$\mathrm{Ca}$ & 0,86 & 0,85 & $\mathbf{0 , 8 8}$ & 0,8 & 0,02 \\
$\mathrm{Na}$ & $\mathbf{0 , 0 6}$ & $\mathbf{0 , 0 6}$ & 0,05 & 0,07 & 0 \\
$\mathrm{~K}$ & 0 & 0 & 0 & 0 & 0 \\
\hline$\# \mathrm{mg}$ & 74,18 & 74,44 & $\mathbf{7 8 , 3 4}$ & 67,85 & 58,4 \\
\hline \hline
\end{tabular}

Nos perfis composicionais é visível a semelhança entre as análises de piroxênio das amostras TPR-01-C e TPR-01-B, indicando composição homogênea no litotipo. Em ambas amostras, os cristais apresentam perfis homogêneos e planos, sem muita diferença entre núcleo e bordas, com paralelismo de Ca e \#Mg em valores entre 0,7 e 0,9, respectivamente, bordas enriquecidas e sempre com o primeiro superior ao segundo. Comportamento inverso ocorre em Al e $\mathrm{Fe}^{2+}$, com valores entre 0,1 e 0,3 e bordas empobrecidas em relação ao núcleo (TPR-01-C-clinopiroxênio 2 e 3; TPR-01-B-clinopiroxênio 7; Figura 51). As análises de piroxênio da amostra TPR-01-F1 apresentam as mesmas relações entre os pares Ca-\#Mg e $\mathrm{Al}-\mathrm{Fe}^{2+}$, com o primeiro entre 0,75 e acima de 0,9 e o segundo com valores que comumente se sobrepõe em aproximadamente 0,2 (TPR-01-F1-clinopiroxênio 5; Figura 51). Análise de borda em contato com granada tem variações acentuadas, com aumento em \#Mg e decréscimo em Al e Fe ${ }^{2+}$ (TPR-01-C-clinopiroxênio 4: análise 1; Figura 51 e TPR-01-Bclinopiroxênio 7: análise 10; Figura 50). 
TPR-01-C (clinopiroxênio 2)

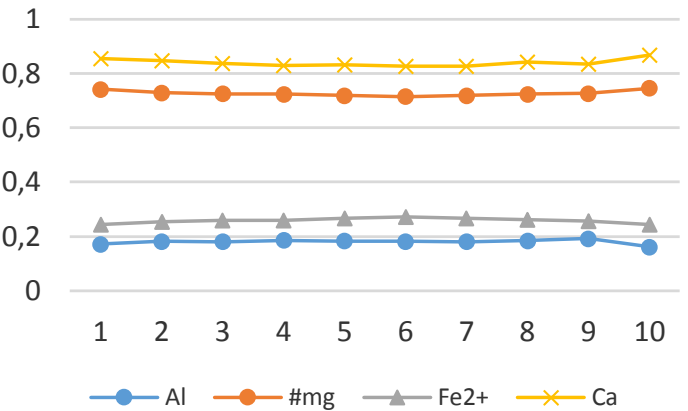

TPR-01-C (clinopiroxênio 3)

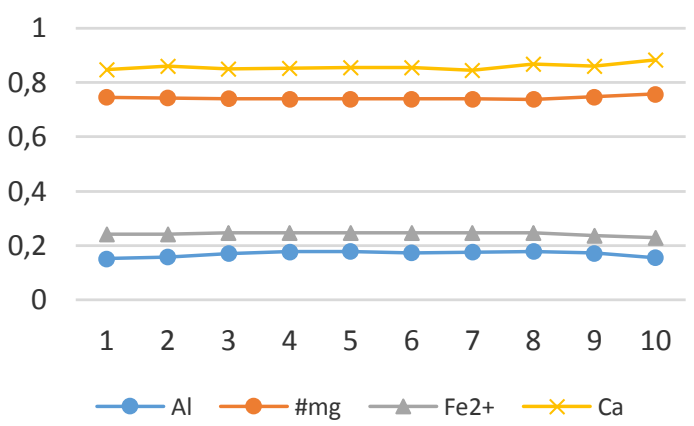

TPR-01-B (clinopiroxênio 7)

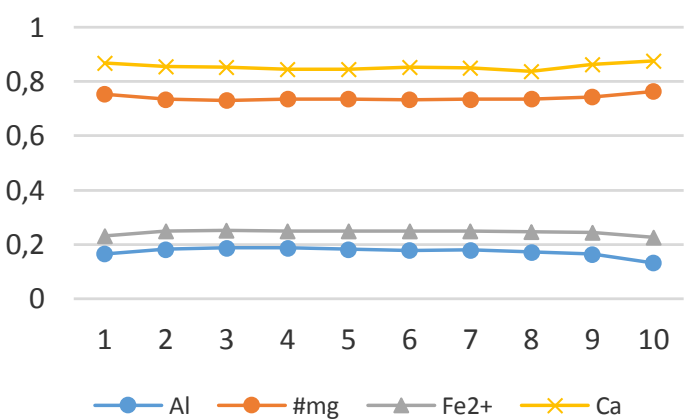

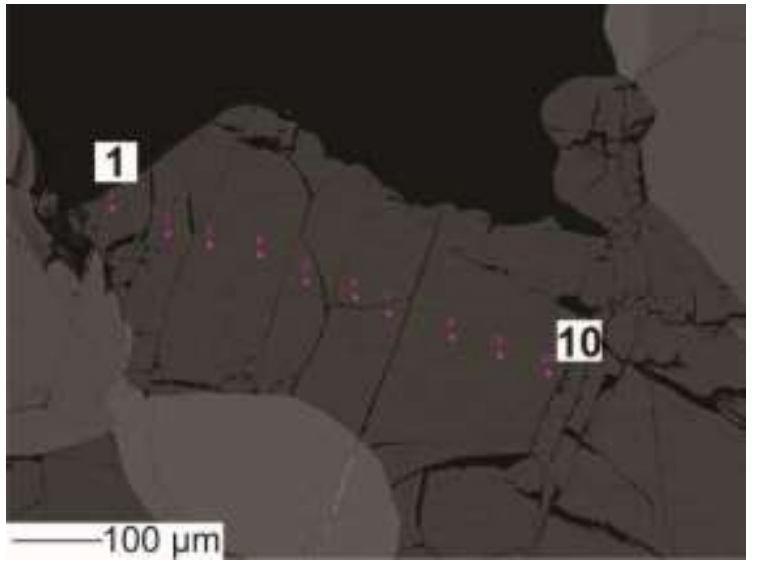
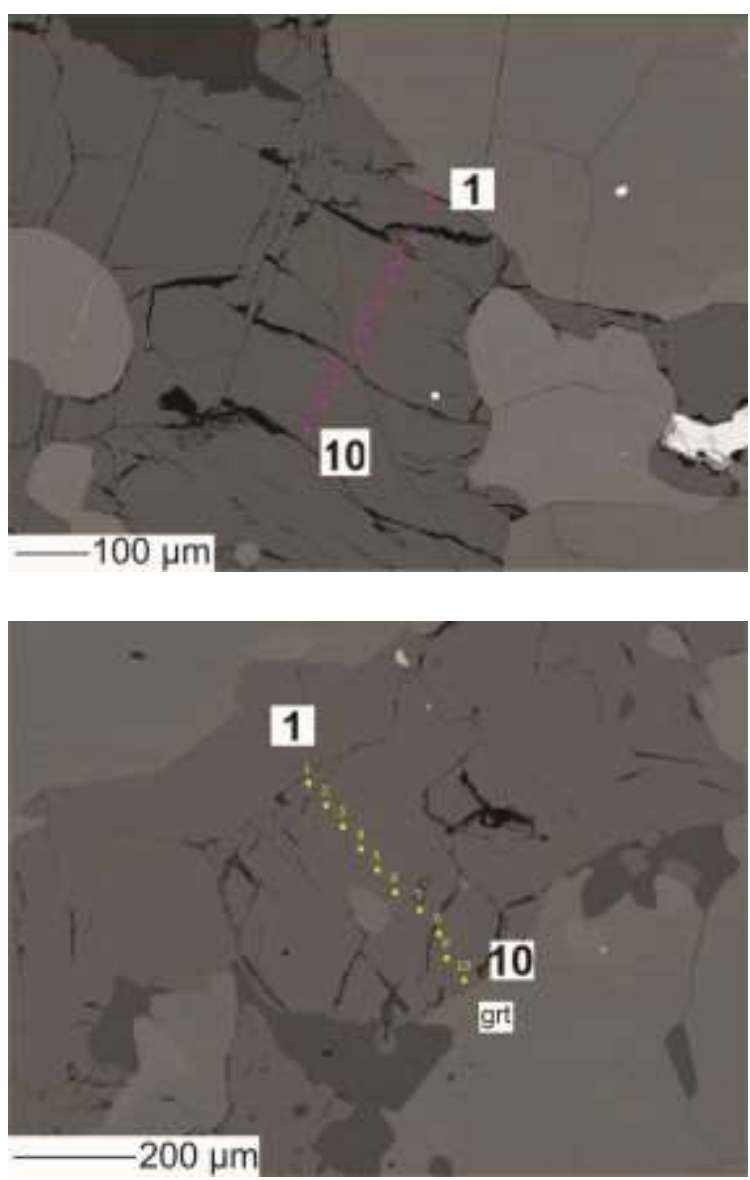

Figura 50 - Perfis composicionais de clinopiroxênio das amostras TPR-01-C e -B (eixo X representa as análises pontuais plotadas na imagem de elétrons retroespalhados. 
TPR-01-C (clinopiroxênio 4)

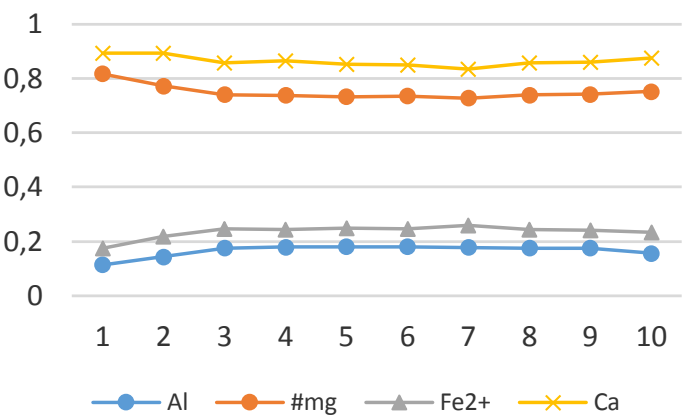

\section{TPR-01-F1 (clinopiroxênio 5)}

$$
1
$$

0,8

0,6

0,4

0,2

0
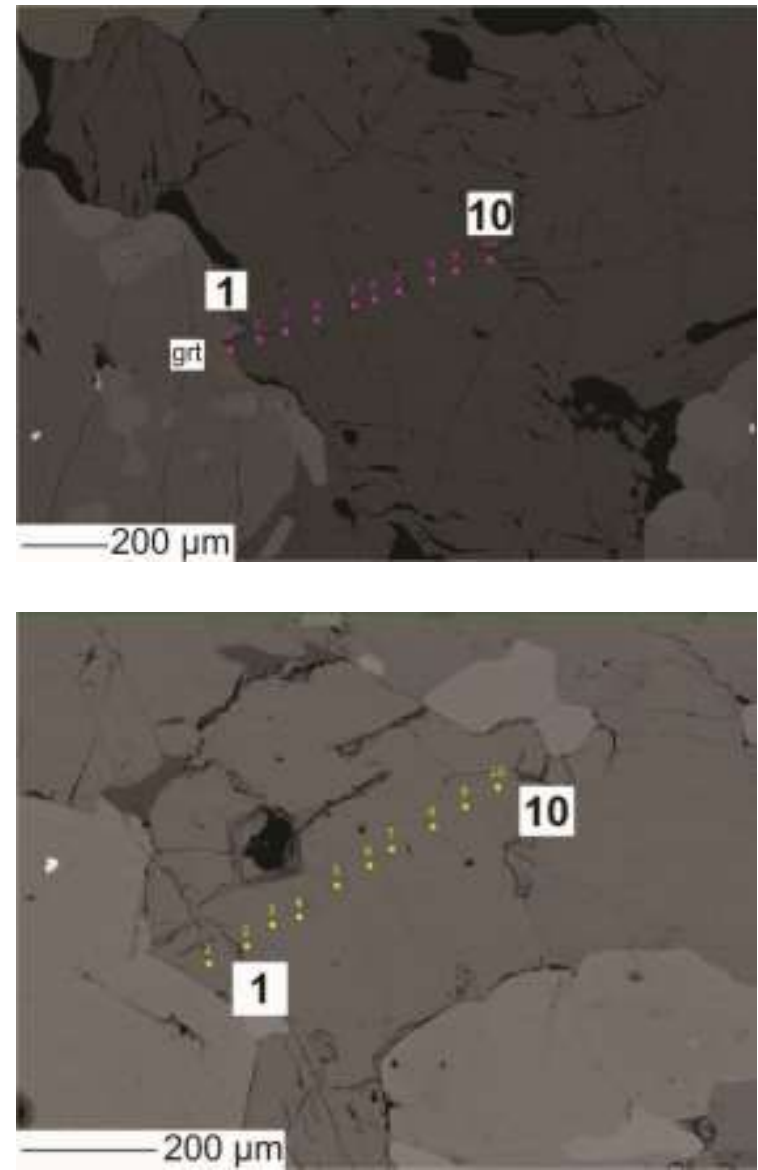

Figura 51 - Perfis composicionais de clinopiroxênio das amostras TPR-01-C e -F1 (eixo X representa as análises pontuais plotadas na imagem de elétrons retroespalhados.

Os resultados obtidos nos perfis composicionais com teores diferenciados na relação núcleo-borda sugerem suave zoneamento químico concêntrico em todos os grãos analisados. Com os mapas composicionais é possível ratificar tal sugestão, com Ca e Mg apresentando leve enriquecimento na borda enquanto que o oposto ocorre com Al e Fe. Também é possível observar as interações da borda dos grãos com a granada, caracterizadas por intensificação nos teores de $\mathrm{Mg}$ e diminuição nos de $\mathrm{Al}$ e $\mathrm{Fe}^{2+}$. No contato com hornblenda é comum o aumento na proporção de $\mathrm{Mg}$ e diminuição na de $\mathrm{Al}$, indicando que a hornblenda é retrometamórfica. Já com titanita, fase acessória comum na rocha, não há indícios de qualquer influência (Figura 52, Figura 53 e Figura 54). 

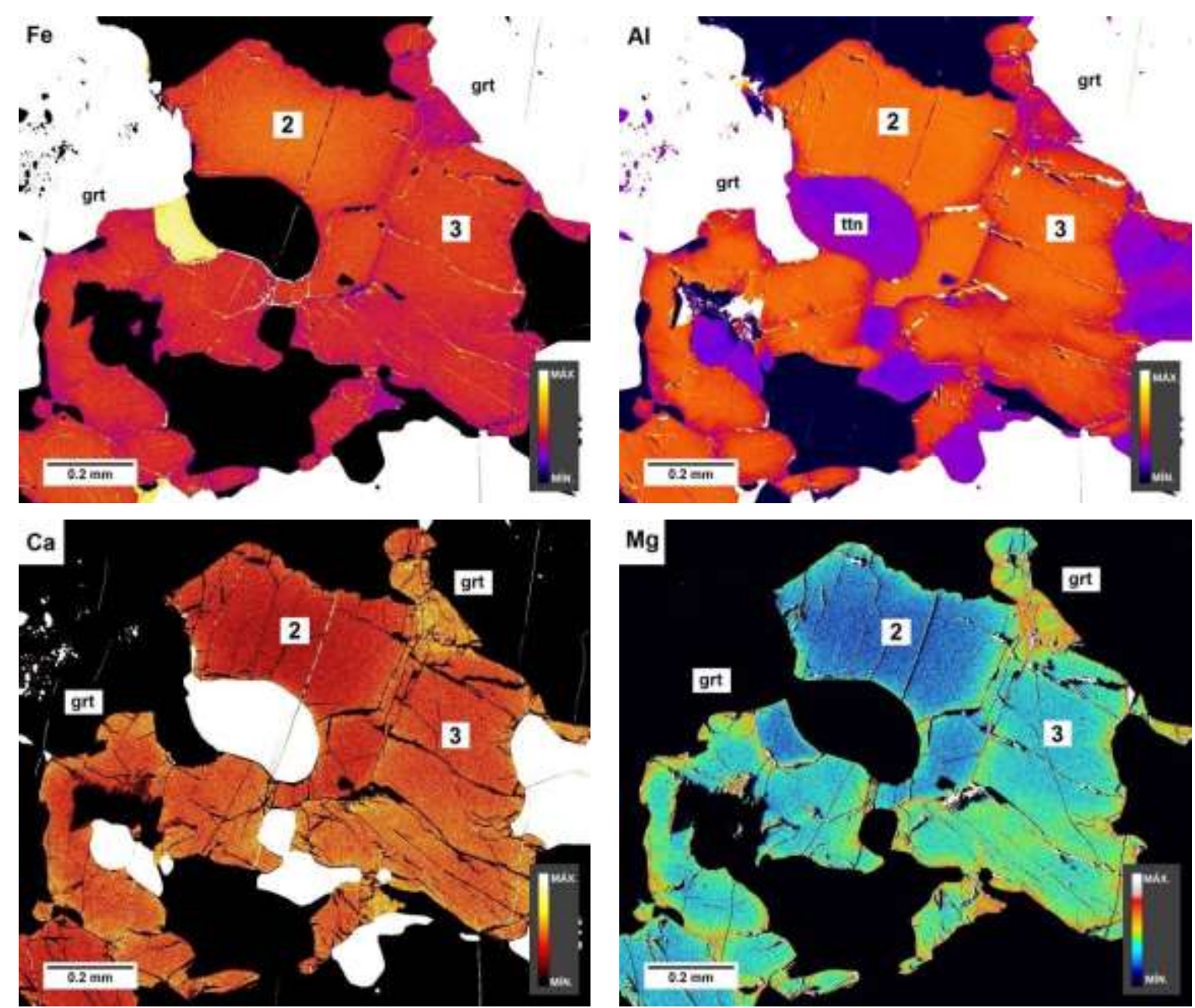

Figura 52 - Mapas composicionais dos clinopiroxênios 2 e 3 da amostra TPR-01-C para Fe, Al, Ca e Mg. Cristais 2 e 3 são os analisados nos perfis composicionais da Figura 51. 

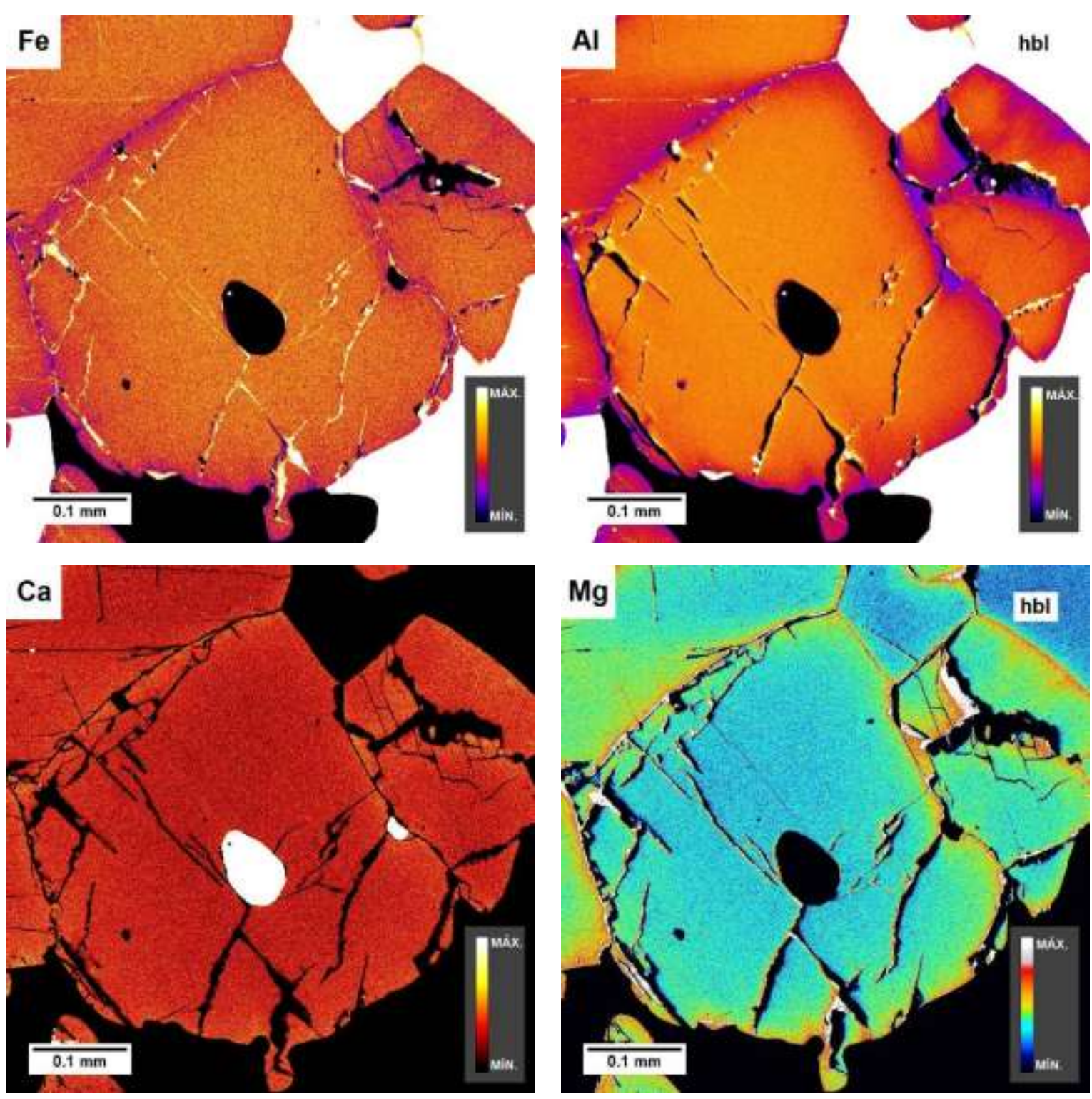

Figura 53 - Mapas composicionais do clinopiroxênio 7 da amostra TPR-01-B para Fe, Al, Ca e Mg. 

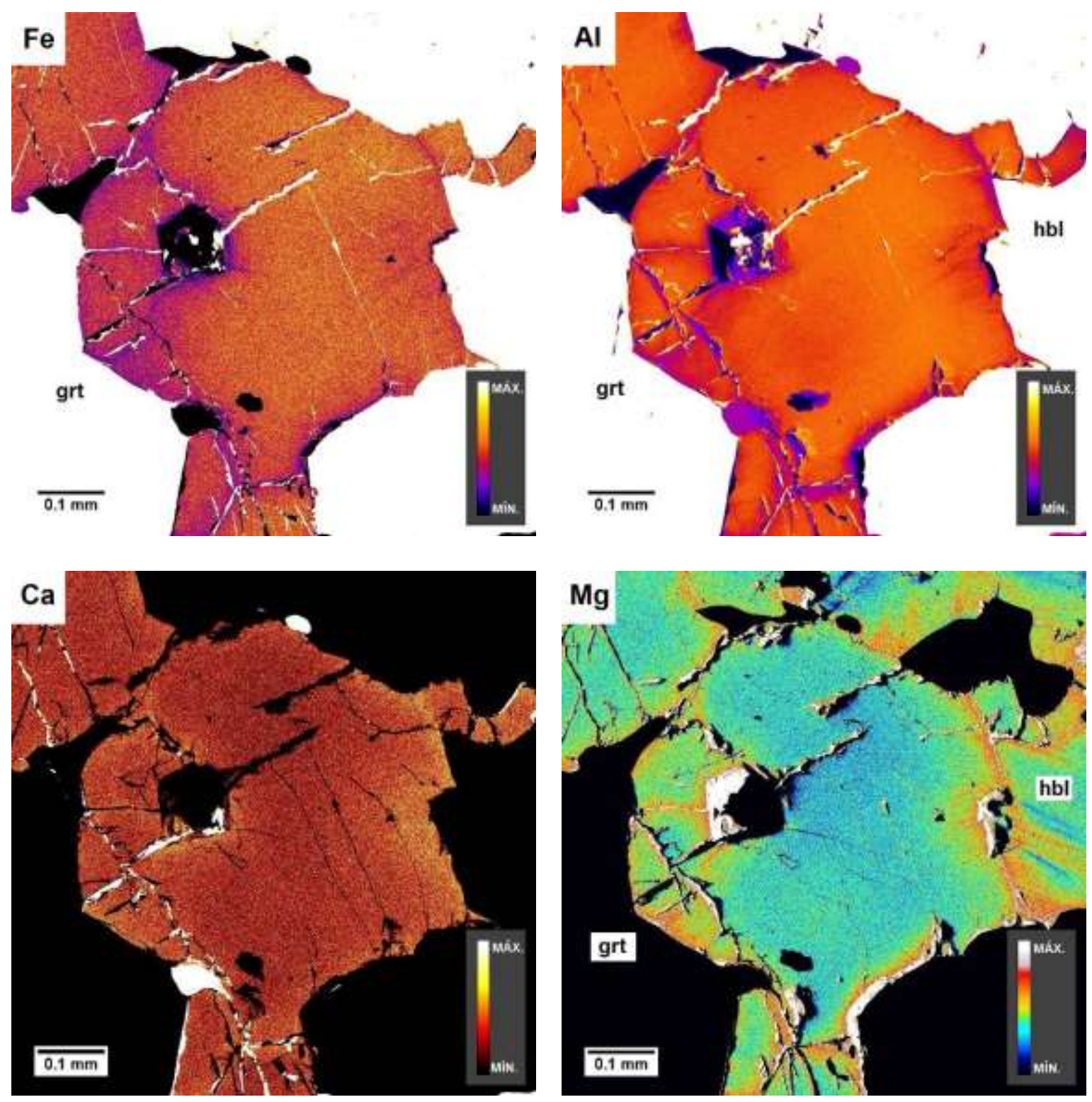

Figura 54 - Mapas composicionais do clinopiroxênio 5 da amostra TPR-01-F1 para Fe, Al, Ca e Mg.

\section{Nappe Socorro-Guaxupé}

No granulito félsico da Nappe Socorro-Guaxupé foram analisados clino- e ortopiroxênio. O clinopiroxênio apresenta proporções de Ca entre 0,71 e 0,86 a.p.f.u., com média de 0,80, e $\mathrm{Mg}$ entre 0,63 e 0,70 a.p.f.u. e média de 0,66, enquanto as de $\mathrm{Fe}^{2+}$ estão entre 0,27 e 0,39 a.p.f.u. com média de 0,31. Proporções menores de outros elementos ocorrem, com Al entre 0,14 e 0,19 a.p.f.u. e média de 0,18, Na entre 0,06 e 0,08 a.p.f.u. e $\mathrm{Fe}^{3+}$ entre 0 e 0,06 a.p.f.u., com média de 0,04, concentração calculada por balanço de cargas, usando quatro cátions e seis átomos de oxigênio. $\mathrm{O}$ \#Mg fica entre 63,8 e 72,3, com 67,85 de média. Ao comparar esses valores médios com os das rochas calciossilicáticas da Nappe Três Pontas-Varginha, o clinopiroxênio da unidade é mais rico em $\mathrm{Fe}_{\mathrm{Tot}} \mathrm{e} \mathrm{Na}$. O ortopiroxênio é característico por apresentar altas proporções de Mg, entre 1,06 e 1,16 a.p.f.u. com média 
de 1,11, e Fe ${ }^{2+}$, entre 0,76 e 0,82 a.p.f.u. com média de 0,79, e moderadas de Al, 0,08 a 0,12 a.p.f.u. e média de 0,10. Os valores médios dos elementos analisados, assim como a comparação entre as duas unidades estudadas estão na Tabela 7.

Tabela 7 - Valores médios dos elementos (em a.p.f.u.) analisados em clinopiroxênio e ortopiroxênio de cada amostra de ambas as unidades; Número subscrito entre parênteses = número de análises. Maiores proporções médias em negrito

\begin{tabular}{|c|c|c|c|c|c|}
\hline \multirow{3}{*}{ Elemento } & \multirow{2}{*}{\multicolumn{2}{|c|}{$\begin{array}{c}\text { Nappe Socorro- } \\
\text { Guaxupé } \\
\text { IC-06- } R_{(69)}\end{array}$}} & \multicolumn{3}{|c|}{ Nappe Três Pontas-Varginha } \\
\hline & & & \multirow{2}{*}{$\frac{\text { TPR-01-C (69) }}{\mathrm{cpx}}$} & TPR-01-B $(80)$ & \multirow{2}{*}{$\frac{\text { TPR-01-F1 }}{\mathrm{cpx}}$} \\
\hline & $\mathrm{cpx}_{(29)}$ & $o p x_{(40)}$ & & $\mathrm{cpx}$ & \\
\hline Si & 1,92 & 1,95 & 1,94 & 1,95 & 1,92 \\
\hline $\mathrm{Ti}$ & 0,01 & 0,00 & 0,01 & 0,01 & 0,01 \\
\hline $\mathrm{Al}$ & 0,18 & 0,10 & 0,17 & 0,17 & 0,20 \\
\hline $\mathrm{Cr}$ & 0,00 & 0,00 & 0,00 & 0,00 & 0,00 \\
\hline $\mathrm{Fe}^{3+}$ & 0,04 & 0,01 & 0,00 & 0,00 & 0,00 \\
\hline $\mathrm{Fe}^{2+}$ & 0,31 & 0,79 & 0,24 & 0,24 & 0,20 \\
\hline $\mathrm{Mn}$ & 0,01 & 0,02 & 0,00 & 0,00 & 0,00 \\
\hline $\mathrm{Mg}$ & 0,66 & 1,11 & 0,70 & 0,70 & 0,72 \\
\hline $\mathrm{Ca}$ & 0,80 & 0,02 & 0,86 & 0,85 & 0,88 \\
\hline $\mathrm{Na}$ & 0,07 & 0,00 & 0,06 & 0,06 & 0,05 \\
\hline $\mathrm{K}$ & 0,00 & 0,00 & 0,00 & 0,00 & 0,00 \\
\hline$\# \mathrm{Mg}$ & 67,85 & 58,40 & 74,18 & 74,44 & 78,34 \\
\hline
\end{tabular}

Nos perfis composicionais de clinopiroxênio são observados os mesmos padrões apresentados na unidade anterior, ou seja, perfis praticamente planos, mas variando apenas em relação aos diferentes teores. Ca e \#Mg são paralelos com valores entre 0,6 e 0,9, respectivamente, e bordas relativamente enriquecidas, enquanto que $\mathrm{Fe}^{2+}$ e $\mathrm{Al}$ apresentam padrões semelhantes, entre 0,1 e 0,4, porém com bordas empobrecidas. Tais valores sugerem distribuição concêntrica dos elementos (IC-06-R clinopiroxênio 1; Figura 55). Os perfis de ortopiroxênio indicam homogeneidade nos teores ao longo do grão, em que $\mathrm{Mg}$ se situa entre 1,0 e 1,2 com leve aumento nas bordas, $\mathrm{Fe}^{2+}$ com valores em torno de 0,8, por vezes com borda também apresentando suave enriquecimento (IC-06-R ortopiroxênio 4, análise 1: aumento de $\mathrm{Fe}^{2+}$ gera correspondente diminuição em \#Mg; Figura 55), \#mg em 0,6, Al em 0,1 com ligeira diminuição nas bordas e Ca constante em 0,02 com poucos pequenos saltos até 0,06 (IC-06-R-ortopiroxênio 2 e 4; Figura 55). De maneira geral, suave distribuição concêntrica também é determinada para o ortopiroxênio nos perfis composicionais (Figura $55)$. 


\section{IC-06-R (clinopiroxênio 1)}

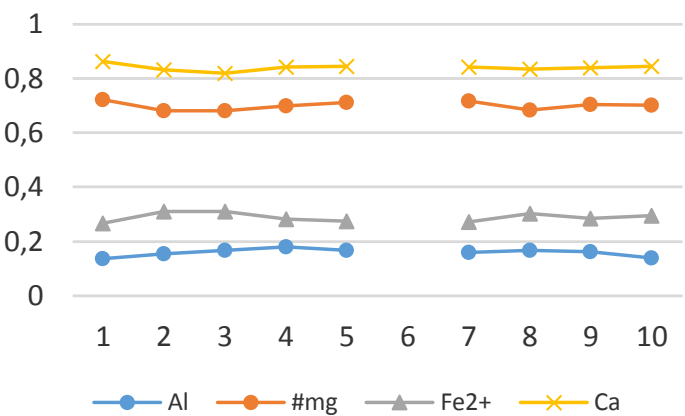

\section{IC-06-R (ortopiroxênio 2)}

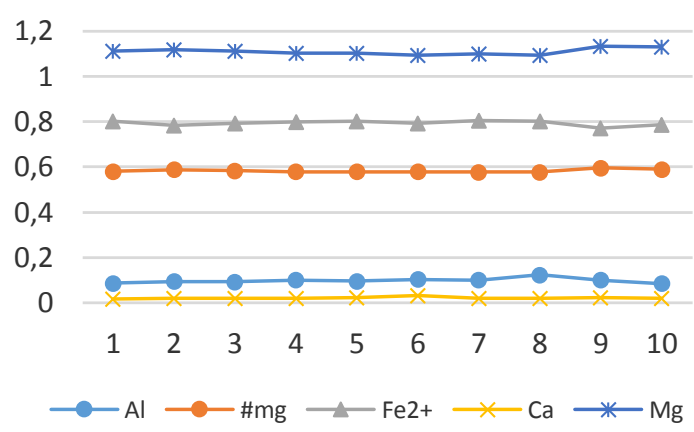

\section{IC-06-R (ortopiroxênio 4)}

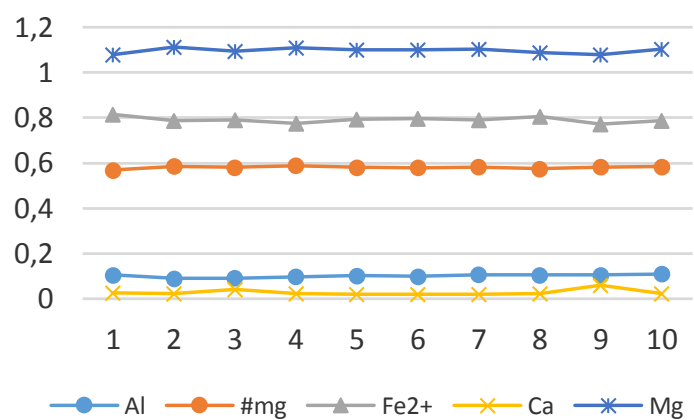

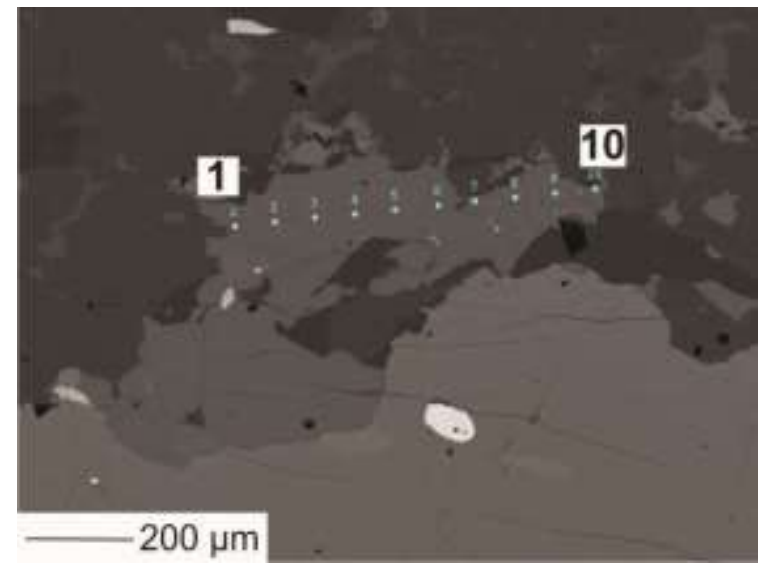
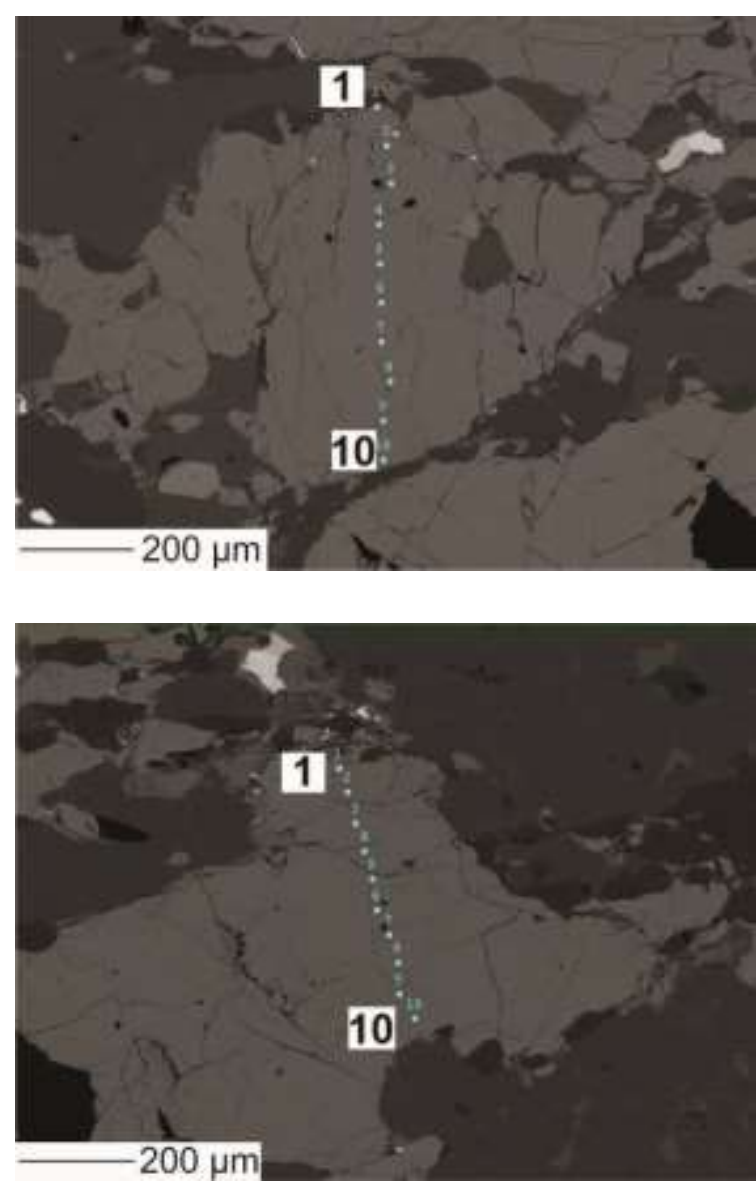

Figura 55 - Perfis composicionais de clinopiroxênio e ortopiroxênio da amostra IC-06-R (eixo X representa as análises pontuais plotadas na imagem de elétrons retroespalhados.

A aparente homogeneidade de $\mathrm{Mg}$ e $\mathrm{Fe}^{2+}$, com suave enriquecimento de borda, a constância de Ca com saltos nos teores, o empobrecimento em Al nas bordas, e a distribuição concêntrica em certos elementos, são postos a prova na confecção e análise de mapas composicionais (Figura 56). 

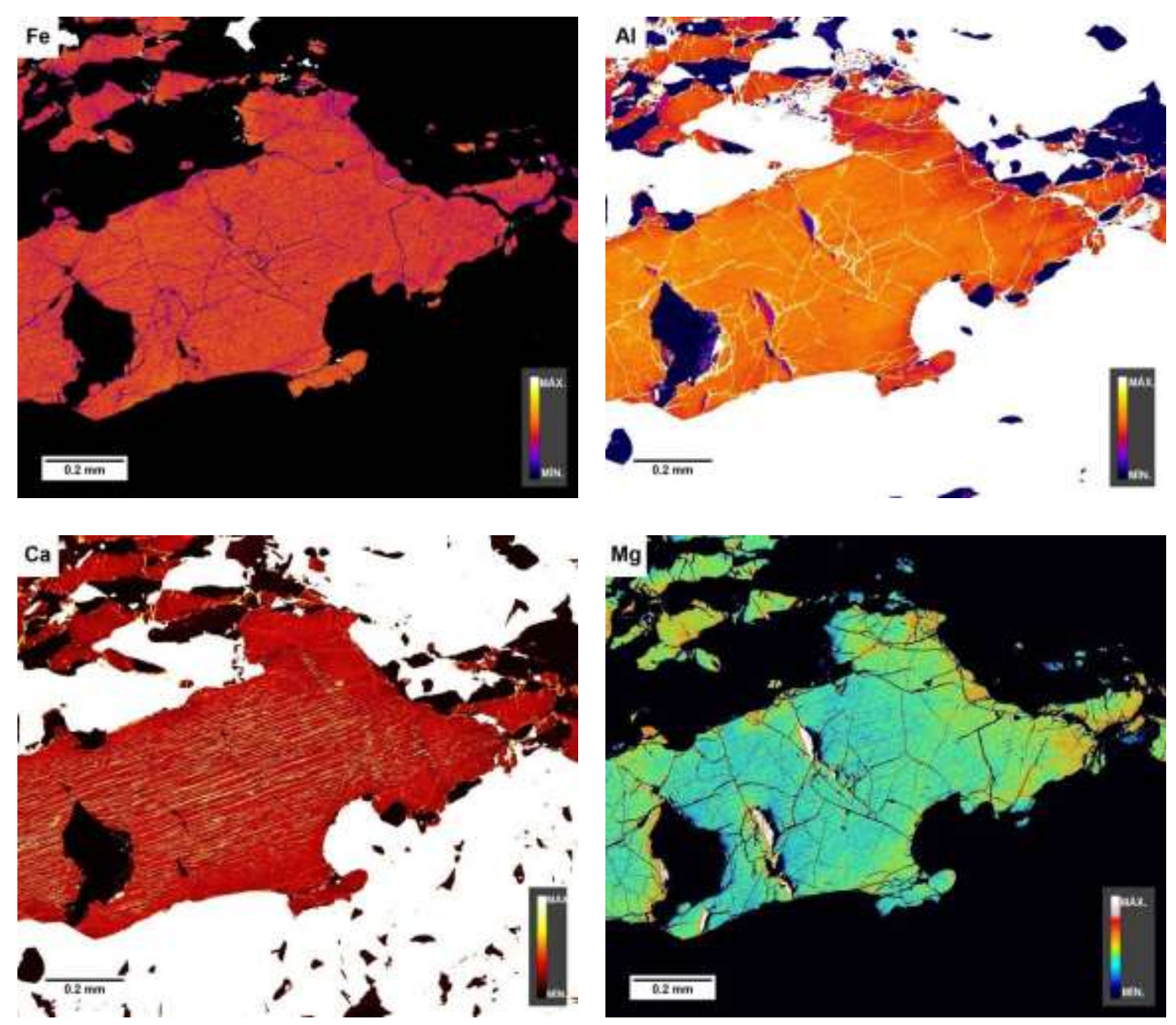

Figura 56 - Mapas composicionais do ortopiroxênio 4 da amostra IC-06-R para Fe, Al, Ca e Mg.

A partir dos mapas composicionais de $\mathrm{Fe}^{2+}$ e $\mathrm{Al}$ é verificado o predominante empobrecimento de teores nas bordas, mostrando que os perfis não são tão representativos da variação composicional. Para o $\mathrm{Ca}$, a constância nos teores é confirmada e os saltos podem ser explicados pelas exsoluções de clinopiroxênio ricas no elemento. $O$ de magnésio confirma o enriquecimento de borda previamente indicado na descrição dos perfis, e por fim, é verificada suave distribuição concêntrica, positiva no caso do $\mathrm{Mg}$, com aumento do teor em direção às bordas, e negativa nos de $\mathrm{Fe}^{2+}$ e Al.

\subsubsection{Plagioclásio}

Feldspato é o mineral mais abundante da crosta terrestre. Está presente na grande maioria das rochas ígneas e em muitas metamórficas e sedimentares. Quimicamente, o grupo dos feldspatos pode ser classificado como membros do sistema ternário albita $\left(\mathrm{NaAISl}_{3} \mathrm{O}_{8}\right)-$ feldspato potássico $\left(\mathrm{KAISi}_{3} \mathrm{O}_{8}\right)$ - anortita $\left(\mathrm{CaAl}_{2} \mathrm{Si}_{2} \mathrm{O}_{8}\right)$. Membros com composições químicas entre albita e feldspato potássico são chamados de feldspato alcalino, e aqueles entre albita e anortita de plagioclásio, que embora estejam distantes do termo potássico, apresentam até 
5 moles por cento de ortoclásio, com tendência de aumento em direção ao termo rico em $\mathrm{Na}$ da série. Íons de $\mathrm{Ti}, \mathrm{Fe}^{3+}, \mathrm{Fe}^{2+}, \mathrm{Mn}, \mathrm{Mg}, \mathrm{Ba}$ e $\mathrm{Sr}$ podem estar presentes em menores proporções (Deer et al. 1982).

Nas rochas calciossilicáticas da Nappe Três Pontas-Varginha há quantidade restrita de plagioclásio. São raros os exemplos existentes junto ao resíduo, sendo mais comum no leucossoma. Para o estudo geotermobarométrico, a fim de se obter temperaturas e pressões mais próximas possíveis das condições de pico metamórfico, é necessário analisar grãos do resíduo e evitar os de leucossoma, pois estes teoricamente foram cristalizados durante o resfriamento e suas composições não estão em equilíbrio com os minerais do pico metamórfico. O plagioclásio nessas rochas é subidioblástico, por vezes intersticial, de granulação fina. Quando mais bem formado ocorre isolado em meio ou incluso em minerais máficos, e indica tratar-se de exemplo de mais alto grau, e quando sem forma/ intersticial, junto a quartzo, sugere ser resultado de cristalização de líquido aprisionado. Já o plagioclásio no granulito félsico da Nappe Socorro-Guaxupé é bastante abundante. No leucossoma apresenta proporções superiores a $60 \%$, granulação fina, é subidioblástico a xenoblástico com terminações afinadas e raramente formam junções tríplices de $120^{\circ}$. O resíduo também apresenta proporções significativas, acima dos $20 \%$, sendo difícil a determinação de sua origem, se do metamorfismo progressivo ou cristalização de líquido aprisionado. Ocorre principalmente na matriz, subidioblástico ou intersticial, acompanhado por quartzo e minerais máficos, e em inclusões em granada junto a quartzo. Este sugere tratar-se de resultado de cristalização de líquido aprisionado.

Em ambas as unidades preferiu-se analisar cristais com texturas indicativas de mais alto grau, ou seja grãos com formato mais regular e de contatos retos. Mas devido a sua escassez e com fins comparativos, foram estudados conjuntamente grãos texturalmente de cristalização tardia. Dos 20 grãos analisados, 10 são de rochas calciossilicáticas da Nappe Três Pontas-Varginha e 10 são do granulito félsico da Nappe Socorro-Guaxupé. A Tabela 8 apresenta as fórmulas estruturais médias.

Tabela 8 - Fórmulas estruturais aproximadas (médias) de plagioclásio para cada amostra analisada

\begin{tabular}{|c|c|c|}
\hline Unidade & Amostra & Fórmula estrutural (média) \\
\hline \multirow{2}{*}{$\begin{array}{c}\text { Nappe } \\
\text { Três } \\
\text { Pontas- } \\
\text { Varginha }\end{array}$} & TPR-01-C & $\mathrm{K}_{0,02,} \mathrm{Ca}_{0,32-0,37}, \mathrm{Na}_{0,55-0,62,} \mathrm{Fe}^{3+}{ }_{0-0,01}, \mathrm{Al}_{1,34-1,42,} \mathrm{Si}_{2,60-2,68,} \mathrm{O}_{8}$ \\
\hline & TPR-01-F1 & $\mathrm{K}_{0,01-0,02,} \mathrm{Ca}_{0,42-0,63}, \mathrm{Na}_{0,35-0,51,} \mathrm{Fe}^{3+}{ }_{0-0,01}, \mathrm{Al}_{1,42-1,63}, \mathrm{Si}_{2,33-2,54}, \mathrm{O}_{8}$ \\
\hline \multirow{2}{*}{$\begin{array}{l}\text { Nappe } \\
\text { Socorro- } \\
\text { Guaxupé }\end{array}$} & $\begin{array}{c}\text { IC-06-R } \\
\text { (inclusão) }\end{array}$ & $\mathrm{K}_{0,02-0,03}, \mathrm{Ca}_{0,30-0,32,} \mathrm{Na}_{0,60-0,63,} \mathrm{Fe}^{3+}{ }_{0,01-0,02}, \mathrm{Al}_{1,34-1,35}, \mathrm{Si}_{2,64-2,68}, \mathrm{O}_{8}$ \\
\hline & $\begin{array}{l}\text { IC-06-R } \\
\text { (matriz) }\end{array}$ & $\mathrm{K}_{0,02,} \mathrm{Ca}_{0,29-0,32,} \mathrm{Na}_{0,62-0,64,} \mathrm{Fe}^{3+}{ }_{0-0,01}, \mathrm{Al}_{1,33-1,35}, \mathrm{Si}_{2,66-2,69}, \mathrm{O}_{8}$ \\
\hline
\end{tabular}




\section{Nappe Três Pontas-Varginha}

O plagioclásio das rochas calciossilicáticas da Nappe Três Pontas-Varginha apresenta Al em teores entre 1,33 e 1,79 a.p.f.u., Ca entre 0,29 e 0,72 a.p.f.u., $\mathrm{Na}$ na faixa de 0,22 a 0,65 a.p.f.u. e teor de anortita entre 30,7 e 76,4. Os grãos da amostra TPR-01-C, em média, são os mais ricos em $\mathrm{Na}$ (0,60 a.p.f.u.), enquanto que os da TPR-01-F1 possuem as maiores médias de $\mathrm{Al}$ (1,51 a.p.f.u.), Ca (0,47 a.p.f.u.) e consequentemente de teor de anortita $(49,62)$. A Tabela 9 resume os teores médios (em a.p.f.u.) de cada amostra.

Tabela 9 - Valores médios dos elementos (em a.p.f.u.) analisados em plagioclásio de cada amostra de ambas as unidades; Número subscrito entre parênteses = número de análises. Maiores proporções médias em negrito (apenas para as amostras da Nappe Três Pontas-Varginha).

\begin{tabular}{c|cc|cc}
\hline \multirow{2}{*}{ Elemento } & \multicolumn{2}{|c|}{ Nappe Três Pontas-Varginha } & \multicolumn{2}{c}{ Nappe Socorro-Guaxupé } \\
\cline { 2 - 5 } & TPR-01-C $_{(18)}$ & TPR-01-F $1_{(56)}$ & IC-06-R $(20)$ & IC-06- $\mathrm{R}_{(23)}$ \\
\hline & & & inclusão & matriz \\
\cline { 3 - 5 } $\mathrm{Si}$ & $\mathbf{2 , 6 4}$ & 2,50 & 2,66 & 2,68 \\
$\mathrm{Ti}$ & 0,00 & 0,01 & 0,00 & 0,00 \\
$\mathrm{Al}$ & 1,38 & $\mathbf{1 , 5 1}$ & 1,35 & 1,34 \\
$\mathrm{Cr}$ & 0,00 & 0,00 & 0,00 & 0,00 \\
$\mathrm{Fe}^{3+}$ & 0,00 & 0,00 & 0,01 & 0,00 \\
$\mathrm{Fe}^{2+}$ & 0,00 & 0,00 & 0,00 & 0,00 \\
$\mathrm{Mn}$ & 0,00 & 0,00 & 0,00 & 0,00 \\
$\mathrm{Mg}$ & 0,00 & 0,00 & 0,01 & 0,00 \\
$\mathrm{Ca}$ & 0,34 & $\mathbf{0 , 4 7}$ & 0,31 & 0,30 \\
$\mathrm{Na}$ & $\mathbf{0 , 6 0}$ & 0,48 & 0,62 & 0,64 \\
$\mathrm{~K}$ & 0,02 & 0,02 & 0,02 & 0,02 \\
\hline Anortita & 36,43 & $\mathbf{4 9 , 6 2}$ & 33,51 & 32,26 \\
\hline \hline
\end{tabular}

Os perfis composicionais de plagioclásio de ambas amostras mostram a mesma simetria, com bordas mais ricas em anortita em relação ao núcleo, variando apenas nos teores em cada caso, com os grãos de TPR-01-F1 mais ricos que TPR-01-C. Esses padrões nos perfis sugerem distribuição de $\mathrm{Ca}$ e $\mathrm{Na}$ de maneira concêntrica, sendo o primeiro com maiores valores na borda do que no núcleo. Os perfis composicionais de plagioclásio 5 e 6 da amostra TPR-01-F1 foram plotados em apenas um gráfico devido à continuidade das análises, e mesmo dessa maneira, é possível verificar através do pico nos teores entre as análises $10 \mathrm{e}$ 11 que o contato entre ambos ocorre nessa posição (Figura 57). 
TPR-01-F1 (plagioclásio 5 e 6)
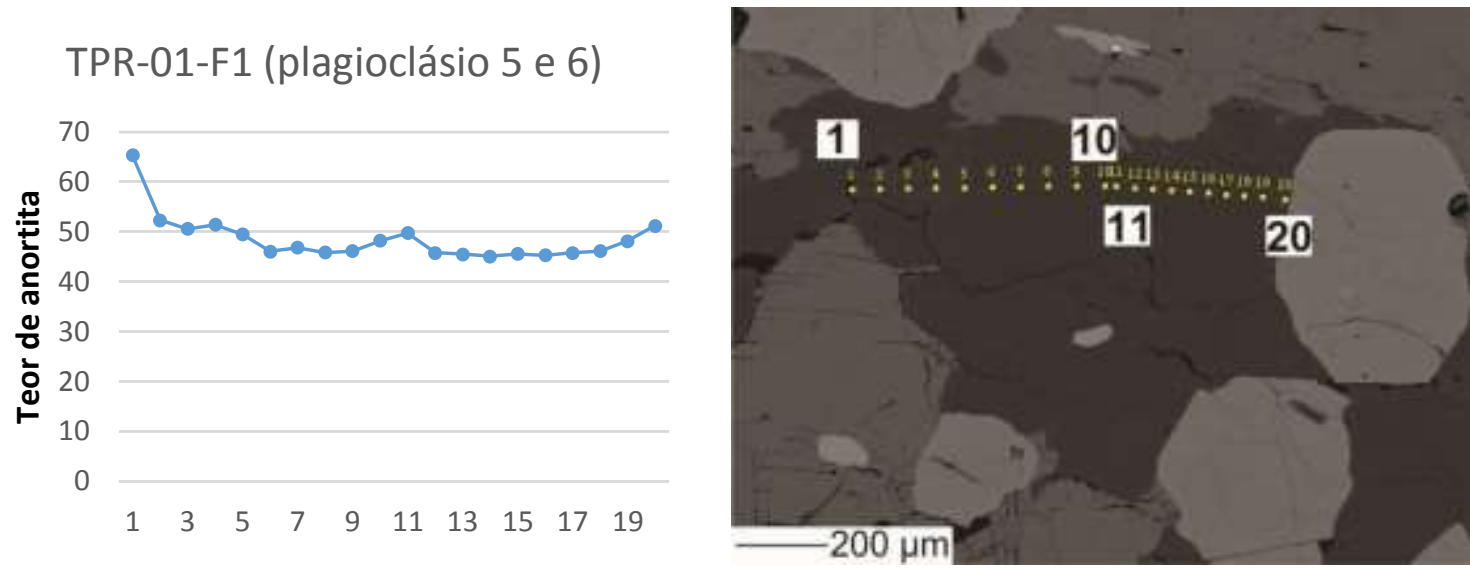

TPR-01-C (plagioclásio 3)
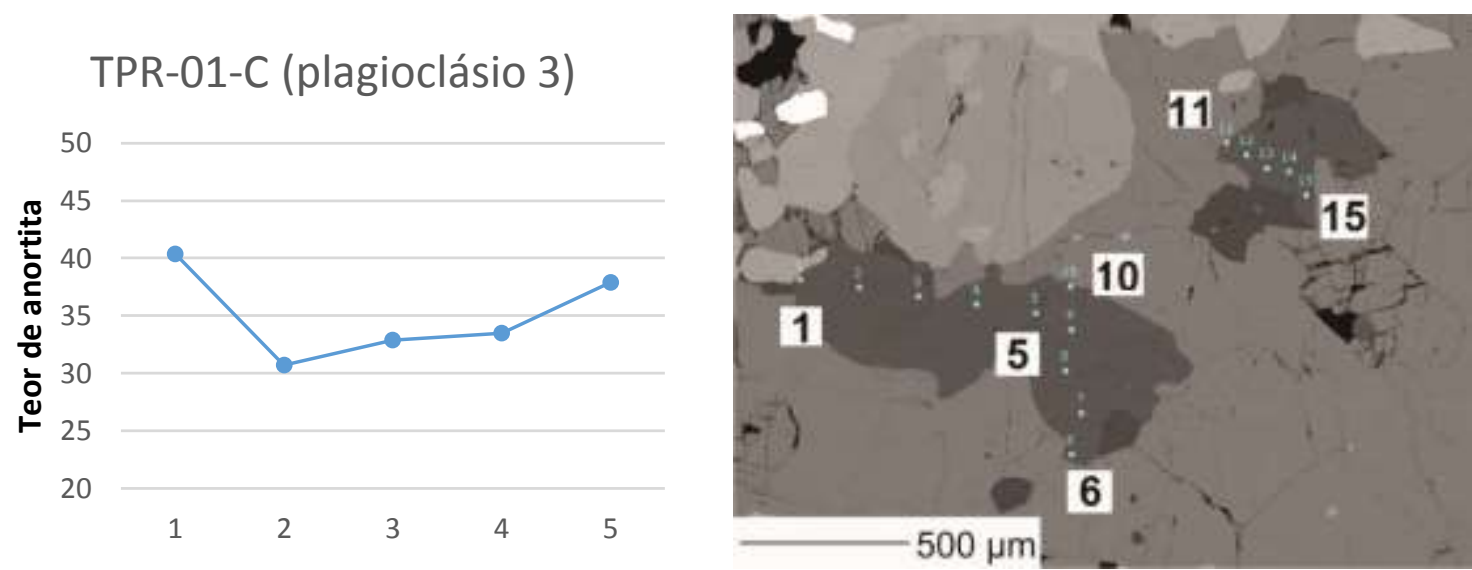

TPR-01-C (plagioclásio 4)

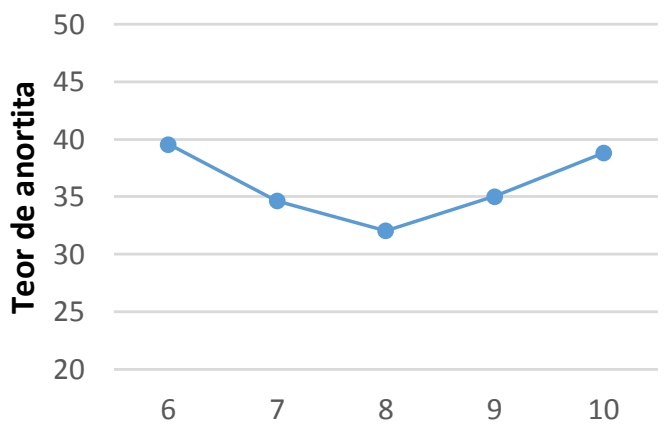

\section{TPR-01-C (plagioclásio 5)}

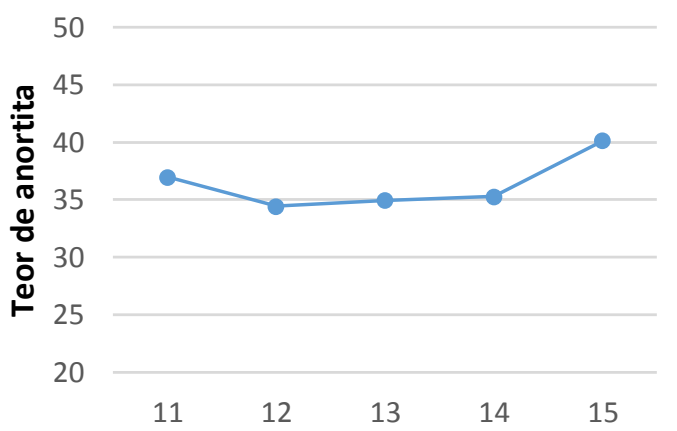

Figura 57 - Perfis composicionais de plagioclásio das amostras TPR-01-F1 e TPR-01-C (eixo X representa as análises pontuais plotadas na imagem de elétrons retroespalhados.

A partir de mapas composicionais é verificada suave distribuição concêntrica para Ca e $\mathrm{Na}$. Os grãos 5 e 6 de plagioclásio da amostra TPR-01-F1 exibem enriquecimento de $\mathrm{Ca}$ em direção às bordas, principalmente nos contatos com outro plagioclásio, hornblenda e clinopiroxênio. Para Na ocorre o inverso, com empobrecimento de teor em direção às bordas que predomina nos contatos com os mesmos minerais do caso anterior. Em ambos exemplos o contato com granada parece não surtir qualquer efeito na composição do plagioclásio (Figura 58). 

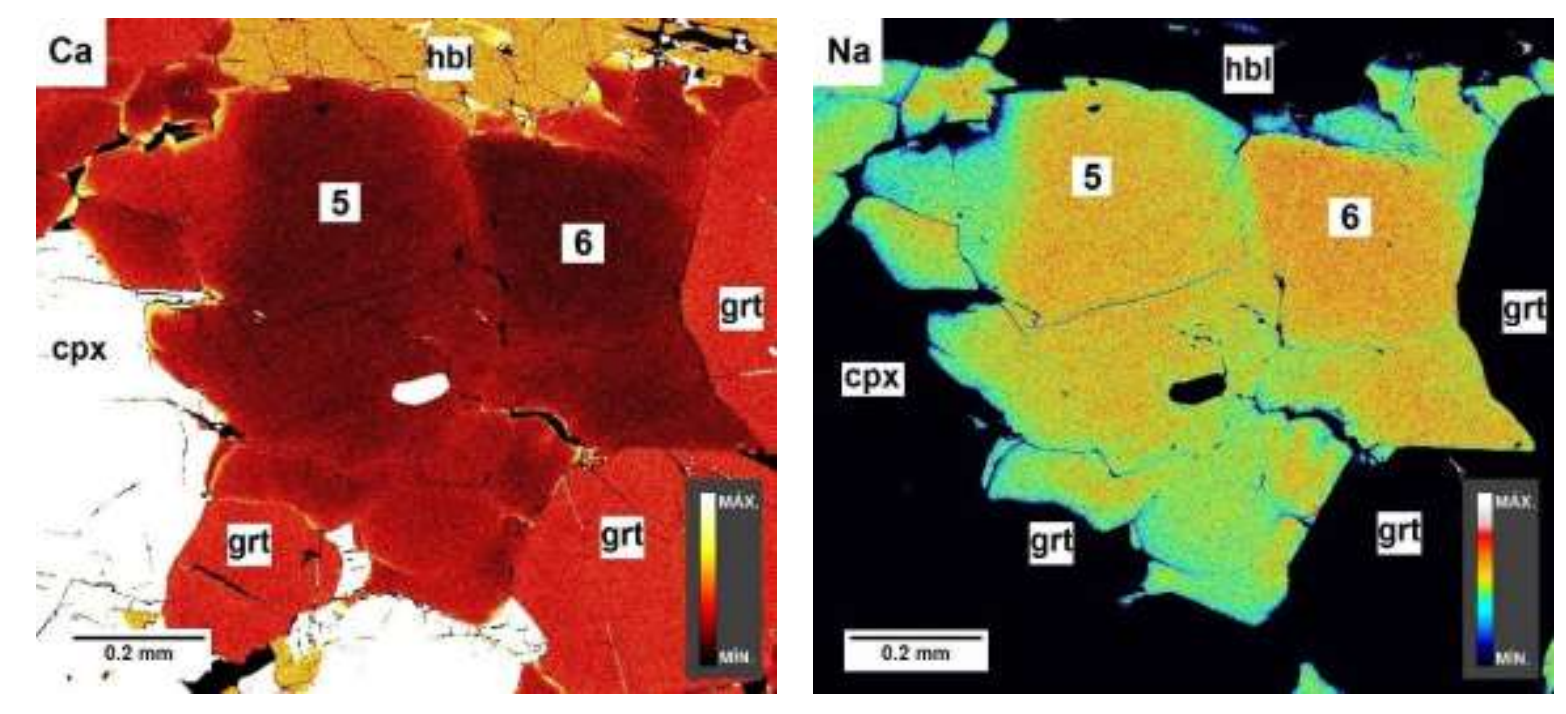

Figura 58 - Mapas composicionais de plagioclásio 5 e 6 da amostra TPR-01-F1 para Ca e Na

Os grãos 3 e 4 da amostra TPR-01-C mostram distribuição concêntrica de Ca e Na de maneira mais nítida, principalmente devido à presença de hornblenda circundante. O padrão de $\mathrm{Ca}$ e $\mathrm{Na}$ na relação plagioclásio-hornblenda apresentado nos exemplos anteriores ocorre da mesma maneira nessa amostra (Figura 59).

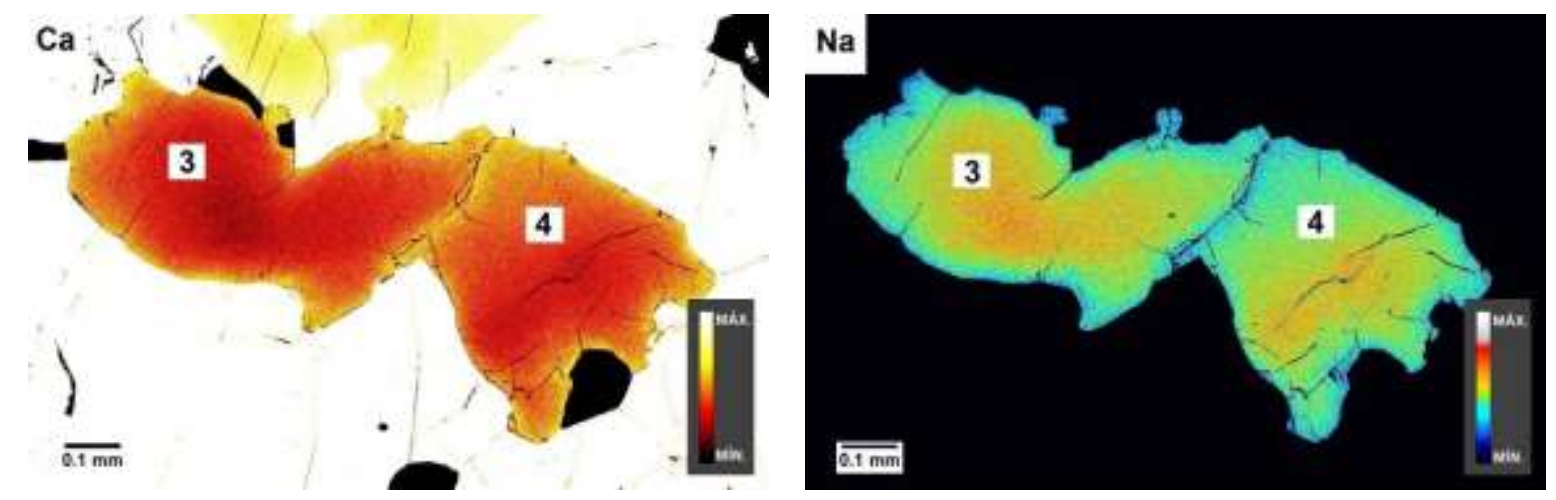

Figura 59 - Mapas composicionais de plagioclásio 3 e 4 da amostra TPR-01-C para Ca e Na.

\section{Nappe Socorro-Guaxupé}

O plagioclásio do granulito félsico da Nappe Socorro-Guaxupé foi dividido de acordo com a característica textural, em matriz ou incluso em outros minerais. O incluso em granada e ortopiroxênio possui teor de $\mathrm{Na}$ de 0,58 a 0,65 a.p.f.u., Ca entre 0,29 e 0,34 a.p.f.u., K entre 0,01 e 0,06 a.p.f.u., $\mathrm{Fe}^{3+}$ de 0 e 0,06 a.p.f.u., e teor de anortita que varia entre 30,9 e 35,6. Os grãos da matriz apresentam valores bastante semelhantes, com $\mathrm{Na}$ entre 0,61 e 0,65 a.p.f.u., $\mathrm{Ca}$ de 0,29 a 0,34 a.p.f.u., $\mathrm{K}$ entre 0,01 e 0,03 a.p.f.u., $\mathrm{Fe}^{3+}$ de 0 a 0,02 a.p.f.u., e teor de anortita entre 30,8 e 36,0. Ao compará-los pelos teores médios a semelhança prossegue. Com o plagioclásio de inclusão sendo pouco mais rico em $\mathrm{Ca}$ (0,31 a.p.f.u.) que o de matriz (0,30 a.p.f.u.), mais pobre em $\mathrm{Na}(0,62$ a.p.f.u. contra 0,64 a.p.f.u.), e consequentemente com 
maior teor de anortita $(33,51$ contra 32,26). Ao comparar o mineral dessa unidade com o das rochas calciossilicáticas da Nappe Três Pontas-Varginha é verificada forte correlação com os da amostra TPR-01-C, enquanto que os de TPR-01-F1 são relativamente enriquecidos em $\mathrm{Ca}$, empobrecidos em $\mathrm{Na}$, e apresentam maior teor de anortita médio, com 49,62. A Tabela 10 apresenta os teores médios de plagioclásio incluso e de matriz da Nappe SocorroGuaxupé, e também os valores da unidade anterior para efeito comparativo.

Tabela 10 - Valores médios dos elementos (em a.p.f.u.) analisados em plagioclásio de cada amostra de ambas as unidades; Número subscrito entre parênteses = número de análises. Maiores proporções médias em negrito (apenas para as amostras da Nappe Socorro-Guaxupé).

\begin{tabular}{|c|c|c|c|c|}
\hline \multirow{2}{*}{ Elemento } & \multicolumn{2}{|c|}{ Nappe Socorro-Guaxupé } & \multicolumn{2}{|c|}{ Nappe Três Pontas-Varginha } \\
\hline & IC-06-R (20) & IC-06- $\mathrm{R}_{(23)}$ & TPR-01- $\mathrm{C}_{(18)}$ & TPR-01-F1 ${ }_{(56)}$ \\
\hline \multirow[b]{2}{*}{$\mathrm{Si}$} & inclusão & matriz & \multirow[b]{2}{*}{2,64} & \multirow[b]{2}{*}{2,50} \\
\hline & 2,66 & 2,68 & & \\
\hline $\mathrm{Ti}$ & 0,00 & 0,00 & 0,00 & 0,01 \\
\hline Al & 1,35 & 1,34 & 1,38 & 1,51 \\
\hline $\mathrm{Cr}$ & 0,00 & 0,00 & 0,00 & 0,00 \\
\hline $\mathrm{Fe}^{3+}$ & 0,01 & 0,00 & 0,00 & 0,00 \\
\hline $\mathrm{Fe}^{2+}$ & 0,00 & 0,00 & 0,00 & 0,00 \\
\hline $\mathrm{Mn}$ & 0,00 & 0,00 & 0,00 & 0,00 \\
\hline $\mathrm{Mg}$ & 0,01 & 0,00 & 0,00 & 0,00 \\
\hline $\mathrm{Ca}$ & 0,31 & 0,30 & 0,34 & 0,47 \\
\hline $\mathrm{Na}$ & 0,62 & 0,64 & 0,60 & 0,48 \\
\hline $\mathrm{K}$ & 0,02 & 0,02 & 0,02 & 0,02 \\
\hline Anortita & 33,51 & 32,26 & 36,43 & 49,62 \\
\hline
\end{tabular}

Os perfis composicionais de anortita do plagioclásio da unidade, independente do aspecto textural, apresentam os mesmos padrões de enriquecimento de borda e por vezes, com suave sinuosidade (a sinuosidade do plagioclásio 6 , análise 6 , é explicada por sua localização na borda do grão, local de maior teor de anortita). Esse enriquecimento de borda por anortita sugere distribuição concêntrica de $\mathrm{Ca}$ e $\mathrm{Na}$, com o primeiro apresentando maiores teores em borda e o segundo em núcleo (Figura 60). 
IC-06-R (plagioclásio 6)
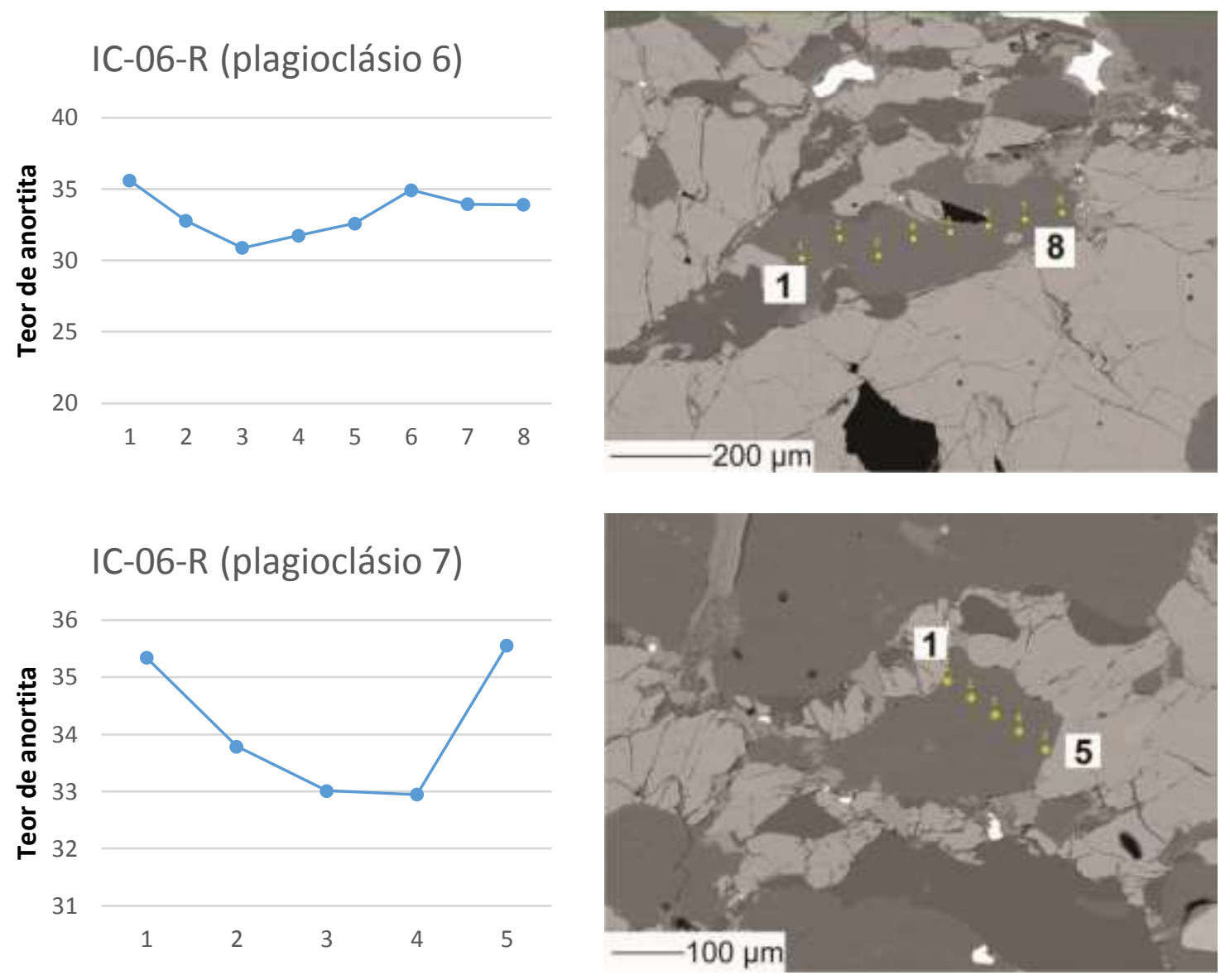

\section{IC-06-R (plagioclásio 8)}
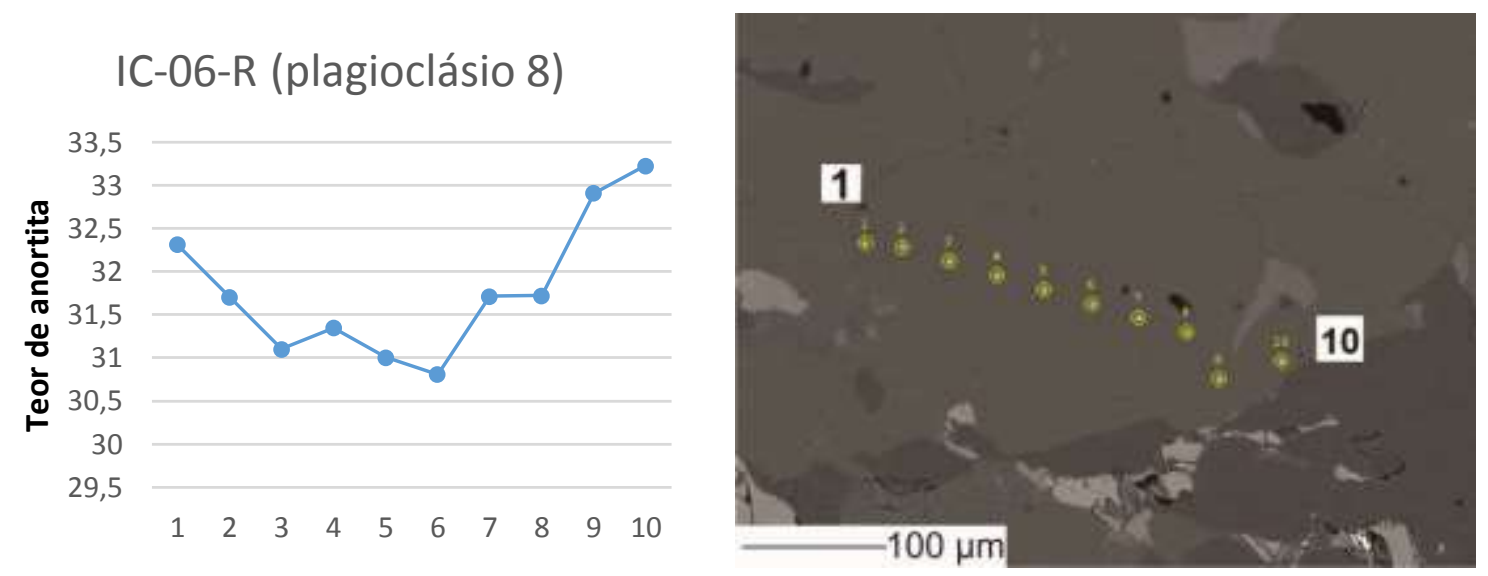

Figura 60 - Perfis composicionais de plagioclásio da amostra IC-06-R (eixo X representa as análises pontuais plotadas na imagem de elétrons retroespalhados).

A distribuição concêntrica nos teores de $\mathrm{Ca}$ e $\mathrm{Na}$, assim como o pico de anortita na análise 6 do plagioclásio 6 relacionado com enriquecimento de Ca e empobrecimento de $\mathrm{Na}$ em borda, indicados previamente através dos perfis composicionais são confirmados por mapas composicionais dos elementos (Figura 61). 

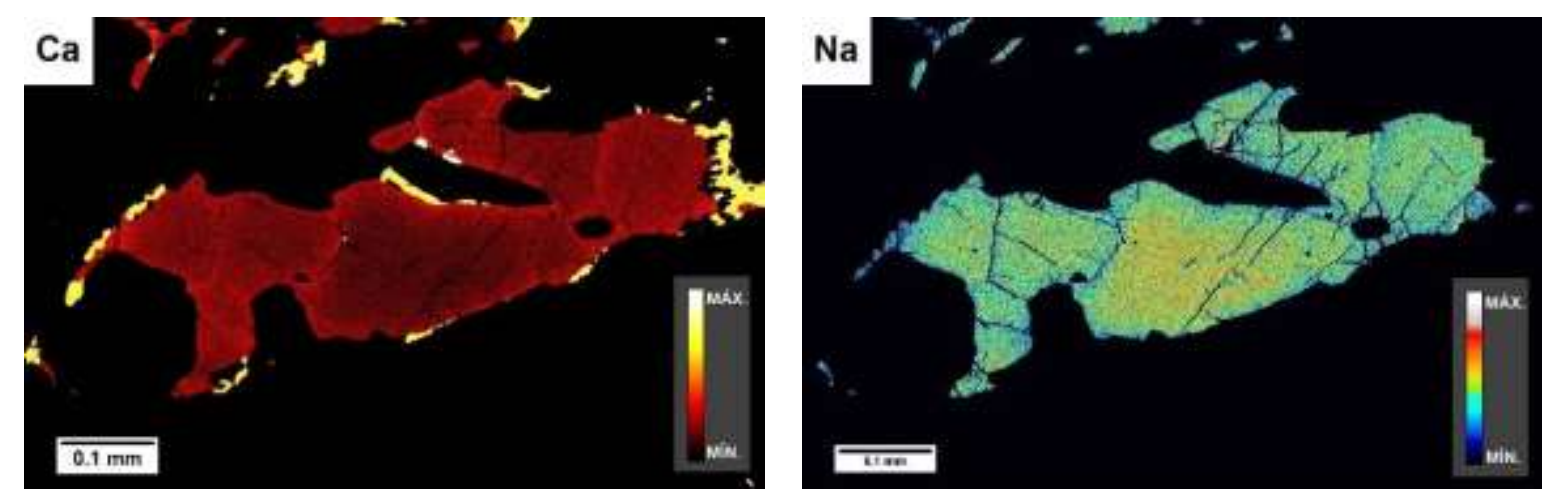

Figura 61 - Mapas composicionais de plagioclásio 6 da amostra IC-06-R para Ca e Na.

Os mapas composicionais do plagioclásio 6 da amostra IC-06-R (Figura 61) apresentam claro enriquecimento de borda em $\mathrm{Ca}$, inclusive nos contatos internos entre grãos, com o inverso ocorrendo para o $\mathrm{Na}$. No mapa de $\mathrm{Ca}$ ocorrem estreitas porções ricas no elemento, e é provável que sejam bordas de alteração do ortopiroxênio circundante para clinopiroxênio.

\subsubsection{Análises por Laser Ablation (LA-ICP-MS)}

\subsubsection{Considerações Gerais}

\section{Preparação das amostras}

A partir de três amostras do rt-ky-grt granulito da nappe Três Pontas-Varginha (TPR01-E, TPR-01-F e TPR-01-G), escolhidas por apresentarem textura e mineralogia mais refratárias, foram confeccionadas nove seções polidas de $80 \mu \mathrm{m}$ de espessura (IGc-USP), das quais quatro foram escolhidas para análises de quartzo e rutilo por apresentarem os melhores grãos (TPR-01-E2, TPR-01-F3, TPR-01-G1 e TPR-01-G2). Antes das análises foram produzidas imagens sob luz refletida em microscópio petrográfico a fim de identificar os grãos aflorantes e obter controle sobre cada análise. Para as análises de zircão, duas amostras (TPR-01-E e TPR-01-F) foram moídas e peneiradas nas frações de 100 e 150 mesh no Laboratório de Tratamento de Amostras do IGc-USP. Esse material foi enviado a Universidade de Brasília (UnB) para separação mineral. Com o concentrado mineral, foram selecionados manualmente à lupa os cristais de zircão e confeccionadas as montagens de grãos em discos de resina de $2.5 \mathrm{~cm}$, os quais foram polidos a fim de alcançar exposição satisfatória para análise. Imagens de catodo-luminescência ( $C L)$ foram produzidas para identificar domínios de crescimento. 


\section{$\underline{L A-I C P-M S}$}

As análises de elementos traço de quartzo, rutilo e zircão foram realizadas através de equipamento Laser-Ablation NWR213 (ESI) acoplado a ICP-MS 8800 Triple Quadruple (Agilent Technologies) na Universidade de Gotemburgo, Suécia. Como padrões para todos os minerais foram utilizados os vidros BCR-2 e GSD-1G do United States Geological Survey (USGS, 1996), e NIST SRM 610. Para quartzo ( $\left.{ }^{49} \mathrm{Ti}\right)$, cristais naturais de quartzo bastante puros de Varberg (Suécia) e do Brasil, vidro de sílica Herasil 102 (bastante puro) e Heraeus Ti 50, 100 e 600 (com concentrações variadas de Ti), da Heraeus Company, Hanau, Alemanha. Para rutilo ( ${ }^{90} \mathrm{Zr}$ ) foi utilizado o padrão natural R10, de Gjerstad, sul da Noruega, e rutilo sintético bastante puro. E por fim, para zircão ( $\left.{ }^{49} \mathrm{Ti}\right)$ foram utilizados os padrões 91500 (Harvard), GJ, M257, MT (Carbonatito Mud Tank, Austrália), BR266, M127, SRI, Temora e KVT. Para a acuracidade nos resultados, os padrões foram analisados a cada uma hora de funcionamento do equipamento. A ablação foi efetuada em atmosfera de argônio. Os cálculos das concentrações dos elementos traço foram conduzidos com o uso do Software GLITTER (versão 4.4.4), bastante eficiente na interpretação dos dados e nas correções necessárias devido a analises de "impurezas" como inclusões imperceptíveis e borda de granada em análise de inclusão de dimensões próximas ao diâmetro do feixe. Os padrões de ablação utilizados para cada mineral são apresentados na Tabela 11:

Tabela 11 - Padrões de ablação utilizados para cada mineral durante as análises de Laser Ablation

\begin{tabular}{c|cccccc}
\hline Mineral & $\begin{array}{c}\text { Diâmetro } \\
\text { do raio }\end{array}$ & $\begin{array}{c}\text { Taxa de } \\
\text { repetição }\end{array}$ & $\begin{array}{c}\text { Energia } \\
\text { (mJ) }\end{array}$ & $\begin{array}{c}\text { Densidade } \\
\text { de energia }\end{array}$ & $\begin{array}{c}\text { Tempo de } \\
\text { ablação }\end{array}$ & $\begin{array}{c}\text { Aquisição de } \\
\text { background }\end{array}$ \\
\hline $\begin{array}{c}\text { Quartzo } \\
\text { (Ti) }\end{array}$ & $30 \mu \mathrm{m}$ & $4 \mathrm{~Hz}$ & 0.213 & $31 \mathrm{~J} / \mathrm{cm}^{2}$ & $\sim 50-52 \mathrm{~s}$ & $\sim 18-20 \mathrm{~s}$ \\
$\begin{array}{c}\text { Rutilo } \\
(\mathrm{Zr})\end{array}$ & $15 \mu \mathrm{m}$ & $5 \mathrm{~Hz}$ & 0.011 & $6.1 \mathrm{~J} / \mathrm{cm}^{2}$ & $\sim 30-40 \mathrm{~s}$ & $\sim 18-20 \mathrm{~s}$ \\
$\begin{array}{c}\text { Zircão } \\
(\mathrm{Ti})\end{array}$ & $20 \mu \mathrm{m}$ & $5 \mathrm{~Hz}$ & 0.023 & $7.3 \mathrm{~J} / \mathrm{cm}^{2}$ & $\sim 40 \mathrm{~s}$ & $\sim 18 \mathrm{~s}$ \\
\hline \hline
\end{tabular}

Deu-se preferência a cristais de quartzo e rutilo inclusos em porfiroblastos de granada, principalmente quando próximos uns aos outros (provavelmente em equilíbrio químico desde o início da blastese), porém grãos da matriz e inclusos em cianita também foram analisados. Para as inclusões de quartzo foram escolhidas preferencialmente as monocristalinas e arredondadas localizadas longe de fraturas. Quando isso não foi possível, exemplares policristalinos e/ ou próximos a fraturas foram analisados. Em porfiroblastos de granada com muitas inclusões, analisou-se grãos localizados desde núcleo até as bordas a fim de verificar possíveis padrões/ diferenças nos teores dos elementos traço em questão. Múltiplas análises em um mesmo grão também foram feitas com o objetivo de avaliar possíveis gradientes de 
teores, como núcleo-borda de rutilo. Em relação aos isótopos de titânio, foi escolhido o de massa 49 para os cálculos devido a possíveis interferências do 47 com sílica e do 48 com cálcio. No total foram realizadas 212 análises, das quais 88 em quartzo, 100 em rutilo e 24 em zircão. Valores de temperatura foram calculados através do termômetro $\mathrm{Zr}$-rutilo de Tomkins et al. (2007) sob condições de pressão de quartzo $\beta$ a 15 kbar, Ti-quartzo de Thomas et. al. (2010) a 15 kbar e Ti-zircão de Watson et al. (2006). O cálculo pareado envolvendo os dois minerais, utilizado em Thomas et al. (2010), foi aqui utilizado para obter resultados mais precisos de temperatura e pressão (Figura 62). Para todos os casos foi assumido e interpretado por relações texturais que rutilo, quartzo e zircão cresceram em equilíbrio.

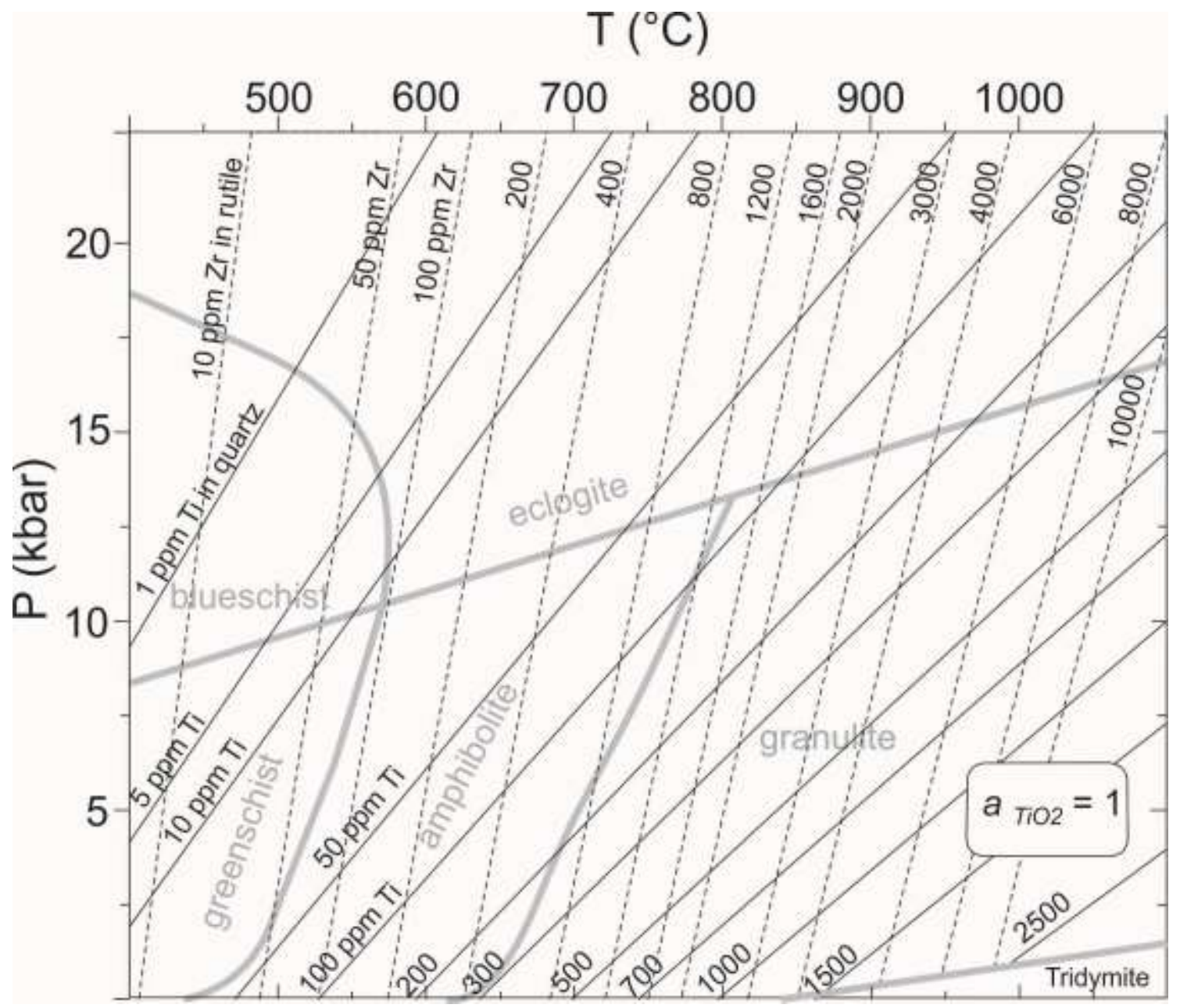

Figura 62 - Diagrama PT modificado de Thomas et al. (2010) que relaciona os geotermômetros Zr-rutilo e Tiquartzo.

\subsubsection{2. $\quad \underline{\text { Rutilo }}$}

As concentrações de 15 elementos traço (e.g. Cr, Nb, Ta, W, Al, Hf, Fe), além do Ti, foram determinadas em cada uma das 100 análises de rutilo do rutilo-cianita-granada granulito de alta pressão da nappe Três Pontas-Varginha. Os grãos contêm 14 - 3806 ppm Cr, 257 38225 ppm Nb, 20 - 4536 ppm Ta, 2 - 328 ppm W, 16 - 400 ppm Al, 14 - 57 ppm Hf e < 
64.71 - 5929 pp Fe. Resultados discrepantes nesses elementos, como alta de Fe e Al, provavelmente são relacionados à contaminação por análise de granada hospedeira da inclusão e/ou lamelas de ilmenita no rutilo. Valores de $\log (\mathrm{Cr} / \mathrm{Nb})$ ocorrem entre $-2,4$ e 0,2 . Os resultados de $\log (\mathrm{Cr} / \mathrm{Nb})<0$, em 93 grãos, indicam protolito pelítico (Zack et. al. 2004b; Triebold et al. 2007), por outro lado, valores de $\log (\mathrm{Cr} / \mathrm{Nb})>0$ que sugerem protolito máfico (Zack et. al. 2004b; Triebold et al. 2007), por apenas ocorrerem em sete grãos, isto é, uma baixa proporção do total de resultados (7\%) e por possuírem valores pouco acima de zero, tiveram essa sugestão desconsiderada. O conteúdo de $\mathrm{Zr}$ dos grãos de rutilo varia entre 374 e 1518 ppm, e produz temperaturas entre $693^{\circ} \mathrm{C}$ e $826,4^{\circ} \mathrm{C}$ (Figura 63). Utilizando apenas a média dos maiores teores (faixa azul na Figura 63; 1433 ppm) é obtida temperatura de ca. $820 \pm 30^{\circ} \mathrm{C}$. A distribuição dos grãos de diferentes teores não se apresenta uniforme, porém, de maneira geral os maiores valores são encontrados em cristais inclusos em granada quando comparados aos da matriz. Não foi verificada diferença nos teores em relação à posição da inclusão dentro da granada (núcleo-manto-borda). Análises de núcleo e borda em um cristal de rutilo não apresentaram variação considerável de teores.
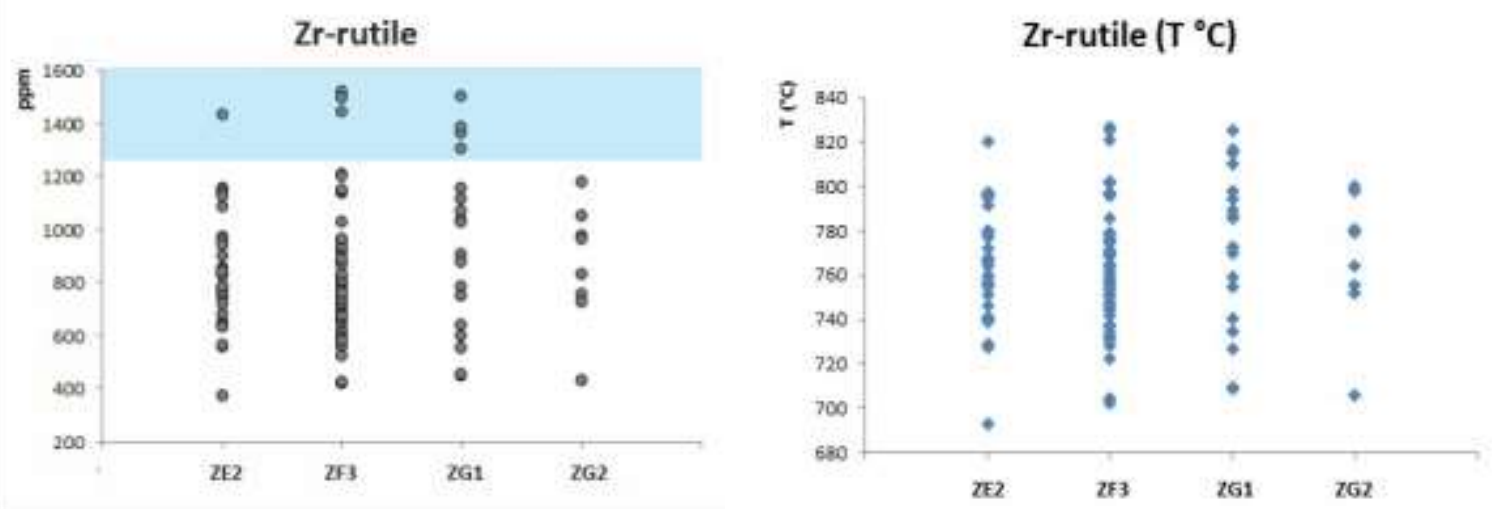

Figura 63 - a) Teores de $\mathrm{Zr}$ em rutilo com campo delimitando faixa com os maiores valores; b) Respectivas temperaturas Zr-rutilo através do termômetro quartzo $\beta$, a 15 kbar, de Tomkins et. al. (2007).

\subsubsection{3. $\underline{\text { Quartzo }}$}

Foram determinadas as concentrações de 7 elementos traço, além de três isótopos de $\mathrm{Ti}$ (Li, Al, Si, Ca, Mn, Fe, Ge, ${ }^{47} \mathrm{Ti},{ }^{48} \mathrm{Ti}$ e ${ }^{49} \mathrm{Ti}$ ), em cada uma das 88 análises de quartzo do rutilo-cianita-granada granulito de alta pressão da nappe Três Pontas-Varginha. Os grãos contêm < 0,113 a 11 ppm Li, 24 a 162 ppm Al, <231,59 a 513,51 ppm Ca, 24 a 75 ppm ${ }^{47} \mathrm{Ti}$, 25 a 71 ppm ${ }^{48} \mathrm{Ti}, 23$ a 72 ppm ${ }^{49} \mathrm{Ti},<0,70$ a 1,1 ppm Mn, < 8,54 a 264 ppm Fe e < 0,30 a 1,23 ppm Ge. Valores altos e discrepantes de Al, Ca, Mn e Fe são provavelmente resultado de contaminação por análise de granada hospedeira da inclusão. O conteúdo de ${ }^{49} \mathrm{Ti}$ apresentado produz temperaturas entre $727,6^{\circ} \mathrm{C}$ e $843,7^{\circ} \mathrm{C}$ (Figura 64). Utilizando a média dos maiores valores (faixa azul na Figura 64; 68,1 ppm) é produzida temperatura de ca. 837 $\pm 20^{\circ} \mathrm{C}$. Foi verificado em algumas das inclusões de granada o aumento do teor de titânio em 
direção às localizadas nas bordas da granada. O teor de Ti em inclusão policristalina apresenta variação de no máximo 23 ppm. Não foi verificada diferença entre os teores encontrados em inclusões e em cristais de matriz.
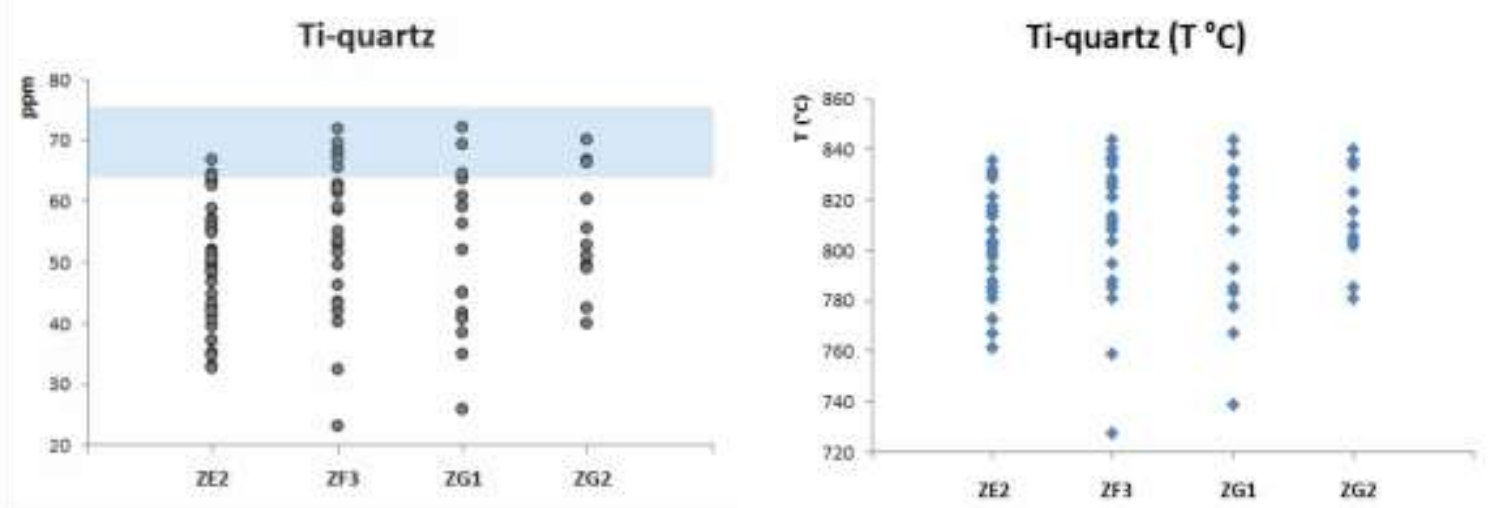

Figura 64 - a) Teores de Ti em quartzo com campo delimitando faixa com os maiores valores; b) Respectivas temperaturas Ti-quartzo através do termômetro de Thomas et. al. (2010) a 15 kbar.

\subsubsection{Z Zircão}

Zircão foi analisado para 21 elementos (e.g. Y, La, Ce, Nd, Sm, Eu), além de dois isótopos de $\mathrm{Ti}\left({ }^{48} \mathrm{Ti} \mathrm{e}{ }^{49} \mathrm{Ti}\right)$, em cada uma das 24 análises de zircão do rutilo-cianita-granada granulito de alta pressão da nappe Três Pontas-Varginha. Devido às diminutas dimensões dos grãos, semelhantes ao diâmetro do feixe $(20 \mu \mathrm{m})$, não foi possível analisar os diferentes domínios de crescimento observados em imagens de CL, sendo os resultados apresentados aqui não confiáveis para interpretações. O teor de ${ }^{49} \mathrm{Ti}$ varia entre 4,4 e 12,5 ppm e fornece temperaturas de $673,4^{\circ} \mathrm{C}$ a $760,8^{\circ} \mathrm{C}$.

\subsubsection{5. $\quad$ Cálculo pareado Zr-rutilo - Ti-quartzo}

A partir cálculo pareado utilizando os termômetros Zr-rutilo (Tomkins et al. 2007) e Tiquartzo (Thomas et al. 2010) é possível obter tanto valores de temperatura como de pressão. Dentre as 212 análises realizadas em rutilo, quartzo e zircão, 34 de quartzo e 35 de rutilo (os números de análises não coincidem, pois um mesmo grão pode ser pareado mais de uma vez) foram utilizadas para o cálculo de 37 pares, isto é, cristais separados por pequenas distâncias $(\sim 0,75 \mathrm{~mm})$ e por vezes em contato físico. Esses pares foram divididos entre inclusos em granada, levando em consideração sua posição (núcleo, manto e borda), e na matriz. Dessa maneira, entre o total de pares, trinta são de inclusões em granada (seis em núcleo, onze em manto e treze em borda) e sete são de matriz. Neste, as condições variam de $736{ }^{\circ} \mathrm{C}$ e $11,3 \mathrm{kbar}$ a $805,6^{\circ} \mathrm{C}$ e $17,6 \mathrm{kbar}$, com média de $754,7^{\circ} \mathrm{C}$ e $13,9 \mathrm{kbar}$. Para os inclusos em granada são obtidos: $692^{\circ} \mathrm{C}$ e $9 \mathrm{kbar}$ a $837^{\circ} \mathrm{C}$ e $21,4 \mathrm{kbar}$, com média de 763 ${ }^{\circ} \mathrm{C}$ e 14 kbar para inclusões em núcleo; $713,3^{\circ} \mathrm{C}$ e $10,9 \mathrm{kbar}$ a $844^{\circ} \mathrm{C}$ e $21 \mathrm{kbar}$, com média 
de $776,5^{\circ} \mathrm{C}$ e $14,4 \mathrm{kbar}$ nas de manto; e $660^{\circ} \mathrm{C}$ e $8,3 \mathrm{kbar}$ a $837,4^{\circ} \mathrm{C}$ e $18,6 \mathrm{kbar}$, com média de $759{ }^{\circ} \mathrm{C}$ e $12,8 \mathrm{kbar}$ para as de borda. A Figura 65 apresenta todos os 37 pares rutiloquartzo calculados e plotados em diagrama $P-T$.

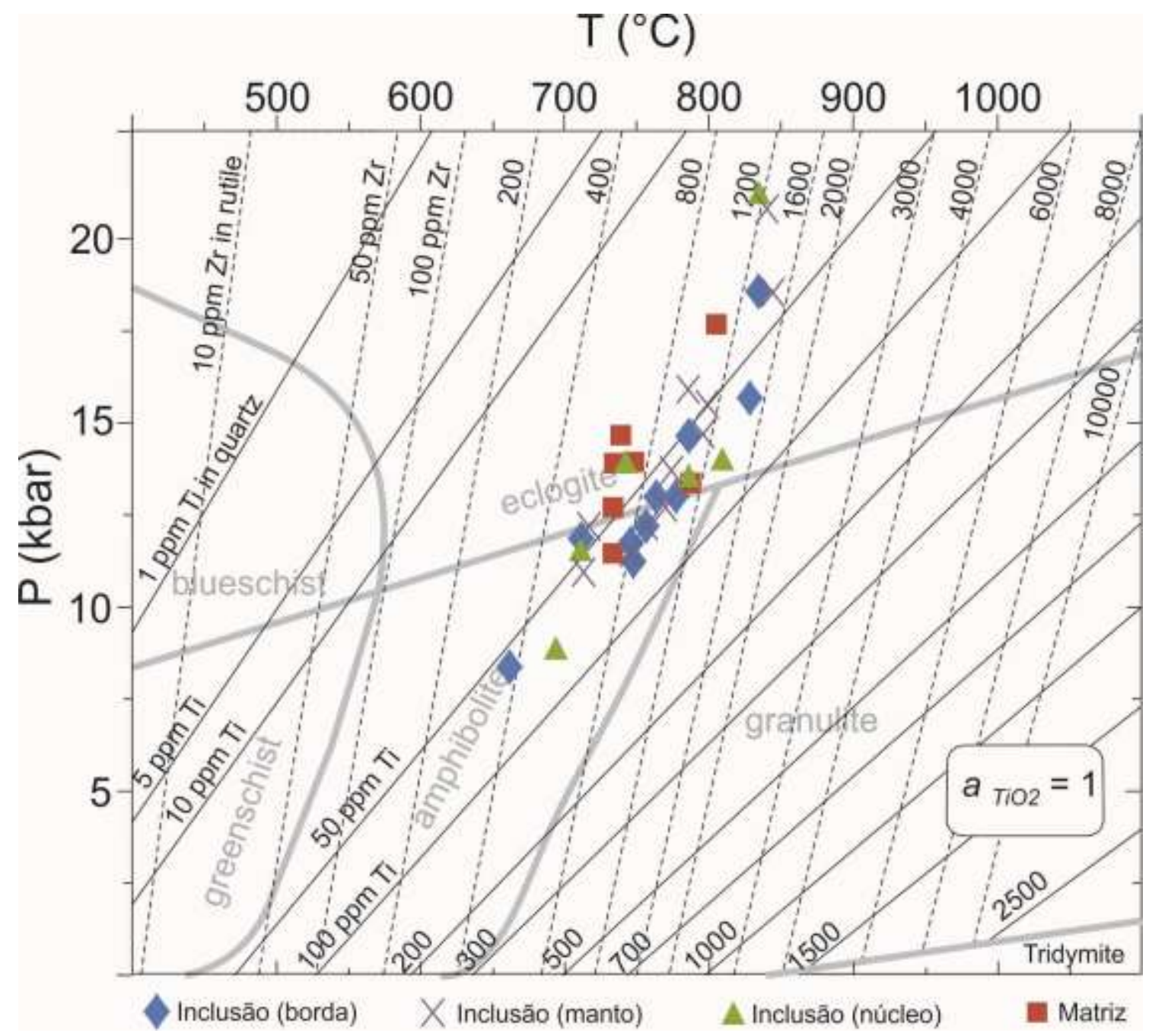

Figura 65 - Diagrama modificado de Thomas et al. (2010) com os resultados obtidos a partir do cálculo pareado utilizando os termômetros Zr-rutilo (Tomkins et al. 2007) e Ti-quartzo (Thomas et al. 2010) para os 37 pares minerais. 


\subsection{Geotermobarometria}

Para comparação com os resultados obtidos com o cálculo pareado Zr-rutilo - Ti-quartzo, outros métodos de geotermobarometria são aplicados usando rocha calciossilicática da Nappe Três Pontas-Varginha e granulito félsico da Nappe Socorro-Guaxupé.

\subsubsection{Geotermobarometria convencional}

\subsubsection{1. $\quad$ Considerações gerais}

Para os cálculos geotermobarométricos foram selecionadas análises de núcleo de granada e piroxênio com o intuito de se obter valores o mais próximo da composição dos minerais no pico metamórfico, e de borda de plagioclásio, característica por apresentar os maiores teores de anortita. Nas quatro amostras foi utilizado o geotermômetro de Ellis \& Green (1979) através do cálculo pareado granada-clinopiroxênio e o geobarômetro GADS de Eckert et al. (1991) com granada-clinopiroxênio-plagioclásio, exceto pela amostra TPR-01-B que não apresenta plagioclásio e impossibilita determinação de pressão. Ainda foram utilizados os geobarômetros de Newton \& Perkins (1982), Perkins \& Chipera (1985), Paria et al. (1988) e Eckert et al. (1991) e o geotermômetro de Harley (1984) para a amostra IC-06-R, portadora de ortopiroxênio, e pertencente à Nappe Socorro-Guaxupé.

\subsubsection{Nappe Três Pontas-Varginha}

Na química mineral, como já apresentado, verificam-se semelhanças composicionais dos minerais das amostras TPR-01-C e TPR-01-B, com granada e clinopiroxênio relativamente ricos em Fe quando comparados aos cristais de TPR-01-F1, que por sua vez, apresentam maiores teores de Mg e Ca (granada) e Al, Ca, Mg e \#mg (clinopiroxênio). Essas diferenças composicionais, mesmo que pequenas, resultam em diferentes valores de $T$ e $P$, bastante semelhantes nos dois primeiros casos, porém, ao considerar os respectivos erros, podem ser situados na mesma janela $P-T$.

Para os cálculos de temperatura foram utilizadas seis análises de granada e seis de clinopiroxênio de TPR-01-C, cinco de granada e seis de clinopiroxênio de TPR-01-B e cinco de granada e sete de clinopiroxênio de TPR-01-F1. Foram pareadas análises de grãos localizados em uma mesma região/ banda/ textura em cada amostra, o que totalizou dezoito cálculos para a primeira amostra, quinze para a segunda e dezessete para a terceira. Os cálculos de temperatura foram feitos para 10, 15 e 20 kbar. Sob condições de pressão de 15 kbar, os valores de temperatura de TPR-01-C situam-se entre $768,73^{\circ} \mathrm{C}$ e $862,06{ }^{\circ} \mathrm{C}$, média de $821,08^{\circ} \mathrm{C}$, de TPR-01-B bem semelhantes à anterior, entre $791,00^{\circ} \mathrm{C}$ e $853,80^{\circ} \mathrm{C}$, média 
de $821,99{ }^{\circ} \mathrm{C}$, e de TPR-01-F1 entre 833,47 e 876,72 , média de $851,38{ }^{\circ} \mathrm{C}$. Todas as temperaturas calculadas sob as três condições de pressão estão listadas na Tabela 12.

Utilizando-se os valores de temperatura anteriores para os cálculos geobarométricos, seis pares minerais de TPR-01-C foram combinados com duas análises de plagioclásio e forneceram doze valores de pressão. Os cálculos com análise do plagioclásio $3\left(\mathrm{An}_{40}\right)$ indicam pressões entre 13,60 kbar e 15,37 kbar, com 14,54 kbar de média, e com o plagioclásio 4 $\left(A n_{39}\right)$, entre 13,85 kbar a 15,64 kbar, e 14,78 kbar de média. Para a amostra TPR-01-F1 os oito pares minerais foram utilizados com quatro análises de plagioclásio, sendo realizados trinta e dois cálculos de pressão. Os valores obtidos com o plagioclásio $1\left(\mathrm{An}_{55}\right)$ estão entre 12,77 kbar e 13,21 kbar, com média de 12,98 kbar, com o plagioclásio $3\left(A n_{76}\right)$ entre 10,35 kbar e 10,78 kbar, média de 10,56 kbar, com o grão $5\left(A n_{65}\right)$ entre 11,52 kbar e 11,96 kbar, média de 11,73 kbar, e com o plagioclásio $6\left(A n_{51}\right)$ entre 13,23 kbar e 13,67 kbar e média de 13,44 kbar. Os valores produzidos a partir das combinações com os grãos 1, 5 e 6 situam-se dentro da mesma janela de pressão ao se considerar o erro de $\pm 1,9 \mathrm{kbar}$. Já aqueles com o grão 3 são realmente inferiores e explicados pelo caráter tardio do plagioclásio em questão, provavelmente resultado de cristalização tardia de fundido aprisionado (Figura 57). Todos os valores de pressão calculados estão listados na Tabela 13. 
Tabela 12 - Temperaturas em ${ }^{\circ} \mathrm{C}$ calculadas pelo geotermômetro de Ellis \& Green (1979) para pressões de 10, 15 e 20 kbar. Número entre parênteses indica a análise do grão.

\begin{tabular}{|c|c|c|c|c|c|}
\hline \multicolumn{6}{|c|}{ Geotermômetro de Ellis \& Green (1979) } \\
\hline \multirow{56}{*}{ 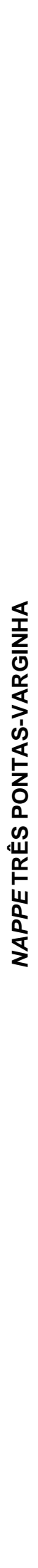 } & \multirow{20}{*}{ 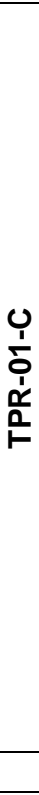 } & Minerais & $T\left({ }^{\circ} \mathrm{C}\right)$ a $10 \mathrm{kbar}$ & $T\left({ }^{\circ} \mathrm{C}\right)$ a $15 \mathrm{kbar}$ & $T\left({ }^{\circ} \mathrm{C}\right)$ a $20 \mathrm{kbar}$ \\
\hline & & $\operatorname{grt} 1_{(6)}-\mathrm{cpx} 1_{(5)}$ & 811,63 & 826,24 & 840,86 \\
\hline & & $\operatorname{grt1} 1_{(6)}-\mathrm{cp} 2_{(4)}$ & 832,96 & 847,86 & 862,76 \\
\hline & & $\operatorname{art1}_{(6)}-\mathrm{cp} \times 3_{(5)}$ & 809,19 & 823,77 & 832,36 \\
\hline & & $\operatorname{grt} 2_{(7)}-\mathrm{cpx} 1_{(5)}$ & 817,12 & 831,96 & 846,79 \\
\hline & & $\operatorname{grt2}(7)-c p \times 2_{(4)}$ & 838,89 & 854,02 & 869,15 \\
\hline & & $\operatorname{grt2}(7)-c p \times 3_{(5)}$ & 814,63 & 829,44 & 844,24 \\
\hline & & $\operatorname{grt} 3_{(9)}-\mathrm{cpx} 1_{(5)}$ & 778,29 & 792,30 & 806,30 \\
\hline & & $\operatorname{grt3}(9)-c p \times 2_{(4)}$ & 798,09 & 812,36 & 826,63 \\
\hline & & $\operatorname{grt3}(9)-c p \times 3_{(5)}$ & 776,03 & 790,00 & 803,98 \\
\hline & & $\operatorname{grt4}(7)-c p \times 5_{(4)}$ & 795,45 & 810,28 & 825,11 \\
\hline & & $\operatorname{grt} 4_{(7)}-\mathrm{cp} \times 6_{(7)}$ & 813,10 & 828,17 & 843,25 \\
\hline & & $\operatorname{grt}_{(7)-c p x 7_{(6)}}$ & 816,68 & 831,80 & 846,93 \\
\hline & & $\operatorname{grt5}(8)-c p \times 5_{(4)}$ & 755,23 & 768,73 & 782,22 \\
\hline & & $\operatorname{grt5}(8)-c p \times 6(7)$ & 770,66 & 784,37 & 798,07 \\
\hline & & $\operatorname{art5}_{(8)-c p x} 7_{(6)}$ & 773,79 & 787,53 & 801,28 \\
\hline & & $\operatorname{grt6}_{(9)-c p \times 5_{(4)}}$ & 825,45 & 840,15 & 854,84 \\
\hline & & $\operatorname{grt6}_{(9)-c p \times 6_{(7)}}$ & 843,43 & 858,37 & 873,30 \\
\hline & & $\operatorname{grt6}_{(9)-\mathrm{cp} \times 7_{(6)}}$ & 847,08 & 862,06 & 877,05 \\
\hline & & Média & 806,54 & 821,08 & 835,28 \\
\hline & \multirow{17}{*}{ 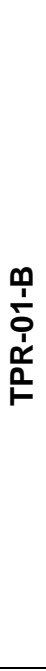 } & Minerais & $T\left({ }^{\circ} \mathrm{C}\right)$ a $10 \mathrm{kbar}$ & $T\left({ }^{\circ} \mathrm{C}\right)$ a $15 \mathrm{kbar}$ & $T\left({ }^{\circ} \mathrm{C}\right)$ a $20 \mathrm{kbar}$ \\
\hline & & $\operatorname{grt} 1_{(8)}-\mathrm{cpx} 1_{(5)}$ & 819,93 & 835,20 & 850,47 \\
\hline & & $\operatorname{grt} 1_{(8)}-\mathrm{cpx} 2_{(6)}$ & 797,14 & 812,09 & 827,04 \\
\hline & & $\operatorname{grt} 1_{(8)}-\mathrm{cp} \times 4_{(3)}$ & 797,59 & 812,54 & 827,50 \\
\hline & & $\operatorname{art} 2_{(6)}-\mathrm{cpx} 1_{(5)}$ & 822,93 & 837,51 & 852,09 \\
\hline & & grt2 $(6)-c p \times 2_{(6)}$ & 801,09 & 815,38 & 829,67 \\
\hline & & $\operatorname{grt} 2_{(6)}-\mathrm{cp} \times 4_{(3)}$ & 801,52 & 815,81 & 830,11 \\
\hline & & $\operatorname{grt}_{(5)}-\mathrm{cpx} 1_{(5)}$ & 817,95 & 833,37 & 848,80 \\
\hline & & $\operatorname{grt}_{(5)}-\mathrm{cp} 2_{(6)}$ & 794,97 & 810,08 & 825,18 \\
\hline & & $\operatorname{grt} 3_{(5)}-\mathrm{cp} \times 4_{(3)}$ & 795,42 & 810,53 & 825,64 \\
\hline & & $\operatorname{grt}_{(6)}-\mathrm{cp} \times 5_{(5)}$ & 818,95 & 834,42 & 849,90 \\
\hline & & $\operatorname{grt}_{(6)}-\mathrm{cp} \times 7_{(4)}$ & 804,07 & 819,34 & 834,60 \\
\hline & & $\operatorname{grt} 4_{(6)}-\mathrm{cp} \times 8_{(5)}$ & 776,13 & 791,00 & 805,87 \\
\hline & & $\operatorname{grt5}(7)-c p \times 5_{(5)}$ & 838,53 & 853,80 & 869,08 \\
\hline & & $\operatorname{grt5}_{(7)-c p x 7_{(4)}}$ & 823,58 & 838,65 & 853,72 \\
\hline & & $\operatorname{grt5}(7)-c p x 8_{(5)}$ & 795,49 & 810,18 & 824,86 \\
\hline & & Média & 807,02 & 821,99 & 836,97 \\
\hline & \multirow{19}{*}{ 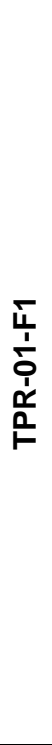 } & Minerais & $T\left({ }^{\circ} \mathrm{C}\right)$ a $10 \mathrm{kbar}$ & $T\left({ }^{\circ} \mathrm{C}\right)$ a $15 \mathrm{kbar}$ & $T\left({ }^{\circ} \mathrm{C}\right)$ a $20 \mathrm{kbar}$ \\
\hline & & $\operatorname{grt1} 1_{(6)}-\mathrm{cpx} 5_{(6)}$ & 851,66 & 866,88 & 882,10 \\
\hline & & $\operatorname{grt1}_{(6)}-\mathrm{cp} \times 6_{(7)}$ & 841,26 & 856,34 & 871,42 \\
\hline & & $\operatorname{grt} 1_{(6)}-\mathrm{cpx} 7_{(6)}$ & 848,63 & 863,81 & 878,99 \\
\hline & & grt2 $(5)-c p \times 5_{(6)}$ & 840,86 & 855,90 & 870,94 \\
\hline & & grt2 $(5)-c p \times 6_{(7)}$ & 830,68 & 845,58 & 860,49 \\
\hline & & $\operatorname{grt}_{(5)}-\mathrm{cpx} 7_{(6)}$ & 837,90 & 852,90 & 867,90 \\
\hline & & $\operatorname{grt}_{(6)}-\mathrm{cp} \times 5_{(6)}$ & 861,42 & 876,72 & 892,02 \\
\hline & & $\operatorname{grt}_{(6)}-\mathrm{cp} \times 6_{(7)}$ & 850,88 & 866,03 & 881,19 \\
\hline & & $\operatorname{grt3}_{(6)}-\mathrm{cpx} 7_{(6)}$ & 858,35 & 873,61 & 888,87 \\
\hline & & $\operatorname{grt} 4_{(4)}-\mathrm{cp} \times 1_{(6)}$ & 822,48 & 837,33 & 852,18 \\
\hline & & $\operatorname{art}_{(4)-c p \times 2_{(8)}}$ & 822,30 & 837,15 & 852,00 \\
\hline & & $\operatorname{grt}_{(4)}-\mathrm{cp} \times 3_{(6)}$ & 829,21 & 844,15 & 859,09 \\
\hline & & $\operatorname{grt}_{(4)-\mathrm{cp} \times 4_{(5)}}$ & 831,76 & 846,74 & 861,71 \\
\hline & & $\operatorname{grt5}(9)-c p x 1_{(6)}$ & 819,03 & 833,64 & 848,26 \\
\hline & & $\operatorname{grt5}(9)-c p \times 2_{(8)}$ & 818,85 & 833,47 & 848,08 \\
\hline & & $\operatorname{grt5}(9)-c p \times 3_{(6)}$ & 825,63 & 840,33 & 855,03 \\
\hline & & $\operatorname{grt5}(9)-c p \times 4_{(5)}$ & 828,13 & 842,87 & 857,60 \\
\hline & & Média & 836,41 & 851,38 & 866,35 \\
\hline
\end{tabular}


Tabela 13 - Pressões em kbar calculadas pelo geobarômetro de Eckert et al. (1991) utilizando as temperaturas calculadas a 15 kbar. Número entre parênteses indica a análise do grão.

\begin{tabular}{|c|c|c|c|c|c|}
\hline \multicolumn{6}{|c|}{ Geobarômetro de Eckert et al. (1991) } \\
\hline \multirow{27}{*}{ 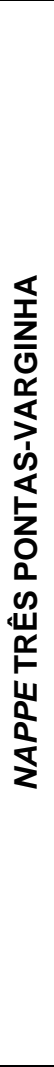 } & \multirow{8}{*}{ 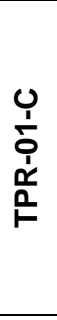 } & Minerais & $P$ (kbar) & Minerais & $P$ (kbar) \\
\hline & & $\operatorname{grt}_{(8)}-\mathrm{cpx} 5_{(4)}-\mathrm{pl} 3_{(1)}$ & 13,60 & $\operatorname{grt5}_{(8)}-\mathrm{cpx} 5_{(4)}-\mathrm{pl} 4_{(5)}$ & 13,85 \\
\hline & & $\operatorname{grt5}(8)-c p \times 6_{(7)}-\mathrm{pl} 3_{(1)}$ & 13,97 & $\operatorname{grt5}(8)-c p \times 6_{(7)}-p_{1} 4_{(5)}$ & 14,22 \\
\hline & & $\operatorname{art} 5_{(8)}-\mathrm{cp} \times 7_{(6)}-\mathrm{pl} 3_{(1)}$ & 14,04 & $\left.\operatorname{art5}(8)-c p x 7_{(6)}\right)-p \mid 4_{(5)}$ & 14,30 \\
\hline & & grt6(9)-cpx5(4)-pl3 $(1)$ & 14,96 & grt6(9)-cpx5(4)-pl4(5) & 15,13 \\
\hline & & grt6(9)-cpx6 $(7)-p \mid 3_{(1)}$ & 15,28 & grt6(9)-cpx6 $(7)-p \mid 4_{(5)}$ & 15,55 \\
\hline & & grt6 $(9)-c p x 7_{(6)}-\mathrm{pl}_{(1)}$ & 15,37 & grt6(9)-cpx7 $7_{(6)}-\mathrm{pl}_{(5)}$ & 15,64 \\
\hline & & Média & 14,54 & Média & 14,78 \\
\hline & \multirow{19}{*}{ 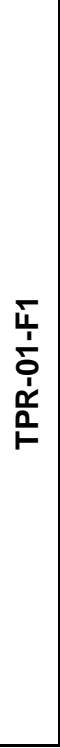 } & Minerais & $P$ (kbar) & Minerais & $P$ (kbar) \\
\hline & & $\operatorname{grt} 4_{(4)}-\mathrm{cpx} 1_{(6)}-\mathrm{pl} 1_{(1)}$ & 12,77 & $\operatorname{grt} 4_{(4)-}-\mathrm{cpx} 1_{(6)-}-\mathrm{pl} 3_{(10)}$ & 10,35 \\
\hline & & $\operatorname{grt}_{(4)}-\mathrm{cp} 2_{(8)}-\mathrm{pl} 1_{(1)}$ & 12,79 & $\operatorname{grt}_{(4)}-\mathrm{cp} 2_{(8)}-\mathrm{pl} 3_{(10)}$ & 10,37 \\
\hline & & $\operatorname{grt}_{(4)}-\mathrm{cp} \times 3_{(6)}-\mathrm{pl} 1_{(1)}$ & 13,02 & $\operatorname{grt}_{(4)}-\mathrm{cp} \times 3_{(6)}-\mathrm{pl} 3_{(10)}$ & 10,58 \\
\hline & & $\operatorname{grt}_{(4)}-\mathrm{cpx} 4_{(5)}-\mathrm{pl} 1_{(1)}$ & 13,06 & $\operatorname{grt} 4_{(4)-}-\mathrm{cpx} 4_{(5)-}-\mathrm{pl} 3_{(10)}$ & 10,62 \\
\hline & & $\operatorname{grt} 5_{(9)}-\mathrm{cpx} 1_{(6)}-\mathrm{pl} 1_{(1)}$ & 12,91 & $\operatorname{grt5}(9)-c p x 1_{(6)}-p \mid 3_{(10)}$ & 10,50 \\
\hline & & grt5(9)-cpx2 ${ }_{(8)}-\mathrm{pl} 1_{(1)}$ & 12,93 & $\operatorname{grt5}(9)-c p \times 2_{(8)}-\mathrm{pl} 3_{(10)}$ & 10,52 \\
\hline & & $\operatorname{art5}(9)-c p \times 3_{(6)}-\mathrm{pl} 1_{(1)}$ & 13,16 & $\operatorname{art5}(9)-c p \times 3_{(6)}-\mathrm{p} \mid 3_{(10)}$ & 10,74 \\
\hline & & $\operatorname{art5}(9)-c p \times 4_{(5)}-\mathrm{pl} 1_{(1)}$ & 13,21 & $\operatorname{art5}(9)-c p x 4_{(5)}-\mathrm{pl} 3_{(10)}$ & 10,78 \\
\hline & & Média & 12,98 & Média & 10,56 \\
\hline & & 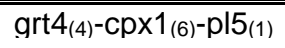 & 11,52 & 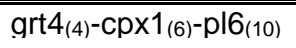 & 13,23 \\
\hline & & $\operatorname{grt}_{(4)}-\mathrm{cpx} 2_{(8)}-\mathrm{pl} 5_{(1)}$ & 11,54 & $\operatorname{grt}_{(4)-}-\mathrm{cpx} 2_{(8)}-\mathrm{pl} 6_{(10)}$ & 13,25 \\
\hline & & $\operatorname{grt}_{(4)}-\mathrm{cp} \times 3_{(6)}-\mathrm{pl} 5_{(1)}$ & 11,76 & $\operatorname{grt}_{(4)}-\mathrm{cpx} 3_{(6)}-\mathrm{pl} 6_{(10)}$ & 13.48 \\
\hline & & $\operatorname{grt}_{(4)}-\mathrm{cpx} 4_{(5)}-\mathrm{pl}_{(1)}$ & 11,80 & $\operatorname{grt}_{(4)-}-\mathrm{cpx} 4_{(5)-}-\mathrm{pl} 6_{(10)}$ & 13,53 \\
\hline & & $\operatorname{grt5}(9)-c p x 1_{(6)}-\mathrm{pl} 5_{(1)}$ & 11,67 & $\operatorname{grt5}(9)-\operatorname{cpx} 1_{(6)}-\mathrm{pl} 6_{(10)}$ & 13,38 \\
\hline & & $\operatorname{grt5}(9)-\mathrm{cp} \times 2_{(8)}-\mathrm{pl} 5_{(1)}$ & 11,69 & $\operatorname{grt5}(9)-c p \times 2_{(8)}-\mathrm{pl} 6_{(10)}$ & 13,40 \\
\hline & & grt5(9)-cpx3 $(6)-p l 5_{(1)}$ & 11,92 & $\operatorname{grt5}{ }_{(9)}-\mathrm{cp} \times 3_{(6)}-\mathrm{pl} 6_{(10)}$ & 13,63 \\
\hline & & $\operatorname{art5}(9)-c p \times 4_{(5)}-p_{15}$ & 11,96 & $\operatorname{art5}(9)-c p x 4_{(5)}-p \mid 6_{(10)}$ & 13,67 \\
\hline & & Média & 11,73 & Média & 13,44 \\
\hline
\end{tabular}

\subsubsection{Nappe Socorro-Guaxupé}

Como visto nas análises de química mineral, granada e clinopiroxênio desta unidade são relativamente ricos em $\mathrm{Fe}$ e $\mathrm{Mg}$, e Fe, respectivamente, em comparação às análises das amostras da Nappe Varginha-Três Pontas. Essas características na interpretação geotermométrica indicam condições de temperaturas mais altas. Foram calculados quinze valores de temperatura com cinco análises de granada e três de clinopiroxênio da amostra IC-06-R com o geotermômetro granada - clinopiroxênio de Ellis \& Green (1979) para pressões de 12, 15 e 20 kbar (Tabela 14). Já com a equação de Harley (1984) foram pareadas cinco análises de granada com duas de ortopiroxênio, à $12 \mathrm{kbar}$, resultando em dez valores de temperatura calculada (Tabela 15). Assim, sob condições de $12 \mathrm{kbar}$, para o primeiro geotermômetro obtém-se temperaturas entre $814,35^{\circ} \mathrm{C}$ e $891,17^{\circ} \mathrm{C}$, média de $856,32{ }^{\circ} \mathrm{C}$, enquanto que para o segundo, entre $821,06^{\circ} \mathrm{C}$ e $890,05^{\circ} \mathrm{C}$, média de $855,29^{\circ} \mathrm{C}$. Vale notar que em ambas as equações as maiores temperaturas são calculadas para a análises dos grãos 2 e 5 de granada, as quais estão marcadas em negrito nas tabelas. 
Tabela 14 - Temperaturas em ${ }^{\circ} \mathrm{C}$ calculadas pelo geotermômetro de Ellis \& Green (1979) para pressões de 12,15 e 20 kbar. Número entre parênteses indica a análise do grão.

\begin{tabular}{|c|c|c|c|c|}
\hline \multicolumn{5}{|c|}{ Geotermômetro de Ellis \& Green (1979) } \\
\hline \multirow{17}{*}{$\begin{array}{l}\text { ㄸ } \\
\text { ழ் } \\
\text { ப் }\end{array}$} & Associação Mineral & $T\left({ }^{\circ} \mathrm{C}\right)$ a $12 \mathrm{kbar}$ & $T\left({ }^{\circ} \mathrm{C}\right)$ a $15 \mathrm{kbar}$ & $T\left({ }^{\circ} \mathrm{C}\right)$ a $20 \mathrm{kbar}$ \\
\hline & grt2(10)-cpx1(4) & 832,47 & 842,48 & 859,16 \\
\hline & $\operatorname{grt2}(10)-\operatorname{cpx} 2(6)$ & 872,80 & 883,18 & 900,47 \\
\hline & $\operatorname{grt2}(10)-\mathrm{cp} \times 3(7)$ & 883,45 & 893,93 & 911,38 \\
\hline & $\operatorname{grt3}(6)-\operatorname{cpx} 1(4)$ & 814,35 & 823,96 & 839,99 \\
\hline & grt3(6)-cpx2(6) & 852,40 & 862,36 & 878,95 \\
\hline & $\operatorname{grt3}(6)-\operatorname{cpx3}(7)$ & 862,44 & 872,48 & 889,22 \\
\hline & $\operatorname{grt} 4(13)-\operatorname{cpx} 1(4)$ & 817,70 & 827,43 & 843,72 \\
\hline & $\operatorname{grt} 4(13)-\operatorname{cpx} 2(6)$ & 856,45 & 866,56 & 883,40 \\
\hline & $\operatorname{grt} 4(13)-\mathrm{cp} \times 3(7)$ & 866,68 & 876,88 & 893,87 \\
\hline & $\operatorname{grt5}(8)-\operatorname{cpx} 1(4)$ & 840,89 & 850,70 & 867,04 \\
\hline & $\operatorname{grt5}(8)-c p x 2(6)$ & 880,67 & 890,83 & 907,76 \\
\hline & grt5(8)-cpx3(7) & 891,17 & 901,42 & 918,50 \\
\hline & grt6(5)-cpx1(4) & 828,34 & 838,07 & 854,28 \\
\hline & grt6(5)- cpx2(6) & 867,34 & 877,41 & 894,19 \\
\hline & grt6(5)-cpx3(7) & 877,62 & 887.79 & 904,72 \\
\hline & Média & 856,32 & 864,84 & 883,11 \\
\hline
\end{tabular}

Tabela 15 - Temperaturas em ${ }^{\circ} \mathrm{C}$ calculadas pelo geotermômetro de Harley (1984) para pressão de 12 kbar. Número entre parênteses indica a análise do grão.

\begin{tabular}{|c|c|}
\hline \multicolumn{2}{|c|}{ Geotermômetro de Harley (1984) } \\
\hline Associação Mineral & $T\left({ }^{\circ} \mathrm{C}\right)$ a $12 \mathrm{kbar}$ \\
\hline grt2(10)-opx2(6) & 897,73 \\
\hline $\operatorname{grt}_{(10)}-\mathrm{opx} 4_{(7)}$ & 890,05 \\
\hline grt3 $3_{(6)}-o p \times 2_{(6)}$ & 827,79 \\
\hline $\operatorname{grt}_{(6)}-\mathrm{opx} 4_{(7)}$ & 821,06 \\
\hline grt4(13)-opx2 ${ }_{(6)}$ & 850,94 \\
\hline $\operatorname{grt} 4_{(13)}-\mathrm{opx} 4_{(7)}$ & 843,89 \\
\hline $\operatorname{grt5}_{(8)-o p \times 2_{(6)}}$ & 867,74 \\
\hline $\operatorname{grt5}_{(8)}-\mathrm{opx} 4_{(7)}$ & 860,53 \\
\hline $\operatorname{grt6}_{(5)}-\mathrm{opx} 2_{(6)}$ & 850,09 \\
\hline $\operatorname{grt6}_{(5)}-\mathrm{opx} 4_{(7)}$ & 843,09 \\
\hline Média & 855,29 \\
\hline
\end{tabular}

Ao utilizar os valores de temperatura calculados à 12 kbar e as mesmas associações minerais de granada e clinopiroxênio com 3 análises de plagioclásio, dois de matriz e um de inclusão em granada, foram calculados quarenta e cinco valores de pressão, quinze para cada análise de plagioclásio usando o geobarômetro de Eckert et al. (1991), sendo que os 
resultados são apresentados na Tabela 16. Para as associações minerais com o plagioclásio 5 da matriz $\left(\mathrm{An}_{36}\right)$ são obtidas pressões entre 11,34 kbar e 13,88 kbar, média de 12,73 kbar, com o plagioclásio 8, também da matriz $\left(A n_{33}\right)$, valores entre 11,80 kbar e 14,36 kbar, média de 13,19 kbar, e com o plagioclásio 6, que é a inclusão $\left(A n_{36}\right)$, pressões entre 11,38 kbar e 13,92 kbar, e média de 12,77 kbar. Cálculos de pressão utilizando análise do plagioclásio 6 $\left(A n_{36}\right)$ foram realizadas para fins comparativos, visto que é provavelmente produto de cristalização tardia de fundido aprisionado, e não serão utilizadas (Tabela 16).

Tabela 16 - Pressões em kbar calculadas pelo geobarômetro de Eckert et al. (1991) utilizando as respectivas temperaturas à 12kbar calculadas para cada par mineral pelo geotermômetro de Ellis \& Green (1979) encontradas na Tabela 14.

\begin{tabular}{|c|c|c|c|c|c|}
\hline \multicolumn{6}{|c|}{ Geobarômetro de Eckert et al. (1991) } \\
\hline Associação Mineral & $P$ (kbar) & Associação Mineral & $P$ (kbar) & Associação Mineral & $P$ (kbar) \\
\hline $\operatorname{grt}_{(10)}-\mathrm{cpx} 1_{(4)}-\mathrm{pl} 5_{(1)}$ & 11,34 & $\operatorname{grt2}_{(10)}-\mathrm{cpx} 1_{(4)}-\mathrm{pl} 8_{(10)}$ & 11,80 & grt2 ${ }_{(10)}-\mathrm{cpx} 1_{(4)}-\mathrm{pl} 6_{(1)}$ & 11,38 \\
\hline grt2(10)-cpx2(6)-pl5 (1) & 12,20 & $\operatorname{grt} 2_{(10)}-c p \times 2_{(6)}-p \mid 8_{(10)}$ & 12,67 & grt2(10)-cpx2(6)-pl6 $(1)$ & 12,24 \\
\hline $\operatorname{grt}_{(10)}-\mathrm{cp} \times 3_{(7)}-\mathrm{pl} 5_{(1)}$ & 12,35 & $\operatorname{grt}_{(10)}-\mathrm{cpx} 3_{(7)}-\mathrm{pl} 8_{(10)}$ & 12,83 & $\operatorname{grt} 2_{(10)}-\mathrm{cp} \times 3_{(7)}-\mathrm{pl} 6_{(1)}$ & 12,39 \\
\hline $\operatorname{grt}_{(6)}-\mathrm{cpx} 1_{(4)}-\mathrm{pl} 5_{(1)}$ & 12,14 & $\operatorname{grt} 3_{(6)}-c p x 1_{(4)}-p \mid 8_{(10)}$ & 12,59 & grt3 ${ }_{(6)}-\mathrm{cpx} 1_{(4)}-\mathrm{pl} 6_{(1)}$ & 12,18 \\
\hline grt3 ${ }_{(6)}-\mathrm{cpx} 2_{(6)}-\mathrm{pl} 5_{(1)}$ & 13,01 & $\operatorname{grt}_{(6)}-\mathrm{cpx} 2_{(6)}-\mathrm{pl} 8_{(10)}$ & 13,47 & $\operatorname{grt}_{(6)}-\mathrm{cp} \times 2_{(6)}-\mathrm{pl} 6_{(1)}$ & 13,05 \\
\hline $\operatorname{grt}_{(6)}-\mathrm{cpx} 3_{(7)}-\mathrm{pl} 5_{(1)}$ & 13,16 & $\operatorname{grt}_{(6)}-\mathrm{cp} \times 3_{(7)}-\mathrm{p} \mid 8_{(10)}$ & 13,63 & $\operatorname{grt}_{(6)}-\mathrm{cpx} 3_{(7)}-\mathrm{pl} 6_{(1)}$ & 13,20 \\
\hline $\operatorname{grt}_{(13)-\operatorname{cpx}} 1_{(4)}-\mathrm{pl} 5_{(1)}$ & 11,71 & $\operatorname{grt}_{(13)}-\mathrm{cpx} 1_{(4)}-\mathrm{pl} 8_{(10)}$ & 12,16 & $\operatorname{grt}_{(13)}-\mathrm{cpx} 1_{(4)}-\mathrm{pl} 6_{(1)}$ & 11,75 \\
\hline $\operatorname{grt}_{(13)-\mathrm{cp}} 2_{(6)}-\mathrm{pl} 5_{(1)}$ & 12,57 & $\operatorname{grt}_{(13)}-\mathrm{cpx} 2_{(6)}-\mathrm{pl} 8_{(10)}$ & 13,04 & $\operatorname{grt} 4_{(13)-c p \times 2_{(6)}-p \mid 6_{(1)}}$ & 12,61 \\
\hline $\operatorname{grt}_{(13)}-\mathrm{cp} \times 3_{(7)}-\mathrm{pl} 5_{(1)}$ & 12,72 & $\operatorname{grt}_{(13)}-\mathrm{cpx} 3_{(7)}-\mathrm{pl} 8_{(10)}$ & 13,19 & $\operatorname{grt}_{(13)}-\mathrm{cp} \times 3_{(7)}-\mathrm{pl} 6_{(1)}$ & 12,76 \\
\hline $\operatorname{grt5}(8)-c p x 1_{(4)}-\mathrm{pl}_{(1)}$ & 12,81 & $\operatorname{grt5}(8)-c p x 1_{(4)}-p \mid 8_{(10)}$ & 13,27 & $\operatorname{grt5}_{(8)}-\mathrm{cpx} 1_{(4)}-\mathrm{pl} 6_{(1)}$ & 12,85 \\
\hline grt5(8)-cpx2 $2_{(6)}-\mathrm{pl}_{(1)}$ & 13,71 & $\operatorname{grt5}_{(8)}-\mathrm{cpx} 2_{(6)}-\mathrm{pl} 8_{(10)}$ & 14,19 & grt5(8)-cpx2 $2_{(6)}-\mathrm{pl} 6_{(1)}$ & 13,76 \\
\hline $\mathrm{grt5}_{(8)}-\mathrm{cpx} 3_{(7)}-\mathrm{pl} 5_{(1)}$ & 13,88 & $\operatorname{grt5}_{(8)}-\mathrm{cpx} 3_{(5)}-\mathrm{pl} 8_{(10)}$ & 14,36 & grt5(8)-cpx3(7)-pl6 $(1)$ & 13,92 \\
\hline grt6 $(5)-c p x 1_{(4)}-\mathrm{pl} 5_{(1)}$ & 12,45 & $\operatorname{grt6}_{(5)}-\mathrm{cpx} 1_{(4)}-\mathrm{pl} 8_{(10)}$ & 12,91 & grt6 $(5)-c p x 1_{(4)}-p \mid 6_{(1)}$ & 12,49 \\
\hline $\operatorname{grt}_{(5)}-\operatorname{cpx} 2_{(6)}-\mathrm{pl} 5_{(1)}$ & 13,34 & $\operatorname{grt}_{(5)}-\mathrm{cpx} 2_{(6)}-\mathrm{pl} 8_{(10)}$ & 13,81 & $\operatorname{grt} 6_{(5)}-\operatorname{cpx} 2_{(6)}-p \mid 6_{(1)}$ & 13,38 \\
\hline $\operatorname{grt6}_{(5)-\mathrm{cpx}} 3_{(7)}-\mathrm{pl} 5_{(1)}$ & 13,50 & $\operatorname{grt6}_{(5)}-\mathrm{cpx} 3_{(7)-p \mid 8_{(10)}}$ & 13,97 & $\operatorname{grt6}_{(5)}-\mathrm{cpx} 3_{(7)}-\mathrm{pl}_{(1)}$ & 13,54 \\
\hline Média & 12,73 & Média & 13,19 & Média & 12,77 \\
\hline
\end{tabular}

A partir dos maiores valores de temperatura, calculados com as composições das granadas 2 e 5, à 12 kbar (Tabela 14), que provavelmente indicam as condições do pico metamórfico, com o uso das duas análises de plagioclásio de matriz, análise 1 do plagioclásio 5 e análise 10 do plagioclásio 8 , e de duas análises de ortopiroxênio, análise 6 do grão 2 e análise 7 do grão 4, foram calculados quarenta valores de pressão com outros quatro geobarômetros. Utilizando a associação granada-ortopiroxênio-plagioclásio obteve-se oito valores de pressão para cada uma das três calibrações: Newton \& Perkins (1982), entre 12,95 kbar e 13,78 kbar, média de 13,37 kbar, Perkins \& Chipera (1985), entre 11,22 kbar a 12,26 kbar, média de 11,74 kbar, e Eckert et al. (1991), entre 13,38 kbar e 14,24 kbar, média de 13,81 kbar. Já com a associação granada-clinopiroxênio-ortopiroxênio-plagioclásio foi utilizado o geobarômetro calibrado por Paria et al. (1988) com o qual obteve-se dezesseis 
valores de pressão, entre 12,28 kbar e 12,70 kbar, média de 12,49 kbar. Todos os valores de pressão calculados com geobarômetros que utilizam ortopiroxênio estão listados na Tabela 17.

Tabela 17 - Pressões calculadas com os geobarômetros de Newton \& Perkins (1982), Perkins \& Chipera (1985), Paria et al. (1988) e Eckert et al. (1991). Valores em kbar.

\begin{tabular}{|c|c|c|c|c|}
\hline Associação Mineral & $\begin{array}{c}\text { Newton \& } \\
\text { Perkins(1982) }\end{array}$ & $\begin{array}{c}\text { Perkins \& } \\
\text { Chipera (1985) }\end{array}$ & $\begin{array}{c}\text { Paria et al. } \\
(1988)\end{array}$ & $\begin{array}{c}\text { Eckert et al. } \\
(1991)\end{array}$ \\
\hline grt2(10)-opx2(6)-pl5(1) & 13,02 & 11,22 & - & 13,45 \\
\hline $\operatorname{grt5}_{(8)}-\mathrm{opx} 2_{(6)}-\mathrm{pl} 5_{(1)}$ & 13,35 & 11,96 & - & 13,77 \\
\hline $\operatorname{grt2}_{(10)-o p x 2_{(6)}-\text { pl8 }}(10)$ & 13,45 & 11,49 & - & 13,91 \\
\hline $\operatorname{grt5}(8)-o p \times 2_{(6)}-\mathrm{pl} 8_{(10)}$ & 13,78 & 12,24 & - & 14,24 \\
\hline $\operatorname{grt2}_{(10)}-\mathrm{opx} 4_{(7)}-\mathrm{pl}_{(1)}$ & 12,95 & 11,25 & - & 13,38 \\
\hline grt5(8)-opx4(7)-pl5 $(1)$ & 13,28 & 11,99 & - & 13,70 \\
\hline grt2 $(10)-o p \times 4_{(7)}-$ pl $8_{(10)}$ & 13,38 & 11,52 & - & 13,84 \\
\hline $\operatorname{grt5}_{(8)-o p x 4_{(7)}-\mathrm{pl}} 8_{(10)}$ & 13,71 & 12,26 & - & 14,17 \\
\hline grt2 ${ }_{(10)}-\mathrm{cpx} 2_{(6)}-\mathrm{opx} 2_{(6)}-\mathrm{pl} 5_{(1)}$ & - & - & 12,31 & - \\
\hline grt2 $(10)-c p \times 3_{(7)}-o p \times 2_{(6)}-p \mid 5_{(1)}$ & - & - & 12,36 & - \\
\hline grt5(8)-cpx2 $2_{(6)}-\mathrm{opx} 2_{(6)}-\mathrm{pl} 5_{(1)}$ & - & - & 12,28 & - \\
\hline grt5(8)-cpx3(7)-opx2(6)-pl5(1) & - & - & 12,33 & - \\
\hline $\operatorname{grt} 2_{(10)}-\mathrm{cpx} 2_{(6)}-\mathrm{opx} 2_{(6)}-\mathrm{pl} 8_{(10)}$ & - & - & 12,60 & - \\
\hline $\operatorname{grt}_{(10)}-\mathrm{cpx} 3_{(7)-o p \times 2_{(6)}-\mathrm{pl} 8_{(10)}}$ & - & - & 12,65 & - \\
\hline $\operatorname{grt5}(8)-c p x 2_{(6)}-o p \times 2_{(6)}-p \mid 8_{(10)}$ & - & - & 12,56 & - \\
\hline $\operatorname{grt5}_{(8)}-\mathrm{cpx} 3_{(7)}-\mathrm{opx} 2_{(6)}-\mathrm{pl} 8_{(10)}$ & - & - & 12,61 & - \\
\hline $\operatorname{grt}_{(10)}-\mathrm{cpx} 2_{(6)}-\mathrm{opx} 4_{(7)}-\mathrm{pl} 5_{(1)}$ & - & - & 12,36 & - \\
\hline $\operatorname{grt2}_{(10)}-\mathrm{cpx} 3_{(7)}-\mathrm{opx} 4_{(7)}-\mathrm{pl} 5_{(1)}$ & - & - & 12,41 & - \\
\hline $\operatorname{grt5}{ }_{(8)}-\mathrm{cpx} 2_{(6)}-\mathrm{opx} 4_{(7)-}-\mathrm{pl} 5_{(1)}$ & - & - & 12,33 & - \\
\hline $\operatorname{grt5}_{(8)}-\mathrm{cpx} 3_{(7)}-\mathrm{opx} 4_{(7)-p \mid 5_{(1)}}$ & - & - & 12,38 & - \\
\hline $\operatorname{grt}_{(10)}-\mathrm{cpx} 2_{(6)}-\mathrm{op} \times 4_{(7)}-\mathrm{pl} 8_{(10)}$ & - & - & 12,65 & - \\
\hline grt2 ${ }_{(10)}-\mathrm{cpx} 3_{(7)}-\mathrm{opx} 4_{(7)}-\mathrm{pl} 8_{(10)}$ & - & - & 12,70 & - \\
\hline $\operatorname{grt}_{(8)}-\mathrm{cpx} 2_{(6)}-\mathrm{opx} 4_{(7)}-\mathrm{pl} 8_{(10)}$ & - & - & 12,61 & - \\
\hline $\operatorname{grt5}_{(8)}-\mathrm{cpx} 3_{(7)-\mathrm{opx}} 4_{(7)-\mathrm{pl}} 8_{(10)}$ & - & - & 12,66 & - \\
\hline Média & 13,37 & 11,74 & 12,49 & 13,81 \\
\hline
\end{tabular}

\subsubsection{Geotermobarometria otimizada}

\subsubsection{Nappe Socorro-Guaxupé}

As condições $P$ - $T$ também foram calculadas por métodos otimizados com o uso de softwares como THERMOCALC (Holland \& Powell 2011) e RCLC (Pattison et al. 2003). No primeiro caso, os cálculos de $T$ e $P$ foram feitos separadamente e no modo "avPT", seguindo recomendações de Powell \& Holland (1994). As associações minerais utilizadas foram as mesmas daquelas dos cálculos feitos com o geobarômetro de Paria et al. (1988), e obteve-se 
dezesseis valores de pressão e de temperatura, e outros dezesseis de maneira conjunta (avPT). Todos os resultados estão dispostos na Tabela 18.

Tabela 18 - Valores P-T para o granulito félsico da Nappe Socorro-Guaxupé determinados por THERMOCALC. Correl. $=$ Correlação entre os valores de pressão e temperatura calculados conjuntamente.

\begin{tabular}{|c|c|c|c|c|}
\hline \multicolumn{5}{|c|}{ THERMOCALC - Holland \& Powell (2011) } \\
\hline Associação mineral & $P($ kbar) & $T\left({ }^{\circ} \mathrm{C}\right)$ & $P($ kbar $) / T\left({ }^{\circ} \mathrm{C}\right)$ & correl. \\
\hline grt2(10)-cpx2(6)-opx2(6)-pl5(1) & $11,90 \pm 0,69$ & $885 \pm 53$ & $11,8 \pm 1,4 / 937 \pm 105$ & 0,82 \\
\hline $\operatorname{grt2}_{(10)}-\mathrm{cp} \times 3_{(7)}-\mathrm{opx} 2_{(6)}-\mathrm{pl} 5_{(1)}$ & $11,87 \pm 0,65$ & $948 \pm 49$ & $11,8 \pm 1,3 / 941 \pm 98$ & 0,83 \\
\hline $\operatorname{grt5}(8)-c p \times 2_{(6)}-o p \times 2_{(6)}-\mathrm{pl} 5_{(1)}$ & $11,67 \pm 0,62$ & $923 \pm 42$ & $11,6 \pm 1,1 / 896 \pm 81$ & 0.830 \\
\hline grt5(8)-cpx3(7)-opx2 ${ }_{(6)}-\mathrm{pl} 5_{(1)}$ & $11,66 \pm 0,61$ & $825 \pm 44$ & $11,7 \pm 1,1 / 901 \pm 82$ & 0.831 \\
\hline $\operatorname{grt} 2_{(10)}-\mathrm{cpx} 2_{(6)}-\mathrm{op} \times 2_{(6)}-\mathrm{pl} 8_{(10)}$ & $11,64 \pm 0,68$ & $929 \pm 50$ & $12,1 \pm 1,4 / 941 \pm 106$ & 0,83 \\
\hline $\operatorname{grt}_{(10)}-\mathrm{cp} \times 3_{(7)}-\mathrm{op} \times 2_{(6)}-\mathrm{pl} 8_{(10)}$ & $11,62 \pm 0,64$ & $872 \pm 52$ & $12,1 \pm 1,3 / 946 \pm 99$ & 0,83 \\
\hline grt5(8)-cpx2 $(6)-o p \times 2_{(6)}-\mathrm{pl} 8_{(10)}$ & $11,97 \pm 0,61$ & $869 \pm 45$ & $12,0 \pm 1,1 / 901 \pm 82$ & 0,84 \\
\hline 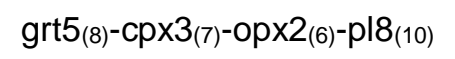 & $11,95 \pm 0,61$ & $903 \pm 45$ & $12,0 \pm 1,1 / 905 \pm 83$ & 0,84 \\
\hline $\operatorname{grt2}_{(10)}-\mathrm{cpx} 2_{(6)-o p x 4_{(7)}-\mathrm{pl} 5_{(1)}}$ & $11,33 \pm 0,66$ & $913 \pm 49$ & $11,6 \pm 1,4 / 926 \pm 104$ & 0,83 \\
\hline $\operatorname{grt2}_{(10)}-\mathrm{cpx} 3_{(7)}-\mathrm{opx} 4_{(7)}-\mathrm{pl} 5_{(1)}$ & $11,31 \pm 0,62$ & $887 \pm 48$ & $11,6 \pm 1,3 / 931 \pm 97$ & 0,83 \\
\hline $\operatorname{grt5}(8)-\operatorname{cpx} 2_{(6)}-\mathrm{opx} 4_{(7)}-\mathrm{pl} 5_{(1)}$ & $11,65 \pm 0,61$ & $883 \pm 45$ & $11,5 \pm 1,1 / 883 \pm 81$ & 0,83 \\
\hline 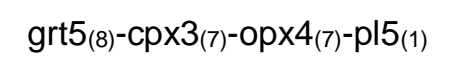 & $11,63 \pm 0,61$ & $886 \pm 44$ & $11,5 \pm 1,1 / 888 \pm 82$ & 0,83 \\
\hline $\operatorname{grt}_{(10)}-\mathrm{cpx} 2_{(6)}-\mathrm{op} \mathrm{4}_{(7)}-\mathrm{pl} 8_{(10)}$ & $11,62 \pm 0,66$ & $863 \pm 51$ & $12,0 \pm 1,4 / 929 \pm 105$ & 0,83 \\
\hline $\operatorname{grt}_{(10)}-\mathrm{cp} \times 3_{(7)}-\mathrm{op} \times 4_{(7)}-\mathrm{pl} 8_{(10)}$ & $11,60 \pm 0,62$ & $837 \pm 55$ & $12,0 \pm 1,3 / 935 \pm 98$ & 0,84 \\
\hline grt5(8)-cpx2 $2_{(6)}-\mathrm{opx} 4_{(7)}-\mathrm{pl} 8_{(10)}$ & $11,94 \pm 0,61$ & $850 \pm 44$ & $11,8 \pm 1,1 / 887 \pm 82$ & 0,84 \\
\hline $\operatorname{grt5}_{(8)-}-\mathrm{cpx} 3_{(7)-\mathrm{opx}} 4_{(7)}-\mathrm{pl} 8_{(10)}$ & $11,92 \pm 0,61$ & $884 \pm 78$ & $11,8 \pm 1,1 / 892 \pm 83$ & 0,84 \\
\hline
\end{tabular}

Os resultados de pressão calculados separadamente indicam excelente homogeneidade, com valores entre 11,31 \pm 0,62 e 11,97 \pm 0,61 kbar, já os de temperatura apresentam maior variação, entre $825 \pm 44$ e $948 \pm 49^{\circ} \mathrm{C}$. No cálculo com o método av $P-T$, em que pressão e temperatura são calculadas simultaneamente, as condições vão de 11,5 \pm 1,1 kbar e $883 \pm 81^{\circ} \mathrm{C}$ a $12,1 \pm 1,3$ kbar e $946 \pm 99^{\circ} \mathrm{C}$, com correlações por volta de 0,83 . A grande similaridade dos resultados, aliada à alta correlação em todos os casos, indica valores confiáveis de pressão e temperatura para essas rochas calculados com esse método.

Para o segundo método otimizado, RCLC, foram combinadas entre si as mesmas análises de granada, ortopiroxênio e plagioclásio usadas no método anterior, e calculados oito valores de pressão e temperatura conjuntamente. O objetivo desse método é tentar recalcular as composições dos minerais, por meio de balanço de massas, às prováveis existentes durante o pico metamórfico, excluindo/ amenizando assim, trocas Fe-Mg entre granada e ortopiroxênio e alterações no teor de Al da última fase, ocorridas durante a resfriamento/ exumação da rocha. Assim, foram obtidos valores iniciais, isto é, sem correções, e ajustados. Os iniciais situam-se acima dos $960{ }^{\circ} \mathrm{C}$ e $12 \mathrm{kbar}$, variando entre $968^{\circ} \mathrm{C}$ e $13,49 \mathrm{kbar}$ e 989 
${ }^{\circ} \mathrm{C}$ e $13,54 \mathrm{kbar}$, já os ajustados são inferiores, entre $845^{\circ} \mathrm{C}$ e 11,36 kbar e $922{ }^{\circ} \mathrm{C}$ e 13,27 kbar. A Tabela 19 sintetiza todos os valores de $P$ e $T$ calculados com esse método.

Tabela 19 - Valores P-T iniciais e ajustados para o granulito félsico da Nappe Socorro-Guaxupé determinados por RCLC.

\begin{tabular}{|c|c|c|}
\hline \multicolumn{3}{|c|}{ RCLC - Pattison et al. (2003) } \\
\hline Associação Mineral & Inicial & Ajustado \\
\hline $\operatorname{grt} 2_{(8)}-o p \times 2_{(6)}-p \mid 5_{(1)}$ & $986^{\circ} \mathrm{C} / 13,08 \mathrm{kbar}$ & $845^{\circ} \mathrm{C} / 11,36 \mathrm{kbar}$ \\
\hline $\operatorname{grt5}_{(8)}-\mathrm{opx} 2_{(6)}-\mathrm{pl} 5_{(1)}$ & $980^{\circ} \mathrm{C} / 13,67 \mathrm{kbar}$ & $896^{\circ} \mathrm{C} / 12,56 \mathrm{kbar}$ \\
\hline $\operatorname{grt2}(8)-o p x 2_{(6)}-p \mid 8_{(8)}$ & $989^{\circ} \mathrm{C} / 13,54 \mathrm{kbar}$ & $856^{\circ} \mathrm{C} / 11,84 \mathrm{kbar}$ \\
\hline $\operatorname{grt5}(8)-o p \times 2_{(6)}-p \mid 8_{(8)}$ & $984^{\circ} \mathrm{C} / 14,13 \mathrm{kbar}$ & $908^{\circ} \mathrm{C} / 13,10 \mathrm{kbar}$ \\
\hline $\operatorname{grt}_{(8)}-\mathrm{opx} 4_{(7)-\mathrm{pl}} 5_{(1)}$ & $973^{\circ} \mathrm{C} / 12,90 \mathrm{kbar}$ & $858^{\circ} \mathrm{C} / 11,49 \mathrm{kbar}$ \\
\hline $\operatorname{grt5}_{(8)}-\mathrm{opx} 4_{(7)}-\mathrm{pl} 5_{(1)}$ & $968^{\circ} \mathrm{C} / 13,49 \mathrm{kbar}$ & $910^{\circ} \mathrm{C} / 12,73 \mathrm{kbar}$ \\
\hline $\operatorname{grt} 2_{(8)}-\mathrm{opx} 4_{(7)}-\mathrm{pl} 8_{(8)}$ & $977^{\circ} \mathrm{C} / 13,36 \mathrm{kbar}$ & $870^{\circ} \mathrm{C} / 11,99 \mathrm{kbar}$ \\
\hline $\operatorname{grt5}_{(8)}-\mathrm{opx} 4_{(7)}-\mathrm{p} \mid 8_{(8)}$ & $972{ }^{\circ} \mathrm{C} / 13,95 \mathrm{kbar}$ & $922^{\circ} \mathrm{C} / 13,27 \mathrm{kbar}$ \\
\hline
\end{tabular}

\subsubsection{Pseudosseções}

Foram construídas duas pseudosseções no intervalo de 2,0 a 20,0 kbar e 650 a 1000 ${ }^{\circ} \mathrm{C}$, campo $P$-T que extrapola a janela das reações metamórficas e campos de estabilidade observados no rutilo-cianita-granada granulito da Nappe Três Pontas-Varginha, porém ajuda a entender as possíveis paragêneses e reações ocorridas durante o metamorfismo, fusão parcial e o retrometamorfismo. Para o cálculo de pseudosseções é necessário conhecer a composição da rocha, pré-fusão parcial, mas o fato dessas rochas sempre serem observadas com leucossoma associado, indica que a sua composição original não pode ser determinada nos locais em que aflora. Foram pesquisadas diversas composições químicas de folhelhos, sempre restringindo pelos mais ricos em $\mathrm{Ca}$ e $\mathrm{Na}$ para produção líquido rico nesses componentes com cristalização de plagioclásio no leucossoma. Assim, foi utilizada como base a composição de um filito bandado porfiroblástico da transição da fácies xisto-verde para anfibolito (amostra SC-07, de Pavan 2010) da Klippe Carrancas em que algum $\mathrm{CaO}$ e $\mathrm{Na}_{2} \mathrm{O}$ foram adicionados

A pseudosseção 1 tem composição semelhante à SC-07 de Pavan (2010) salvo a diminuição da porcentagem de água. A pseudosseção 2 foi calculada com ajustes na proporção de água e na razão $\mathrm{CaO} / \mathrm{Na}_{2} \mathrm{O}$ numa tentativa de se aproximar dos prováveis valores das rochas em estudo. Ambas composições foram calculadas em proporções molares a $100 \%$, no sistema químico modelo NCKFMASHTO ( $\mathrm{Na}_{2} \mathrm{O}-\mathrm{CaO}-\mathrm{K}_{2} \mathrm{O}-\mathrm{FeO}_{\mathrm{T}}-\mathrm{MgO}-$ $\mathrm{Al}_{2} \mathrm{O}_{3}-\mathrm{SiO}_{2}-\mathrm{H}_{2} \mathrm{O}-\mathrm{TiO}_{2}-\mathrm{O}_{2}$ ), um dos mais completos, a fim de tentar aproximar o máximo possível as condições calculadas das existentes nas rochas reais investigadas. Como ilmenita e quartzo estão presentes durante todos os cálculos, salvo o último, ausente apenas em 
temperaturas altas e pressões muito baixas, foram considerados em excesso. Em cada exemplo foram determinadas sete isopletas de proporção de fundido, de $5 \%$ a $60 \%$ na pseudosseção 1 e entre $20 \%$ e $80 \%$ na 2 . A partir da confecção dos dois diagramas é possível realizar comparações principalmente a respeito do campo de estabilidade do plagioclásio, mineral fundamental nessas rochas, limitante no avanço das reações de fusão. A Tabela 20 apresenta as composições químicas em proporções molares do filito original e das utilizadas nesse trabalho.

Tabela 20 - Composições químicas utilizadas nos cálculos das pseudosseções, e do filito original (SC-07) de Pavan (2010). Valores em proporções molares.

\begin{tabular}{c|ccccccccccc}
\hline Amostra & $\mathbf{H}_{2} \mathbf{O}$ & $\mathrm{SiO}_{2}$ & $\mathbf{A l}_{2} \mathbf{O}_{3}$ & $\mathbf{F e O}$ & $\mathbf{M g O}$ & $\mathbf{C a O}$ & $\mathbf{N a}_{2} \mathbf{O}$ & $\mathbf{K}_{2} \mathbf{O}$ & $\mathbf{T i O}_{2}$ & $\mathbf{O}$ & Total \\
\hline SC-07 (Pavan 2010) & 13,95 & 60,21 & 13,89 & 5,34 & 2,11 & 0,04 & 0,99 & 2,69 & 0,78 & - & 100,00 \\
Pseudosseção 1 & 5,67 & 65,93 & 15,20 & 5,84 & 2,32 & 0,05 & 1,09 & 2,95 & 0,85 & 0,10 & 100,00 \\
Pseudosseção 2 & 6,89 & 63,15 & 14,57 & 5,60 & 2,22 & 1,74 & 2,11 & 2,82 & 0,82 & 0,10 & 100,00 \\
\hline \hline
\end{tabular}

A pseudosseção 1 é apresentada na Figura 66. Devido ao grande número componentes e fases a ao amplo campo $P-T$, apresenta abrangente conjunto de campos de diferentes variâncias, desde octavariante a divariante. No total, incluindo campos ínfimos não sinalizados no diagrama, aparecem um campo octavariante, quatro heptavariantes, nove hexavariantes, dezessete pentavariantes, dezesseis tetravariantes, cinco trivariantes e um divariante, totalizando 53 campos de paragêneses minerais. De maneira geral, maiores variâncias ocorrem na porção de alta temperatura e baixa pressão, variâncias médias na região central e de média a alta pressão e baixa temperatura, e menores variâncias nos estreitos campos onde líquido e muscovita coexistem. Como a composição usada para o cálculo do diagrama possui baixa proporção de $\mathrm{CaO}$, o campo de estabilidade de plagioclásio é restrito, com o mineral totalmente consumido antes da quebra da muscovita em altas pressões e temperaturas, e a paragênese encontrada nas rochas da Nappe Três PontasVarginha é representada pelo campo da associação quartzo, ortoclásio, granada, cianita, rutilo e ilmenita, ocupando temperaturas maiores que $830^{\circ} \mathrm{C}$ e pressões maiores que $10,6 \mathrm{kbar}$. Dentro do campo, ocorre mínimo de $20 \%$ de fusão parcial e máximo de $40 \%$. 


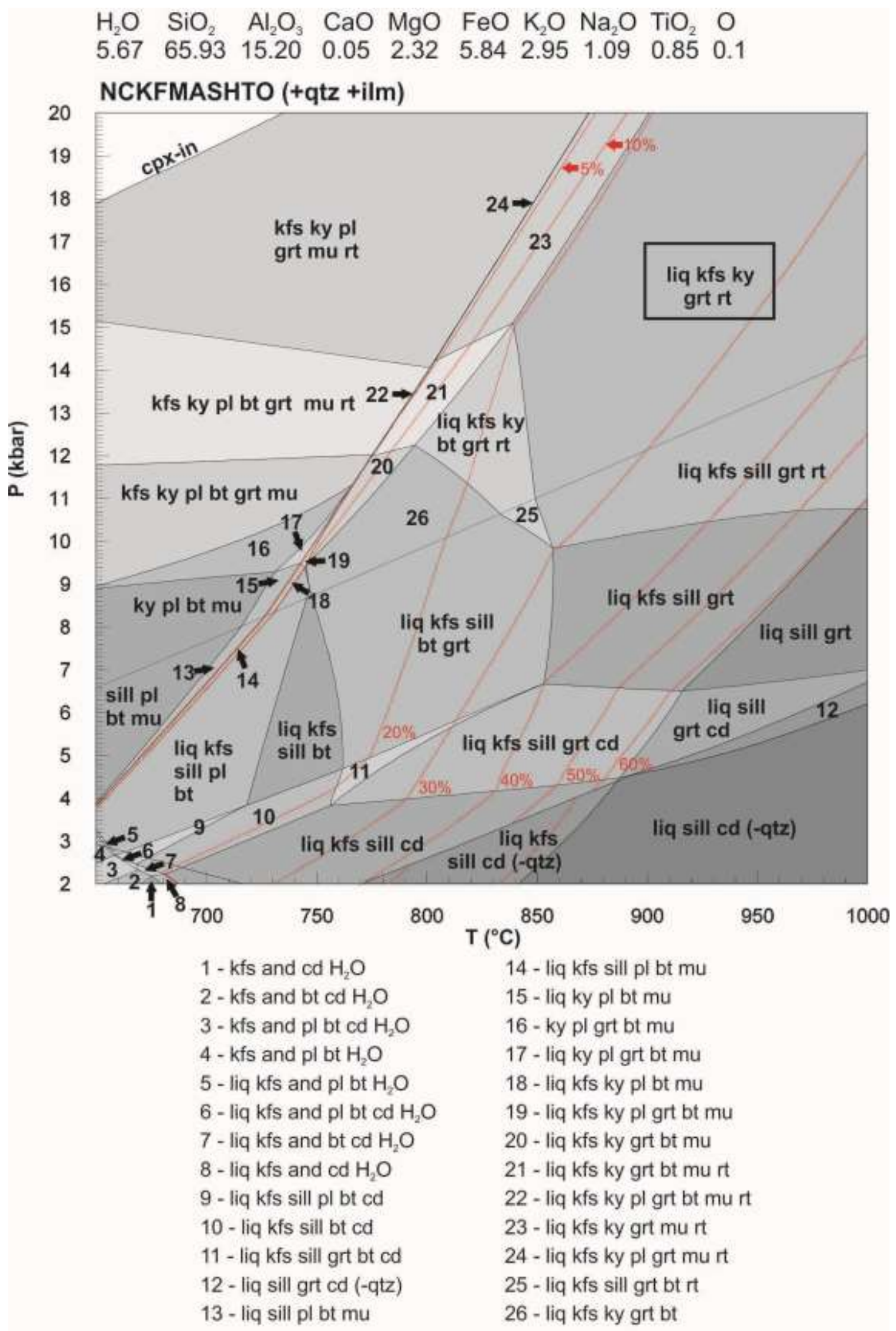

Figura 66 - Pseudosseção 1 P-T no sistema química NCKFMASHTO com ilmenita e quartzo em excesso. Paragênese do rt-ky-grt granulito demarcada pelo retângulo preto. Curvas em vermelho indicam proporção de fusão parcial produzida na rocha. Composição química calculada a partir da proporção molar normalizada. 
A pseudosseção 2 é apresentada na Figura 67. Assim como o diagrama anterior, devido ao grande número componentes e fases e ao amplo campo $P$ - $T$ calculado, apresenta campos de diferentes variâncias, desde octavariante a divariante. Entre os 57 campos de estabilidade mineral ocorre apenas um octavariante, três heptavariantes, cinco hexavariantes, dezoito pentavariantes, dezenove tetravariantes, nove trivariantes e dois divariantes. Da mesma maneira como apresentado na pseudosseção 1, aqui os campos de maior variância também ocorrem na porção de alta temperatura e baixa pressão, variâncias intermediárias em baixas pressão e temperatura e altas pressões, e baixas variâncias em campos estreitos com maior variação de pressão que de temperatura, como o 24. Com os ajustes de composição, o campo de estabilidade do plagioclásio é ampliado e ocorre na maior parte do diagrama, sendo "quebrado" sob altas pressões, entre $\sim 15$ e 16,7 kbar e a partir de $\sim 840^{\circ} \mathrm{C}$, assim, a paregenêse encontrada no granulito metapelítico da Nappe Três Pontas-Varinha, liqkfs-ky-grt-rt-ilm-qtz, é representada e ocorre no campo pentavariante entre $\sim 840-1000{ }^{\circ} \mathrm{C} \mathrm{e}$ pressão maior que $15 \mathrm{kbar}$, com proporção de fusão parcial entre $>20 \%$ e $\sim 50 \%$.

A Figura 68 é a sobreposição das duas pseudosseções na qual as curvas univariantes grossas representam a pseudosseção 1, enquanto as finas, a 2. A partir dela, fica claro que para a composição do diagrama 1, com menos $\mathrm{H}_{2} \mathrm{O}, \mathrm{CaO}$ e $\mathrm{Na}_{2} \mathrm{O}$, as reações de quebra de biotita e aparecimento de rutilo ocorrem em maiores temperaturas e pressões $\left(20-30{ }^{\circ} \mathrm{C}\right.$ e 0,7 - 1 kbar) quando comparadas às do diagrama 2. Plagioclásio e ortoclásio também têm comportamentos bastante distintos, com campo de estabilidade do primeiro mineral muito maior no segundo diagrama, estável $1000{ }^{\circ} \mathrm{C}$ e $\sim 15 \mathrm{kbar}$, enriquecido em $\mathrm{H}_{2} \mathrm{O}$, CaO e $\mathrm{N}_{2} \mathrm{O}$, enquanto o oposto ocorre com o outro mineral, praticamente ausente na pseudosseção 1 , ocorrendo somente em pequeno campo triangular, entre 650 e $765^{\circ} \mathrm{C}$ e 4 e 11 kbar. Outro comportamento diferenciado em relação às duas composições é a proporção de fusão parcial na pseudosseção 2, com início da produção de líquido em menores temperaturas mesmo em altas pressões, porcentagens que chegam à ordem de $80 \%$ em alta temperatura e baixa pressão, contra $60 \%$ no outro caso e, na maioria das condições $P$ - $T$, fundindo $\sim 10 \%$ ou mais que a pseudosseção 1, demonstrando a importância de plagioclásio e água na produção de fundido. 


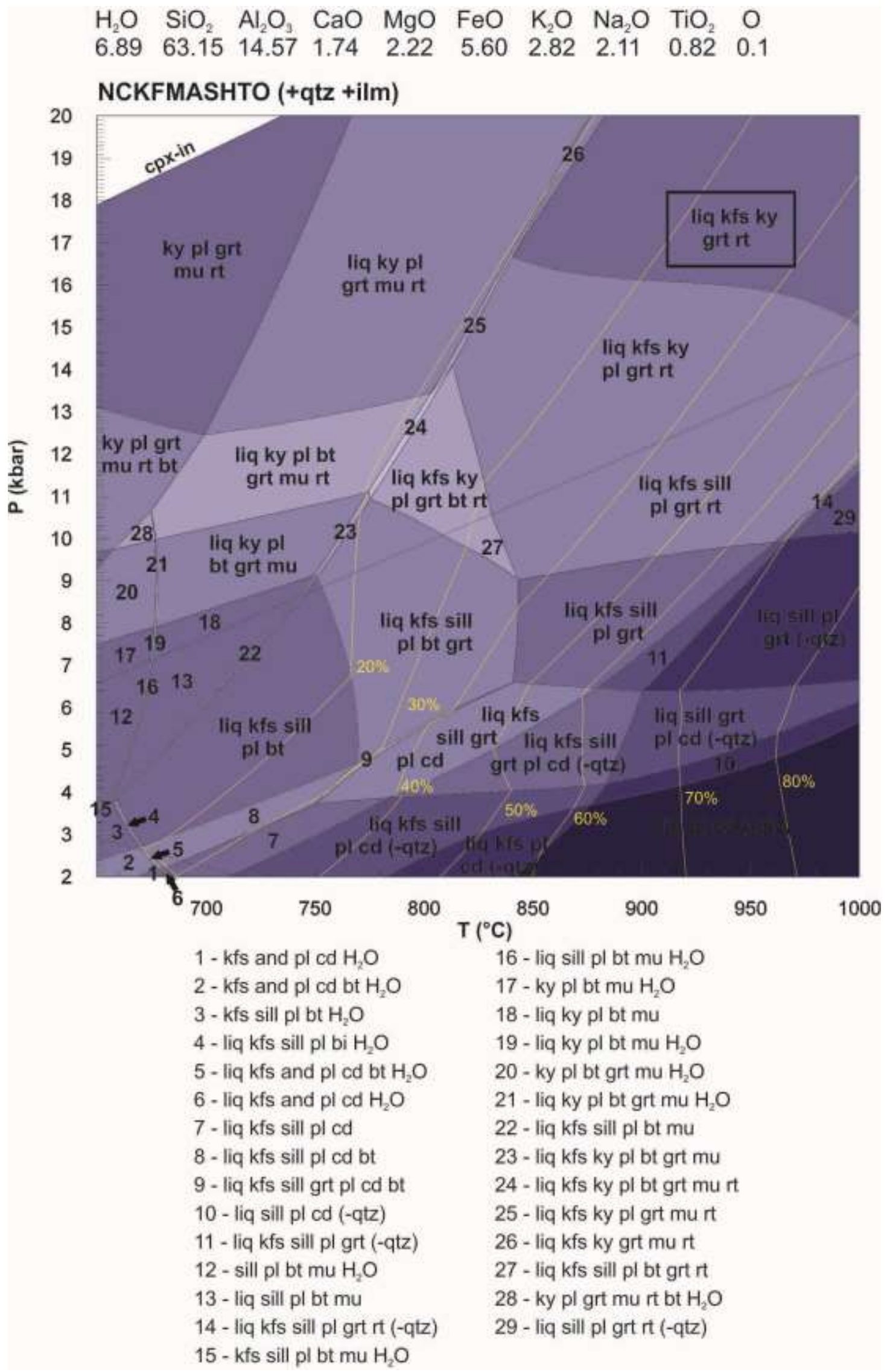

Figura 67 - Pseudosseção 2 P-T no sistema química NCKFMASHTO com ilmenita e quartzo em excesso. Paragênese do rt-ky-grt granulito demarcada pelo retângulo preto. Curvas em amarelo indicam proporção de fundido na rocha. Composição química calculada a partir da proporção molar normalizada. 


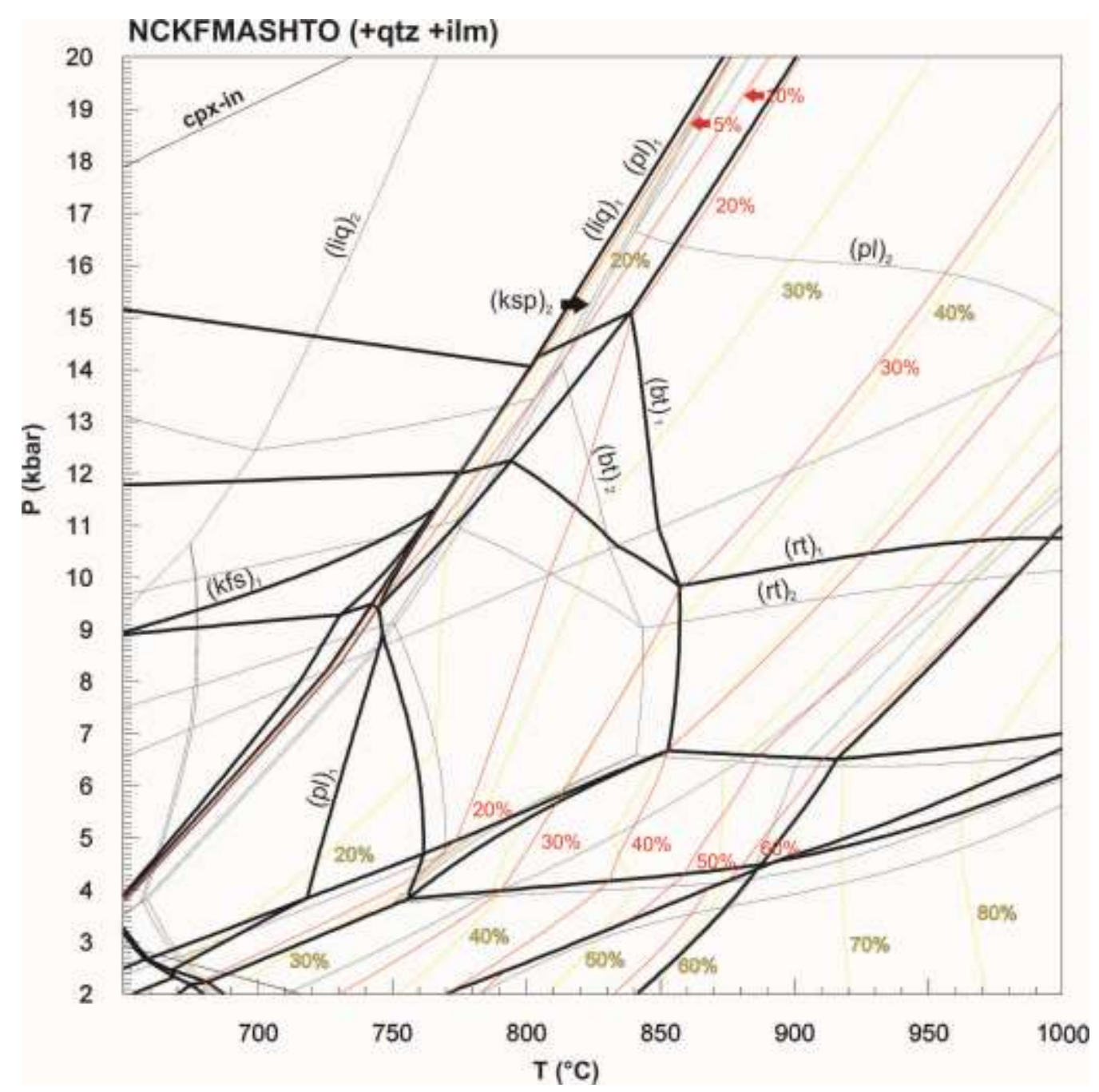

Figura 68 - Sobreposição das pseudosseções 1 e 2 com apenas as curvas univariantes e as isopletas de fusão parcial indicadas. Curvas grossas e isopletas vermelhas são do diagrama 1, e curvas finas e isopletas amarelas do 2. Índices nos minerais indicam a respectiva pseudosseção. 


\section{DISCUSSÃO}

5.1. Nappe Três Pontas-Varginha

As condições $P-T$ calculadas para as amostras de rocha calciossilicática da Nappe Três Pontas-Varginha, TPR-01-C e TPR-01-B, apresentam resultados semelhantes, haja visto a composição dos minerais não variar muito entre as amostras. Em ambas amostras são obtidas condições $P$-T para o pico metamórfico entre $\sim 850$ e $860^{\circ} \mathrm{C}$ a $\sim 15,5$ kbar. As análises de química mineral de TPR-01-F1, com granada ligeiramente mais rica em Mg e clinopiroxênio com maior \#Mg, resultam em condições $P-T$ superiores às das outras amostras, com pico metamórfico por volta dos $876{ }^{\circ} \mathrm{C}$ e $13,5 \mathrm{kbar}$. Ao considerar os erros de $\pm 50{ }^{\circ} \mathrm{C}$ e $1,9 \mathrm{kbar}$, todos os valores calculados são concordantes e corroboram o metamorfismo de alto grau e de alta pressão. Os cálculos geobarométricos efetuados com análises da última amostra, que relacionam o plagioclásio $3\left(A_{76}\right)$, mineral cristalizado a partir de líquido silicático aprisionado, posterior ao pico metamórfico, apresentam valores em torno dos $10 \mathrm{kbar}$, e foram calculados para exemplificar o resultado de um pareamento mineral incorreto, relacionando minerais que não estiveram em equilíbrio no auge do metamorfismo. É importante atentar para perfis de química mineral comumente planos, característica comum para rochas de alto grau que tiveram equilíbrio químico completo e pouco modificados durante o resfriamento.

Em relação à geotermobarometria não convencional com os termômetros Zr-rutilo e Ti-quartzo, como já mencionado, não foram verificadas diferenças significativas entre teores dos elementos traço nos grãos de inclusões e de matriz. São encontrados valores altos e baixos em ambos casos. No caso de Zr em rutilo, é comum a presença de cristais com menores variações quando inclusos em granada. É recorrente a presença de finos cristais de zircão junto aos cristais de rutilo que apresentam os menores teores de $\mathrm{Zr}$, o que sugere mobilização do $\mathrm{Zr}$ durante resfriamento. Por vezes, foi verificada gradação nos teores de $\mathrm{Ti}$ em quartzo de inclusões, com aumento do teor em direção a borda, possivelmente indicando enriquecimento durante o crescimento do porfiroblasto com fechamento do sistema quando o grão foi englobado pelo porfiroblasto. Em relação à coloração do rutilo, que varia de tons amarelados a amarronzados, não foi verificada relação com seu teor de $\mathrm{Zr}$.

A grande variação nos teores de Zr em rutilo, entre 374 e 1518 ppm, o que implica temperaturas entre $693^{\circ} \mathrm{C}$ e $826,4{ }^{\circ} \mathrm{C}$, e nos de Ti em quartzo, de 23 a $72 \mathrm{ppm}$, com temperaturas entre $727,6^{\circ} \mathrm{C}$ e $843,7^{\circ} \mathrm{C}$, mostra a necessidade de análise do maior número possível de grãos. De maneira geral, quando feitos separadamente os cálculos de temperatura, os obtidos com o termômetro de Ti-Quartzo são maiores em relação aos do Zrrutilo, com média de $805,4{ }^{\circ} \mathrm{C}$ contra $765,4{ }^{\circ} \mathrm{C}$, respectivamente, mostrando talvez a maior capacidade de retenção do elemento em questão durante exumação por parte do quartzo. A 
partir dos cálculos das médias dos maiores teores encontrados para cada mineral (faixas demarcadas na Figura 63a e Figura 64a) obtêm-se temperaturas de $820 \pm 30$ e $837 \pm 20^{\circ} \mathrm{C}$ para o pico metamórfico, nos termômetros de rutilo e quartzo, respectivamente.

Para os cálculos pareados, a projeção dos pares no diagrama $P-T$ apresenta correlação que sugere exumação das rochas com diminuição conjunta de temperatura e pressão em trajetória horária e estágio de descompressão isotermal. Não há distinção entre os resultados de pares de diferentes localizações, distribuindo-se ao longo de uma linha (Figura 65). Este fato pode ser verificado pelos valores médios bastante semelhantes: temperaturas entre $754,7^{\circ} \mathrm{C}$ e $776,5^{\circ} \mathrm{C}$ e pressões de $12,8 \mathrm{kbar}$ a $14,4 \mathrm{kbar}$. Ao utilizar os maiores teores encontrados nos dois minerais, 1518 ppm de $\mathrm{Zr}$ no rutilo e 72 ppm de Ti no quartzo, independente das amostras em que se encontram, são obtidas condições de 825,2 ${ }^{\circ} \mathrm{C}$ e 14,8 kbar.

Os maiores valores de pressão calculados, acima dos $20 \mathrm{kbar}$, possivelmente são superestimados. Na Figura 69, por exemplo, é ilustrado o resultado de grãos de quartzo e rutilo analisados dentro de porfiroblasto de granada. O par quartzo-rutilo (Q7-R7) é responsável por fornecer condições de $837^{\circ} \mathrm{C}$ e $21,4 \mathrm{kbar}$. O fator determinante para tamanha pressão é o baixo teor de Ti no quartzo (23 ppm). O mesmo cristal de quartzo, policristalino, foi analisado em outros dois locais, região superior da imagem, e apresenta em ambas as análises teores na ordem de 68 ppm, indicando assim possível obliteração do conteúdo de Ti na análise utilizada para o cálculo, talvez relacionada ao grande fraturamento na região ou pelo contato com o cristal de rutilo. Vale ressaltar que, nesse mesmo porfiroblasto de granada, apenas essa análise de quartzo apresenta teor abaixo de 30 ppm, sendo o restante bastante superior, com média de 54,9 ppm em 24 análises e valores que chegam a 72 ppm, o maior encontrado entre todas as amostras. 


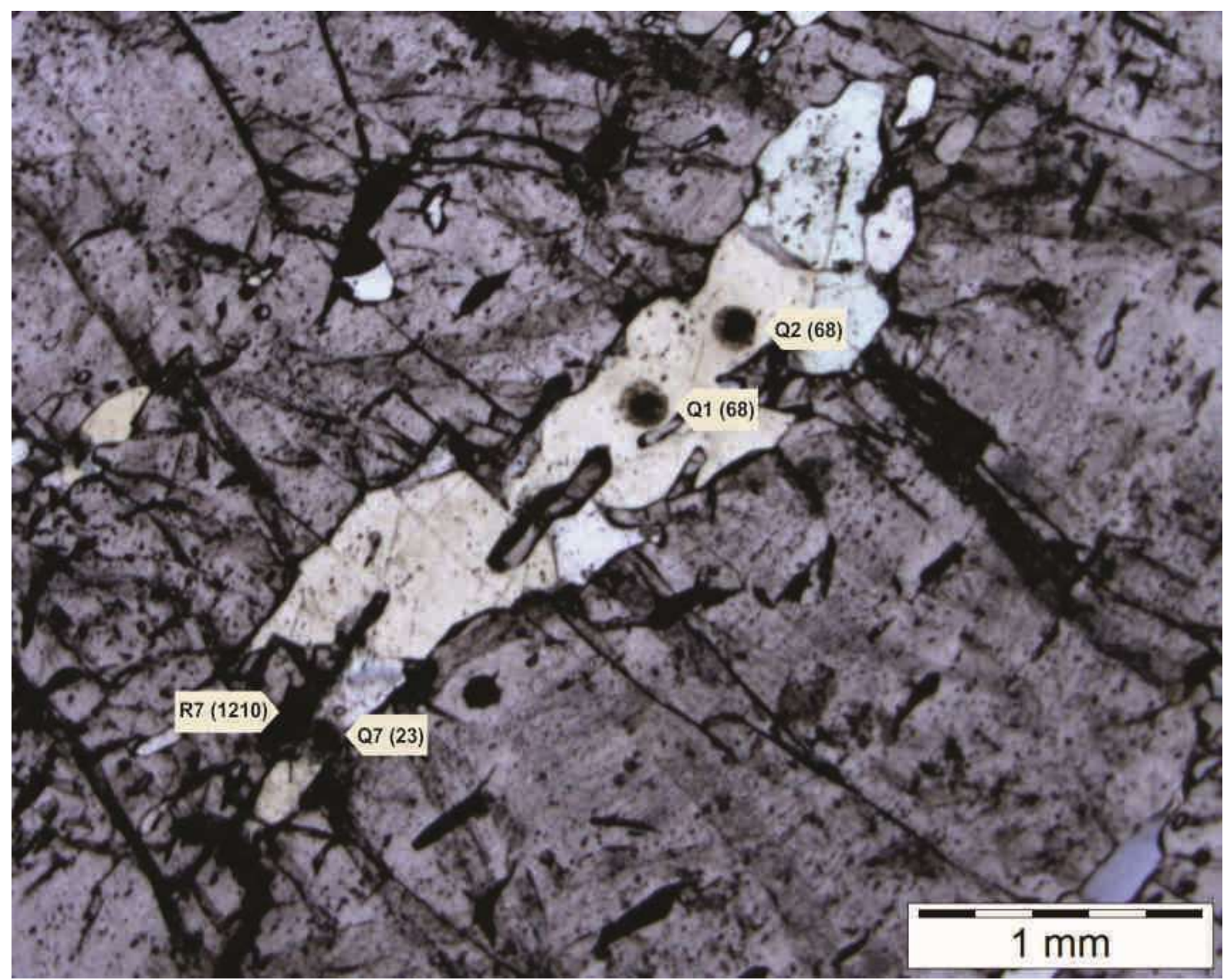

Figura 69. Fotomicrografia. Amostra TPR-01-ZF3. Porfiroblasto de granada rico em inclusões de quartzo e rutilo. Notação utilizada: Q7 = identificação da análise de quartzo; (23) = teor de Ti. O mesmo padrão de notação foi utilizado nas análises de rutilo. Feições arredondadas nas áreas sinalizadas são os locais analisados por laser. Polarizador inferior.

A partir dos dados apresentados na Figura 65, e dos discutidos acima, é possível sugerir para o pico metamórfico valores na ordem de 805 a $845^{\circ} \mathrm{C}$ e 15,7 a $18,6 \mathrm{kbar}$. Em todos os resultados aqui apresentados é possível afirmar que essas rochas alcançaram condições de fácies eclogito. Ao comparar todos os resultados apresentados até aqui, da geotermobarometria convencional e de Ti-quartzo e Zr-rutilo, é possível observar boa concordância nos valores $P$-T. O mesmo ocorre com a pseudosseção 1. Nela, a paragênese existente nas rochas metapelíticas da Nappe Três Pontas-Varginha é representada pelo campo pentavariante, liq-kfs-ky-grt-rt-ilm-qtz, entre $830-1000^{\circ} \mathrm{C}$ e acima de $10,6 \mathrm{kbar}$, com proporção de fusão parcial entre $>20 \%$ e $40 \%$. Provavelmente as rochas desse estudo encontram-se próximas aos maiores valores de pressão dessa janela, acima das temperaturas de quebra do plagioclásio, mineral limitante no processo de fusão parcial e não encontrado nas porções residuais. Ao localizar as condições de $850-876{ }^{\circ} \mathrm{C}$ no respectivo campo, é possível sugerir proporção de fusão parcial em torno dos $25 \%$, contudo, observações de campo, como grandes leitos de leucossoma e de melanossoma, este 
constituído por granada + cianita + rutilo, indicam proporções maiores de fusão parcial, superiores aos modelados na pseudosseção, em torno dos 35 - 40\%. Assim, é possível que a quantidade de água utilizada nos cálculos tenha sido subestimada ou que a composição da rocha fosse mais fértil que a do filito utilizado.

\subsection{Nappe Socorro-Guaxupé}

O granulito félsico, representativo da unidade basal da Nappe Socorro-Guaxupé, teve suas condições $P$-T estudadas com conhecidos e amplamente utilizados geotermobarômetros convencionais, e pelos métodos otimizados e menos usuais. Os valores de temperatura, a 12 kbar, obtidos com o geotermômetro granada-clinopiroxênio de Ellis \& Green (1979) e granadaortopiroxênio de Harley (1984) apresentam boa homogeneidade, com valores médios próximos, por volta dos $855^{\circ} \mathrm{C}$, e máximos provavelmente relacionados ao pico metamórfico entre 891,17 e $897,73^{\circ} \mathrm{C}$, respectivamente. Pressões entre 12 e $13 \mathrm{kbar}$ foram produzidas pelo barômetro GADS de Eckert et al. (1991) e GAPES de Newton \& Perkins (1982), Perkins \& Chipera (1985) e Eckert et al. (1991). Valores acima de 13 kbar na primeira e terceira calibração referida do GAPES, e abaixo de 12 kbar na segunda, ao considerar as respectivas incertezas podem ser considerados no intervalo citado anteriormente. O geobarômetro de Paria et al. (1988) apresenta boa consistência, com resultados na ordem de 12,5 kbar, no mesmo intervalo dos demais.

A geotermobarometria otimizada com o método de Pattison et al. (2003), que tenta corrigir as composições de granada e ortopiroxênio para as existentes no auge do metamorfismo, apresenta resultados curiosos, com os valores corrigidos inferiores aos iniciais, em até mais de $100^{\circ} \mathrm{C}$. Esse fato andica que os cálculos de correção não conseguem reintegrar as composições químicas, pois não consideram as exsoluções ricas em cálcio abundantes no ortopiroxênio. Assim, da mesma maneira que os autores do método em todos os casos apenas consideram os maiores valores calculados, independente de corrigidos ou não, serão utilizados aqui os iniciais não corrigidos, que sugerem pico metamórfico em torno de $989{ }^{\circ} \mathrm{C}$ a 13,67 kbar, indicando que a unidade foi submetida a metamorfismo de temperatura ultra-alta, como definido por Harley (1998), com temperaturas superiores a 900 ${ }^{\circ} \mathrm{C}$, e verificado em regiões próximas em trabalhos anteriores (Del Lama et al. 1994; Silva 2013). Os resultados obtidos com o THERMOCALC são concordantes com todos os apresentados até aqui, com valores para pico na ordem de $948{ }^{\circ} \mathrm{C}$ a $11,87 \mathrm{kbar}$. Nesse método, as condições $P$-T foram calculadas de maneira separada e conjunta. Em ambas condições os resultados são coerentes, entre si com alta correlação, e com os demais. Assim, optou-se por utilizar os calculados pela primeira forma pois apresentam incertezas inferiores às da segunda opção. 
Os maiores valores de temperatura produzidos com os métodos convencionais são no mínimo $50{ }^{\circ} \mathrm{C}$ inferiores aos dos otimizados, fato consistente com a observação feita por Harley (1984) de que seus resultados são inferiores em relação aos outros métodos de forma recorrente (e.g. Ellis \& Green 1979; neste caso, semelhantes) em até $50{ }^{\circ} \mathrm{C}$. As pressões calculadas variam desde $11 \mathrm{kbar}$ a superiores a $14 \mathrm{kbar}$, porém é possível considerar tais rochas nos valores intermediários entre 12 e 13 kbar devido à maior consistência desses resultados. 


\section{CONCLUSÕES}

Com base nos métodos geotermobarométricos convencionais utilizados nas rochas calciossilicáticas, e os alternativos, Zr-rutilo e Ti-quartzo, no granulito metapelítico, e pelas pseudosseções da Nappe Três Pontas-Varginha, podem ser indicadas para o pico metamórfico temperaturas de pelo menos $850^{\circ} \mathrm{C}$ a pressões em torno de $15 \mathrm{kbar}$, condições condizentes com a literatura (e.g. Campos Neto \& Caby 2000, Garcia \& Campos Neto 2003, Reno et al. 2009).

Para o granulito félsico basal da Nappe Socorro-Guaxupé são indicadas condições de temperaturas ultra-altas, salvo pelo uso dos métodos convencionais com temperaturas próximas ao valor mínimo de $900{ }^{\circ} \mathrm{C}$, os métodos otimizados produziram valores de pico de pelo menos $950{ }^{\circ} \mathrm{C}$. As pressões encontradas são predominantemente inferiores às determinadas para a unidade inferior, sempre girando em torno de 12 e $13 \mathrm{kbar}$. Tais condições P-T são condizentes com a literatura (e.g. Del Lama et al. 1994; Silva 2013).

O uso de pseudosseções como método geotermobarométrico se mostra bastante útil e preciso, inclusive para rochas da fácies granulito, recorrentemente relacionadas à altas proporções de material fundido, nas quais a determinação de composições de protolito pode se tornar inviável. Deve-se haver critério rigoroso na escolha da proporção de água e da composição inicial, afim de se obter mínima precisão nos cálculos, tanto das associações minerais em equilíbrio como das proporções de líquido produzido durante o evento de metamorfismo e fusão parcial.

Os métodos otimizados THERMOCALC E RCLC apresentam resultados mais homogêneos e precisos, quando comparados com outras calibrações disponíveis, principalmente no primeiro, com utilização de um conjunto de reações linearmente independentes, que difere dos métodos convencionais, os quais utilizam uma única reação, como a troca Fe-Mg entre granada e clinopiroxênio de Ellis \& Green (1979).

Os métodos alternativos e as calibrações recentes dos geotermômetros Zr-rutilo e Tiquartzo apresentam bons resultados e se colocam como métodos investigativos precisos para rochas de fácies granulito. Quando utilizados em parceria podem fornecer resultados completos com temperatura e pressão (Thomas et al. 2010). O lado positivo desses métodos, além de apresentarem boas precisões nos resultados, é que dependem de análise química de apenas uma fase mineral em cada caso, desde que haja equilíbrio quartzo-rutilo-zircão na rocha, e não de uma associação mineral. Fatores que podem dificultar o uso do método são a aparelhagem utilizada nas análises químicas, preferencialmente $L A-I C P-M S$ devido ao 
menor limite de detecção necessário pelas baixas proporções dos elementos analisados, na ordem de ppm, e a mobilização tardia de Zr e Ti durante o resfriamento com cristalização de zircão e rutilo.

A partir dos resultados apresentados nesse trabalho é possível concluir:

- As rochas da Nappe Socorro-Guaxupé são mais quentes (UHT) que as da Nappe Três Pontas-Varginha, inferior, e sofreram metamorfismo em profundidades menores na crosta continental.

- A unidade dos metapelitos, com pressões na ordem de 15 kbar, foi metamorfizado em grandes profundidades, entre 10 e $12 \mathrm{~km}$ ( $\sim 3 \mathrm{kbar})$, abaixo da unidade superior.

- Além das condições P-T bastante distintas em ambas unidades, critérios petrográficos e composicionais corroboram a teoria de geração em diferentes níveis crustais.

Assim, todos os fatos listados acima, aliados às características estruturais como lineações minerais orientadas W-SW, levam à ideia de grande transporte tectônico por meio de nappes, defendida em diversos trabalhos (e.g. Campos Neto \& Caby 1999, 2000, Campos Neto 2004, Garcia \& Campos Neto 2003), com cavalgamento da unidade Socorro-Guaxupé, mais quente, sobre a unidade Três Pontas-Varginha, mais profunda, em ambiente tectônico em que grande aporte de calor foi envolvido durante o metamorfismo regional. 


\section{REFERÊNCIAS BIBLIOGRÁFICAS}

Ai Y. 1994. A revision of the garnet-clinopyroxene $\mathrm{Fe}^{2+}-\mathrm{Mg}$ exchange geothermometer. Contribution to Mineralogy and Petrolology, 115, 467-473.

Alkmim F. F., Marshak S., Pedrosa-Soares A. C., Peres G. G., Cruz S. C. P. \& Whittington A. 2006. Kinematic evolution of the Araçuai-West Congo orogen in Brazil and Africa: Nutcracker tectonics during the Neoproterozoic assembly of Gondwana. Precambrian Research, 149, 43-64.

Almeida F. F. M. de., Hasui Y., Brito Neves B. B. de., Fuck R. A. 1981. Brazilian structural provinces: an introduction. Earth-Science Reviews, 17, 1-21.

Aranovich L. Ya. \& Berman R. G. 1997. A new garnet-orthopyroxene thermometer based on reversed $\mathrm{Al} 2 \mathrm{O} 3$ solubility in $\mathrm{FeO}-\mathrm{Ale2O} 3-\mathrm{SiO} 2$ orthopyroxene. American Mineralogist, 82, 345-353.

Banno S. 1970. Classification of eclogites in terms of their physical conditions of origin. Phys. Earth Planet. Inter. 3, 405-421

Bea F. 1996. Residence of REE, Y, Th and U in Granites and Crustal Protoliths; Implications for the Chemistry of Crustal Melts. Journal of Petrology, 37(3), 521-552.

Bégin, N. J. \& Pattison D. R. M. 1994. Metamorphic evolution of granulites in the Minto Block, northern Quebec: extraction of peak P-T conditions taking account of late $\mathrm{Fe}-\mathrm{Mg}$ exchange. Journal of Metamorphic Geology, 12, 411-428.

Berman, R.G. 1988. Internally-consistent thermodynamic data for minerals in the system $\mathrm{Na}_{2} \mathrm{O}-\mathrm{K}_{2} \mathrm{O}-\mathrm{CaO}-\mathrm{MgO}-\mathrm{FeO}-\mathrm{Fe}_{2} \mathrm{O}_{3}-\mathrm{Al}_{2} \mathrm{O}_{3}-\mathrm{SiO}_{2}-\mathrm{TiO}_{2}-\mathrm{H}_{2} \mathrm{O}-\mathrm{CO}_{2}$. Journal of Petrology, 29, 445-522.

Berman R. G. 1991. Thermobarometry using multi-equilibrium calculations: a new technique, with petrological applications. Canadian Mineralogist, 29, 833-855.

Berman R. G. \& Aranovich L. Y. 1996. Optimized standard state and mixing properties of minerals: I. Model calibration for olivine, orthopyroxene, cordierite, garnet and ilmenite in the system FeO-MgO-CaO- $\mathrm{Al}_{2} \mathrm{SiO}_{3}-\mathrm{SiO}_{2}-\mathrm{TiO}_{2}$. Contributions to Mineralogy and Petrology, 126, 1-24.

Berman R. G. Aranovich L. Ya, Pattison D. R. M. 1995. Reassessment of the garnetclinopyroxene Fe-Mg exchange thermometer: II. Thermodynamic analysis. Contribution to Mineralogy and Petrolology, 119, 30-42.

Bohlen S. R. \& Liotta J. J. 1986 A barometer for garnet amphibolites and garnet granulites. Journal of Petrology, 27, 1025-1034.

Bohlen S. R., Wall V. J., Boettcher A. L. 1983. Experimental investigations and geological applications of equilibria in the system $\mathrm{FeO}-\mathrm{TiO}_{2}-\mathrm{Al}_{2} \mathrm{O}_{3}-\mathrm{SiO}_{2}-\mathrm{H}_{2} \mathrm{O}$. American Mineralogist, 68, 1049-1058.

Burnham, C. W. 1979. The importance of volatile constituents. In: The Evolution of the Igneous Rock - Fiftieth Anniversary Perspectives. Princeton University Press, Princeton, NY. 439482. 
Campos Neto M. C. \& Caby R. 1999. Tectonic constrain on Neoproterozoic high-pressure metamorphism and nappe system south of São Francisco craton, southeast Brazil. Precambrian Research, 97, 3-26.

Campos Neto M. C. \& Caby R. 2000. Lower crust extrusion and terrane accretion in the Neoproterozoic nappes of southeast Brazil. Tectonics, 19, 669-687.

Carswell D. A. \& Harley S. L. 1990. Mineral barometry and thermometry. In Carswell, D.A. (Ed) Eclogite Facies Rocks. Chapman \& Hall, New York, 82-110.

Cherniak D. J., Watson E. B., Wark D. A. 2007. Ti diffusion in quartz. Chemical Geology, 236, 65-74.

Coleman R. G., Lee D. E., Beany L. B., Brannock W.W. 1965. Eclogites and eclogites: their differences and similarities. Geology Society American Bulletin 76, 483-504.

Costa L. A. M. \& Angeiras A. G. 1971. Geosynclinal Evolution in the Epi-Baikalian Plataform of Central Brazil: Geologische Rundschau, 60(2), 1024-1050

Dardenne M. A. 2000. The Brasilia Fold Belt. In. Cordani U. G., Milani E. J., Thomaz Filho A., Campos D. A. (Eds.). Tectonic Evolution of South America. 31 $1^{\text {st }}$ International Geology Congress, Rio de Janeiro, p. 231-263.

Deer W. A., Howie R. A., Zussman J. 1982. Rock-forming minerals. Longman Group Limited, London.

Degeling H. S. 2003. Zr equilibria in metamorphic rocks. Unpublished PhD Thesis, Australian National University, 231p.

Delgado I. M., Souza J. D., Silva L. C., Silveira Filho N. C., Santos R. G., Pedreira A. J., Guimarães J. T., Angelim L. A. A., Vasconcelos A. M., Gomes I. P., Lacerda Filho J. V., Valente C. R., Perrota M. M., Heineck C. A. 2003. Geotectônica do Escudo Atlântico. In.: Bizzi L. A., Schobbenhaus C., Vidotti R. M., Golçalves J. H. (Eds.). Geologia, tectônica e recursos minerais do Brasil: texto, mapas \& SIG. CPRM, p. 227-334.

Del Lama E. A., Oliveira M. A. F., Zanardo A. 1994. Geotermobarometria em rochas do Complexo Campos Gerais ao norte da zona de cisalhamento Varginha. Revista Brasileira de Geociências, 24, 233-239.

Dodson M. H. 1973. Closure temperature in cooling geochronological and petrological systems. Contributions in Mineralogy and Petrology, 40, 259-274.

Ebert H. 1956. Relatório Anual do Diretor (DGM/DNPM). Relatório Anual DGM/DNPM, Ano de 1955:62-81.

Ebert H. 1984. Os Paraibides entre São Joao del Rei e Itapira e a bifurcação entre Paraibides e Araxaídes. Publicação Especial SBG, 12, 72-103.

Ebert H. D., Chemale jr. F., Babinsky M., Artur A. C., van Schmus W. R. 1996. Tectonic setting and $\mathrm{U} / \mathrm{Pb}$ zircon dating of the plutonic Socorro Complex in the Transpressive Rio Paraíba do Sul Shear Belt, SE Brazil. Tectonics, 15(3), 688-699.

Eckert J. O., Newton R. C., Kleppa O. J. 1991. The $\Delta H$ of reaction and recalibration of garnetpyroxene-plagioclase-quartz geobarometers in the CMAS system by solution calorimetry. American Mineralogist, 76, 148-160. 
Ellis D. J. \& Green D. H. 1979. An experimental study of the effect of Ca upon garnetclinopyroxene Fe-Mg exchange equilibria. Contributions to Mineralogy and Petrology, 71, 13-22.

Essene E. J. 1982. Geologic thermometry and barometry. In: FERRY, J. M. (ed.) Characterization of Metamorphism Through Mineral Equilibria, Reviews in Mineralogy, Mineralogical Society of America, 10, 153-206.

Ewing T. A., Hermann J., Rubatto D. 2012. The robustness of the Zr-in-rutile and Ti-in-zircon thermometers during high-temperature metamorphism (Ivrea-Verbano Zone, northern Italy). Contributions in Mineralogy and Petrology, 165,757-779.

Ferris E. D. A., Essene E. J., Becker U. 2008. Computational study of the effect of pressure on the Ti-in-zircon geothermometer. European Journal of Mineralogy, 20, 745-755.

Ferry J. M. \& Spear F. S. 1978. Experimental Calibration of the Partitioning of $\mathrm{Fe}$ and $\mathrm{Mg}$ Between Biotite and Garnet. Contributions in Mineralogy and Petrology, 66, 113-117.

Ferry J. M. \& Watson E. B. 2007. New thermodynamic models and revised calibrations for the Ti-in-zircon and Zr-in-rutile thermometers. Contributions in Mineralogy and Petrology, 154, 429-437.

Fuck R. A. 1994. A Faixa Brasília e a compartimentação tectônica na Província Tocantins. In. SBG, Simpósio de Geologia do Centro-Oeste, 4, Brasília, 1994. Atas..., Brasília, p. 184187.

Ganguly J. \& Saxena S. K. 1984. Mixing properties of aluminosilicate garnets: constraints from natural and experimental data, and applications to geothermobarometry. American Mineralogist, 69, 88-97.

Garcia M. G. M. 2001. Associações metamórficas de alta pressão: Nappes Neoproterozóicas a sul do Cráton São Francisco. Tese de Doutoramento. Instituto de Geociências, Universidade de São Paulo, 199p.

Garcia M. G. M. \& Campos Neto M. C. 2003. Contrasting metamorphic conditions in the Neoproterozoic collision-related nappes, south of São Francisco Craton, SE Brazil. Journal of South American Earth Sciences, 15(8), 853-870.

Ghent E. D. 1976. Plagioclase-garnet- $\mathrm{Al}_{2} \mathrm{SiO}_{5}$-quartz: a potencial geobarometergeothermometer. American Mineralogist, 61, 700-714.

Ghent E. D. \& Stout M. Z. 1984. $\mathrm{TiO}_{2}$ activity in metamorphosed politic and basic rocks principles and applications to metamorphism in southeastern Canadian cordillera. Contributions in Mineralogy and Petrology, 86, 248-255.

Harley S. L. 1984. An experimental study of the partitioning of $\mathrm{Fe}$ and $\mathrm{Mg}$ between garnet and orthopyroxene. Contributions to Mineralogy and Petrology, 86, 359-373.

Harley S. L 1989. The origins of granulites: a metamorphic perspective. Geological Magazine, 126(3), 215-247.

Heilbron M. \& Machado N. 2003. Timing of terrane accretion in the NeoproterozoicEopaleozoic Ribeira orogen (SE Brazil). Precambrian Research, 125, 87-112. 
Heilbron M., Valeriano C. M., Tassinari C. C. G., Almeida J. C. H., Tupinamba M., Siga O., Trouw R.A.J. 2008. Correlation of Neoproterozoic terranes between the Ribeira Belt, SE Brazil and its African counterpart: comparative tectonic evolution and open questions. In: Pankhurst R. J., Trouw R. A. J., Brito Neves B. B. de, de Wit M. J. (eds) West Gondwana: Pre-Cenozoic Correlations Across the South Atlantic Region. Geological Society, London. Special Publications, 294, 211-238.

Helgeson H. C., Delany J. M., Nesbitt H. W., Bird D. K. 1978. Summary and critiquee of the thermodynamic properties of rock-forming minerals. American Journal of Science. 278A, $1-229$.

Holland T. J. B. \& Powell R. 1985. An internally consistent thermodynamic dataset with uncertainties and correlations: 2. Data and results. Journal of Metamorphic Geology, 3, 343-370.

Holland T. J. B. \& Powell R. 2011. An improved and extended internally consistent thermodynamic dataset for phases of petrological interest, involving a new equation of state for solids. Journal of Metamorphic Geology 29, 333-383.

Holtz F. \& Johannes W. 1994. Maximum and minimum water contents of granitic melts: implications for chemical and physical properties of ascending magmas. Lithos, 32, 149159.

Indares A. \& Martignole J. 1985. Biotite-garnet geothermometry in the granulite facies: the influence of Ti and Al in biotite. American Mineralory, 70, 272-278.

Jamieson R. A., Beaumont C., Medvedev S. \& Nguyen M. H. 2004. Crustal channel flows: 2. Numerical models with implications for metamorphism in the Himalayan-Tibetan orogen. Journal of Geophysical Research, 109, B06407, 24p.

Janasi V. A. 1999. Petrogênese de granitos crustais na Nappe de Empurrão Socorro Guaxupé (SP-MG): uma contribuição da geoquímica elemental e isotópica. Tese de Livre Docência, IG/USP, 200p.

Kohn M. J. \& Spear F. 2000. Retrograde net transfer reaction insurance for pressuretemperature estimates. Geology. December 2000, 28 (12); 1127-1130.

Krogh E. J. 1988. The garnet-clinopyroxene Fe-Mg geothermometer - a reinterpretation of existing experimental data. Contribution to Mineralogy and Petrology, 99, 44-48.

Levien L., Prewitt C. T., Weidner D. J. 1980. Structure and elastic properties of quartz at pressure. American Mineralogy, 65, 920-930.

Lovering J. F. \& White A. J. R. 1969. Granulitic and eclogitic inclusions in basic pipes at Delegate, Australia. Journal of Petrology, 21, 9-52.

Machado N., Valladares C., Heilbron M., Valeriano C. 1996. U-Pb geochronology of the central Ribeira belt (Brazil) and implications for the evolution of the Brazilian Orogeny. Precambrian Research, 79, 347-361.

Maciel R. R. 1986. Mapeamento geológico-estrutural de uma área a leste da cidade de Três Pontas, MG. Dissertação de Mestrado. Instituto de Geociências. Universidade Federal do Rio de Janeiro. Rio de Janeiro. 102p. 
Manchester J. E., Cherniak D. J., Watson E. B. 2007. Diffusion of Zr and Hf in rutile. Earth and Planetary Science Letters, 261, 267-279.

Marini O. J., Fuck R. A., Danni J. C., Dardenne M. A. 1981. A evolução geotectônica da Faixa Brasília e do seu embasamento. In. Simpósio Sobre o Cráton do São Francisco e suas faixas marginais, 1, Salvador. Anais..., Salvador, p. 100-105.

McLennan S. M., Taylor S. R., McCulloch M. T., Maynard J. B. 1990. Geochemical and Nd$\mathrm{Sr}$ isotopic composition of deep-sea turbidites: crustal evolution and plate tectonic associations. Geochimica et Cosmochimica Acta , 54: 2015-2050.

Moraes R., Brown M., Fuck R. A., Camargo M. A. \& Lima T. M. 2002. Characterization and P$T$ evolution of melt-bearing ultrahigh-temperature granulites: an example from the Anápolis-Itauçu Complex of the Brasília Fold Belt, Brazil. Journal of Petrology, 43, 16731705.

Motta R. G. 2009. Evolução tectono-metamórfica do Domínio Serra da Natureza, Terreno Andrelândia, MG. Dissertação de Mestrado. Instituto de Geociências. Universidade de São Paulo. São Paulo. 158p.

Mysen B. \& Heier K. S. 1972. Petrogenesis of eclogites in high grade metamorphic gneisses exemplified by the Hareidland Eclogite, Western Norway. Contributions to Mineralogy and Petrology, 36, 73-94

Newton R. C. \& Perkins D. III. 1982. Thermodynamic calibration of geobarometers based on the assemblages garnet-plagioclase-orthopyroxene(clinopyroxene)-quartz. American Mineralogist, 67, 203-222.

Oliveira M. A. F. \& Ruberti E. 1979. Granada-cordierita gnaisses do Complexo GranulíticoMigmatítico São José do Rio Pardo, Caconde, SP: Indicações sobre pressão e temperatura de formação. Boletim Mineral, 6, 15-29.

van Orman J. A., Grove T. L., Shimizu N., Layne G. D. 2002. Rare earth element diffusion in a natural pyrope single crystal at 2.8 GPa. Contributions in Mineralogy and Petrology, 142, 416-424.

Ostapenko G. T., Tarashchan A. N., Mitsyuk B. M. 2007. Rutile-quartz geothermobarometer. Geochemistry International, 45, 506-508.

Paria P., Bhattacharya A., Sen S. K. 1988. The reaction garnet + clinopyroxene + quartz = 2 orthopyroxene + anorthite: A potential geobarometer for granulites. Contributions to Mineralogy and Petrology, 99, 126-133.

Pattison D. R. M. \& Newton R. C. 1989. Reversed experimental calibration of the garnetclinopyroxene Fe-Mg exchange thermometer. Contribution to Mineralogy and Petrolology, 101, 87-103.

Pattison D. R. M. \& Bégin N. J. 1994. Zoning patterns in orthopyroxene and garnet in granulites: implications for geothermometry. Journal of Metamorphic Geology, 12, 387410.

Pattison D. R. M., Chacko T., Farquhar J., McFarlane C. R. M. 2003. Temperatures of Granulite-facies Metamorphism: Constrains from Experimental Phase Equilibria and 
Thermobarometry Corrected for Retrograde Exchange. Journal of Petrology, 44(5), 867900 .

Pavan M. 2010. Modelamento metamórfico de rochas das fácies xisto-verde e anfibolito com o uso de pseudosseções: Exemplo das rochas da Klippe Carrancas, sul de Minas gerais. Dissertação de Mestrado. Instituto de Geociências. Universidade de São Paulo. 147p.

Perkins D. III \& Chipera S. J. 1985. Garnet-orthopyroxene-plagioclase-quartz barometry: refinement and application to the English River subprovince and the Minnesota River Valley. Contributions to Mineralogy and Petrology, 89, 69-80.

Peterson, J. W. \& Newton, R. C. 1990. Experimental biotite-quartz melting in the $\mathrm{KMASH}-\mathrm{CO}_{2}$ system and the role of $\mathrm{CO}_{2}$ in the petrogenesis of granites and related rocks. American Mineralogists, 75, 1029-1042.

Philpotts A. R. 1990. Principles of lgneous and Metamorphic Petrology. Prentice HII, Englewood Cliffs.

Philpotts A. R. \& Ague J. J. 2009. Principles of Igneous and Metamorphic Petrology, $2^{\text {nd }}$ Ed., Cambridge University Press, 667p.

Pimentel M. M., Fuck R. A., Jost H., Ferreira-Filho C. F., Araújo S. M. 2000. The Basement of the Brasilia Belt and the Goias Magmatic Arc. In. Cordani U. G., Milani E. J., Thomaz Filho A., Campos D. A. (Eds.). Tectonic Evolution of South America. $31^{\text {st }}$ International Geology Congress, Rio de Janeiro, p. 195-229.

Powell R. 1985. Regression diagnostics and robust regression in geothermometer/geobarometer calibration: the garnet-clinopyroxene geothermometer revisited. Journal of Metamorphic Geology, 3, 231-243.

Powell R. \& Holland T. J. B. 1994. Optimal geothermometry and geobarometry. American Mineralogist, 79, 120-133.

Powell R., Holland T. J. B., Worley B. 1998. Calculating phase diagrams involving solid solutions via non-linear equations, with examples using THERMOCALC. Journal of Metamorphic Geology. 16, 577-588.

Powell R., Guiraud M. \& White R. W. 2005. Truth and beauty in metamorphic phase equilibria: Conjugate variables and phase diagrams. The Canadian Mineralogist, 43, 21-33.

Pyle J. M. \& Spear F. S. 2000. An empirical garnet (YAG)-xenotime thermometer. Contributions to Mineralogy and Petrology, 138, 51-58.

Pyle J. M., Spear, F. S., Rudnick, R. L. \& McDonough, W. F. 2001. Monazite-xenotime-Garnet equilibrium in metapelites and a new monazite-garnet thermometer. Journal of Petrology, 11, 2083-2107.

Raheim A. \& Green D. H. 1974. Experimental determination of the temperature and pressure dependence of the Fe--Mg partition coefficient for coexisting clinopyroxene and garnet. Contributions to Mineralogy and Petrology, 48, 179-203.

Ravna E. K. 2000. The garnet-clinopyroxene Fe2+-Mg geothermometer: an updated calibration. Journal of Metamorphic Geology, 18, 211-219. 
Reno B. L., Brown M., Kobayashi K., Nakamura E., Piccoli P. M., Trouw R. A. J. 2009. Eclogitehigh-pressure granulite metamorphism records early collision in West Gondwana: new data from the Southern Brasilia Belt, Brazil. Journal of the Geological Society, London, 166, 1013-1032.

Sandiford M. \& Powell R. 1986. Deep crustal metamorphism during continental extension; modern and ancient examples. Earth and Planetary Science Letters, 79(1-2), 151-158.

Saunders A. D., Tarney J., Weaver S. D. 1980. Transverse geochemical variations across the Antarctic Peninsula: implications for the genesis of calc-alkaline magmas. Earth Planet Science Letture, 46, 344-360.

Sawyer E. W. 2008. Working with migmatites: Nomenclature for the constituent parts, Short Course Ser. Mineral. Assoc. Canada, Quebec City, Quebec, Canada. 38, 1-28.

Saxena S. K.\& Erikson G. 1983. Theoretical computation of mineral assemblages in pyrolite and Iherzolite. Journal of Petrology, 24, 538-555.

Schmitt R. S., Trouw R. A. J., Van Schmus W. R. 1999. The characterisation of a Cambrian ( 520 Ma) tectonometamorphic event in the Coastal domain using U/Pb in syntectonics veins. In: SEGEMAR, South America Symposium on Isotope Geology, 2, 1999, Cordoba, Argentina. Atas..., 363-366.

Schmitt R. S., Trouw R. A. J., Van Schmus W. R., Pimentel M. M. 2004. Late amalgamation in the central part of Western Gondwana: new geochronological data and the characterization of a Cambrian collision orogeny in the Ribeira belt (SE Brazil). Precambrian Research, 133, 29-61.

Schmitt R. D., Trouw R. A. J., Medeiros S. R. \& Dantas E. L. 2008. Age and geotectonic setting of Late Neoproterozoic juvenile mafic gneisses and associated paragneisses from the Ribeira belt (SE Brazil) based on geochemistry and $\mathrm{Sm}-\mathrm{Nd}$ data-Implications on Gondwana assembly. Gondwana Research, 13, 502-515.

Seer H. J. 1999. Evolução tectônica dos grupos Araxá, Ibiá e Canastra na sinforma de Araxá, Minas Gerais. Tese de Doutoramento. Brasília, IG-UnB, 267p.

Shannon R. D. 1976. Revised effective ionic radii and systematic studies of interatomic distances in halides and chalcogenides. Acta Crystallographica, A32, 751-767.

Silva B. Y. B. 2013. Termobarometria das rochas da Nappe Socorro-Guaxupé, na região de Varginha, MG. Monografia de Trabalho de Formatura. Instituo de Geociências da Universidade de São Paulo, 36p.

Spear F. S. 1993. Metamorphic Phase Equilibria and Pressure-Temperature-Time Paths. Mineralogical Society of America Monograph. Chelsea, Michigan. p 799.

Spear F. S. \& Florence F. P. 1992. Thermobarometry in Granulites: pitfalls and new approaches. Precambrian Research, 55, 209-241.

Thomas J. B., Spear F. S., Nayak S. K. 2010. TitaniQ under pressure: the effect of pressure and temperature on the solubility of Ti in quartz. Contribution to Mineral Petrology, 160, 743-759. 
Thompson A. B., Schulmann K., Jezek J. 1997. Thermal Evolution and exhumation in obliquely convergent (transpressive) orogens. Tectonophysics, 280, 171-184.

Tomkins H. S., Powell R., Ellis D. J. 2007. The pressure dependence of the zirconium-in-rutile thermometer. Accepted by Journal of Metamorphic Geology, 25(6), 703-713.

Triebold S., von Eynatten H., Luvizotto G. L., Zack T. 2007. Deducing source rock lithology from detrital rutile geochemistry: an example from the Erzgebirge, Germany. Chemical Geology, 244(3-4), 421-436.

Trouw R. A. J., Ribeiro A., Paciullo F. V. P. 1986. Contribuição à geologia da Folha Barbacena 1:250.000. In: Congresso Brasileiro de Geologia, 34, Goiânia, 1986. Anais..., SBG/Núcleo Centro-Oeste, 2, 974-984.

Trouw R. A. J. \& Castro E. M. 1996. O significado tectônico dos granulitos brasilianos de alta pressão no Sul de Minas Gerais. XXIX Congresso Brasileiro de Geologia, Salvador, 6, 14-151.

Trouw R. A. J., Moraes R., Reno B. L., Brown M. 2006. The high-pressure granulites of the Andrelândia nappe complex, Minas Gerais, Brazil. Guia de Excursão Pré-conferência Granulites \& Granulites 2006. 45pp.

Trouw R. A. J., Ribeiro A., Paciullo F., Heilbron M. 2000. Interference between the Neoproterozoic Brasília and Ribeira Belts, with special emphasis on high pressure granulites. 31st International Geological Congress. Field Trip Guide. Rio de Janeiro, Brazil. p. 45.

USGS. 1996. Microbeam standard Columbia River basalt (Glass) BCR-2G. United States Geological Survey, Special Bulletin (Reference Materials Project), Preliminary report, 10p

Valeriano C. M., Simões L. S. A., Teixeira W., Heilbron M. 2000. Southern Brasilia Belt (SE Brazil): tectonic discontinuities, K-Ar data and evolution during the Neoproterozoic Brasiliano Orogeny. Revista Brasileira de Geociências, 30, 195-199.

Valeriano C. M., Dardenne M. A., Fonseca M. A., Simões L. S. A., Seer H. J. 2004. A evolução tectônica da Faixa Brasília. In: Mantesso-Neto V., Bartorelli A., Carneiro C. D. R., BritoNeves B. B. de (Eds.) Geologia do Continente Sul-Americano: Evolução da Obra de Fernando Flávio Marques De Almeida, São Paulo, 575-592. Ed. Beca

Wark D. A. \& Watson E. B. 2006. TitaniQ: a titanium-in-quartz geothermometer. Contributions in Mineralogy and Petrology, 152, 743-754.

Watson E. B., Wark, D. A., Thomas J. B. 2006. Crystallization thermometers for zircon and rutile. Contributions in Mineralogy and Petrology, 151, 413-433.

White R. W. \& Powell R. 2002. Melt loss and the preservation of granulite facies mineral assemblages. Journal of Metamorphic Geology, 20, 621-632.

White R. W. \& Powell R. 2010. Retrograde melt-residue interaction and the formation of nearanhydrous leucosomes in migmatites, Journal of Metamorphic Geology, 28, 579-597.

White R. W., Powell R., Holland T. J. B. 2007. Progress relating to calculation of partial melting equilibria for metapelites. Journal of Metamorphic Geology, 25, 511-527. 
Wood B. J. \& Banno S. 1973. Garnet-orthopyroxene and orthopyroxene-clinopyroxene relationships in simple and complex systems. Contribution to Mineralogy and Petrology 42:109-124.

Zack T., Moraes R., Kronz A. 2004a. Temperature dependence of $\mathrm{Zr}$ in rutile: empirical calibration of a rutile thermometer. Contributions in Mineralogy and Petrology, 148, 471488.

Zack T., von Eynatten H., Kronz A. 2004b. Rutile geochemistry and its potential use in quatitative provenance studies. Sediment Geology, 171(1-4), 37-58.

Zack T., Luvizotto G. L., Moraes R., Möller A., Kronz A. 2006. Rutile and Zircon Thermometry of Granulites: Premetamorphic Relicts, Prograde Growth, Disequilibrium and Diffusional Resetting. In Brown \& Piccoli (Eds.) Granulites \& Granulites 2006, Abstracts and Program. Universidade de Brasília, Brasília, Brasil. 98. 


\section{APÊNDICES}

Apêndice 1 - Mapa e perfil geológico e mapa de pontos

Apêndice 2 - Tabelas de análises químicas e fórmulas estruturais de granada, clinopiroxênio, ortopiroxênio e plagioclásio, e Geotermometria Zr-rutilo e Ti-quartzo. 


\section{APÊNDICE 1}

MAPA E PERFIL GEOLÓGICO E MAPA DE PONTOS 



APÊNDICE 2

QUÍMICA MINERAL E GEOTERMOMETRIA ZR-RUTILO E TI-QUARTZO 



\section{APÊNDICE 2}

Tabela 1 - Análises químicas de granada da Nappe Três Pontas-Varginha

\begin{tabular}{|c|c|c|c|c|c|c|c|c|c|c|c|c|}
\hline \multicolumn{13}{|c|}{ TPR-01-C } \\
\hline Grão-Análise & grt1-1 & grt1-2 & grt1-3 & grt1-4 & grt 1-5 & grt1-6 & grt1-7 & grt1-8 & grt1-9 & grt1-10 & grt1-11 & grt1-12 \\
\hline $\mathrm{SiO}_{2}$ & 39,42 & 39,13 & 39,37 & 39,45 & 38,75 & 39,17 & 39,07 & 39,04 & 38,69 & 39,21 & 39,01 & 39,61 \\
\hline $\mathrm{TiO}_{2}$ & 0,03 & 0,11 & 0,05 & 0,05 & 0,07 & 0,08 & 0,11 & 0,10 & 0,08 & 0,12 & 0,12 & 0,06 \\
\hline $\mathrm{Al}_{2} \mathrm{O}_{3}$ & 22,60 & 22,12 & 22,32 & 22,24 & 22,36 & 22,16 & 21,75 & 22,04 & 22,17 & 22,19 & 22,05 & 22,32 \\
\hline $\mathrm{Cr}_{2} \mathrm{O}_{3}$ & 0,04 & 0,02 & 0,03 & 0,01 & 0,03 & 0,01 & 0,04 & 0,00 & 0,08 & 0,05 & 0,02 & 0,00 \\
\hline $\mathrm{Fe}_{2} \mathrm{O}_{3}$ & 0,00 & 0,22 & 0,07 & 0,11 & 1,26 & 0,57 & 0,81 & 0,53 & 0,81 & 0,27 & 0,67 & 0,00 \\
\hline $\mathrm{FeO}$ & 24,06 & 23,27 & 22,97 & 22,93 & 21,98 & 22,43 & 22,31 & 22,26 & 21,99 & 22,83 & 22,58 & 23,46 \\
\hline $\mathrm{MnO}$ & 0,50 & 0,48 & 0,53 & 0,61 & 0,65 & 0,69 & 0,77 & 0,77 & 0,70 & 0,59 & 0,54 & 0,50 \\
\hline $\mathrm{MgO}$ & 6,22 & 6,65 & 6,55 & 6,49 & 6,08 & 5,79 & 5,54 & 5,63 & 5,77 & 6,37 & 6,68 & 6,60 \\
\hline $\mathrm{CaO}$ & 8,83 & 8,80 & 9,32 & 9,44 & 10,09 & 10,51 & 10,81 & 10,69 & 10,42 & 9,54 & 9,15 & 8,91 \\
\hline $\mathrm{Na}_{2} \mathrm{O}$ & 0,00 & 0,00 & 0,00 & 0,00 & 0,00 & 0,00 & 0,00 & 0,00 & 0,00 & 0,00 & 0,00 & 0,00 \\
\hline $\mathrm{K}_{2} \mathrm{O}$ & 0,00 & 0,00 & 0,00 & 0,00 & 0,00 & 0,00 & 0,00 & 0,00 & 0,00 & 0,00 & 0,00 & 0,00 \\
\hline Total & 101,70 & 100,80 & 101,20 & 101,33 & 101,26 & 101,40 & 101,20 & 101,06 & 100,72 & 101,17 & 100,83 & 101,46 \\
\hline Oxigênios & 12,00 & 12,00 & 12,00 & 12,00 & 12,00 & 12,00 & 12,00 & 12,00 & 12,00 & 12,00 & 12,00 & 12,00 \\
\hline $\mathrm{Si}$ & 2,991 & 2,990 & 2,994 & 2,998 & 2,954 & 2,984 & 2,989 & 2,985 & 2,967 & 2,987 & 2,980 & 3,004 \\
\hline $\mathrm{Ti}$ & 0,002 & 0,006 & 0,003 & 0,003 & 0,004 & 0,004 & 0,006 & 0,006 & 0,005 & 0,007 & 0,007 & 0,003 \\
\hline Al & 2,021 & 1,993 & 2,001 & 1,992 & 2,010 & 1,990 & 1,962 & 1,987 & 2,004 & 1,993 & 1,986 & 1,996 \\
\hline $\mathrm{Cr}$ & 0,002 & 0,001 & 0,002 & 0,000 & 0,002 & 0,000 & 0,002 & 0,000 & 0,005 & 0,003 & 0,001 & 0,000 \\
\hline $\mathrm{Fe}^{3+}$ & 0,000 & 0,013 & 0,004 & 0,006 & 0,072 & 0,033 & 0,046 & 0,030 & 0,047 & 0,016 & 0,039 & 0,000 \\
\hline $\mathrm{Fe}^{2+}$ & 1,527 & 1,488 & 1,461 & 1,458 & 1,401 & 1,429 & 1,428 & 1,424 & 1,410 & 1,454 & 1,443 & 1,488 \\
\hline $\mathrm{Mn}$ & 0,032 & 0,031 & 0,034 & 0,039 & 0,042 & 0,044 & 0,050 & 0,050 & 0,046 & 0,038 & 0,035 & 0,032 \\
\hline $\mathrm{Mg}$ & 0,703 & 0,757 & 0,742 & 0,735 & 0,691 & 0,657 & 0,632 & 0,642 & 0,659 & 0,723 & 0,761 & 0,746 \\
\hline $\mathrm{Ca}$ & 0,718 & 0,721 & 0,759 & 0,769 & 0,824 & 0,858 & 0,886 & 0,876 & 0,856 & 0,779 & 0,749 & 0,724 \\
\hline $\mathrm{Na}$ & 0,000 & 0,000 & 0,000 & 0,000 & 0,000 & 0,000 & 0,000 & 0,000 & 0,000 & 0,000 & 0,000 & 0,000 \\
\hline $\mathrm{K}$ & 0,000 & 0,000 & 0,000 & 0,000 & 0,000 & 0,000 & 0,000 & 0,000 & 0,000 & 0,000 & 0,000 & 0,000 \\
\hline Soma & 7,996 & 8,000 & 8,000 & 8,000 & 8,000 & 8,000 & 8,000 & 8,000 & 8,000 & 8,000 & 8,000 & 7,994 \\
\hline \multicolumn{13}{|l|}{ Membros-finais } \\
\hline Almandina & $51,24 \%$ & $49,65 \%$ & $48,77 \%$ & $48,58 \%$ & $47,36 \%$ & $47,82 \%$ & $47,66 \%$ & $47,59 \%$ & $47,46 \%$ & $48,56 \%$ & $48,29 \%$ & $49,77 \%$ \\
\hline Piropo & $23,59 \%$ & $25,26 \%$ & $24,77 \%$ & $24,49 \%$ & $23,36 \%$ & $21,99 \%$ & $21,09 \%$ & $21,46 \%$ & $22,18 \%$ & $24,15 \%$ & $25,47 \%$ & $24,95 \%$ \\
\hline Grossulária & $24,00 \%$ & $23,36 \%$ & $25,03 \%$ & $25,32 \%$ & $24,31 \%$ & $27,08 \%$ & $27,18 \%$ & $27,79 \%$ & $26,28 \%$ & $25,07 \%$ & $23,09 \%$ & $24,21 \%$ \\
\hline Espessartita & $1,07 \%$ & $1,03 \%$ & $1,13 \%$ & $1,30 \%$ & $1,42 \%$ & $1,47 \%$ & $1,67 \%$ & $1,67 \%$ & $1,55 \%$ & $1,27 \%$ & $1,17 \%$ & $1,07 \%$ \\
\hline Andradita & $0,00 \%$ & $0,65 \%$ & $0,20 \%$ & $0,30 \%$ & $3,45 \%$ & $1,63 \%$ & $2,29 \%$ & $1,49 \%$ & $2,29 \%$ & $0,80 \%$ & $1,92 \%$ & $0,00 \%$ \\
\hline Uvarovita & $0,10 \%$ & $0,05 \%$ & $0,10 \%$ & $0,00 \%$ & $0,10 \%$ & $0,00 \%$ & $0,10 \%$ & $0,00 \%$ & $0,24 \%$ & $0,15 \%$ & $0,05 \%$ & $0,00 \%$ \\
\hline
\end{tabular}


Tabela 2- Análises químicas de granada da Nappe Três Pontas-Varginha

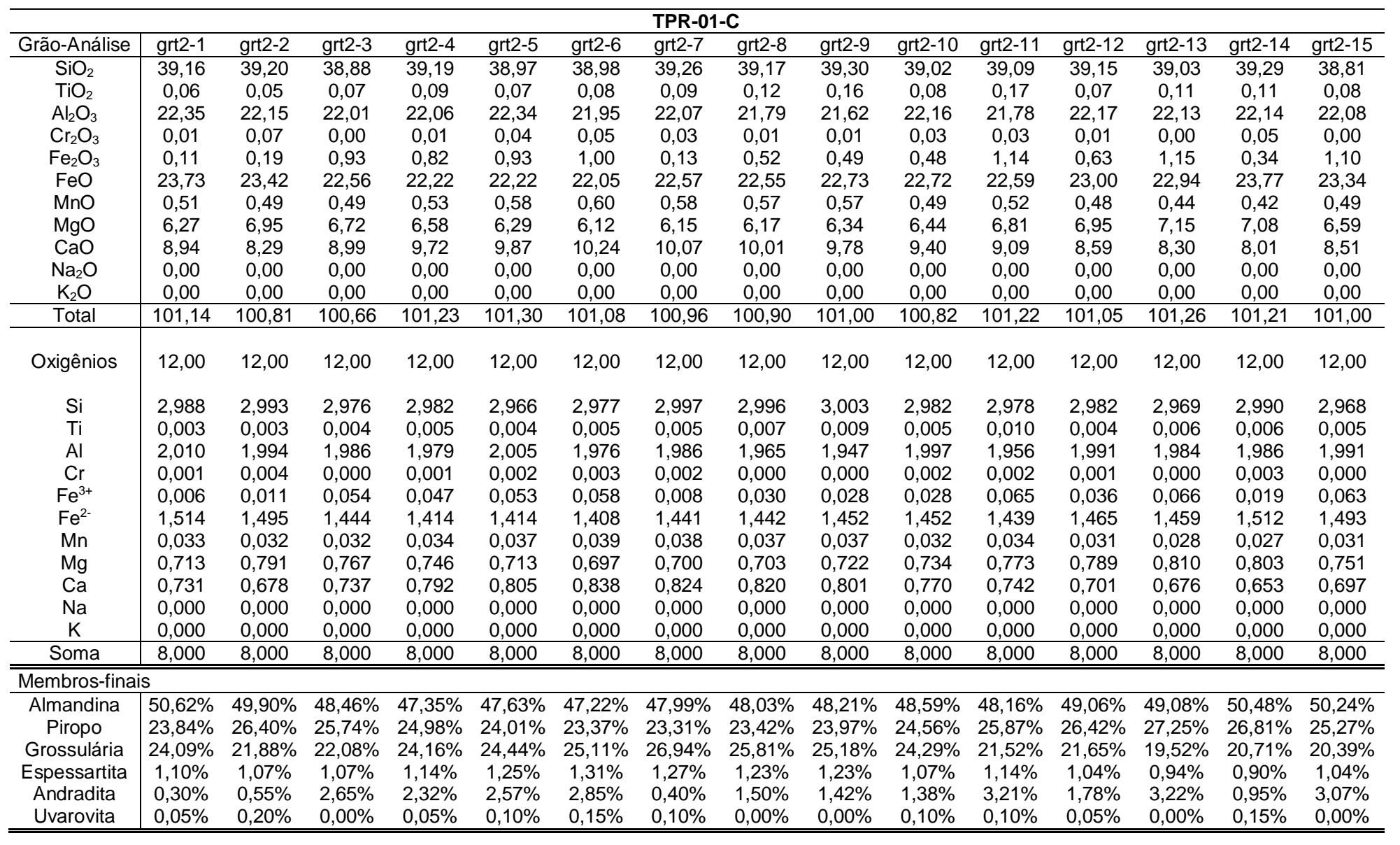


Tabela 3- Análises químicas de granada da Nappe Três Pontas-Varginha

\begin{tabular}{|c|c|c|c|c|c|c|c|c|c|c|c|c|c|c|c|c|c|c|}
\hline \multicolumn{19}{|c|}{ TPR-01-C } \\
\hline Grão-Análise & grt3-1 & grt3-2 & grt3-3 & grt3-4 & grt3-5 & grt3-6 & grt3-7 & grt3-8 & grt3-9 & grt3-10 & grt3-11 & grt3-12 & grt3-13 & grt3-14 & grt3-15 & grt3-16 & grt3-17 & grt3-18 \\
\hline $\mathrm{SiO}_{2}$ & 39,17 & 39,03 & 38,93 & 39,24 & 38,92 & 39,34 & 38,96 & 39,21 & 38,92 & 39,04 & 38,77 & 39,19 & 39,27 & 38,92 & 39,38 & 39,29 & 38,82 & 39,08 \\
\hline $\mathrm{TiO}_{2}$ & 0,12 & 0,15 & 0,19 & 0,13 & 0,08 & 0,06 & 0,16 & 0,11 & 0,10 & 0,07 & 0,09 & 0,08 & 0,09 & 0,19 & 0,16 & 0,12 & 0,08 & 0,05 \\
\hline $\mathrm{Al}_{2} \mathrm{O}_{3}$ & 21,83 & 21,95 & 21,88 & 21,66 & 21,87 & 22,14 & 22,16 & 22,25 & 21,90 & 22,06 & 22,05 & 21,83 & 22,04 & 21,83 & 21,74 & 21,78 & 22,12 & 22,11 \\
\hline $\mathrm{Cr}_{2} \mathrm{O}_{3}$ & 0,04 & 0,01 & 0,01 & 0,00 & 0,02 & 0,03 & 0,02 & 0,01 & 0,03 & 0,04 & 0,02 & 0,01 & 0,06 & 0,02 & 0,03 & 0,02 & 0,03 & 0,02 \\
\hline $\mathrm{Fe}_{2} \mathrm{O}_{3}$ & 0,11 & 0,64 & 1,07 & 0,89 & 0,88 & 0,30 & 0,46 & 0,38 & 0,38 & 0,58 & 1,36 & 0,64 & 0,66 & 0,60 & 0,22 & 0,66 & 1,22 & 0,39 \\
\hline $\mathrm{FeO}$ & 23,98 & 22,85 & 22,68 & 22,80 & 22,36 & 22,91 & 22,44 & 22,81 & 22,65 & 22,21 & 21,80 & 22,61 & 22,83 & 22,91 & 23,21 & 22,91 & 22,80 & 23,54 \\
\hline $\mathrm{MnO}$ & 0,49 & 0,51 & 0,52 & 0,61 & 0,70 & 0,83 & 0,95 & 1,02 & 1,03 & 0,97 & 0,82 & 0,65 & 0,54 & 0,47 & 0,47 & 0,44 & 0,46 & 0,47 \\
\hline $\mathrm{MgO}$ & 6,33 & 6,72 & 6,57 & 6,33 & 5,96 & 5,61 & 5,29 & 5,22 & 4,97 & 5,16 & 5,68 & 6,10 & 6,54 & 6,59 & 6,77 & 6,77 & 7,03 & 6,60 \\
\hline $\mathrm{CaO}$ & 8,73 & 8,94 & 9,21 & 9,63 & 10,09 & 10,42 & 10,85 & 10,80 & 10,99 & 11,20 & 10,68 & 9,98 & 9,37 & 9,03 & 8,96 & 9,11 & 8,35 & 8,58 \\
\hline $\mathrm{Na}_{2} \mathrm{O}$ & 0,00 & 0,00 & 0,00 & 0,00 & 0,00 & 0,00 & 0,00 & 0,00 & 0,00 & 0,00 & 0,00 & 0,00 & 0,00 & 0,00 & 0,00 & 0,00 & 0,00 & 0,00 \\
\hline $\mathrm{K}_{2} \mathrm{O}$ & 0,00 & 0,00 & 0,00 & 0,00 & 0,00 & 0,00 & 0,00 & 0,00 & 0,00 & 0,00 & 0,00 & 0,00 & 0,00 & 0,00 & 0,00 & 0,00 & 0,00 & 0,00 \\
\hline Total & 100,80 & 100,80 & 101,06 & 101,30 & 100,88 & 101,63 & 101,29 & 101,82 & 100,97 & 101,33 & 101,27 & 101,10 & 101,40 & 100,56 & 100,93 & 101,11 & 100,92 & 100,84 \\
\hline Oxigênios & 12,00 & 12,00 & 12,00 & 12,00 & 12,00 & 12,00 & 12,00 & 12,00 & 12,00 & 12,00 & 12,00 & 12,00 & 12,00 & 12,00 & 12,00 & 12,00 & 12,00 & 12,00 \\
\hline $\mathrm{Si}$ & 3,002 & 2,984 & 2,973 & 2,993 & 2,982 & 2,994 & 2,978 & 2,984 & 2,990 & 2,984 & 2,962 & 2,994 & 2,986 & 2,985 & 3,006 & 2,995 & 2,964 & 2,989 \\
\hline $\mathrm{Ti}$ & 0,007 & 0,008 & 0,011 & 0,008 & 0,005 & 0,003 & 0,009 & 0,006 & 0,006 & 0,004 & 0,005 & 0,005 & 0,005 & 0,011 & 0,009 & 0,007 & 0,005 & 0,003 \\
\hline Al & 1,973 & 1,978 & 1,970 & 1,948 & 1,975 & 1,986 & 1,997 & 1,996 & 1,984 & 1,988 & 1,986 & 1,966 & 1,976 & 1,974 & 1,956 & 1,957 & 1,991 & 1,993 \\
\hline $\mathrm{Cr}$ & 0,002 & 0,001 & 0,000 & 0,000 & 0,001 & 0,002 & 0,001 & 0,000 & 0,002 & 0,002 & 0,001 & 0,001 & 0,003 & 0,001 & 0,002 & 0,001 & 0,002 & 0,001 \\
\hline $\mathrm{Fe}^{3+}$ & 0,007 & 0,037 & 0,062 & 0,051 & 0,051 & 0,017 & 0,027 & 0,022 & 0,022 & 0,033 & 0,078 & 0,037 & 0,038 & 0,035 & 0,013 & 0,038 & 0,070 & 0,022 \\
\hline $\mathrm{Fe}^{2-}$ & 1,537 & 1,461 & 1,449 & 1,454 & 1,432 & 1,458 & 1,435 & 1,452 & 1,455 & 1,420 & 1,393 & 1,445 & 1,452 & 1,469 & 1,482 & 1,461 & 1,456 & 1,506 \\
\hline $\mathrm{Mn}$ & 0,032 & 0,033 & 0,034 & 0,040 & 0,045 & 0,053 & 0,061 & 0,066 & 0,067 & 0,063 & 0,053 & 0,042 & 0,035 & 0,031 & 0,030 & 0,028 & 0,030 & 0,030 \\
\hline $\mathrm{Mg}$ & 0,723 & 0,766 & 0,748 & 0,720 & 0,680 & 0,636 & 0,603 & 0,592 & 0,569 & 0,588 & 0,647 & 0,694 & 0,741 & 0,753 & 0,770 & 0,769 & 0,800 & 0,752 \\
\hline $\mathrm{Ca}$ & 0,717 & 0,732 & 0,754 & 0,787 & 0,828 & 0,850 & 0,889 & 0,881 & 0,905 & 0,917 & 0,874 & 0,817 & 0,763 & 0,742 & 0,733 & 0,744 & 0,683 & 0,703 \\
\hline $\mathrm{Na}$ & 0,000 & 0,000 & 0,000 & 0,000 & 0,000 & 0,000 & 0,000 & 0,000 & 0,000 & 0,000 & 0,000 & 0,000 & 0,000 & 0,000 & 0,000 & 0,000 & 0,000 & 0,000 \\
\hline $\mathrm{K}$ & 0,000 & 0,000 & 0,000 & 0,000 & 0,000 & 0,000 & 0,000 & 0,000 & 0,000 & 0,000 & 0,000 & 0,000 & 0,000 & 0,000 & 0,000 & 0,000 & 0,000 & 0,000 \\
\hline Soma & 8,000 & 8,000 & 8,000 & 8,000 & 8,000 & 8,000 & 8,000 & 8,000 & 8,000 & 8,000 & 8,000 & 8,000 & 8,000 & 8,000 & 8,000 & 8,000 & 8,000 & 8,000 \\
\hline \multicolumn{19}{|c|}{ Membros-finais } \\
\hline Almandina & $51,08 \%$ & $48,83 \%$ & $48,54 \%$ & $48,45 \%$ & $47,97 \%$ & $48,65 \%$ & $48,03 \%$ & $48,55 \%$ & $48,56 \%$ & $47,52 \%$ & $46,95 \%$ & $48,20 \%$ & $48,55 \%$ & $49,05 \%$ & $49,15 \%$ & $48,67 \%$ & $49,04 \%$ & $50,35 \%$ \\
\hline Piropo & $24,03 \%$ & $25,60 \%$ & $25,06 \%$ & $23,99 \%$ & $22,78 \%$ & $21,22 \%$ & $20,18 \%$ & $19,79 \%$ & $18,99 \%$ & $19,68 \%$ & $21,81 \%$ & $23,15 \%$ & $24,77 \%$ & $25,14 \%$ & $25,54 \%$ & $25,62 \%$ & $26,95 \%$ & $25,14 \%$ \\
\hline Grossulária & $23,37 \%$ & $22,58 \%$ & $22,21 \%$ & $23,67 \%$ & $25,17 \%$ & $27,41 \%$ & $28,37 \%$ & $28,36 \%$ & $29,01 \%$ & $28,96 \%$ & $25,63 \%$ & $25,36 \%$ & $23,48 \%$ & $22,98 \%$ & $23,55 \%$ & $22,83 \%$ & $19,51 \%$ & $22,36 \%$ \\
\hline Espessartita & $1,06 \%$ & $1,10 \%$ & $1,14 \%$ & $1,33 \%$ & $1,51 \%$ & $1,77 \%$ & $2,04 \%$ & $2,21 \%$ & $2,24 \%$ & $2,11 \%$ & $1,79 \%$ & $1,40 \%$ & $1,17 \%$ & $1,04 \%$ & $1,00 \%$ & $0,93 \%$ & $1,01 \%$ & $1,00 \%$ \\
\hline Andradita & $0,35 \%$ & $1,84 \%$ & $3,05 \%$ & $2,55 \%$ & $2,52 \%$ & $0,85 \%$ & $1,33 \%$ & $1,09 \%$ & $1,10 \%$ & $1,63 \%$ & $3,78 \%$ & $1,85 \%$ & $1,88 \%$ & $1,74 \%$ & $0,66 \%$ & $1,90 \%$ & $3,39 \%$ & $1,09 \%$ \\
\hline Uvarovita & $0,10 \%$ & $0,05 \%$ & $0,00 \%$ & $0,00 \%$ & $0,05 \%$ & $0,10 \%$ & $0,05 \%$ & $0,00 \%$ & $0,10 \%$ & $0,10 \%$ & $0,05 \%$ & $0,05 \%$ & $0,15 \%$ & $0,05 \%$ & $0,10 \%$ & $0,05 \%$ & $0,10 \%$ & $0,05 \%$ \\
\hline
\end{tabular}




\section{TPR-01-C}

\begin{tabular}{|c|c|c|c|c|c|c|c|c|c|c|c|c|c|c|c|c|c|c|}
\hline \multicolumn{19}{|c|}{ TPR-01-C } \\
\hline Grão-Análise & grt4-1 & grt4-2 & grt4-3 & grt4-4 & grt4-5 & grt4-6 & grt4-7 & grt4-8 & grt4-9 & grt4-10 & grt4-11 & grt4-12 & grt4-13 & grt4-14 & grt4-15 & grt4-16 & grt4-17 & grt4-18 \\
\hline $\mathrm{SiO}_{2}$ & 38,86 & 39,44 & 39,12 & 39,29 & 39,06 & 39,33 & 39,32 & 39,04 & 38,87 & 38,97 & 39,11 & 38,84 & 39,10 & 39,42 & 39,00 & 39,20 & 39,09 & 38,42 \\
\hline $\mathrm{TiO}_{2}$ & 0,07 & 0,11 & 0,14 & 0,05 & 0,15 & 0,09 & 0,12 & 0,12 & 0,04 & 0,11 & 0,04 & 0,10 & 0,08 & 0,10 & 0,10 & 0,13 & 0,11 & 0,09 \\
\hline $\mathrm{Al}_{2} \mathrm{O}_{3}$ & 22,23 & 22,22 & 22,14 & 22,18 & 22,05 & 21,95 & 22,12 & 21,88 & 21,94 & 22,00 & 22,10 & 21,92 & 22,05 & 21,93 & 22,02 & 22,04 & 22,07 & 21,97 \\
\hline $\mathrm{Cr}_{2} \mathrm{O}_{3}$ & 0,02 & 0,02 & 0,04 & 0,03 & 0,01 & 0,04 & 0,04 & 0,00 & 0,00 & 0,02 & 0,03 & 0,01 & 0,05 & 0,06 & 0,04 & 0,06 & 0,05 & 0,03 \\
\hline $\mathrm{Fe}_{2} \mathrm{O}_{3}$ & 0,00 & 0,31 & 0,23 & 0,40 & 0,52 & 0,21 & 0,00 & 0,90 & 0,74 & 0,51 & 0,66 & 0,98 & 0,66 & 0,38 & 0,88 & 0,70 & 0,20 & 1,43 \\
\hline $\mathrm{FeO}$ & 24,10 & 23,70 & 23,29 & 23,18 & 22,91 & 23,40 & 23,11 & 22,58 & 22,57 & 22,51 & 22,47 & 22,31 & 22,31 & 22,76 & 22,49 & 22,74 & 23,68 & 23,34 \\
\hline $\mathrm{MnO}$ & 0,50 & 0,46 & 0,43 & 0,46 & 0,50 & 0,53 & 0,57 & 0,60 & 0,64 & 0,68 & 0,66 & 0,62 & 0,60 & 0,57 & 0,55 & 0,53 & 0,50 & 0,50 \\
\hline $\mathrm{MgO}$ & 5,89 & 6,93 & 6,99 & 6,81 & 6,67 & 6,56 & 6,44 & 6,38 & 6,21 & 6,09 & 6,17 & 6,13 & 6,20 & 6,34 & 6,53 & 6,82 & 6,84 & 6,41 \\
\hline $\mathrm{CaO}$ & 8,88 & 8,38 & 8,37 & 8,77 & 9,01 & 8,96 & 9,12 & 9,55 & 9,54 & 9,87 & 9,89 & 9,89 & 10,03 & 9,83 & 9,39 & 9,02 & 8,17 & 8,39 \\
\hline $\mathrm{Na}_{2} \mathrm{O}$ & 0,00 & 0,00 & 0,00 & 0,00 & 0,00 & 0,00 & 0,00 & 0,00 & 0,00 & 0,00 & 0,00 & 0,00 & 0,00 & 0,00 & 0,00 & 0,00 & 0,00 & 0,00 \\
\hline $\mathrm{K}_{2} \mathrm{O}$ & 0,00 & 0,00 & 0,00 & 0,00 & 0,00 & 0,00 & 0,00 & 0,00 & 0,00 & 0,00 & 0,00 & 0,00 & 0,00 & 0,00 & 0,00 & 0,00 & 0,00 & 0,00 \\
\hline Total & 100,55 & 101,57 & 100,73 & 101,17 & 100,88 & 101,06 & 100,83 & 101,04 & 100,56 & 100,76 & 101,13 & 100,79 & 101,08 & 101,38 & 101,01 & 101,24 & 100,71 & 100,57 \\
\hline Oxigênios & 12,00 & 12,00 & 12,00 & 12,00 & 12,00 & 12,00 & 12,00 & 12,00 & 12,00 & 12,00 & 12,00 & 12,00 & 12,00 & 12,00 & 12,00 & 12,00 & 12,00 & 12,00 \\
\hline $\mathrm{Si}$ & 2,989 & 2,991 & 2,988 & 2,990 & 2,983 & 3,001 & 3,002 & 2,982 & 2,984 & 2,985 & 2,984 & 2,976 & 2,983 & 2,998 & 2,977 & 2,982 & 2,991 & 2,956 \\
\hline $\mathrm{Ti}$ & 0,004 & 0,006 & 0,008 & 0,003 & 0,009 & 0,005 & 0,007 & 0,007 & 0,002 & 0,006 & 0,002 & 0,006 & 0,004 & 0,006 & 0,005 & 0,007 & 0,006 & 0,005 \\
\hline $\mathrm{Al}$ & 2,016 & 1,987 & 1,994 & 1,990 & 1,985 & 1,974 & 1,991 & 1,970 & 1,985 & 1,987 & 1,988 & 1,980 & 1,984 & 1,967 & 1,982 & 1,977 & 1,991 & 1,993 \\
\hline $\mathrm{Cr}$ & 0,001 & 0,001 & 0,002 & 0,002 & 0,001 & 0,002 & 0,002 & 0,000 & 0,000 & 0,001 & 0,002 & 0,001 & 0,003 & 0,004 & 0,003 & 0,004 & 0,003 & 0,002 \\
\hline $\mathrm{Fe}^{3+}$ & 0,000 & 0,018 & 0,013 & 0,023 & 0,030 & 0,012 & 0,000 & 0,052 & 0,043 & 0,029 & 0,038 & 0,056 & 0,038 & 0,022 & 0,051 & 0,040 & 0,012 & 0,083 \\
\hline $\mathrm{Fe}^{2-}$ & 1,550 & 1,503 & 1,487 & 1,475 & 1,463 & 1,493 & 1,476 & 1,442 & 1,449 & 1,442 & 1,433 & 1,430 & 1,424 & 1,448 & 1,436 & 1,447 & 1,515 & 1,502 \\
\hline $\mathrm{Mn}$ & 0,032 & 0,030 & 0,028 & 0,030 & 0,032 & 0,034 & 0,037 & 0,038 & 0,042 & 0,044 & 0,043 & 0,040 & 0,039 & 0,036 & 0,036 & 0,034 & 0,032 & 0,033 \\
\hline $\mathrm{Mg}$ & 0,675 & 0,783 & 0,796 & 0,772 & 0,759 & 0,746 & 0,733 & 0,726 & 0,710 & 0,695 & 0,702 & 0,700 & 0,705 & 0,719 & 0,743 & 0,773 & 0,780 & 0,735 \\
\hline $\mathrm{Ca}$ & 0,732 & 0,681 & 0,685 & 0,715 & 0,737 & 0,732 & 0,746 & 0,782 & 0,785 & 0,810 & 0,808 & 0,812 & 0,820 & 0,801 & 0,768 & 0,735 & 0,670 & 0,692 \\
\hline $\mathrm{Na}$ & 0,000 & 0,000 & 0,000 & 0,000 & 0,000 & 0,000 & 0,000 & 0,000 & 0,000 & 0,000 & 0,000 & 0,000 & 0,000 & 0,000 & 0,000 & 0,000 & 0,000 & 0,000 \\
\hline $\mathrm{K}$ & 0,000 & 0,000 & 0,000 & 0,000 & 0,000 & 0,000 & 0,000 & 0,000 & 0,000 & 0,000 & 0,000 & 0,000 & 0,000 & 0,000 & 0,000 & 0,000 & 0,000 & 0,000 \\
\hline Soma & 7,999 & 8,000 & 8,000 & 8,000 & 8,000 & 8,000 & 7,994 & 8,000 & 8,000 & 8,000 & 8,000 & 8,000 & 8,000 & 8,000 & 8,000 & 8,000 & 8,000 & 8,000 \\
\hline \multicolumn{19}{|c|}{ Membros-finais } \\
\hline Almandina & $51,86 \%$ & $50,15 \%$ & $49,63 \%$ & $49,30 \%$ & $48,91 \%$ & $49,68 \%$ & $49,33 \%$ & $48,26 \%$ & $48,53 \%$ & $48,21 \%$ & $47,99 \%$ & $47,95 \%$ & $47,66 \%$ & $48,20 \%$ & $48,14 \%$ & $48,41 \%$ & $50,55 \%$ & $50,71 \%$ \\
\hline Piropo & $22,58 \%$ & $26,13 \%$ & $26,57 \%$ & $25,80 \%$ & $25,38 \%$ & $24,83 \%$ & $24,50 \%$ & $24,30 \%$ & $23,78 \%$ & $23,24 \%$ & $23,51 \%$ & $23,47 \%$ & $23,59 \%$ & $23,93 \%$ & $24,91 \%$ & $25,86 \%$ & $26,03 \%$ & $24,81 \%$ \\
\hline Grossulária & $24,44 \%$ & $21,78 \%$ & $22,12 \%$ & $22,66 \%$ & $23,10 \%$ & $23,66 \%$ & $24,83 \%$ & $23,60 \%$ & $24,17 \%$ & $25,59 \%$ & $25,09 \%$ & $24,43 \%$ & $25,42 \%$ & $25,36 \%$ & $23,09 \%$ & $22,41 \%$ & $21,61 \%$ & $19,27 \%$ \\
\hline Espessartita & $1,07 \%$ & $1,00 \%$ & $0,93 \%$ & $1,00 \%$ & $1,07 \%$ & $1,13 \%$ & $1,24 \%$ & $1,27 \%$ & $1,41 \%$ & $1,47 \%$ & $1,44 \%$ & $1,34 \%$ & $1,31 \%$ & $1,20 \%$ & $1,21 \%$ & $1,14 \%$ & $1,07 \%$ & $1,11 \%$ \\
\hline Andradita & $0,00 \%$ & $0,90 \%$ & $0,65 \%$ & $1,14 \%$ & $1,49 \%$ & $0,60 \%$ & $0,00 \%$ & $2,57 \%$ & $2,12 \%$ & $1,44 \%$ & $1,87 \%$ & $2,75 \%$ & $1,88 \%$ & $1,10 \%$ & $2,50 \%$ & $1,98 \%$ & $0,60 \%$ & $3,99 \%$ \\
\hline Uvarovita & $0,05 \%$ & $0,05 \%$ & $0,10 \%$ & $0,10 \%$ & $0,05 \%$ & $0,10 \%$ & $0,10 \%$ & $0,00 \%$ & $0,00 \%$ & $0,05 \%$ & $0,10 \%$ & $0,05 \%$ & $0,15 \%$ & $0,20 \%$ & $0,15 \%$ & $0,20 \%$ & $0,15 \%$ & $0,10 \%$ \\
\hline
\end{tabular}


Tabela 5- Análises químicas de granada da Nappe Três Pontas-Varginha

\begin{tabular}{|c|c|c|c|c|c|c|c|c|c|c|c|c|c|c|c|c|c|c|}
\hline \multicolumn{19}{|c|}{ TPR-01-C } \\
\hline Grão-Análise & grt5-1 & grt5-2 & grt5-3 & grt5-4 & grt5-5 & grt5-6 & grt5-7 & grt5-8 & grt5-9 & grt5-10 & grt5-11 & grt5-12 & grt5-13 & grt5-14 & grt5-15 & grt5-16 & grt5-17 & grt5-18 \\
\hline $\mathrm{SiO}_{2}$ & 38,84 & 38,85 & 39,06 & 39,31 & 38,98 & 38,81 & 38,85 & 38,91 & 38,91 & 38,80 & 38,75 & 38,96 & 38,97 & 39,02 & 38,84 & 39,24 & 39,43 & 39,07 \\
\hline $\mathrm{TiO}_{2}$ & 0,05 & 0,08 & 0,08 & 0,07 & 0,11 & 0,13 & 0,12 & 0,08 & 0,12 & 0,12 & 0,11 & 0,07 & 0,05 & 0,13 & 0,07 & 0,12 & 0,07 & 0,09 \\
\hline $\mathrm{Al}_{2} \mathrm{O}_{3}$ & 22,01 & 22,17 & 22,00 & 22,06 & 22,15 & 21,87 & 21,54 & 21,81 & 21,68 & 21,61 & 21,88 & 22,16 & 22,06 & 21,92 & 22,11 & 21,99 & 22,22 & 22,02 \\
\hline $\mathrm{Cr}_{2} \mathrm{O}_{3}$ & 0,05 & 0,02 & 0,01 & 0,00 & 0,00 & 0,01 & 0,02 & 0,00 & 0,02 & 0,02 & 0,01 & 0,01 & 0,00 & 0,05 & 0,03 & 0,03 & 0,03 & 0,06 \\
\hline $\mathrm{Fe}_{2} \mathrm{O}_{3}$ & 0,12 & 0,65 & 0,27 & 0,12 & 0,27 & 0,68 & 0,14 & 0,13 & 0,39 & 0,86 & 0,68 & 0,00 & 0,36 & 0,49 & 1,47 & 0,07 & 0,18 & 0,16 \\
\hline $\mathrm{FeO}$ & 24,14 & 23,29 & 23,03 & 22,63 & 22,42 & 22,01 & 22,39 & 22,58 & 22,55 & 22,12 & 22,22 & 22,78 & 22,90 & 22,77 & 22,39 & 23,53 & 23,54 & 23,66 \\
\hline $\mathrm{MnO}$ & 0,47 & 0,50 & 0,52 & 0,68 & 0,87 & 1,02 & 1,21 & 1,20 & 1,23 & 1,18 & 1,00 & 0,85 & 0,72 & 0,65 & 0,53 & 0,46 & 0,45 & 0,46 \\
\hline $\mathrm{MgO}$ & 5,95 & 6,80 & 6,49 & 5,97 & 5,35 & 4,80 & 4,41 & 4,39 & 4,41 & 4,36 & 4,79 & 5,40 & 5,90 & 6,28 & 6,83 & 7,00 & 7,07 & 6,12 \\
\hline $\mathrm{CaO}$ & 8,79 & 8,28 & 9,09 & 10,23 & 10,83 & 11,65 & 11,77 & 11,69 & 11,69 & 12,03 & 11,44 & 10,44 & 9,75 & 9,49 & 8,90 & 8,24 & 8,29 & 9,19 \\
\hline $\mathrm{Na}_{2} \mathrm{O}$ & 0,00 & 0,00 & 0,00 & 0,00 & 0,00 & 0,00 & 0,00 & 0,00 & 0,00 & 0,00 & 0,00 & 0,00 & 0,00 & 0,00 & 0,00 & 0,00 & 0,00 & 0,00 \\
\hline $\mathrm{K}_{2} \mathrm{O}$ & 0,00 & 0,00 & 0,00 & 0,00 & 0,00 & 0,00 & 0,00 & 0,00 & 0,00 & 0,00 & 0,00 & 0,00 & 0,00 & 0,00 & 0,00 & 0,00 & 0,00 & 0,00 \\
\hline Total & 100,43 & 100,65 & 100,56 & 101,07 & 100,98 & 100,98 & 100,45 & 100,80 & 101,01 & 101,09 & 100,88 & 100,66 & 100,72 & 100,81 & 101,17 & 100,69 & 101,27 & 100,83 \\
\hline Oxigênios & 12,00 & 12,00 & 12,00 & 12,00 & 12,00 & 12,00 & 12,00 & 12,00 & 12,00 & 12,00 & 12,00 & 12,00 & 12,00 & 12,00 & 12,00 & 12,00 & 12,00 & 12,00 \\
\hline $\mathrm{Si}$ & 2,992 & 2,975 & 2,993 & 3,000 & 2,986 & 2,982 & 3,006 & 3,000 & 2,997 & 2,987 & 2,982 & 2,993 & 2,989 & 2,987 & 2,960 & 2,999 & 2,995 & 2,994 \\
\hline $\mathrm{Ti}$ & 0,003 & 0,005 & 0,004 & 0,004 & 0,007 & 0,008 & 0,007 & 0,005 & 0,007 & 0,007 & 0,006 & 0,004 & 0,003 & 0,008 & 0,004 & 0,007 & 0,004 & 0,005 \\
\hline Al & 1,999 & 2,002 & 1,988 & 1,985 & 2,000 & 1,981 & 1,965 & 1,982 & 1,968 & 1,961 & 1,985 & 2,007 & 1,995 & 1,978 & 1,986 & 1,981 & 1,990 & 1,989 \\
\hline $\mathrm{Cr}$ & 0,003 & 0,001 & 0,001 & 0,000 & 0,000 & 0,001 & 0,001 & 0,000 & 0,001 & 0,001 & 0,000 & 0,001 & 0,000 & 0,003 & 0,002 & 0,002 & 0,002 & 0,004 \\
\hline $\mathrm{Fe}^{3+}$ & 0,007 & 0,038 & 0,016 & 0,007 & 0,015 & 0,039 & 0,008 & 0,008 & 0,023 & 0,050 & 0,039 & 0,000 & 0,021 & 0,028 & 0,084 & 0,004 & 0,010 & 0,009 \\
\hline $\mathrm{Fe}^{2-}$ & 1,555 & 1,492 & 1,476 & 1,445 & 1,436 & 1,414 & 1,449 & 1,456 & 1,453 & 1,424 & 1,430 & 1,463 & 1,469 & 1,458 & 1,427 & 1,504 & 1,495 & 1,516 \\
\hline $\mathrm{Mn}$ & 0,031 & 0,033 & 0,034 & 0,044 & 0,057 & 0,067 & 0,080 & 0,079 & 0,080 & 0,077 & 0,065 & 0,055 & 0,047 & 0,042 & 0,034 & 0,030 & 0,029 & 0,030 \\
\hline $\mathrm{Mg}$ & 0,683 & 0,776 & 0,741 & 0,679 & 0,611 & 0,550 & 0,509 & 0,504 & 0,506 & 0,500 & 0,549 & 0,618 & 0,674 & 0,717 & 0,776 & 0,797 & 0,800 & 0,699 \\
\hline $\mathrm{Ca}$ & 0,726 & 0,679 & 0,746 & 0,837 & 0,889 & 0,959 & 0,976 & 0,966 & 0,965 & 0,992 & 0,943 & 0,859 & 0,801 & 0,778 & 0,727 & 0,675 & 0,675 & 0,754 \\
\hline $\mathrm{Na}$ & 0,000 & 0,000 & 0,000 & 0,000 & 0,000 & 0,000 & 0,000 & 0,000 & 0,000 & 0,000 & 0,000 & 0,000 & 0,000 & 0,000 & 0,000 & 0,000 & 0,000 & 0,000 \\
\hline $\mathrm{K}$ & 0,000 & 0,000 & 0,000 & 0,000 & 0,000 & 0,000 & 0,000 & 0,000 & 0,000 & 0,000 & 0,000 & 0,000 & 0,000 & 0,000 & 0,000 & 0,000 & 0,000 & 0,000 \\
\hline Soma & 8,000 & 8,000 & 8,000 & 8,000 & 8,000 & 8,000 & 8,000 & 8,000 & 8,000 & 8,000 & 8,000 & 8,000 & 8,000 & 8,000 & 8,000 & 8,000 & 8,000 & 8,000 \\
\hline \multicolumn{19}{|c|}{ Membros-finais } \\
\hline Almandina & $51,92 \%$ & $50,07 \%$ & $49,25 \%$ & $48,09 \%$ & $47,98 \%$ & $47,29 \%$ & $48,08 \%$ & $48,45 \%$ & $48,37 \%$ & $47,58 \%$ & $47,87 \%$ & $48,85 \%$ & $49,11 \%$ & $48,68 \%$ & $48,14 \%$ & $50,03 \%$ & $49,85 \%$ & $50,55 \%$ \\
\hline Piropo & $22,80 \%$ & $26,04 \%$ & $24,72 \%$ & $22,60 \%$ & $20,41 \%$ & $18,39 \%$ & $16,89 \%$ & $16,77 \%$ & $16,84 \%$ & $16,71 \%$ & $18,38 \%$ & $20,63 \%$ & $22,53 \%$ & $23,94 \%$ & $26,18 \%$ & $26,51 \%$ & $26,68 \%$ & $23,31 \%$ \\
\hline Grossulária & $23,74 \%$ & $20,87 \%$ & $24,04 \%$ & $27,50 \%$ & $28,96 \%$ & $30,09 \%$ & $31,93 \%$ & $31,74 \%$ & $30,92 \%$ & $30,61 \%$ & $29,64 \%$ & $28,63 \%$ & $25,74 \%$ & $24,43 \%$ & $20,38 \%$ & $22,15 \%$ & $21,91 \%$ & $24,49 \%$ \\
\hline Espessartita & $1,04 \%$ & $1,11 \%$ & $1,13 \%$ & $1,46 \%$ & $1,90 \%$ & $2,24 \%$ & $2,65 \%$ & $2,63 \%$ & $2,66 \%$ & $2,57 \%$ & $2,18 \%$ & $1,84 \%$ & $1,57 \%$ & $1,40 \%$ & $1,15 \%$ & $1,00 \%$ & $0,97 \%$ & $1,00 \%$ \\
\hline Andradita & $0,35 \%$ & $1,86 \%$ & $0,80 \%$ & $0,35 \%$ & $0,74 \%$ & $1,93 \%$ & $0,41 \%$ & $0,40 \%$ & $1,15 \%$ & $2,49 \%$ & $1,93 \%$ & $0,00 \%$ & $1,04 \%$ & $1,39 \%$ & $4,05 \%$ & $0,20 \%$ & $0,50 \%$ & $0,45 \%$ \\
\hline Uvarovita & $0,15 \%$ & $0,05 \%$ & $0,05 \%$ & $0,00 \%$ & $0,00 \%$ & $0,05 \%$ & $0,05 \%$ & $0,00 \%$ & $0,05 \%$ & $0,05 \%$ & $0,00 \%$ & $0,05 \%$ & $0,00 \%$ & $0,15 \%$ & $0,10 \%$ & $0,10 \%$ & $0,10 \%$ & $0,20 \%$ \\
\hline
\end{tabular}


Tabela 6- Análises químicas de granada da Nappe Três Pontas-Varginha

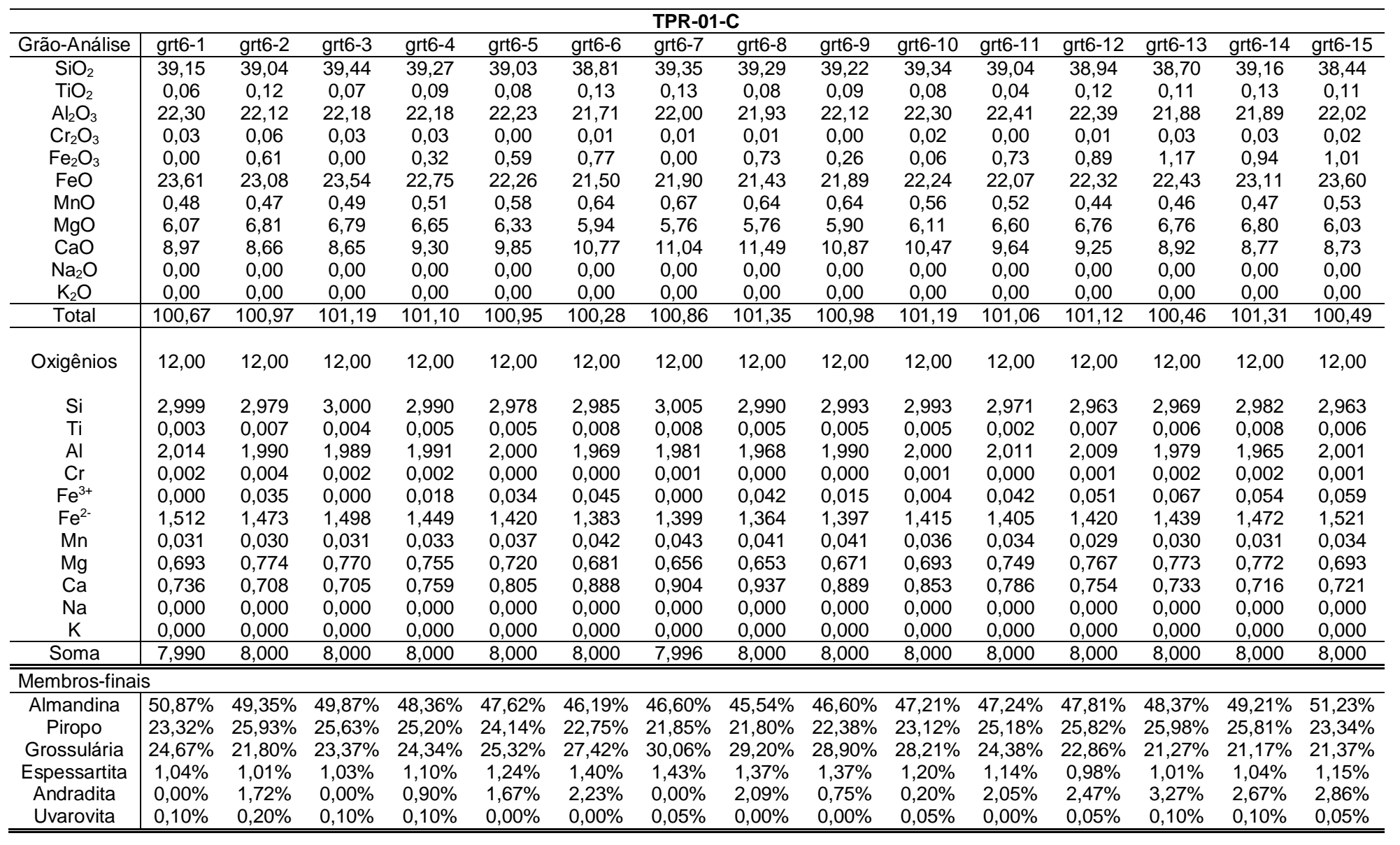


Tabela 7- Análises químicas de granada da Nappe Três Pontas-Varginha

\begin{tabular}{|c|c|c|c|c|c|c|c|c|c|c|c|c|c|c|c|}
\hline \multicolumn{16}{|c|}{ TPR-01-B } \\
\hline Grão-Análise & grt1-1 & grt1-2 & grt1-3 & grt1-4 & grt1-5 & grt1-6 & grt1-7 & grt1-8 & grt1-9 & grt1-10 & grt1-11 & grt1-12 & grt1-13 & grt1-14 & grt1-15 \\
\hline $\mathrm{SiO}_{2}$ & 39,40 & 38,73 & 38,75 & 38,80 & 39,11 & 38,68 & 38,96 & 38,84 & 38,81 & 38,97 & 38,84 & 38,96 & 39,13 & 38,65 & 38,33 \\
\hline $\mathrm{TiO}_{2}$ & 0,14 & 0,09 & 0,11 & 0,07 & 0,11 & 0,07 & 0,06 & 0,07 & 0,11 & 0,05 & 0,10 & 0,08 & 0,10 & 0,06 & 0,10 \\
\hline $\mathrm{Al}_{2} \mathrm{O}_{3}$ & 22,23 & 21,77 & 21,80 & 21,74 & 21,76 & 21,80 & 22,00 & 21,73 & 21,70 & 21,95 & 21,76 & 21,92 & 22,08 & 22,04 & 21,88 \\
\hline $\mathrm{Cr}_{2} \mathrm{O}_{3}$ & 0,02 & 0,02 & 0,03 & 0,03 & 0,03 & 0,04 & 0,04 & 0,07 & 0,05 & 0,05 & 0,00 & 0,02 & 0,04 & 0,02 & 0,04 \\
\hline $\mathrm{Fe}_{2} \mathrm{O}_{3}$ & 0,00 & 0,02 & 0,16 & 0,25 & 0,00 & 0,24 & 0,15 & 0,05 & 0,29 & 0,00 & 0,45 & 0,30 & 0,00 & 0,69 & 0,00 \\
\hline $\mathrm{FeO}$ & 23,52 & 23,28 & 23,27 & 23,00 & 23,04 & 22,55 & 22,74 & 22,86 & 22,70 & 22,97 & 22,97 & 23,22 & 23,35 & 23,14 & 23,89 \\
\hline $\mathrm{MnO}$ & 0,45 & 0,50 & 0,48 & 0,50 & 0,50 & 0,47 & 0,48 & 0,51 & 0,48 & 0,47 & 0,47 & 0,46 & 0,47 & 0,46 & 0,45 \\
\hline $\mathrm{MgO}$ & 6,48 & 6,72 & 6,63 & 6,64 & 6,66 & 6,66 & 6,69 & 6,69 & 6,91 & 6,85 & 6,88 & 6,82 & 6,84 & 6,83 & 5,94 \\
\hline $\mathrm{CaO}$ & 8,24 & 8,29 & 8,48 & 8,68 & 8,71 & 8,91 & 8,97 & 8,75 & 8,59 & 8,54 & 8,45 & 8,45 & 8,47 & 8,19 & 8,56 \\
\hline $\mathrm{Na}_{2} \mathrm{O}$ & 0,00 & 0,00 & 0,00 & 0,00 & 0,00 & 0,00 & 0,00 & 0,00 & 0,00 & 0,00 & 0,00 & 0,00 & 0,00 & 0,00 & 0,00 \\
\hline $\mathrm{K}_{2} \mathrm{O}$ & 0,00 & 0,00 & 0,00 & 0,00 & 0,00 & 0,00 & 0,00 & 0,00 & 0,00 & 0,00 & 0,00 & 0,00 & 0,00 & 0,00 & 0,00 \\
\hline Total & 100,49 & 99,42 & 99,70 & 99,70 & 99,92 & 99,42 & 100,08 & 99,57 & 99,64 & 99,86 & 99,92 & 100,23 & 100,48 & 100,08 & 99,20 \\
\hline Oxigênios & 12,00 & 12,00 & 12,00 & 12,00 & 12,00 & 12,00 & 12,00 & 12,00 & 12,00 & 12,00 & 12,00 & 12,00 & 12,00 & 12,00 & 12,00 \\
\hline $\mathrm{Si}$ & 3,014 & 3,000 & 2,995 & 2,998 & 3,011 & 2,993 & 2,994 & 3,002 & 2,996 & 3,000 & 2,993 & 2,993 & 2,997 & 2,976 & 2,988 \\
\hline $\mathrm{Ti}$ & 0,008 & 0,005 & 0,006 & 0,004 & 0,006 & 0,004 & 0,003 & 0,004 & 0,007 & 0,003 & 0,006 & 0,005 & 0,006 & 0,004 & 0,006 \\
\hline Al & 2,004 & 1,988 & 1,986 & 1,980 & 1,975 & 1,989 & 1,993 & 1,980 & 1,975 & 1,992 & 1,977 & 1,985 & 1,993 & 2,000 & 2,011 \\
\hline $\mathrm{Cr}$ & 0,001 & 0,001 & 0,002 & 0,002 & 0,002 & 0,003 & 0,002 & 0,004 & 0,003 & 0,003 & 0,000 & 0,001 & 0,003 & 0,001 & 0,003 \\
\hline $\mathrm{Fe}^{3+}$ & 0,000 & 0,001 & 0,009 & 0,015 & 0,000 & 0,014 & 0,008 & 0,003 & 0,017 & 0,000 & 0,026 & 0,018 & 0,000 & 0,040 & 0,000 \\
\hline $\mathrm{Fe}^{2-}$ & 1,504 & 1,508 & 1,504 & 1,486 & 1,484 & 1,460 & 1,462 & 1,478 & 1,466 & 1,479 & 1,480 & 1,492 & 1,495 & 1,490 & 1,557 \\
\hline $\mathrm{Mn}$ & 0,029 & 0,033 & 0,031 & 0,033 & 0,033 & 0,031 & 0,031 & 0,033 & 0,031 & 0,031 & 0,031 & 0,030 & 0,031 & 0,030 & 0,030 \\
\hline $\mathrm{Mg}$ & 0,739 & 0,776 & 0,764 & 0,765 & 0,764 & 0,768 & 0,766 & 0,771 & 0,795 & 0,786 & 0,790 & 0,781 & 0,781 & 0,784 & 0,690 \\
\hline $\mathrm{Ca}$ & 0,675 & 0,688 & 0,702 & 0,719 & 0,719 & 0,739 & 0,739 & 0,725 & 0,711 & 0,704 & 0,698 & 0,696 & 0,695 & 0,676 & 0,715 \\
\hline $\mathrm{Na}$ & 0,000 & 0,000 & 0,000 & 0,000 & 0,000 & 0,000 & 0,000 & 0,000 & 0,000 & 0,000 & 0,000 & 0,000 & 0,000 & 0,000 & 0,000 \\
\hline $\mathrm{K}$ & 0,000 & 0,000 & 0,000 & 0,000 & 0,000 & 0,000 & 0,000 & 0,000 & 0,000 & 0,000 & 0,000 & 0,000 & 0,000 & 0,000 & 0,000 \\
\hline Soma & 7,975 & 8,000 & 8,000 & 8,000 & 7,994 & 8,000 & 8,000 & 8,000 & 8,000 & 7,999 & 8,000 & 8,000 & 8,000 & 8,000 & 8,000 \\
\hline \multicolumn{16}{|l|}{ Membros-finais } \\
\hline Almandina & $51,03 \%$ & $50,18 \%$ & $50,12 \%$ & $49,48 \%$ & $49,47 \%$ & $48,70 \%$ & $48,77 \%$ & $49,15 \%$ & $48,82 \%$ & $49,30 \%$ & $49,35 \%$ & $49,75 \%$ & $49,80 \%$ & $50,00 \%$ & $52,04 \%$ \\
\hline Piropo & $25,08 \%$ & $25,82 \%$ & $25,46 \%$ & $25,47 \%$ & $25,47 \%$ & $25,62 \%$ & $25,55 \%$ & $25,64 \%$ & $26,47 \%$ & $26,20 \%$ & $26,34 \%$ & $26,04 \%$ & $26,02 \%$ & $26,31 \%$ & $23,06 \%$ \\
\hline Grossulária & $22,85 \%$ & $22,79 \%$ & $22,84 \%$ & $23,09 \%$ & $23,87 \%$ & $23,80 \%$ & $24,15 \%$ & $23,76 \%$ & $22,67 \%$ & $23,32 \%$ & $21,98 \%$ & $22,26 \%$ & $23,00 \%$ & $20,68 \%$ & $23,75 \%$ \\
\hline Espessartita & $0,98 \%$ & $1,10 \%$ & $1,03 \%$ & $1,10 \%$ & $1,10 \%$ & $1,03 \%$ & $1,03 \%$ & $1,10 \%$ & $1,03 \%$ & $1,03 \%$ & $1,03 \%$ & $1,00 \%$ & $1,03 \%$ & $1,01 \%$ & $1,00 \%$ \\
\hline Andradita & $0,00 \%$ & $0,05 \%$ & $0,45 \%$ & $0,75 \%$ & $0,00 \%$ & $0,70 \%$ & $0,40 \%$ & $0,15 \%$ & $0,85 \%$ & $0,00 \%$ & $1,30 \%$ & $0,90 \%$ & $0,00 \%$ & $1,96 \%$ & $0,00 \%$ \\
\hline Uvarovita & $0,05 \%$ & $0,05 \%$ & $0,10 \%$ & $0,10 \%$ & $0,10 \%$ & $0,15 \%$ & $0,10 \%$ & $0,20 \%$ & $0,15 \%$ & $0,15 \%$ & $0,00 \%$ & $0,05 \%$ & $0,15 \%$ & $0,05 \%$ & $0,15 \%$ \\
\hline
\end{tabular}


Tabela 8- Análises químicas de granada da Nappe Três Pontas-Varginha

\begin{tabular}{|c|c|c|c|c|c|c|c|c|c|c|c|c|c|c|c|}
\hline \multicolumn{16}{|c|}{ TPR-01-B } \\
\hline Grão-Análise & grt2-1 & grt2-2 & grt2-3 & grt2-4 & grt2-5 & grt2-6 & grt2-7 & grt2-8 & grt2-9 & grt2-10 & grt2-11 & grt2-12 & grt2-13 & grt2-14 & grt2-15 \\
\hline $\mathrm{SiO}_{2}$ & 38,54 & 38,79 & 38,88 & 38,82 & 38,97 & 38,62 & 39,13 & 38,45 & 38,84 & 38,76 & 39,16 & 38,97 & 39,24 & 38,97 & 39,26 \\
\hline $\mathrm{TiO}_{2}$ & 0,07 & 0,09 & 0,08 & 0,11 & 0,10 & 0,08 & 0,10 & 0,12 & 0,11 & 0,09 & 0,13 & 0,04 & 0,08 & 0,06 & 0,05 \\
\hline $\mathrm{Al}_{2} \mathrm{O}_{3}$ & 21,93 & 21,75 & 21,70 & 21,84 & 22,03 & 21,55 & 21,49 & 21,57 & 21,91 & 21,75 & 21,63 & 22,08 & 21,70 & 21,93 & 21,99 \\
\hline $\mathrm{Cr}_{2} \mathrm{O}_{3}$ & 0,02 & 0,04 & 0,07 & 0,04 & 0,00 & 0,01 & 0,00 & 0,04 & 0,01 & 0,00 & 0,01 & 0,03 & 0,01 & 0,03 & 0,01 \\
\hline $\mathrm{Fe}_{2} \mathrm{O}_{3}$ & 0,28 & 0,27 & 0,00 & 0,00 & 0,00 & 0,00 & 0,00 & 0,37 & 0,22 & 0,11 & 0,00 & 0,00 & 0,00 & 0,00 & 0,00 \\
\hline $\mathrm{FeO}$ & 22,81 & 22,77 & 22,64 & 21,67 & 21,65 & 21,73 & 21,89 & 21,66 & 21,88 & 22,10 & 22,34 & 22,27 & 22,95 & 23,13 & 23,23 \\
\hline $\mathrm{MnO}$ & 0,47 & 0,48 & 0,54 & 0,58 & 0,71 & 0,83 & 0,83 & 0,79 & 0,70 & 0,67 & 0,59 & 0,52 & 0,54 & 0,47 & 0,49 \\
\hline $\mathrm{MgO}$ & 6,57 & 6,60 & 6,43 & 6,09 & 5,86 & 5,38 & 5,46 & 5,63 & 5,96 & 6,20 & 6,37 & 6,52 & 6,57 & 6,74 & 6,34 \\
\hline $\mathrm{CaO}$ & 8,70 & 8,93 & 9,15 & 9,94 & 10,60 & 10,95 & 10,91 & 10,60 & 10,40 & 9,83 & 9,46 & 9,01 & 8,91 & 8,55 & 8,63 \\
\hline $\mathrm{Na}_{2} \mathrm{O}$ & 0,00 & 0,00 & 0,00 & 0,00 & 0,00 & 0,00 & 0,00 & 0,00 & 0,00 & 0,00 & 0,00 & 0,00 & 0,00 & 0,00 & 0,00 \\
\hline $\mathrm{K}_{2} \mathrm{O}$ & 0,00 & 0,00 & 0,00 & 0,00 & 0,00 & 0,00 & 0,00 & 0,00 & 0,00 & 0,00 & 0,00 & 0,00 & 0,00 & 0,00 & 0,00 \\
\hline Total & 99,39 & 99,72 & 99,49 & 99,10 & 99,92 & 99,16 & 99,82 & 99,23 & 100,03 & 99,51 & 99,68 & 99,44 & 100,00 & 99,88 & 99,99 \\
\hline Oxigênios & 12,00 & 12,00 & 12,00 & 12,00 & 12,00 & 12,00 & 12,00 & 12,00 & 12,00 & 12,00 & 12,00 & 12,00 & 12,00 & 12,00 & 12,00 \\
\hline $\mathrm{Si}$ & 2,986 & 2,996 & 3,008 & 3,009 & 3,001 & 3,007 & 3,024 & 2,992 & 2,992 & 2,999 & 3,020 & 3,007 & 3,019 & 3,002 & 3.020 \\
\hline $\mathrm{Ti}$ & 0,004 & 0,005 & 0,005 & 0,007 & 0,006 & 0,005 & 0,006 & 0,007 & 0,006 & 0,005 & 0,007 & 0,002 & 0,005 & 0,004 & 0,003 \\
\hline $\mathrm{Al}$ & 2,003 & 1,980 & 1,979 & 1,996 & 2,000 & 1,978 & 1,958 & 1,979 & 1,990 & 1,984 & 1,967 & 2,009 & 1,968 & 1,991 & 1,994 \\
\hline $\mathrm{Cr}$ & 0,001 & 0,002 & 0,004 & 0,003 & 0,000 & 0,001 & 0,000 & 0,002 & 0,000 & 0,000 & 0,001 & 0,002 & 0,000 & 0,002 & 0,000 \\
\hline $\mathrm{Fe}^{3+}$ & 0,016 & 0,016 & 0,000 & 0,000 & 0,000 & 0,000 & 0,000 & 0,022 & 0,013 & 0,006 & 0,000 & 0,000 & 0,000 & 0,000 & 0,000 \\
\hline $\mathrm{Fe}^{2-}$ & 1,478 & 1,471 & 1,465 & 1,405 & 1,394 & 1,415 & 1,415 & 1,410 & 1,410 & 1,430 & 1,441 & 1,437 & 1,477 & 1,490 & 1,494 \\
\hline $\mathrm{Mn}$ & 0,031 & 0,031 & 0,035 & 0,038 & 0,046 & 0,055 & 0,055 & 0,052 & 0,046 & 0,044 & 0,038 & 0,034 & 0,035 & 0,031 & 0,032 \\
\hline $\mathrm{Mg}$ & 0,759 & 0,760 & 0,741 & 0,703 & 0,672 & 0,624 & 0,629 & 0,653 & 0,684 & 0,715 & 0,732 & 0,750 & 0,753 & 0,774 & 0,727 \\
\hline $\mathrm{Ca}$ & 0,722 & 0,739 & 0,758 & 0,826 & 0,875 & 0,914 & 0,904 & 0,884 & 0,858 & 0,815 & 0,782 & 0,745 & 0,735 & 0,706 & 0,711 \\
\hline $\mathrm{Na}$ & 0,000 & 0,000 & 0,000 & 0,000 & 0,000 & 0,000 & 0,000 & 0,000 & 0,000 & 0,000 & 0,000 & 0,000 & 0,000 & 0,000 & 0,000 \\
\hline $\mathrm{K}$ & 0,000 & 0,000 & 0,000 & 0,000 & 0,000 & 0,000 & 0,000 & 0,000 & 0,000 & 0,000 & 0,000 & 0,000 & 0,000 & 0,000 & 0,000 \\
\hline Soma & 8,000 & 8,000 & 7,996 & 7,986 & 7,994 & 7,999 & 7,991 & 8,000 & 8,000 & 8,000 & 7,989 & 7,986 & 7,992 & 7,998 & 7,981 \\
\hline \multicolumn{16}{|l|}{ Membros-finais } \\
\hline Almandina & $49,43 \%$ & $49,02 \%$ & $48,85 \%$ & $47,27 \%$ & $46,67 \%$ & $47,04 \%$ & $47,12 \%$ & $47,02 \%$ & $47,03 \%$ & $47,60 \%$ & $48,15 \%$ & $48,45 \%$ & $49,23 \%$ & $49,65 \%$ & $50,40 \%$ \\
\hline Piropo & $25,38 \%$ & $25,32 \%$ & $24,71 \%$ & $23,65 \%$ & $22,50 \%$ & $20,74 \%$ & $20,95 \%$ & $21,77 \%$ & $22,82 \%$ & $23,80 \%$ & $24,46 \%$ & $25,29 \%$ & $25,10 \%$ & $25,79 \%$ & $24,53 \%$ \\
\hline Grossulária & $23,31 \%$ & $23,72 \%$ & $25,07 \%$ & $27,64 \%$ & $29,29 \%$ & $30,34 \%$ & $30,10 \%$ & $28,28 \%$ & $27,97 \%$ & $26,83 \%$ & $26,08 \%$ & $25,02 \%$ & $24,50 \%$ & $23,43 \%$ & $23,99 \%$ \\
\hline Espessartita & $1,04 \%$ & $1,03 \%$ & $1,17 \%$ & $1,28 \%$ & $1,54 \%$ & $1,83 \%$ & $1,83 \%$ & $1,73 \%$ & $1,53 \%$ & $1,46 \%$ & $1,27 \%$ & $1,15 \%$ & $1,17 \%$ & $1,03 \%$ & $1,08 \%$ \\
\hline Andradita & $0,79 \%$ & $0,80 \%$ & $0,00 \%$ & $0,00 \%$ & $0,00 \%$ & $0,00 \%$ & $0,00 \%$ & $1,10 \%$ & $0,65 \%$ & $0,30 \%$ & $0,00 \%$ & $0,00 \%$ & $0,00 \%$ & $0,00 \%$ & $0,00 \%$ \\
\hline Uvarovita & $0,05 \%$ & $0,10 \%$ & $0,20 \%$ & $0,15 \%$ & $0,00 \%$ & $0,05 \%$ & $0,00 \%$ & $0,10 \%$ & $0,00 \%$ & $0,00 \%$ & $0,05 \%$ & $0,10 \%$ & $0,00 \%$ & $0,10 \%$ & $0,00 \%$ \\
\hline
\end{tabular}


Tabela 9- Análises químicas de granada da Nappe Três Pontas-Varginha

\begin{tabular}{|c|c|c|c|c|c|c|c|c|c|c|c|c|}
\hline \multicolumn{13}{|c|}{ TPR-01-B } \\
\hline Grão-Análise & grt3-1 & grt3-2 & grt3-3 & grt3-4 & grt3-5 & grt3-6 & grt3-7 & grt3-8 & grt3-9 & grt3-10 & grt3-11 & grt3-12 \\
\hline $\mathrm{SiO}_{2}$ & 38,78 & 38,88 & 39,01 & 38,86 & 38,73 & 39,51 & 38,80 & 38,47 & 38,91 & 38,98 & 38,69 & 38,94 \\
\hline $\mathrm{TiO}_{2}$ & 0,12 & 0,07 & 0,09 & 0,12 & 0,17 & 0,13 & 0,19 & 0,07 & 0,09 & 0,14 & 0,08 & 0,03 \\
\hline $\mathrm{Al}_{2} \mathrm{O}_{3}$ & 21,85 & 21,84 & 21,74 & 21,70 & 21,72 & 21,64 & 21,69 & 21,81 & 21,91 & 21,79 & 21,77 & 21,67 \\
\hline $\mathrm{Cr}_{2} \mathrm{O}_{3}$ & 0,05 & 0,04 & 0,04 & 0,06 & 0,05 & 0,02 & 0,00 & 0,03 & 0,04 & 0,05 & 0,07 & 0,07 \\
\hline $\mathrm{Fe}_{2} \mathrm{O}_{3}$ & 0,00 & 0,18 & 0,00 & 0,28 & 0,37 & 0,00 & 0,10 & 0,78 & 0,00 & 0,01 & 0,83 & 0,00 \\
\hline $\mathrm{FeO}$ & 23,45 & 23,11 & 23,12 & 22,88 & 22,78 & 23,22 & 22,79 & 22,58 & 23,19 & 23,53 & 23,11 & 23,87 \\
\hline $\mathrm{MnO}$ & 0,46 & 0,46 & 0,45 & 0,44 & 0,45 & 0,45 & 0,46 & 0,45 & 0,46 & 0,48 & 0,47 & 0,49 \\
\hline $\mathrm{MgO}$ & 6,51 & 6,87 & 6,82 & 6,85 & 6,91 & 6,90 & 6,91 & 6,85 & 6,84 & 6,92 & 6,92 & 6,34 \\
\hline $\mathrm{CaO}$ & 8,49 & 8,38 & 8,52 & 8,62 & 8,52 & 8,50 & 8,58 & 8,45 & 8,37 & 8,11 & 8,13 & 8,43 \\
\hline $\mathrm{Na}_{2} \mathrm{O}$ & 0,00 & 0,00 & 0,00 & 0,00 & 0,00 & 0,00 & 0,00 & 0,00 & 0,00 & 0,00 & 0,00 & 0,00 \\
\hline $\mathrm{K}_{2} \mathrm{O}$ & 0,00 & 0,00 & 0,00 & 0,00 & 0,00 & 0,00 & 0,00 & 0,00 & 0,00 & 0,00 & 0,00 & 0,00 \\
\hline Total & 99,71 & 99,82 & 99,80 & 99,80 & 99,69 & 100,37 & 99,53 & 99,48 & 99,81 & 100,01 & 100,06 & 99,84 \\
\hline Oxigênios & 12,00 & 12,00 & 12,00 & 12,00 & 12,00 & 12,00 & 12,00 & 12,00 & 12,00 & 12,00 & 12,00 & 12,00 \\
\hline $\mathrm{Si}$ & 2,998 & 2,997 & 3,007 & 2,997 & 2,990 & 3,026 & 2,998 & 2,977 & 2,999 & 3,001 & 2,981 & 3,011 \\
\hline $\mathrm{Ti}$ & 0,007 & 0,004 & 0,005 & 0,007 & 0,010 & 0,008 & 0,011 & 0,004 & 0,005 & 0,008 & 0,004 & 0,002 \\
\hline Al & 1,991 & 1,985 & 1,976 & 1,973 & 1,977 & 1,954 & 1,976 & 1,990 & 1,991 & 1,978 & 1,977 & 1,975 \\
\hline $\mathrm{Cr}$ & 0,003 & 0,002 & 0,002 & 0,003 & 0,003 & 0,001 & 0,000 & 0,002 & 0,002 & 0,003 & 0,004 & 0,004 \\
\hline $\mathrm{Fe}^{3+}$ & 0,000 & 0,010 & 0,000 & 0,016 & 0,022 & 0,000 & 0,006 & 0,046 & 0,000 & 0,001 & 0,048 & 0,000 \\
\hline $\mathrm{Fe}^{2-}$ & 1,516 & 1,490 & 1,491 & 1,475 & 1,470 & 1,487 & 1,473 & 1,461 & 1,495 & 1,515 & 1,489 & 1,544 \\
\hline $\mathrm{Mn}$ & 0,030 & 0,030 & 0,030 & 0,029 & 0,029 & 0,029 & 0,030 & 0,029 & 0,030 & 0,031 & 0,031 & 0,032 \\
\hline $\mathrm{Mg}$ & 0,750 & 0,789 & 0,784 & 0,787 & 0,795 & 0,787 & 0,796 & 0,790 & 0,786 & 0,794 & 0,795 & 0,731 \\
\hline $\mathrm{Ca}$ & 0,703 & 0,692 & 0,704 & 0,712 & 0,705 & 0,697 & 0,710 & 0,701 & 0,691 & 0,669 & 0,671 & 0,698 \\
\hline $\mathrm{Na}$ & 0,000 & 0,000 & 0,000 & 0,000 & 0,000 & 0,000 & 0,000 & 0,000 & 0,000 & 0,000 & 0,000 & 0,000 \\
\hline $\mathrm{K}$ & 0,000 & 0,000 & 0,000 & 0,000 & 0,000 & 0,000 & 0,000 & 0,000 & 0,000 & 0,000 & 0,000 & 0,000 \\
\hline Soma & 7,998 & 8,000 & 7,999 & 8,000 & 8,000 & 7,990 & 8,000 & 8,000 & 7,999 & 8,000 & 8,000 & 7,998 \\
\hline \multicolumn{13}{|l|}{ Membros-finais } \\
\hline Almandina & $50,55 \%$ & $49,65 \%$ & $49,55 \%$ & $49,12 \%$ & $49,02 \%$ & $49,57 \%$ & $48,95 \%$ & $49,01 \%$ & $49,80 \%$ & $50,35 \%$ & $49,87 \%$ & $51,38 \%$ \\
\hline Piropo & $25,01 \%$ & $26,29 \%$ & $26,06 \%$ & $26,21 \%$ & $26,51 \%$ & $26,23 \%$ & $26,45 \%$ & $26,50 \%$ & $26,18 \%$ & $26,39 \%$ & $26,62 \%$ & $24,33 \%$ \\
\hline Grossulária & $23,29 \%$ & $22,46 \%$ & $23,30 \%$ & $22,76 \%$ & $22,26 \%$ & $23,18 \%$ & $23,29 \%$ & $21,16 \%$ & $22,92 \%$ & $22,03 \%$ & $19,91 \%$ & $23,03 \%$ \\
\hline Espessartita & $1,00 \%$ & $1,00 \%$ & $1,00 \%$ & $0,97 \%$ & $0,97 \%$ & $0,97 \%$ & $1,00 \%$ & $0,97 \%$ & $1,00 \%$ & $1,03 \%$ & $1,04 \%$ & $1,06 \%$ \\
\hline Andradita & $0,00 \%$ & $0,50 \%$ & $0,00 \%$ & $0,80 \%$ & $1,10 \%$ & $0,00 \%$ & $0,30 \%$ & $2,26 \%$ & $0,00 \%$ & $0,05 \%$ & $2,37 \%$ & $0,00 \%$ \\
\hline Uvarovita & $0,15 \%$ & $0,10 \%$ & $0,10 \%$ & $0,15 \%$ & $0,15 \%$ & $0,05 \%$ & $0,00 \%$ & $0,10 \%$ & $0,10 \%$ & $0,15 \%$ & $0,20 \%$ & $0,20 \%$ \\
\hline
\end{tabular}


Tabela 10- Análises químicas de granada da Nappe Três Pontas-Varginha

\begin{tabular}{|c|c|c|c|c|c|c|c|c|c|c|c|c|c|c|c|}
\hline \multicolumn{16}{|c|}{ TPR-01-B } \\
\hline Grão-Análise & grt4-1 & grt4-2 & grt4-3 & grt4-4 & grt4-5 & grt4-6 & grt4-7 & grt4-8 & grt4-9 & grt4-10 & grt4-11 & grt4-12 & grt4-13 & grt4-14 & grt4-15 \\
\hline $\mathrm{SiO}_{2}$ & 38,55 & 38,87 & 38,70 & 39,16 & 39,14 & 38,91 & 39,46 & 39,15 & 38,81 & 39,31 & 39,13 & 39,25 & 39,29 & 38,91 & 39,38 \\
\hline $\mathrm{TiO}_{2}$ & 0,02 & 0,03 & 0,10 & 0,10 & 0,05 & 0,12 & 0,09 & 0,10 & 0,10 & 0,07 & 0,10 & 0,11 & 0,06 & 0,06 & 0,07 \\
\hline $\mathrm{Al}_{2} \mathrm{O}_{3}$ & 21,92 & 21,98 & 21,81 & 22,18 & 21,88 & 21,91 & 22,04 & 21,89 & 21,91 & 22,07 & 22,05 & 21,95 & 22,03 & 22,14 & 22,15 \\
\hline $\mathrm{Cr}_{2} \mathrm{O}_{3}$ & 0,02 & 0,04 & 0,01 & 0,01 & 0,00 & 0,00 & 0,01 & 0,01 & 0,03 & 0,02 & 0,00 & 0,00 & 0,02 & 0,00 & 0,02 \\
\hline $\mathrm{Fe}_{2} \mathrm{O}_{3}$ & 0,06 & 0,21 & 0,56 & 0,00 & 0,14 & 0,03 & 0,00 & 0,12 & 0,63 & 0,07 & 0,00 & 0,04 & 0,00 & 0,48 & 0,00 \\
\hline $\mathrm{FeO}$ & 23,71 & 23,39 & 23,08 & 23,37 & 23,50 & 23,31 & 23,27 & 23,01 & 22,65 & 23,33 & 23,38 & 23,53 & 23,76 & 23,29 & 23,25 \\
\hline $\mathrm{MnO}$ & 0,52 & 0,51 & 0,51 & 0,48 & 0,51 & 0,47 & 0,50 & 0,46 & 0,46 & 0,48 & 0,48 & 0,50 & 0,48 & 0,48 & 0,50 \\
\hline $\mathrm{MgO}$ & 6,20 & 6,79 & 6,93 & 6,80 & 7,02 & 6,97 & 6,96 & 6,93 & 7,06 & 6,86 & 6,89 & 6,99 & 6,87 & 6,79 & 6,44 \\
\hline $\mathrm{CaO}$ & 8,45 & 8,19 & 8,13 & 8,17 & 8,05 & 8,13 & 8,32 & 8,64 & 8,43 & 8,61 & 8,17 & 8,23 & 8,17 & 8,36 & 8,42 \\
\hline $\mathrm{Na}_{2} \mathrm{O}$ & 0,00 & 0,00 & 0,00 & 0,00 & 0,00 & 0,00 & 0,00 & 0,00 & 0,00 & 0,00 & 0,00 & 0,00 & 0,00 & 0,00 & 0,00 \\
\hline $\mathrm{K}_{2} \mathrm{O}$ & 0,00 & 0,00 & 0,00 & 0,00 & 0,00 & 0,00 & 0,00 & 0,00 & 0,00 & 0,00 & 0,00 & 0,00 & 0,00 & 0,00 & 0,00 \\
\hline Total & 99,45 & 100,02 & 99,83 & 100,26 & 100,28 & 99,85 & 100,66 & 100,31 & 100,07 & 100,81 & 100,20 & 100,59 & 100,68 & 100,51 & 100,22 \\
\hline Oxigênios & 12,00 & 12,00 & 12,00 & 12,00 & 12,00 & 12,00 & 12,00 & 12,00 & 12,00 & 12,00 & 12,00 & 12,00 & 12,00 & 12,00 & 12,00 \\
\hline $\mathrm{Si}$ & 2,993 & 2,993 & 2,986 & 3,002 & 3,004 & 2,997 & 3,012 & 3,001 & 2,983 & 3,000 & 3,003 & 3,003 & 3,004 & 2,982 & 3,019 \\
\hline $\mathrm{Ti}$ & 0,001 & 0,002 & 0,006 & 0,006 & 0,003 & 0,007 & 0,005 & 0,006 & 0,006 & 0,004 & 0,006 & 0,006 & 0,003 & 0,004 & 0,004 \\
\hline Al & 2,007 & 1,995 & 1,984 & 2,005 & 1,980 & 1,990 & 1,983 & 1,978 & 1,985 & 1,986 & 1,995 & 1,980 & 1,986 & 2,001 & 2,002 \\
\hline $\mathrm{Cr}$ & 0,001 & 0,002 & 0,001 & 0,000 & 0,000 & 0,000 & 0,001 & 0,001 & 0,002 & 0,001 & 0,000 & 0,000 & 0,001 & 0,000 & 0,001 \\
\hline $\mathrm{Fe}^{3+}$ & 0,004 & 0,012 & 0,032 & 0,000 & 0,008 & 0,002 & 0,000 & 0,007 & 0,036 & 0,004 & 0,000 & 0,002 & 0,000 & 0,028 & 0,000 \\
\hline $\mathrm{Fe}^{2-}$ & 1,540 & 1,507 & 1,489 & 1,498 & 1,508 & 1,502 & 1,485 & 1,475 & 1,456 & 1,489 & 1,500 & 1,505 & 1,520 & 1,493 & 1,491 \\
\hline $\mathrm{Mn}$ & 0,034 & 0,034 & 0,033 & 0,031 & 0,033 & 0,031 & 0,032 & 0,030 & 0,030 & 0,031 & 0,031 & 0,032 & 0,031 & 0,031 & 0,032 \\
\hline $\mathrm{Mg}$ & 0,717 & 0,779 & 0,797 & 0,777 & 0,803 & 0,800 & 0,792 & 0,792 & 0,809 & 0,780 & 0,788 & 0,797 & 0,783 & 0,776 & 0,736 \\
\hline $\mathrm{Ca}$ & 0,703 & 0,676 & 0,672 & 0,671 & 0,662 & 0,671 & 0,680 & 0,710 & 0,694 & 0,704 & 0,672 & 0,675 & 0,669 & 0,687 & 0,692 \\
\hline $\mathrm{Na}$ & 0,000 & 0,000 & 0,000 & 0,000 & 0,000 & 0,000 & 0,000 & 0,000 & 0,000 & 0,000 & 0,000 & 0,000 & 0,000 & 0,000 & 0,000 \\
\hline $\mathrm{K}$ & 0,000 & 0,000 & 0,000 & 0,000 & 0,000 & 0,000 & 0,000 & 0,000 & 0,000 & 0,000 & 0,000 & 0,000 & 0,000 & 0,000 & 0,000 \\
\hline Soma & 8,000 & 8,000 & 8,000 & 7,990 & 8,000 & 8,000 & 7,991 & 8,000 & 8,000 & 8,000 & 7,994 & 8,000 & 7,999 & 8,000 & 7,976 \\
\hline \multicolumn{16}{|l|}{ Membros-finais } \\
\hline Almandina & $51,44 \%$ & $50,30 \%$ & $49,78 \%$ & $50,32 \%$ & $50,17 \%$ & $50,00 \%$ & $49,68 \%$ & $49,05 \%$ & $48,71 \%$ & $49,57 \%$ & $50,15 \%$ & $50,02 \%$ & $50,62 \%$ & $49,98 \%$ & $50,53 \%$ \\
\hline Piropo & $23,95 \%$ & $26,00 \%$ & $26,65 \%$ & $26,10 \%$ & $26,71 \%$ & $26,63 \%$ & $26,50 \%$ & $26,34 \%$ & $27,07 \%$ & $25,97 \%$ & $26,35 \%$ & $26,49 \%$ & $26,07 \%$ & $25,98 \%$ & $24,94 \%$ \\
\hline Grossulária & $23,23 \%$ & $21,87 \%$ & $20,83 \%$ & $22,54 \%$ & $21,62 \%$ & $22,24 \%$ & $22,70 \%$ & $23,21 \%$ & $21,34 \%$ & $23,18 \%$ & $22,47 \%$ & $22,33 \%$ & $22,23 \%$ & $21,62 \%$ & $23,40 \%$ \\
\hline Espessartita & $1,14 \%$ & $1,13 \%$ & $1,10 \%$ & $1,04 \%$ & $1,10 \%$ & $1,03 \%$ & $1,07 \%$ & $1,00 \%$ & $1,00 \%$ & $1,03 \%$ & $1,04 \%$ & $1,06 \%$ & $1,03 \%$ & $1,04 \%$ & $1,08 \%$ \\
\hline Andradita & $0,20 \%$ & $0,60 \%$ & $1,59 \%$ & $0,00 \%$ & $0,40 \%$ & $0,10 \%$ & $0,00 \%$ & $0,35 \%$ & $1,78 \%$ & $0,20 \%$ & $0,00 \%$ & $0,10 \%$ & $0,00 \%$ & $1,38 \%$ & $0,00 \%$ \\
\hline Uvarovita & $0,05 \%$ & $0,10 \%$ & $0,05 \%$ & $0,00 \%$ & $0,00 \%$ & $0,00 \%$ & $0,05 \%$ & $0,05 \%$ & $0,10 \%$ & $0,05 \%$ & $0,00 \%$ & $0,00 \%$ & $0,05 \%$ & $0,00 \%$ & $0,05 \%$ \\
\hline
\end{tabular}


Tabela 11- Análises químicas de granada da Nappe Três Pontas-Varginha

\begin{tabular}{|c|c|c|c|c|c|c|c|c|c|c|c|c|c|}
\hline \multicolumn{14}{|c|}{ TPR-01-B } \\
\hline Grão-Análise & grt5-1 & grt5-2 & grt5-3 & grt5-5 & grt5-6 & grt5-7 & grt5-8 & grt5-10 & grt5-11 & grt5-12 & grt5-13 & grt5-14 & grt5-15 \\
\hline $\mathrm{SiO}_{2}$ & 38,82 & 38,75 & 39,00 & 38,82 & 39,14 & 39,35 & 38,94 & 38,68 & 39,34 & 39,49 & 38,80 & 39,13 & 38,81 \\
\hline $\mathrm{TiO}_{2}$ & 0,06 & 0,10 & 0,06 & 0,11 & 0,11 & 0,07 & 0,10 & 0,07 & 0,07 & 0,06 & 0,12 & 0,11 & 0,13 \\
\hline $\mathrm{Al}_{2} \mathrm{O}_{3}$ & 21,69 & 22,13 & 21,89 & 22,06 & 21,95 & 21,72 & 21,74 & 21,88 & 22,11 & 21,97 & 21,91 & 21,90 & 22,07 \\
\hline $\mathrm{Cr}_{2} \mathrm{O}_{3}$ & 0,04 & 0,04 & 0,04 & 0,04 & 0,04 & 0,02 & 0,05 & 0,03 & 0,00 & 0,03 & 0,06 & 0,03 & 0,03 \\
\hline $\mathrm{Fe}_{2} \mathrm{O}_{3}$ & 0,00 & 0,51 & 0,00 & 0,33 & 0,31 & 0,15 & 0,28 & 1,04 & 0,00 & 0,00 & 0,79 & 0,00 & 0,15 \\
\hline $\mathrm{FeO}$ & 24,74 & 23,76 & 23,66 & 22,88 & 22,77 & 22,67 & 22,43 & 21,77 & 22,45 & 22,83 & 22,14 & 23,02 & 23,45 \\
\hline $\mathrm{MnO}$ & 0,58 & 0,49 & 0,47 & 0,49 & 0,55 & 0,55 & 0,60 & 0,59 & 0,57 & 0,56 & 0,55 & 0,52 & 0,52 \\
\hline $\mathrm{MgO}$ & 5,89 & 6,69 & 6,85 & 6,73 & 6,61 & 6,47 & 6,29 & 6,18 & 6,35 & 6,44 & 6,54 & 6,51 & 6,29 \\
\hline $\mathrm{CaO}$ & 8,24 & 8,00 & 8,03 & 8,70 & 9,20 & 9,64 & 9,68 & 10,09 & 9,81 & 9,62 & 9,48 & 8,98 & 8,85 \\
\hline $\mathrm{Na}_{2} \mathrm{O}$ & 0,00 & 0,00 & 0,00 & 0,00 & 0,00 & 0,00 & 0,00 & 0,00 & 0,00 & 0,00 & 0,00 & 0,00 & 0,00 \\
\hline $\mathrm{K}_{2} \mathrm{O}$ & 0,00 & 0,00 & 0,00 & 0,00 & 0,00 & 0,00 & 0,00 & 0,00 & 0,00 & 0,00 & 0,00 & 0,00 & 0,00 \\
\hline Total & 100,06 & 100,48 & 100,00 & 100,16 & 100,68 & 100,65 & 100,11 & 100,32 & 100,71 & 101,00 & 100,39 & 100,20 & 100,30 \\
\hline Oxigênios & 12,00 & 12,00 & 12,00 & 12,00 & 12,00 & 12,00 & 12,00 & 12,00 & 12,00 & 12,00 & 12,00 & 12,00 & 12,00 \\
\hline $\mathrm{Si}$ & 3,007 & 2,976 & 3,003 & 2,984 & 2,994 & 3,011 & 2,998 & 2,974 & 3,004 & 3,010 & 2,977 & 3,006 & 2,986 \\
\hline $\mathrm{Ti}$ & 0,003 & 0,006 & 0,003 & 0,006 & 0,006 & 0,004 & 0,006 & 0,004 & 0,004 & 0,003 & 0,007 & 0,006 & 0,008 \\
\hline $\mathrm{Al}$ & 1,981 & 2,004 & 1,987 & 1,999 & 1,980 & 1,960 & 1,973 & 1,983 & 1,991 & 1,974 & 1,982 & 1,983 & 2,002 \\
\hline $\mathrm{Cr}$ & 0,002 & 0,002 & 0,003 & 0,002 & 0,002 & 0,001 & 0,003 & 0,002 & 0,000 & 0,002 & 0,004 & 0,002 & 0,002 \\
\hline $\mathrm{Fe}^{3+}$ & 0,000 & 0,030 & 0,000 & 0,019 & 0,018 & 0,009 & 0,016 & 0,060 & 0,000 & 0,000 & 0,046 & 0,000 & 0,009 \\
\hline $\mathrm{Fe}^{2-}$ & 1,603 & 1,526 & 1,524 & 1,471 & 1,457 & 1,451 & 1,444 & 1,400 & 1,434 & 1,455 & 1,421 & 1,479 & 1,509 \\
\hline $\mathrm{Mn}$ & 0,038 & 0,032 & 0,031 & 0,032 & 0,036 & 0,036 & 0,039 & 0,039 & 0,037 & 0,036 & 0,036 & 0,034 & 0,034 \\
\hline $\mathrm{Mg}$ & 0,680 & 0,766 & 0,786 & 0,771 & 0,754 & 0,738 & 0,722 & 0,708 & 0,723 & 0,732 & 0,748 & 0,745 & 0,721 \\
\hline $\mathrm{Ca}$ & 0,684 & 0,658 & 0,663 & 0,716 & 0,754 & 0,790 & 0,799 & 0,831 & 0,803 & 0,786 & 0,780 & 0,739 & 0,730 \\
\hline $\mathrm{Na}$ & 0,000 & 0,000 & 0,000 & 0,000 & 0,000 & 0,000 & 0,000 & 0,000 & 0,000 & 0,000 & 0,000 & 0,000 & 0,000 \\
\hline $\mathrm{K}$ & 0,000 & 0,000 & 0,000 & 0,000 & 0,000 & 0,000 & 0,000 & 0,000 & 0,000 & 0,000 & 0,000 & 0,000 & 0,000 \\
\hline Soma & 7,998 & 8,000 & 7,999 & 8,000 & 8,000 & 8,000 & 8,000 & 8,000 & 7,996 & 7,999 & 8,000 & 7,995 & 8,000 \\
\hline \multicolumn{14}{|l|}{ Membros-finais } \\
\hline Almandina & $53,34 \%$ & $51,17 \%$ & $50,73 \%$ & $49,20 \%$ & $48,55 \%$ & $48,13 \%$ & $48,07 \%$ & $47,01 \%$ & $47,85 \%$ & $48,35 \%$ & $47,60 \%$ & $49,35 \%$ & $50,40 \%$ \\
\hline Piropo & $22,63 \%$ & $25,69 \%$ & $26,17 \%$ & $25,79 \%$ & $25,12 \%$ & $24,48 \%$ & $24,03 \%$ & $23,77 \%$ & $24,12 \%$ & $24,33 \%$ & $25,06 \%$ & $24,86 \%$ & $24,08 \%$ \\
\hline Grossulária & $22,66 \%$ & $20,49 \%$ & $21,92 \%$ & $22,91 \%$ & $24,12 \%$ & $25,69 \%$ & $25,64 \%$ & $24,87 \%$ & $26,79 \%$ & $26,02 \%$ & $23,67 \%$ & $24,56 \%$ & $23,84 \%$ \\
\hline Espessartita & $1,26 \%$ & $1,07 \%$ & $1,03 \%$ & $1,07 \%$ & $1,20 \%$ & $1,19 \%$ & $1,30 \%$ & $1,31 \%$ & $1,23 \%$ & $1,20 \%$ & $1,21 \%$ & $1,13 \%$ & $1,14 \%$ \\
\hline Andradita & $0,00 \%$ & $1,47 \%$ & $0,00 \%$ & $0,94 \%$ & $0,90 \%$ & $0,46 \%$ & $0,80 \%$ & $2,93 \%$ & $0,00 \%$ & $0,00 \%$ & $2,26 \%$ & $0,00 \%$ & $0,45 \%$ \\
\hline Uvarovita & $0,10 \%$ & $0,10 \%$ & $0,15 \%$ & $0,10 \%$ & $0,10 \%$ & $0,05 \%$ & $0,15 \%$ & $0,10 \%$ & $0,00 \%$ & $0,10 \%$ & $0,20 \%$ & $0,10 \%$ & $0,10 \%$ \\
\hline
\end{tabular}


Tabela 12- Análises químicas de granada da Nappe Três Pontas-Varginha

\begin{tabular}{|c|c|c|c|c|c|c|c|c|c|c|c|c|c|c|c|}
\hline \multicolumn{16}{|c|}{ TPR-01-B } \\
\hline Grão-Análise & grt6-1 & grt6-2 & grt6-3 & grt6-4 & grt6-5 & grt6-6 & grt6-7 & grt6-8 & grt6-9 & grt6-10 & grt6-11 & grt6-12 & grt6-13 & grt6-14 & grt6-15 \\
\hline $\mathrm{SiO}_{2}$ & 38,87 & 38,89 & 39,03 & 39,31 & 39,20 & 39,10 & 39,29 & 39,22 & 39,28 & 39,33 & 39,46 & 38,77 & 39,13 & 38,91 & 38,78 \\
\hline $\mathrm{TiO}_{2}$ & 0,02 & 0,11 & 0,13 & 0,05 & 0,10 & 0,10 & 0,13 & 0,10 & 0,07 & 0,09 & 0,09 & 0,11 & 0,07 & 0,10 & 0,06 \\
\hline $\mathrm{Al}_{2} \mathrm{O}_{3}$ & 22,22 & 21,81 & 21,81 & 22,38 & 22,12 & 22,19 & 21,82 & 21,78 & 22,00 & 21,89 & 21,86 & 22,03 & 21,84 & 22,11 & 21,84 \\
\hline $\mathrm{Cr}_{2} \mathrm{O}_{3}$ & 0,00 & 0,01 & 0,04 & 0,00 & 0,02 & 0,00 & 0,02 & 0,01 & 0,00 & 0,00 & 0,00 & 0,00 & 0,00 & 0,03 & 0,01 \\
\hline $\mathrm{Fe}_{2} \mathrm{O}_{3}$ & 0,00 & 0,74 & 0,42 & 0,00 & 0,05 & 0,42 & 0,32 & 0,00 & 0,00 & 0,00 & 0,00 & 0,91 & 0,23 & 0,72 & 0,64 \\
\hline $\mathrm{FeO}$ & 23,84 & 23,25 & 23,10 & 22,98 & 22,66 & 22,45 & 22,77 & 23,20 & 23,33 & 23,23 & 23,22 & 22,46 & 23,22 & 22,99 & 23,53 \\
\hline $\mathrm{MnO}$ & 0,54 & 0,51 & 0,52 & 0,50 & 0,51 & 0,54 & 0,50 & 0,47 & 0,53 & 0,47 & 0,47 & 0,54 & 0,47 & 0,49 & 0,50 \\
\hline $\mathrm{MgO}$ & 6,16 & 6,56 & 6,58 & 6,70 & 6,71 & 6,64 & 6,69 & 6,69 & 6,79 & 6,79 & 6,74 & 6,83 & 6,76 & 6,75 & 6,23 \\
\hline $\mathrm{CaO}$ & 8,69 & 8,70 & 8,93 & 8,85 & 9,23 & 9,37 & 9,29 & 8,89 & 8,55 & 8,77 & 8,88 & 8,81 & 8,67 & 8,66 & 8,81 \\
\hline $\mathrm{Na}_{2} \mathrm{O}$ & 0,00 & 0,00 & 0,00 & 0,00 & 0,00 & 0,00 & 0,00 & 0,00 & 0,00 & 0,00 & 0,00 & 0,00 & 0,00 & 0,00 & 0,00 \\
\hline $\mathrm{K}_{2} \mathrm{O}$ & 0,00 & 0,00 & 0,00 & 0,00 & 0,00 & 0,00 & 0,00 & 0,00 & 0,00 & 0,00 & 0,00 & 0,00 & 0,00 & 0,00 & 0,00 \\
\hline Total & 100,35 & 100,58 & 100,56 & 100,78 & 100,60 & 100,81 & 100,83 & 100,36 & 100,55 & 100,58 & 100,72 & 100,46 & 100,39 & 100,76 & 100,40 \\
\hline Oxigênios & 12,00 & 12,00 & 12,00 & 12,00 & 12,00 & 12,00 & 12,00 & 12,00 & 12,00 & 12,00 & 12,00 & 12,00 & 12,00 & 12,00 & 12,00 \\
\hline $\mathrm{Si}$ & 2,991 & 2,985 & 2,993 & 2,997 & 2,996 & 2,984 & 3,000 & 3,009 & 3,006 & 3,009 & 3,014 & 2,972 & 3,002 & 2,976 & 2,986 \\
\hline $\mathrm{Ti}$ & 0,001 & 0,007 & 0,008 & 0,003 & 0,006 & 0,006 & 0,008 & 0,006 & 0,004 & 0,005 & 0,005 & 0,007 & 0,004 & 0,006 & 0,004 \\
\hline Al & 2,016 & 1,974 & 1,972 & 2,012 & 1,993 & 1,997 & 1,964 & 1,970 & 1,985 & 1,974 & 1,969 & 1,991 & 1,975 & 1,994 & 1,983 \\
\hline $\mathrm{Cr}$ & 0,000 & 0,000 & 0,003 & 0,000 & 0,001 & 0,000 & 0,001 & 0,001 & 0,000 & 0,000 & 0,000 & 0,000 & 0,000 & 0,002 & 0,001 \\
\hline $\mathrm{Fe}^{3+}$ & 0,000 & 0,043 & 0,024 & 0,000 & 0,003 & 0,024 & 0,019 & 0,000 & 0,000 & 0,000 & 0,000 & 0,053 & 0,013 & 0,041 & 0,037 \\
\hline $\mathrm{Fe}^{2-}$ & 1,534 & 1,493 & 1,481 & 1,465 & 1,448 & 1,433 & 1,454 & 1,489 & 1,493 & 1,486 & 1,483 & 1,440 & 1,490 & 1,471 & 1,515 \\
\hline $\mathrm{Mn}$ & 0,035 & 0,033 & 0,034 & 0,032 & 0,033 & 0,035 & 0,032 & 0,030 & 0,034 & 0,031 & 0,030 & 0,035 & 0,030 & 0,032 & 0,033 \\
\hline $\mathrm{Mg}$ & 0,706 & 0,750 & 0,752 & 0,761 & 0,764 & 0,755 & 0,761 & 0,765 & 0,774 & 0,774 & 0,767 & 0,780 & 0,773 & 0,769 & 0,715 \\
\hline $\mathrm{Ca}$ & 0,716 & 0,716 & 0,734 & 0,723 & 0,756 & 0,766 & 0,760 & 0,731 & 0,701 & 0,719 & 0,727 & 0,724 & 0,713 & 0,710 & 0,727 \\
\hline $\mathrm{Na}$ & 0,000 & 0,000 & 0,000 & 0,000 & 0,000 & 0,000 & 0,000 & 0,000 & 0,000 & 0,000 & 0,000 & 0,000 & 0,000 & 0,000 & 0,000 \\
\hline $\mathrm{K}$ & 0,000 & 0,000 & 0,000 & 0,000 & 0,000 & 0,000 & 0,000 & 0,000 & 0,000 & 0,000 & 0,000 & 0,000 & 0,000 & 0,000 & 0,000 \\
\hline Soma & 8,000 & 8,000 & 8,000 & 7,994 & 8,000 & 8,000 & 8,000 & 8,000 & 7,998 & 7,999 & 7,996 & 8,000 & 8,000 & 8,000 & 8,000 \\
\hline \multicolumn{16}{|l|}{ Membros-finais } \\
\hline Almandina & $51,29 \%$ & $49,90 \%$ & $49,35 \%$ & $49,14 \%$ & $48,25 \%$ & $47,94 \%$ & $48,35 \%$ & $49,39 \%$ & $49,73 \%$ & $49,37 \%$ & $49,32 \%$ & $48,34 \%$ & $49,57 \%$ & $49,33 \%$ & $50,67 \%$ \\
\hline Piropo & $23,60 \%$ & $25,07 \%$ & $25,06 \%$ & $25,53 \%$ & $25,46 \%$ & $25,26 \%$ & $25,31 \%$ & $25,37 \%$ & $25,78 \%$ & $25,71 \%$ & $25,51 \%$ & $26,18 \%$ & $25,72 \%$ & $25,79 \%$ & $23,91 \%$ \\
\hline Grossulária & $23,94 \%$ & $21,80 \%$ & $23,11 \%$ & $24,25 \%$ & $24,99 \%$ & $24,44 \%$ & $24,27 \%$ & $24,19 \%$ & $23,35 \%$ & $23,89 \%$ & $24,18 \%$ & $21,71 \%$ & $23,07 \%$ & $21,70 \%$ & $22,43 \%$ \\
\hline Espessartita & $1,17 \%$ & $1,10 \%$ & $1,13 \%$ & $1,07 \%$ & $1,10 \%$ & $1,17 \%$ & $1,06 \%$ & $1,00 \%$ & $1,13 \%$ & $1,03 \%$ & $1,00 \%$ & $1,17 \%$ & $1,00 \%$ & $1,07 \%$ & $1,10 \%$ \\
\hline Andradita & $0,00 \%$ & $2,13 \%$ & $1,20 \%$ & $0,00 \%$ & $0,15 \%$ & $1,19 \%$ & $0,96 \%$ & $0,00 \%$ & $0,00 \%$ & $0,00 \%$ & $0,00 \%$ & $2,59 \%$ & $0,65 \%$ & $2,01 \%$ & $1,83 \%$ \\
\hline Uvarovita & $0,00 \%$ & $0,00 \%$ & $0,15 \%$ & $0,00 \%$ & $0,05 \%$ & $0,00 \%$ & $0,05 \%$ & $0,05 \%$ & $0,00 \%$ & $0,00 \%$ & $0,00 \%$ & $0,00 \%$ & $0,00 \%$ & $0,10 \%$ & $0,05 \%$ \\
\hline
\end{tabular}


Tabela 13- Análises químicas de granada da Nappe Três Pontas-Varginha

\begin{tabular}{|c|c|c|c|c|c|c|c|c|c|c|c|c|c|c|c|}
\hline \multicolumn{16}{|c|}{ TPR-01-B } \\
\hline Grão-Análise & grt7-1 & grt7-2 & grt7-3 & grt7-4 & grt7-5 & grt7-6 & grt7-7 & grt7-8 & grt7-9 & grt7-10 & grt7-11 & grt7-12 & grt7-13 & grt7-14 & grt7-15 \\
\hline $\mathrm{SiO}_{2}$ & 38,84 & 39,01 & 39,06 & 39,21 & 38,88 & 39,02 & 39,01 & 38,85 & 39,11 & 39,10 & 38,98 & 39,24 & 39,17 & 38,91 & 38,88 \\
\hline $\mathrm{TiO}_{2}$ & 0,06 & 0,09 & 0,10 & 0,11 & 0,07 & 0,11 & 0,08 & 0,10 & 0,11 & 0,09 & 0,06 & 0,08 & 0,11 & 0,07 & 0,11 \\
\hline $\mathrm{Al}_{2} \mathrm{O}_{3}$ & 21,99 & 22,16 & 21,85 & 22,13 & 22,14 & 21,95 & 22,00 & 21,75 & 21,99 & 22,03 & 21,77 & 21,78 & 21,77 & 21,94 & 22,04 \\
\hline $\mathrm{Cr}_{2} \mathrm{O}_{3}$ & 0,03 & 0,01 & 0,00 & 0,00 & 0,03 & 0,03 & 0,03 & 0,00 & 0,04 & 0,04 & 0,03 & 0,02 & 0,03 & 0,03 & 0,02 \\
\hline $\mathrm{Fe}_{2} \mathrm{O}_{3}$ & 0,11 & 0,42 & 0,00 & 0,00 & 0,42 & 0,44 & 0,16 & 0,29 & 0,00 & 0,16 & 0,32 & 0,41 & 0,50 & 0,42 & 0,04 \\
\hline $\mathrm{FeO}$ & 25,12 & 23,73 & 23,59 & 23,58 & 22,72 & 22,82 & 22,99 & 22,61 & 22,73 & 22,61 & 22,28 & 22,42 & 22,35 & 22,87 & 24,12 \\
\hline $\mathrm{MnO}$ & 0,58 & 0,48 & 0,47 & 0,48 & 0,51 & 0,47 & 0,50 & 0,52 & 0,51 & 0,52 & 0,55 & 0,55 & 0,53 & 0,51 & 0,58 \\
\hline $\mathrm{MgO}$ & 5,97 & 6,81 & 6,85 & 6,98 & 6,96 & 6,84 & 6,85 & 6,78 & 6,74 & 6,65 & 6,57 & 6,55 & 6,67 & 6,60 & 6,18 \\
\hline $\mathrm{CaO}$ & 7,92 & 8,09 & 8,00 & 8,02 & 8,52 & 8,79 & 8,60 & 8,84 & 9,04 & 9,25 & 9,46 & 9,63 & 9,50 & 8,93 & 8,48 \\
\hline $\mathrm{Na}_{2} \mathrm{O}$ & 0,00 & 0,00 & 0,00 & 0,00 & 0,00 & 0,00 & 0,00 & 0,00 & 0,00 & 0,00 & 0,00 & 0,00 & 0,00 & 0,00 & 0,00 \\
\hline $\mathrm{K}_{2} \mathrm{O}$ & 0,00 & 0,00 & 0,00 & 0,00 & 0,00 & 0,00 & 0,00 & 0,00 & 0,00 & 0,00 & 0,00 & 0,00 & 0,00 & 0,00 & 0,00 \\
\hline Total & 100,61 & 100,80 & 99,93 & 100,51 & 100,26 & 100,48 & 100,22 & 99,75 & 100,28 & 100,44 & 100,03 & 100,68 & 100,63 & 100,27 & 100,45 \\
\hline Oxigênios & 12,00 & 12,00 & 12,00 & 12,00 & 12,00 & 12,00 & 12,00 & 12,00 & 12,00 & 12,00 & 12,00 & 12,00 & 12,00 & 12,00 & 12,00 \\
\hline $\mathrm{Si}$ & 2,994 & 2,984 & 3,008 & 3,000 & 2,982 & 2,989 & 2,994 & 2,997 & 2,999 & 2,995 & 2,999 & 3,001 & 2,996 & 2,989 & 2,992 \\
\hline $\mathrm{Ti}$ & 0,003 & 0,005 & 0,006 & 0,006 & 0,004 & 0,006 & 0,005 & 0,006 & 0,007 & 0,005 & 0,004 & 0,004 & 0,006 & 0,004 & 0,006 \\
\hline Al & 1,998 & 1,998 & 1,984 & 1,996 & 2,002 & 1,982 & 1,991 & 1,978 & 1,988 & 1,989 & 1,974 & 1,964 & 1,963 & 1,987 & 2,000 \\
\hline $\mathrm{Cr}$ & 0,002 & 0,000 & 0,000 & 0,000 & 0,002 & 0,002 & 0,002 & 0,000 & 0,003 & 0,002 & 0,002 & 0,001 & 0,002 & 0,002 & 0,001 \\
\hline $\mathrm{Fe}^{3+}$ & 0,006 & 0,024 & 0,000 & 0,000 & 0,024 & 0,025 & 0,010 & 0,017 & 0,000 & 0,009 & 0,019 & 0,024 & 0,029 & 0,024 & 0,002 \\
\hline $\mathrm{Fe}^{2-}$ & 1,619 & 1,518 & 1,519 & 1,509 & 1,457 & 1,462 & 1,476 & 1,459 & 1,458 & 1,448 & 1,433 & 1,434 & 1,430 & 1,469 & 1,552 \\
\hline $\mathrm{Mn}$ & 0,038 & 0,031 & 0,031 & 0,031 & 0,033 & 0,031 & 0,032 & 0,034 & 0,033 & 0,033 & 0,036 & 0,036 & 0,034 & 0,033 & 0,038 \\
\hline $\mathrm{Mg}$ & 0,686 & 0,776 & 0,786 & 0,796 & 0,795 & 0,781 & 0,784 & 0,779 & 0,770 & 0,759 & 0,753 & 0,747 & 0,760 & 0,756 & 0,709 \\
\hline $\mathrm{Ca}$ & 0,654 & 0,663 & 0,660 & 0,657 & 0,700 & 0,721 & 0,707 & 0,731 & 0,743 & 0,759 & 0,780 & 0,789 & 0,779 & 0,735 & 0,699 \\
\hline $\mathrm{Na}$ & 0,000 & 0,000 & 0,000 & 0,000 & 0,000 & 0,000 & 0,000 & 0,000 & 0,000 & 0,000 & 0,000 & 0,000 & 0,000 & 0,000 & 0,000 \\
\hline $\mathrm{K}$ & 0,000 & 0,000 & 0,000 & 0,000 & 0,000 & 0,000 & 0,000 & 0,000 & 0,000 & 0,000 & 0,000 & 0,000 & 0,000 & 0,000 & 0,000 \\
\hline Soma & 8,000 & 8,000 & 7,994 & 7,996 & 8,000 & 8,000 & 8,000 & 8,000 & 8,000 & 8,000 & 8,000 & 8,000 & 8,000 & 8,000 & 8,000 \\
\hline \multicolumn{16}{|l|}{ Membros-finais } \\
\hline Almandina & $54,02 \%$ & $50,80 \%$ & $50,70 \%$ & $50,42 \%$ & $48,81 \%$ & $48,81 \%$ & $49,22 \%$ & $48,58 \%$ & $48,54 \%$ & $48,28 \%$ & $47,73 \%$ & $47,70 \%$ & $47,62 \%$ & $49,08 \%$ & $51,77 \%$ \\
\hline Piropo & $22,89 \%$ & $25,97 \%$ & $26,23 \%$ & $26,60 \%$ & $26,63 \%$ & $26,08 \%$ & $26,14 \%$ & $25,94 \%$ & $25,63 \%$ & $25,31 \%$ & $25,08 \%$ & $24,85 \%$ & $25,31 \%$ & $25,26 \%$ & $23,65 \%$ \\
\hline Grossulária & $21,42 \%$ & $21,00 \%$ & $22,03 \%$ & $21,95 \%$ & $22,17 \%$ & $22,73 \%$ & $22,98 \%$ & $23,49 \%$ & $24,58 \%$ & $24,76 \%$ & $24,93 \%$ & $24,99 \%$ & $24,39 \%$ & $23,27 \%$ & $23,17 \%$ \\
\hline Espessartita & $1,27 \%$ & $1,04 \%$ & $1,03 \%$ & $1,04 \%$ & $1,11 \%$ & $1,04 \%$ & $1,07 \%$ & $1,13 \%$ & $1,10 \%$ & $1,10 \%$ & $1,20 \%$ & $1,20 \%$ & $1,13 \%$ & $1,10 \%$ & $1,27 \%$ \\
\hline Andradita & $0,30 \%$ & $1,19 \%$ & $0,00 \%$ & $0,00 \%$ & $1,18 \%$ & $1,24 \%$ & $0,50 \%$ & $0,85 \%$ & $0,00 \%$ & $0,45 \%$ & $0,95 \%$ & $1,21 \%$ & $1,45 \%$ & $1,19 \%$ & $0,10 \%$ \\
\hline Uvarovita & $0,10 \%$ & $0,00 \%$ & $0,00 \%$ & $0,00 \%$ & $0,10 \%$ & $0,10 \%$ & $0,10 \%$ & $0,00 \%$ & $0,15 \%$ & $0,10 \%$ & $0,10 \%$ & $0,05 \%$ & $0,10 \%$ & $0,10 \%$ & $0,05 \%$ \\
\hline
\end{tabular}


Tabela 14- Análises químicas de granada da Nappe Três Pontas-Varginha

\begin{tabular}{|c|c|c|c|c|c|c|c|c|c|c|c|c|}
\hline \multicolumn{13}{|c|}{ TPR-01-F1 } \\
\hline Grão-Análise & grt1-1 & grt1-2 & grt1-3 & grt1-4 & grt1-5 & grt1-6 & grt1-7 & grt1-8 & grt1-9 & grt1-10 & grt1-11 & grt1-12 \\
\hline $\mathrm{SiO}_{2}$ & 39,68 & 39,50 & 39,71 & 39,48 & 39,78 & 39,62 & 39,38 & 39,46 & 39,58 & 39,75 & 39,24 & 38,92 \\
\hline $\mathrm{TiO}_{2}$ & 0,07 & 0,08 & 0,10 & 0,08 & 0,07 & 0,08 & 0,15 & 0,08 & 0,05 & 0,00 & 0,04 & 0,03 \\
\hline $\mathrm{Al}_{2} \mathrm{O}_{3}$ & 22,50 & 22,51 & 22,39 & 22,50 & 22,73 & 22,35 & 22,29 & 22,40 & 22,58 & 22,42 & 22,30 & 22,14 \\
\hline $\mathrm{Cr}_{2} \mathrm{O}_{3}$ & 0,04 & 0,05 & 0,08 & 0,09 & 0,13 & 0,01 & 0,04 & 0,04 & 0,05 & 0,07 & 0,08 & 0,10 \\
\hline $\mathrm{Fe}_{2} \mathrm{O}_{3}$ & 0,00 & 0,04 & 0,00 & 0,32 & 0,00 & 0,23 & 0,59 & 0,09 & 0,00 & 0,23 & 0,27 & 1,24 \\
\hline $\mathrm{FeO}$ & 21,51 & 20,69 & 20,81 & 20,25 & 20,23 & 20,17 & 19,93 & 20,17 & 20,32 & 20,46 & 20,37 & 19,91 \\
\hline $\mathrm{MnO}$ & 0,45 & 0,44 & 0,46 & 0,46 & 0,44 & 0,49 & 0,46 & 0,47 & 0,46 & 0,42 & 0,43 & 0,45 \\
\hline $\mathrm{MgO}$ & 6,45 & 7,39 & 7,45 & 7,46 & 7,48 & 7,53 & 7,53 & 7,43 & 7,37 & 7,45 & 7,49 & 7,26 \\
\hline $\mathrm{CaO}$ & 10,29 & 10,14 & 10,06 & 10,36 & 10,30 & 10,43 & 10,47 & 10,44 & 10,47 & 10,43 & 9,99 & 10,35 \\
\hline $\mathrm{Na}_{2} \mathrm{O}$ & 0,00 & 0,00 & 0,00 & 0,00 & 0,00 & 0,00 & 0,00 & 0,00 & 0,00 & 0,00 & 0,00 & 0,00 \\
\hline $\mathrm{K}_{2} \mathrm{O}$ & 0,00 & 0,00 & 0,00 & 0,00 & 0,00 & 0,00 & 0,00 & 0,00 & 0,00 & 0,00 & 0,00 & 0,00 \\
\hline Total & 101,00 & 100,85 & 101,07 & 100,98 & 101,16 & 100,91 & 100,84 & 100,57 & 100,88 & 101,23 & 100,22 & 100,40 \\
\hline Oxigênios & 12,00 & 12,00 & 12,00 & 12,00 & 12,00 & 12,00 & 12,00 & 12,00 & 12,00 & 12,00 & 12,00 & 12,00 \\
\hline $\mathrm{Si}$ & 3,008 & 2,989 & 2,998 & 2,982 & 2,993 & 2,993 & 2,979 & 2,991 & 2,991 & 2,996 & 2,987 & 2,965 \\
\hline $\mathrm{Ti}$ & 0,004 & 0,004 & 0,006 & 0,004 & 0,004 & 0,005 & 0,008 & 0,005 & 0,003 & 0,000 & 0,002 & 0,002 \\
\hline Al & 2,011 & 2,008 & 1,993 & 2,004 & 2,016 & 1,991 & 1,988 & 2,002 & 2,011 & 1,992 & 2,001 & 1,989 \\
\hline $\mathrm{Cr}$ & 0,002 & 0,003 & 0,005 & 0,005 & 0,008 & 0,001 & 0,003 & 0,002 & 0,003 & 0,004 & 0,005 & 0,006 \\
\hline $\mathrm{Fe}^{3+}$ & 0,000 & 0,003 & 0,000 & 0,018 & 0,000 & 0,013 & 0,034 & 0,005 & 0,000 & 0,013 & 0,016 & 0,071 \\
\hline $\mathrm{Fe}^{2-}$ & 1,364 & 1,309 & 1,314 & 1,279 & 1,273 & 1,274 & 1,261 & 1,279 & 1,284 & 1,290 & 1,297 & 1,269 \\
\hline $\mathrm{Mn}$ & 0,029 & 0,028 & 0,030 & 0,029 & 0,028 & 0,031 & 0,029 & 0,030 & 0,030 & 0,027 & 0,028 & 0,029 \\
\hline $\mathrm{Mg}$ & 0,729 & 0,833 & 0,838 & 0,840 & 0,839 & 0,848 & 0,849 & 0,839 & 0,830 & 0,837 & 0,850 & 0,824 \\
\hline $\mathrm{Ca}$ & 0,836 & 0,822 & 0,814 & 0,839 & 0,830 & 0,844 & 0,849 & 0,848 & 0,848 & 0,842 & 0,815 & 0,845 \\
\hline $\mathrm{Na}$ & 0,000 & 0,000 & 0,000 & 0,000 & 0,000 & 0,000 & 0,000 & 0,000 & 0,000 & 0,000 & 0,000 & 0,000 \\
\hline $\mathrm{K}$ & 0,000 & 0,000 & 0,000 & 0,000 & 0,000 & 0,000 & 0,000 & 0,000 & 0,000 & 0,000 & 0,000 & 0,000 \\
\hline Soma & 7,982 & 8,000 & 7,998 & 8,000 & 7,991 & 8,000 & 8,000 & 8,000 & 8,000 & 8,000 & 8,000 & 8,000 \\
\hline \multicolumn{13}{|l|}{ Membros-finais } \\
\hline Almandina & $46,11 \%$ & $43,75 \%$ & $43,86 \%$ & $42,82 \%$ & $42,86 \%$ & $42,51 \%$ & $42,20 \%$ & $42,69 \%$ & $42,91 \%$ & $43,06 \%$ & $43,38 \%$ & $42,77 \%$ \\
\hline Piropo & $24,65 \%$ & $27,84 \%$ & $27,97 \%$ & $28,12 \%$ & $28,25 \%$ & $28,29 \%$ & $28,41 \%$ & $28,00 \%$ & $27,74 \%$ & $27,94 \%$ & $28,43 \%$ & $27,77 \%$ \\
\hline Grossulária & $28,16 \%$ & $27,18 \%$ & $26,92 \%$ & $26,95 \%$ & $27,55 \%$ & $27,46 \%$ & $26,59 \%$ & $27,96 \%$ & $28,19 \%$ & $27,26 \%$ & $26,22 \%$ & $24,75 \%$ \\
\hline Espessartita & $0,98 \%$ & $0,94 \%$ & $1,00 \%$ & $0,97 \%$ & $0,94 \%$ & $1,03 \%$ & $0,97 \%$ & $1,00 \%$ & $1,00 \%$ & $0,90 \%$ & $0,94 \%$ & $0,98 \%$ \\
\hline Andradita & $0,00 \%$ & $0,15 \%$ & $0,00 \%$ & $0,89 \%$ & $0,00 \%$ & $0,65 \%$ & $1,68 \%$ & $0,25 \%$ & $0,00 \%$ & $0,65 \%$ & $0,79 \%$ & $3,44 \%$ \\
\hline Uvarovita & $0,10 \%$ & $0,15 \%$ & $0,25 \%$ & $0,25 \%$ & $0,40 \%$ & $0,05 \%$ & $0,15 \%$ & $0,10 \%$ & $0,15 \%$ & $0,20 \%$ & $0,25 \%$ & $0,29 \%$ \\
\hline
\end{tabular}


Tabela 15- Análises químicas de granada da Nappe Três Pontas-Varginha

\begin{tabular}{|c|c|c|c|c|c|c|c|c|c|c|c|c|}
\hline \multicolumn{13}{|c|}{ TPR-01-F1 } \\
\hline Grão-Análise & grt2-1 & grt2-2 & grt2-3 & grt2-4 & grt2-5 & grt2-6 & grt2-7 & grt2-8 & grt2-9 & grt2-10 & grt2-11 & grt2-12 \\
\hline $\mathrm{SiO}_{2}$ & 39,36 & 39,52 & 39,38 & 39,61 & 39,76 & 39,47 & 39,59 & 39,37 & 39,49 & 39,65 & 39,38 & 38,78 \\
\hline $\mathrm{TiO}_{2}$ & 0,06 & 0,06 & 0,12 & 0,09 & 0,05 & 0,08 & 0,09 & 0,12 & 0,09 & 0,07 & 0,05 & 0,00 \\
\hline $\mathrm{Al}_{2} \mathrm{O}_{3}$ & 22,40 & 22,41 & 22,36 & 22,46 & 22,38 & 22,33 & 22,34 & 22,29 & 22,33 & 22,36 & 22,21 & 22,14 \\
\hline $\mathrm{Cr}_{2} \mathrm{O}_{3}$ & 0,09 & 0,11 & 0,12 & 0,02 & 0,12 & 0,13 & 0,06 & 0,05 & 0,08 & 0,05 & 0,13 & 0,13 \\
\hline $\mathrm{Fe}_{2} \mathrm{O}_{3}$ & 0,00 & 0,05 & 0,24 & 0,00 & 0,00 & 0,51 & 0,56 & 0,12 & 0,00 & 0,00 & 0,03 & 0,98 \\
\hline $\mathrm{FeO}$ & 21,87 & 20,83 & 20,12 & 20,18 & 20,29 & 19,99 & 19,87 & 20,08 & 20,64 & 20,71 & 20,90 & 20,68 \\
\hline $\mathrm{MnO}$ & 0,50 & 0,47 & 0,45 & 0,48 & 0,47 & 0,48 & 0,46 & 0,46 & 0,45 & 0,44 & 0,47 & 0,50 \\
\hline $\mathrm{MgO}$ & 6,38 & 7,21 & 7,42 & 7,34 & 7,26 & 7,42 & 7,58 & 7,48 & 7,37 & 7,37 & 7,24 & 6,72 \\
\hline $\mathrm{CaO}$ & 10,30 & 10,27 & 10,46 & 10,37 & 10,47 & 10,59 & 10,59 & 10,39 & 10,19 & 9,96 & 10,03 & 10,31 \\
\hline $\mathrm{Na}_{2} \mathrm{O}$ & 0,00 & 0,00 & 0,00 & 0,00 & 0,00 & 0,00 & 0,00 & 0,00 & 0,00 & 0,00 & 0,00 & 0,00 \\
\hline $\mathrm{K}_{2} \mathrm{O}$ & 0,00 & 0,00 & 0,00 & 0,00 & 0,00 & 0,00 & 0,00 & 0,00 & 0,00 & 0,00 & 0,00 & 0,00 \\
\hline Total & 100,96 & 100,94 & 100,67 & 100,54 & 100,80 & 101,00 & 101,14 & 100,36 & 100,64 & 100,61 & 100,44 & 100,23 \\
\hline Oxigênios & 12,00 & 12,00 & 12,00 & 12,00 & 12,00 & 12,00 & 12,00 & 12,00 & 12,00 & 12,00 & 12,00 & 12,00 \\
\hline $\mathrm{Si}$ & 2,993 & 2,992 & 2,984 & 3,000 & 3,006 & 2,982 & 2,985 & 2,990 & 2,995 & 3,005 & 2,996 & 2,969 \\
\hline $\mathrm{Ti}$ & 0,004 & 0,004 & 0,007 & 0,005 & 0,003 & 0,004 & 0,005 & 0,007 & 0,005 & 0,004 & 0,003 & 0,000 \\
\hline Al & 2,008 & 2,000 & 1,997 & 2,006 & 1,995 & 1,989 & 1,986 & 1,996 & 1,996 & 1,998 & 1,992 & 1,998 \\
\hline $\mathrm{Cr}$ & 0,005 & 0,007 & 0,007 & 0,001 & 0,007 & 0,008 & 0,003 & 0,003 & 0,005 & 0,003 & 0,008 & 0,008 \\
\hline $\mathrm{Fe}^{3+}$ & 0,000 & 0,003 & 0,014 & 0,000 & 0,000 & 0,029 & 0,032 & 0,007 & 0,000 & 0,000 & 0,002 & 0,056 \\
\hline $\mathrm{Fe}^{2-}$ & 1,391 & 1,319 & 1,275 & 1,278 & 1,283 & 1,263 & 1,253 & 1,275 & 1,309 & 1,313 & 1,330 & 1,324 \\
\hline $\mathrm{Mn}$ & 0,032 & 0,030 & 0,029 & 0,031 & 0,030 & 0,031 & 0,029 & 0,029 & 0,029 & 0,028 & 0,030 & 0,032 \\
\hline $\mathrm{Mg}$ & 0,723 & 0,813 & 0,838 & 0,829 & 0,818 & 0,836 & 0,852 & 0,847 & 0,833 & 0,832 & 0,821 & 0,767 \\
\hline $\mathrm{Ca}$ & 0,839 & 0,833 & 0,849 & 0,842 & 0,848 & 0,857 & 0,855 & 0,846 & 0,828 & 0,809 & 0,818 & 0,846 \\
\hline $\mathrm{Na}$ & 0,000 & 0,000 & 0,000 & 0,000 & 0,000 & 0,000 & 0,000 & 0,000 & 0,000 & 0,000 & 0,000 & 0,000 \\
\hline $\mathrm{K}$ & 0,000 & 0,000 & 0,000 & 0,000 & 0,000 & 0,000 & 0,000 & 0,000 & 0,000 & 0,000 & 0,000 & 0,000 \\
\hline Soma & 7,997 & 8,000 & 8,000 & 7,992 & 7,990 & 8,000 & 8,000 & 8,000 & 8,000 & 7,991 & 8,000 & 8,000 \\
\hline \multicolumn{13}{|l|}{ Membros-finais } \\
\hline Almandina & $46,60 \%$ & $44,04 \%$ & $42,63 \%$ & $42,89 \%$ & $43,07 \%$ & $42,28 \%$ & $41,92 \%$ & $42,54 \%$ & $43,65 \%$ & $44,03 \%$ & $44,35 \%$ & $44,59 \%$ \\
\hline Piropo & $24,22 \%$ & $27,15 \%$ & $28,02 \%$ & $27,82 \%$ & $27,46 \%$ & $27,99 \%$ & $28,50 \%$ & $28,26 \%$ & $27,78 \%$ & $27,90 \%$ & $27,38 \%$ & $25,83 \%$ \\
\hline Grossulária & $27,86 \%$ & $27,32 \%$ & $27,34 \%$ & $28,21 \%$ & $28,12 \%$ & $26,86 \%$ & $26,87 \%$ & $27,73 \%$ & $27,36 \%$ & $26,98 \%$ & $26,78 \%$ & $25,39 \%$ \\
\hline Espessartita & $1,07 \%$ & $1,00 \%$ & $0,97 \%$ & $1,04 \%$ & $1,01 \%$ & $1,04 \%$ & $0,97 \%$ & $0,97 \%$ & $0,97 \%$ & $0,94 \%$ & $1,00 \%$ & $1,08 \%$ \\
\hline Andradita & $0,00 \%$ & $0,15 \%$ & $0,69 \%$ & $0,00 \%$ & $0,00 \%$ & $1,43 \%$ & $1,58 \%$ & $0,35 \%$ & $0,00 \%$ & $0,00 \%$ & $0,10 \%$ & $2,72 \%$ \\
\hline Uvarovita & $0,25 \%$ & $0,35 \%$ & $0,35 \%$ & $0,05 \%$ & $0,35 \%$ & $0,39 \%$ & $0,15 \%$ & $0,15 \%$ & $0,25 \%$ & $0,15 \%$ & $0,40 \%$ & $0,39 \%$ \\
\hline
\end{tabular}


Tabela 16- Análises químicas de granada da Nappe Três Pontas-Varginha

\begin{tabular}{|c|c|c|c|c|c|c|c|c|c|c|c|c|c|c|}
\hline \multicolumn{15}{|c|}{ TPR-01-F1 } \\
\hline Grão-Análise & grt3-1 & grt3-2 & grt3-3 & grt3-4 & grt3-5 & grt3-6 & grt3-7 & grt3-8 & grt3-9 & grt3-11 & grt3-12 & grt3-13 & grt3-14 & grt3-15 \\
\hline $\mathrm{SiO}_{2}$ & 39,46 & 39,53 & 39,66 & 39,61 & 39,76 & 39,53 & 39,62 & 39,53 & 39,61 & 39,15 & 39,38 & 39,29 & 39,71 & 39,36 \\
\hline $\mathrm{TiO}_{2}$ & 0,15 & 0,09 & 0,05 & 0,04 & 0,03 & 0,06 & 0,04 & 0,00 & 0,09 & 0,03 & 0,05 & 0,06 & 0,07 & 0,05 \\
\hline $\mathrm{Al}_{2} \mathrm{O}_{3}$ & 22,23 & 22,14 & 22,22 & 22,37 & 22,54 & 22,39 & 22,48 & 22,56 & 22,75 & 22,26 & 22,21 & 22,66 & 22,47 & 22,21 \\
\hline $\mathrm{Cr}_{2} \mathrm{O}_{3}$ & 0,09 & 0,02 & 0,07 & 0,02 & 0,04 & 0,11 & 0,07 & 0,03 & 0,06 & 0,05 & 0,12 & 0,06 & 0,01 & 0,10 \\
\hline $\mathrm{Fe}_{2} \mathrm{O}_{3}$ & 0,33 & 0,28 & 0,21 & 0,22 & 0,00 & 0,27 & 0,02 & 0,49 & 0,13 & 0,63 & 0,46 & 0,32 & 0,24 & 0,00 \\
\hline $\mathrm{FeO}$ & 21,22 & 20,86 & 20,42 & 20,20 & 20,14 & 19,83 & 20,34 & 20,06 & 20,53 & 20,37 & 20,66 & 20,93 & 20,99 & 21,66 \\
\hline $\mathrm{MnO}$ & 0,48 & 0,48 & 0,50 & 0,51 & 0,48 & 0,49 & 0,51 & 0,49 & 0,51 & 0,46 & 0,48 & 0,48 & 0,46 & 0,50 \\
\hline $\mathrm{MgO}$ & 6,87 & 7,13 & 7,54 & 7,52 & 7,44 & 7,55 & 7,37 & 7,45 & 7,36 & 7,27 & 7,09 & 6,99 & 7,05 & 6,33 \\
\hline $\mathrm{CaO}$ & 10,43 & 10,37 & 10,23 & 10,36 & 10,28 & 10,57 & 10,48 & 10,49 & 10,37 & 10,18 & 10,42 & 10,27 & 10,56 & 10,57 \\
\hline $\mathrm{Na}_{2} \mathrm{O}$ & 0,00 & 0,00 & 0,00 & 0,00 & 0,00 & 0,00 & 0,00 & 0,00 & 0,00 & 0,00 & 0,00 & 0,00 & 0,00 & 0,00 \\
\hline $\mathrm{K}_{2} \mathrm{O}$ & 0,00 & 0,00 & 0,00 & 0,00 & 0,00 & 0,00 & 0,00 & 0,00 & 0,00 & 0,00 & 0,00 & 0,00 & 0,00 & 0,00 \\
\hline Total & 101,26 & 100,90 & 100,90 & 100,85 & 100,71 & 100,81 & 100,92 & 101,10 & 101,40 & 100,40 & 100,87 & 101,07 & 101,55 & 100,78 \\
\hline Oxigênios & 12,00 & 12,00 & 12,00 & 12,00 & 12,00 & 12,00 & 12,00 & 12,00 & 12,00 & 12,00 & 12,00 & 12,00 & 12,00 & 12,00 \\
\hline $\mathrm{Si}$ & 2,987 & 2,997 & 2,999 & 2,994 & 3,004 & 2,988 & 2,994 & 2,982 & 2,981 & 2,980 & 2,987 & 2,974 & 2,991 & 2,999 \\
\hline $\mathrm{Ti}$ & 0,008 & 0,005 & 0,003 & 0,002 & 0,002 & 0,004 & 0,003 & 0,000 & 0,005 & 0,002 & 0,003 & 0,004 & 0,004 & 0,003 \\
\hline $\mathrm{Al}$ & 1,984 & 1,979 & 1,981 & 1,994 & 2,008 & 1,995 & 2,003 & 2,006 & 2,018 & 1,998 & 1,986 & 2,022 & 1,995 & 1,995 \\
\hline $\mathrm{Cr}$ & 0,005 & 0,001 & 0,004 & 0,001 & 0,003 & 0,007 & 0,004 & 0,002 & 0,003 & 0,003 & 0,007 & 0,004 & 0,001 & 0,006 \\
\hline $\mathrm{Fe}^{3+}$ & 0,019 & 0,016 & 0,012 & 0,013 & 0,000 & 0,016 & 0,001 & 0,028 & 0,007 & 0,036 & 0,026 & 0,018 & 0,013 & 0,000 \\
\hline $\mathrm{Fe}^{2-}$ & 1,344 & 1,323 & 1,291 & 1,277 & 1,273 & 1,254 & 1,285 & 1,265 & 1,292 & 1,297 & 1,311 & 1,325 & 1,322 & 1,380 \\
\hline $\mathrm{Mn}$ & 0,031 & 0,031 & 0,032 & 0,033 & 0,031 & 0,031 & 0,033 & 0,031 & 0,032 & 0,030 & 0,031 & 0,031 & 0,029 & 0,032 \\
\hline $\mathrm{Mg}$ & 0,775 & 0,806 & 0,850 & 0,847 & 0,838 & 0,850 & 0,830 & 0,838 & 0,825 & 0,825 & 0,802 & 0,789 & 0,791 & 0,719 \\
\hline $\mathrm{Ca}$ & 0,846 & 0,842 & 0,829 & 0,839 & 0,832 & 0,856 & 0,849 & 0,848 & 0,836 & 0,830 & 0,847 & 0,833 & 0,852 & 0,863 \\
\hline $\mathrm{Na}$ & 0,000 & 0,000 & 0,000 & 0,000 & 0,000 & 0,000 & 0,000 & 0,000 & 0,000 & 0,000 & 0,000 & 0,000 & 0,000 & 0,000 \\
\hline $\mathrm{K}$ & 0,000 & 0,000 & 0,000 & 0,000 & 0,000 & 0,000 & 0,000 & 0,000 & 0,000 & 0,000 & 0,000 & 0,000 & 0,000 & 0,000 \\
\hline Soma & 8,000 & 8,000 & 8,000 & 8,000 & 7,989 & 8,000 & 8,000 & 8,000 & 8,000 & 8,000 & 8,000 & 8,000 & 8,000 & 7,998 \\
\hline \multicolumn{15}{|l|}{ Membros-finais } \\
\hline Almandina & $44,86 \%$ & $44,07 \%$ & $43,00 \%$ & $42,62 \%$ & $42,80 \%$ & $41,93 \%$ & $42,88 \%$ & $42,42 \%$ & $43,28 \%$ & $43,49 \%$ & $43,83 \%$ & $44,49 \%$ & $44,15 \%$ & $46,09 \%$ \\
\hline Piropo & $25,87 \%$ & $26,85 \%$ & $28,31 \%$ & $28,27 \%$ & $28,18 \%$ & $28,42 \%$ & $27,69 \%$ & $28,10 \%$ & $27,64 \%$ & $27,67 \%$ & $26,81 \%$ & $26,49 \%$ & $26,42 \%$ & $24,01 \%$ \\
\hline Grossulária & $27,04 \%$ & $27,20 \%$ & $26,81 \%$ & $27,31 \%$ & $27,83 \%$ & $27,48 \%$ & $28,08 \%$ & $26,96 \%$ & $27,51 \%$ & $25,92 \%$ & $26,68 \%$ & $26,90 \%$ & $27,76 \%$ & $28,52 \%$ \\
\hline Espessartita & $1,03 \%$ & $1,03 \%$ & $1,07 \%$ & $1,10 \%$ & $1,04 \%$ & $1,04 \%$ & $1,10 \%$ & $1,04 \%$ & $1,07 \%$ & $1,01 \%$ & $1,04 \%$ & $1,04 \%$ & $0,97 \%$ & $1,07 \%$ \\
\hline Andradita & $0,95 \%$ & $0,80 \%$ & $0,60 \%$ & $0,65 \%$ & $0,00 \%$ & $0,79 \%$ & $0,05 \%$ & $1,38 \%$ & $0,35 \%$ & $1,77 \%$ & $1,29 \%$ & $0,88 \%$ & $0,65 \%$ & $0,00 \%$ \\
\hline Uvarovita & $0,25 \%$ & $0,05 \%$ & $0,20 \%$ & $0,05 \%$ & $0,15 \%$ & $0,35 \%$ & $0,20 \%$ & $0,10 \%$ & $0,15 \%$ & $0,15 \%$ & $0,35 \%$ & $0,20 \%$ & $0,05 \%$ & $0,30 \%$ \\
\hline
\end{tabular}


Tabela 17 - Análises químicas de granada da Nappe Três Pontas-Varginha

\begin{tabular}{|c|c|c|c|c|c|c|c|c|c|c|c|c|}
\hline \multicolumn{13}{|c|}{ TPR-01-F1 } \\
\hline Grão-Análise & grt4-1 & grt4-2 & grt4-3 & grt4-4 & grt4-5 & grt4-6 & grt4-7 & grt4-8 & grt4-9 & grt4-10 & grt4-11 & grt4-12 \\
\hline $\mathrm{SiO}_{2}$ & 39,52 & 39,82 & 39,47 & 39,62 & 39,53 & 39,19 & 39,36 & 39,47 & 39,43 & 39,06 & 38,92 & 38,60 \\
\hline $\mathrm{TiO}_{2}$ & 0,00 & 0,04 & 0,08 & 0,03 & 0,04 & 0,06 & 0,08 & 0,01 & 0,10 & 0,12 & 0,08 & 0,07 \\
\hline $\mathrm{Al}_{2} \mathrm{O}_{3}$ & 22,23 & 22,08 & 22,28 & 22,29 & 22,37 & 22,36 & 22,34 & 22,32 & 22,25 & 22,20 & 22,08 & 22,14 \\
\hline $\mathrm{Cr}_{2} \mathrm{O}_{3}$ & 0,04 & 0,09 & 0,05 & 0,01 & 0,02 & 0,04 & 0,02 & 0,03 & 0,05 & 0,11 & 0,11 & 0,07 \\
\hline $\mathrm{Fe}_{2} \mathrm{O}_{3}$ & 0,00 & 0,00 & 0,12 & 0,22 & 0,54 & 0,80 & 0,19 & 0,15 & 0,38 & 1,13 & 0,67 & 0,29 \\
\hline $\mathrm{FeO}$ & 21,67 & 21,23 & 20,81 & 20,81 & 20,56 & 20,29 & 20,91 & 21,10 & 20,99 & 20,57 & 20,90 & 22,13 \\
\hline $\mathrm{MnO}$ & 0,50 & 0,48 & 0,46 & 0,45 & 0,48 & 0,49 & 0,46 & 0,50 & 0,50 & 0,51 & 0,56 & 0,63 \\
\hline $\mathrm{MgO}$ & 6,44 & 6,87 & 7,21 & 7,23 & 7,26 & 7,04 & 6,96 & 6,75 & 6,79 & 6,66 & 6,42 & 5,63 \\
\hline $\mathrm{CaO}$ & 10,45 & 10,36 & 10,26 & 10,34 & 10,39 & 10,60 & 10,43 & 10,59 & 10,64 & 10,82 & 10,70 & 10,47 \\
\hline $\mathrm{Na}_{2} \mathrm{O}$ & 0,00 & 0,00 & 0,00 & 0,00 & 0,00 & 0,00 & 0,00 & 0,00 & 0,00 & 0,00 & 0,00 & 0,00 \\
\hline $\mathrm{K}_{2} \mathrm{O}$ & 0,00 & 0,00 & 0,00 & 0,00 & 0,00 & 0,00 & 0,00 & 0,00 & 0,00 & 0,00 & 0,00 & 0,00 \\
\hline Total & 100,86 & 100,97 & 100,75 & 101,00 & 101,20 & 100,87 & 100,75 & 100,93 & 101,14 & 101,17 & 100,43 & 100,03 \\
\hline Oxigênios & 12,00 & 12,00 & 12,00 & 12,00 & 12,00 & 12,00 & 12,00 & 12,00 & 12,00 & 12,00 & 12,00 & 12,00 \\
\hline $\mathrm{Si}$ & 3,006 & 3,017 & 2,994 & 2,998 & 2,986 & 2,973 & 2,989 & 2,996 & 2,988 & 2,965 & 2,977 & 2,978 \\
\hline $\mathrm{Ti}$ & 0,000 & 0,002 & 0,005 & 0,002 & 0,002 & 0,003 & 0,005 & 0,000 & 0,006 & 0,007 & 0,005 & 0,004 \\
\hline Al & 1,994 & 1,973 & 1,992 & 1,988 & 1,992 & 2,000 & 2,000 & 1,997 & 1,988 & 1,986 & 1,991 & 2,014 \\
\hline $\mathrm{Cr}$ & 0,002 & 0,005 & 0,003 & 0,000 & 0,001 & 0,002 & 0,001 & 0,002 & 0,003 & 0,006 & 0,006 & 0,005 \\
\hline $\mathrm{Fe}^{3+}$ & 0,000 & 0,000 & 0,007 & 0,013 & 0,031 & 0,046 & 0,011 & 0,009 & 0,022 & 0,064 & 0,039 & 0,017 \\
\hline $\mathrm{Fe}^{2-}$ & 1,379 & 1,345 & 1,320 & 1,317 & 1,299 & 1,287 & 1,328 & 1,339 & 1,331 & 1,305 & 1,337 & 1,428 \\
\hline $\mathrm{Mn}$ & 0,032 & 0,031 & 0,030 & 0,029 & 0,031 & 0,032 & 0,029 & 0,032 & 0,032 & 0,033 & 0,036 & 0,041 \\
\hline $\mathrm{Mg}$ & 0,730 & 0,776 & 0,815 & 0,815 & 0,817 & 0,796 & 0,788 & 0,763 & 0,767 & 0,753 & 0,732 & 0,647 \\
\hline $\mathrm{Ca}$ & 0,852 & 0,841 & 0,834 & 0,838 & 0,841 & 0,862 & 0,849 & 0,861 & 0,864 & 0,880 & 0,877 & 0,866 \\
\hline $\mathrm{Na}$ & 0,000 & 0,000 & 0,000 & 0,000 & 0,000 & 0,000 & 0,000 & 0,000 & 0,000 & 0,000 & 0,000 & 0,000 \\
\hline $\mathrm{K}$ & 0,000 & 0,000 & 0,000 & 0,000 & 0,000 & 0,000 & 0,000 & 0,000 & 0,000 & 0,000 & 0,000 & 0,000 \\
\hline Soma & 7,996 & 7,991 & 8,000 & 8,000 & 8,000 & 8,000 & 8,000 & 8,000 & 8,000 & 8,000 & 8,000 & 8,000 \\
\hline \multicolumn{13}{|l|}{ Membros-finais } \\
\hline Almandina & $46,07 \%$ & $44,94 \%$ & $44,01 \%$ & $43,91 \%$ & $43,47 \%$ & $43,23 \%$ & $44,36 \%$ & $44,71 \%$ & $44,46 \%$ & $43,92 \%$ & $44,84 \%$ & $47,89 \%$ \\
\hline Piropo & $24,39 \%$ & $25,93 \%$ & $27,18 \%$ & $27,18 \%$ & $27,34 \%$ & $26,74 \%$ & $26,32 \%$ & $25,48 \%$ & $25,62 \%$ & $25,35 \%$ & $24,55 \%$ & $21,70 \%$ \\
\hline Grossulária & $28,37 \%$ & $27,85 \%$ & $27,31 \%$ & $27,29 \%$ & $26,56 \%$ & $26,61 \%$ & $27,76 \%$ & $28,20 \%$ & $27,62 \%$ & $26,21 \%$ & $27,20 \%$ & $27,96 \%$ \\
\hline Espessartita & $1,07 \%$ & $1,04 \%$ & $1,00 \%$ & $0,97 \%$ & $1,04 \%$ & $1,07 \%$ & $0,97 \%$ & $1,07 \%$ & $1,07 \%$ & $1,11 \%$ & $1,21 \%$ & $1,37 \%$ \\
\hline Andradita & $0,00 \%$ & $0,00 \%$ & $0,35 \%$ & $0,65 \%$ & $1,53 \%$ & $2,25 \%$ & $0,55 \%$ & $0,45 \%$ & $1,09 \%$ & $3,11 \%$ & $1,92 \%$ & $0,83 \%$ \\
\hline Uvarovita & $0,10 \%$ & $0,25 \%$ & $0,15 \%$ & $0,00 \%$ & $0,05 \%$ & $0,10 \%$ & $0,05 \%$ & $0,10 \%$ & $0,15 \%$ & $0,29 \%$ & $0,29 \%$ & $0,25 \%$ \\
\hline
\end{tabular}


Tabela 18 - Análises químicas de granada da Nappe Três Pontas-Varginha

\begin{tabular}{|c|c|c|c|c|c|c|c|c|c|c|c|c|c|c|}
\hline \multicolumn{15}{|c|}{ TPR-01-F1 } \\
\hline Grão-Análise & grt5-2 & grt5-3 & grt5-4 & grt5-5 & grt5-6 & grt5-7 & grt5-8 & grt5-9 & grt5-10 & grt5-11 & grt5-12 & grt5-13 & grt5-14 & grt5-15 \\
\hline $\mathrm{SiO}_{2}$ & 39,57 & 39,41 & 39,53 & 39,33 & 39,16 & 39,55 & 39,24 & 39,33 & 39,26 & 39,53 & 39,42 & 39,48 & 39,47 & 39,10 \\
\hline $\mathrm{TiO}_{2}$ & 0,10 & 0,14 & 0,11 & 0,08 & 0,08 & 0,05 & 0,10 & 0,07 & 0,09 & 0,09 & 0,08 & 0,08 & 0,06 & 0,02 \\
\hline $\mathrm{Al}_{2} \mathrm{O}_{3}$ & 22,41 & 22,49 & 22,08 & 22,44 & 22,55 & 22,36 & 22,42 & 22,28 & 22,47 & 22,24 & 22,28 & 22,63 & 22,62 & 21,95 \\
\hline $\mathrm{Cr}_{2} \mathrm{O}_{3}$ & 0,05 & 0,07 & 0,08 & 0,04 & 0,06 & 0,05 & 0,03 & 0,04 & 0,02 & 0,07 & 0,10 & 0,07 & 0,07 & 0,04 \\
\hline $\mathrm{Fe}_{2} \mathrm{O}_{3}$ & 0,00 & 0,00 & 0,04 & 0,30 & 0,33 & 0,00 & 0,68 & 0,32 & 0,51 & 0,17 & 0,07 & 0,43 & 0,22 & 0,56 \\
\hline $\mathrm{FeO}$ & 20,95 & 20,82 & 20,77 & 20,45 & 20,51 & 20,76 & 20,20 & 20,43 & 20,18 & 20,43 & 20,57 & 20,42 & 20,76 & 20,72 \\
\hline $\mathrm{MnO}$ & 0,50 & 0,56 & 0,66 & 0,70 & 0,77 & 0,84 & 0,78 & 0,78 & 0,68 & 0,66 & 0,62 & 0,53 & 0,51 & 0,49 \\
\hline $\mathrm{MgO}$ & 7,17 & 7,09 & 6,85 & 6,65 & 6,51 & 6,56 & 6,76 & 6,69 & 6,83 & 6,94 & 7,01 & 7,34 & 7,50 & 6,95 \\
\hline $\mathrm{CaO}$ & 10,17 & 10,26 & 10,71 & 11,00 & 10,93 & 10,90 & 10,91 & 10,89 & 10,91 & 10,84 & 10,55 & 10,34 & 9,84 & 10,28 \\
\hline $\mathrm{Na}_{2} \mathrm{O}$ & 0,00 & 0,00 & 0,00 & 0,00 & 0,00 & 0,00 & 0,00 & 0,00 & 0,00 & 0,00 & 0,00 & 0,00 & 0,00 & 0,00 \\
\hline $\mathrm{K}_{2} \mathrm{O}$ & 0,00 & 0,00 & 0,00 & 0,00 & 0,00 & 0,00 & 0,00 & 0,00 & 0,00 & 0,00 & 0,00 & 0,00 & 0,00 & 0,00 \\
\hline Total & 100,92 & 100,83 & 100,84 & 100,99 & 100,90 & 101,08 & 101,12 & 100,83 & 100,95 & 100,96 & 100,69 & 101,30 & 101,04 & 100,10 \\
\hline Oxigênios & 12,00 & 12,00 & 12,00 & 12,00 & 12,00 & 12,00 & 12,00 & 12,00 & 12,00 & 12,00 & 12,00 & 12,00 & 12,00 & 12,00 \\
\hline $\mathrm{Si}$ & 2,996 & 2,987 & 3,002 & 2,983 & 2,975 & 2,998 & 2,973 & 2,988 & 2,976 & 2,995 & 2,993 & 2,976 & 2,981 & 2,992 \\
\hline $\mathrm{Ti}$ & 0,006 & 0,008 & 0,006 & 0,004 & 0,004 & 0,003 & 0,006 & 0,004 & 0,005 & 0,005 & 0,005 & 0,004 & 0,003 & 0,001 \\
\hline Al & 2,000 & 2,010 & 1,977 & 2,006 & 2,019 & 1,998 & 2,002 & 1,995 & 2,008 & 1,986 & 1,995 & 2,011 & 2,014 & 1,980 \\
\hline $\mathrm{Cr}$ & 0,003 & 0,004 & 0,005 & 0,003 & 0,003 & 0,003 & 0,002 & 0,002 & 0,001 & 0,004 & 0,006 & 0,004 & 0,004 & 0,002 \\
\hline $\mathrm{Fe}^{3+}$ & 0,000 & 0,000 & 0,002 & 0,017 & 0,019 & 0,000 & 0,039 & 0,018 & 0,029 & 0,010 & 0,004 & 0,024 & 0,013 & 0,032 \\
\hline $\mathrm{Fe}^{2-}$ & 1,326 & 1,320 & 1,319 & 1,297 & 1,303 & 1,316 & 1,280 & 1,298 & 1,280 & 1,294 & 1,306 & 1,287 & 1,311 & 1,326 \\
\hline $\mathrm{Mn}$ & 0,032 & 0,036 & 0,042 & 0,045 & 0,049 & 0,054 & 0,050 & 0,050 & 0,044 & 0,042 & 0,040 & 0,034 & 0,033 & 0,032 \\
\hline $\mathrm{Mg}$ & 0,809 & 0,801 & 0,775 & 0,752 & 0,737 & 0,741 & 0,763 & 0,757 & 0,772 & 0,784 & 0,793 & 0,825 & 0,844 & 0,793 \\
\hline $\mathrm{Ca}$ & 0,825 & 0,833 & 0,871 & 0,894 & 0,890 & 0,885 & 0,886 & 0,886 & 0,886 & 0,880 & 0,858 & 0,835 & 0,796 & 0,843 \\
\hline $\mathrm{Na}$ & 0,000 & 0,000 & 0,000 & 0,000 & 0,000 & 0,000 & 0,000 & 0,000 & 0,000 & 0,000 & 0,000 & 0,000 & 0,000 & 0,000 \\
\hline $\mathrm{K}$ & 0,000 & 0,000 & 0,000 & 0,000 & 0,000 & 0,000 & 0,000 & 0,000 & 0,000 & 0,000 & 0,000 & 0,000 & 0,000 & 0,000 \\
\hline Soma & 7,997 & 7,998 & 8,000 & 8,000 & 8,000 & 7,999 & 8,000 & 8,000 & 8,000 & 8,000 & 8,000 & 8,000 & 8,000 & 8,000 \\
\hline Almandina & $44,32 \%$ & $44,15 \%$ & $43,86 \%$ & $43,41 \%$ & $43,74 \%$ & $43,93 \%$ & $42,97 \%$ & $43,40 \%$ & $42,92 \%$ & $43,13 \%$ & $43,58 \%$ & $43,17 \%$ & $43,93 \%$ & $44,29 \%$ \\
\hline Piropo & $27,04 \%$ & $26,79 \%$ & $25,77 \%$ & $25,17 \%$ & $24,74 \%$ & $24,73 \%$ & $25,61 \%$ & $25,31 \%$ & $25,89 \%$ & $26,13 \%$ & $26,46 \%$ & $27,68 \%$ & $28,28 \%$ & $26,49 \%$ \\
\hline Grossulária & $27,42 \%$ & $27,66 \%$ & $28,61 \%$ & $28,93 \%$ & $28,80 \%$ & $29,39 \%$ & $27,73 \%$ & $28,63 \%$ & $28,24 \%$ & $28,63 \%$ & $28,13 \%$ & $26,64 \%$ & $25,84 \%$ & $26,47 \%$ \\
\hline Espessartita & $1,07 \%$ & $1,20 \%$ & $1,40 \%$ & $1,51 \%$ & $1,64 \%$ & $1,80 \%$ & $1,68 \%$ & $1,67 \%$ & $1,48 \%$ & $1,40 \%$ & $1,33 \%$ & $1,14 \%$ & $1,11 \%$ & $1,07 \%$ \\
\hline Andradita & $0,00 \%$ & $0,00 \%$ & $0,10 \%$ & $0,84 \%$ & $0,93 \%$ & $0,00 \%$ & $1,91 \%$ & $0,89 \%$ & $1,42 \%$ & $0,50 \%$ & $0,20 \%$ & $1,18 \%$ & $0,64 \%$ & $1,59 \%$ \\
\hline Uvarovita & $0,15 \%$ & $0,20 \%$ & $0,25 \%$ & $0,15 \%$ & $0,15 \%$ & $0,15 \%$ & $0,10 \%$ & $0,10 \%$ & $0,05 \%$ & $0,20 \%$ & $0,30 \%$ & $0,20 \%$ & $0,20 \%$ & $0,10 \%$ \\
\hline
\end{tabular}


Tabela 19- Análises químicas de granada da Nappe Socorro-Guaxupé

\begin{tabular}{|c|c|c|c|c|c|c|c|c|c|c|c|}
\hline \multicolumn{12}{|c|}{ IC-06-R } \\
\hline Grão-Análise & grt1-1 & grt1-2 & grt1-4 & grt1-5 & grt1-6 & grt1-7 & grt1-8 & grt1-9 & grt1-10 & grt1-11 & grt1-12 \\
\hline $\mathrm{SiO}_{2}$ & 39,20 & 38,74 & 38,61 & 39,14 & 38,72 & 39,25 & 38,93 & 38,89 & 38,85 & 38,90 & 38,69 \\
\hline $\mathrm{TiO}_{2}$ & 0,01 & 0,09 & 0,10 & 0,07 & 0,10 & 0,10 & 0,11 & 0,07 & 0,10 & 0,10 & 0,06 \\
\hline $\mathrm{Al}_{2} \mathrm{O}_{3}$ & 21,94 & 21,61 & 21,42 & 21,69 & 21,36 & 21,63 & 21,59 & 21,49 & 21,68 & 21,69 & 21,44 \\
\hline $\mathrm{Cr}_{2} \mathrm{O}_{3}$ & 0,03 & 0,01 & 0,02 & 0,02 & 0,02 & 0,02 & 0,04 & 0,04 & 0,05 & 0,00 & 0,03 \\
\hline $\mathrm{Fe}_{2} \mathrm{O}_{3}$ & 0,00 & 0,89 & 0,96 & 0,83 & 1,24 & 0,78 & 0,49 & 1,20 & 0,88 & 0,75 & 0,64 \\
\hline $\mathrm{FeO}$ & 25,37 & 24,18 & 23,33 & 23,92 & 23,55 & 24,43 & 24,39 & 24,24 & 24,17 & 24,81 & 25,53 \\
\hline $\mathrm{MnO}$ & 1,50 & 1,47 & 1,36 & 1,42 & 1,44 & 1,45 & 1,45 & 1,47 & 1,45 & 1,51 & 1,66 \\
\hline $\mathrm{MgO}$ & 6,86 & 7,21 & 7,26 & 7,19 & 7,26 & 7,32 & 7,14 & 7,13 & 6,95 & 6,86 & 6,34 \\
\hline $\mathrm{CaO}$ & 6,05 & 6,15 & 6,72 & 6,79 & 6,59 & 6,31 & 6,30 & 6,34 & 6,65 & 6,27 & 6,09 \\
\hline $\mathrm{Na}_{2} \mathrm{O}$ & 0,00 & 0,00 & 0,00 & 0,00 & 0,00 & 0,00 & 0,00 & 0,00 & 0,00 & 0,00 & 0,00 \\
\hline $\mathrm{K}_{2} \mathrm{O}$ & 0,00 & 0,00 & 0,00 & 0,00 & 0,00 & 0,00 & 0,00 & 0,00 & 0,00 & 0,00 & 0,00 \\
\hline Total & 100,96 & 100,35 & 99,79 & 101,07 & 100,29 & 101,29 & 100,44 & 100,87 & 100,78 & 100,90 & 100,48 \\
\hline Oxigênios & 12,00 & 12,00 & 12,00 & 12,00 & 12,00 & 12,00 & 12,00 & 12,00 & 12,00 & 12,00 & 12,00 \\
\hline $\mathrm{Si}$ & 3,007 & 2,987 & 2,988 & 2,993 & 2,986 & 2,997 & 2,998 & 2,987 & 2,985 & 2,990 & 2,998 \\
\hline $\mathrm{Ti}$ & 0,000 & 0,005 & 0,006 & 0,004 & 0,006 & 0,006 & 0,006 & 0,004 & 0,006 & 0,006 & 0,003 \\
\hline Al & 1,984 & 1,964 & 1,954 & 1,956 & 1,942 & 1,947 & 1,960 & 1,946 & 1,964 & 1,965 & 1,958 \\
\hline $\mathrm{Cr}$ & 0,002 & 0,001 & 0,001 & 0,001 & 0,001 & 0,001 & 0,002 & 0,003 & 0,003 & 0,000 & 0,002 \\
\hline $\mathrm{Fe}^{3+}$ & 0,000 & 0,051 & 0,056 & 0,048 & 0,072 & 0,045 & 0,029 & 0,069 & 0,051 & 0,044 & 0,037 \\
\hline $\mathrm{Fe}^{2-}$ & 1,628 & 1,559 & 1,510 & 1,530 & 1,519 & 1,560 & 1,571 & 1,557 & 1,553 & 1,595 & 1,655 \\
\hline $\mathrm{Mn}$ & 0,097 & 0,096 & 0,089 & 0,092 & 0,094 & 0,094 & 0,095 & 0,096 & 0,094 & 0,098 & 0,109 \\
\hline $\mathrm{Mg}$ & 0,784 & 0,828 & 0,837 & 0,820 & 0,834 & 0,833 & 0,819 & 0,816 & 0,796 & 0,786 & 0,732 \\
\hline $\mathrm{Ca}$ & 0,497 & 0,508 & 0,557 & 0,556 & 0,545 & 0,516 & 0,520 & 0,522 & 0,548 & 0,516 & 0,506 \\
\hline $\mathrm{Na}$ & 0,000 & 0,000 & 0,000 & 0,000 & 0,000 & 0,000 & 0,000 & 0,000 & 0,000 & 0,000 & 0,000 \\
\hline $\mathrm{K}$ & 0,000 & 0,000 & 0,000 & 0,000 & 0,000 & 0,000 & 0,000 & 0,000 & 0,000 & 0,000 & 0,000 \\
\hline Soma & 8,000 & 8,000 & 8,000 & 8,000 & 8,000 & 8,000 & 8,000 & 8,000 & 8,000 & 8,000 & 8,000 \\
\hline \multicolumn{12}{|l|}{ Membros-finais } \\
\hline Almandina & $54,16 \%$ & $52,12 \%$ & $50,45 \%$ & $51,03 \%$ & $50,77 \%$ & $51,95 \%$ & $52,28 \%$ & $52,06 \%$ & $51,92 \%$ & $53,26 \%$ & $55,13 \%$ \\
\hline Piropo & $26,08 \%$ & $27,68 \%$ & $27,97 \%$ & $27,35 \%$ & $27,87 \%$ & $27,74 \%$ & $27,25 \%$ & $27,28 \%$ & $26,61 \%$ & $26,24 \%$ & $24,38 \%$ \\
\hline Grossulária & $16,43 \%$ & $14,40 \%$ & $15,78 \%$ & $16,10 \%$ & $14,59 \%$ & $14,87 \%$ & $15,75 \%$ & $13,88 \%$ & $15,65 \%$ & $15,04 \%$ & $14,90 \%$ \\
\hline Espessartita & $3,23 \%$ & $3,21 \%$ & $2,97 \%$ & $3,07 \%$ & $3,14 \%$ & $3,13 \%$ & $3,16 \%$ & $3,21 \%$ & $3,14 \%$ & $3,27 \%$ & $3,63 \%$ \\
\hline Andradita & $0,00 \%$ & $2,53 \%$ & $2,78 \%$ & $2,39 \%$ & $3,57 \%$ & $2,26 \%$ & $1,46 \%$ & $3,42 \%$ & $2,53 \%$ & $2,19 \%$ & $1,85 \%$ \\
\hline Uvarovita & $0,10 \%$ & $0,05 \%$ & $0,05 \%$ & $0,05 \%$ & $0,05 \%$ & $0,05 \%$ & $0,10 \%$ & $0,15 \%$ & $0,15 \%$ & $0,00 \%$ & $0,10 \%$ \\
\hline
\end{tabular}




\begin{tabular}{|c|c|c|c|c|c|c|c|c|c|c|c|c|c|c|c|c|c|}
\hline \multicolumn{18}{|c|}{ IC-06-R } \\
\hline Grão-Análise & grt2-1 & grt2-2 & grt2-3 & grt2-4 & grt2-6 & grt2-7 & grt2-8 & grt2-9 & grt2-10 & grt2-11 & grt2-12 & grt2-13 & grt2-14 & grt2-15 & grt2-16 & grt2-17 & grt2-18 \\
\hline $\mathrm{SiO}_{2}$ & 38,92 & 38,68 & 38,77 & 39,10 & 39,06 & 39,30 & 39,04 & 39,12 & 39,03 & 39,16 & 38,82 & 38,81 & 38,94 & 39,25 & 39,20 & 39,09 & 38,77 \\
\hline $\mathrm{TiO}_{2}$ & 0,01 & 0,09 & 0,10 & 0,06 & 0,05 & 0,07 & 0,04 & 0,07 & 0,08 & 0,04 & 0,05 & 0,03 & 0,08 & 0,08 & 0,06 & 0,07 & 0,07 \\
\hline $\mathrm{Al}_{2} \mathrm{O}_{3}$ & 21,47 & 21,77 & 21,85 & 21,72 & 21,95 & 22,07 & 22,12 & 22,09 & 22,12 & 21,82 & 21,89 & 21,93 & 21,70 & 21,64 & 21,53 & 21,88 & 21,70 \\
\hline $\mathrm{Cr}_{2} \mathrm{O}_{3}$ & 0,04 & 0,00 & 0,03 & 0,01 & 0,00 & 0,00 & 0,01 & 0,00 & 0,00 & 0,01 & 0,01 & 0,01 & 0,02 & 0,00 & 0,02 & 0,05 & 0,01 \\
\hline $\mathrm{Fe}_{2} \mathrm{O}_{3}$ & 0,49 & 0,89 & 0,59 & 0,45 & 0,53 & 0,09 & 0,42 & 0,47 & 0,32 & 0,20 & 0,69 & 0,07 & 0,86 & 0,26 & 0,59 & 0,33 & 0,94 \\
\hline $\mathrm{FeO}$ & 24,62 & 23,80 & 23,44 & 24,02 & 23,80 & 24,39 & 24,04 & 24,25 & 24,10 & 24,26 & 23,64 & 23,87 & 23,52 & 24,30 & 24,26 & 24,42 & 24,29 \\
\hline $\mathrm{MnO}$ & 1,49 & 1,41 & 1,37 & 1,39 & 1,44 & 1,47 & 1,50 & 1,49 & 1,48 & 1,58 & 1,50 & 1,40 & 1,38 & 1,40 & 1,44 & 1,38 & 1,50 \\
\hline $\mathrm{MgO}$ & 7,07 & 7,32 & 7,57 & 7,61 & 7,74 & 8,09 & 8,17 & 8,05 & 8,16 & 7,83 & 7,75 & 7,48 & 7,67 & 7,58 & 7,57 & 7,33 & 7,30 \\
\hline $\mathrm{CaO}$ & 6,10 & 6,29 & 6,34 & 6,10 & 6,01 & 5,28 & 5,15 & 5,26 & 5,15 & 5,50 & 5,85 & 6,10 & 6,28 & 6,07 & 6,02 & 6,18 & 5,93 \\
\hline $\mathrm{Na}_{2} \mathrm{O}$ & 0,00 & 0,00 & 0,00 & 0,00 & 0,00 & 0,00 & 0,00 & 0,00 & 0,00 & 0,00 & 0,00 & 0,00 & 0,00 & 0,00 & 0,00 & 0,00 & 0,00 \\
\hline $\mathrm{K}_{2} \mathrm{O}$ & 0,00 & 0,00 & 0,00 & 0,00 & 0,00 & 0,00 & 0,00 & 0,00 & 0,00 & 0,00 & 0,00 & 0,00 & 0,00 & 0,00 & 0,00 & 0,00 & 0,00 \\
\hline Total & 100,20 & 100,25 & 100,05 & 100,46 & 100,57 & 100,76 & 100,50 & 100,80 & 100,44 & 100,40 & 100,20 & 99,71 & 100,45 & 100,59 & 100,68 & 100,73 & 100,51 \\
\hline Oxigênios & 12,00 & 12,00 & 12,00 & 12,00 & 12,00 & 12,00 & 12,00 & 12,00 & 12,00 & 12,00 & 12,00 & 12,00 & 12,00 & 12,00 & 12,00 & 12,00 & 12,00 \\
\hline $\mathrm{Si}$ & 3,007 & 2,980 & 2,985 & 3,001 & 2,991 & 3,000 & 2,987 & 2,988 & 2,988 & 3,005 & 2,985 & 2,997 & 2,988 & 3,010 & 3,006 & 2,996 & 2,984 \\
\hline $\mathrm{Ti}$ & 0,000 & 0,005 & 0,006 & 0,004 & 0,003 & 0,004 & 0,003 & 0,004 & 0,005 & 0,002 & 0,003 & 0,002 & 0,004 & 0,005 & 0,003 & 0,004 & 0,004 \\
\hline $\mathrm{Al}$ & 1,955 & 1,977 & 1,983 & 1,965 & 1,982 & 1,986 & 1,995 & 1,989 & 1,996 & 1,974 & 1,984 & 1,997 & 1,963 & 1,956 & 1,946 & 1,977 & 1,969 \\
\hline $\mathrm{Cr}$ & 0,002 & 0,000 & 0,002 & 0,000 & 0,000 & 0,000 & 0,001 & 0,000 & 0,000 & 0,001 & 0,000 & 0,000 & 0,001 & 0,000 & 0,001 & 0,003 & 0,000 \\
\hline $\mathrm{Fe}^{3+}$ & 0,029 & 0,052 & 0,034 & 0,026 & 0,030 & 0,005 & 0,024 & 0,027 & 0,018 & 0,012 & 0,040 & 0,004 & 0,050 & 0,015 & 0,034 & 0,019 & 0,055 \\
\hline $\mathrm{Fe}^{2-}$ & 1,591 & 1,534 & 1,510 & 1,542 & 1,524 & 1,557 & 1,539 & 1,549 & 1,543 & 1,557 & 1,520 & 1,542 & 1,509 & 1,559 & 1,556 & 1,566 & 1,564 \\
\hline $\mathrm{Mn}$ & 0,097 & 0,092 & 0,089 & 0,090 & 0,093 & 0,095 & 0,097 & 0,096 & 0,096 & 0,103 & 0,098 & 0,092 & 0,090 & 0,091 & 0,094 & 0,090 & 0,098 \\
\hline $\mathrm{Mg}$ & 0,814 & 0,841 & 0,869 & 0,870 & 0,883 & 0,920 & 0,932 & 0,916 & 0,931 & 0,895 & 0,888 & 0,861 & 0,877 & 0,866 & 0,865 & 0,837 & 0,837 \\
\hline $\mathrm{Ca}$ & 0,505 & 0,519 & 0,523 & 0,502 & 0,493 & 0,432 & 0,422 & 0,430 & 0,422 & 0,452 & 0,482 & 0,505 & 0,516 & 0,499 & 0,495 & 0,508 & 0,489 \\
\hline $\mathrm{Na}$ & 0,000 & 0,000 & 0,000 & 0,000 & 0,000 & 0,000 & 0,000 & 0,000 & 0,000 & 0,000 & 0,000 & 0,000 & 0,000 & 0,000 & 0,000 & 0,000 & 0,000 \\
\hline $\mathrm{K}$ & 0,000 & 0,000 & 0,000 & 0,000 & 0,000 & 0,000 & 0,000 & 0,000 & 0,000 & 0,000 & 0,000 & 0,000 & 0,000 & 0,000 & 0,000 & 0,000 & 0,000 \\
\hline Soma & 8,000 & 8,000 & 8,000 & 8,000 & 8,000 & 8,000 & 8,000 & 8,000 & 8,000 & 8,000 & 8,000 & 8,000 & 8,000 & 8,000 & 8,000 & 8,000 & 8,000 \\
\hline \multicolumn{18}{|c|}{ Membros-finais } \\
\hline Almandina & $52,91 \%$ & $51,37 \%$ & $50,48 \%$ & $51,33 \%$ & $50,92 \%$ & $51,83 \%$ & $51,47 \%$ & $51,79 \%$ & $51,57 \%$ & $51,78 \%$ & $50,87 \%$ & $51,40 \%$ & $50,43 \%$ & $51,71 \%$ & $51,69 \%$ & $52,18 \%$ & $52,34 \%$ \\
\hline Piropo & $27,07 \%$ & $28,16 \%$ & $29,05 \%$ & $28,96 \%$ & $29,50 \%$ & $30,63 \%$ & $31,17 \%$ & $30,63 \%$ & $31,12 \%$ & $29,76 \%$ & $29,72 \%$ & $28,70 \%$ & $29,31 \%$ & $28,72 \%$ & $28,74 \%$ & $27,89 \%$ & $28,01 \%$ \\
\hline Grossulária & $15,23 \%$ & $14,82 \%$ & $15,70 \%$ & $15,41 \%$ & $14,98 \%$ & $14,13 \%$ & $12,88 \%$ & $13,04 \%$ & $13,21 \%$ & $14,38 \%$ & $14,15 \%$ & $16,63 \%$ & $14,71 \%$ & $15,79 \%$ & $14,68 \%$ & $15,83 \%$ & $13,65 \%$ \\
\hline Espessartita & $3,23 \%$ & $3,08 \%$ & $2,98 \%$ & $3,00 \%$ & $3,11 \%$ & $3,16 \%$ & $3,24 \%$ & $3,21 \%$ & $3,21 \%$ & $3,43 \%$ & $3,28 \%$ & $3,07 \%$ & $3,01 \%$ & $3,02 \%$ & $3,12 \%$ & $3,00 \%$ & $3,28 \%$ \\
\hline Andradita & $1,46 \%$ & $2,56 \%$ & $1,68 \%$ & $1,31 \%$ & $1,49 \%$ & $0,25 \%$ & $1,19 \%$ & $1,34 \%$ & $0,89 \%$ & $0,60 \%$ & $1,98 \%$ & $0,20 \%$ & $2,48 \%$ & $0,76 \%$ & $1,72 \%$ & $0,95 \%$ & $2,72 \%$ \\
\hline Uvarovita & $0,10 \%$ & $0,00 \%$ & $0,10 \%$ & $0,00 \%$ & $0,00 \%$ & $0,00 \%$ & $0,05 \%$ & $0,00 \%$ & $0,00 \%$ & $0,05 \%$ & $0,00 \%$ & $0,00 \%$ & $0,05 \%$ & $0,00 \%$ & $0,05 \%$ & $0,15 \%$ & $0,00 \%$ \\
\hline
\end{tabular}


Tabela 21- Análises químicas de granada da Nappe Socorro-Guaxupé

\begin{tabular}{|c|c|c|c|c|c|c|c|c|c|c|c|c|c|c|c|}
\hline \multicolumn{16}{|c|}{ IC-06-R } \\
\hline Grão-Análise & grt3-1 & grt3-2 & grt3-3 & grt3-4 & grt3-5 & grt3-6 & grt3-7 & grt3-8 & grt3-9 & grt3-10 & grt3-11 & grt3-12 & grt3-13 & grt3-14 & grt3-15 \\
\hline $\mathrm{SiO}_{2}$ & 39,03 & 38,82 & 38,44 & 38,63 & 39,19 & 38,88 & 38,81 & 38,70 & 38,95 & 38,77 & 38,92 & 38,93 & 39,20 & 38,97 & 38,27 \\
\hline $\mathrm{TiO}_{2}$ & 0,10 & 0,07 & 0,10 & 0,07 & 0,10 & 0,04 & 0,07 & 0,03 & 0,08 & 0,04 & 0,08 & 0,07 & 0,06 & 0,03 & 0,07 \\
\hline $\mathrm{Al}_{2} \mathrm{O}_{3}$ & 21,81 & 21,34 & 21,71 & 21,54 & 21,77 & 21,55 & 21,74 & 21,22 & 21,52 & 21,61 & 21,50 & 21,74 & 21,48 & 21,47 & 21,25 \\
\hline $\mathrm{Cr}_{2} \mathrm{O}_{3}$ & 0,03 & 0,01 & 0,04 & 0,03 & 0,04 & 0,00 & 0,00 & 0,05 & 0,03 & 0,00 & 0,01 & 0,04 & 0,00 & 0,02 & 0,03 \\
\hline $\mathrm{Fe}_{2} \mathrm{O}_{3}$ & 0,00 & 0,64 & 1,49 & 1,75 & 0,89 & 0,86 & 0,88 & 1,54 & 0,76 & 0,70 & 1,25 & 0,75 & 0,50 & 0,57 & 1,27 \\
\hline $\mathrm{FeO}$ & 26,73 & 25,36 & 24,35 & 24,07 & 24,72 & 24,37 & 24,28 & 23,90 & 24,51 & 24,48 & 24,39 & 24,78 & 25,20 & 25,09 & 24,76 \\
\hline $\mathrm{MnO}$ & 1,70 & 1,58 & 1,45 & 1,45 & 1,43 & 1,42 & 1,44 & 1,39 & 1,41 & 1,45 & 1,50 & 1,45 & 1,48 & 1,53 & 1,65 \\
\hline $\mathrm{MgO}$ & 5,81 & 6,69 & 6,96 & 7,14 & 7,11 & 7,22 & 7,00 & 7,22 & 6,84 & 6,71 & 6,73 & 6,59 & 6,52 & 6,57 & 6,39 \\
\hline $\mathrm{CaO}$ & 5,92 & 5,93 & 6,11 & 6,24 & 6,33 & 6,13 & 6,44 & 6,34 & 6,65 & 6,63 & 6,80 & 6,73 & 6,72 & 6,46 & 6,25 \\
\hline $\mathrm{Na}_{2} \mathrm{O}$ & 0,00 & 0,00 & 0,00 & 0,00 & 0,00 & 0,00 & 0,00 & 0,00 & 0,00 & 0,00 & 0,00 & 0,00 & 0,00 & 0,00 & 0,00 \\
\hline $\mathrm{K}_{2} \mathrm{O}$ & 0,00 & 0,00 & 0,00 & 0,00 & 0,00 & 0,00 & 0,00 & 0,00 & 0,00 & 0,00 & 0,00 & 0,00 & 0,00 & 0,00 & 0,00 \\
\hline Total & 101,13 & 100,45 & 100,64 & 100,92 & 101,60 & 100,47 & 100,67 & 100,39 & 100,75 & 100,40 & 101,18 & 101,07 & 101,16 & 100,70 & 99,94 \\
\hline Oxigênios & 12,00 & 12,00 & 12,00 & 12,00 & 12,00 & 12,00 & 12,00 & 12,00 & 12,00 & 12,00 & 12,00 & 12,00 & 12,00 & 12,00 & 12,00 \\
\hline $\mathrm{Si}$ & 3,010 & 3,004 & 2,963 & 2,969 & 2,989 & 2,994 & 2,985 & 2,987 & 2,997 & 2,993 & 2,986 & 2,989 & 3,010 & 3,005 & 2,982 \\
\hline $\mathrm{Ti}$ & 0,006 & 0,004 & 0,006 & 0,004 & 0,006 & 0,002 & 0,004 & 0,002 & 0,005 & 0,003 & 0,005 & 0,004 & 0,004 & 0,002 & 0,004 \\
\hline Al & 1,983 & 1,947 & 1,973 & 1,952 & 1,957 & 1,957 & 1,971 & 1,931 & 1,952 & 1,967 & 1,945 & 1,968 & 1,944 & 1,952 & 1,952 \\
\hline $\mathrm{Cr}$ & 0,002 & 0,001 & 0,002 & 0,002 & 0,003 & 0,000 & 0,000 & 0,003 & 0,002 & 0,000 & 0,001 & 0,002 & 0,000 & 0,001 & 0,002 \\
\hline $\mathrm{Fe}^{3+}$ & 0,000 & 0,038 & 0,086 & 0,101 & 0,051 & 0,050 & 0,051 & 0,090 & 0,044 & 0,041 & 0,072 & 0,043 & 0,029 & 0,033 & 0,074 \\
\hline $\mathrm{Fe}^{2-}$ & 1,724 & 1,641 & 1,570 & 1,547 & 1,577 & 1,570 & 1,562 & 1,543 & 1,577 & 1,581 & 1,565 & 1,591 & 1,618 & 1,618 & 1,613 \\
\hline $\mathrm{Mn}$ & 0,111 & 0,104 & 0,095 & 0,094 & 0,092 & 0,093 & 0,094 & 0,091 & 0,092 & 0,095 & 0,097 & 0,094 & 0,096 & 0,100 & 0,109 \\
\hline $\mathrm{Mg}$ & 0,668 & 0,771 & 0,800 & 0,818 & 0,808 & 0,829 & 0,802 & 0,830 & 0,784 & 0,772 & 0,770 & 0,754 & 0,746 & 0,755 & 0,742 \\
\hline $\mathrm{Ca}$ & 0,489 & 0,492 & 0,505 & 0,514 & 0,517 & 0,506 & 0,531 & 0,524 & 0,548 & 0,549 & 0,559 & 0,554 & 0,553 & 0,534 & 0,522 \\
\hline $\mathrm{Na}$ & 0,000 & 0,000 & 0,000 & 0,000 & 0,000 & 0,000 & 0,000 & 0,000 & 0,000 & 0,000 & 0,000 & 0,000 & 0,000 & 0,000 & 0,000 \\
\hline $\mathrm{K}$ & 0,000 & 0,000 & 0,000 & 0,000 & 0,000 & 0,000 & 0,000 & 0,000 & 0,000 & 0,000 & 0,000 & 0,000 & 0,000 & 0,000 & 0,000 \\
\hline Soma & 7,992 & 8,000 & 8,000 & 8,000 & 8,000 & 8,000 & 8,000 & 8,000 & 8,000 & 8,000 & 8,000 & 8,000 & 8,000 & 8,000 & 8,000 \\
\hline \multicolumn{16}{|l|}{ Membros-finais } \\
\hline Almandina & $57,62 \%$ & $54,55 \%$ & $52,86 \%$ & $52,03 \%$ & $52,67 \%$ & $52,37 \%$ & $52,26 \%$ & $51,64 \%$ & $52,55 \%$ & $52,75 \%$ & $52,32 \%$ & $53,16 \%$ & $53,70 \%$ & $53,81 \%$ & $54,02 \%$ \\
\hline Piropo & $22,33 \%$ & $25,63 \%$ & $26,94 \%$ & $27,51 \%$ & $26,99 \%$ & $27,65 \%$ & $26,83 \%$ & $27,78 \%$ & $26,12 \%$ & $25,76 \%$ & $25,74 \%$ & $25,19 \%$ & $24,76 \%$ & $25,11 \%$ & $24,85 \%$ \\
\hline Grossulária & $16,24 \%$ & $14,39 \%$ & $12,73 \%$ & $12,28 \%$ & $14,58 \%$ & $14,39 \%$ & $15,24 \%$ & $12,94 \%$ & $15,96 \%$ & $16,28 \%$ & $15,07 \%$ & $16,27 \%$ & $16,88 \%$ & $16,05 \%$ & $13,73 \%$ \\
\hline Espessartita & $3,71 \%$ & $3,46 \%$ & $3,20 \%$ & $3,16 \%$ & $3,07 \%$ & $3,10 \%$ & $3,14 \%$ & $3,05 \%$ & $3,07 \%$ & $3,17 \%$ & $3,24 \%$ & $3,14 \%$ & $3,19 \%$ & $3,33 \%$ & $3,65 \%$ \\
\hline Andradita & $0,00 \%$ & $1,91 \%$ & $4,17 \%$ & $4,91 \%$ & $2,54 \%$ & $2,49 \%$ & $2,52 \%$ & $4,45 \%$ & $2,20 \%$ & $2,04 \%$ & $3,57 \%$ & $2,14 \%$ & $1,47 \%$ & $1,66 \%$ & $3,65 \%$ \\
\hline Uvarovita & $0,10 \%$ & $0,05 \%$ & $0,10 \%$ & $0,10 \%$ & $0,15 \%$ & $0,00 \%$ & $0,00 \%$ & $0,15 \%$ & $0,10 \%$ & $0,00 \%$ & $0,05 \%$ & $0,10 \%$ & $0,00 \%$ & $0,05 \%$ & $0,10 \%$ \\
\hline
\end{tabular}


IC-06-R

\begin{tabular}{|c|c|c|c|c|c|c|c|c|c|c|c|c|c|c|c|c|c|c|c|c|}
\hline $\begin{array}{c}\text { Grão- } \\
\text { Análise }\end{array}$ & grt4-1 & grt4-2 & grt4-3 & grt4-4 & grt4-5 & grt4-6 & grt4-7 & grt4-8 & grt4-9 & grt4-10 & grt4-11 & grt4-12 & grt4-13 & grt4-14 & grt4-15 & grt4-16 & grt4-17 & grt4-18 & grt4-19 & grt4-20 \\
\hline $\mathrm{SiO}_{2}$ & 38,82 & 39,16 & 38,97 & 38,87 & 38,59 & 38,93 & 39,04 & 39,04 & 38,83 & 39,21 & 38,91 & 39,20 & 39,19 & 39,13 & 39,11 & 39,53 & 39,32 & 38,71 & 38,14 & 38,62 \\
\hline $\mathrm{TiO}_{2}$ & 0,06 & 0,07 & 0,09 & 0,06 & 0,07 & 0,08 & 0,04 & 0,10 & 0,09 & 0,01 & 0,07 & 0,04 & & 0,07 & 0,10 & 0,0 & 0,04 & 0,03 & 0,04 & 0,08 \\
\hline $\mathrm{Al}_{2} \mathrm{O}_{3}$ & 21,77 & 21,84 & 21,70 & 21,56 & 21,85 & 21,95 & 22,00 & 21,70 & 22,11 & 21,98 & 21,88 & 22,00 & 21,85 & 21,87 & 21,88 & 21,65 & 21,85 & 22,17 & 21,28 & 21,69 \\
\hline $\mathrm{Cr}_{2} \mathrm{O}_{3}$ & 0,00 & 0,00 & 0,00 & 0,01 & 0,01 & 0,00 & 0,00 & 0,00 & 0,00 & 0,02 & 0,00 & 0,01 & 0,03 & 0,02 & 0,00 & 0,00 & 0,00 & 0,01 & 0,01 & 0,04 \\
\hline $\mathrm{Fe}_{2} \mathrm{O}_{3}$ & 0,61 & 0,30 & 0,87 & 0,64 & 1,19 & 1,22 & 0,43 & 0,49 & 0,71 & 0,60 & 1,14 & 0,94 & 0,00 & 0,39 & 0,61 & 0,00 & 0,52 & 0,82 & 1,10 & 0,21 \\
\hline $\mathrm{FeO}$ & 25,12 & 25,04 & 24,33 & 24,33 & 23,84 & 23,96 & 24,42 & 24,33 & 24,15 & 24,41 & 24,00 & 24,18 & 24,48 & 24,32 & 24,33 & 24,78 & $\begin{array}{r}24,49 \\
\end{array}$ & 24,15 & 23,92 & 26,22 \\
\hline $\mathrm{MnO}$ & 1,36 & 1,35 & 1,31 & 1,34 & 1,25 & 1,26 & 1,25 & 1,28 & 1,30 & 1,30 & 1,30 & 1,32 & 1,31 & 1,26 & 1,28 & 1,27 & 1,28 & 1,37 & 1,34 & 1,51 \\
\hline $\mathrm{MgO}$ & 7,03 & 7,34 & 7,57 & 7,54 & & 7,82 & 7,73 & 7,73 & 7,65 & 7,73 & 7,7 & 7,82 & & & 7,6 & 7,5 & 7,6 & 7,2 & 7,28 & 6,02 \\
\hline $\mathrm{CaO}$ & 5,81 & 5,77 & 5,88 & 5,78 & 5,73 & 5,81 & 5,66 & 5,75 & 5,78 & 5,77 & 5,78 & 5,82 & 5,64 & 5,90 & 5,87 & 5,93 & 5, & 5,8 & 5,77 & 6,07 \\
\hline $\mathrm{Na}_{2} \mathrm{O}$ & & 0,00 & & & & & & & & & & & & & & & & & & 0,00 \\
\hline $\mathrm{K}_{2} \mathrm{O}$ & 0,00 & 0,00 & 0,00 & 0,00 & 0,00 & 0,00 & 0,00 & 0,0 & 0,00 & 0, & 0, & 0, & 0, & 0 & 0 & 0,00 & $0, \mathrm{C}$ & 0, & 0, & 0,00 \\
\hline Total & 100,58 & 100,86 & 100,72 & 100,13 & 100,25 & 101,04 & 100,57 & 100,42 & 100,62 & 101,03 & 100,86 & 101,32 & 100,18 & 100,65 & 100,87 & 100,81 & 101,09 & 100,55 & 98,88 & 100,46 \\
\hline Oxigênios & 12,00 & 12,00 & 12,00 & 12,00 & 12,00 & 12,00 & 12,00 & 12,00 & 12,00 & 12,00 & 12,00 & 12,00 & 12,00 & 12,00 & 12,00 & 12,00 & 12,00 & 12,00 & 12,00 & 12,00 \\
\hline $\mathrm{Si}$ & 2,990 & 3,001 & 2,989 & 2,998 & 2,970 & 2,972 & 2,992 & & 2,976 & 2,9 & & 2,9 & & $2, \mathrm{~s}$ & & & & & & \\
\hline $\mathrm{Ti}$ & 0,004 & 0,004 & 0,005 & 0,003 & 0,004 & 0,005 & 0,002 & 0,00 & 0,005 & 0,000 & 0,004 & 0,002 & 0,0 & 0,0 & 0,0 & & 0,0 & & & 0,005 \\
\hline Al & 1,977 & 1,973 & 1,962 & 1,960 & 1,983 & 1,976 & 1,987 & 1,965 & 1,998 & 1,978 & 1,973 & 1,974 & 1,980 & 1,9 & 1,9 & & 1,9 & & & 1,984 \\
\hline $\mathrm{Cr}$ & 0,000 & 0,000 & 0,000 & 0,000 & 0,000 & 0,000 & 0,000 & 0,000 & 0,000 & 0,001 & 0,000 & 0,001 & 0,002 & 0,001 & 0,000 & 0,000 & 0,0 & 0,0 & 0,0 & 0,002 \\
\hline $\mathrm{Fe}^{3+}$ & 0,035 & 0,017 & 050 & 0,037 & 0,0 & 0,0 & 0,0 & & & & 0,0 & & & 3 & & & & & & 0,012 \\
\hline $\mathrm{Fe}^{2-}$ & 619 & 1,605 & 1,560 & 1,569 & 1,534 & 1,530 & 1,565 & 1,562 & 1,548 & 1,558 & 1,536 & 1,539 & 1,574 & 1,557 & 1,556 & 1,585 & 1,5 & 1,5 & 1,5 & 1,701 \\
\hline $\mathrm{Mn}$ & 0,089 & 0,088 & 0,085 & 0,088 & 0,082 & 0,082 & 0,081 & & 0,084 & & & & & & & & & & & 0,099 \\
\hline $\mathrm{Mg}$ & 0,807 & 0,838 & 0,865 & 0,867 & 0,885 & 0,890 & 0,883 & 0,885 & 0,874 & 0,879 & 0,887 & 0,887 & 0,873 & 0,878 & 0,8 & & 0,873 & 0,8 & 0,849 & 0,696 \\
\hline $\mathrm{Ca}$ & 0,480 & 0,474 & 0,483 & 0,478 & 0,473 & 0,475 & 0,465 & 0,473 & 0,475 & 0,472 & 0,4 & 0,4 & & 0,4 & & & & & & \\
\hline $\mathrm{Na}$ & 0,000 & 0,000 & 000 & 0,000 & 0,000 & 0,000 & 0,000 & 0,0 & 0,000 & 0,000 & 0,000 & & & 0 & & & & & & 0,000 \\
\hline $\mathrm{K}$ & 0,000 & 0,000 & 0,000 & 0,000 & 0,000 & 0,000 & 0,000 & 0,000 & 0,000 & 0,000 & 0,000 & 0,000 & 0,000 & 0,000 & 0,000 & 0, & 0,000 & 0,000 & 0,000 & 0,000 \\
\hline Soma & 8,000 & 8,000 & 8,000 & 8,000 & 8,000 & 8,000 & 8,000 & 8,000 & 8,000 & 8,000 & 8,000 & 8,000 & 7,994 & 8,000 & 8,000 & 7,997 & 8,000 & 8,000 & 8,000 & 8,000 \\
\hline \multicolumn{21}{|c|}{ Membros-finais } \\
\hline Almandina & $\begin{array}{c}54,06 \\
\%\end{array}$ & $\begin{array}{c}53,41 \\
\%\end{array}$ & $\begin{array}{c}52,12 \\
\%\end{array}$ & $\begin{array}{c}52,27 \\
\%\end{array}$ & $\begin{array}{c}51,58 \\
\%\end{array}$ & $\begin{array}{c}51,39 \\
\%\end{array}$ & $\begin{array}{c}52,27 \\
\%\end{array}$ & $\begin{array}{c}52,01 \\
\%\end{array}$ & $\begin{array}{c}51,93 \\
\%\end{array}$ & $\begin{array}{c}52,05 \\
\%\end{array}$ & $\begin{array}{c}51,53 \\
\%\end{array}$ & $\begin{array}{c}51,54 \\
\%\end{array}$ & $\begin{array}{c}52,52 \\
\%\end{array}$ & $\begin{array}{c}51,88 \\
\%\end{array}$ & $\begin{array}{c}51,94 \\
\%\end{array}$ & $\begin{array}{c}52,52 \\
\%\end{array}$ & $\begin{array}{c}52,07 \\
\%\end{array}$ & $\begin{array}{c}52,14 \\
\%\end{array}$ & $\begin{array}{c}52,39 \\
\%\end{array}$ & $\begin{array}{c}56,68 \\
\%\end{array}$ \\
\hline & 26,94 & 27,89 & 28,90 & 28,88 & 29,76 & 29,90 & 29,49 & 29,47 & 29,32 & 29,37 & 29,76 & 29,71 & 29,13 & 29,26 & 29,24 & 28,63 & 29,08 & 28,79 & 28,42 & 23,19 \\
\hline & & $\%$ & $\%$ & & $\%$ & $\%$ & $\%$ & $\%$ & & & & & & & $\%$ & $\%$ & $\%$ & $\%$ & $\%$ & 20,10 \\
\hline & 14,29 & 14,92 & 13,65 & 14,07 & 12,54 & 12,53 & 14,29 & 14,35 & 13,92 & 13,98 & 12,66 & 13,20 & 15,41 & 14,93 & 14,31 & 16,10 & 14,59 & 13,69 & 12,95 & 16,13 \\
\hline & & & & & & & & & & & & & & & & & & & & \\
\hline $\begin{array}{c}\text { Espessartit } \\
\text { a }\end{array}$ & $2,97 \%$ & $2,93 \%$ & $2,84 \%$ & $2,93 \%$ & $2,76 \%$ & $2,75 \%$ & $2,71 \%$ & $2,76 \%$ & $2,82 \%$ & $2,81 \%$ & $2,82 \%$ & $2,85 \%$ & $2,84 \%$ & $2,73 \%$ & $2,77 \%$ & $2,75 \%$ & $2,76 \%$ & $2,99 \%$ & $2,98 \%$ & $3,30 \%$ \\
\hline Andradita & $1,74 \%$ & $0,85^{\circ}$ & $2,49 \%$ & $1,85 \%$ & 3,36 & $3,42 \%$ & $1,24 \%$ & & $2,01 \%$ & 1,74 & $3,24 \%$ & & & & $1,74 \%$ & & & & $3,20 \%$ & \\
\hline Uvarovita & $0,00 \%$ & $0,00 \%$ & $0,00 \%$ & $0,00 \%$ & $0,00 \%$ & $0,00 \%$ & $0,00 \%$ & $0,00 \%$ & $0,00 \%$ & $0,05 \%$ & $0,00 \%$ & $0,05 \%$ & $0,10 \%$ & $0,05 \%$ & $0,00 \%$ & $0,00 \%$ & $0,00 \%$ & $0,05 \%$ & $0,05 \%$ & $0,10 \%$ \\
\hline
\end{tabular}


Tabela 23 - Análises químicas de granada da Nappe Socorro-Guaxupé

\begin{tabular}{|c|c|c|c|c|c|c|c|c|c|c|c|c|c|c|c|}
\hline \multicolumn{16}{|c|}{ IC-06-R } \\
\hline Grão-Análise & grt5-1 & grt5-2 & grt5-3 & grt5-4 & grt5-5 & grt5-6 & grt5-7 & grt5-8 & grt5-9 & grt5-10 & grt5-11 & grt5-12 & grt5-13 & grt5-14 & grt5-15 \\
\hline $\mathrm{SiO}_{2}$ & 38,96 & 39,01 & 39,25 & 38,96 & 38,82 & 38,86 & 38,82 & 39,21 & 38,91 & 39,19 & 39,02 & 39,12 & 38,92 & 39,05 & 38,89 \\
\hline $\mathrm{TiO}_{2}$ & 0,08 & 0,09 & 0,01 & 0,04 & 0,10 & 0,06 & 0,07 & 0,08 & 0,07 & 0,06 & 0,10 & 0,08 & 0,07 & 0,08 & 0,03 \\
\hline $\mathrm{Al}_{2} \mathrm{O}_{3}$ & 21,47 & 21,73 & 21,88 & 21,93 & 21,81 & 21,88 & 21,84 & 21,98 & 21,85 & 22,06 & 21,87 & 21,85 & 21,95 & 21,78 & 21,50 \\
\hline $\mathrm{Cr}_{2} \mathrm{O}_{3}$ & 0,03 & 0,02 & 0,02 & 0,02 & 0,02 & 0,02 & 0,01 & 0,01 & 0,03 & 0,01 & 0,00 & 0,01 & 0,00 & 0,02 & 0,03 \\
\hline $\mathrm{Fe}_{2} \mathrm{O}_{3}$ & 0,43 & 0,64 & 0,34 & 1,03 & 1,08 & 0,83 & 0,67 & 0,29 & 0,85 & 0,15 & 0,50 & 0,60 & 1,12 & 0,12 & 0,76 \\
\hline $\mathrm{FeO}$ & 25,66 & 24,71 & 24,70 & 23,94 & 23,63 & 23,88 & 23,93 & 24,06 & 23,58 & 24,06 & 23,60 & 23,12 & 22,93 & 24,07 & 24,55 \\
\hline $\mathrm{MnO}$ & 1,43 & 1,30 & 1,23 & 1,25 & 1,15 & 1,14 & 1,09 & 1,13 & 1,10 & 1,09 & 1,08 & 1,08 & 1,10 & 1,21 & 1,41 \\
\hline $\mathrm{MgO}$ & 6,74 & 7,35 & 7,56 & 7,66 & 7,80 & 7,78 & 7,63 & 7,61 & 7,65 & 7,60 & 7,45 & 7,20 & 7,03 & 7,02 & 7,09 \\
\hline $\mathrm{CaO}$ & 5,88 & 5,93 & 5,88 & 6,06 & 6,10 & 5,95 & 6,12 & 6,39 & 6,45 & 6,41 & 6,85 & 7,65 & 7,83 & 6,99 & 6,18 \\
\hline $\mathrm{Na}_{2} \mathrm{O}$ & 0,00 & 0,00 & 0,00 & 0,00 & 0,00 & 0,00 & 0,00 & 0,00 & 0,00 & 0,00 & 0,00 & 0,00 & 0,00 & 0,00 & 0,00 \\
\hline $\mathrm{K}_{2} \mathrm{O}$ & 0,00 & 0,00 & 0,00 & 0,00 & 0,00 & 0,00 & 0,00 & 0,00 & 0,00 & 0,00 & 0,00 & 0,00 & 0,00 & 0,00 & 0,00 \\
\hline Total & 100,68 & 100,78 & 100,87 & 100,89 & 100,50 & 100,41 & 100,18 & 100,76 & 100,49 & 100,63 & 100,47 & 100,71 & 100,95 & 100,34 & 100,44 \\
\hline Oxigênios & 12,00 & 12,00 & 12,00 & 12,00 & 12,00 & 12,00 & 12,00 & 12,00 & 12,00 & 12,00 & 12,00 & 12,00 & 12,00 & 12,00 & 12,00 \\
\hline $\mathrm{Si}$ & 3,006 & 2,993 & 3,002 & 2,979 & 2,977 & 2,982 & 2,986 & 2,997 & 2,983 & 2,997 & 2,992 & 2,993 & 2,975 & 3,004 & 2,998 \\
\hline $\mathrm{Ti}$ & 0,004 & 0,005 & 0,001 & 0,002 & 0,005 & 0,004 & 0,004 & 0,004 & 0,004 & 0,004 & 0,005 & 0,005 & 0,004 & 0,005 & 0,002 \\
\hline Al & 1,953 & 1,966 & 1,973 & 1,977 & 1,972 & 1,979 & 1,981 & 1,980 & 1,975 & 1,989 & 1,977 & 1,971 & 1,978 & 1,975 & 1,954 \\
\hline $\mathrm{Cr}$ & 0,002 & 0,001 & 0,001 & 0,001 & 0,001 & 0,001 & 0,000 & 0,001 & 0,002 & 0,000 & 0,000 & 0,000 & 0,000 & 0,001 & 0,002 \\
\hline $\mathrm{Fe}^{3+}$ & 0,025 & 0,037 & 0,019 & 0,059 & 0,063 & 0,048 & 0,039 & 0,017 & 0,049 & 0,008 & 0,029 & 0,034 & 0,065 & 0,007 & 0,044 \\
\hline $\mathrm{Fe}^{2-}$ & 1,656 & 1,586 & 1,580 & 1,531 & 1,515 & 1,533 & 1,540 & 1,538 & 1,512 & 1,539 & 1,513 & 1,479 & 1,466 & 1,549 & 1,583 \\
\hline $\mathrm{Mn}$ & 0,093 & 0,084 & 0,080 & 0,081 & 0,075 & 0,074 & 0,071 & 0,073 & 0,072 & 0,071 & 0,070 & 0,070 & 0,071 & 0,079 & 0,092 \\
\hline $\mathrm{Mg}$ & 0,775 & 0,840 & 0,862 & 0,873 & 0,891 & 0,890 & 0,875 & 0,867 & 0,874 & 0,866 & 0,851 & 0,821 & 0,801 & 0,805 & 0,815 \\
\hline $\mathrm{Ca}$ & 0,486 & 0,488 & 0,482 & 0,497 & 0,501 & 0,489 & 0,504 & 0,523 & 0,530 & 0,525 & 0,563 & 0,627 & 0,641 & 0,576 & 0,511 \\
\hline $\mathrm{Na}$ & 0,000 & 0,000 & 0,000 & 0,000 & 0,000 & 0,000 & 0,000 & 0,000 & 0,000 & 0,000 & 0,000 & 0,000 & 0,000 & 0,000 & 0,000 \\
\hline $\mathrm{K}$ & 0,000 & 0,000 & 0,000 & 0,000 & 0,000 & 0,000 & 0,000 & 0,000 & 0,000 & 0,000 & 0,000 & 0,000 & 0,000 & 0,000 & 0,000 \\
\hline Soma & 8,000 & 8,000 & 8,000 & 8,000 & 8,000 & 8,000 & 8,000 & 8,000 & 8,000 & 8,000 & 8,000 & 8,000 & 8,000 & 8,000 & 8,000 \\
\hline \multicolumn{16}{|l|}{ Membros-finais } \\
\hline Almandina & $55,02 \%$ & $52,90 \%$ & $52,60 \%$ & $51,34 \%$ & $50,80 \%$ & $51,34 \%$ & $51,51 \%$ & $51,25 \%$ & $50,60 \%$ & $51,28 \%$ & $50,48 \%$ & $49,35 \%$ & $49,21 \%$ & $51,48 \%$ & $52,75 \%$ \\
\hline Piropo & $25,75 \%$ & $28,02 \%$ & $28,70 \%$ & $29,28 \%$ & $29,88 \%$ & $29,81 \%$ & $29,26 \%$ & $28,89 \%$ & $29,25 \%$ & $28,86 \%$ & $28,40 \%$ & $27,39 \%$ & $26,89 \%$ & $26,75 \%$ & $27,16 \%$ \\
\hline Grossulária & $14,78 \%$ & $14,38 \%$ & $15,04 \%$ & $13,72 \%$ & $13,66 \%$ & $13,96 \%$ & $14,93 \%$ & $16,53 \%$ & $15,22 \%$ & $17,09 \%$ & $17,34 \%$ & $19,23 \%$ & $18,34 \%$ & $18,74 \%$ & $14,73 \%$ \\
\hline Espessartita & $3,09 \%$ & $2,80 \%$ & $2,66 \%$ & $2,72 \%$ & $2,52 \%$ & $2,48 \%$ & $2,37 \%$ & $2,43 \%$ & $2,41 \%$ & $2,37 \%$ & $2,34 \%$ & $2,34 \%$ & $2,38 \%$ & $2,63 \%$ & $3,07 \%$ \\
\hline Andradita & $1,26 \%$ & $1,85 \%$ & $0,95 \%$ & $2,90 \%$ & $3,09 \%$ & $2,37 \%$ & $1,93 \%$ & $0,85 \%$ & $2,42 \%$ & $0,40 \%$ & $1,45 \%$ & $1,70 \%$ & $3,18 \%$ & $0,35 \%$ & $2,20 \%$ \\
\hline Uvarovita & $0,10 \%$ & $0,05 \%$ & $0,05 \%$ & $0,05 \%$ & $0,05 \%$ & $0,05 \%$ & $0,00 \%$ & $0,05 \%$ & $0,10 \%$ & $0,00 \%$ & $0,00 \%$ & $0,00 \%$ & $0,00 \%$ & $0,05 \%$ & $0,10 \%$ \\
\hline
\end{tabular}


Tabela 24- Análises químicas de granada da Nappe Socorro-Guaxupé

\begin{tabular}{|c|c|c|c|c|c|c|c|c|c|c|c|c|c|c|c|}
\hline \multicolumn{16}{|c|}{ IC-06-R } \\
\hline Grão-Análise & grt6-1 & grt6-2 & grt6-3 & grt6-4 & grt6-5 & grt6-6 & grt6-7 & grt6-8 & grt6-9 & grt6-10 & grt6-11 & grt6-12 & grt6-13 & grt6-14 & grt6-15 \\
\hline $\mathrm{SiO}_{2}$ & 39,02 & 38,91 & 39,15 & 39,09 & 38,98 & 38,98 & 38,53 & 38,98 & 38,89 & 38,87 & 39,08 & 38,91 & 39,05 & 39,02 & 38,78 \\
\hline $\mathrm{TiO}_{2}$ & 0,05 & 0,05 & 0,07 & 0,04 & 0,07 & 0,10 & 0,03 & 0,05 & 0,08 & 0,09 & 0,05 & 0,07 & 0,04 & 0,11 & 0,06 \\
\hline $\mathrm{Al}_{2} \mathrm{O}_{3}$ & 21,57 & 21,86 & 21,93 & 21,82 & 21,60 & 21,88 & 22,04 & 22,11 & 21,78 & 22,13 & 21,87 & 22,09 & 21,67 & 21,40 & 21,71 \\
\hline $\mathrm{Cr}_{2} \mathrm{O}_{3}$ & 0,02 & 0,01 & 0,01 & 0,01 & 0,00 & 0,00 & 0,01 & 0,02 & 0,00 & 0,00 & 0,01 & 0,00 & 0,00 & 0,01 & 0,05 \\
\hline $\mathrm{Fe}_{2} \mathrm{O}_{3}$ & 0,15 & 0,80 & 0,25 & 0,67 & 0,75 & 0,72 & 1,22 & 0,35 & 0,86 & 0,75 & 0,13 & 0,38 & 0,24 & 0,15 & 0,71 \\
\hline $\mathrm{FeO}$ & 25,39 & 24,52 & 24,52 & 24,12 & 24,15 & 23,84 & 23,06 & 23,49 & 23,20 & 23,28 & 23,41 & 23,18 & 24,45 & 25,04 & 25,17 \\
\hline $\mathrm{MnO}$ & 1,43 & 1,42 & 1,31 & 1,28 & 1,30 & 1,29 & 1,22 & 1,18 & 1,20 & 1,21 & 1,20 & 1,20 & 1,27 & 1,42 & 1,56 \\
\hline $\mathrm{MgO}$ & 6,73 & 7,33 & 7,36 & 7,55 & 7,43 & 7,44 & 7,29 & 7,17 & 7,17 & 7,30 & 7,05 & 7,07 & 6,95 & 6,91 & 6,60 \\
\hline $\mathrm{CaO}$ & 6,14 & 5,89 & 6,18 & 6,17 & 6,22 & 6,48 & 6,88 & 7,17 & 7,32 & 7,06 & 7,48 & 7,49 & 6,72 & 6,22 & 6,17 \\
\hline $\mathrm{Na}_{2} \mathrm{O}$ & 0,00 & 0,00 & 0,00 & 0,00 & 0,00 & 0,00 & 0,00 & 0,00 & 0,00 & 0,00 & 0,00 & 0,00 & 0,00 & 0,00 & 0,00 \\
\hline $\mathrm{K}_{2} \mathrm{O}$ & 0,00 & 0,00 & 0,00 & 0,00 & 0,00 & 0,00 & 0,00 & 0,00 & 0,00 & 0,00 & 0,00 & 0,00 & 0,00 & 0,00 & 0,00 \\
\hline Total & 100,51 & 100,79 & 100,78 & 100,75 & 100,50 & 100,72 & 100,28 & 100,52 & 100,50 & 100,69 & 100,28 & 100,39 & 100,38 & 100,27 & 100,81 \\
\hline Oxigênios & 12,00 & 12,00 & 12,00 & 12,00 & 12,00 & 12,00 & 12,00 & 12,00 & 12,00 & 12,00 & 12,00 & 12,00 & 12,00 & 12,00 & 12,00 \\
\hline $\mathrm{Si}$ & 3,011 & 2,985 & 2,998 & 2,993 & 2,996 & 2,986 & 2,963 & 2,988 & 2,985 & 2,975 & 3,003 & 2,986 & 3,007 & 3,014 & 2,989 \\
\hline $\mathrm{Ti}$ & 0,003 & 0,003 & 0,004 & 0,002 & 0,004 & 0,006 & 0,002 & 0,003 & 0,004 & 0,005 & 0,003 & 0,004 & 0,002 & 0,006 & 0,003 \\
\hline Al & 1,962 & 1,977 & 1,980 & 1,970 & 1,957 & 1,976 & 1,998 & 1,998 & 1,971 & 1,997 & 1,981 & 1,998 & 1,967 & 1,949 & 1,972 \\
\hline $\mathrm{Cr}$ & 0,001 & 0,001 & 0,001 & 0,000 & 0,000 & 0,000 & 0,000 & 0,001 & 0,000 & 0,000 & 0,001 & 0,000 & 0,000 & 0,001 & 0,003 \\
\hline $\mathrm{Fe}^{3+}$ & 0,009 & 0,046 & 0,014 & 0,038 & 0,043 & 0,041 & 0,071 & 0,020 & 0,050 & 0,043 & 0,008 & 0,022 & 0,014 & 0,009 & 0,041 \\
\hline $\mathrm{Fe}^{2-}$ & 1,639 & 1,573 & 1,570 & 1,545 & 1,552 & 1,527 & 1,483 & 1,506 & 1,490 & 1,490 & 1,504 & 1,488 & 1,574 & 1,617 & 1,623 \\
\hline $\mathrm{Mn}$ & 0,093 & 0,092 & 0,085 & 0,083 & 0,085 & 0,083 & 0,079 & 0,077 & 0,078 & 0,079 & 0,078 & 0,078 & 0,083 & 0,093 & 0,102 \\
\hline $\mathrm{Mg}$ & 0,774 & 0,838 & 0,840 & 0,862 & 0,851 & 0,849 & 0,836 & 0,819 & 0,820 & 0,833 & 0,807 & 0,809 & 0,798 & 0,796 & 0,758 \\
\hline $\mathrm{Ca}$ & 0,508 & 0,484 & 0,507 & 0,506 & 0,512 & 0,532 & 0,567 & 0,589 & 0,602 & 0,579 & 0,616 & 0,616 & 0,555 & 0,515 & 0,509 \\
\hline $\mathrm{Na}$ & 0,000 & 0,000 & 0,000 & 0,000 & 0,000 & 0,000 & 0,000 & 0,000 & 0,000 & 0,000 & 0,000 & 0,000 & 0,000 & 0,000 & 0,000 \\
\hline $\mathrm{K}$ & 0,000 & 0,000 & 0,000 & 0,000 & 0,000 & 0,000 & 0,000 & 0,000 & 0,000 & 0,000 & 0,000 & 0,000 & 0,000 & 0,000 & 0,000 \\
\hline Soma & 8,000 & 8,000 & 8,000 & 8,000 & 8,000 & 8,000 & 8,000 & 8,000 & 8,000 & 8,000 & 8,000 & 8,000 & 8,000 & 8,000 & 8,000 \\
\hline \multicolumn{16}{|l|}{ Membros-finais } \\
\hline Almandina & $54,38 \%$ & $52,66 \%$ & $52,30 \%$ & $51,57 \%$ & $51,73 \%$ & $51,05 \%$ & $50,02 \%$ & $50,35 \%$ & $49,83 \%$ & $49,98 \%$ & $50,05 \%$ & $49,75 \%$ & $52,29 \%$ & $53,53 \%$ & $54,24 \%$ \\
\hline Piropo & $25,68 \%$ & $28,05 \%$ & $27,98 \%$ & $28,77 \%$ & $28,37 \%$ & $28,39 \%$ & $28,20 \%$ & $27,38 \%$ & $27,42 \%$ & $27,94 \%$ & $26,86 \%$ & $27,05 \%$ & $26,51 \%$ & $26,35 \%$ & $25,33 \%$ \\
\hline Grossulária & $16,35 \%$ & $13,88 \%$ & $16,14 \%$ & $15,00 \%$ & $14,92 \%$ & $15,75 \%$ & $15,69 \%$ & $18,65 \%$ & $17,66 \%$ & $17,32 \%$ & $20,05 \%$ & $19,51 \%$ & $17,73 \%$ & $16,54 \%$ & $14,83 \%$ \\
\hline Espessartita & $3,09 \%$ & $3,08 \%$ & $2,83 \%$ & $2,77 \%$ & $2,83 \%$ & $2,77 \%$ & $2,66 \%$ & $2,57 \%$ & $2,61 \%$ & $2,65 \%$ & $2,60 \%$ & $2,61 \%$ & $2,76 \%$ & $3,08 \%$ & $3,41 \%$ \\
\hline Andradita & $0,46 \%$ & $2,27 \%$ & $0,70 \%$ & $1,89 \%$ & $2,15 \%$ & $2,03 \%$ & $3,43 \%$ & $0,99 \%$ & $2,47 \%$ & $2,11 \%$ & $0,40 \%$ & $1,09 \%$ & $0,71 \%$ & $0,46 \%$ & $2,03 \%$ \\
\hline Uvarovita & $0,05 \%$ & $0,05 \%$ & $0,05 \%$ & $0,00 \%$ & $0,00 \%$ & $0,00 \%$ & $0,00 \%$ & $0,05 \%$ & $0,00 \%$ & $0,00 \%$ & $0,05 \%$ & $0,00 \%$ & $0,00 \%$ & $0,05 \%$ & $0,15 \%$ \\
\hline
\end{tabular}


Tabela 25 - Fórmulas estruturais e proporções moleculares de granada das nappes Três Pontas-Varginha e Socorro-Guaxupé

\begin{tabular}{|c|c|c|c|}
\hline Unidade & Amostra & Cristal & $\begin{array}{l}\text { Fórmula estrutural e proporções moleculares } \\
\end{array}$ \\
\hline \multirow{18}{*}{ 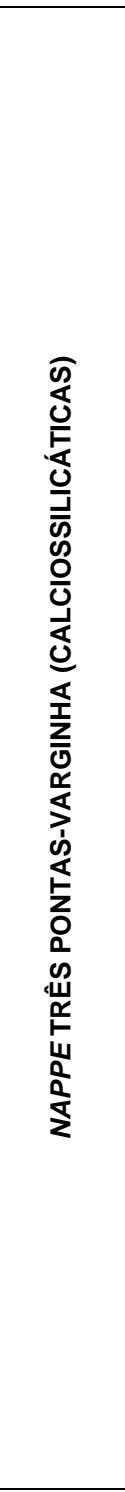 } & \multirow{6}{*}{ 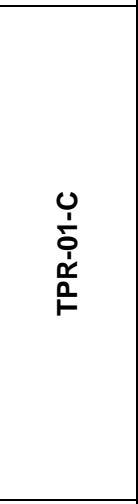 } & granada 1 & $\begin{array}{c}\left(\mathrm{Fe}^{2+}{ }_{1,40-1,53}, \mathrm{Mn}_{0,03-0,05}, \mathrm{Mg}_{0,63-0,76}, \mathrm{Ca}_{0,72-0,89}\right) \mathrm{Ti}_{0-0.01}, \mathrm{Fe}^{3+}{ }_{0-0,07}, \mathrm{Al}_{1,95-2,00}\left(\mathrm{Al}_{0-0,05}, \mathrm{Si}_{2,95-3,00}\right) \mathrm{O}_{12} \\
\mathrm{Alm}_{47,36-51,24} \operatorname{Prp}_{21,09-25,47} \mathrm{Sps}_{1,03-1,67} \mathrm{GrS}_{23,09-27,79} \mathrm{And}_{0-3,45} \mathrm{Uv}_{0-0,24}\end{array}$ \\
\hline & & granada 2 & $\begin{array}{c}\left(\mathrm{Fe}^{2+}{ }_{1,41-1,51}, \mathrm{Mn}_{0,03-0,04}, \mathrm{Mg}_{0,70-0,81}, \mathrm{Ca}_{0,65-0,84}\right) \mathrm{Ti}_{0-0.01}, \mathrm{Fe}^{3+}{ }_{0,01-0,07}, \mathrm{Al}_{1,93-2,00}\left(\mathrm{Al}_{0-0,03}, \mathrm{Si}_{2,97-3,00}\right) \mathrm{O}_{12} \\
\mathrm{Alm}_{47,22-50,62} \operatorname{Prp}_{23,31-27,25} \mathrm{Sps}_{0,90-1,31} \mathrm{Grs}_{19,52-26,94} \mathrm{And}_{0,30-3,22} \mathrm{Uv}_{0-0,20}\end{array}$ \\
\hline & & granada 3 & $\begin{array}{c}\left(\mathrm{Fe}^{2+}{ }_{1,39-1,54}, \mathrm{Mn}_{0,03-0,07}, \mathrm{Mg}_{0,57-0,80}, \mathrm{Ca}_{0,68-0,92}\right) \mathrm{Ti}_{0-0.01}, \mathrm{Fe}^{3+}{ }_{0,01-0,08}, \mathrm{Al}_{1,91-2,00}\left(\mathrm{Al}_{0-0,04}, \mathrm{Si}_{2,96-3,00}\right) \mathrm{O}_{12} \\
\mathrm{Alm}_{46,95-51,08} \operatorname{Prp}_{18,99-26,95} \mathrm{Sps}_{0,93-2,24} \mathrm{Grs}_{19,51-29,01} \mathrm{And}_{0,35-3,78} \mathrm{Uv}_{0-0,15}\end{array}$ \\
\hline & & granada 4 & $\begin{array}{c}\left(\mathrm{Fe}^{2+}{ }_{1,42-1,55}, \mathrm{Mn}_{0,03-0,04}, \mathrm{Mg}_{0,68-0,80}, \mathrm{Ca}_{0,67-0,82}\right) \mathrm{Ti}_{0-0.01}, \mathrm{Fe}^{3+}{ }_{0-0,08}, \mathrm{Al}_{1,95-2,00}\left(\mathrm{Al}_{0-0,04}, \mathrm{Si}_{2,96-3,00}\right) \mathrm{O}_{12} \\
\mathrm{Alm}_{47,66-51,86} \operatorname{Prp}_{22,58-26,57} \mathrm{Sps}_{0,93-1,47} \mathrm{Grs}_{19,27-25,59} \mathrm{And}_{0-3,99} \mathrm{Uv}_{0-0,20}\end{array}$ \\
\hline & & granada 5 & $\begin{array}{c}\left(\mathrm{Fe}^{2+}{ }_{1,41-1,56}, \mathrm{Mn}_{0,03-0,08}, \mathrm{Mg}_{0,50-0,80}, \mathrm{Ca}_{0,68-0,99}\right) \mathrm{Ti}_{0-0.01}, \mathrm{Fe}^{3+}{ }_{0-0,08}, \mathrm{Al}_{1,93-2,00}\left(\mathrm{Al}_{0-0,04}, \mathrm{Si}_{2,96-3,00}\right) \mathrm{O}_{12} \\
\mathrm{Alm}_{47,29-51,92} \operatorname{Prp}_{16,71-26,68} \mathrm{Sps}_{0,97-2,66} \mathrm{GrS}_{20,38-31,93} \mathrm{And}_{0-4,05} \mathrm{Uv}_{0-0,20}\end{array}$ \\
\hline & & granada 6 & $\begin{array}{c}\left(\mathrm{Fe}^{2+}{ }_{1,36-1,52}, \mathrm{Mn}_{0,03-0,04}, \mathrm{Mg}_{0,65-0,77}, \mathrm{Ca}_{0,71-0,94}\right) \mathrm{Ti}_{0-0.01}, \mathrm{Fe}^{3+}{ }_{0-0,07}, \mathrm{Al}_{1,93-2,00}\left(\mathrm{Al}_{0-0,04}, \mathrm{Si}_{2,96-3,00}\right) \mathrm{O}_{12} \\
\mathrm{Alm}_{45,54-51,23} \operatorname{Prp}_{21,80-25,98} \mathrm{Sps}_{0,98-1,43} \mathrm{Grs}_{21,17-30.06} \mathrm{And}_{0-3,27} \mathrm{Uv}_{0-0,20}\end{array}$ \\
\hline & \multirow{7}{*}{ 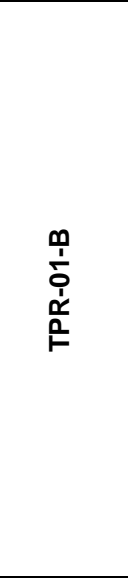 } & granada 1 & $\begin{array}{c}\left(\mathrm{Fe}^{2+}{ }_{1,46-1,56}, \mathrm{Mn}_{0,03}, \mathrm{Mg}_{0,69-0,80}, \mathrm{Ca}_{0,68-0,74}\right) \mathrm{Ti}_{0-0.01}, \mathrm{Fe}^{3+}{ }_{0-0,04}, \mathrm{Al}_{1,96-2,00}\left(\mathrm{Al}_{0-0,02}, \mathrm{Si}_{2,98-3,00}\right) \mathrm{O}_{12} \\
\mathrm{Alm}_{48,70-52,04} \mathrm{Prp}_{23,06-26,47} \mathrm{Sps}_{0,98-1,10} \mathrm{Grs}_{20,68-24,15} \mathrm{And}_{0-1,96} \mathrm{Uv}_{0-0,20}\end{array}$ \\
\hline & & granada 2 & $\begin{array}{c}\left(\mathrm{Fe}^{2+}{ }_{1,39-1,49}, \mathrm{Mn}_{0,03-0,06}, \mathrm{Mg}_{0,62-0,77}, \mathrm{Ca}_{0,71-0,91}\right) \mathrm{Ti}_{0-0.01}, \mathrm{Fe}^{3+}{ }_{0-0,02}, \mathrm{Al}_{1,95-2,00}\left(\mathrm{Al}_{0-0,01}, \mathrm{Si}_{2,99-3,00}\right) \mathrm{O}_{12} \\
\mathrm{Alm}_{46,67-50,40} \operatorname{Prp}_{20,74-25,79} \mathrm{Sps}_{1,03-1,83} \mathrm{Grs}_{23.31-30.34} \mathrm{And}_{0-1,10} \mathrm{Uv}_{0-0,20}\end{array}$ \\
\hline & & granada 3 & $\begin{array}{c}\left(\mathrm{Fe}^{2+}{ }_{1,46-1,54}, \mathrm{Mn}_{0,03}, \mathrm{Mg}_{0,73-0,80}, \mathrm{Ca}_{0,67-0,71}\right) \mathrm{Ti}_{0-0.01}, \mathrm{Fe}^{3+0-}{ }_{0,05}, \mathrm{Al}_{1,93-1,99}\left(\mathrm{Al}_{0-0,02}, \mathrm{Si}_{2,98-3,00}\right) \mathrm{O}_{12} \\
\mathrm{Alm}_{48,95-51,38} \operatorname{Prp}_{24,33-26,62} \mathrm{Sps}_{0,97-1,06} \mathrm{Grs}_{19,91-23,30} \mathrm{And}_{0-2,37} \mathrm{Uv}_{0-0,20}\end{array}$ \\
\hline & & granada 4 & $\begin{array}{c}\left(\mathrm{Fe}^{2+}{ }_{1,36-1,54}, \mathrm{Mn}_{0,03}, \mathrm{Mg}_{0,72-0,81}, \mathrm{Ca}_{0,66-0,71}\right) \mathrm{Ti}_{0-0.01}, \mathrm{Fe}^{3+}{ }_{0-0,04}, \mathrm{Al}_{1,96-2,00}\left(\mathrm{Al}_{0-0,02}, \mathrm{Si}_{2,98-3,00}\right) \mathrm{O}_{12} \\
\mathrm{Alm}_{48,71-51,44} \operatorname{Prp}_{23,95-27,07} \mathrm{Sps}_{1,00-1,14} \mathrm{Grs}_{20,83-23,40} \mathrm{And}_{0-1,78} \mathrm{Uv}_{0-0,10}\end{array}$ \\
\hline & & granada 5 & $\begin{array}{c}\left(\mathrm{Fe}^{2+}{ }_{1,40-1,60}, \mathrm{Mn}_{0,03-0,04}, \mathrm{Mg}_{0,68-0,79}, \mathrm{Ca}_{0,66-0,83}\right) \mathrm{Ti}_{0-0.01}, \mathrm{Fe}^{3+}{ }_{0-0,06}, \mathrm{Al}_{1,93-2,00}\left(\mathrm{Al}_{0-0,03}, \mathrm{Si}_{2,97-3,00}\right) \mathrm{O}_{12} \\
\mathrm{Alm}_{47,01-53,34} \operatorname{Prp}_{22,63-26,17} \mathrm{Sps}_{1,03-1,31} \mathrm{Grs}_{20,49-26,79} \mathrm{And}_{0-2,93} \mathrm{Uv}_{0-0,20}\end{array}$ \\
\hline & & granada 6 & $\begin{array}{c}\left(\mathrm{Fe}^{2+}{ }_{1,43-1,53}, \mathrm{Mn}_{0,03-0,04}, \mathrm{Mg}_{0,71-0,78}, \mathrm{Ca}_{0,70-0,77}\right) \mathrm{Ti}_{0-0.01}, \mathrm{Fe}^{3+}{ }_{0-0,05}, \mathrm{Al}_{1,93-2,00}\left(\mathrm{Al}_{0-0,03}, \mathrm{Si}_{2,97-3,00}\right) \mathrm{O}_{12} \\
\mathrm{Alm}_{47,94-51,29} \operatorname{Prp}_{23,60-26,18} \mathrm{Sps}_{1,00-1,17} \mathrm{Grs}_{21,70-24,99} \mathrm{And}_{0-2,59} \mathrm{Uv}_{0-0,15}\end{array}$ \\
\hline & & granada 7 & $\begin{array}{c}\left(\mathrm{Fe}^{2+}{ }_{1,43-1,162}, \mathrm{Mn}_{0,03-0,04}, \mathrm{Mg}_{0,69-0,80}, \mathrm{Ca}_{0,65-0,79}\right) \mathrm{Ti}_{0-0.01}, \mathrm{Fe}^{3+}{ }_{0-0,03}, \mathrm{Al}_{1,94-2,00}\left(\mathrm{Al}_{0-0,02}, \mathrm{Si}_{2,98-3,00}\right) \mathrm{O}_{12} \\
\mathrm{Alm}_{47,62-54,02} \operatorname{Prp}_{22,89-26,63} \mathrm{Sps}_{1,03-1,27} \mathrm{GrS}_{21,00-24,99} \mathrm{And}_{0-1,45} \mathrm{Uv}_{0-0,15}\end{array}$ \\
\hline & \multirow{5}{*}{ 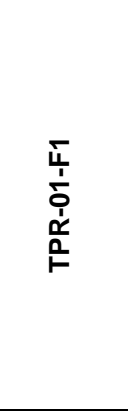 } & granada 1 & $\begin{array}{c}\left(\mathrm{Fe}^{2+}{ }_{1,26-1,36}, \mathrm{Mn}_{0,03}, \mathrm{Mg}_{0,73-0,85}, \mathrm{Ca}_{0,81-0,85}\right) \mathrm{Ti}_{0-0.01}, \mathrm{Fe}^{3+}{ }_{0-0,07}, \mathrm{Al}_{1,96-2,00}\left(\mathrm{Al}_{0-0,03}, \mathrm{Si}_{2,97-3,00}\right) \mathrm{O}_{12} \\
\mathrm{Alm}_{42,20-46,11} \operatorname{Prp}_{24,65-28,43} \mathrm{Sps}_{0,90-1,03} \mathrm{Grs}_{24,75-28,19} \mathrm{And}_{0-3,44} \mathrm{Uv}_{0,05-0,40}\end{array}$ \\
\hline & & granada 2 & $\begin{array}{c}\left(\mathrm{Fe}^{2+}{ }_{1,25-1,39}, \mathrm{Mn}_{0,03}, \mathrm{Mg}_{0,72-0,85}, \mathrm{Ca}_{0,81-0,86}\right) \mathrm{Ti}_{0-0.01}, \mathrm{Fe}^{3+}{ }_{0-0,06}, \mathrm{Al}_{1,96-2,00}\left(\mathrm{Al}_{0-0,03}, \mathrm{Si}_{2,97-3,00}\right) \mathrm{O}_{12} \\
\mathrm{Alm}_{41,92-46,60} \operatorname{Prp}_{24,22-28,50} \mathrm{Sps}_{0,94-1,08} \mathrm{Grs}_{25,39-28,21} \mathrm{And}_{0-2,72} \mathrm{Uv}_{0,05-0,40}\end{array}$ \\
\hline & & granada 3 & $\begin{array}{c}\left(\mathrm{Fe}^{2+}{ }_{1,25-1,38}, \mathrm{Mn}_{0,03}, \mathrm{Mg}_{0,72-0,85}, \mathrm{Ca}_{0,83-0,86}\right) \mathrm{Ti}_{0-0.01}, \mathrm{Fe}^{3+}{ }_{0-0,04}, \mathrm{Al}_{1,95-2,00}\left(\mathrm{Al}_{0-0,03}, \mathrm{Si}_{2,97-3,00}\right) \mathrm{O}_{12} \\
\mathrm{Alm}_{41,93-46,09} \operatorname{Prp}_{24,01-28,42} \mathrm{Sps}_{0,97-1,10} \mathrm{Grs}_{25,92-28,52} \mathrm{And}_{0-1,77} \mathrm{Uv}_{0,05-0,35}\end{array}$ \\
\hline & & granada 4 & $\begin{array}{c}\left(\mathrm{Fe}^{2+}{ }_{1,29-1,43}, \mathrm{Mn}_{0,03-0,04}, \mathrm{Mg}_{0,65-0,82}, \mathrm{Ca}_{0,83-0,88}\right) \mathrm{Ti}_{0-0.01}, \mathrm{Fe}^{3+}{ }_{0-0,06}, \mathrm{Al}_{1,95-2,00}\left(\mathrm{Al}_{0-0,03}, \mathrm{Si}_{2,97-3,00}\right) \mathrm{O}_{12} \\
\mathrm{Alm}_{43,23-47,89} \operatorname{Prp}_{21,70-27,34} \mathrm{Sps}_{0,97-1,37} \mathrm{Grs}_{26.21-28,37} \mathrm{And}_{0-3,11} \mathrm{Uv}_{0-0,24}\end{array}$ \\
\hline & & granada 5 & $\begin{array}{c}\left(\mathrm{Fe}^{2+}{ }_{1,28-1,33}, \mathrm{Mn}_{0,03-0,05}, \mathrm{Mg}_{0,74-0,84}, \mathrm{Ca}_{0,80-0,89}\right) \mathrm{Ti}_{0-0.01}, \mathrm{Fe}^{3+}{ }_{0-0,04}, \mathrm{Al}_{1,95-2,00}\left(\mathrm{Al}_{0-0,03}, \mathrm{Si}_{2,97-3,00}\right) \mathrm{O}_{12} \\
\mathrm{Alm}_{42,92-44,32} \operatorname{Prp}_{24,73-28,28} \mathrm{Sps}_{1,07-1,80} \mathrm{Grs}_{25,84-29,39} \mathrm{And}_{0-1,91} \mathrm{Uv}_{0,05-0,30}\end{array}$ \\
\hline \multirow{6}{*}{ 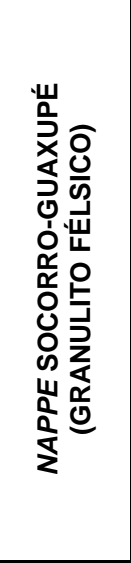 } & \multirow{6}{*}{$\begin{array}{l}\text { 品 } \\
\text { ơ } \\
\underline{0}\end{array}$} & granada 1 & $\begin{array}{c}\left(\mathrm{Fe}^{2+}{ }_{1,51-1,66}, \mathrm{Mn}_{0,09-0,11}, \mathrm{Mg}_{0,73-0,84}, \mathrm{Ca}_{0,50-0,56}\right) \mathrm{Ti}_{0-0.01}, \mathrm{Fe}^{3+}{ }_{0-0,07}, \mathrm{Al}_{1,93-1,99}\left(\mathrm{Al}_{0-0,01}, \mathrm{Si}_{2,99-3,00}\right) \mathrm{O}_{12} \\
\mathrm{Alm}_{50,45-55,13} \operatorname{Prp}_{24,38-27,97} \mathrm{Sps}_{2,97-3,63} \mathrm{Grs}_{13,88-16,43} \mathrm{And}_{0-3,57} \mathrm{Uv}_{0-0,15}\end{array}$ \\
\hline & & granada 2 & $\begin{array}{c}\left(\mathrm{Fe}^{2+}{ }_{1,51-1,59}, \mathrm{Mn}_{0,09-0,10}, \mathrm{Mg}_{0,81-0,93}, \mathrm{Ca}_{0,42-0,52}\right) \mathrm{Ti}_{0-0.01}, \mathrm{Fe}^{3+}{ }_{0-0,06}, \mathrm{Al}_{1,93-2,00}\left(\mathrm{Al}_{0-0,02}, \mathrm{Si}_{2,98-3,00}\right) \mathrm{O}_{12} \\
\mathrm{Alm}_{50,43-52.91} \operatorname{Prp}_{27,07-31,17} \mathrm{Sps}_{2,98-3,43} \mathrm{Grs}_{12,88-16,63} \mathrm{And}_{0,20-2,72} \mathrm{Uv}_{0-0,15}\end{array}$ \\
\hline & & granada 3 & $\begin{array}{c}\left(\mathrm{Fe}^{2+}{ }_{1,54-1,72}, \mathrm{Mn}_{0,09-0,11}, \mathrm{Mg}_{0,67-0,83}, \mathrm{Ca}_{0,49-0,56}\right) \mathrm{Ti}_{0-0.01}, \mathrm{Fe}^{3+}{ }_{0-0,01}, \mathrm{Al}_{1,89-1,99}\left(\mathrm{Al}_{0-0,04}, \mathrm{Si}_{2,96-3,00}\right) \mathrm{O}_{12} \\
\mathrm{Alm}_{51,64-57,62} \operatorname{Prp}_{22,33-27,78} \mathrm{Sps}_{3,05-3,71} \mathrm{Grs}_{12,28-16,88} \mathrm{And}_{0-4,91} \mathrm{Uv}_{0-0,15}\end{array}$ \\
\hline & & granada 4 & $\begin{array}{c}\left(\mathrm{Fe}^{2+}{ }_{1,53-1,70}, \mathrm{Mn}_{0,08-0,10}, \mathrm{Mg}_{0,70-0,89}, \mathrm{Ca}_{0,47-0,51}\right) \mathrm{Ti}_{0-0.01}, \mathrm{Fe}^{3+}{ }_{0-0,07}, \mathrm{Al}_{1,92-2,00}\left(\mathrm{Al}_{0-0,03}, \mathrm{Si}_{2,97-3,00}\right) \mathrm{O}_{12} \\
\mathrm{Alm}_{51,39-56,68} \operatorname{Prp}_{23,19-29,90} \mathrm{Sps}_{2,71-3,30} \mathrm{Grs}_{12,53-16,13} \mathrm{And}_{0-3,42} \mathrm{Uv}_{0-0,10}\end{array}$ \\
\hline & & granada 5 & $\begin{array}{c}\left(\mathrm{Fe}^{2+}{ }_{1,47-1,66}, \mathrm{Mn}_{0,07-0,09}, \mathrm{Mg}_{0,78-0,89}, \mathrm{Ca}_{0,48-0,64}\right) \mathrm{Ti}_{0-0.01}, \mathrm{Fe}^{3+}{ }_{0,01-0,07}, \mathrm{Al}_{1,93-2,00}\left(\mathrm{Al}_{0-0,02}, \mathrm{Si}_{2,98-3,00}\right) \mathrm{O}_{12} \\
\mathrm{Alm}_{49,21-55,02} \operatorname{Prp}_{25,75-29,88} \mathrm{Sps}_{2,34-3,09} \mathrm{Grs}_{13,66-19,23} \mathrm{And}_{0,35-3,18} \mathrm{Uv}_{0-0,10}\end{array}$ \\
\hline & & granada 6 & $\begin{array}{c}\left(\mathrm{Fe}^{2+}{ }_{1,48-1,64}, \mathrm{Mn}_{0,08-0,10}, \mathrm{Mg}_{0,76-0,86}, \mathrm{Ca}_{0,48-0,62}\right) \mathrm{Ti}_{0-0.01}, \mathrm{Fe}^{3+}{ }_{0,01-0,07}, \mathrm{Al}_{1,91-2,00}\left(\mathrm{Al}_{0-0,04}, \mathrm{Si}_{2,96-3,00}\right) \mathrm{O}_{12} \\
\mathrm{Alm}_{49,75-54,38} \operatorname{Prp}_{25,33-28,77} \mathrm{Sps}_{2,57-3,41} \mathrm{Grs}_{13,88-20,05} \mathrm{And}_{0,40-3,43} \mathrm{Uv}_{0-0,15} \\
\end{array}$ \\
\hline
\end{tabular}


Tabela 26 - Análises químicas de clinopiroxênio da Nappe Três Pontas-Varginha

\begin{tabular}{|c|c|c|c|c|c|c|c|c|c|}
\hline \multicolumn{10}{|c|}{ TPR-01-C } \\
\hline Grão-Análise & cpx1-1 & cpx1-2 & cpx1-4 & cpx1-5 & cpx1-6 & cpx1-7 & $\mathrm{cp \times 1-8}$ & cpx1-9 & $\mathrm{cp} \times 1-10$ \\
\hline $\mathrm{SiO}_{2}$ & 53,44 & 52,94 & 53,05 & 52,99 & 52,90 & 52,94 & 53,55 & 53,54 & 53,26 \\
\hline $\mathrm{TiO}_{2}$ & 0,35 & 0,38 & 0,36 & 0,34 & 0,37 & 0,30 & 0,27 & 0,39 & 0,25 \\
\hline $\mathrm{Al}_{2} \mathrm{O}_{3}$ & 3,39 & 4,27 & 4,27 & 4,24 & 4,19 & 4,02 & 3,15 & 3,27 & 3,91 \\
\hline $\mathrm{Cr}_{2} \mathrm{O}_{3}$ & 0,01 & 0,01 & 0,00 & 0,03 & 0,02 & 0,05 & 0,04 & 0,05 & 0,00 \\
\hline $\mathrm{Fe}_{2} \mathrm{O}_{3}$ & 0,00 & 0,00 & 0,00 & 0,00 & 0,00 & 0,00 & 0,00 & 0,00 & 0,00 \\
\hline $\mathrm{FeO}$ & 7,12 & 7,86 & 8,15 & 8,07 & 8,02 & 7,83 & 6,95 & 7,32 & 7,54 \\
\hline $\mathrm{MnO}$ & 0,06 & 0,04 & 0,06 & 0,07 & 0,05 & 0,07 & 0,05 & 0,06 & 0,02 \\
\hline $\mathrm{MgO}$ & 13,57 & 13,06 & 12,78 & 12,74 & 12,72 & 12,95 & 13,61 & 13,37 & 12,99 \\
\hline $\mathrm{CaO}$ & 22,55 & 22,12 & 21,88 & 21,66 & 21,75 & 22,15 & 22,58 & 22,51 & 21,89 \\
\hline $\mathrm{Na}_{2} \mathrm{O}$ & 0,68 & 0,85 & 0,91 & 0,86 & 0,92 & 0,86 & 0,68 & 0,68 & 0,83 \\
\hline $\mathrm{K}_{2} \mathrm{O}$ & 0,00 & 0,00 & 0,00 & 0,00 & 0,00 & 0,00 & 0,01 & 0,00 & 0,00 \\
\hline Total & 101,17 & 101,53 & 101,45 & 100,99 & 100,93 & 101,18 & 100,89 & 101,18 & 100,70 \\
\hline Oxigênios & 6,00 & 6,00 & 6,00 & 6,00 & 6,00 & 6,00 & 6,00 & 6,00 & 6,00 \\
\hline $\mathrm{Si}$ & 1,950 & 1,930 & 1,936 & 1,940 & 1,939 & 1,937 & 1,958 & 1,954 & 1,951 \\
\hline $\mathrm{Ti}$ & 0,009 & 0,011 & 0,010 & 0,009 & 0,010 & 0,008 & 0,007 & 0,011 & 0,007 \\
\hline Al & 0,146 & 0,183 & 0,184 & 0,183 & 0,181 & 0,173 & 0,136 & 0,141 & 0,169 \\
\hline $\mathrm{Cr}$ & 0,000 & 0,000 & 0,000 & 0,001 & 0,001 & 0,001 & 0,001 & 0,001 & 0,000 \\
\hline $\mathrm{Fe}^{3+}$ & 0,000 & 0,000 & 0,000 & 0,000 & 0,000 & 0,000 & 0,000 & 0,000 & 0,000 \\
\hline $\mathrm{Fe}^{2-}$ & 0,217 & 0,240 & 0,249 & 0,247 & 0,246 & 0,240 & 0,212 & 0,223 & 0,231 \\
\hline $\mathrm{Mn}$ & 0,002 & 0,001 & 0,002 & 0,002 & 0,001 & 0,002 & 0,002 & 0,002 & 0,001 \\
\hline $\mathrm{Mg}$ & 0,738 & 0,709 & 0,695 & 0,695 & 0,695 & 0,706 & 0,742 & 0,727 & 0,709 \\
\hline $\mathrm{Ca}$ & 0,881 & 0,864 & 0,856 & 0,850 & 0,854 & 0,868 & 0,885 & 0,880 & 0,859 \\
\hline $\mathrm{Na}$ & 0,048 & 0,060 & 0,064 & 0,061 & 0,065 & 0,061 & 0,048 & 0,048 & 0,059 \\
\hline $\mathrm{K}$ & 0,000 & 0,000 & 0,000 & 0,000 & 0,000 & 0,000 & 0,000 & 0,000 & 0,000 \\
\hline Soma & 3,992 & 3,998 & 3,995 & 3,989 & 3,993 & 3,998 & 3,991 & 3,988 & 3,987 \\
\hline$\# \mathrm{Mg}$ & 77,277 & 74,710 & 73,623 & 73,779 & 73,858 & 74,630 & 77,778 & 76,526 & 75,426 \\
\hline
\end{tabular}


Tabela 27 - Análises químicas de clinopiroxênio da Nappe Três Pontas-Varginha

\begin{tabular}{|c|c|c|c|c|c|c|c|c|c|c|}
\hline \multicolumn{11}{|c|}{ TPR-01-C } \\
\hline Grão-Análise & cpx2-1 & cpx2-2 & cpx2-3 & cp $22-4$ & $\operatorname{cp} \times 2-5$ & cpx2-6 & cpx2-7 & cpx2-8 & cpx2-9 & $c p \times 2-10$ \\
\hline $\mathrm{SiO}_{2}$ & 52,89 & 52,68 & 52,55 & 52,77 & 52,58 & 52,74 & 52,87 & 52,71 & 52,65 & 52,91 \\
\hline $\mathrm{TiO}_{2}$ & 0,31 & 0,35 & 0,36 & 0,35 & 0,37 & 0,40 & 0,38 & 0,41 & 0,34 & 0,30 \\
\hline $\mathrm{Al}_{2} \mathrm{O}_{3}$ & 3,96 & 4,19 & 4,15 & 4,27 & 4,21 & 4,20 & 4,18 & 4,25 & 4,41 & 3,73 \\
\hline $\mathrm{Cr}_{2} \mathrm{O}_{3}$ & 0,06 & 0,00 & 0,00 & 0,00 & 0,03 & 0,00 & 0,00 & 0,03 & 0,03 & 0,03 \\
\hline $\mathrm{Fe}_{2} \mathrm{O}_{3}$ & 0,00 & 0,00 & 0,00 & 0,00 & 0,09 & 0,00 & 0,00 & 0,00 & 0,00 & 0,00 \\
\hline $\mathrm{FeO}$ & 7,99 & 8,23 & 8,36 & 8,43 & 8,66 & 8,80 & 8,67 & 8,50 & 8,31 & 7,95 \\
\hline $\mathrm{MnO}$ & 0,03 & 0,09 & 0,06 & 0,06 & 0,06 & 0,07 & 0,07 & 0,10 & 0,05 & 0,06 \\
\hline $\mathrm{MgO}$ & 12,82 & 12,46 & 12,43 & 12,39 & 12,44 & 12,41 & 12,45 & 12,53 & 12,38 & 13,05 \\
\hline $\mathrm{CaO}$ & 21,75 & 21,44 & 21,14 & 20,96 & 21,07 & 20,93 & 20,96 & 21,39 & 21,14 & 22,05 \\
\hline $\mathrm{Na}_{2} \mathrm{O}$ & 0,94 & 1,05 & 1,08 & 1,13 & 1,15 & 1,17 & 1,19 & 1,05 & 1,03 & 0,82 \\
\hline $\mathrm{K}_{2} \mathrm{O}$ & 0,00 & 0,00 & 0,00 & 0,01 & 0,00 & 0,01 & 0,00 & 0,01 & 0,03 & 0,00 \\
\hline Total & 100,74 & 100,49 & 100,12 & 100,37 & 100,66 & 100,72 & 100,77 & 100,99 & 100,38 & 100,91 \\
\hline Oxigênios & 6,00 & 6,00 & 6,00 & 6,00 & 6,00 & 6,00 & 6,00 & 6,00 & 6,00 & 6,00 \\
\hline $\mathrm{Si}$ & 1,943 & 1,941 & 1,943 & 1,945 & 1,938 & 1,942 & 1,944 & 1,935 & 1,941 & 1,942 \\
\hline $\mathrm{Ti}$ & 0,009 & 0,010 & 0,010 & 0,010 & 0,010 & 0,011 & 0,010 & 0,011 & 0,010 & 0,008 \\
\hline Al & 0,171 & 0,182 & 0,181 & 0,186 & 0,183 & 0,182 & 0,181 & 0,184 & 0,192 & 0,161 \\
\hline $\mathrm{Cr}$ & 0,002 & 0,000 & 0,000 & 0,000 & 0,001 & 0,000 & 0,000 & 0,001 & 0,001 & 0,001 \\
\hline $\mathrm{Fe}^{3+}$ & 0,000 & 0,000 & 0,000 & 0,000 & 0,003 & 0,000 & 0,000 & 0,000 & 0,000 & 0,000 \\
\hline $\mathrm{Fe}^{2-}$ & 0,245 & 0,254 & 0,259 & 0,260 & 0,267 & 0,271 & 0,267 & 0,261 & 0,256 & 0,244 \\
\hline $\mathrm{Mn}$ & 0,001 & 0,003 & 0,002 & 0,002 & 0,002 & 0,002 & 0,002 & 0,003 & 0,002 & 0,002 \\
\hline $\mathrm{Mg}$ & 0,702 & 0,684 & 0,685 & 0,681 & 0,683 & 0,681 & 0,682 & 0,686 & 0,680 & 0,714 \\
\hline $\mathrm{Ca}$ & 0,856 & 0,847 & 0,838 & 0,828 & 0,832 & 0,826 & 0,826 & 0,842 & 0,835 & 0,867 \\
\hline $\mathrm{Na}$ & 0,067 & 0,075 & 0,077 & 0,081 & 0,082 & 0,083 & 0,085 & 0,075 & 0,074 & 0,059 \\
\hline $\mathrm{K}$ & 0,000 & 0,000 & 0,000 & 0,000 & 0,000 & 0,000 & 0,000 & 0,000 & 0,001 & 0,000 \\
\hline Soma & 3,995 & 3,995 & 3,995 & 3,992 & 4,000 & 3,998 & 3,997 & 3,998 & 3,991 & 3,998 \\
\hline$\# M g$ & 74,129 & 72,921 & 72,564 & 72,370 & 71,895 & 71,534 & 71,865 & 72,439 & 72,650 & 74,530 \\
\hline
\end{tabular}


Tabela 28 - Análises químicas de clinopiroxênio da Nappe Três Pontas-Varginha

\begin{tabular}{|c|c|c|c|c|c|c|c|c|c|c|}
\hline \multicolumn{11}{|c|}{$\begin{array}{l}\text { TPR-01-C } \\
\end{array}$} \\
\hline Grão-Análise & $\mathrm{cp} \times 3-1$ & cp $\times 3-2$ & cp $\times 3-3$ & $\mathrm{cp} \times 3-4$ & $\mathrm{cp \times 3}-5$ & cpx3-6 & cpх3-7 & $\mathrm{cp} \times 3-8$ & cp $\times 3-9$ & $\mathrm{cp} \times 3-10$ \\
\hline $\mathrm{SiO}_{2}$ & 53,61 & 53,73 & 53,11 & 53,08 & 53,10 & 53,18 & 53,41 & 53,08 & 53,07 & 53,25 \\
\hline $\mathrm{TiO}_{2}$ & 0,29 & 0,23 & 0,39 & 0,41 & 0,40 & 0,36 & 0,31 & 0,32 & 0,39 & 0,26 \\
\hline $\mathrm{Al}_{2} \mathrm{O}_{3}$ & 3,52 & 3,69 & 3,97 & 4,10 & 4,14 & 4,02 & 4,09 & 4,14 & 3,97 & 3,60 \\
\hline $\mathrm{Cr}_{2} \mathrm{O}_{3}$ & 0,02 & 0,01 & 0,00 & 0,02 & 0,00 & 0,10 & 0,01 & 0,02 & 0,05 & 0,06 \\
\hline $\mathrm{Fe}_{2} \mathrm{O}_{3}$ & 0,00 & 0,00 & 0,00 & 0,00 & 0,00 & 0,00 & 0,00 & 0,00 & 0,00 & 0,00 \\
\hline $\mathrm{FeO}$ & 7,86 & 7,93 & 8,02 & 8,06 & 8,04 & 8,08 & 8,05 & 8,09 & 7,70 & 7,48 \\
\hline $\mathrm{MnO}$ & 0,07 & 0,06 & 0,07 & 0,06 & 0,08 & 0,07 & 0,05 & 0,07 & 0,02 & 0,05 \\
\hline $\mathrm{MgO}$ & 13,00 & 12,94 & 12,87 & 12,82 & 12,82 & 12,86 & 12,84 & 12,80 & 12,77 & 13,14 \\
\hline $\mathrm{CaO}$ & 21,62 & 22,07 & 21,68 & 21,76 & 21,81 & 21,84 & 21,61 & 22,19 & 21,87 & 22,57 \\
\hline $\mathrm{Na}_{2} \mathrm{O}$ & 0,87 & 0,84 & 0,89 & 0,89 & 0,89 & 0,88 & 0,84 & 0,90 & 0,82 & 0,75 \\
\hline $\mathrm{K}_{2} \mathrm{O}$ & 0,00 & 0,00 & 0,00 & 0,00 & 0,00 & 0,00 & 0,01 & 0,00 & 0,00 & 0,00 \\
\hline Total & 100,86 & 101,49 & 100,99 & 101,19 & 101,28 & 101,39 & 101,22 & 101,61 & 100,66 & 101,16 \\
\hline Oxigênios & 6,00 & 6,00 & 6,00 & 6,00 & 6,00 & 6,00 & 6,00 & 6,00 & 6,00 & 6,00 \\
\hline $\mathrm{Si}$ & 1,962 & 1,957 & 1,945 & 1,941 & 1,940 & 1,941 & 1,949 & 1,936 & 1,947 & 1,947 \\
\hline $\mathrm{Ti}$ & 0,008 & 0,006 & 0,011 & 0,011 & 0,011 & 0,010 & 0,009 & 0,009 & 0,011 & 0,007 \\
\hline Al & 0,152 & 0,158 & 0,171 & 0,177 & 0,178 & 0,173 & 0,176 & 0,178 & 0,172 & 0,155 \\
\hline $\mathrm{Cr}$ & 0,001 & 0,000 & 0,000 & 0,000 & 0,000 & 0,003 & 0,000 & 0,000 & 0,001 & 0,002 \\
\hline $\mathrm{Fe}^{3+}$ & 0,000 & 0,000 & 0,000 & 0,000 & 0,000 & 0,000 & 0,000 & 0,000 & 0,000 & 0,000 \\
\hline $\mathrm{Fe}^{2-}$ & 0,241 & 0,242 & 0,246 & 0,246 & 0,246 & 0,247 & 0,246 & 0,247 & 0,236 & 0,229 \\
\hline $\mathrm{Mn}$ & 0,002 & 0,002 & 0,002 & 0,002 & 0,002 & 0,002 & 0,002 & 0,002 & 0,001 & 0,001 \\
\hline $\mathrm{Mg}$ & 0,709 & 0,702 & 0,702 & 0,699 & 0,698 & 0,700 & 0,698 & 0,696 & 0,698 & 0,716 \\
\hline $\mathrm{Ca}$ & 0,848 & 0,861 & 0,851 & 0,852 & 0,854 & 0,854 & 0,845 & 0,867 & 0,860 & 0,884 \\
\hline $\mathrm{Na}$ & 0,062 & 0,059 & 0,063 & 0,063 & 0,063 & 0,062 & 0,060 & 0,063 & 0,058 & 0,053 \\
\hline $\mathrm{K}$ & 0,000 & 0,000 & 0,000 & 0,000 & 0,000 & 0,000 & 0,001 & 0,000 & 0,000 & 0,000 \\
\hline Soma & 3,984 & 3,987 & 3,990 & 3,991 & 3,992 & 3,992 & 3,985 & 3,998 & 3,985 & 3,994 \\
\hline$\# \mathrm{Mg}$ & 74,632 & 74,364 & 74,051 & 73,968 & 73,941 & 73,918 & 73,941 & 73,807 & 74,732 & 75,767 \\
\hline
\end{tabular}


Tabela 29 - Análises químicas de clinopiroxênio da Nappe Três Pontas-Varginha

\begin{tabular}{|c|c|c|c|c|c|c|c|c|c|c|}
\hline \multicolumn{11}{|c|}{ TPR-01-C } \\
\hline Grão-Análise & cpx4-1 & cp $x 4-2$ & cp x4-3 & cp $x 4-4$ & cpx4-5 & cpx4-6 & cpx4-7 & cpx4-8 & cpx4-9 & cp $\times 4-10$ \\
\hline $\mathrm{SiO}_{2}$ & 53,46 & 53,21 & 52,99 & 52,81 & 53,08 & 52,96 & 53,22 & 53,22 & 53,01 & 53,17 \\
\hline $\mathrm{TiO}_{2}$ & 0,21 & 0,25 & 0,34 & 0,44 & 0,36 & 0,44 & 0,36 & 0,35 & 0,30 & 0,31 \\
\hline $\mathrm{Al}_{2} \mathrm{O}_{3}$ & 2,66 & 3,34 & 4,08 & 4,13 & 4,19 & 4,16 & 4,13 & 4,08 & 4,08 & 3,60 \\
\hline $\mathrm{Cr}_{2} \mathrm{O}_{3}$ & 0,03 & 0,01 & 0,02 & 0,00 & 0,03 & 0,04 & 0,01 & 0,04 & 0,03 & 0,02 \\
\hline $\mathrm{Fe}_{2} \mathrm{O}_{3}$ & 1,31 & 0,44 & 0,00 & 0,00 & 0,00 & 0,00 & 0,00 & 0,00 & 0,00 & 0,00 \\
\hline $\mathrm{FeO}$ & 5,79 & 7,11 & 8,04 & 7,96 & 8,13 & 8,00 & 8,48 & 8,05 & 7,90 & 7,58 \\
\hline $\mathrm{MnO}$ & 0,08 & 0,04 & 0,06 & 0,04 & 0,07 & 0,07 & 0,05 & 0,07 & 0,04 & 0,08 \\
\hline $\mathrm{MgO}$ & 14,48 & 13,55 & 12,88 & 12,59 & 12,48 & 12,49 & 12,73 & 12,78 & 12,75 & 12,95 \\
\hline $\mathrm{CaO}$ & 22,97 & 22,84 & 21,87 & 22,00 & 21,67 & 21,57 & 21,34 & 21,97 & 21,93 & 22,25 \\
\hline $\mathrm{Na}_{2} \mathrm{O}$ & 0,64 & 0,71 & 0,82 & 0,89 & 0,95 & 0,97 & 0,98 & 0,94 & 0,88 & 0,74 \\
\hline $\mathrm{K}_{2} \mathrm{O}$ & 0,01 & 0,00 & 0,00 & 0,00 & 0,01 & 0,01 & 0,00 & 0,01 & 0,01 & 0,01 \\
\hline Total & 101,63 & 101,49 & 101,11 & 100,86 & 100,97 & 100,71 & 101,30 & 101,53 & 100,94 & 100,71 \\
\hline Oxigênios & 6,00 & 6,00 & 6,00 & 6,00 & 6,00 & 6,00 & 6,00 & 6,00 & 6,00 & 6,00 \\
\hline $\mathrm{Si}$ & 1,942 & 1,940 & 1,939 & 1,938 & 1,945 & 1,945 & 1,945 & 1,941 & 1,943 & 1,952 \\
\hline $\mathrm{Ti}$ & 0,006 & 0,007 & 0,009 & 0,012 & 0,010 & 0,012 & 0,010 & 0,010 & 0,008 & 0,009 \\
\hline $\mathrm{Al}$ & 0,114 & 0,144 & 0,176 & 0,179 & 0,181 & 0,180 & 0,178 & 0,175 & 0,176 & 0,156 \\
\hline $\mathrm{Cr}$ & 0,001 & 0,000 & 0,000 & 0,000 & 0,001 & 0,001 & 0,000 & 0,001 & 0,001 & 0,000 \\
\hline $\mathrm{Fe}^{3+}$ & 0,036 & 0,012 & 0,000 & 0,000 & 0,000 & 0,000 & 0,000 & 0,000 & 0,000 & 0,000 \\
\hline $\mathrm{Fe}^{2-}$ & 0,176 & 0,217 & 0,246 & 0,244 & 0,249 & 0,246 & 0,259 & 0,245 & 0,242 & 0,233 \\
\hline $\mathrm{Mn}$ & 0,002 & 0,001 & 0,002 & 0,001 & 0,002 & 0,002 & 0,001 & 0,002 & 0,001 & 0,002 \\
\hline $\mathrm{Mg}$ & 0,784 & 0,736 & 0,703 & 0,689 & 0,681 & 0,683 & 0,693 & 0,695 & 0,696 & 0,708 \\
\hline $\mathrm{Ca}$ & 0,894 & 0,892 & 0,858 & 0,865 & 0,851 & 0,849 & 0,835 & 0,858 & 0,861 & 0,875 \\
\hline $\mathrm{Na}$ & 0,045 & 0,050 & 0,058 & 0,064 & 0,067 & 0,069 & 0,070 & 0,067 & 0,063 & 0,053 \\
\hline $\mathrm{K}$ & 0,000 & 0,000 & 0,000 & 0,000 & 0,001 & 0,001 & 0,000 & 0,001 & 0,001 & 0,000 \\
\hline Soma & 4,000 & 4,000 & 3,992 & 3,992 & 3,988 & 3,988 & 3,991 & 3,995 & 3,992 & 3,988 \\
\hline$\# M g$ & 81,667 & 77,230 & 74,078 & 73,848 & 73,226 & 73,520 & 72,794 & 73,936 & 74,200 & 75,239 \\
\hline
\end{tabular}


Tabela 30 - Análises químicas de clinopiroxênio da Nappe Três Pontas-Varginha

\begin{tabular}{|c|c|c|c|c|c|c|c|c|c|c|}
\hline \multicolumn{11}{|c|}{ TPR-01-C } \\
\hline Grão-Análise & cpx5-1 & cpx5-2 & cpx5-3 & cpx5-4 & cpx5-5 & cpx5-6 & cpx5-7 & cpx5-8 & cpx5-9 & cp $\times 5-10$ \\
\hline $\mathrm{SiO}_{2}$ & 53,17 & 52,67 & 52,52 & 52,79 & 52,72 & 52,89 & 53,12 & 52,88 & 52,59 & 53,12 \\
\hline $\mathrm{TiO}_{2}$ & 0,35 & 0,29 & 0,32 & 0,32 & 0,38 & 0,34 & 0,31 & 0,31 & 0,32 & 0,35 \\
\hline $\mathrm{Al}_{2} \mathrm{O}_{3}$ & 3,92 & 4,24 & 4,11 & 4,07 & 4,30 & 4,10 & 3,53 & 3,95 & 4,07 & 3,29 \\
\hline $\mathrm{Cr}_{2} \mathrm{O}_{3}$ & 0,02 & 0,03 & 0,02 & 0,00 & 0,02 & 0,00 & 0,04 & 0,01 & 0,03 & 0,03 \\
\hline $\mathrm{Fe}_{2} \mathrm{O}_{3}$ & 0,00 & 0,00 & 0,00 & 0,00 & 0,14 & 0,00 & 0,00 & 0,00 & 0,00 & 0,00 \\
\hline $\mathrm{FeO}$ & 7,78 & 7,92 & 7,93 & 7,90 & 7,82 & 7,83 & 7,45 & 7,84 & 7,98 & 7,45 \\
\hline $\mathrm{MnO}$ & 0,05 & 0,06 & 0,09 & 0,06 & 0,05 & 0,08 & 0,08 & 0,06 & 0,05 & 0,02 \\
\hline $\mathrm{MgO}$ & 12,74 & 12,65 & 12,63 & 12,78 & 12,76 & 12,97 & 13,15 & 12,87 & 12,84 & 13,20 \\
\hline $\mathrm{CaO}$ & 22,22 & 21,95 & 22,03 & 21,98 & 22,32 & 21,94 & 22,35 & 22,08 & 21,79 & 22,43 \\
\hline $\mathrm{Na}_{2} \mathrm{O}$ & 0,82 & 0,82 & 0,92 & 0,79 & 0,90 & 0,88 & 0,67 & 0,85 & 0,83 & 0,68 \\
\hline $\mathrm{K}_{2} \mathrm{O}$ & 0,00 & 0,02 & 0,01 & 0,01 & 0,00 & 0,01 & 0,00 & 0,01 & 0,00 & 0,02 \\
\hline Total & 101,08 & 100,65 & 100,58 & 100,70 & 101,41 & 101,05 & 100,71 & 100,87 & 100,49 & 100,59 \\
\hline Oxigênios & 6,00 & 6,00 & 6,00 & 6,00 & 6,00 & 6,00 & 6,00 & 6,00 & 6,00 & 6,00 \\
\hline $\mathrm{Si}$ & 1,946 & 1,937 & 1,935 & 1,940 & 1,927 & 1,937 & 1,949 & 1,940 & 1,937 & 1,952 \\
\hline $\mathrm{Ti}$ & 0,010 & 0,008 & 0,009 & 0,009 & 0,011 & 0,009 & 0,009 & 0,009 & 0,009 & 0,010 \\
\hline $\mathrm{Al}$ & 0,169 & 0,184 & 0,179 & 0,176 & 0,185 & 0,177 & 0,153 & 0,171 & 0,177 & 0,143 \\
\hline $\mathrm{Cr}$ & 0,000 & 0,001 & 0,001 & 0,000 & 0,001 & 0,000 & 0,001 & 0,000 & 0,001 & 0,001 \\
\hline $\mathrm{Fe}^{3+}$ & 0,000 & 0,000 & 0,000 & 0,000 & 0,004 & 0,000 & 0,000 & 0,000 & 0,000 & 0,000 \\
\hline $\mathrm{Fe}^{2-}$ & 0,238 & 0,244 & 0,244 & 0,243 & 0,239 & 0,240 & 0,229 & 0,241 & 0,246 & 0,229 \\
\hline $\mathrm{Mn}$ & 0,002 & 0,002 & 0,003 & 0,002 & 0,002 & 0,002 & 0,003 & 0,002 & 0,002 & 0,001 \\
\hline $\mathrm{Mg}$ & 0,695 & 0,693 & 0,694 & 0,700 & 0,695 & 0,708 & 0,719 & 0,704 & 0,705 & 0,723 \\
\hline $\mathrm{Ca}$ & 0,871 & 0,865 & 0,870 & 0,865 & 0,874 & 0,861 & 0,879 & 0,868 & 0,860 & 0,883 \\
\hline $\mathrm{Na}$ & 0,059 & 0,058 & 0,066 & 0,056 & 0,064 & 0,063 & 0,048 & 0,061 & 0,059 & 0,048 \\
\hline $\mathrm{K}$ & 0,000 & 0,001 & 0,001 & 0,001 & 0,000 & 0,001 & 0,000 & 0,001 & 0,000 & 0,001 \\
\hline Soma & 3,989 & 3,992 & 4,000 & 3,992 & 4,000 & 3,997 & 3,989 & 3,996 & 3,995 & 3,991 \\
\hline \#Mg & 74,491 & 73,959 & 73,987 & 74,231 & 74,411 & 74,684 & 75,844 & 74,497 & 74,132 & 75,945 \\
\hline
\end{tabular}


Tabela 31 - Análises químicas de clinopiroxênio da Nappe Três Pontas-Varginha

\begin{tabular}{|c|c|c|c|c|c|c|c|c|c|c|}
\hline \multicolumn{11}{|c|}{ TPR-01-C } \\
\hline Grão-Análise & cpx6-1 & cp x6-2 & cp $\times 6-3$ & cpx6-4 & cpx6-5 & cpx6-6 & cpx6-7 & cpx6-8 & cpx6-9 & cpx6-10 \\
\hline $\mathrm{SiO}_{2}$ & 52,71 & 52,51 & 53,04 & 52,95 & 52,70 & 52,65 & 52,90 & 52,77 & 52,60 & 53,18 \\
\hline $\mathrm{TiO}_{2}$ & 0,45 & 0,40 & 0,40 & 0,31 & 0,43 & 0,46 & 0,47 & 0,34 & 0,35 & 0,34 \\
\hline $\mathrm{Al}_{2} \mathrm{O}_{3}$ & 4,19 & 4,36 & 4,29 & 4,24 & 4,31 & 4,30 & 4,30 & 4,25 & 4,11 & 3,44 \\
\hline $\mathrm{Cr}_{2} \mathrm{O}_{3}$ & 0,02 & 0,02 & 0,00 & 0,04 & 0,00 & 0,00 & 0,00 & 0,00 & 0,00 & 0,00 \\
\hline $\mathrm{Fe}_{2} \mathrm{O}_{3}$ & 0,00 & 0,00 & 0,00 & 0,00 & 0,00 & 0,00 & 0,00 & 0,00 & 0,00 & 0,00 \\
\hline $\mathrm{FeO}$ & 7,73 & 8,02 & 8,13 & 8,22 & 8,12 & 8,14 & 8,21 & 7,88 & 7,88 & 7,61 \\
\hline $\mathrm{MnO}$ & 0,04 & 0,03 & 0,07 & 0,05 & 0,07 & 0,09 & 0,07 & 0,03 & 0,06 & 0,06 \\
\hline $\mathrm{MgO}$ & 12,59 & 12,45 & 12,59 & 12,43 & 12,51 & 12,49 & 12,51 & 12,66 & 12,74 & 13,17 \\
\hline $\mathrm{CaO}$ & 22,01 & 21,46 & 21,28 & 21,32 & 21,47 & 21,69 & 21,42 & 21,67 & 21,73 & 22,18 \\
\hline $\mathrm{Na}_{2} \mathrm{O}$ & 0,93 & 0,97 & 1,00 & 1,01 & 0,97 & 0,99 & 0,96 & 0,84 & 0,83 & 0,75 \\
\hline $\mathrm{K}_{2} \mathrm{O}$ & 0,00 & 0,02 & 0,01 & 0,00 & 0,01 & 0,01 & 0,01 & 0,00 & 0,00 & 0,00 \\
\hline Total & 100,68 & 100,25 & 100,81 & 100,57 & 100,59 & 100,82 & 100,85 & 100,44 & 100,30 & 100,73 \\
\hline Oxigênios & 6,00 & 6,00 & 6,00 & 6,00 & 6,00 & 6,00 & 6,00 & 6,00 & 6,00 & 6,00 \\
\hline $\mathrm{Si}$ & 1,937 & 1,938 & 1,944 & 1,947 & 1,938 & 1,935 & 1,940 & 1,941 & 1,940 & 1,952 \\
\hline $\mathrm{Ti}$ & 0,012 & 0,011 & 0,011 & 0,009 & 0,012 & 0,013 & 0,013 & 0,009 & 0,010 & 0,009 \\
\hline $\mathrm{Al}$ & 0,182 & 0,190 & 0,185 & 0,184 & 0,187 & 0,186 & 0,186 & 0,184 & 0,179 & 0,149 \\
\hline $\mathrm{Cr}$ & 0,001 & 0,001 & 0,000 & 0,001 & 0,000 & 0,000 & 0,000 & 0,000 & 0,000 & 0,000 \\
\hline $\mathrm{Fe}^{3+}$ & 0,000 & 0,000 & 0,000 & 0,000 & 0,000 & 0,000 & 0,000 & 0,000 & 0,000 & 0,000 \\
\hline $\mathrm{Fe}^{2-}$ & 0,238 & 0,248 & 0,249 & 0,253 & 0,250 & 0,250 & 0,252 & 0,242 & 0,243 & 0,234 \\
\hline $\mathrm{Mn}$ & 0,001 & 0,001 & 0,002 & 0,002 & 0,002 & 0,003 & 0,002 & 0,001 & 0,002 & 0,002 \\
\hline $\mathrm{Mg}$ & 0,689 & 0,685 & 0,688 & 0,681 & 0,686 & 0,684 & 0,684 & 0,694 & 0,700 & 0,720 \\
\hline $\mathrm{Ca}$ & 0,867 & 0,849 & 0,836 & 0,840 & 0,846 & 0,854 & 0,842 & 0,854 & 0,859 & 0,872 \\
\hline $\mathrm{Na}$ & 0,066 & 0,070 & 0,071 & 0,072 & 0,069 & 0,071 & 0,068 & 0,060 & 0,059 & 0,053 \\
\hline $\mathrm{K}$ & 0,000 & 0,001 & 0,000 & 0,000 & 0,000 & 0,000 & 0,000 & 0,000 & 0,000 & 0,000 \\
\hline Soma & 3,993 & 3,991 & 3,988 & 3,988 & 3,991 & 3,995 & 3,988 & 3,987 & 3,991 & 3,991 \\
\hline$\# M g$ & 74,326 & 73,419 & 73,426 & 72,912 & 73,291 & 73,233 & 73,077 & 74,145 & 74,231 & 75,472 \\
\hline
\end{tabular}


Tabela 32 - Análises químicas de clinopiroxênio da Nappe Três Pontas-Varginha

\begin{tabular}{|c|c|c|c|c|c|c|c|c|c|c|}
\hline \multicolumn{11}{|c|}{$\begin{array}{l}\text { TPR-01-C } \\
\end{array}$} \\
\hline Grão-Análise & cpx7-1 & cpx7-2 & cpx7-3 & cpx7-4 & cpx7-5 & cpx7-6 & cpx7-7 & cpx7-8 & cpx7-9 & cpx7-10 \\
\hline $\mathrm{SiO}_{2}$ & 53,76 & 52,65 & 52,87 & 52,66 & 52,84 & 52,92 & 53,08 & 52,95 & 52,90 & 52,97 \\
\hline $\mathrm{TiO}_{2}$ & 0,26 & 0,32 & 0,38 & 0,43 & 0,36 & 0,46 & 0,42 & 0,33 & 0,28 & 0,35 \\
\hline $\mathrm{Al}_{2} \mathrm{O}_{3}$ & 2,85 & 4,18 & 4,17 & 4,26 & 4,29 & 4,28 & 4,18 & 4,11 & 4,21 & 3,95 \\
\hline $\mathrm{Cr}_{2} \mathrm{O}_{3}$ & 0,02 & 0,00 & 0,00 & 0,04 & 0,03 & 0,02 & 0,06 & 0,00 & 0,00 & 0,00 \\
\hline $\mathrm{Fe}_{2} \mathrm{O}_{3}$ & 0,00 & 0,00 & 0,00 & 0,00 & 0,00 & 0,00 & 0,00 & 0,00 & 0,00 & 0,00 \\
\hline $\mathrm{FeO}$ & 7,03 & 7,80 & 8,18 & 8,36 & 8,63 & 8,31 & 8,36 & 8,61 & 8,38 & 7,54 \\
\hline $\mathrm{MnO}$ & 0,08 & 0,05 & 0,05 & 0,05 & 0,08 & 0,06 & 0,07 & 0,04 & 0,08 & 0,04 \\
\hline $\mathrm{MgO}$ & 13,87 & 12,88 & 12,67 & 12,57 & 12,53 & 12,51 & 12,55 & 12,66 & 12,61 & 13,13 \\
\hline $\mathrm{CaO}$ & 22,78 & 21,93 & 21,54 & 21,34 & 21,27 & 21,36 & 21,37 & 21,27 & 21,31 & 22,16 \\
\hline $\mathrm{Na}_{2} \mathrm{O}$ & 0,58 & 0,86 & 0,94 & 1,00 & 1,05 & 1,02 & 1,03 & 0,96 & 0,94 & 0,78 \\
\hline $\mathrm{K}_{2} \mathrm{O}$ & 0,00 & 0,00 & 0,01 & 0,00 & 0,02 & 0,00 & 0,00 & 0,03 & 0,00 & 0,01 \\
\hline Total & 101,23 & 100,67 & 100,82 & 100,70 & 101,09 & 100,94 & 101,11 & 100,97 & 100,72 & 100,93 \\
\hline Oxigênios & 6,00 & 6,00 & 6,00 & 6,00 & 6,00 & 6,00 & 6,00 & 6,00 & 6,00 & 6,00 \\
\hline $\mathrm{Si}$ & 1,960 & 1,935 & 1,941 & 1,937 & 1,938 & 1,940 & 1,943 & 1,943 & 1,944 & 1,939 \\
\hline $\mathrm{Ti}$ & 0,007 & 0,009 & 0,011 & 0,012 & 0,010 & 0,013 & 0,012 & 0,009 & 0,008 & 0,010 \\
\hline $\mathrm{Al}$ & 0,123 & 0,181 & 0,180 & 0,185 & 0,185 & 0,185 & 0,180 & 0,178 & 0,182 & 0,171 \\
\hline $\mathrm{Cr}$ & 0,001 & 0,000 & 0,000 & 0,001 & 0,001 & 0,001 & 0,002 & 0,000 & 0,000 & 0,000 \\
\hline $\mathrm{Fe}^{3+}$ & 0,000 & 0,000 & 0,000 & 0,000 & 0,000 & 0,000 & 0,000 & 0,000 & 0,000 & 0,000 \\
\hline $\mathrm{Fe}^{2-}$ & 0,214 & 0,240 & 0,251 & 0,257 & 0,265 & 0,255 & 0,256 & 0,264 & 0,258 & 0,231 \\
\hline $\mathrm{Mn}$ & 0,002 & 0,002 & 0,002 & 0,002 & 0,003 & 0,002 & 0,002 & 0,001 & 0,003 & 0,001 \\
\hline $\mathrm{Mg}$ & 0,754 & 0,705 & 0,693 & 0,689 & 0,685 & 0,684 & 0,685 & 0,692 & 0,691 & 0,716 \\
\hline $\mathrm{Ca}$ & 0,890 & 0,864 & 0,847 & 0,841 & 0,836 & 0,839 & 0,838 & 0,836 & 0,839 & 0,869 \\
\hline $\mathrm{Na}$ & 0,041 & 0,061 & 0,067 & 0,071 & 0,075 & 0,072 & 0,073 & 0,068 & 0,067 & 0,055 \\
\hline $\mathrm{K}$ & 0,000 & 0,000 & 0,000 & 0,000 & 0,001 & 0,000 & 0,000 & 0,002 & 0,000 & 0,001 \\
\hline Soma & 3,992 & 3,996 & 3,992 & 3,994 & 3,997 & 3,990 & 3,991 & 3,994 & 3,991 & 3,994 \\
\hline$\# \mathrm{Mg}$ & 77,893 & 74,603 & 73,411 & 72,833 & 72,105 & 72,843 & 72,795 & 72,385 & 72,813 & 75,607 \\
\hline
\end{tabular}


Tabela 33 - Análises químicas de clinopiroxênio da Nappe Três Pontas-Varginha

\begin{tabular}{|c|c|c|c|c|c|c|c|c|c|c|}
\hline \multicolumn{11}{|c|}{ TPR-01-B } \\
\hline Grão-Análise & $\mathrm{cp} \times 1-1$ & $\mathrm{cp} \times 1-2$ & $\mathrm{cpx} \times 1-3$ & $\mathrm{cp} \times 1-4$ & cpx1-5 & cpx1-6 & cpx1-7 & cpx1-8 & cpx1-9 & $\mathrm{cpx} 1-10$ \\
\hline $\mathrm{SiO}_{2}$ & 52,78 & 52,70 & 52,62 & 52,55 & 52,60 & 52,96 & 52,76 & 52,83 & 52,59 & 53,01 \\
\hline $\mathrm{TiO}_{2}$ & 0,30 & 0,21 & 0,36 & 0,28 & 0,35 & 0,42 & 0,42 & 0,34 & 0,36 & 0,28 \\
\hline $\mathrm{Al}_{2} \mathrm{O}_{3}$ & 3,23 & 3,65 & 3,85 & 4,01 & 4,04 & 4,04 & 4,04 & 3,98 & 3,95 & 4,03 \\
\hline $\mathrm{Cr}_{2} \mathrm{O}_{3}$ & 0,01 & 0,01 & 0,06 & 0,02 & 0,00 & 0,01 & 0,03 & 0,05 & 0,01 & 0,00 \\
\hline $\mathrm{Fe}_{2} \mathrm{O}_{3}$ & 0,00 & 0,00 & 0,00 & 0,00 & 0,00 & 0,00 & 0,00 & 0,00 & 0,00 & 0,00 \\
\hline $\mathrm{FeO}$ & 7,59 & 7,84 & 7,96 & 8,00 & 8,17 & 7,92 & 7,84 & 7,52 & 7,51 & 7,36 \\
\hline $\mathrm{MnO}$ & 0,07 & 0,04 & 0,06 & 0,08 & 0,07 & 0,06 & 0,05 & 0,04 & 0,07 & 0,07 \\
\hline $\mathrm{MgO}$ & 13,14 & 12,90 & 12,70 & 12,62 & 12,48 & 12,37 & 12,48 & 12,80 & 12,83 & 12,75 \\
\hline $\mathrm{CaO}$ & 21,84 & 21,42 & 21,10 & 21,29 & 21,11 & 21,19 & 21,22 & 21,58 & 21,96 & 21,63 \\
\hline $\mathrm{Na}_{2} \mathrm{O}$ & 0,83 & 0,92 & 0,87 & 0,94 & 0,93 & 0,90 & 0,95 & 0,88 & 0,83 & 0,86 \\
\hline $\mathrm{K}_{2} \mathrm{O}$ & 0,01 & 0,00 & 0,00 & 0,00 & 0,00 & 0,00 & 0,00 & 0,00 & 0,00 & 0,01 \\
\hline Total & 99,80 & 99,68 & 99,59 & 99,80 & 99,75 & 99,87 & 99,80 & 100,01 & 100,12 & 100,01 \\
\hline Oxigênios & 6,00 & 6,00 & 6,00 & 6,00 & 6,00 & 6,00 & 6,00 & 6,00 & 6,00 & 6,00 \\
\hline $\mathrm{Si}$ & 1,956 & 1,954 & 1,952 & 1,947 & 1,950 & 1,957 & 1,952 & 1,949 & 1,941 & 1,954 \\
\hline $\mathrm{Ti}$ & 0,008 & 0,006 & 0,010 & 0,008 & 0,010 & 0,012 & 0,012 & 0,009 & 0,010 & 0,008 \\
\hline $\mathrm{Al}$ & 0,141 & 0,160 & 0,168 & 0,175 & 0,177 & 0,176 & 0,176 & 0,173 & 0,172 & 0,175 \\
\hline $\mathrm{Cr}$ & 0,000 & 0,000 & 0,002 & 0,001 & 0,000 & 0,000 & 0,001 & 0,001 & 0,000 & 0,000 \\
\hline $\mathrm{Fe}^{3+}$ & 0,000 & 0,000 & 0,000 & 0,000 & 0,000 & 0,000 & 0,000 & 0,000 & 0,000 & 0,000 \\
\hline $\mathrm{Fe}^{2-}$ & 0,235 & 0,243 & 0,247 & 0,248 & 0,253 & 0,245 & 0,243 & 0,232 & 0,232 & 0,227 \\
\hline $\mathrm{Mn}$ & 0,002 & 0,001 & 0,002 & 0,003 & 0,002 & 0,002 & 0,002 & 0,001 & 0,002 & 0,002 \\
\hline $\mathrm{Mg}$ & 0,726 & 0,713 & 0,702 & 0,697 & 0,689 & 0,681 & 0,688 & 0,704 & 0,706 & 0,700 \\
\hline $\mathrm{Ca}$ & 0,867 & 0,851 & 0,839 & 0,845 & 0,838 & 0,839 & 0,841 & 0,853 & 0,869 & 0,854 \\
\hline $\mathrm{Na}$ & 0,060 & 0,066 & 0,063 & 0,068 & 0,067 & 0,064 & 0,068 & 0,063 & 0,060 & 0,062 \\
\hline $\mathrm{K}$ & 0,001 & 0,000 & 0,000 & 0,000 & 0,000 & 0,000 & 0,000 & 0,000 & 0,000 & 0,000 \\
\hline Soma & 3,995 & 3,993 & 3,985 & 3,991 & 3,986 & 3,976 & 3,982 & 3,986 & 3,992 & 3,982 \\
\hline$\# M g$ & 75,546 & 74,582 & 73,973 & 73,757 & 73,142 & 73,542 & 73,899 & 75,214 & 75,267 & 75,512 \\
\hline
\end{tabular}


Tabela 34 - Análises químicas de clinopiroxênio da Nappe Três Pontas-Varginha

\begin{tabular}{|c|c|c|c|c|c|c|c|c|c|c|}
\hline \multicolumn{11}{|c|}{$\begin{array}{c}\text { TPR-01-B } \\
\end{array}$} \\
\hline Grão-Análise & $\mathrm{cp} \times 2-1$ & $\mathrm{cp} \times 2-2$ & $\mathrm{cp} \times 2-3$ & $\mathrm{cp} \times 2-4$ & cpx2-5 & cp $\times 2-6$ & $\mathrm{cp} \times 2-7$ & cpx2-8 & cpx2-9 & $\mathrm{cp} \times 2-10$ \\
\hline $\mathrm{SiO}_{2}$ & 53,10 & 52,67 & 52,56 & 52,52 & 52,51 & 52,33 & 52,24 & 52,22 & 52,45 & 52,61 \\
\hline $\mathrm{TiO}_{2}$ & 0,25 & 0,33 & 0,40 & 0,34 & 0,38 & 0,43 & 0,37 & 0,33 & 0,32 & 0,32 \\
\hline $\mathrm{Al}_{2} \mathrm{O}_{3}$ & 3,25 & 3,83 & 3,87 & 3,95 & 3,83 & 4,03 & 4,03 & 4,06 & 4,08 & 3,54 \\
\hline $\mathrm{Cr}_{2} \mathrm{O}_{3}$ & 0,04 & 0,00 & 0,02 & 0,00 & 0,02 & 0,03 & 0,03 & 0,06 & 0,04 & 0,04 \\
\hline $\mathrm{Fe}_{2} \mathrm{O}_{3}$ & 0,00 & 0,00 & 0,00 & 0,00 & 0,00 & 0,00 & 0,00 & 0,00 & 0,00 & 0,00 \\
\hline $\mathrm{FeO}$ & 7,42 & 7,60 & 8,07 & 7,88 & 7,44 & 7,75 & 7,84 & 7,74 & 7,68 & 7,41 \\
\hline $\mathrm{MnO}$ & 0,07 & 0,09 & 0,05 & 0,04 & 0,08 & 0,03 & 0,04 & 0,07 & 0,01 & 0,04 \\
\hline $\mathrm{MgO}$ & 13,15 & 12,77 & 12,64 & 12,60 & 12,82 & 12,79 & 12,57 & 12,61 & 12,62 & 12,92 \\
\hline $\mathrm{CaO}$ & 21,72 & 21,53 & 21,34 & 21,55 & 21,74 & 21,76 & 21,45 & 21,41 & 21,20 & 21,68 \\
\hline $\mathrm{Na}_{2} \mathrm{O}$ & 0,77 & 0,84 & 0,88 & 0,86 & 0,88 & 0,92 & 0,88 & 0,88 & 0,91 & 0,82 \\
\hline $\mathrm{K}_{2} \mathrm{O}$ & 0,00 & 0,00 & 0,00 & 0,01 & 0,01 & 0,00 & 0,00 & 0,00 & 0,00 & 0,00 \\
\hline Total & 99,77 & 99,65 & 99,83 & 99,75 & 99,71 & 100,07 & 99,45 & 99,38 & 99,30 & 99,37 \\
\hline Oxigênios & 6,00 & 6,00 & 6,00 & 6,00 & 6,00 & 6,00 & 6,00 & 6,00 & 6,00 & 6,00 \\
\hline $\mathrm{Si}$ & 1,964 & 1,951 & 1,947 & 1,947 & 1,946 & 1,935 & 1,942 & 1,942 & 1,949 & 1,954 \\
\hline $\mathrm{Ti}$ & 0,007 & 0,009 & 0,011 & 0,009 & 0,011 & 0,012 & 0,010 & 0,009 & 0,009 & 0,009 \\
\hline $\mathrm{Al}$ & 0,142 & 0,167 & 0,169 & 0,173 & 0,167 & 0,176 & 0,177 & 0,178 & 0,179 & 0,155 \\
\hline $\mathrm{Cr}$ & 0,001 & 0,000 & 0,001 & 0,000 & 0,001 & 0,001 & 0,001 & 0,002 & 0,001 & 0,001 \\
\hline $\mathrm{Fe}^{3+}$ & 0,000 & 0,000 & 0,000 & 0,000 & 0,000 & 0,000 & 0,000 & 0,000 & 0,000 & 0,000 \\
\hline $\mathrm{Fe}^{2-}$ & 0,229 & 0,235 & 0,250 & 0,244 & 0,231 & 0,240 & 0,244 & 0,241 & 0,239 & 0,230 \\
\hline $\mathrm{Mn}$ & 0,002 & 0,003 & 0,002 & 0,001 & 0,003 & 0,001 & 0,001 & 0,002 & 0,000 & 0,001 \\
\hline $\mathrm{Mg}$ & 0,725 & 0,705 & 0,698 & 0,696 & 0,708 & 0,705 & 0,697 & 0,699 & 0,699 & 0,715 \\
\hline $\mathrm{Ca}$ & 0,861 & 0,855 & 0,847 & 0,856 & 0,863 & 0,862 & 0,855 & 0,853 & 0,844 & 0,863 \\
\hline $\mathrm{Na}$ & 0,055 & 0,060 & 0,063 & 0,062 & 0,063 & 0,066 & 0,063 & 0,063 & 0,065 & 0,059 \\
\hline $\mathrm{K}$ & 0,000 & 0,000 & 0,000 & 0,000 & 0,000 & 0,000 & 0,000 & 0,000 & 0,000 & 0,000 \\
\hline Soma & 3,986 & 3,986 & 3,988 & 3,989 & 3,992 & 3,998 & 3,990 & 3,990 & 3,985 & 3,988 \\
\hline \#Mg & 75,996 & 75,000 & 73,629 & 74,043 & 75,399 & 74,603 & 74,070 & 74,362 & 74,520 & 75,661 \\
\hline
\end{tabular}


Tabela 35 - Análises químicas de clinopiroxênio da Nappe Três Pontas-Varginha

\begin{tabular}{|c|c|c|c|c|c|c|c|c|c|c|}
\hline \multicolumn{11}{|c|}{ TPR-01-B } \\
\hline Grão-Análise & $\mathrm{cp} \times 3-1$ & $\mathrm{cp} \times 3-2$ & $\mathrm{cp} \times 3-3$ & $\mathrm{cp} \times 3-4$ & cp $\times 3-5$ & cp $\times 3-6$ & cp $\times 3-7$ & cp $\times 3-8$ & cp $\times 3-9$ & $\mathrm{cp} \times 3-10$ \\
\hline $\mathrm{SiO}_{2}$ & 52,76 & 52,46 & 52,52 & 52,19 & 52,44 & 52,62 & 52,60 & 53,09 & 52,86 & 52,88 \\
\hline $\mathrm{TiO}_{2}$ & 0,30 & 0,33 & 0,32 & 0,37 & 0,39 & 0,40 & 0,32 & 0,14 & 0,28 & 0,29 \\
\hline $\mathrm{Al}_{2} \mathrm{O}_{3}$ & 3,35 & 3,98 & 4,17 & 4,22 & 4,29 & 4,19 & 3,79 & 3,22 & 3,46 & 3,79 \\
\hline $\mathrm{Cr}_{2} \mathrm{O}_{3}$ & 0,04 & 0,00 & 0,07 & 0,03 & 0,00 & 0,05 & 0,02 & 0,02 & 0,00 & 0,01 \\
\hline $\mathrm{Fe}_{2} \mathrm{O}_{3}$ & 0,00 & 0,00 & 0,00 & 0,00 & 0,00 & 0,00 & 0,00 & 0,00 & 0,00 & 0,00 \\
\hline $\mathrm{FeO}$ & 7,63 & 7,55 & 7,58 & 7,83 & 7,84 & 7,94 & 7,33 & 7,67 & 7,93 & 7,71 \\
\hline $\mathrm{MnO}$ & 0,06 & 0,05 & 0,06 & 0,04 & 0,05 & 0,06 & 0,06 & 0,05 & 0,04 & 0,06 \\
\hline $\mathrm{MgO}$ & 12,96 & 12,38 & 12,33 & 12,42 & 12,43 & 12,49 & 12,77 & 12,91 & 12,94 & 12,77 \\
\hline $\mathrm{CaO}$ & 22,07 & 21,54 & 21,57 & 21,39 & 21,47 & 21,40 & 21,93 & 21,41 & 21,76 & 21,52 \\
\hline $\mathrm{Na}_{2} \mathrm{O}$ & 0,82 & 0,86 & 0,87 & 0,90 & 0,93 & 0,96 & 0,80 & 0,80 & 0,83 & 0,80 \\
\hline $\mathrm{K}_{2} \mathrm{O}$ & 0,00 & 0,00 & 0,00 & 0,03 & 0,02 & 0,00 & 0,00 & 0,02 & 0,00 & 0,00 \\
\hline Total & 99,99 & 99,15 & 99,49 & 99,42 & 99,86 & 100,11 & 99,62 & 99,32 & 100,10 & 99,82 \\
\hline Oxigênios & 6,00 & 6,00 & 6,00 & 6,00 & 6,00 & 6,00 & 6,00 & 6,00 & 6,00 & 6,00 \\
\hline $\mathrm{Si}$ & 1,952 & 1,953 & 1,949 & 1,941 & 1,941 & 1,943 & 1,949 & 1,972 & 1,954 & 1,955 \\
\hline $\mathrm{Ti}$ & 0,008 & 0,009 & 0,009 & 0,010 & 0,011 & 0,011 & 0,009 & 0,004 & 0,008 & 0,008 \\
\hline $\mathrm{Al}$ & 0,146 & 0,175 & 0,182 & 0,185 & 0,187 & 0,182 & 0,166 & 0,141 & 0,151 & 0,165 \\
\hline $\mathrm{Cr}$ & 0,001 & 0,000 & 0,002 & 0,001 & 0,000 & 0,001 & 0,001 & 0,001 & 0,000 & 0,000 \\
\hline $\mathrm{Fe}^{3+}$ & 0,000 & 0,000 & 0,000 & 0,000 & 0,000 & 0,000 & 0,000 & 0,000 & 0,000 & 0,000 \\
\hline $\mathrm{Fe}^{2-}$ & 0,236 & 0,235 & 0,235 & 0,244 & 0,243 & 0,245 & 0,227 & 0,238 & 0,245 & 0,238 \\
\hline $\mathrm{Mn}$ & 0,002 & 0,002 & 0,002 & 0,001 & 0,002 & 0,002 & 0,002 & 0,001 & 0,001 & 0,002 \\
\hline $\mathrm{Mg}$ & 0,715 & 0,687 & 0,682 & 0,688 & 0,686 & 0,687 & 0,705 & 0,715 & 0,713 & 0,704 \\
\hline $\mathrm{Ca}$ & 0,875 & 0,859 & 0,858 & 0,852 & 0,852 & 0,847 & 0,871 & 0,852 & 0,862 & 0,853 \\
\hline $\mathrm{Na}$ & 0,059 & 0,062 & 0,063 & 0,065 & 0,067 & 0,069 & 0,057 & 0,057 & 0,060 & 0,057 \\
\hline $\mathrm{K}$ & 0,000 & 0,000 & 0,000 & 0,001 & 0,001 & 0,000 & 0,000 & 0,001 & 0,000 & 0,000 \\
\hline Soma & 3,995 & 3,982 & 3,981 & 3,989 & 3,988 & 3,988 & 3,987 & 3,982 & 3,993 & 3,983 \\
\hline$\# M g$ & 75,184 & 74,512 & 74,373 & 73,820 & 73,843 & 73,712 & 75,644 & 75,026 & 74,426 & 74,735 \\
\hline
\end{tabular}


Tabela 36 - Análises químicas de clinopiroxênio da Nappe Três Pontas-Varginha

\begin{tabular}{|c|c|c|c|c|c|c|c|c|c|c|}
\hline \multicolumn{11}{|c|}{ TPR-01-B } \\
\hline Grão-Análise & cpx4-1 & cpx4-2 & cpx4-3 & cp x4-4 & cpx4-5 & cpx4-6 & cpx4-7 & cpx4-8 & cpx4-9 & cp $44-10$ \\
\hline $\mathrm{SiO}_{2}$ & 52,41 & 52,46 & 52,53 & 52,38 & 51,80 & 52,33 & 52,45 & 52,63 & 52,89 & 53,01 \\
\hline $\mathrm{TiO}_{2}$ & 0,32 & 0,39 & 0,39 & 0,34 & 0,31 & 0,33 & 0,31 & 0,30 & 0,23 & 0,22 \\
\hline $\mathrm{Al}_{2} \mathrm{O}_{3}$ & 3,57 & 4,02 & 4,07 & 4,08 & 4,03 & 3,99 & 3,94 & 3,77 & 3,31 & 2,86 \\
\hline $\mathrm{Cr}_{2} \mathrm{O}_{3}$ & 0,02 & 0,00 & 0,00 & 0,01 & 0,04 & 0,00 & 0,00 & 0,00 & 0,02 & 0,00 \\
\hline $\mathrm{Fe}_{2} \mathrm{O}_{3}$ & 0,00 & 0,00 & 0,00 & 0,00 & 0,00 & 0,00 & 0,00 & 0,00 & 0,00 & 0,00 \\
\hline $\mathrm{FeO}$ & 7,00 & 7,69 & 7,73 & 8,12 & 7,85 & 7,66 & 7,63 & 7,51 & 7,46 & 7,21 \\
\hline $\mathrm{MnO}$ & 0,08 & 0,09 & 0,08 & 0,03 & 0,04 & 0,05 & 0,08 & 0,03 & 0,08 & 0,03 \\
\hline $\mathrm{MgO}$ & 13,05 & 12,60 & 12,72 & 12,62 & 12,64 & 12,59 & 12,67 & 12,80 & 13,15 & 13,29 \\
\hline $\mathrm{CaO}$ & 21,76 & 21,50 & 21,59 & 21,26 & 20,86 & 21,15 & 21,56 & 21,47 & 21,96 & 22,12 \\
\hline $\mathrm{Na}_{2} \mathrm{O}$ & 0,72 & 0,89 & 0,90 & 0,91 & 0,94 & 0,89 & 0,86 & 0,82 & 0,72 & 0,67 \\
\hline $\mathrm{K}_{2} \mathrm{O}$ & 0,00 & 0,00 & 0,02 & 0,00 & 0,00 & 0,02 & 0,01 & 0,00 & 0,03 & 0,02 \\
\hline Total & 98,93 & 99,64 & 100,04 & 99,76 & 98,51 & 99,01 & 99,50 & 99,33 & 99,85 & 99,43 \\
\hline Oxigênios & 6,00 & 6,00 & 6,00 & 6,00 & 6,00 & 6,00 & 6,00 & 6,00 & 6,00 & 6,00 \\
\hline $\mathrm{Si}$ & 1,953 & 1,945 & 1,941 & 1,942 & 1,943 & 1,951 & 1,947 & 1,955 & 1,957 & 1,968 \\
\hline $\mathrm{Ti}$ & 0,009 & 0,011 & 0,011 & 0,010 & 0,009 & 0,009 & 0,009 & 0,008 & 0,006 & 0,006 \\
\hline $\mathrm{Al}$ & 0,157 & 0,176 & 0,177 & 0,178 & 0,178 & 0,175 & 0,172 & 0,165 & 0,144 & 0,125 \\
\hline $\mathrm{Cr}$ & 0,001 & 0,000 & 0,000 & 0,000 & 0,001 & 0,000 & 0,000 & 0,000 & 0,001 & 0,000 \\
\hline $\mathrm{Fe}^{3+}$ & 0,000 & 0,000 & 0,000 & 0,000 & 0,000 & 0,000 & 0,000 & 0,000 & 0,000 & 0,000 \\
\hline $\mathrm{Fe}^{2-}$ & 0,218 & 0,238 & 0,239 & 0,252 & 0,246 & 0,239 & 0,237 & 0,233 & 0,231 & 0,224 \\
\hline $\mathrm{Mn}$ & 0,002 & 0,003 & 0,002 & 0,001 & 0,001 & 0,002 & 0,002 & 0,001 & 0,003 & 0,001 \\
\hline $\mathrm{Mg}$ & 0,725 & 0,696 & 0,701 & 0,697 & 0,707 & 0,699 & 0,701 & 0,708 & 0,725 & 0,735 \\
\hline $\mathrm{Ca}$ & 0,869 & 0,854 & 0,855 & 0,845 & 0,839 & 0,845 & 0,858 & 0,854 & 0,871 & 0,880 \\
\hline $\mathrm{Na}$ & 0,052 & 0,064 & 0,064 & 0,065 & 0,068 & 0,064 & 0,062 & 0,059 & 0,052 & 0,048 \\
\hline $\mathrm{K}$ & 0,000 & 0,000 & 0,001 & 0,000 & 0,000 & 0,001 & 0,001 & 0,000 & 0,001 & 0,001 \\
\hline Soma & 3,985 & 3,988 & 3,992 & 3,991 & 3,993 & 3,985 & 3,989 & 3,984 & 3,990 & 3,988 \\
\hline$\# \mathrm{Mg}$ & 76,882 & 74,518 & 74,574 & 73,446 & 74,187 & 74,520 & 74,733 & 75,239 & 75,837 & 76,642 \\
\hline
\end{tabular}


Tabela 37 - Análises químicas de clinopiroxênio da Nappe Três Pontas-Varginha

\begin{tabular}{|c|c|c|c|c|c|c|c|c|c|c|}
\hline \multicolumn{11}{|c|}{ TPR-01-B } \\
\hline Grão-Análise & cpx5-1 & cp $\times 5-2$ & cpx5-3 & cpx5-4 & cpx5-5 & cpx5-6 & cpx5-7 & cpx5-8 & cpx5-9 & cpx5-10 \\
\hline $\mathrm{SiO}_{2}$ & 53,31 & 52,75 & 52,69 & 52,74 & 52,84 & 52,77 & 52,85 & 52,48 & 52,81 & 52,83 \\
\hline $\mathrm{TiO}_{2}$ & 0,22 & 0,36 & 0,34 & 0,39 & 0,44 & 0,35 & 0,35 & 0,35 & 0,36 & 0,36 \\
\hline $\mathrm{Al}_{2} \mathrm{O}_{3}$ & 3,20 & 4,28 & 4,22 & 4,11 & 4,23 & 4,18 & 4,25 & 4,17 & 4,01 & 4,01 \\
\hline $\mathrm{Cr}_{2} \mathrm{O}_{3}$ & 0,01 & 0,05 & 0,03 & 0,03 & 0,03 & 0,06 & 0,05 & 0,02 & 0,02 & 0,01 \\
\hline $\mathrm{Fe}_{2} \mathrm{O}_{3}$ & 0,00 & 0,00 & 0,00 & 0,00 & 0,00 & 0,00 & 0,00 & 0,00 & 0,00 & 0,00 \\
\hline $\mathrm{FeO}$ & 7,45 & 8,17 & 8,40 & 8,27 & 8,32 & 8,34 & 8,47 & 8,13 & 8,17 & 7,69 \\
\hline $\mathrm{MnO}$ & 0,02 & 0,04 & 0,07 & 0,04 & 0,06 & 0,07 & 0,07 & 0,08 & 0,07 & 0,04 \\
\hline $\mathrm{MgO}$ & 13,34 & 12,49 & 12,53 & 12,52 & 12,37 & 12,27 & 12,41 & 12,45 & 12,71 & 12,69 \\
\hline $\mathrm{CaO}$ & 22,01 & 21,19 & 21,36 & 21,51 & 21,04 & 21,11 & 21,21 & 21,72 & 21,71 & 21,72 \\
\hline $\mathrm{Na}_{2} \mathrm{O}$ & 0,71 & 0,96 & 0,98 & 0,98 & 0,98 & 1,03 & 0,98 & 0,93 & 0,90 & 0,86 \\
\hline $\mathrm{K}_{2} \mathrm{O}$ & 0,01 & 0,00 & 0,00 & 0,01 & 0,00 & 0,00 & 0,00 & 0,00 & 0,00 & 0,00 \\
\hline Total & 100,29 & 100,29 & 100,62 & 100,61 & 100,32 & 100,19 & 100,64 & 100,33 & 100,76 & 100,21 \\
\hline Oxigênios & 6,00 & 6,00 & 6,00 & 6,00 & 6,00 & 6,00 & 6,00 & 6,00 & 6,00 & 6,00 \\
\hline $\mathrm{Si}$ & 1,962 & 1,944 & 1,940 & 1,941 & 1,947 & 1,949 & 1,944 & 1,938 & 1,941 & 1,947 \\
\hline $\mathrm{Ti}$ & 0,006 & 0,010 & 0,009 & 0,011 & 0,012 & 0,010 & 0,010 & 0,010 & 0,010 & 0,010 \\
\hline $\mathrm{Al}$ & 0,139 & 0,186 & 0,183 & 0,178 & 0,184 & 0,182 & 0,184 & 0,182 & 0,174 & 0,174 \\
\hline $\mathrm{Cr}$ & 0,000 & 0,001 & 0,001 & 0,001 & 0,001 & 0,002 & 0,001 & 0,000 & 0,001 & 0,000 \\
\hline $\mathrm{Fe}^{3+}$ & 0,000 & 0,000 & 0,000 & 0,000 & 0,000 & 0,000 & 0,000 & 0,000 & 0,000 & 0,000 \\
\hline $\mathrm{Fe}^{2-}$ & 0,229 & 0,252 & 0,259 & 0,255 & 0,256 & 0,258 & 0,261 & 0,251 & 0,251 & 0,237 \\
\hline $\mathrm{Mn}$ & 0,001 & 0,001 & 0,002 & 0,001 & 0,002 & 0,002 & 0,002 & 0,003 & 0,002 & 0,001 \\
\hline $\mathrm{Mg}$ & 0,732 & 0,686 & 0,687 & 0,687 & 0,679 & 0,675 & 0,680 & 0,685 & 0,696 & 0,697 \\
\hline $\mathrm{Ca}$ & 0,868 & 0,837 & 0,843 & 0,848 & 0,831 & 0,835 & 0,836 & 0,859 & 0,855 & 0,858 \\
\hline $\mathrm{Na}$ & 0,051 & 0,068 & 0,070 & 0,070 & 0,070 & 0,074 & 0,070 & 0,066 & 0,064 & 0,061 \\
\hline $\mathrm{K}$ & 0,000 & 0,000 & 0,000 & 0,000 & 0,000 & 0,000 & 0,000 & 0,000 & 0,000 & 0,000 \\
\hline Soma & 3,988 & 3,986 & 3,994 & 3,993 & 3,983 & 3,986 & 3,989 & 3,995 & 3,994 & 3,986 \\
\hline$\# M g$ & 76,171 & 73,134 & 72,622 & 72,930 & 72,620 & 72,347 & 72,264 & 73,184 & 73,495 & 74,625 \\
\hline
\end{tabular}


Tabela 38 - Análises químicas de clinopiroxênio da Nappe Três Pontas-Varginha

\begin{tabular}{|c|c|c|c|c|c|c|c|c|c|c|}
\hline \multicolumn{11}{|c|}{ TPR-01-B } \\
\hline Grão-Análise & cpx6-1 & cpx6-2 & cpx6-3 & cpx6-4 & cpx6-5 & cpx6-6 & cpx6-7 & cpx6-8 & cpx6-9 & cp $\times 6-10$ \\
\hline $\mathrm{SiO}_{2}$ & 52,88 & 52,79 & 52,68 & 52,63 & 52,69 & 52,55 & 52,87 & 52,51 & 52,98 & 52,98 \\
\hline $\mathrm{TiO}_{2}$ & 0,36 & 0,32 & 0,42 & 0,38 & 0,33 & 0,39 & 0,28 & 0,35 & 0,35 & 0,31 \\
\hline $\mathrm{Al}_{2} \mathrm{O}_{3}$ & 4,14 & 4,04 & 4,17 & 4,11 & 4,16 & 3,90 & 3,97 & 3,89 & 3,80 & 3,65 \\
\hline $\mathrm{Cr}_{2} \mathrm{O}_{3}$ & 0,01 & 0,01 & 0,00 & 0,08 & 0,07 & 0,00 & 0,01 & 0,04 & 0,00 & 0,07 \\
\hline $\mathrm{Fe}_{2} \mathrm{O}_{3}$ & 0,00 & 0,00 & 0,00 & 0,00 & 0,00 & 0,00 & 0,00 & 0,00 & 0,00 & 0,00 \\
\hline $\mathrm{FeO}$ & 8,07 & 8,00 & 8,11 & 8,02 & 8,14 & 7,93 & 7,93 & 7,84 & 7,91 & 7,63 \\
\hline $\mathrm{MnO}$ & 0,06 & 0,05 & 0,08 & 0,08 & 0,07 & 0,02 & 0,08 & 0,07 & 0,08 & 0,04 \\
\hline $\mathrm{MgO}$ & 12,66 & 12,77 & 12,64 & 12,75 & 12,70 & 12,76 & 12,79 & 12,82 & 12,94 & 12,94 \\
\hline $\mathrm{CaO}$ & 21,52 & 21,51 & 21,35 & 21,71 & 21,85 & 21,67 & 21,43 & 21,57 & 21,59 & 22,18 \\
\hline $\mathrm{Na}_{2} \mathrm{O}$ & 0,95 & 0,91 & 0,93 & 0,91 & 0,90 & 0,81 & 0,91 & 0,87 & 0,89 & 0,78 \\
\hline $\mathrm{K}_{2} \mathrm{O}$ & 0,00 & 0,01 & 0,00 & 0,00 & 0,01 & 0,00 & 0,00 & 0,03 & 0,02 & 0,00 \\
\hline Total & 100,65 & 100,41 & 100,38 & 100,67 & 100,92 & 100,03 & 100,27 & 99,99 & 100,56 & 100,58 \\
\hline Oxigênios & 6,00 & 6,00 & 6,00 & 6,00 & 6,00 & 6,00 & 6,00 & 6,00 & 6,00 & 6,00 \\
\hline $\mathrm{Si}$ & 1,943 & 1,944 & 1,941 & 1,936 & 1,935 & 1,943 & 1,949 & 1,943 & 1,948 & 1,948 \\
\hline $\mathrm{Ti}$ & 0,010 & 0,009 & 0,012 & 0,010 & 0,009 & 0,011 & 0,008 & 0,010 & 0,010 & 0,009 \\
\hline $\mathrm{Al}$ & 0,179 & 0,175 & 0,181 & 0,178 & 0,180 & 0,170 & 0,172 & 0,170 & 0,165 & 0,158 \\
\hline $\mathrm{Cr}$ & 0,000 & 0,000 & 0,000 & 0,002 & 0,002 & 0,000 & 0,000 & 0,001 & 0,000 & 0,002 \\
\hline $\mathrm{Fe}^{3+}$ & 0,000 & 0,000 & 0,000 & 0,000 & 0,000 & 0,000 & 0,000 & 0,000 & 0,000 & 0,000 \\
\hline $\mathrm{Fe}^{2-}$ & 0,248 & 0,246 & 0,250 & 0,247 & 0,250 & 0,245 & 0,244 & 0,243 & 0,243 & 0,235 \\
\hline $\mathrm{Mn}$ & 0,002 & 0,002 & 0,002 & 0,002 & 0,002 & 0,001 & 0,003 & 0,002 & 0,002 & 0,001 \\
\hline $\mathrm{Mg}$ & 0,693 & 0,701 & 0,694 & 0,699 & 0,695 & 0,703 & 0,703 & 0,707 & 0,709 & 0,709 \\
\hline $\mathrm{Ca}$ & 0,847 & 0,849 & 0,843 & 0,856 & 0,860 & 0,859 & 0,846 & 0,855 & 0,851 & 0,874 \\
\hline $\mathrm{Na}$ & 0,068 & 0,065 & 0,066 & 0,065 & 0,064 & 0,058 & 0,065 & 0,063 & 0,063 & 0,056 \\
\hline $\mathrm{K}$ & 0,000 & 0,000 & 0,000 & 0,000 & 0,000 & 0,000 & 0,000 & 0,001 & 0,001 & 0,000 \\
\hline Soma & 3,991 & 3,992 & 3,990 & 3,996 & 3,997 & 3,990 & 3,990 & 3,994 & 3,992 & 3,991 \\
\hline$\# \mathrm{Mg}$ & 73,645 & 74,023 & 73,517 & 73,890 & 73,545 & 74,156 & 74,234 & 74,421 & 74,475 & 75,106 \\
\hline
\end{tabular}


Tabela 39 - Análises químicas de clinopiroxênio da Nappe Três Pontas-Varginha

\begin{tabular}{|c|c|c|c|c|c|c|c|c|c|c|}
\hline \multicolumn{11}{|c|}{$\begin{array}{c}\text { TPR-01-B } \\
\end{array}$} \\
\hline Grão-Análise & cpx7-1 & cpx7-2 & cpx7-3 & cpx7-4 & cp $\times 7-5$ & cpx7-6 & cpx7-7 & cpx7-8 & cpx7-9 & cpx7-10 \\
\hline $\mathrm{SiO}_{2}$ & 52,85 & 52,61 & 52,68 & 52,58 & 52,66 & 52,73 & 52,70 & 53,09 & 52,79 & 53,62 \\
\hline $\mathrm{TiO}_{2}$ & 0,27 & 0,45 & 0,40 & 0,39 & 0,40 & 0,34 & 0,42 & 0,38 & 0,27 & 0,27 \\
\hline $\mathrm{Al}_{2} \mathrm{O}_{3}$ & 3,82 & 4,19 & 4,33 & 4,32 & 4,22 & 4,10 & 4,15 & 3,96 & 3,79 & 3,07 \\
\hline $\mathrm{Cr}_{2} \mathrm{O}_{3}$ & 0,03 & 0,00 & 0,01 & 0,06 & 0,01 & 0,01 & 0,02 & 0,03 & 0,04 & 0,06 \\
\hline $\mathrm{Fe}_{2} \mathrm{O}_{3}$ & 0,00 & 0,00 & 0,00 & 0,00 & 0,00 & 0,00 & 0,00 & 0,00 & 0,00 & 0,00 \\
\hline $\mathrm{FeO}$ & 7,52 & 8,12 & 8,21 & 8,13 & 8,07 & 8,11 & 8,10 & 8,06 & 7,92 & 7,37 \\
\hline $\mathrm{MnO}$ & 0,04 & 0,08 & 0,06 & 0,07 & 0,08 & 0,05 & 0,07 & 0,07 & 0,08 & 0,04 \\
\hline $\mathrm{MgO}$ & 12,96 & 12,59 & 12,46 & 12,70 & 12,62 & 12,51 & 12,56 & 12,62 & 12,90 & 13,41 \\
\hline $\mathrm{CaO}$ & 22,01 & 21,70 & 21,62 & 21,41 & 21,39 & 21,58 & 21,56 & 21,21 & 21,89 & 22,31 \\
\hline $\mathrm{Na}_{2} \mathrm{O}$ & 0,79 & 0,88 & 0,92 & 0,97 & 0,91 & 0,92 & 0,90 & 0,86 & 0,87 & 0,72 \\
\hline $\mathrm{K}_{2} \mathrm{O}$ & 0,00 & 0,01 & 0,00 & 0,00 & 0,00 & 0,00 & 0,00 & 0,01 & 0,00 & 0,01 \\
\hline Total & 100,29 & 100,62 & 100,68 & 100,63 & 100,36 & 100,35 & 100,48 & 100,28 & 100,55 & 100,88 \\
\hline Oxigênios & 6,00 & 6,00 & 6,00 & 6,00 & 6,00 & 6,00 & 6,00 & 6,00 & 6,00 & 6,00 \\
\hline $\mathrm{Si}$ & 1,947 & 1,936 & 1,937 & 1,934 & 1,941 & 1,944 & 1,941 & 1,955 & 1,944 & 1,962 \\
\hline $\mathrm{Ti}$ & 0,007 & 0,012 & 0,011 & 0,011 & 0,011 & 0,009 & 0,012 & 0,011 & 0,007 & 0,007 \\
\hline Al & 0,166 & 0,182 & 0,188 & 0,187 & 0,183 & 0,178 & 0,180 & 0,172 & 0,165 & 0,132 \\
\hline $\mathrm{Cr}$ & 0,001 & 0,000 & 0,000 & 0,002 & 0,000 & 0,000 & 0,001 & 0,001 & 0,001 & 0,002 \\
\hline $\mathrm{Fe}^{3+}$ & 0,000 & 0,000 & 0,000 & 0,000 & 0,000 & 0,000 & 0,000 & 0,000 & 0,000 & 0,000 \\
\hline $\mathrm{Fe}^{2-}$ & 0,232 & 0,250 & 0,252 & 0,250 & 0,249 & 0,250 & 0,249 & 0,248 & 0,244 & 0,226 \\
\hline $\mathrm{Mn}$ & 0,001 & 0,003 & 0,002 & 0,002 & 0,002 & 0,002 & 0,002 & 0,002 & 0,003 & 0,001 \\
\hline $\mathrm{Mg}$ & 0,711 & 0,691 & 0,683 & 0,696 & 0,693 & 0,687 & 0,689 & 0,692 & 0,708 & 0,731 \\
\hline $\mathrm{Ca}$ & 0,869 & 0,856 & 0,852 & 0,844 & 0,845 & 0,853 & 0,851 & 0,837 & 0,864 & 0,875 \\
\hline $\mathrm{Na}$ & 0,056 & 0,063 & 0,065 & 0,069 & 0,065 & 0,065 & 0,064 & 0,061 & 0,062 & 0,051 \\
\hline $\mathrm{K}$ & 0,000 & 0,000 & 0,000 & 0,000 & 0,000 & 0,000 & 0,000 & 0,000 & 0,000 & 0,000 \\
\hline Soma & 3,990 & 3,992 & 3,991 & 3,996 & 3,989 & 3,990 & 3,989 & 3,979 & 3,997 & 3,989 \\
\hline$\# \mathrm{Mg}$ & 75,398 & 73,433 & 73,048 & 73,573 & 73,567 & 73,319 & 73,454 & 73,617 & 74,370 & 76,385 \\
\hline
\end{tabular}


Tabela 40 - Análises químicas de clinopiroxênio da Nappe Três Pontas-Varginha

\begin{tabular}{|c|c|c|c|c|c|c|c|c|c|c|}
\hline \multicolumn{11}{|c|}{$\begin{array}{c}\text { TPR-01-B } \\
\end{array}$} \\
\hline Grão-Análise & cpx8-1 & cp $\times 8-2$ & cp $\times 8-3$ & $\mathrm{cp} \times 8-4$ & $\mathrm{cpx} \times-5$ & cpx8-6 & cpх8-7 & cpx8-8 & cpx8-9 & cpx8-10 \\
\hline $\mathrm{SiO}_{2}$ & 52,97 & 53,07 & 52,63 & 52,76 & 53,13 & 53,12 & 52,77 & 52,85 & 52,80 & 53,19 \\
\hline $\mathrm{TiO}_{2}$ & 0,30 & 0,24 & 0,33 & 0,37 & 0,26 & 0,27 & 0,33 & 0,30 & 0,29 & 0,33 \\
\hline $\mathrm{Al}_{2} \mathrm{O}_{3}$ & 3,15 & 3,71 & 3,95 & 3,84 & 3,87 & 3,29 & 3,72 & 3,72 & 3,91 & 3,28 \\
\hline $\mathrm{Cr}_{2} \mathrm{O}_{3}$ & 0,02 & 0,04 & 0,03 & 0,04 & 0,07 & 0,00 & 0,00 & 0,00 & 0,02 & 0,06 \\
\hline $\mathrm{Fe}_{2} \mathrm{O}_{3}$ & 0,00 & 0,00 & 0,00 & 0,00 & 0,00 & 0,00 & 0,00 & 0,00 & 0,00 & 0,00 \\
\hline $\mathrm{FeO}$ & 7,36 & 7,55 & 7,60 & 7,60 & 7,50 & 7,44 & 7,86 & 7,83 & 7,60 & 7,36 \\
\hline $\mathrm{MnO}$ & 0,06 & 0,07 & 0,06 & 0,06 & 0,10 & 0,08 & 0,05 & 0,03 & 0,03 & 0,07 \\
\hline $\mathrm{MgO}$ & 13,20 & 12,78 & 12,84 & 12,77 & 12,89 & 13,14 & 12,91 & 12,84 & 12,87 & 13,42 \\
\hline $\mathrm{CaO}$ & 22,36 & 21,64 & 21,66 & 21,63 & 21,54 & 21,97 & 22,14 & 21,70 & 21,73 & 22,22 \\
\hline $\mathrm{Na}_{2} \mathrm{O}$ & 0,75 & 0,76 & 0,83 & 0,88 & 0,85 & 0,77 & 0,81 & 0,77 & 0,84 & 0,72 \\
\hline $\mathrm{K}_{2} \mathrm{O}$ & 0,00 & 0,01 & 0,00 & 0,00 & 0,00 & 0,00 & 0,01 & 0,01 & 0,00 & 0,01 \\
\hline Total & 100,18 & 99,88 & 99,94 & 99,95 & 100,20 & 100,08 & 100,60 & 100,06 & 100,09 & 100,65 \\
\hline Oxigênios & 6,00 & 6,00 & 6,00 & 6,00 & 6,00 & 6,00 & 6,00 & 6,00 & 6,00 & 6,00 \\
\hline $\mathrm{Si}$ & 1,955 & 1,960 & 1,945 & 1,949 & 1,955 & 1,960 & 1,943 & 1,952 & 1,948 & 1,952 \\
\hline $\mathrm{Ti}$ & 0,008 & 0,007 & 0,009 & 0,010 & 0,007 & 0,007 & 0,009 & 0,008 & 0,008 & 0,009 \\
\hline Al & 0,137 & 0,162 & 0,172 & 0,167 & 0,168 & 0,143 & 0,161 & 0,162 & 0,170 & 0,142 \\
\hline $\mathrm{Cr}$ & 0,001 & 0,001 & 0,001 & 0,001 & 0,002 & 0,000 & 0,000 & 0,000 & 0,001 & 0,002 \\
\hline $\mathrm{Fe}^{3+}$ & 0,000 & 0,000 & 0,000 & 0,000 & 0,000 & 0,000 & 0,000 & 0,000 & 0,000 & 0,000 \\
\hline $\mathrm{Fe}^{2-}$ & 0,227 & 0,233 & 0,235 & 0,235 & 0,231 & 0,230 & 0,242 & 0,242 & 0,234 & 0,226 \\
\hline $\mathrm{Mn}$ & 0,002 & 0,002 & 0,002 & 0,002 & 0,003 & 0,002 & 0,001 & 0,001 & 0,001 & 0,002 \\
\hline $\mathrm{Mg}$ & 0,726 & 0,703 & 0,707 & 0,703 & 0,707 & 0,723 & 0,708 & 0,707 & 0,708 & 0,734 \\
\hline $\mathrm{Ca}$ & 0,884 & 0,856 & 0,858 & 0,856 & 0,849 & 0,869 & 0,873 & 0,859 & 0,859 & 0,874 \\
\hline $\mathrm{Na}$ & 0,054 & 0,055 & 0,060 & 0,063 & 0,060 & 0,055 & 0,058 & 0,055 & 0,060 & 0,051 \\
\hline $\mathrm{K}$ & 0,000 & 0,000 & 0,000 & 0,000 & 0,000 & 0,000 & 0,001 & 0,001 & 0,000 & 0,001 \\
\hline Soma & 3,995 & 3,980 & 3,989 & 3,987 & 3,983 & 3,989 & 3,997 & 3,987 & 3,989 & 3,993 \\
\hline$\# \mathrm{Mg}$ & 76,180 & 75,107 & 75,053 & 74,947 & 75,373 & 75,866 & 74,526 & 74,499 & 75,159 & 76,458 \\
\hline
\end{tabular}


Tabela 41 - Análises químicas de clinopiroxênio da Nappe Três Pontas-Varginha

\begin{tabular}{|c|c|c|c|c|c|c|c|c|c|c|c|c|c|c|}
\hline \multicolumn{15}{|c|}{ TPR-01-F1 } \\
\hline Grão-Análise & $\operatorname{cpx} \times 1-2$ & $\mathrm{cpx} 1-3$ & $\mathrm{cpx1-4}$ & cpx1-5 & $\operatorname{cpx} 1-6$ & cpx1-7 & cpx1-8 & cpx1-9 & $\mathrm{cp} \times 1-10$ & $c p \times 1-11$ & $c p \times 1-12$ & $\mathrm{cp} \times 1-13$ & $\mathrm{cp} \times 1-14$ & cpx1-15 \\
\hline $\mathrm{SiO}_{2}$ & 52,38 & 52,19 & 52,19 & 52,36 & 52,48 & 51,85 & 52,31 & 52,29 & 52,36 & 52,57 & 52,34 & 52,33 & 51,65 & 52,07 \\
\hline $\mathrm{TiO}_{2}$ & 0,29 & 0,43 & 0,39 & 0,31 & 0,32 & 0,32 & 0,36 & 0,33 & 0,26 & 0,29 & 0,28 & 0,36 & 0,42 & 0,44 \\
\hline $\mathrm{Al}_{2} \mathrm{O}_{3}$ & 4,21 & 4,53 & 4,50 & 4,21 & 4,28 & 4,36 & 4,24 & 4,08 & 4,30 & 4,30 & 4,45 & 4,63 & 4,98 & 5,16 \\
\hline $\mathrm{Cr}_{2} \mathrm{O}_{3}$ & 0,00 & 0,06 & 0,03 & 0,02 & 0,00 & 0,04 & 0,01 & 0,05 & 0,05 & 0,07 & 0,04 & 0,04 & 0,03 & 0,04 \\
\hline $\mathrm{Fe}_{2} \mathrm{O}_{3}$ & 0,00 & 0,00 & 0,00 & 0,00 & 0,00 & 0,48 & 0,00 & 0,05 & 0,10 & 0,00 & 0,00 & 0,00 & 0,00 & 0,00 \\
\hline $\mathrm{FeO}$ & 6,55 & 6,67 & 6,47 & 6,63 & 6,62 & 6,29 & 6,69 & 6,52 & 6,57 & 6,74 & 6,61 & 6,57 & 6,62 & 6,67 \\
\hline $\mathrm{MnO}$ & 0,07 & 0,05 & 0,09 & 0,07 & 0,07 & 0,05 & 0,09 & 0,08 & 0,07 & 0,09 & 0,05 & 0,07 & 0,05 & 0,05 \\
\hline $\mathrm{MgO}$ & 13,30 & 13,24 & 13,14 & 13,28 & 13,25 & 13,36 & 13,29 & 13,42 & 13,31 & 13,22 & 13,25 & 13,02 & 13,06 & 13,08 \\
\hline $\mathrm{CaO}$ & 22,89 & 22,77 & 22,49 & 22,03 & 22,69 & 22,64 & 22,48 & 22,46 & 22,56 & 22,47 & 22,33 & 22,43 & 22,40 & 22,25 \\
\hline $\mathrm{Na}_{2} \mathrm{O}$ & 0,58 & 0,66 & 0,63 & 0,68 & 0,69 & 0,67 & 0,6 & 0,74 & 0,77 & 0,75 & 0,77 & 0,76 & 0,74 & 0,73 \\
\hline $\mathrm{K}_{2} \mathrm{O}$ & 0,01 & 0,00 & 0,00 & 0,02 & 0,00 & 0,01 & 0,01 & 0,04 & 0,01 & 0,00 & 0,00 & 0,01 & 0,01 & 0,00 \\
\hline Total & 100,28 & 100,60 & 99,92 & 99,61 & 100,40 & 100,06 & 100,16 & 100,05 & 100,35 & 100,50 & 100,13 & 100,22 & 99,96 & 100,50 \\
\hline Oxigênios & 6,00 & 6,00 & 6,00 & 6,00 & 6,00 & 6,00 & 6,00 & 6,00 & 6,00 & 6,00 & 6,00 & 6,00 & 6,00 & 6,00 \\
\hline $\mathrm{Si}$ & 1,927 & 1,915 & 1,924 & 1,935 & 1,928 & 1,913 & 1,92 & 1,928 & 1,925 & 1,929 & 1,926 & 1,924 & 1,907 & 1,909 \\
\hline $\mathrm{Ti}$ & 0,008 & 0,012 & 0,011 & 0,009 & 0,009 & 0,009 & 0,010 & 0,009 & 0,007 & 0,008 & 0,008 & 0,010 & 0,012 & 0,012 \\
\hline $\mathrm{Al}$ & 0,183 & 0,196 & 0,196 & 0,183 & 0,185 & 0,190 & 0,184 & 0,177 & 0,186 & 0,186 & 0,193 & 0,201 & 0,217 & 0,223 \\
\hline $\mathrm{Cr}$ & 0,000 & 0,002 & 0,001 & 0,000 & 0,000 & 0,001 & 0,000 & 0,002 & 0,001 & 0,002 & 0,001 & 0,001 & 0,001 & 0,001 \\
\hline $\mathrm{Fe}^{3+}$ & 0,000 & 0,000 & 0,000 & 0,000 & 0,000 & 0,013 & 0,000 & 0,001 & 0,003 & 0,000 & 0,000 & 0,000 & 0,000 & 0,000 \\
\hline $\mathrm{Fe}^{2-}$ & 0,202 & 0,205 & 0,200 & 0,205 & 0,203 & 0,194 & 0,206 & 0,201 & 0,202 & 0,207 & 0,203 & 0,202 & 0,204 & 0,205 \\
\hline $\mathrm{Mn}$ & 0,002 & 0,002 & 0,003 & 0,002 & 0,002 & 0,001 & & 0,002 & 0,002 & 0,003 & 0,002 & 0,002 & 0,001 & 0,002 \\
\hline $\mathrm{Mg}$ & 0,729 & 0,724 & 0,722 & 0,732 & 0,725 & 0,735 & 0,729 & 0,737 & 0,729 & 0,723 & 0,727 & 0,713 & 0,718 & 0,715 \\
\hline $\mathrm{Ca}$ & 0,902 & 0,895 & 0,889 & 0,873 & 0,893 & 0,895 & 0,887 & 0,887 & 0,889 & 0,884 & 0,881 & 0,884 & 0,886 & 0,874 \\
\hline $\mathrm{Na}$ & 0,041 & 0,047 & 0,045 & 0,049 & 0,049 & 0,048 & & 0,053 & 0,055 & 0,054 & 0,055 & 0,054 & 0,053 & 0,052 \\
\hline $\mathrm{K}$ & 0,001 & 0,000 & 0,000 & 0,001 & 0,000 & 0,000 & 0,000 & 0,002 & 0,000 & 0,000 & 0,000 & 0,000 & 0,001 & 0,000 \\
\hline Soma & & 3,997 & 3,989 & 3,989 & 3,995 & 4,000 & 3,996 & 4,000 & 4,000 & 3,995 & 3,996 & 3,992 & 4,000 & 3,993 \\
\hline$\# \mathrm{Mg}$ & 78,303 & 77,933 & 78,308 & 78,122 & 78,125 & 79,117 & 77,968 & 78,571 & 78,303 & 77,742 & 78,172 & 77,923 & 77,874 & 77,717 \\
\hline
\end{tabular}


Tabela 42 - Análises químicas de clinopiroxênio da Nappe Três Pontas-Varginha

TPR-01-F1

\begin{tabular}{|c|c|c|c|c|c|c|c|c|c|c|c|c|c|c|}
\hline \\
\hline Grão-Análise & cp $\times 2-1$ & cpx2-2 & $\mathrm{cp} \times 2-4$ & $\mathrm{cp} \times 2-5$ & $\mathrm{cp} \times 2-6$ & cpx2-7 & cpx2-8 & cpx2-9 & cpx2-10 & cpx2-11 & cpx2-12 & cp $\times 2-13$ & cpx2-14 & cpx2-15 \\
\hline $\mathrm{SiO}_{2}$ & 53,11 & 52,45 & 52,26 & 52,41 & 52,18 & 52,03 & 52,16 & 52,16 & 52,14 & 52,65 & 52,39 & 52,48 & 52,70 & 52,92 \\
\hline $\mathrm{TiO}_{2}$ & 0,20 & 0,34 & 0,36 & 0,29 & 0,36 & 0,38 & 0,29 & 0,27 & 0,34 & 0,32 & 0,36 & 0,36 & 0,26 & 0,19 \\
\hline $\mathrm{Al}_{2} \mathrm{O}_{3}$ & 3,11 & 4,04 & 4,46 & 4,34 & 4,39 & 4,83 & 4,37 & 4,25 & 4,23 & 4,39 & 4,56 & 4,28 & 3,66 & 3,71 \\
\hline $\mathrm{Cr}_{2} \mathrm{O}_{3}$ & 0,06 & 0,08 & 0,07 & 0,05 & 0,00 & 0,09 & 0,10 & 0,04 & 0,03 & 0,06 & 0,07 & 0,02 & 0,06 & 0,05 \\
\hline $\mathrm{Fe}_{2} \mathrm{O}_{3}$ & 0,00 & 0,00 & 0,00 & 0,00 & 0,00 & 0,00 & 0,00 & 0,00 & 0,10 & 0,00 & 0,00 & 0,00 & 0,00 & 0,00 \\
\hline $\mathrm{FeO}$ & 6,29 & 6,31 & 6,61 & 6,42 & 6,59 & 6,61 & 6,63 & 6,68 & 6,64 & 6,68 & 6,66 & 6,72 & 6,66 & 6,51 \\
\hline $\mathrm{MnO}$ & 0,05 & 0,02 & 0,09 & 0,11 & 0,06 & 0,04 & 0,04 & 0,07 & 0,01 & 0,06 & 0,05 & 0,07 & 0,08 & 0,06 \\
\hline $\mathrm{MgO}$ & 13,91 & 13,40 & 13,33 & 13,23 & 13,28 & 13,16 & 13,27 & 13,37 & 13,32 & 13,25 & 13,18 & 13,22 & 13,67 & 13,59 \\
\hline $\mathrm{CaO}$ & 23,06 & 22,68 & 22,57 & 22,50 & 22,52 & 22,74 & 22,53 & 22,63 & 22,74 & 22,77 & 22,81 & 22,74 & 22,94 & 22,94 \\
\hline $\mathrm{Na}_{2} \mathrm{O}$ & 0,52 & 0,62 & 0,68 & 0,66 & 0,62 & 0,67 & 0,62 & 0,64 & 0,66 & 0,62 & 0,67 & 0,60 & 0,59 & 0,58 \\
\hline $\mathrm{K}_{2} \mathrm{O}$ & 0,00 & 0,00 & 0,00 & 0,00 & 0,00 & 0,01 & 0,00 & 0,01 & 0,03 & 0,00 & 0,00 & 0,01 & 0,00 & 0,00 \\
\hline Total & 100,31 & 99,94 & 100,42 & 100,01 & 100,01 & 100,55 & 100,01 & 100,12 & 100,24 & 100,79 & 100,75 & 100,50 & 100,62 & 100,55 \\
\hline Oxigênios & 6,00 & 6,00 & 6,00 & 6,00 & 6,00 & 6,00 & 6,00 & 6,00 & 6,00 & 6,00 & 6,00 & 6,00 & 6,00 & 6,00 \\
\hline $\mathrm{Si}$ & 1,951 & 1,933 & 1,920 & 1,930 & 1,924 & 1,910 & 1,924 & 1,923 & 1,921 & 1,926 & 1,919 & 1,927 & 1,934 & 1,940 \\
\hline $\mathrm{Ti}$ & 0,006 & 0,009 & 0,010 & 0,008 & 0,010 & 0,010 & 0,008 & 0,008 & 0,010 & 0,009 & 0,010 & 0,010 & 0,007 & 0,005 \\
\hline Al & 0,135 & 0,176 & 0,193 & 0,188 & 0,191 & 0,209 & 0,190 & 0,185 & 0,184 & 0,189 & 0,197 & 0,185 & 0,158 & 0,160 \\
\hline $\mathrm{Cr}$ & 0,002 & 0,002 & 0,002 & 0,002 & 0,000 & 0,003 & 0,003 & 0,001 & 0,001 & 0,002 & 0,002 & 0,001 & 0,002 & 0,001 \\
\hline $\mathrm{Fe}^{3+}$ & 0,000 & 0,000 & 0,000 & 0,000 & 0,000 & 0,000 & 0,000 & 0,000 & 0,003 & 0,000 & 0,000 & 0,000 & 0,000 & 0,000 \\
\hline $\mathrm{Fe}^{2-}$ & 0,193 & 0,194 & 0,203 & 0,198 & 0,203 & 0,203 & 0,204 & 0,206 & 0,205 & 0,204 & 0,204 & 0,206 & 0,204 & 0,200 \\
\hline $\mathrm{Mn}$ & 0,001 & 0,001 & 0,003 & 0,003 & 0,002 & 0,001 & 0,001 & 0,002 & 0,000 & 0,002 & 0,002 & 0,002 & 0,002 & 0,002 \\
\hline $\mathrm{Mg}$ & 0,761 & 0,736 & 0,730 & 0,726 & 0,730 & 0,720 & 0,729 & 0,735 & 0,731 & 0,722 & 0,719 & 0,723 & 0,748 & 0,743 \\
\hline $\mathrm{Ca}$ & 0,908 & 0,896 & 0,888 & 0,888 & 0,890 & 0,894 & 0,890 & 0,894 & 0,898 & 0,893 & 0,895 & 0,895 & 0,902 & 0,901 \\
\hline $\mathrm{Na}$ & 0,037 & 0,044 & 0,048 & 0,047 & 0,045 & 0,048 & 0,044 & 0,046 & 0,047 & 0,044 & 0,047 & 0,043 & 0,042 & 0,041 \\
\hline $\mathrm{K}$ & 0,000 & 0,000 & 0,000 & 0,000 & 0,000 & 0,001 & 0,000 & 0,000 & 0,001 & 0,000 & 0,000 & 0,000 & 0,000 & 0,000 \\
\hline Soma & 3,994 & 3,991 & 3,997 & 3,990 & 3,993 & 3,998 & 3,994 & 4,000 & 4,000 & 3,991 & 3,995 & 3,992 & 4,000 & 3,994 \\
\hline \#Mg & 79,769 & 79,140 & 78,242 & 78,571 & 78,242 & 78,007 & 78,135 & 78,108 & 78,098 & 77,970 & 77,898 & 77,826 & 78,571 & 78,791 \\
\hline
\end{tabular}


Tabela 43 - Análises químicas de clinopiroxênio da Nappe Três Pontas-Varginha

\begin{tabular}{|c|c|c|c|c|c|c|c|c|c|c|}
\hline \multicolumn{11}{|c|}{$\begin{array}{c}\text { TPR-01-F1 } \\
\end{array}$} \\
\hline Grão-Análise & cp $\times 3-1$ & cp x3-2 & cp $\times 3-3$ & $\mathrm{cp} \times 3-4$ & cp $\times 3-5$ & cp $\times 3-6$ & cp $\times 3-7$ & cpx3-8 & cp $\times 3-9$ & cp $\times 3-10$ \\
\hline $\mathrm{SiO}_{2}$ & 53,52 & 52,62 & 52,62 & 52,71 & 52,45 & 52,23 & 52,09 & 52,13 & 52,25 & 51,94 \\
\hline $\mathrm{TiO}_{2}$ & 0,30 & 0,36 & 0,38 & 0,35 & 0,37 & 0,36 & 0,40 & 0,42 & 0,47 & 0,37 \\
\hline $\mathrm{Al}_{2} \mathrm{O}_{3}$ & 3,28 & 4,50 & 4,57 & 4,80 & 4,75 & 5,01 & 5,38 & 5,29 & 5,13 & 5,24 \\
\hline $\mathrm{Cr}_{2} \mathrm{O}_{3}$ & 0,02 & 0,02 & 0,03 & 0,03 & 0,04 & 0,03 & 0,08 & 0,06 & 0,10 & 0,06 \\
\hline $\mathrm{Fe}_{2} \mathrm{O}_{3}$ & 0,00 & 0,00 & 0,00 & 0,00 & 0,00 & 0,00 & 0,00 & 0,00 & 0,00 & 0,00 \\
\hline $\mathrm{FeO}$ & 6,52 & 6,70 & 6,62 & 6,78 & 6,70 & 6,62 & 6,62 & 6,52 & 6,66 & 6,47 \\
\hline $\mathrm{MnO}$ & 0,05 & 0,06 & 0,09 & 0,04 & 0,05 & 0,08 & 0,06 & 0,04 & 0,05 & 0,07 \\
\hline $\mathrm{MgO}$ & 13,48 & 13,16 & 13,03 & 13,14 & 13,14 & 12,95 & 12,88 & 12,82 & 12,86 & 12,98 \\
\hline $\mathrm{CaO}$ & 23,16 & 22,25 & 22,46 & 22,50 & 22,68 & 22,29 & 22,09 & 22,25 & 22,28 & 22,12 \\
\hline $\mathrm{Na}_{2} \mathrm{O}$ & 0,53 & 0,68 & 0,66 & 0,71 & 0,69 & 0,74 & 0,70 & 0,76 & 0,78 & 0,80 \\
\hline $\mathrm{K}_{2} \mathrm{O}$ & 0,01 & 0,00 & 0,03 & 0,00 & 0,00 & 0,02 & 0,00 & 0,00 & 0,01 & 0,02 \\
\hline Total & 100,87 & 100,35 & 100,49 & 101,06 & 100,87 & 100,32 & 100,31 & 100,28 & 100,59 & 100,07 \\
\hline Oxigênios & 6,00 & 6,00 & 6,00 & 6,00 & 6,00 & 6,00 & 6,00 & 6,00 & 6,00 & 6,00 \\
\hline $\mathrm{Si}$ & 1,955 & 1,931 & 1,929 & 1,922 & 1,918 & 1,918 & 1,911 & 1,913 & 1,914 & 1,911 \\
\hline $\mathrm{Ti}$ & 0,008 & 0,010 & 0,010 & 0,010 & 0,010 & 0,010 & 0,011 & 0,011 & 0,013 & 0,010 \\
\hline $\mathrm{Al}$ & 0,141 & 0,195 & 0,197 & 0,206 & 0,205 & 0,217 & 0,233 & 0,229 & 0,222 & 0,227 \\
\hline $\mathrm{Cr}$ & 0,001 & 0,001 & 0,001 & 0,001 & 0,001 & 0,001 & 0,002 & 0,002 & 0,003 & 0,002 \\
\hline $\mathrm{Fe}^{3+}$ & 0,000 & 0,000 & 0,000 & 0,000 & 0,000 & 0,000 & 0,000 & 0,000 & 0,000 & 0,000 \\
\hline $\mathrm{Fe}^{2-}$ & 0,199 & 0,206 & 0,203 & 0,207 & 0,205 & 0,203 & 0,203 & 0,200 & 0,204 & 0,199 \\
\hline $\mathrm{Mn}$ & 0,002 & 0,002 & 0,003 & 0,001 & 0,002 & 0,003 & 0,002 & 0,001 & 0,002 & 0,002 \\
\hline $\mathrm{Mg}$ & 0,734 & 0,720 & 0,712 & 0,714 & 0,716 & 0,709 & 0,704 & 0,701 & 0,702 & 0,712 \\
\hline $\mathrm{Ca}$ & 0,907 & 0,875 & 0,882 & 0,879 & 0,889 & 0,877 & 0,868 & 0,875 & 0,874 & 0,872 \\
\hline $\mathrm{Na}$ & 0,037 & 0,049 & 0,047 & 0,050 & 0,049 & 0,052 & 0,050 & 0,054 & 0,055 & 0,057 \\
\hline $\mathrm{K}$ & 0,001 & 0,000 & 0,002 & 0,000 & 0,000 & 0,001 & 0,000 & 0,000 & 0,000 & 0,001 \\
\hline Soma & 3,984 & 3,986 & 3,986 & 3,990 & 3,994 & 3,990 & 3,985 & 3,987 & 3,989 & 3,993 \\
\hline \#Mg & 78,671 & 77,754 & 77,814 & 77,524 & 77,742 & 77,741 & 77,619 & 77,802 & 77,483 & 78,156 \\
\hline
\end{tabular}


Tabela 44 - Análises químicas de clinopiroxênio da Nappe Três Pontas-Varginha

\begin{tabular}{|c|c|c|c|c|c|c|c|c|c|c|}
\hline \multicolumn{11}{|c|}{ TPR-01-F1 } \\
\hline Grão-Análise & cpx4-1 & cpx4-2 & cpx4-3 & cpx4-4 & $\mathrm{cp} \times 4-5$ & cpx4-6 & cpx4-7 & cpx4-8 & cpx4-9 & $\mathrm{cp \times 4-10}$ \\
\hline $\mathrm{SiO}_{2}$ & 53,01 & 52,19 & 52,21 & 51,97 & 52,42 & 52,28 & 52,01 & 52,00 & 52,12 & 51,92 \\
\hline $\mathrm{TiO}_{2}$ & 0,38 & 0,40 & 0,43 & 0,42 & 0,37 & 0,44 & 0,40 & 0,40 & 0,46 & 0,39 \\
\hline $\mathrm{Al}_{2} \mathrm{O}_{3}$ & 4,49 & 5,20 & 5,34 & 5,38 & 5,06 & 5,14 & 5,08 & 5,24 & 4,82 & 4,65 \\
\hline $\mathrm{Cr}_{2} \mathrm{O}_{3}$ & 0,06 & 0,08 & 0,07 & 0,05 & 0,04 & 0,05 & 0,14 & 0,07 & 0,04 & 0,07 \\
\hline $\mathrm{Fe}_{2} \mathrm{O}_{3}$ & 0,00 & 0,00 & 0,00 & 0,00 & 0,00 & 0,00 & 0,00 & 0,00 & 0,00 & 0,00 \\
\hline $\mathrm{FeO}$ & 6,50 & 6,61 & 6,81 & 6,47 & 6,70 & 6,51 & 6,57 & 6,82 & 6,67 & 6,80 \\
\hline $\mathrm{MnO}$ & 0,04 & 0,07 & 0,06 & 0,05 & 0,02 & 0,06 & 0,04 & 0,04 & 0,03 & 0,05 \\
\hline $\mathrm{MgO}$ & 13,31 & 13,08 & 12,93 & 12,98 & 13,03 & 13,00 & 12,99 & 13,21 & 12,91 & 13,01 \\
\hline $\mathrm{CaO}$ & 22,90 & 22,58 & 22,78 & 22,57 & 22,37 & 22,59 & 22,41 & 22,16 & 22,67 & 22,87 \\
\hline $\mathrm{Na}_{2} \mathrm{O}$ & 0,58 & 0,68 & 0,71 & 0,73 & 0,79 & 0,80 & 0,70 & 0,71 & 0,67 & 0,64 \\
\hline $\mathrm{K}_{2} \mathrm{O}$ & 0,00 & 0,03 & 0,02 & 0,00 & 0,00 & 0,00 & 0,00 & 0,03 & 0,01 & 0,00 \\
\hline Total & 101,28 & 100,92 & 101,36 & 100,61 & 100,80 & 100,86 & 100,35 & 100,67 & 100,40 & 100,40 \\
\hline Oxigênios & 6,00 & 6,00 & 6,00 & 6,00 & 6,00 & 6,00 & 6,00 & 6,00 & 6,00 & 6,00 \\
\hline $\mathrm{Si}$ & 1,927 & 1,907 & 1,902 & 1,903 & 1,916 & 1,910 & 1,910 & 1,905 & 1,915 & 1,911 \\
\hline $\mathrm{Ti}$ & 0,010 & 0,011 & 0,012 & 0,011 & 0,010 & 0,012 & 0,011 & 0,011 & 0,013 & 0,011 \\
\hline $\mathrm{Al}$ & 0,192 & 0,224 & 0,229 & 0,232 & 0,218 & 0,221 & 0,220 & 0,226 & 0,209 & 0,202 \\
\hline $\mathrm{Cr}$ & 0,002 & 0,002 & 0,002 & 0,001 & 0,001 & 0,001 & 0,004 & 0,002 & 0,001 & 0,002 \\
\hline $\mathrm{Fe}^{3+}$ & 0,000 & 0,000 & 0,000 & 0,000 & 0,000 & 0,000 & 0,000 & 0,000 & 0,000 & 0,000 \\
\hline $\mathrm{Fe}^{2-}$ & 0,198 & 0,202 & 0,207 & 0,198 & 0,205 & 0,199 & 0,202 & 0,209 & 0,205 & 0,209 \\
\hline $\mathrm{Mn}$ & 0,001 & 0,002 & 0,002 & 0,002 & 0,001 & 0,002 & 0,001 & 0,001 & 0,001 & 0,002 \\
\hline $\mathrm{Mg}$ & 0,721 & 0,712 & 0,702 & 0,708 & 0,710 & 0,708 & 0,711 & 0,721 & 0,707 & 0,714 \\
\hline $\mathrm{Ca}$ & 0,892 & 0,884 & 0,889 & 0,886 & 0,876 & 0,884 & 0,882 & 0,870 & 0,893 & 0,902 \\
\hline $\mathrm{Na}$ & 0,041 & 0,048 & 0,050 & 0,052 & 0,056 & 0,057 & 0,050 & 0,050 & 0,047 & 0,046 \\
\hline $\mathrm{K}$ & 0,000 & 0,001 & 0,001 & 0,000 & 0,000 & 0,000 & 0,000 & 0,001 & 0,001 & 0,000 \\
\hline Soma & 3,986 & 3,994 & 3,996 & 3,994 & 3,993 & 3,995 & 3,992 & 3,996 & 3,991 & 3,999 \\
\hline$\# \mathrm{Mg}$ & 78,455 & 77,899 & 77,228 & 78,146 & 77,596 & 78,060 & 77,875 & 77,527 & 77,522 & 77,356 \\
\hline
\end{tabular}


Tabela 45 - Análises químicas de clinopiroxênio da Nappe Três Pontas-Varginha

\begin{tabular}{|c|c|c|c|c|c|c|c|c|c|c|}
\hline \multicolumn{11}{|c|}{ TPR-01-F1 } \\
\hline Grão-Análise & cpx5-1 & cpx5-2 & cpx5-3 & cpx5-4 & cpx5-5 & cpx5-6 & cpx5-7 & cpx5-8 & cpx5-9 & cp $\times 5-10$ \\
\hline $\mathrm{SiO}_{2}$ & 53,05 & 53,28 & 52,69 & 52,51 & 52,78 & 52,47 & 52,59 & 52,33 & 52,30 & 52,93 \\
\hline $\mathrm{TiO}_{2}$ & 0,29 & 0,27 & 0,35 & 0,45 & 0,37 & 0,49 & 0,46 & 0,41 & 0,39 & 0,35 \\
\hline $\mathrm{Al}_{2} \mathrm{O}_{3}$ & 4,20 & 4,59 & 4,77 & 4,69 & 4,97 & 5,04 & 5,20 & 5,40 & 5,06 & 4,40 \\
\hline $\mathrm{Cr}_{2} \mathrm{O}_{3}$ & 0,04 & 0,08 & 0,07 & 0,12 & 0,02 & 0,02 & 0,11 & 0,03 & 0,06 & 0,07 \\
\hline $\mathrm{Fe}_{2} \mathrm{O}_{3}$ & 0,00 & 0,00 & 0,00 & 0,00 & 0,00 & 0,00 & 0,00 & 0,00 & 0,00 & 0,00 \\
\hline $\mathrm{FeO}$ & 5,79 & 6,04 & 6,40 & 6,62 & 6,49 & 6,53 & 6,50 & 6,22 & 6,27 & 6,26 \\
\hline $\mathrm{MnO}$ & 0,02 & 0,05 & 0,05 & 0,06 & 0,07 & 0,04 & 0,06 & 0,07 & 0,07 & 0,06 \\
\hline $\mathrm{MgO}$ & 13,87 & 13,11 & 13,24 & 13,26 & 13,02 & 12,89 & 12,92 & 12,82 & 13,10 & 13,41 \\
\hline $\mathrm{CaO}$ & 23,13 & 22,60 & 22,29 & 22,18 & 22,51 & 22,32 & 22,29 & 22,32 & 22,53 & 22,62 \\
\hline $\mathrm{Na}_{2} \mathrm{O}$ & 0,67 & 0,70 & 0,73 & 0,80 & 0,79 & 0,78 & 0,76 & 0,75 & 0,79 & 0,69 \\
\hline $\mathrm{K}_{2} \mathrm{O}$ & 0,00 & 0,00 & 0,00 & 0,00 & 0,00 & 0,00 & 0,00 & 0,01 & 0,00 & 0,02 \\
\hline Total & 101,06 & 100,71 & 100,59 & 100,69 & 101,02 & 100,58 & 100,90 & 100,36 & 100,58 & 100,81 \\
\hline Oxigênios & 6,00 & 6,00 & 6,00 & 6,00 & 6,00 & 6,00 & 6,00 & 6,00 & 6,00 & 6,00 \\
\hline $\mathrm{Si}$ & 1,929 & 1,941 & 1,926 & 1,921 & 1,923 & 1,920 & 1,917 & 1,916 & 1,914 & 1,931 \\
\hline $\mathrm{Ti}$ & 0,008 & 0,007 & 0,010 & 0,012 & 0,010 & 0,013 & 0,013 & 0,011 & 0,011 & 0,010 \\
\hline Al & 0,180 & 0,197 & 0,206 & 0,202 & 0,213 & 0,217 & 0,224 & 0,233 & 0,218 & 0,189 \\
\hline $\mathrm{Cr}$ & 0,001 & 0,002 & 0,002 & 0,003 & 0,001 & 0,001 & 0,003 & 0,001 & 0,002 & 0,002 \\
\hline $\mathrm{Fe}^{3+}$ & 0,000 & 0,000 & 0,000 & 0,000 & 0,000 & 0,000 & 0,000 & 0,000 & 0,000 & 0,000 \\
\hline $\mathrm{Fe}^{2-}$ & 0,176 & 0,184 & 0,196 & 0,203 & 0,198 & 0,200 & 0,198 & 0,190 & 0,192 & 0,191 \\
\hline $\mathrm{Mn}$ & 0,001 & 0,001 & 0,002 & 0,002 & 0,002 & 0,001 & 0,002 & 0,002 & 0,002 & 0,002 \\
\hline $\mathrm{Mg}$ & 0,752 & 0,712 & 0,721 & 0,723 & 0,707 & 0,703 & 0,702 & 0,700 & 0,714 & 0,729 \\
\hline $\mathrm{Ca}$ & 0,901 & 0,882 & 0,873 & 0,869 & 0,879 & 0,875 & 0,871 & 0,876 & 0,883 & 0,884 \\
\hline $\mathrm{Na}$ & 0,047 & 0,049 & 0,052 & 0,057 & 0,056 & 0,055 & 0,054 & 0,053 & 0,056 & 0,049 \\
\hline $\mathrm{K}$ & 0,000 & 0,000 & 0,000 & 0,000 & 0,000 & 0,000 & 0,000 & 0,000 & 0,000 & 0,001 \\
\hline Soma & 3,995 & 3,977 & 3,987 & 3,992 & 3,988 & 3,985 & 3,983 & 3,983 & 3,993 & 3,988 \\
\hline$\# \mathrm{Mg}$ & 81,034 & 79,464 & 78,626 & 78,078 & 78,122 & 77,852 & 78,000 & 78,652 & 78,808 & 79,239 \\
\hline
\end{tabular}


Tabela 46 - Análises químicas de clinopiroxênio da Nappe Três Pontas-Varginha

\begin{tabular}{|c|c|c|c|c|c|c|c|c|c|c|}
\hline \multicolumn{11}{|c|}{ TPR-01-F1 } \\
\hline Grão-Análise & cpx6-1 & cpx6-2 & cpx6-3 & cpx6-4 & cpx6-5 & cpx6-6 & сpх6-7 & cpx6-8 & cpx6-9 & cp $\times 6-10$ \\
\hline $\mathrm{SiO}_{2}$ & 53,09 & 52,63 & 52,46 & 52,37 & 52,45 & 52,33 & 52,39 & 52,34 & 52,52 & 52,30 \\
\hline $\mathrm{TiO}_{2}$ & 0,37 & 0,43 & 0,46 & 0,51 & 0,38 & 0,47 & 0,40 & 0,54 & 0,42 & 0,43 \\
\hline $\mathrm{Al}_{2} \mathrm{O}_{3}$ & 4,29 & 4,74 & 5,02 & 5,45 & 5,38 & 5,44 & 5,28 & 5,30 & 5,33 & 5,21 \\
\hline $\mathrm{Cr}_{2} \mathrm{O}_{3}$ & 0,13 & 0,07 & 0,01 & 0,10 & 0,09 & 0,04 & 0,12 & 0,09 & 0,01 & 0,02 \\
\hline $\mathrm{Fe}_{2} \mathrm{O}_{3}$ & 0,00 & 0,00 & 0,00 & 0,00 & 0,00 & 0,00 & 0,00 & 0,00 & 0,00 & 0,00 \\
\hline $\mathrm{FeO}$ & 6,02 & 6,07 & 6,23 & 6,30 & 6,45 & 6,38 & 6,36 & 6,45 & 6,29 & 6,35 \\
\hline $\mathrm{MnO}$ & 0,06 & 0,03 & 0,03 & 0,06 & 0,04 & 0,07 & 0,08 & 0,03 & 0,07 & 0,04 \\
\hline $\mathrm{MgO}$ & 13,48 & 13,48 & 13,08 & 12,87 & 12,96 & 12,98 & 12,96 & 12,97 & 12,83 & 13,13 \\
\hline $\mathrm{CaO}$ & 22,89 & 22,50 & 22,40 & 22,12 & 22,28 & 22,27 & 22,34 & 22,08 & 22,20 & 22,31 \\
\hline $\mathrm{Na}_{2} \mathrm{O}$ & 0,65 & 0,67 & 0,71 & 0,80 & 0,78 & 0,84 & 0,83 & 0,82 & 0,83 & 0,81 \\
\hline $\mathrm{K}_{2} \mathrm{O}$ & 0,00 & 0,00 & 0,02 & 0,00 & 0,00 & 0,00 & 0,00 & 0,00 & 0,01 & 0,01 \\
\hline Total & 100,99 & 100,62 & 100,42 & 100,58 & 100,81 & 100,82 & 100,76 & 100,61 & 100,53 & 100,62 \\
\hline Oxigênios & 6,00 & 6,00 & 6,00 & 6,00 & 6,00 & 6,00 & 6,00 & 6,00 & 6,00 & 6,00 \\
\hline $\mathrm{Si}$ & 1,933 & 1,922 & 1,920 & 1,913 & 1,913 & 1,909 & 1,913 & 1,913 & 1,920 & 1,912 \\
\hline $\mathrm{Ti}$ & 0,010 & 0,012 & 0,013 & 0,014 & 0,011 & 0,013 & 0,011 & 0,015 & 0,012 & 0,012 \\
\hline $\mathrm{Al}$ & 0,184 & 0,204 & 0,217 & 0,235 & 0,231 & 0,234 & 0,227 & 0,228 & 0,230 & 0,225 \\
\hline $\mathrm{Cr}$ & 0,004 & 0,002 & 0,000 & 0,003 & 0,003 & 0,001 & 0,003 & 0,002 & 0,000 & 0,001 \\
\hline $\mathrm{Fe}^{3+}$ & 0,000 & 0,000 & 0,000 & 0,000 & 0,000 & 0,000 & 0,000 & 0,000 & 0,000 & 0,000 \\
\hline $\mathrm{Fe}^{2-}$ & 0,183 & 0,185 & 0,191 & 0,192 & 0,197 & 0,195 & 0,194 & 0,197 & 0,192 & 0,194 \\
\hline $\mathrm{Mn}$ & 0,002 & 0,001 & 0,001 & 0,002 & 0,001 & 0,002 & 0,002 & 0,001 & 0,002 & 0,001 \\
\hline $\mathrm{Mg}$ & 0,731 & 0,734 & 0,713 & 0,701 & 0,705 & 0,706 & 0,705 & 0,706 & 0,699 & 0,715 \\
\hline $\mathrm{Ca}$ & 0,893 & 0,880 & 0,878 & 0,866 & 0,871 & 0,871 & 0,874 & 0,865 & 0,869 & 0,874 \\
\hline $\mathrm{Na}$ & 0,046 & 0,047 & 0,051 & 0,056 & 0,055 & 0,059 & 0,058 & 0,058 & 0,059 & 0,058 \\
\hline $\mathrm{K}$ & 0,000 & 0,000 & 0,001 & 0,000 & 0,000 & 0,000 & 0,000 & 0,000 & 0,001 & 0,000 \\
\hline Soma & 3,986 & 3,987 & 3,985 & 3,982 & 3,987 & 3,990 & 3,990 & 3,986 & 3,984 & 3,992 \\
\hline$\# \mathrm{Mg}$ & 79,978 & 79,869 & 78,872 & 78,499 & 78,160 & 78,357 & 78,420 & 78,184 & 78,451 & 78,658 \\
\hline
\end{tabular}


Tabela 47 - Análises químicas de clinopiroxênio da Nappe Três Pontas-Varginha

\begin{tabular}{|c|c|c|c|c|c|c|c|c|c|c|}
\hline \multicolumn{11}{|c|}{ TPR-01-F1 } \\
\hline Grão-Análise & cpx7-1 & cpx7-2 & cpx7-3 & cpx7-4 & cpx7-5 & cpx7-6 & cpx7-7 & cpx7-8 & cpx7-9 & cpx7-10 \\
\hline $\mathrm{SiO}_{2}$ & 52,74 & 52,71 & 52,36 & 52,73 & 53,09 & 52,76 & 52,68 & 53,01 & 52,71 & 52,92 \\
\hline $\mathrm{TiO}_{2}$ & 0,39 & 0,51 & 0,38 & 0,35 & 0,33 & 0,40 & 0,46 & 0,34 & 0,38 & 0,34 \\
\hline $\mathrm{Al}_{2} \mathrm{O}_{3}$ & 4,81 & 5,09 & 4,82 & 4,54 & 4,61 & 4,62 & 4,78 & 4,47 & 4,71 & 4,00 \\
\hline $\mathrm{Cr}_{2} \mathrm{O}_{3}$ & 0,07 & 0,06 & 0,08 & 0,04 & 0,00 & 0,03 & 0,04 & 0,06 & 0,00 & 0,07 \\
\hline $\mathrm{Fe}_{2} \mathrm{O}_{3}$ & 0,00 & 0,00 & 0,00 & 0,00 & 0,00 & 0,00 & 0,00 & 0,00 & 0,00 & 0,00 \\
\hline $\mathrm{FeO}$ & 6,33 & 6,55 & 6,62 & 6,45 & 6,58 & 6,70 & 6,53 & 6,04 & 6,32 & 5,90 \\
\hline $\mathrm{MnO}$ & 0,07 & 0,06 & 0,05 & 0,02 & 0,05 & 0,08 & 0,05 & 0,05 & 0,07 & 0,04 \\
\hline $\mathrm{MgO}$ & 13,12 & 13,04 & 13,18 & 13,36 & 13,32 & 13,33 & 13,31 & 13,44 & 13,39 & 13,92 \\
\hline $\mathrm{CaO}$ & 22,64 & 22,60 & 22,00 & 22,45 & 22,15 & 22,49 & 22,18 & 22,68 & 22,63 & 23,15 \\
\hline $\mathrm{Na}_{2} \mathrm{O}$ & 0,68 & 0,75 & 0,74 & 0,75 & 0,77 & 0,78 & 0,73 & 0,67 & 0,70 & 0,56 \\
\hline $\mathrm{K}_{2} \mathrm{O}$ & 0,01 & 0,00 & 0,00 & 0,00 & 0,00 & 0,01 & 0,02 & 0,03 & 0,01 & 0,00 \\
\hline Total & 100,85 & 101,37 & 100,24 & 100,70 & 100,90 & 101,19 & 100,78 & 100,79 & 100,92 & 100,90 \\
\hline Oxigênios & 6,00 & 6,00 & 6,00 & 6,00 & 6,00 & 6,00 & 6,00 & 6,00 & 6,00 & 6,00 \\
\hline $\mathrm{Si}$ & 1,924 & 1,915 & 1,922 & 1,927 & 1,934 & 1,922 & 1,923 & 1,932 & 1,922 & 1,929 \\
\hline $\mathrm{Ti}$ & 0,011 & 0,014 & 0,011 & 0,010 & 0,009 & 0,011 & 0,013 & 0,009 & 0,010 & 0,009 \\
\hline Al & 0,207 & 0,218 & 0,209 & 0,196 & 0,198 & 0,198 & 0,206 & 0,192 & 0,202 & 0,172 \\
\hline $\mathrm{Cr}$ & 0,002 & 0,002 & 0,002 & 0,001 & 0,000 & 0,001 & 0,001 & 0,002 & 0,000 & 0,002 \\
\hline $\mathrm{Fe}^{3+}$ & 0,000 & 0,000 & 0,000 & 0,000 & 0,000 & 0,000 & 0,000 & 0,000 & 0,000 & 0,000 \\
\hline $\mathrm{Fe}^{2-}$ & 0,193 & 0,199 & 0,203 & 0,197 & 0,200 & 0,204 & 0,199 & 0,184 & 0,193 & 0,180 \\
\hline $\mathrm{Mn}$ & 0,002 & 0,002 & 0,002 & 0,001 & 0,002 & 0,002 & 0,002 & 0,001 & 0,002 & 0,001 \\
\hline $\mathrm{Mg}$ & 0,713 & 0,706 & 0,721 & 0,728 & 0,723 & 0,724 & 0,724 & 0,730 & 0,728 & 0,756 \\
\hline $\mathrm{Ca}$ & 0,885 & 0,880 & 0,865 & 0,879 & 0,865 & 0,878 & 0,868 & 0,886 & 0,884 & 0,904 \\
\hline $\mathrm{Na}$ & 0,048 & 0,053 & 0,053 & 0,053 & 0,054 & 0,055 & 0,051 & 0,047 & 0,049 & 0,040 \\
\hline $\mathrm{K}$ & 0,000 & 0,000 & 0,000 & 0,000 & 0,000 & 0,000 & 0,001 & 0,001 & 0,000 & 0,000 \\
\hline Soma & 3,985 & 3,988 & 3,988 & 3,992 & 3,985 & 3,995 & 3,987 & 3,986 & 3,991 & 3,994 \\
\hline \#Mg & 78,698 & 78,011 & 78,030 & 78,703 & 78,332 & 78,017 & 78,440 & 79,869 & 79,045 & 80,769 \\
\hline
\end{tabular}


Tabela 48 - Análises químicas de ortopiroxênio da Nappe Socorro-Guaxupé

\begin{tabular}{|c|c|c|c|c|c|c|c|c|c|c|}
\hline \multicolumn{11}{|c|}{$\begin{array}{c}\text { IC-06-R } \\
\end{array}$} \\
\hline Grão-Análise & opx1-1 & opx1-2 & opx1-3 & opx1-4 & opx1-5 & opx1-6 & opx1-7 & opx1-8 & opx1-9 & opx1-10 \\
\hline $\mathrm{SiO}_{2}$ & 51,61 & 51,63 & 52,22 & 52,97 & 51,95 & 51,94 & 51,94 & 52,09 & 51,98 & 51,46 \\
\hline $\mathrm{TiO}_{2}$ & 0,04 & 0,14 & 0,07 & 0,10 & 0,13 & 0,07 & 0,11 & 0,17 & 0,09 & 0,03 \\
\hline $\mathrm{Al}_{2} \mathrm{O}_{3}$ & 2,24 & 2,21 & 1,97 & 2,43 & 2,17 & 2,13 & 1,88 & 1,82 & 1,78 & 1,83 \\
\hline $\mathrm{Cr}_{2} \mathrm{O}_{3}$ & 0,01 & 0,00 & 0,01 & 0,01 & 0,02 & 0,05 & 0,03 & 0,03 & 0,03 & 0,01 \\
\hline $\mathrm{Fe}_{2} \mathrm{O}_{3}$ & 0,00 & 0,71 & 0,21 & 0,00 & 0,25 & 0,20 & 0,33 & 0,27 & 0,52 & 0,00 \\
\hline $\mathrm{FeO}$ & 25,67 & 25,05 & 24,84 & 24,62 & 25,05 & 25,15 & 25,34 & 24,93 & 25,17 & 23,94 \\
\hline $\mathrm{MnO}$ & 0,72 & 0,60 & 0,61 & 0,60 & 0,60 & 0,59 & 0,55 & 0,62 & 0,61 & 0,56 \\
\hline $\mathrm{MgO}$ & 19,13 & 19,74 & 19,97 & 19,11 & 20,07 & 19,86 & 19,86 & 19,85 & 20,02 & 20,37 \\
\hline $\mathrm{CaO}$ & 0,52 & 0,61 & 1,02 & 1,31 & 0,52 & 0,75 & 0,63 & 1,00 & 0,50 & 0,47 \\
\hline $\mathrm{Na}_{2} \mathrm{O}$ & 0,02 & 0,03 & 0,02 & 0,07 & 0,02 & 0,02 & 0,02 & 0,05 & 0,03 & 0,02 \\
\hline $\mathrm{K}_{2} \mathrm{O}$ & 0,02 & 0,03 & 0,01 & 0,00 & 0,02 & 0,00 & 0,01 & 0,00 & 0,00 & 0,02 \\
\hline Total & 99,98 & 100,75 & 100,95 & 101,21 & 100,80 & 100,75 & 100,69 & 100,84 & 100,73 & 98,69 \\
\hline Oxigênios & 6,00 & 6,00 & 6,00 & 6,00 & 6,00 & 6,00 & 6,00 & 6,00 & 6,00 & 6,00 \\
\hline $\mathrm{Si}$ & 1,955 & 1,939 & 1,953 & 1,969 & 1,946 & 1,948 & 1,951 & 1,952 & 1,951 & 1,959 \\
\hline $\mathrm{Ti}$ & 0,001 & 0,004 & 0,002 & 0,003 & 0,004 & 0,002 & 0,003 & 0,005 & 0,002 & 0,001 \\
\hline $\mathrm{Al}$ & 0,100 & 0,098 & 0,087 & 0,106 & 0,096 & 0,094 & 0,083 & 0,081 & 0,079 & 0,082 \\
\hline $\mathrm{Cr}$ & 0,000 & 0,000 & 0,000 & 0,000 & 0,001 & 0,001 & 0,001 & 0,001 & 0,001 & 0,000 \\
\hline $\mathrm{Fe}^{3+}$ & 0,000 & 0,020 & 0,006 & 0,000 & 0,007 & 0,006 & 0,009 & 0,008 & 0,015 & 0,000 \\
\hline $\mathrm{Fe}^{2-}$ & 0,813 & 0,787 & 0,777 & 0,765 & 0,785 & 0,789 & 0,796 & 0,782 & 0,790 & 0,762 \\
\hline $\mathrm{Mn}$ & 0,023 & 0,019 & 0,019 & 0,019 & 0,019 & 0,019 & 0,018 & 0,020 & 0,019 & 0,018 \\
\hline $\mathrm{Mg}$ & 1,080 & 1,105 & 1,113 & 1,058 & 1,120 & 1,110 & 1,112 & 1,109 & 1,120 & 1,156 \\
\hline $\mathrm{Ca}$ & 0,021 & 0,025 & 0,041 & 0,052 & 0,021 & 0,030 & 0,025 & 0,040 & 0,020 & 0,019 \\
\hline $\mathrm{Na}$ & 0,001 & 0,002 & 0,002 & 0,005 & 0,001 & 0,001 & 0,001 & 0,003 & 0,002 & 0,002 \\
\hline $\mathrm{K}$ & 0,001 & 0,001 & 0,001 & 0,000 & 0,001 & 0,000 & 0,000 & 0,000 & 0,000 & 0,001 \\
\hline Soma & 3,995 & 4,000 & 4,000 & 3,978 & 4,000 & 4,000 & 4,000 & 4,000 & 4,000 & 4,000 \\
\hline \#Mg & 57,052 & 58,404 & 58,889 & 58,036 & 58,793 & 58,452 & 58,281 & 58,646 & 58,639 & 60,271 \\
\hline
\end{tabular}


Tabela 49 - Análises químicas de ortopiroxênio da Nappe Socorro-Guaxupé

\begin{tabular}{|c|c|c|c|c|c|c|c|c|c|c|}
\hline \multicolumn{11}{|c|}{ IC-06-R } \\
\hline Grão-Análise & opx2-1 & opx2-2 & opx2-3 & opx2-4 & opx2-5 & opx2-6 & opx2-7 & opx2-8 & opx2-9 & opx2-10 \\
\hline $\mathrm{SiO} 2$ & 51,76 & 51,73 & 51,79 & 51,62 & 51,63 & 51,58 & 51,58 & 51,17 & 51,74 & 52,10 \\
\hline $\mathrm{TiO} 2$ & 0,05 & 0,07 & 0,07 & 0,06 & 0,05 & 0,09 & 0,10 & 0,12 & 0,14 & 0,08 \\
\hline $\mathrm{Al} 2 \mathrm{O} 3$ & 1,95 & 2,13 & 2,09 & 2,27 & 2,15 & 2,32 & 2,25 & 2,79 & 2,29 & 1,93 \\
\hline $\mathrm{Cr} 2 \mathrm{O} 3$ & 0,03 & 0,03 & 0,06 & 0,04 & 0,04 & 0,03 & 0,00 & 0,04 & 0,04 & 0,09 \\
\hline $\mathrm{Fe} 2 \mathrm{O} 3$ & 0,00 & 0,68 & 0,29 & 0,31 & 0,30 & 0,31 & 0,38 & 0,18 & 0,24 & 0,00 \\
\hline $\mathrm{FeO}$ & 25,37 & 24,99 & 25,19 & 25,39 & 25,42 & 25,22 & 25,52 & 25,36 & 24,53 & 25,08 \\
\hline $\mathrm{MnO}$ & 0,57 & 0,59 & 0,58 & 0,60 & 0,59 & 0,55 & 0,57 & 0,57 & 0,54 & 0,60 \\
\hline $\mathrm{MgO}$ & 19,71 & 19,97 & 19,85 & 19,64 & 19,64 & 19,52 & 19,57 & 19,47 & 20,22 & 20,22 \\
\hline $\mathrm{CaO}$ & 0,43 & 0,53 & 0,52 & 0,50 & 0,54 & 0,80 & 0,48 & 0,48 & 0,55 & 0,47 \\
\hline $\mathrm{Na} 2 \mathrm{O}$ & 0,01 & 0,01 & 0,03 & 0,03 & 0,01 & 0,04 & 0,03 & 0,01 & 0,04 & 0,00 \\
\hline K2O & 0,00 & 0,01 & 0,01 & 0,00 & 0,01 & 0,00 & 0,02 & 0,00 & 0,00 & 0,01 \\
\hline Total & 99,88 & 100,74 & 100,48 & 100,45 & 100,37 & 100,46 & 100,50 & 100,19 & 100,32 & 100,59 \\
\hline Oxigênios & 6,00 & 6,00 & 6,00 & 6,00 & 6,00 & 6,00 & 6,00 & 6,00 & 6,00 & 6,00 \\
\hline $\mathrm{Si}$ & 1,958 & 1,941 & 1,948 & 1,944 & 1,947 & 1,942 & 1,943 & 1,932 & 1,943 & 1,954 \\
\hline $\mathrm{Ti}$ & 0,001 & 0,002 & 0,002 & 0,002 & 0,001 & 0,003 & 0,003 & 0,003 & 0,004 & 0,002 \\
\hline Al & 0,087 & 0,094 & 0,093 & 0,101 & 0,096 & 0,103 & 0,100 & 0,124 & 0,101 & 0,085 \\
\hline $\mathrm{Cr}$ & 0,001 & 0,001 & 0,002 & 0,001 & 0,001 & 0,001 & 0,000 & 0,001 & 0,001 & 0,003 \\
\hline $\mathrm{Fe}^{3+}$ & 0,000 & 0,019 & 0,008 & 0,009 & 0,009 & 0,009 & 0,011 & 0,005 & 0,007 & 0,000 \\
\hline $\mathrm{Fe}^{2-}$ & 0,803 & 0,784 & 0,792 & 0,800 & 0,801 & 0,794 & 0,804 & 0,801 & 0,770 & 0,787 \\
\hline $\mathrm{Mn}$ & 0,018 & 0,019 & 0,019 & 0,019 & 0,019 & 0,018 & 0,018 & 0,018 & 0,017 & 0,019 \\
\hline $\mathrm{Mg}$ & 1,111 & 1,117 & 1,113 & 1,102 & 1,104 & 1,095 & 1,099 & 1,095 & 1,132 & 1,130 \\
\hline $\mathrm{Ca}$ & 0,017 & 0,021 & 0,021 & 0,020 & 0,022 & 0,032 & 0,020 & 0,020 & 0,022 & 0,019 \\
\hline $\mathrm{Na}$ & 0,001 & 0,001 & 0,002 & 0,002 & 0,001 & 0,003 & 0,002 & 0,000 & 0,003 & 0,000 \\
\hline $\mathrm{K}$ & 0,000 & 0,000 & 0,001 & 0,000 & 0,000 & 0,000 & 0,001 & 0,000 & 0,000 & 0,000 \\
\hline Soma & 3,997 & 4,000 & 4,000 & 4,000 & 4,000 & 4,000 & 4,000 & 4,000 & 4,000 & 4,000 \\
\hline \#Mg & 58,046 & 58,759 & 58,425 & 57,939 & 57,953 & 57,967 & 57,751 & 57,753 & 59,516 & 58,946 \\
\hline
\end{tabular}


Tabela 50 - Análises químicas de ortopiroxênio da Nappe Socorro-Guaxupé

\begin{tabular}{|c|c|c|c|c|c|c|c|c|c|c|}
\hline \multicolumn{11}{|c|}{ IC-06-R } \\
\hline Grão-Análise & opx3-1 & opx3-2 & opx3-3 & op $\times 3-4$ & op $\times 3-5$ & opx3-6 & opx3-7 & opx3-8 & opx3-9 & opx3-10 \\
\hline $\mathrm{SiO}_{2}$ & 52,35 & 52,32 & 52,09 & 51,93 & 52,13 & 51,99 & 51,68 & 51,64 & 51,54 & 51,66 \\
\hline $\mathrm{TiO}_{2}$ & 0,02 & 0,06 & 0,07 & 0,02 & 0,05 & 0,08 & 0,11 & 0,08 & 0,12 & 0,10 \\
\hline $\mathrm{Al}_{2} \mathrm{O}_{3}$ & 1,69 & 1,89 & 1,85 & 2,13 & 1,80 & 2,29 & 2,29 & 2,24 & 2,20 & 2,14 \\
\hline $\mathrm{Cr}_{2} \mathrm{O}_{3}$ & 0,02 & 0,04 & 0,04 & 0,05 & 0,00 & 0,00 & 0,01 & 0,01 & 0,00 & 0,07 \\
\hline $\mathrm{Fe}_{2} \mathrm{O}_{3}$ & 0,00 & 0,00 & 0,00 & 0,30 & 0,00 & 0,00 & 0,33 & 0,01 & 0,17 & 0,00 \\
\hline $\mathrm{FeO}$ & 25,02 & 24,95 & 24,88 & 25,32 & 25,38 & 25,22 & 24,65 & 25,20 & 24,92 & 25,06 \\
\hline $\mathrm{MnO}$ & 0,66 & 0,58 & 0,57 & 0,62 & 0,59 & 0,60 & 0,58 & 0,63 & 0,61 & 0,60 \\
\hline $\mathrm{MgO}$ & 20,16 & 20,14 & 20,28 & 19,96 & 20,04 & 19,89 & 20,04 & 19,76 & 19,64 & 19,82 \\
\hline $\mathrm{CaO}$ & 0,36 & 0,44 & 0,54 & 0,43 & 0,42 & 0,44 & 0,59 & 0,58 & 0,80 & 0,59 \\
\hline $\mathrm{Na}_{2} \mathrm{O}$ & 0,01 & 0,01 & 0,00 & 0,01 & 0,00 & 0,00 & 0,02 & 0,01 & 0,03 & 0,00 \\
\hline $\mathrm{K}_{2} \mathrm{O}$ & 0,02 & 0,00 & 0,00 & 0,00 & 0,00 & 0,00 & 0,03 & 0,00 & 0,01 & 0,00 \\
\hline Total & 100,32 & 100,42 & 100,33 & 100,76 & 100,42 & 100,50 & 100,34 & 100,16 & 100,05 & 100,04 \\
\hline Oxigênios & 6,00 & 6,00 & 6,00 & 6,00 & 6,00 & 6,00 & 6,00 & 6,00 & 6,00 & 6,00 \\
\hline $\mathrm{Si}$ & 1,967 & 1,962 & 1,957 & 1,948 & 1,960 & 1,951 & 1,943 & 1,948 & 1,946 & 1,950 \\
\hline $\mathrm{Ti}$ & 0,001 & 0,002 & 0,002 & 0,001 & 0,001 & 0,002 & 0,003 & 0,002 & 0,003 & 0,003 \\
\hline Al & 0,075 & 0,083 & 0,082 & 0,094 & 0,080 & 0,101 & 0,101 & 0,100 & 0,098 & 0,095 \\
\hline $\mathrm{Cr}$ & 0,001 & 0,001 & 0,001 & 0,001 & 0,000 & 0,000 & 0,000 & 0,000 & 0,000 & 0,002 \\
\hline $\mathrm{Fe}^{3+}$ & 0,000 & 0,000 & 0,000 & 0,008 & 0,000 & 0,000 & 0,009 & 0,000 & 0,005 & 0,000 \\
\hline $\mathrm{Fe}^{2-}$ & 0,786 & 0,783 & 0,782 & 0,794 & 0,798 & 0,792 & 0,775 & 0,795 & 0,787 & 0,791 \\
\hline $\mathrm{Mn}$ & 0,021 & 0,018 & 0,018 & 0,020 & 0,019 & 0,019 & 0,019 & 0,020 & 0,020 & 0,019 \\
\hline $\mathrm{Mg}$ & 1,129 & 1,126 & 1,135 & 1,116 & 1,123 & 1,113 & 1,123 & 1,111 & 1,105 & 1,115 \\
\hline $\mathrm{Ca}$ & 0,015 & 0,018 & 0,022 & 0,017 & 0,017 & 0,018 & 0,024 & 0,024 & 0,032 & 0,024 \\
\hline $\mathrm{Na}$ & 0,001 & 0,000 & 0,000 & 0,001 & 0,000 & 0,000 & 0,001 & 0,000 & 0,002 & 0,000 \\
\hline $\mathrm{K}$ & 0,001 & 0,000 & 0,000 & 0,000 & 0,000 & 0,000 & 0,001 & 0,000 & 0,001 & 0,000 \\
\hline Soma & 3,996 & 3,994 & 3,999 & 4,000 & 3,999 & 3,996 & 4,000 & 4,000 & 4,000 & 3,999 \\
\hline \#Mg & 58,956 & 58,984 & 59,207 & 58,429 & 58,459 & 58,425 & 59,168 & 58,290 & 58,404 & 58,499 \\
\hline
\end{tabular}


Tabela 51 - Análises químicas de ortopiroxênio da Nappe Socorro-Guaxupé

\begin{tabular}{|c|c|c|c|c|c|c|c|c|c|c|}
\hline \multicolumn{11}{|c|}{ IC-06-R } \\
\hline Grão-Análise & opx4-1 & op $x 4-2$ & op $x 4-3$ & opx4-4 & op x4-5 & opx4-6 & opx4-7 & opx4-8 & op $\times 4-9$ & opx4-10 \\
\hline $\mathrm{SiO}_{2}$ & 50,97 & 51,59 & 51,80 & 51,58 & 51,53 & 51,38 & 51,19 & 51,22 & 51,52 & 51,14 \\
\hline $\mathrm{TiO}_{2}$ & 0,09 & 0,14 & 0,07 & 0,08 & 0,05 & 0,10 & 0,07 & 0,09 & 0,11 & 0,04 \\
\hline $\mathrm{Al}_{2} \mathrm{O}_{3}$ & 2,32 & 2,04 & 2,06 & 2,22 & 2,32 & 2,24 & 2,40 & 2,36 & 2,39 & 2,47 \\
\hline $\mathrm{Cr}_{2} \mathrm{O}_{3}$ & 0,06 & 0,01 & 0,02 & 0,02 & 0,03 & 0,03 & 0,02 & 0,00 & 0,01 & 0,00 \\
\hline $\mathrm{Fe}_{2} \mathrm{O}_{3}$ & 0,00 & 0,80 & 0,36 & 1,69 & 0,89 & 0,80 & 0,89 & 0,55 & 0,48 & 0,92 \\
\hline $\mathrm{FeO}$ & 25,54 & 24,99 & 25,07 & 24,78 & 25,29 & 25,29 & 25,05 & 25,51 & 24,54 & 24,93 \\
\hline $\mathrm{MnO}$ & 0,55 & 0,58 & 0,59 & 0,61 & 0,59 & 0,58 & 0,56 & 0,53 & 0,57 & 0,58 \\
\hline $\mathrm{MgO}$ & 18,93 & 19,84 & 19,49 & 19,92 & 19,65 & 19,61 & 19,63 & 19,32 & 19,20 & 19,60 \\
\hline $\mathrm{CaO}$ & 0,62 & 0,59 & 1,05 & 0,56 & 0,50 & 0,48 & 0,46 & 0,59 & 1,52 & 0,54 \\
\hline $\mathrm{Na}_{2} \mathrm{O}$ & 0,03 & 0,01 & 0,05 & 0,03 & 0,01 & 0,01 & 0,00 & 0,02 & 0,08 & 0,01 \\
\hline $\mathrm{K}_{2} \mathrm{O}$ & 0,01 & 0,03 & 0,01 & 0,00 & 0,02 & 0,01 & 0,03 & 0,00 & 0,02 & 0,00 \\
\hline Total & 99,12 & 100,61 & 100,56 & 101,48 & 100,89 & 100,53 & 100,29 & 100,19 & 100,44 & 100,23 \\
\hline Oxigênios & 6,00 & 6,00 & 6,00 & 6,00 & 6,00 & 6,00 & 6,00 & 6,00 & 6,00 & 6,00 \\
\hline $\mathrm{Si}$ & 1,948 & 1,940 & 1,949 & 1,926 & 1,935 & 1,936 & 1,932 & 1,938 & 1,940 & 1,931 \\
\hline $\mathrm{Ti}$ & 0,003 & 0,004 & 0,002 & 0,002 & 0,001 & 0,003 & 0,002 & 0,003 & 0,003 & 0,001 \\
\hline Al & 0,105 & 0,090 & 0,091 & 0,098 & 0,103 & 0,100 & 0,107 & 0,105 & 0,106 & 0,110 \\
\hline $\mathrm{Cr}$ & 0,002 & 0,000 & 0,001 & 0,000 & 0,001 & 0,001 & 0,001 & 0,000 & 0,000 & 0,000 \\
\hline $\mathrm{Fe}^{3+}$ & 0,000 & 0,023 & 0,010 & 0,048 & 0,025 & 0,023 & 0,025 & 0,016 & 0,014 & 0,026 \\
\hline $\mathrm{Fe}^{2-}$ & 0,816 & 0,786 & 0,789 & 0,774 & 0,794 & 0,797 & 0,791 & 0,807 & 0,773 & 0,787 \\
\hline $\mathrm{Mn}$ & 0,018 & 0,019 & 0,019 & 0,019 & 0,019 & 0,019 & 0,018 & 0,017 & 0,018 & 0,019 \\
\hline $\mathrm{Mg}$ & 1,078 & 1,112 & 1,093 & 1,109 & 1,100 & 1,101 & 1,104 & 1,089 & 1,078 & 1,103 \\
\hline $\mathrm{Ca}$ & 0,025 & 0,024 & 0,042 & 0,022 & 0,020 & 0,019 & 0,019 & 0,024 & 0,061 & 0,022 \\
\hline $\mathrm{Na}$ & 0,003 & 0,001 & 0,003 & 0,002 & 0,001 & 0,001 & 0,000 & 0,002 & 0,006 & 0,001 \\
\hline $\mathrm{K}$ & 0,000 & 0,001 & 0,001 & 0,000 & 0,001 & 0,001 & 0,001 & 0,000 & 0,001 & 0,000 \\
\hline Soma & 3,998 & 4,000 & 4,000 & 4,000 & 4,000 & 4,000 & 4,000 & 4,000 & 4,000 & 4,000 \\
\hline \#Mg & 56,917 & 58,588 & 58,077 & 58,895 & 58,078 & 58,008 & 58,259 & 57,437 & 58,239 & 58,360 \\
\hline
\end{tabular}


Tabela 52 - Análises químicas de clinopiroxênio da Nappe Socorro-Guaxupé

\begin{tabular}{|c|c|c|c|c|c|c|c|c|c|}
\hline \multicolumn{10}{|c|}{$\begin{array}{l}\text { IC-06-R } \\
\end{array}$} \\
\hline Grão-Análise & $\mathrm{cpx1-1}$ & $\mathrm{cp} \times 1-2$ & cpx1-3 & $\mathrm{cp} \times 1-4$ & cp $1-5$ & cp $\times 1-7$ & cp $\times 1-8$ & cpx1-9 & $\mathrm{cp} \times 1-10$ \\
\hline $\mathrm{SiO}_{2}$ & 52,56 & 52,11 & 51,73 & 51,54 & 51,82 & 52,05 & 51,83 & 51,86 & 52,19 \\
\hline $\mathrm{TiO}_{2}$ & 0,37 & 0,33 & 0,46 & 0,34 & 0,36 & 0,31 & 0,33 & 0,35 & 0,26 \\
\hline $\mathrm{Al}_{2} \mathrm{O}_{3}$ & 3,12 & 3,53 & 3,81 & 4,12 & 3,83 & 3,65 & 3,80 & 3,69 & 3,17 \\
\hline $\mathrm{Cr}_{2} \mathrm{O}_{3}$ & 0,03 & 0,09 & 0,10 & 0,03 & 0,07 & 0,00 & 0,02 & 0,03 & 0,00 \\
\hline $\mathrm{Fe}_{2} \mathrm{O}_{3}$ & 0,53 & 0,41 & 0,82 & 1,21 & 1,16 & 1,04 & 0,71 & 1,04 & 0,48 \\
\hline $\mathrm{FeO}$ & 8,64 & 9,94 & 9,98 & 9,05 & 8,81 & 8,73 & 9,68 & 9,12 & 9,47 \\
\hline $\mathrm{MnO}$ & 0,22 & 0,28 & 0,24 & 0,25 & 0,21 & 0,23 & 0,24 & 0,23 & 0,21 \\
\hline $\mathrm{MgO}$ & 12,65 & 11,99 & 12,02 & 11,84 & 12,15 & 12,38 & 11,76 & 12,14 & 12,40 \\
\hline $\mathrm{CaO}$ & 21,76 & 20,85 & 20,53 & 21,11 & 21,21 & 21,17 & 20,87 & 21,09 & 21,13 \\
\hline $\mathrm{Na}_{2} \mathrm{O}$ & 0,80 & 0,93 & 0,93 & 0,97 & 0,95 & 0,94 & 1,01 & 0,93 & 0,82 \\
\hline $\mathrm{K}_{2} \mathrm{O}$ & 0,06 & 0,00 & 0,00 & 0,00 & 0,02 & 0,00 & 0,00 & 0,00 & 0,00 \\
\hline Total & 100,74 & 100,45 & 100,62 & 100,46 & 100,58 & 100,50 & 100,25 & 100,48 & 100,13 \\
\hline Oxigênios & 6,00 & 6,00 & 6,00 & 6,00 & 6,00 & 6,00 & 6,00 & 6,00 & 6,00 \\
\hline $\mathrm{Si}$ & 1,944 & 1,940 & 1,924 & 1,918 & 1,923 & 1,931 & 1,933 & 1,928 & 1,946 \\
\hline $\mathrm{Ti}$ & 0,010 & 0,009 & 0,013 & 0,009 & 0,010 & 0,009 & 0,009 & 0,010 & 0,007 \\
\hline Al & 0,136 & 0,155 & 0,167 & 0,181 & 0,168 & 0,160 & 0,167 & 0,162 & 0,139 \\
\hline $\mathrm{Cr}$ & 0,001 & 0,003 & 0,003 & 0,001 & 0,002 & 0,000 & 0,001 & 0,001 & 0,000 \\
\hline $\mathrm{Fe}^{3+}$ & 0,015 & 0,011 & 0,023 & 0,034 & 0,033 & 0,029 & 0,020 & 0,029 & 0,013 \\
\hline $\mathrm{Fe}^{2-}$ & 0,267 & 0,310 & 0,311 & 0,282 & 0,274 & 0,271 & 0,302 & 0,284 & 0,295 \\
\hline $\mathrm{Mn}$ & 0,007 & 0,009 & 0,007 & 0,008 & 0,006 & 0,007 & 0,007 & 0,007 & 0,007 \\
\hline $\mathrm{Mg}$ & 0,697 & 0,665 & 0,666 & 0,657 & 0,672 & 0,684 & 0,654 & 0,673 & 0,689 \\
\hline $\mathrm{Ca}$ & 0,862 & 0,832 & 0,818 & 0,842 & 0,844 & 0,842 & 0,834 & 0,840 & 0,844 \\
\hline $\mathrm{Na}$ & 0,057 & 0,067 & 0,067 & 0,070 & 0,068 & 0,068 & 0,073 & 0,067 & 0,059 \\
\hline $\mathrm{K}$ & 0,003 & 0,000 & 0,000 & 0,000 & 0,001 & 0,000 & 0,000 & 0,000 & 0,000 \\
\hline Soma & 4,000 & 4,000 & 4,000 & 4,000 & 4,000 & 4,000 & 4,000 & 4,000 & 4,000 \\
\hline$\# \mathrm{Mg}$ & 72,303 & 68,205 & 68,168 & 69,968 & 71,036 & 71,623 & 68,410 & 70,324 & 70,020 \\
\hline
\end{tabular}


Tabela 53 - Análises químicas de clinopiroxênio da Nappe Socorro-Guaxupé

\begin{tabular}{|c|c|c|c|c|c|c|c|c|c|c|}
\hline \multicolumn{11}{|c|}{ IC-06-R } \\
\hline Grão-Análise & cpx2-1 & cp $\times 2-2$ & cpx2-3 & cp $\times 2-4$ & cp $\times 2-5$ & cp $\times 2-6$ & cp $\times 2-7$ & cpx2-8 & cpx2-9 & cpx2-10 \\
\hline $\mathrm{SiO}_{2}$ & 51,62 & 51,47 & 51,23 & 51,22 & 51,18 & 51,10 & 51,23 & 51,31 & 51,52 & 51,99 \\
\hline $\mathrm{TiO}_{2}$ & 0,25 & 0,28 & 0,39 & 0,35 & 0,46 & 0,37 & 0,36 & 0,39 & 0,35 & 0,30 \\
\hline $\mathrm{Al}_{2} \mathrm{O}_{3}$ & 3,56 & 3,83 & 3,99 & 4,06 & 4,24 & 4,14 & 3,87 & 4,28 & 3,95 & 3,56 \\
\hline $\mathrm{Cr}_{2} \mathrm{O}_{3}$ & 0,06 & 0,07 & 0,01 & 0,02 & 0,03 & 0,05 & 0,03 & 0,01 & 0,02 & 0,00 \\
\hline $\mathrm{Fe}_{2} \mathrm{O}_{3}$ & 1,11 & 0,72 & 1,15 & 0,36 & 1,02 & 2,18 & 0,62 & 0,00 & 1,06 & 1,27 \\
\hline $\mathrm{FeO}$ & 9,23 & 10,62 & 11,33 & 10,91 & 9,80 & 10,35 & 12,20 & 10,29 & 9,31 & 9,60 \\
\hline $\mathrm{MnO}$ & 0,24 & 0,27 & 0,27 & 0,27 & 0,25 & 0,29 & 0,31 & 0,23 & 0,25 & 0,25 \\
\hline $\mathrm{MgO}$ & 11,93 & 11,78 & 11,99 & 11,70 & 11,45 & 12,07 & 12,08 & 11,42 & 11,74 & 12,50 \\
\hline $\mathrm{CaO}$ & 21,08 & 19,96 & 18,92 & 19,69 & 20,69 & 19,42 & 18,25 & 20,44 & 20,78 & 20,49 \\
\hline $\mathrm{Na}_{2} \mathrm{O}$ & 0,91 & 0,94 & 0,94 & 0,93 & 0,98 & 0,95 & 0,89 & 0,99 & 1,03 & 0,87 \\
\hline $\mathrm{K}_{2} \mathrm{O}$ & 0,00 & 0,00 & 0,01 & 0,00 & 0,03 & 0,00 & 0,00 & 0,01 & 0,02 & 0,00 \\
\hline Total & 100,00 & 99,94 & 100,22 & 99,51 & 100,14 & 100,91 & 99,85 & 99,37 & 100,02 & 100,83 \\
\hline Oxigênios & 6,00 & 6,00 & 6,00 & 6,00 & 6,00 & 6,00 & 6,00 & 6,00 & 6,00 & 6,00 \\
\hline $\mathrm{Si}$ & 1,931 & 1,930 & 1,919 & 1,928 & 1,915 & 1,902 & 1,927 & 1,930 & 1,926 & 1,928 \\
\hline $\mathrm{Ti}$ & 0,007 & 0,008 & 0,011 & 0,010 & 0,013 & 0,010 & 0,010 & 0,011 & 0,010 & 0,008 \\
\hline Al & 0,157 & 0,169 & 0,176 & 0,180 & 0,187 & 0,182 & 0,172 & 0,190 & 0,174 & 0,156 \\
\hline $\mathrm{Cr}$ & 0,002 & 0,002 & 0,000 & 0,001 & 0,001 & 0,001 & 0,001 & 0,000 & 0,001 & 0,000 \\
\hline $\mathrm{Fe}^{3+}$ & 0,031 & 0,020 & 0,032 & 0,010 & 0,029 & 0,061 & 0,017 & 0,000 & 0,030 & 0,035 \\
\hline $\mathrm{Fe}^{2-}$ & 0,289 & 0,333 & 0,355 & 0,343 & 0,307 & 0,322 & 0,384 & 0,324 & 0,291 & 0,298 \\
\hline $\mathrm{Mn}$ & 0,008 & 0,008 & 0,009 & 0,008 & 0,008 & 0,009 & 0,010 & 0,007 & 0,008 & 0,008 \\
\hline $\mathrm{Mg}$ & 0,665 & 0,658 & 0,669 & 0,656 & 0,638 & 0,669 & 0,677 & 0,640 & 0,654 & 0,691 \\
\hline $\mathrm{Ca}$ & 0,845 & 0,802 & 0,759 & 0,794 & 0,830 & 0,774 & 0,736 & 0,824 & 0,832 & 0,814 \\
\hline $\mathrm{Na}$ & 0,066 & 0,068 & 0,068 & 0,068 & 0,071 & 0,068 & 0,065 & 0,072 & 0,074 & 0,063 \\
\hline $\mathrm{K}$ & 0,000 & 0,000 & 0,001 & 0,000 & 0,001 & 0,000 & 0,000 & 0,000 & 0,001 & 0,000 \\
\hline Soma & 4,000 & 4,000 & 4,000 & 4,000 & 4,000 & 4,000 & 4,000 & 4,000 & 4,000 & 4,000 \\
\hline \#Mg & 69,706 & 66,398 & 65,332 & 65,666 & 67,513 & 67,508 & 63,808 & 66,390 & 69,206 & 69,869 \\
\hline
\end{tabular}


Tabela 54 - Análises químicas de clinopiroxênio da Nappe Socorro-Guaxupé

\begin{tabular}{|c|c|c|c|c|c|c|c|c|c|c|}
\hline \multicolumn{11}{|c|}{ IC-06-R } \\
\hline Grão-Análise & cpx3-1 & $\mathrm{cp} \times 3-2$ & cpx3-3 & cp $\times 3-4$ & cp $\times 3-5$ & cp $\times 3-6$ & cpx3-7 & cpx3-8 & cpx3-9 & $\mathrm{cp} \times 3-10$ \\
\hline $\mathrm{SiO}_{2}$ & 51,91 & 51,36 & 50,78 & 51,04 & 51,13 & 51,31 & 51,24 & 50,82 & 51,78 & 52,42 \\
\hline $\mathrm{TiO}_{2}$ & 0,28 & 0,38 & 0,39 & 0,39 & 0,38 & 0,38 & 0,35 & 0,36 & 0,30 & 0,27 \\
\hline $\mathrm{Al}_{2} \mathrm{O}_{3}$ & 3,52 & 3,72 & 3,90 & 4,21 & 4,15 & 4,37 & 4,12 & 4,31 & 3,59 & 3,65 \\
\hline $\mathrm{Cr}_{2} \mathrm{O}_{3}$ & 0,07 & 0,02 & 0,00 & 0,00 & 0,00 & 0,04 & 0,03 & 0,02 & 0,00 & 0,05 \\
\hline $\mathrm{Fe}_{2} \mathrm{O}_{3}$ & 1,27 & 1,52 & 1,53 & 1,19 & 1,12 & 1,62 & 1,99 & 0,93 & 0,89 & 0,26 \\
\hline $\mathrm{FeO}$ & 10,05 & 11,48 & 12,43 & 9,62 & 11,68 & 10,09 & 10,46 & 10,51 & 10,10 & 9,47 \\
\hline $\mathrm{MnO}$ & 0,29 & 0,30 & 0,35 & 0,32 & 0,27 & 0,30 & 0,30 & 0,27 & 0,31 & 0,31 \\
\hline $\mathrm{MgO}$ & 12,23 & 12,22 & 12,27 & 11,32 & 11,64 & 11,50 & 11,85 & 11,36 & 11,63 & 12,32 \\
\hline $\mathrm{CaO}$ & 20,21 & 18,69 & 17,62 & 20,58 & 18,94 & 20,15 & 19,35 & 19,87 & 20,70 & 20,74 \\
\hline $\mathrm{Na}_{2} \mathrm{O}$ & 0,91 & 0,91 & 0,83 & 1,04 & 0,97 & 1,07 & 1,05 & 0,99 & 0,97 & 0,99 \\
\hline $\mathrm{K}_{2} \mathrm{O}$ & 0,02 & 0,00 & 0,00 & 0,02 & 0,01 & 0,00 & 0,02 & 0,00 & 0,01 & 0,01 \\
\hline Total & 100,76 & 100,62 & 100,09 & 99,73 & 100,29 & 100,84 & 100,75 & 99,44 & 100,28 & 100,48 \\
\hline Oxigênios & 6,00 & 6,00 & 6,00 & 6,00 & 6,00 & 6,00 & 6,00 & 6,00 & 6,00 & 6,00 \\
\hline $\mathrm{Si}$ & 1,930 & 1,919 & 1,911 & 1,917 & 1,917 & 1,909 & 1,910 & 1,917 & 1,935 & 1,944 \\
\hline $\mathrm{Ti}$ & 0,008 & 0,011 & 0,011 & 0,011 & 0,011 & 0,011 & 0,010 & 0,010 & 0,009 & 0,007 \\
\hline Al & 0,154 & 0,164 & 0,173 & 0,186 & 0,183 & 0,192 & 0,181 & 0,192 & 0,158 & 0,160 \\
\hline $\mathrm{Cr}$ & 0,002 & 0,001 & 0,000 & 0,000 & 0,000 & 0,001 & 0,001 & 0,001 & 0,000 & 0,001 \\
\hline $\mathrm{Fe}^{3+}$ & 0,035 & 0,043 & 0,043 & 0,034 & 0,031 & 0,045 & 0,056 & 0,026 & 0,025 & 0,007 \\
\hline $\mathrm{Fe}^{2-}$ & 0,312 & 0,359 & 0,391 & 0,302 & 0,366 & 0,314 & 0,326 & 0,332 & 0,316 & 0,294 \\
\hline $\mathrm{Mn}$ & 0,009 & 0,010 & 0,011 & 0,010 & 0,009 & 0,010 & 0,009 & 0,009 & 0,010 & 0,010 \\
\hline $\mathrm{Mg}$ & 0,678 & 0,680 & 0,688 & 0,634 & 0,650 & 0,638 & 0,658 & 0,639 & 0,648 & 0,681 \\
\hline $\mathrm{Ca}$ & 0,805 & 0,748 & 0,711 & 0,828 & 0,761 & 0,803 & 0,773 & 0,803 & 0,829 & 0,824 \\
\hline $\mathrm{Na}$ & 0,066 & 0,066 & 0,060 & 0,076 & 0,070 & 0,078 & 0,076 & 0,072 & 0,071 & 0,071 \\
\hline $\mathrm{K}$ & 0,001 & 0,000 & 0,000 & 0,001 & 0,001 & 0,000 & 0,001 & 0,000 & 0,000 & 0,000 \\
\hline Soma & 4,000 & 4,000 & 4,000 & 4,000 & 4,000 & 4,000 & 4,000 & 4,000 & 4,000 & 4,000 \\
\hline \#Mg & 68,485 & 65,448 & 63,763 & 67,735 & 63,976 & 67,017 & 66,870 & 65,808 & 67,220 & 69,846 \\
\hline
\end{tabular}


Tabela 55 - Fórmulas estruturais de clinopiroxênio e ortopiroxênio das nappes Três Pontas-Varginha e SocorroGuaxupé

\begin{tabular}{|c|c|c|c|}
\hline Unidade & Amostra & Cristal & Fórmula estrutural \\
\hline 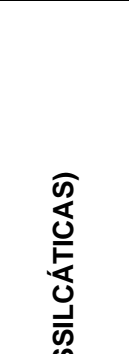 & $\begin{array}{l}0 \\
1 \\
0 \\
\dot{1} \\
\frac{1}{0} \\
\qquad\end{array}$ & $\begin{array}{l}c p \times 1 \\
c p \times 2 \\
c p \times 3 \\
c p \times 4 \\
c p \times 5 \\
c p \times 7\end{array}$ & $\begin{array}{l}\mathrm{Na}_{0,05-0,07}, \mathrm{Ca}_{0,85-0,89}, \mathrm{Fe}^{2+}{ }_{0,21-0,25}, \mathrm{Mg}_{0,70-0,74}, \mathrm{Ti}_{0,01}, \mathrm{Al}_{0,10-0,11}\left(\mathrm{Al}_{0,04-0,07}, \mathrm{Si}_{1,93-1,96}\right) \mathrm{O}_{6} \\
\mathrm{Na}_{0,06-0,09}, \mathrm{Ca}_{0,83-0,87}, \mathrm{Fe}^{2+}{ }_{0,24-0,27}, \mathrm{Mg}_{0,68-0,71}, \mathrm{Ti}_{0,01}, \mathrm{Al}_{0,11-0,13}\left(\mathrm{Al}_{0,05-0,06}, \mathrm{Si}_{1,94-1,95}\right) \mathrm{O}_{6} \\
\mathrm{Na}_{0,05-0,06}, \mathrm{Ca}_{0,85-0,88}, \mathrm{Fe}^{2+}{ }_{0,23-0,24}, \mathrm{Mg}_{0,70-0,72}, \mathrm{Ti}_{0,01}, \mathrm{Al}_{0,11-0,12}\left(\mathrm{Al}_{0,04-0,06}, \mathrm{Si}_{1,94-1,96}\right) \mathrm{O}_{6} \\
\mathrm{Na}_{0,05-0,07}, \mathrm{Ca}_{0,84-0,89}, \mathrm{Fe}^{2+}{ }_{0,18-0,26}, \mathrm{Mg}_{0,68-0,78}, \mathrm{Ti}_{0,01}, \mathrm{Al}_{0,06-0,12}\left(\mathrm{Al}_{0,05-0,06}, \mathrm{Si}_{1,94-1,95}\right) \mathrm{O}_{6} \\
\mathrm{Na}_{0,05-0,07}, \mathrm{Ca}_{0,86-0,88}, \mathrm{Fe}^{2+}{ }_{0,23-0,25}, \mathrm{Mg}_{0,69-0,72}, \mathrm{Ti}_{0,01}, \mathrm{Al}_{0,09-0,12}\left(\mathrm{Al}_{0,05-0,07}, \mathrm{Si}_{1,93-1,95}\right) \mathrm{O}_{6} \\
\mathrm{Na}_{0,05-0,07}, \mathrm{Ca}_{0,84-0,87}, \mathrm{Fe}^{2+}{ }_{0,23-0,25}, \mathrm{Mg}_{0,68-0,72}, \mathrm{Ti}_{0,01}, \mathrm{Al}_{0,10-0,13}\left(\mathrm{Al}_{0,05-0,06}, \mathrm{Si}_{1,94-1,95}\right) \mathrm{O}_{6} \\
\mathrm{Na}_{0,04-0,08}, \mathrm{Ca}_{0,84-0,89}, \mathrm{Fe}^{2+}{ }_{0,21-0,27}, \mathrm{Mg}_{0,68-0,75}, \mathrm{Ti}_{0,01}, \mathrm{Al}_{0,08-0,13}\left(\mathrm{Al}_{0,04-0,06}, \mathrm{Si}_{1,94-1,96}\right) \mathrm{O}_{6}\end{array}$ \\
\hline 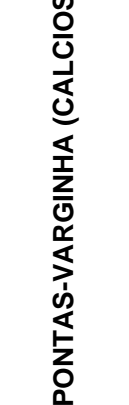 & $\begin{array}{l}\text { m } \\
\frac{1}{0} \\
\dot{1} \\
\frac{\mathfrak{n}}{0} \\
\dot{r}\end{array}$ & 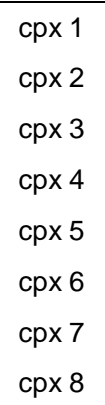 & $\begin{array}{l}\mathrm{Na}_{0,06-0,07}, \mathrm{Ca}_{0,84-0,87}, \mathrm{Fe}^{2+}{ }_{0,23-0,25}, \mathrm{Mg}_{0,68-0,73}, \mathrm{Ti}_{0,01}, \mathrm{Al}_{0,10-0,12}\left(\mathrm{Al}_{0,04-0,06}, \mathrm{Si}_{1,94-1,96}\right) \mathrm{O}_{6} \\
\mathrm{Na}_{0,06-0,07}, \mathrm{Ca}_{0,84-0,86}, \mathrm{Fe}^{2+}{ }_{0,23-0,25}, \mathrm{Mg}_{0,70-0,73}, \mathrm{Ti}_{0,01}, \mathrm{Al}_{0,10-0,12}\left(\mathrm{Al}_{0,04-0,06}, \mathrm{Si}_{1,94-1,96}\right) \mathrm{O}_{6} \\
\mathrm{Na}_{0,06-0,07}, \mathrm{Ca}_{0,85-0,88}, \mathrm{Fe}^{2+}{ }_{0,23-0,25}, \mathrm{Mg}_{0,68-0,72}, \mathrm{Ti}_{0,01}, \mathrm{Al}_{0,11-0,13}\left(\mathrm{Al}_{0,03-0,06}, \mathrm{Si}_{1,94-1,97}\right) \mathrm{O}_{6} \\
\mathrm{Na}_{0,05-0,07}, \mathrm{Ca}_{0,84-0,88}, \mathrm{Fe}^{2+}{ }_{0,22-0,25}, \mathrm{Mg}_{0,70-0,74}, \mathrm{Ti}_{0,01}, \mathrm{Al}_{0,10-0,12}\left(\mathrm{Al}_{0,03-0,06}, \mathrm{Si}_{1,94-1,97}\right) \mathrm{O}_{6} \\
\mathrm{Na}_{0,05-0,07}, \mathrm{Ca}_{0,83-0,87}, \mathrm{Fe}^{2+}{ }_{0,23-0,26}, \mathrm{Mg}_{0,68-0,73}, \mathrm{Ti}_{0,01}, \mathrm{Al}_{0,10-0,13}\left(\mathrm{Al}_{0,04-0,06}, \mathrm{Si}_{1,94-1,96}\right) \mathrm{O}_{6} \\
\mathrm{Na}_{0,06-0,07}, \mathrm{Ca}_{0,84-0,87}, \mathrm{Fe}^{2+}{ }_{0,24-0,25}, \mathrm{Mg}_{0,69-0,71}, \mathrm{Ti}_{0,01}, \mathrm{Al}_{0,11-0,12}\left(\mathrm{Al}_{0,05-0,06}, \mathrm{Si}_{1,94-1,95}\right) \mathrm{O}_{6} \\
\mathrm{Na}_{0,05-0,07}, \mathrm{Ca}_{0,84-0,88}, \mathrm{Fe}^{2+}{ }_{0,23-0,25}, \mathrm{Mg}_{0,68-0,73}, \mathrm{Ti}_{0,01}, \mathrm{Al}_{0,09-0,12}\left(\mathrm{Al}_{0,04-0,07}, \mathrm{Si}_{1,03-1,96}\right) \mathrm{O}_{6} \\
\mathrm{Na}_{0,05-0,06}, \mathrm{Ca}_{0,85-0,88}, \mathrm{Fe}^{2+}{ }_{0,23-0,24}, \mathrm{Mg}_{0,70-0,73}, \mathrm{Ti}_{0,01}, \mathrm{Al}_{0,10-0,11}\left(\mathrm{Al}_{0,04-0,06}, \mathrm{Si}_{1,94-1,96}\right) \mathrm{O}_{6}\end{array}$ \\
\hline 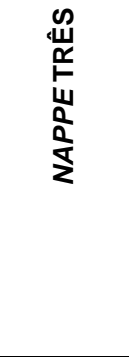 & 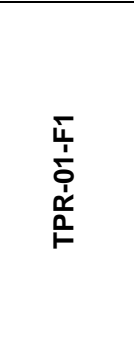 & $\begin{array}{l}c p \times 1 \\
c p \times 2 \\
c p \times 3 \\
c p \times 4 \\
c p \times 5 \\
c p \times 7\end{array}$ & $\begin{array}{c}\mathrm{Na}_{0,04-0,06}, \mathrm{Ca}_{0,87-0,90}, \mathrm{Fe}^{2+}{ }_{0,19-0,21}, \mathrm{Mg}_{0,71-0,74}, \mathrm{Ti}_{0,01}, \mathrm{Fe}^{3+}{ }_{0-0,01}, \mathrm{Al}_{0,12-0,13}\left(\mathrm{Al}_{0,06-0,09}, \mathrm{Si}_{1,91-1,94}\right) \mathrm{O}_{6} \\
\mathrm{Na}_{0,04-0,05}, \mathrm{Ca}_{0,89-0,91}, \mathrm{Fe}^{2+}{ }_{0,19-0,21}, \mathrm{Mg}_{0,72-0,76}, \mathrm{Ti}_{0,01}, \mathrm{Al}_{0,09-0,12}\left(\mathrm{Al}_{0,05-0,09}, \mathrm{Si}_{1,91-1,95}\right) \mathrm{O}_{6} \\
\mathrm{Na}_{0,04-0,06}, \mathrm{Ca}_{0,87-0,91}, \mathrm{Fe}^{2+}{ }_{0,20-0,21}, \mathrm{Mg}_{0,70-0,73}, \mathrm{Ti}_{0,01}, \mathrm{Al}_{0,10-0,14}\left(\mathrm{Al}_{0,04-0,09}, \mathrm{Si}_{1,91-1,96}\right) \mathrm{O}_{6} \\
\mathrm{Na}_{0,04-0,06}, \mathrm{Ca}_{0,87-0,90}, \mathrm{Fe}^{2+}{ }_{0,20-0,21}, \mathrm{Mg}_{0,70-0,72}, \mathrm{Ti}_{0,01}, \mathrm{Al}_{0,12-0,13}\left(\mathrm{Al}_{0,07-0,10}, \mathrm{Si}_{1,90-1,93}\right) \mathrm{O}_{6} \\
\mathrm{Na}_{0,05-0,06}, \mathrm{Ca}_{0,87-0,90}, \mathrm{Fe}^{2+}{ }_{0,18-0,20}, \mathrm{Mg}_{0,70-0,75}, \mathrm{Ti}_{0,01}, \mathrm{Al}_{0,12-0,14}\left(\mathrm{Al}_{0,06-0,09}, \mathrm{Si}_{1,91-1,94}\right) \mathrm{O}_{6} \\
\mathrm{Na}_{0,05-0,06}, \mathrm{Ca}_{0,87-0,89}, \mathrm{Fe}^{2+}{ }_{0,18-0,20}, \mathrm{Mg}_{0,70-0,73}, \mathrm{Ti}_{0,01}, \mathrm{Al}_{0,11-0,15}\left(\mathrm{Al}_{0,07-0,09}, \mathrm{Si}_{1,91-1,93}\right) \mathrm{O}_{6} \\
\mathrm{Na}_{0,04-0,06}, \mathrm{Ca}_{0,87-0,90}, \mathrm{Fe}^{2+}{ }_{0,18-0,20}, \mathrm{Mg}_{0,71-0,76}, \mathrm{Ti}_{0,01}, \mathrm{Al}_{0,10-0,14}\left(\mathrm{Al}_{0,07-0,08}, \mathrm{Si}_{1,92-1,93}\right) \mathrm{O}_{6}\end{array}$ \\
\hline 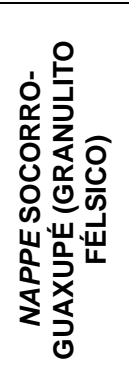 & 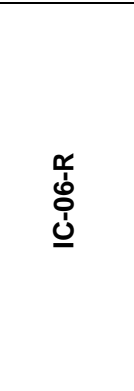 & $\begin{array}{l}\text { opx } 1 \\
\text { opx } 2 \\
\text { opx } 3 \\
\text { opx } 4 \\
\text { cpx } 1\end{array}$ & $\begin{array}{c}\mathrm{Na}_{0-0,01}, \mathrm{Ca}_{0,02-0,05}, \mathrm{Fe}^{2+}{ }_{0,76-0,81}, \mathrm{Mg}_{1,06-1,16}, \mathrm{Ti}_{0-0,01}, \mathrm{Fe}^{3+}{ }_{0-0,02}, \mathrm{Al}_{0,05}\left(\mathrm{Al}_{0,03-0,06}, \mathrm{Si}_{1,94-1,97}\right) \mathrm{O}_{6} \\
\mathrm{Ca}_{0,02-0,03}, \mathrm{Fe}^{2+}{ }_{0,77-0,80}, \mathrm{Mg}_{1,10-1,13}, \mathrm{Fe}^{3+}{ }_{0-0,02}, \mathrm{Al}_{0,05}\left(\mathrm{Al}_{0,04-0,07}, \mathrm{Si}_{1,93-1,96}\right) \mathrm{O}_{6} \\
\mathrm{Ca}_{0,02-0,03}, \mathrm{Fe}^{2+}{ }_{0,78-0,80}, \mathrm{Mg}_{1,11-1,14}, \mathrm{Fe}^{3+}{ }_{0-0,01}, \mathrm{Al}_{0,04-0,05}\left(\mathrm{Al}_{0,03-0,06}, \mathrm{Si}_{1,94-1,97}\right) \mathrm{O}_{6} \\
\mathrm{Na}_{0-0,01}, \mathrm{Ca}_{0,02-0,06}, \mathrm{Fe}^{2+}{ }_{0,77-0,82}, \mathrm{Mg}_{1,08-1,11}, \mathrm{Fe}^{3+}{ }_{0-0,05}, \mathrm{Al}_{0,04}\left(\mathrm{Al}_{0,05-0,07}, \mathrm{Si}_{1,93-1,95}\right) \mathrm{O}_{6} \\
\mathrm{Na}_{0,06-0,07}, \mathrm{Ca}_{0,82-0,86}, \mathrm{Fe}^{2+}{ }_{0,27-0,31}, \mathrm{Mg}_{0,65-0,70}, \mathrm{Fe}^{3+}{ }_{0,01-0,03}, \mathrm{Ti}_{0,01}, \mathrm{Al}_{0,09-0,10}\left(\mathrm{Al}_{0,05-0,08}, \mathrm{Si}_{1,92-1,95}\right) \mathrm{O}_{6} \\
\mathrm{Na}_{0,06-0,07}, \mathrm{Ca}_{0,74-0,85}, \mathrm{Fe}^{2+}{ }_{0,29-0,38}, \mathrm{Mg}_{0,64-0,69}, \mathrm{Fe}^{3+}{ }_{0-0,04}, \mathrm{Ti}_{0,01}, \mathrm{Al}_{0,09-0,11}\left(\mathrm{Al}_{0,07-0,08}, \mathrm{Si}_{1,92-1,93}\right) \mathrm{O}_{6} \\
\mathrm{Na}_{0,06-0,08}, \mathrm{Ca}_{0,71-0,83}, \mathrm{Fe}^{2+}{ }_{0,29-0,39}, \mathrm{Mg}_{0,63-0,69}, \mathrm{Fe}^{3+}{ }_{0,01-0,06}, \mathrm{Ti}_{0,01}, \mathrm{Al}_{0,09-0,10}\left(\mathrm{Al}_{0,06-0,09}, \mathrm{Si}_{1,91-1,94}\right) \mathrm{O}_{6}\end{array}$ \\
\hline
\end{tabular}


Tabela 56 - Análises químicas de plagioclásio da Nappe Três Pontas-Varginha

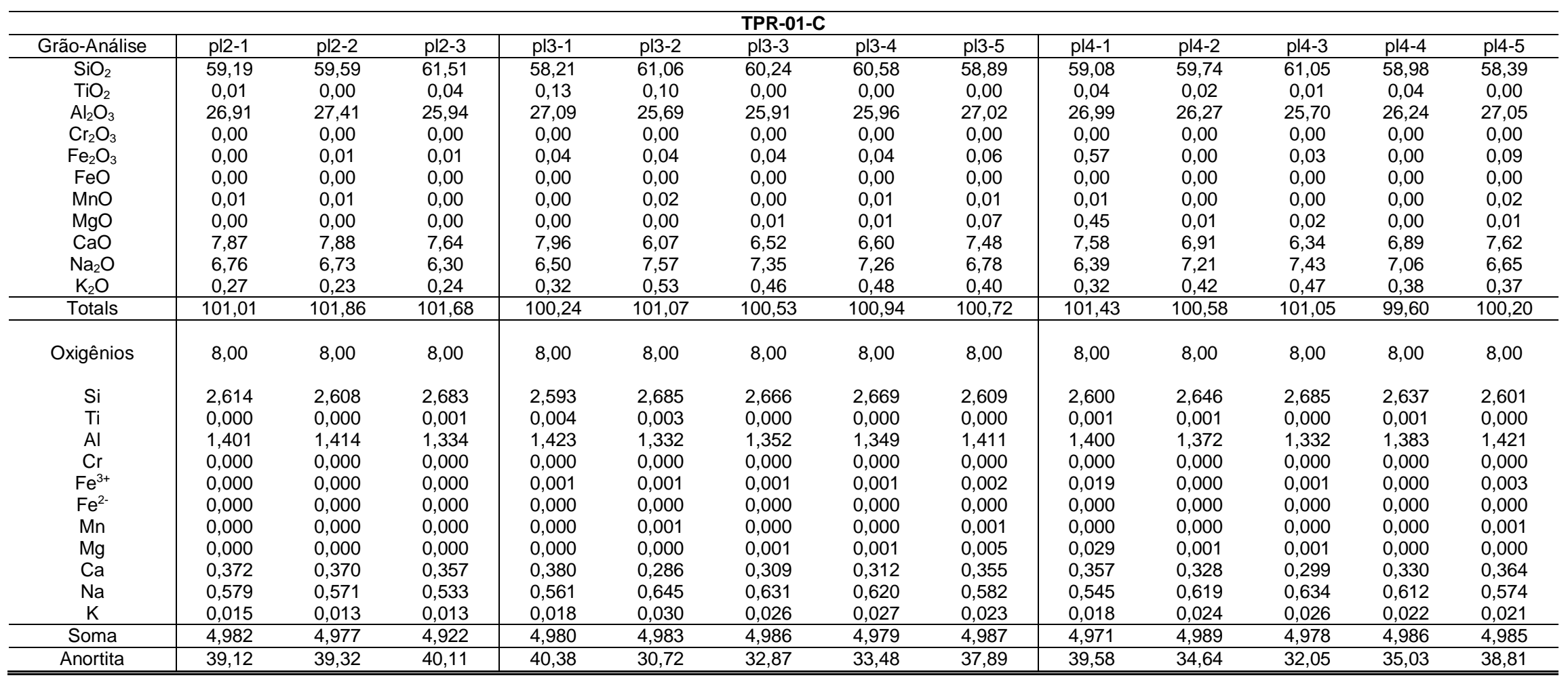


Tabela 57 - Análises químicas de plagioclásio da Nappe Três Pontas-Varginha

\begin{tabular}{|c|c|c|c|c|c|c|c|c|c|c|c|c|c|}
\hline \multicolumn{6}{|c|}{ TPR-01-C } & \multicolumn{8}{|c|}{ TPR-01-F1 } \\
\hline Grão-Análise & pl5-1 & pl5-2 & pl5-3 & pl5-4 & pl5-5 & pl1-1 & pl1-2 & pl1-3 & pl1-4 & pl1-5 & pl1-6 & pl1-7 & pl1-8 \\
\hline $\mathrm{SiO}_{2}$ & 58,81 & 59,87 & 60,20 & 59,61 & 58,72 & 54,62 & 56,64 & 56,84 & 57,02 & 56,90 & 56,65 & 56,84 & 56,27 \\
\hline $\mathrm{TiO}_{2}$ & 0,01 & 0,00 & 0,02 & 0,01 & 0,01 & 0,04 & 0,00 & 0,00 & 0,16 & 0,04 & 0,00 & 0,00 & 0,06 \\
\hline $\mathrm{Al}_{2} \mathrm{O}_{3}$ & 26,75 & 26,25 & 26,26 & 26,42 & 27,13 & 29,49 & 28,36 & 28,18 & 28,05 & 27,95 & 27,96 & 27,95 & 28,55 \\
\hline $\mathrm{Cr}_{2} \mathrm{O}_{3}$ & 0,00 & 0,00 & 0,00 & 0,00 & 0,00 & 0,00 & 0,00 & 0,00 & 0,00 & 0,00 & 0,00 & 0,00 & 0,00 \\
\hline $\mathrm{Fe}_{2} \mathrm{O}_{3}$ & 0,20 & 0,03 & 0,02 & 0,01 & 0,08 & 0,73 & 0,06 & 0,09 & 0,04 & 0,06 & 0,04 & 0,07 & 0,11 \\
\hline $\mathrm{FeO}$ & 0,00 & 0,00 & 0,00 & 0,00 & 0,00 & 0,00 & 0,00 & 0,00 & 0,00 & 0,00 & 0,00 & 0,00 & 0,00 \\
\hline $\mathrm{MnO}$ & 0,01 & 0,00 & 0,00 & 0,00 & 0,01 & 0,01 & 0,00 & 0,00 & 0,01 & 0,01 & 0,00 & 0,00 & 0,01 \\
\hline $\mathrm{MgO}$ & 0,00 & 0,00 & 0,00 & 0,00 & 0,01 & 0,44 & 0,01 & 0,00 & 0,00 & 0,01 & 0,00 & 0,01 & 0,01 \\
\hline $\mathrm{CaO}$ & 7,39 & 6,85 & 6,94 & 7,11 & 7,89 & 10,52 & 9,52 & 8,93 & 8,73 & 8,89 & 8,79 & 8,93 & 9,31 \\
\hline $\mathrm{Na}_{2} \mathrm{O}$ & 6,97 & 7,22 & 7,15 & 7,20 & 6,50 & 4,79 & 5,72 & 6,01 & 6,03 & 6,05 & 6,02 & 5,91 & 5,67 \\
\hline Totals & 100,51 & 100,66 & 101,00 & 100,77 & 100,70 & 100,88 & 100,66 & 100,43 & 100,44 & 100,28 & 99,84 & 100,11 & 100,34 \\
\hline Oxigênios & 8,00 & 8,00 & 8,00 & 8,00 & 8,00 & 8,00 & 8,00 & 8,00 & 8,00 & 8,00 & 8,00 & 8,00 & 8,00 \\
\hline $\mathrm{Si}$ & 2,613 & 2,649 & 2,653 & 2,637 & 2,602 & 2,441 & 2,525 & 2,537 & 2,543 & 2,543 & 2,542 & 2,544 & 2,516 \\
\hline $\mathrm{Ti}$ & 0,000 & 0,000 & 0,001 & 0,000 & 0,000 & 0,001 & 0,000 & 0,000 & 0,005 & 0,001 & 0,000 & 0,000 & 0,002 \\
\hline $\mathrm{Al}$ & 1,401 & 1,369 & 1,364 & 1,378 & 1,417 & 1,554 & 1,490 & 1,483 & 1,475 & 1,473 & 1,479 & 1,475 & 1,505 \\
\hline $\mathrm{Cr}$ & 0,000 & 0,000 & 0,000 & 0,000 & 0,000 & 0,000 & 0,000 & 0,000 & 0,000 & 0,000 & 0,000 & 0,000 & 0,000 \\
\hline $\mathrm{Fe}^{3+}$ & 0,007 & 0,001 & 0,001 & 0,000 & 0,003 & 0,025 & 0,002 & 0,003 & 0,001 & 0,002 & 0,001 & 0,002 & 0,004 \\
\hline $\mathrm{Fe}^{2-}$ & 0,000 & 0,000 & 0,000 & 0,000 & 0,000 & 0,000 & 0,000 & 0,000 & 0,000 & 0,000 & 0,000 & 0,000 & 0,000 \\
\hline $\mathrm{Ca}$ & 0,352 & 0,325 & 0,328 & 0,337 & 0,375 & 0,504 & 0,455 & 0,427 & 0,417 & 0,426 & 0,423 & 0,428 & 0,446 \\
\hline $\mathrm{Na}$ & 0,600 & 0,619 & 0,611 & 0,618 & 0,559 & 0,415 & 0,494 & 0,520 & 0,521 & 0,524 & 0,524 & 0,513 & 0,491 \\
\hline $\mathrm{K}$ & 0,021 & 0,024 & 0,023 & 0,023 & 0,020 & 0,013 & 0,019 & 0,022 & 0,022 & 0,021 & 0,022 & 0,022 & 0,020 \\
\hline Soma & 4,994 & 4,988 & 4,981 & 4,993 & 4,977 & 4,983 & 4,986 & 4,991 & 4,986 & 4,991 & 4,991 & 4,985 & 4,984 \\
\hline Anortita & 36,97 & 34,43 & 34,93 & 35,29 & 40,15 & 54,84 & 47,95 & 45,09 & 44,46 & 44,84 & 44,67 & 45,48 & 47,60 \\
\hline
\end{tabular}


Tabela 58 - Análises químicas de plagioclásio da Nappe Três Pontas-Varginha

\begin{tabular}{|c|c|c|c|c|c|c|c|c|c|c|c|c|c|c|c|c|c|}
\hline \multicolumn{8}{|c|}{ TPR-01-F1 } & \multicolumn{10}{|c|}{ TPR-01-F1 } \\
\hline Grão-Análise & pl2-2 & pl2-3 & pl2-4 & $\mathrm{pl} 2-5$ & pl2-6 & pl2-7 & pl2-8 & pl3-1 & pl3-2 & pl3-3 & pl3-4 & pl3-5 & pl3-6 & pl3-7 & pl3-8 & pl3-9 & pl3-10 \\
\hline $\mathrm{SiO}_{2}$ & 56,14 & 55,42 & 55,91 & 56,47 & 57,22 & 56,75 & 55,21 & 55,55 & 55,27 & 56,74 & 56,20 & 55,98 & 56,34 & 56,02 & 56,20 & 55,99 & 49,11 \\
\hline $\mathrm{TiO}_{2}$ & 0,03 & 0,01 & 0,07 & 0,04 & 0,00 & 0,01 & 0,00 & 0,01 & 0,05 & 0,03 & 0,08 & 0,06 & 0,00 & 0,00 & 0,00 & 0,00 & 0,02 \\
\hline $\mathrm{Al}_{2} \mathrm{O}_{3}$ & 29,13 & 29,40 & 29,10 & 28,50 & 28,47 & 28,19 & 29,15 & 29,51 & 29,23 & 28,53 & 28,40 & 28,96 & 28,63 & 28,60 & 28,90 & 28,98 & 33,59 \\
\hline $\mathrm{Cr}_{2} \mathrm{O}_{3}$ & 0,00 & 0,00 & 0,00 & 0,00 & 0,00 & 0,00 & 0,00 & 0,00 & 0,00 & 0,00 & 0,00 & 0,00 & 0,00 & 0,00 & 0,00 & 0,00 & 0,00 \\
\hline $\mathrm{Fe}_{2} \mathrm{O}_{3}$ & 0,24 & 0,31 & 0,35 & 0,17 & 0,12 & 0,10 & 0,28 & 0,16 & 0,08 & 0,06 & 0,04 & 0,04 & 0,07 & 0,08 & 0,07 & 0,07 & 0,48 \\
\hline $\mathrm{FeO}$ & 0,00 & 0,00 & 0,00 & 0,00 & 0,00 & 0,00 & 0,00 & 0,00 & 0,00 & 0,00 & 0,00 & 0,00 & 0,00 & 0,00 & 0,00 & 0,00 & 0,00 \\
\hline $\mathrm{MnO}$ & 0,01 & 0,02 & 0,01 & 0,00 & 0,00 & 0,00 & 0,00 & 0,00 & 0,01 & 0,00 & 0,00 & 0,00 & 0,00 & 0,00 & 0,00 & 0,00 & 0,00 \\
\hline $\mathrm{MgO}$ & 0,02 & 0,02 & 0,03 & 0,01 & 0,00 & 0,03 & 0,02 & 0,03 & 0,00 & 0,01 & 0,00 & 0,00 & 0,03 & 0,03 & 0,01 & 0,00 & 0,09 \\
\hline $\mathrm{CaO}$ & 10,08 & 10,02 & 10,06 & 9,28 & 9,38 & 8,11 & 10,43 & 10,40 & 10,26 & 9,56 & 9,43 & 9,97 & 9,87 & 9,78 & 9,73 & 9,83 & 14,88 \\
\hline $\mathrm{Na}_{2} \mathrm{O}$ & 5,50 & 5,22 & 5,57 & 5,71 & 5,79 & 5,92 & 5,21 & 5,18 & 5,34 & 5,62 & 5,68 & 5,55 & 5,58 & 5,60 & 5,63 & 5,49 & 2,54 \\
\hline $\mathrm{K}_{2} \mathrm{O}$ & 0,19 & 0,31 & 0,31 & 0,36 & 0,38 & 0,47 & 0,34 & 0,24 & 0,26 & 0,30 & 0,32 & 0,27 & 0,29 & 0,28 & 0,31 & 0,31 & 0,09 \\
\hline Totals & 101,34 & 100,73 & 101,41 & 100,54 & 101,36 & 99,59 & 100,64 & 101,08 & 100,50 & 100,86 & 100,15 & 100,83 & 100,80 & 100,39 & 100,84 & 100,67 & 100,80 \\
\hline Oxigênios & 8,00 & 8,00 & 8,00 & 8,00 & 8,00 & 8,00 & 8,00 & 8,00 & 8,00 & 8,00 & 8,00 & 8,00 & 8,00 & 8,00 & 8,00 & 8,00 & 8,00 \\
\hline $\mathrm{Si}$ & 2,489 & 2,474 & 2,482 & 2,519 & 2,531 & 2,547 & 2,471 & 2,471 & 2,474 & 2,522 & 2,517 & 2,494 & 2,510 & 2,506 & 2,502 & 2,497 & 2,222 \\
\hline $\mathrm{Ti}$ & 0,001 & 0,000 & 0,002 & 0,001 & 0,000 & 0,000 & 0,000 & 0,000 & 0,002 & 0,001 & 0,003 & 0,002 & 0,000 & 0,000 & 0,000 & 0,000 & 0,001 \\
\hline $\mathrm{Al}$ & 1,523 & 1,547 & 1,523 & 1,499 & 1,485 & 1,491 & 1,538 & 1,548 & 1,542 & 1,495 & 1,500 & 1,521 & 1,504 & 1,508 & 1,517 & 1,524 & 1,792 \\
\hline $\mathrm{Cr}$ & 0,000 & 0,000 & 0,000 & 0,000 & 0,000 & 0,000 & 0,000 & 0,000 & 0,000 & 0,000 & 0,000 & 0,000 & 0,000 & 0,000 & 0,000 & 0,000 & 0,000 \\
\hline $\mathrm{Fe}^{3+}$ & 0,008 & 0,010 & 0,012 & 0,006 & 0,004 & 0,003 & 0,010 & 0,005 & 0,003 & 0,002 & 0,001 & 0,001 & 0,002 & 0,003 & 0,002 & 0,002 & 0,016 \\
\hline $\mathrm{Fe}^{2-}$ & 0,000 & 0,000 & 0,000 & 0,000 & 0,000 & 0,000 & 0,000 & 0,000 & 0,000 & 0,000 & 0,000 & 0,000 & 0,000 & 0,000 & 0,000 & 0,000 & 0,000 \\
\hline $\mathrm{Mn}$ & 0,000 & 0,001 & 0,000 & 0,000 & 0,000 & 0,000 & 0,000 & 0,000 & 0,000 & 0,000 & 0,000 & 0,000 & 0,000 & 0,000 & 0,000 & 0,000 & 0,000 \\
\hline $\mathrm{Mg}$ & 0,001 & 0,001 & 0,002 & 0,001 & 0,000 & 0,002 & 0,001 & 0,002 & 0,000 & 0,000 & 0,000 & 0,000 & 0,002 & 0,002 & 0,000 & 0,000 & 0,006 \\
\hline $\mathrm{Ca}$ & 0,479 & 0,479 & 0,479 & 0,444 & 0,445 & 0,390 & 0,500 & 0,496 & 0,492 & 0,455 & 0,453 & 0,476 & 0,471 & 0,469 & 0,464 & 0,470 & 0,721 \\
\hline $\mathrm{Na}$ & 0,473 & 0,452 & 0,479 & 0,494 & 0,497 & 0,515 & 0,452 & 0,447 & 0,463 & 0,484 & 0,493 & 0,480 & 0,482 & 0,486 & 0,486 & 0,475 & 0,223 \\
\hline $\mathrm{K}$ & 0,011 & 0,018 & 0,018 & 0,021 & 0,021 & 0,027 & 0,019 & 0,014 & 0,015 & 0,017 & 0,018 & 0,016 & 0,016 & 0,016 & 0,018 & 0,018 & 0,005 \\
\hline Soma & 4,986 & 4,982 & 4,997 & 4,984 & 4,983 & 4,976 & 4,991 & 4,982 & 4,991 & 4,979 & 4,985 & 4,990 & 4,987 & 4,989 & 4,990 & 4,986 & 4,987 \\
\hline Anortita & 50,32 & 51,45 & 50,00 & 47,33 & 47,24 & 43,09 & 52,52 & 52,60 & 51,52 & 48,46 & 47,89 & 49,79 & 49,42 & 49,11 & 48,84 & 49,74 & 76,38 \\
\hline
\end{tabular}


Tabela 59 - Análises químicas de plagioclásio da Nappe Três Pontas-Varginha

\begin{tabular}{|c|c|c|c|c|c|c|c|c|c|c|c|c|c|c|c|c|c|c|c|c|}
\hline \multicolumn{21}{|c|}{ TPR-01-F1 } \\
\hline Grão-Análise & pl4-1 & pl4-2 & pl4-3 & pl4-4 & pl4-5 & pl4-6 & pl4-7 & pl4-8 & pl4-9 & $\mathrm{pl} 4-10$ & pl5-1 & pl5-2 & pl5-3 & pl5-4 & pl5-5 & pl5-6 & pl5-7 & pl5-8 & pl5-9 & pl5-10 \\
\hline $\mathrm{SiO}_{2}$ & 54,93 & 56,34 & 56,98 & 57,20 & 57,10 & 57,23 & 56,19 & 56,44 & 56,13 & 53,02 & 51,81 & 55,05 & 56,02 & 55,69 & 56,14 & 56,95 & 56,65 & 56,90 & 56,87 & 56,30 \\
\hline $\mathrm{TiO}_{2}$ & 0,05 & 0,00 & 0,03 & 0,04 & 0,08 & 0,00 & 0,08 & 0,04 & 0,00 & 0,00 & 0,00 & 0,04 & 0,02 & 0,00 & 0,02 & 0,02 & 0,01 & 0,00 & 0,00 & 0,01 \\
\hline $\mathrm{Al}_{2} \mathrm{O}_{3}$ & 29,82 & 28,53 & 28,47 & 28,22 & 28,09 & 28,34 & 28,58 & 28,60 & 28,78 & 31,44 & 31,89 & 29,48 & 29,10 & 29,40 & 28,85 & 28,17 & 28,41 & 28,38 & 28,37 & 28,77 \\
\hline $\mathrm{Cr}_{2} \mathrm{O}_{3}$ & 0,00 & 0,00 & 0,00 & 0,00 & 0,00 & 0,00 & 0,00 & 0,00 & 0,00 & 0,00 & 0,00 & 0,00 & 0,00 & 0,00 & 0,00 & 0,00 & 0,00 & 0,00 & 0,00 & 0,00 \\
\hline $\mathrm{Fe}_{2} \mathrm{O}_{3}$ & 0,15 & 0,07 & 0,04 & 0,07 & 0,06 & 0,10 & 0,10 & 0,16 & 0,17 & 0,27 & 0,04 & 0,02 & 0,02 & 0,01 & 0,04 & 0,00 & 0,02 & 0,02 & 0,01 & 0,04 \\
\hline $\mathrm{FeO}$ & 0,00 & 0,00 & 0,00 & 0,00 & 0,00 & 0,00 & 0,00 & 0,00 & 0,00 & 0,00 & 0,00 & 0,00 & 0,00 & 0,00 & 0,00 & 0,00 & 0,00 & 0,00 & 0,00 & 0,00 \\
\hline $\mathrm{MnO}$ & 0,00 & 0,00 & 0,00 & 0,00 & 0,00 & 0,00 & 0,00 & 0,00 & 0,00 & 0,00 & 0,00 & 0,01 & 0,00 & 0,00 & 0,00 & 0,00 & 0,00 & 0,00 & 0,01 & 0,00 \\
\hline $\mathrm{MgO}$ & 0,02 & 0,00 & 0,00 & 0,00 & 0,02 & 0,00 & 0,00 & 0,01 & 0,00 & 0,00 & 0,00 & 0,01 & 0,00 & 0,00 & 0,01 & 0,00 & 0,01 & 0,00 & 0,01 & 0,00 \\
\hline $\mathrm{CaO}$ & 10,84 & 9,47 & 9,26 & 9,04 & 8,95 & 9,16 & 9,58 & 9,62 & 9,84 & 12,28 & 12,89 & 10,31 & 9,95 & 10,09 & 9,76 & 9,08 & 9,21 & 8,97 & 9,11 & 9,71 \\
\hline $\mathrm{Na}_{2} \mathrm{O}$ & 5,00 & 5,67 & 5,84 & 5,94 & 5,88 & 5,99 & 5,73 & 5,68 & 5,58 & 4,04 & 3,78 & 5,21 & 5,38 & 5,28 & 5,52 & 5,87 & 5,78 & 5,85 & 5,88 & 5,76 \\
\hline $\mathrm{K}_{2} \mathrm{O}$ & 0,23 & 0,28 & 0,29 & 0,34 & 0,30 & 0,31 & 0,30 & 0,25 & 0,23 & 0,16 & 0,17 & 0,28 & 0,28 & 0,28 & 0,32 & 0,34 & 0,32 & 0,34 & 0,33 & 0,31 \\
\hline Totals & 101,04 & 100,36 & 100,91 & 100,86 & 100,49 & 101,13 & 100,57 & 100,80 & 100,73 & 101,21 & 100,58 & 100,41 & 100,77 & 100,75 & 100,66 & 100,42 & 100,41 & 100,46 & 100,60 & 100,90 \\
\hline Oxigênios & 8,00 & 8,00 & 8,00 & 8,00 & 8,00 & 8,00 & 8,00 & 8,00 & 8,00 & 8,00 & 8,00 & 8,00 & 8,00 & 8,00 & 8,00 & 8,00 & 8,00 & 8,00 & 8,00 & 8,00 \\
\hline $\mathrm{Si}$ & 2,448 & 2,517 & 2,530 & 2,541 & 2,544 & 2,536 & 2,509 & 2,513 & 2,502 & 2,368 & 2,333 & 2,466 & 2,495 & 2,482 & 2,504 & 2,540 & 2,528 & 2,536 & 2,533 & 2,506 \\
\hline $\mathrm{Ti}$ & 0,002 & 0,000 & 0,001 & 0,001 & 0,003 & 0,000 & 0,003 & 0,001 & 0,000 & 0,000 & 0,000 & 0,001 & 0,001 & 0,000 & 0,001 & 0,001 & 0,000 & 0,000 & 0,000 & 0,000 \\
\hline $\mathrm{Al}$ & 1,567 & 1,503 & 1,490 & 1,478 & 1,475 & 1,481 & 1,504 & 1,501 & 1,513 & 1,655 & 1,693 & 1,557 & 1,528 & 1,545 & 1,517 & 1,481 & 1,495 & 1,491 & 1,490 & 1,510 \\
\hline $\mathrm{Cr}$ & 0,000 & 0,000 & 0,000 & 0,000 & 0,000 & 0,000 & 0,000 & 0,000 & 0,000 & 0,000 & 0,000 & 0,000 & 0,000 & 0,000 & 0,000 & 0,000 & 0,000 & 0,000 & 0,000 & 0,000 \\
\hline $\mathrm{Fe}^{3+}$ & 0,005 & 0,002 & 0,001 & 0,002 & 0,002 & 0,003 & 0,003 & 0,005 & 0,006 & 0,009 & 0,001 & 0,001 & 0,001 & 0,000 & 0,001 & 0,000 & 0,001 & 0,001 & 0,000 & 0,001 \\
\hline $\mathrm{Fe}^{2-}$ & 0,000 & 0,000 & 0,000 & 0,000 & 0,000 & 0,000 & 0,000 & 0,000 & 0,000 & 0,000 & 0,000 & 0,000 & 0,000 & 0,000 & 0,000 & 0,000 & 0,000 & 0,000 & 0,000 & 0,000 \\
\hline $\mathrm{Mn}$ & 0,000 & 0,000 & 0,000 & 0,000 & 0,000 & 0,000 & 0,000 & 0,000 & 0,000 & 0,000 & 0,000 & 0,000 & 0,000 & 0,000 & 0,000 & 0,000 & 0,000 & 0,000 & 0,000 & 0,000 \\
\hline $\mathrm{Mg}$ & 0,002 & 0,000 & 0,000 & 0,000 & 0,002 & 0,000 & 0,000 & 0,001 & 0,000 & 0,000 & 0,000 & 0,001 & 0,000 & 0,000 & 0,000 & 0,000 & 0,001 & 0,000 & 0,000 & 0,000 \\
\hline $\mathrm{Ca}$ & 0,518 & 0,453 & 0,441 & 0,430 & 0,427 & 0,435 & 0,458 & 0,459 & 0,470 & 0,588 & 0,622 & 0,495 & 0,475 & 0,482 & 0,466 & 0,434 & 0,440 & 0,428 & 0,435 & 0,463 \\
\hline $\mathrm{Na}$ & 0,432 & 0,491 & 0,503 & 0,512 & 0,508 & 0,515 & 0,496 & 0,490 & 0,482 & 0,350 & 0,330 & 0,452 & 0,465 & 0,456 & 0,477 & 0,508 & 0,500 & 0,506 & 0,508 & 0,497 \\
\hline $\mathrm{K}$ & 0,013 & 0,016 & 0,016 & 0,019 & 0,017 & 0,017 & 0,017 & 0,014 & 0,013 & 0,009 & 0,010 & 0,016 & 0,016 & 0,016 & 0,018 & 0,019 & 0,018 & 0,019 & 0,019 & 0,018 \\
\hline Soma & 4,987 & 4,983 & 4,983 & 4,983 & 4,978 & 4,988 & 4,991 & 4,985 & 4,986 & 4,979 & 4,990 & 4,989 & 4,980 & 4,981 & 4,985 & 4,982 & 4,983 & 4,981 & 4,985 & 4,996 \\
\hline Anortita & 54,53 & 47,99 & 46,72 & 45,65 & 45,67 & 45,79 & 48,01 & 48,37 & 49,37 & 62,69 & 65,34 & 52,27 & 50,53 & 51,39 & 49,42 & 46,07 & 46,81 & 45,82 & 46,13 & 48,23 \\
\hline
\end{tabular}


Tabela 60 - Análises químicas de plagioclásio da Nappe Três Pontas-Varginha

\begin{tabular}{|c|c|c|c|c|c|c|c|c|c|c|}
\hline \multicolumn{11}{|c|}{$\begin{array}{l}\text { TPR-01-F1 } \\
\end{array}$} \\
\hline Grão-Análise & pl6-1 & pl6-2 & pl6-3 & pl6-4 & pl6-5 & pl6-6 & pl6-7 & pl6-8 & pl6-9 & pl6-10 \\
\hline $\mathrm{SiO}_{2}$ & 56,36 & 57,35 & 57,29 & 57,48 & 57,29 & 57,27 & 57,08 & 57,20 & 56,75 & 55,79 \\
\hline $\mathrm{TiO}_{2}$ & 0,00 & 0,03 & 0,02 & 0,01 & 0,03 & 0,01 & 0,01 & 0,00 & 0,00 & 0,03 \\
\hline $\mathrm{Al}_{2} \mathrm{O}_{3}$ & 28,76 & 28,10 & 28,26 & 28,10 & 28,39 & 28,06 & 28,19 & 28,20 & 28,78 & 29,34 \\
\hline $\mathrm{Cr}_{2} \mathrm{O}_{3}$ & 0,00 & 0,00 & 0,00 & 0,00 & 0,00 & 0,00 & 0,00 & 0,00 & 0,00 & 0,00 \\
\hline $\mathrm{Fe}_{2} \mathrm{O}_{3}$ & 0,04 & 0,03 & 0,01 & 0,04 & 0,02 & 0,01 & 0,03 & 0,04 & 0,07 & 0,28 \\
\hline $\mathrm{FeO}$ & 0,00 & 0,00 & 0,00 & 0,00 & 0,00 & 0,00 & 0,00 & 0,00 & 0,00 & 0,00 \\
\hline $\mathrm{MnO}$ & 0,02 & 0,01 & 0,00 & 0,00 & 0,00 & 0,00 & 0,00 & 0,00 & 0,01 & 0,00 \\
\hline $\mathrm{MgO}$ & 0,00 & 0,02 & 0,00 & 0,00 & 0,00 & 0,00 & 0,01 & 0,00 & 0,00 & 0,00 \\
\hline $\mathrm{CaO}$ & 9,93 & 9,05 & 8,99 & 8,94 & 8,99 & 8,95 & 8,99 & 9,00 & 9,44 & 10,12 \\
\hline $\mathrm{Na}_{2} \mathrm{O}$ & 5,54 & 5,94 & 5,96 & 6,02 & 5,94 & 5,98 & 5,89 & 5,81 & 5,62 & 5,34 \\
\hline $\mathrm{K}_{2} \mathrm{O}$ & 0,26 & 0,28 & 0,32 & 0,29 & 0,30 & 0,30 & 0,27 & 0,28 & 0,26 & 0,24 \\
\hline Totals & 100,91 & 100,81 & 100,85 & 100,88 & 100,96 & 100,58 & 100,47 & 100,54 & 100,93 & 101,14 \\
\hline Oxigênios & 8,00 & 8,00 & 8,00 & 8,00 & 8,00 & 8,00 & 8,00 & 8,00 & 8,00 & 8,00 \\
\hline $\mathrm{Si}$ & 2,507 & 2,547 & 2,543 & 2,550 & 2,540 & 2,549 & 2,543 & 2,545 & 2,519 & 2,480 \\
\hline $\mathrm{Ti}$ & 0,000 & 0,001 & 0,001 & 0,000 & 0,001 & 0,000 & 0,000 & 0,000 & 0,000 & 0,001 \\
\hline $\mathrm{Al}$ & 1,508 & 1,471 & 1,479 & 1,470 & 1,484 & 1,472 & 1,480 & 1,479 & 1,506 & 1,537 \\
\hline $\mathrm{Cr}$ & 0,000 & 0,000 & 0,000 & 0,000 & 0,000 & 0,000 & 0,000 & 0,000 & 0,000 & 0,000 \\
\hline $\mathrm{Fe}^{3+}$ & 0,001 & 0,001 & 0,000 & 0,001 & 0,001 & 0,000 & 0,001 & 0,001 & 0,002 & 0,010 \\
\hline $\mathrm{Fe}^{2-}$ & 0,000 & 0,000 & 0,000 & 0,000 & 0,000 & 0,000 & 0,000 & 0,000 & 0,000 & 0,000 \\
\hline $\mathrm{Mn}$ & 0,001 & 0,000 & 0,000 & 0,000 & 0,000 & 0,000 & 0,000 & 0,000 & 0,000 & 0,000 \\
\hline Mg & 0,000 & 0,001 & 0,000 & 0,000 & 0,000 & 0,000 & 0,001 & 0,000 & 0,000 & 0,000 \\
\hline $\mathrm{Ca}$ & 0,473 & 0,431 & 0,428 & 0,425 & 0,427 & 0,427 & 0,429 & 0,429 & 0,449 & 0,482 \\
\hline $\mathrm{Na}$ & 0,478 & 0,511 & 0,513 & 0,518 & 0,511 & 0,516 & 0,509 & 0,501 & 0,484 & 0,460 \\
\hline $\mathrm{K}$ & 0,015 & 0,016 & 0,018 & 0,017 & 0,017 & 0,017 & 0,016 & 0,016 & 0,015 & 0,013 \\
\hline Soma & 4,984 & 4,979 & 4,982 & 4,981 & 4,980 & 4,981 & 4,978 & 4,973 & 4,976 & 4,983 \\
\hline Anortita & 49,74 & 45,75 & 45,48 & 45,07 & 45,52 & 45,28 & 45,74 & 46,13 & 48,12 & 51,17 \\
\hline
\end{tabular}


Tabela 61 - Análises químicas de plagioclásio da Nappe Socorro-Guaxupé

\begin{tabular}{|c|c|c|c|c|c|c|c|c|}
\hline \multicolumn{9}{|c|}{ IC-06-R } \\
\hline Grão-Análise & pl2-1 & pl2-2 & $\mathrm{pl} 2-3$ & $\mathrm{pl3-1}$ & pl3-2 & pl3-3 & pl4-2 & pl4-3 \\
\hline $\mathrm{SiO}_{2}$ & 60,42 & 58,45 & 60,01 & 60,26 & 60,66 & 60,32 & 59,72 & 59,86 \\
\hline $\mathrm{TiO}_{2}$ & 0,05 & 0,00 & 0,01 & 0,01 & 0,05 & 0,02 & 0,07 & 0,00 \\
\hline $\mathrm{Al}_{2} \mathrm{O}_{3}$ & 25,62 & 25,34 & 25,95 & 25,67 & 25,81 & 25,96 & 25,81 & 25,78 \\
\hline $\mathrm{Cr}_{2} \mathrm{O}_{3}$ & 0,00 & 0,00 & 0,00 & 0,00 & 0,00 & 0,00 & 0,00 & 0,00 \\
\hline $\mathrm{Fe}_{2} \mathrm{O}_{3}$ & 0,35 & 1,66 & 0,21 & 0,38 & 0,22 & 0,33 & 0,18 & 0,22 \\
\hline $\mathrm{FeO}$ & 0,00 & 0,00 & 0,00 & 0,00 & 0,00 & 0,00 & 0,00 & 0,00 \\
\hline $\mathrm{MnO}$ & 0,00 & 0,03 & 0,00 & 0,02 & 0,00 & 0,01 & 0,00 & 0,03 \\
\hline $\mathrm{MgO}$ & 0,00 & 1,13 & 0,00 & 0,01 & 0,00 & 0,01 & 0,00 & 0,01 \\
\hline $\mathrm{CaO}$ & 6,59 & 6,22 & 6,85 & 6,67 & 6,71 & 6,67 & 6,67 & 6,75 \\
\hline $\mathrm{Na}_{2} \mathrm{O}$ & 7,20 & 6,77 & 7,20 & 7,09 & 7,24 & 7,20 & 7,35 & 7,31 \\
\hline $\mathrm{K}_{2} \mathrm{O}$ & 0,43 & 0,42 & 0,40 & 0,42 & 0,40 & 0,39 & 0,10 & 0,11 \\
\hline Totals & 100,67 & 100,03 & 100,63 & 100,52 & 101,09 & 100,91 & 99,90 & 100,07 \\
\hline Oxigênios & 8,00 & 8,00 & 8,00 & 8,00 & 8,00 & 8,00 & 8,00 & 8,00 \\
\hline $\mathrm{Si}$ & 2,671 & 2,615 & 2,656 & 2,668 & 2,670 & 2,661 & 2,658 & 2,661 \\
\hline $\mathrm{Ti}$ & 0,002 & 0,000 & 0,000 & 0,000 & 0,002 & 0,001 & 0,002 & 0,000 \\
\hline $\mathrm{Al}$ & 1,335 & 1,337 & 1,354 & 1,340 & 1,339 & 1,350 & 1,354 & 1,351 \\
\hline $\mathrm{Cr}$ & 0,000 & 0,000 & 0,000 & 0,000 & 0,000 & 0,000 & 0,000 & 0,000 \\
\hline $\mathrm{Fe}^{3+}$ & 0,012 & 0,056 & 0,007 & 0,013 & 0,007 & 0,011 & 0,006 & 0,008 \\
\hline $\mathrm{Fe}^{2-}$ & 0,000 & 0,000 & 0,000 & 0,000 & 0,000 & 0,000 & 0,000 & 0,000 \\
\hline $\mathrm{Mn}$ & 0,000 & 0,001 & 0,000 & 0,001 & 0,000 & 0,000 & 0,000 & 0,001 \\
\hline $\mathrm{Mg}$ & 0,000 & 0,076 & 0,000 & 0,001 & 0,000 & 0,001 & 0,000 & 0,001 \\
\hline $\mathrm{Ca}$ & 0,312 & 0,298 & 0,325 & 0,316 & 0,316 & 0,315 & 0,318 & 0,321 \\
\hline $\mathrm{Na}$ & 0,617 & 0,587 & 0,618 & 0,609 & 0,618 & 0,616 & 0,634 & 0,630 \\
\hline $\mathrm{K}$ & 0,024 & 0,024 & 0,023 & 0,024 & 0,022 & 0,022 & 0,006 & 0,006 \\
\hline Soma & 4,974 & 4,994 & 4,983 & 4,971 & 4,975 & 4,977 & 4,979 & 4,978 \\
\hline Anortita & 33,58 & 33,67 & 34,46 & 34,16 & 33,83 & 33,83 & 33,40 & 33,75 \\
\hline
\end{tabular}


Tabela 62 - Análises químicas de plagioclásio da Nappe Socorro-Guaxupé

\begin{tabular}{|c|c|c|c|c|c|c|c|c|c|c|c|c|c|}
\hline \multicolumn{14}{|c|}{ IC-06-R } \\
\hline Grão-Análise & pl5-1 & pl5-2 & pl5-3 & pl5-4 & pl5-5 & pl6-1 & pl6-2 & pl6-3 & pl6-4 & pl6-5 & pl6-6 & pl6-7 & pl6-8 \\
\hline $\mathrm{SiO}_{2}$ & 60,03 & 60,69 & 60,65 & 60,09 & 60,39 & 58,23 & 60,23 & 60,98 & 60,56 & 59,86 & 59,36 & 60,17 & 60,15 \\
\hline $\mathrm{TiO}_{2}$ & 0,01 & 0,02 & 0,02 & 0,03 & 0,00 & 0,00 & 0,01 & 0,02 & 0,03 & 0,02 & 0,03 & 0,04 & 0,07 \\
\hline $\mathrm{Al}_{2} \mathrm{O}_{3}$ & 25,71 & 25,58 & 25,67 & 25,52 & 25,90 & 25,70 & 25,85 & 25,41 & 25,52 & 25,67 & 26,09 & 26,11 & 26,05 \\
\hline $\mathrm{Cr}_{2} \mathrm{O}_{3}$ & 0,00 & 0,00 & 0,00 & 0,00 & 0,00 & 0,00 & 0,00 & 0,00 & 0,00 & 0,00 & 0,00 & 0,00 & 0,00 \\
\hline $\mathrm{Fe}_{2} \mathrm{O}_{3}$ & 0,11 & 0,09 & 0,08 & 0,33 & 0,51 & 1,18 & 0,11 & 0,09 & 0,16 & 0,35 & 0,16 & 0,19 & 0,23 \\
\hline $\mathrm{FeO}$ & 0,00 & 0,00 & 0,00 & 0,00 & 0,00 & 0,00 & 0,00 & 0,00 & 0,00 & 0,00 & 0,00 & 0,00 & 0,00 \\
\hline $\mathrm{MnO}$ & 0,01 & 0,00 & 0,01 & 0,00 & 0,01 & 0,01 & 0,00 & 0,01 & 0,00 & 0,01 & 0,00 & 0,00 & 0,00 \\
\hline $\mathrm{MgO}$ & 0,04 & 0,00 & 0,00 & 0,15 & 0,02 & 0,66 & 0,02 & 0,00 & 0,02 & 0,15 & 0,01 & 0,02 & 0,01 \\
\hline $\mathrm{CaO}$ & 7,21 & 6,45 & 6,50 & 6,60 & 6,69 & 6,89 & 6,46 & 6,13 & 6,35 & 6,45 & 6,92 & 6,79 & 6,84 \\
\hline $\mathrm{Na}_{2} \mathrm{O}$ & 7,09 & 7,45 & 7,42 & 7,13 & 7,13 & 6,89 & 7,33 & 7,58 & 7,54 & 7,37 & 7,12 & 7,31 & 7,37 \\
\hline $\mathrm{K}_{2} \mathrm{O}$ & 0,28 & 0,42 & 0,43 & 0,45 & 0,37 & 0,21 & 0,28 & 0,26 & 0,25 & 0,25 & 0,19 & 0,19 & 0,20 \\
\hline Totals & 100,48 & 100,70 & 100,78 & 100,30 & 101,02 & 99,77 & 100,28 & 100,48 & 100,44 & 100,14 & 99,88 & 100,82 & 100,92 \\
\hline Oxigênios & 8,00 & 8,00 & 8,00 & 8,00 & 8,00 & 8,00 & 8,00 & 8,00 & 8,00 & 8,00 & 8,00 & 8,00 & 8,00 \\
\hline $\mathrm{Si}$ & 2,661 & 2,680 & 2,677 & 2,667 & 2,662 & 2,611 & 2,669 & 2,693 & 2,680 & 2,660 & 2,645 & 2,655 & 2,653 \\
\hline $\mathrm{Ti}$ & 0,000 & 0,001 & 0,001 & 0,001 & 0,000 & 0,000 & 0,000 & 0,001 & 0,001 & 0,001 & 0,001 & 0,001 & 0,002 \\
\hline $\mathrm{Al}$ & 1,343 & 1,332 & 1,336 & 1,336 & 1,346 & 1,358 & 1,350 & 1,323 & 1,331 & 1,345 & 1,371 & 1,358 & 1,355 \\
\hline $\mathrm{Cr}$ & 0,000 & 0,000 & 0,000 & 0,000 & 0,000 & 0,000 & 0,000 & 0,000 & 0,000 & 0,000 & 0,000 & 0,000 & 0,000 \\
\hline $\mathrm{Fe}^{3+}$ & 0,004 & 0,003 & 0,003 & 0,011 & 0,017 & 0,040 & 0,004 & 0,003 & 0,005 & 0,012 & 0,005 & 0,006 & 0,008 \\
\hline $\mathrm{Fe}^{2-}$ & 0,000 & 0,000 & 0,000 & 0,000 & 0,000 & 0,000 & 0,000 & 0,000 & 0,000 & 0,000 & 0,000 & 0,000 & 0,000 \\
\hline $\mathrm{Mn}$ & 0,000 & 0,000 & 0,000 & 0,000 & 0,001 & 0,001 & 0,000 & 0,001 & 0,000 & 0,001 & 0,000 & 0,000 & 0,000 \\
\hline $\mathrm{Mg}$ & 0,002 & 0,000 & 0,000 & 0,010 & 0,001 & 0,044 & 0,001 & 0,000 & 0,001 & 0,010 & 0,001 & 0,001 & 0,001 \\
\hline $\mathrm{Ca}$ & 0,342 & 0,305 & 0,307 & 0,314 & 0,316 & 0,331 & 0,307 & 0,290 & 0,301 & 0,307 & 0,330 & 0,321 & 0,323 \\
\hline $\mathrm{Na}$ & 0,609 & 0,638 & 0,635 & 0,614 & 0,609 & 0,599 & 0,630 & 0,649 & 0,647 & 0,635 & 0,615 & 0,625 & 0,630 \\
\hline $\mathrm{K}$ & 0,016 & 0,024 & 0,024 & 0,026 & 0,021 & 0,012 & 0,016 & 0,015 & 0,014 & 0,014 & 0,011 & 0,011 & 0,011 \\
\hline Soma & 4,978 & 4,983 & 4,983 & 4,978 & 4,972 & 4,996 & 4,977 & 4,975 & 4,981 & 4,985 & 4,979 & 4,979 & 4,984 \\
\hline Anortita & 35,96 & 32,34 & 32,59 & 33,84 & 34,16 & 35,59 & 32,76 & 30,88 & 31,75 & 32,59 & 34,92 & 33,93 & 33,89 \\
\hline
\end{tabular}


Tabela 63 - Análises químicas de plagioclásio da Nappe Socorro-Guaxupé

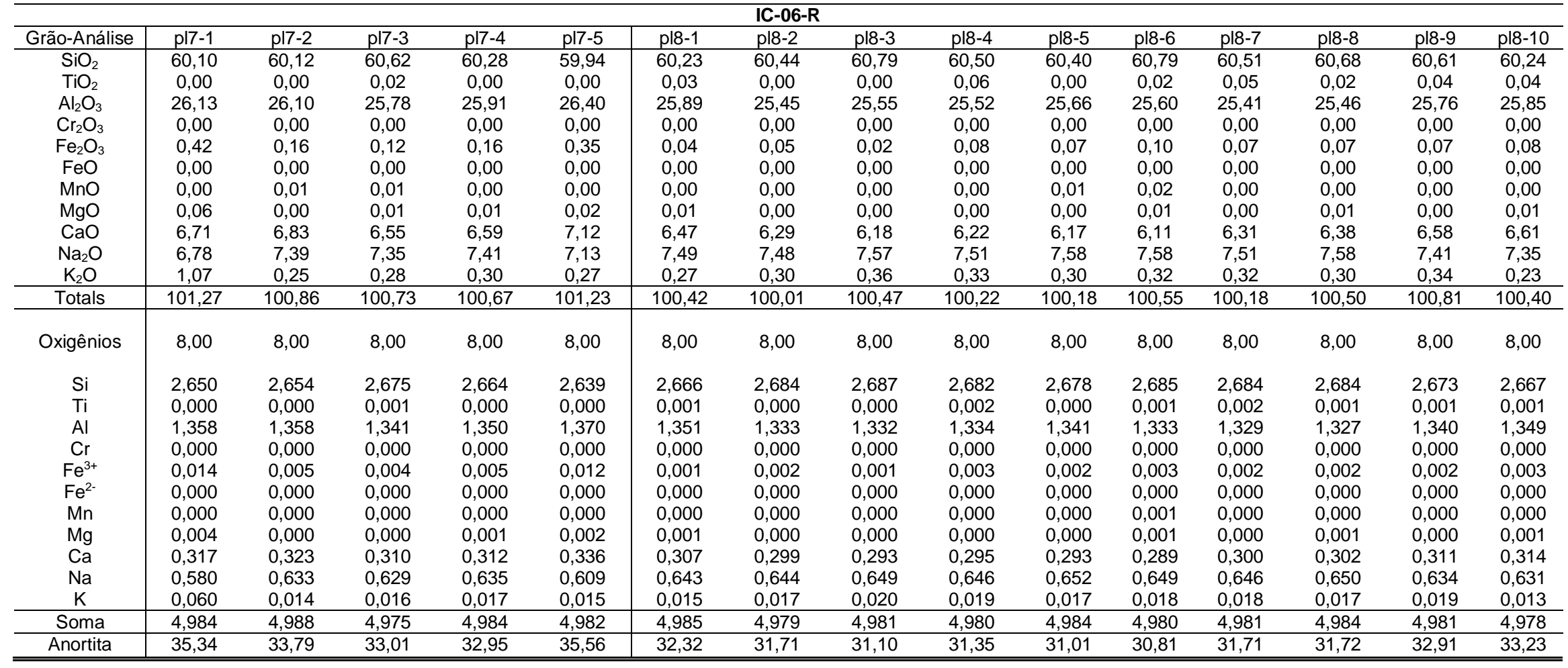


Tabela 64 - Análises químicas de plagioclásio da Nappe Socorro-Guaxupé

\begin{tabular}{|c|c|c|c|c|c|c|c|c|c|c|}
\hline \multicolumn{11}{|c|}{ IC-06-R } \\
\hline Grão-Análise & pl9-9 & pl9-10 & pl10-1 & pl10-2 & pl10-3 & pl10-4 & pl10-5 & pl10-6 & pl10-7 & pl10-8 \\
\hline $\mathrm{SiO}_{2}$ & 60,15 & 60,91 & 60,98 & 60,76 & 60,67 & 60,54 & 60,74 & 60,73 & 60,81 & 60,43 \\
\hline $\mathrm{TiO}_{2}$ & 0,06 & 0,03 & 0,04 & 0,00 & 0,00 & 0,01 & 0,00 & 0,03 & 0,01 & 0,04 \\
\hline $\mathrm{Al}_{2} \mathrm{O}_{3}$ & 25,22 & 25,56 & 25,41 & 25,37 & 25,50 & 25,39 & 25,52 & 25,57 & 25,47 & 25,90 \\
\hline $\mathrm{Cr}_{2} \mathrm{O}_{3}$ & 0,00 & 0,00 & 0,00 & 0,00 & 0,00 & 0,00 & 0,00 & 0,00 & 0,00 & 0,00 \\
\hline $\mathrm{Fe}_{2} \mathrm{O}_{3}$ & 0,33 & 0,08 & 0,08 & 0,09 & 0,06 & 0,06 & 0,05 & 0,08 & 0,12 & 0,29 \\
\hline $\mathrm{FeO}$ & 0,00 & 0,00 & 0,00 & 0,00 & 0,00 & 0,00 & 0,00 & 0,00 & 0,00 & 0,00 \\
\hline $\mathrm{MnO}$ & 0,02 & 0,00 & 0,00 & 0,01 & 0,00 & 0,01 & 0,00 & 0,01 & 0,00 & 0,01 \\
\hline $\mathrm{MgO}$ & 0,16 & 0,00 & 0,00 & 0,00 & 0,01 & 0,00 & 0,01 & 0,00 & 0,00 & 0,00 \\
\hline $\mathrm{CaO}$ & 6,01 & 6,24 & 6,30 & 6,03 & 6,20 & 6,19 & 6,40 & 6,24 & 6,22 & 6,63 \\
\hline $\mathrm{Na}_{2} \mathrm{O}$ & 7,16 & 7,52 & 7,47 & 7,38 & 7,47 & 7,45 & 7,39 & 7,33 & 7,44 & 7,26 \\
\hline $\mathrm{K}_{2} \mathrm{O}$ & 0,48 & 0,48 & 0,46 & 0,45 & 0,43 & 0,47 & 0,49 & 0,44 & 0,43 & 0,39 \\
\hline Totals & 99,60 & 100,82 & 100,74 & 100,09 & 100,35 & 100,12 & 100,60 & 100,44 & 100,50 & 100,96 \\
\hline Oxigênios & 8,00 & 8,00 & 8,00 & 8,00 & 8,00 & 8,00 & 8,00 & 8,00 & 8,00 & 8,00 \\
\hline $\mathrm{Si}$ & 2,684 & 2,686 & 2,690 & 2,695 & 2,686 & 2,687 & 2,684 & 2,686 & 2,688 & 2,664 \\
\hline $\mathrm{Ti}$ & 0,002 & 0,001 & 0,001 & 0,000 & 0,000 & 0,000 & 0,000 & 0,001 & 0,000 & 0,001 \\
\hline $\mathrm{Al}$ & 1,327 & 1,329 & 1,322 & 1,326 & 1,331 & 1,329 & 1,330 & 1,333 & 1,327 & 1,346 \\
\hline $\mathrm{Cr}$ & 0,000 & 0,000 & 0,000 & 0,000 & 0,000 & 0,000 & 0,000 & 0,000 & 0,000 & 0,000 \\
\hline $\mathrm{Fe}^{3+}$ & 0,011 & 0,003 & 0,003 & 0,003 & 0,002 & 0,002 & 0,002 & 0,003 & 0,004 & 0,010 \\
\hline $\mathrm{Fe}^{2-}$ & 0,000 & 0,000 & 0,000 & 0,000 & 0,000 & 0,000 & 0,000 & 0,000 & 0,000 & 0,000 \\
\hline $\mathrm{Mn}$ & 0,001 & 0,000 & 0,000 & 0,000 & 0,000 & 0,000 & 0,000 & 0,000 & 0,000 & 0,000 \\
\hline $\mathrm{Mg}$ & 0,011 & 0,000 & 0,000 & 0,000 & 0,000 & 0,000 & 0,000 & 0,000 & 0,000 & 0,000 \\
\hline $\mathrm{Ca}$ & 0,287 & 0,295 & 0,298 & 0,287 & 0,294 & 0,294 & 0,303 & 0,296 & 0,295 & 0,313 \\
\hline $\mathrm{Na}$ & 0,619 & 0,643 & 0,639 & 0,635 & 0,641 & 0,641 & 0,633 & 0,629 & 0,638 & 0,621 \\
\hline $\mathrm{K}$ & 0,027 & 0,027 & 0,026 & 0,026 & 0,024 & 0,027 & 0,028 & 0,025 & 0,024 & 0,022 \\
\hline Soma & 4,969 & 4,983 & 4,979 & 4,971 & 4,980 & 4,981 & 4,980 & 4,972 & 4,977 & 4,978 \\
\hline Anortita & 31,68 & 31,45 & 31,80 & 31,13 & 31,44 & 31,44 & 32,37 & 32,00 & 31,62 & 33,51 \\
\hline
\end{tabular}


Tabela 65 - Fórmulas estruturais de plagioclásio das nappes Três Pontas-Varginha e Socorro-Guaxupé

\begin{tabular}{|c|c|c|c|}
\hline Unidade & tra & Cris & Fórmula estrutural \\
\hline 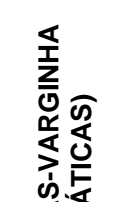 & TPR-01-C & $\begin{array}{l}\text { plagioclásio } 2 \\
\text { plagioclásio } 3 \\
\text { plagioclásio } 4 \\
\text { plagioclásio } 5\end{array}$ & $\begin{array}{c}\mathrm{K}_{0,01-0,02}, \mathrm{Ca}_{0,36-0,37}, \mathrm{Na}_{0,53-0,58}, \mathrm{Al}_{1,33-1,41}, \mathrm{Si}_{2,61-2,68}, \mathrm{O}_{8} \\
\mathrm{~K}_{0,02-0,03}, \mathrm{Ca}_{0,29-0,38}, \mathrm{Na}_{0,56-0,65}, \mathrm{Al}_{1,33-1,42,} \mathrm{Si}_{2,59-2,69}, \mathrm{O}_{8} \\
\mathrm{~K}_{0,02-0,03,}, \mathrm{Ca}_{0,30-0,36}, \mathrm{Na}_{0,55-0,63,} \mathrm{Al}_{1,33-1,42,} \mathrm{Si}_{2,60-2,69,} \mathrm{O}_{8} \\
\mathrm{~K}_{0,02,} \mathrm{Ca}_{0,33-0,38,} \mathrm{Na}_{0,56-0,62,} \mathrm{Al}_{1,36-1,42,} \mathrm{Si}_{2,60-2,65,} \mathrm{O}_{8}\end{array}$ \\
\hline 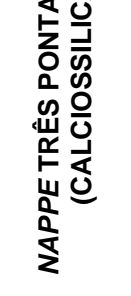 & TPR-01-F1 & $\begin{array}{l}\text { plagioclásio } 1 \\
\text { plagioclásio } 2 \\
\text { plagioclásio } 3 \\
\text { plagioclásio } 4 \\
\text { plagioclásio } 5 \\
\text { plagioclásio } 6\end{array}$ & 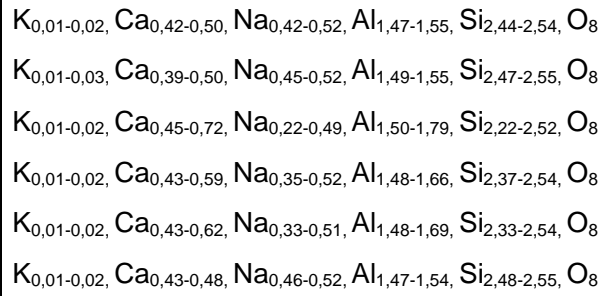 \\
\hline 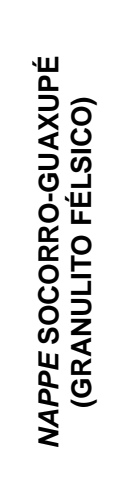 & IC-06-R & $\begin{array}{l}\text { plagioclásio } 2 \\
\text { plagioclásio } 3 \\
\text { plagioclásio } 4 \\
\text { plagioclásio } 5 \\
\text { plagioclásio } 6 \\
\text { plagioclásio } 7 \\
\text { plagioclásio } 8 \\
\text { plagioclásio } 9\end{array}$ & 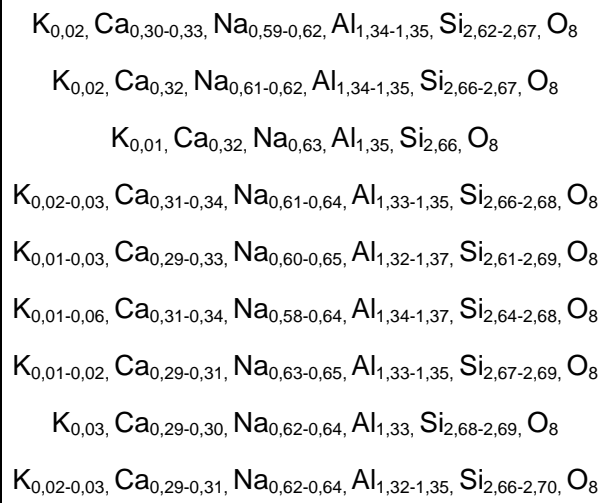 \\
\hline
\end{tabular}


Tabela 66 - Teores de titânio (ppm; massa 49) em quartzo da Nappe Três Pontas-Varginha e respectivas temperaturas pelo geotermômetro de Thomas et al. (2010) a 15 kbar. Textura incluso $=$ incluso em granada

\begin{tabular}{|c|c|c|c|c|c|c|c|c|c|c|c|c|c|c|}
\hline Amostra & Cristal & Textura & Ti49 & $\mathrm{T}\left({ }^{\circ} \mathrm{C}\right)$ & Amostra & Cristal & Textura & Ti49 & $\mathrm{T}\left({ }^{\circ} \mathrm{C}\right)$ & Amostra & Cristal & Textura & Ti49 & $\mathrm{T}\left({ }^{\circ} \mathrm{C}\right)$ \\
\hline \multirow{26}{*}{ 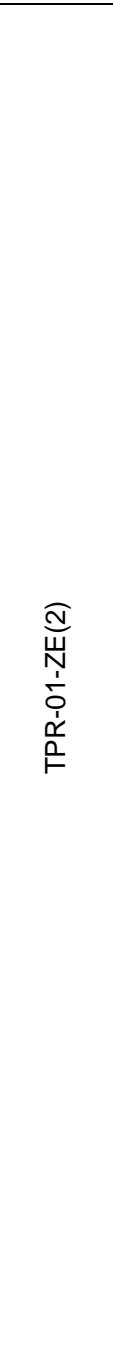 } & qtz1 & incluso & 49 & 801,68 & \multirow{6}{*}{ 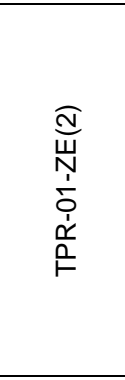 } & qtz33 & incluso & 37 & 773,67 & \multirow{3}{*}{ TPR-01-ZF(3) } & qtz21 & incluso/ borda & 59 & 821,89 \\
\hline & qtz1 & incluso & 42 & 785,72 & & qtz34 & incluso & 49 & 800,71 & & qtz22 & incluso/ borda & 67 & 836,00 \\
\hline & qtz2 & incluso & 33 & 761,68 & & qtz35 & incluso & 57 & 817,55 & & qtz23 & incluso/ borda & 62 & 827,33 \\
\hline & qtz4 & incluso & 55 & 814,87 & & qtz41 & matriz & 55 & 813,61 & \multirow{12}{*}{ 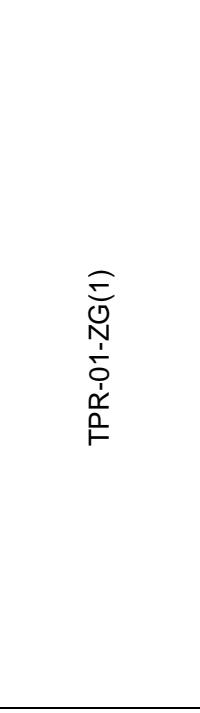 } & qtz2 & incluso/ borda & 52 & 808,17 \\
\hline & qtz5 & incluso & 56 & 815,44 & & qtz42 & matriz & 50 & 804,84 & & qtz3 & incluso/ borda & 39 & 777,02 \\
\hline & qtz6 & incluso & 52 & 808,12 & & qtz43 & matriz & 42 & 785,94 & & qtz4 & incluso/ borda & 26 & 738,42 \\
\hline & qtz8 & incluso & 41 & 782,50 & \multirow{20}{*}{ 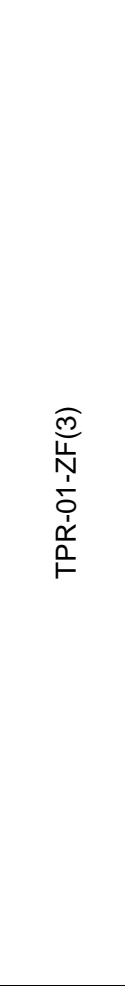 } & qtz1 & incluso & 68 & 837,36 & & qtz6 & incluso & 61 & 825,06 \\
\hline & qtz9 & matriz & 42 & 785,96 & & qtz2 & incluso & 68 & 837,92 & & qtz7 & incluso & 72 & 843,91 \\
\hline & qtz10 & matriz & 52 & 807,43 & & qtz3 & incluso & 46 & 795,82 & & qtz8 & incluso & 42 & 784,79 \\
\hline & qtz11 & matriz & 47 & 796,89 & & qtz4 & incluso & 53 & 809,45 & & qtz9 & incluso & 41 & 782,82 \\
\hline & qtz12 & matriz & 57 & 817,91 & & qtz5 & incluso & 40 & 781,32 & & qtz9 & incluso & 45 & 792,87 \\
\hline & qtz13 & incluso & 63 & 829,44 & & qtz6 & incluso & 32 & 760,10 & & qtz10 & incluso & 64 & 829,82 \\
\hline & qtz14 & incluso & 48 & 800,54 & & $\mathrm{qtz} 7$ & incluso & 23 & 728,33 & & qtz11 & matriz & 69 & 839,53 \\
\hline & qtz16 & incluso & 59 & 821,41 & & qtz9 & incluso & 52 & 806,98 & & qtz14 & incluso & 59 & 821,58 \\
\hline & qtz17 & incluso & 49 & 802,58 & & qtz9 & incluso & 42 & 785,43 & & qtz15 & incluso & 45 & 792,94 \\
\hline & qtz21 & matriz & 35 & 767,67 & & qtz10 & incluso & 54 & 811,13 & \multirow{11}{*}{ 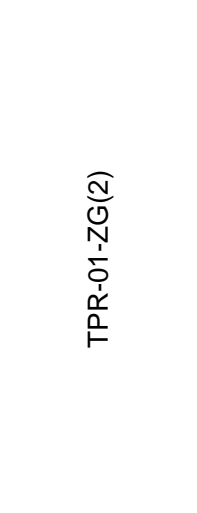 } & qtz2 & incluso & 40 & 780,71 \\
\hline & qtz22 & matriz & 37 & 773,56 & & qtz11 & incluso & 43 & 789,05 & & qtz2 & incluso & 53 & 809,47 \\
\hline & qtz23 & matriz & 35 & 766,37 & & qtz12 & incluso & 55 & 813,90 & & qtz3 & incluso & 60 & 824,29 \\
\hline & qtz25 & matriz & 33 & 760,64 & & qtz13 & incluso & 70 & 840,10 & & qtz4 & incluso & 70 & 841,00 \\
\hline & qtz26 & matriz & 50 & 803,51 & & qtz14 & incluso & 59 & 820,91 & & qtz4 & incluso & 67 & 835,32 \\
\hline & qtz27 & incluso & 67 & 835,30 & & qtz15 & incluso & 68 & 837,74 & & qtz5 & incluso & 56 & 815,01 \\
\hline & qtz28 & incluso & 49 & 800,75 & & qtz16 & incluso & 63 & 828,76 & & qtz6 & incluso & 66 & 834,56 \\
\hline & qtz29 & incluso & 45 & 792,32 & & qtz17 & incluso & 43 & 788,77 & & qtz7 & incluso & 50 & 803,07 \\
\hline & qtz30 & incluso & 52 & 807,28 & & qtz18 & incluso & 66 & 833,38 & & qtz8 & incluso & 51 & 805,94 \\
\hline & qtz31 & incluso & 43 & 788,74 & & qtz19 & incluso/ borda & 72 & 843,42 & & qtz9 & incluso & 49 & 801,61 \\
\hline & qtz32 & incluso & 48 & 800,28 & & qtz20 & incluso/ borda & 61 & 825,71 & & qtz10 & incluso & 42 & 786,64 \\
\hline
\end{tabular}


Tabela 67 - Teores de zircônio (ppm; massa 90) em rutilo da Nappe Três Pontas-Varginha e respectivas temperaturas pelo geotermômetro de Tomkins et al. (2007), quartzo $\beta$, a 15 kbar. Textura incluso = incluso em granada

\begin{tabular}{|c|c|c|c|c|c|c|c|c|c|c|c|c|c|c|}
\hline Amostra & Cristal & Textura & Zr90 & $\mathrm{T}\left({ }^{\circ} \mathrm{C}\right)$ & Amostra & Cristal & Textura & Zr90 & $\mathrm{T}\left({ }^{\circ} \mathrm{C}\right)$ & Amostra & Cristal & Textura & Zr90 & $\mathrm{T}\left({ }^{\circ} \mathrm{C}\right)$ \\
\hline \multirow{29}{*}{ 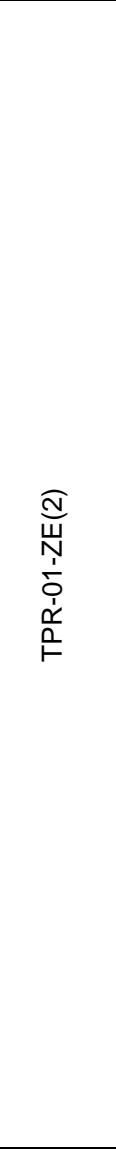 } & $\mathrm{rt} 12$ & incluso & 558 & 727,77 & \multirow{34}{*}{ 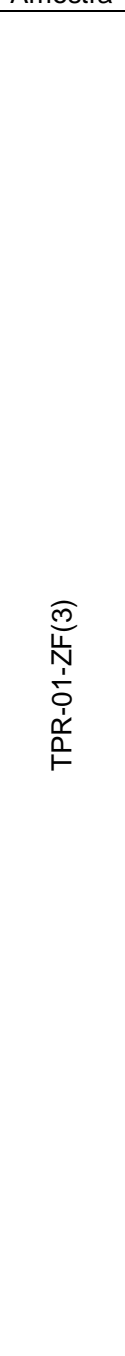 } & rt6 & incluso & 579 & 731,01 & & $\mathrm{rt} 40$ & matriz & 672 & 744,63 \\
\hline & rt13 & incluso & 564 & 728,70 & & rt7 & incluso & 1210 & 802,31 & & $\mathrm{rt} 41$ & matriz & 892 & 771,67 \\
\hline & $\mathrm{rt14}$ & incluso & 855 & 767,49 & & rt8 & incluso & 1202 & 801,66 & & $\mathrm{rt} 42$ & matriz & 964 & 779,25 \\
\hline & rt15 & incluso & 1133 & 795,53 & & rt9 & incluso & 1139 & 796,09 & & $r t 43$ & incluso (ky) & 674 & 744,88 \\
\hline & rt16 & matriz & 644 & 740,76 & & rt10 & incluso & 828 & 764,41 & & $r t 44$ & matriz & 672 & 744,71 \\
\hline & $\mathrm{rt} 17$ & matriz & 788 & 759,66 & & rt11 & incluso & 1142 & 796,38 & & rt 45 & matriz & 764 & 756,73 \\
\hline & rt18 & matriz & 1089 & 791,50 & & rt12 & incluso & 1150 & 797,13 & \multirow{18}{*}{ 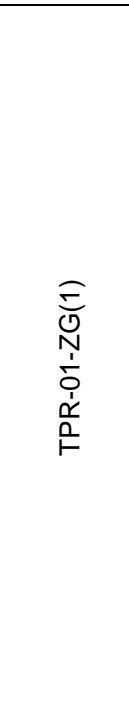 } & $\mathrm{rt1} 1$ & incluso & 601 & 734,40 \\
\hline & rt19 & matriz & 767 & 757,07 & & rt13 & incluso & 881 & 770,40 & & rt2 & matriz & 1158 & 797,77 \\
\hline & rt20 & matriz & 645 & 740,93 & & rt14 & incluso & 418 & 702,36 & & rt3 & incluso/ borda & 905 & 773,10 \\
\hline & rt21 & matriz & 635 & 739,49 & & rt15 & incluso & 622 & 737,47 & & rt4 & incluso/ borda & 1032 & 786,14 \\
\hline & rt22 & matriz & 634 & 739,31 & & rt16 & incluso & 560 & 727,98 & & $r+5$ & incluso/ borda & 1027 & 785,64 \\
\hline & rt23 & matriz & 970 & 779,93 & & rt17 & incluso & 427 & 704,17 & & rt6 & incluso & 1504 & 825,40 \\
\hline & rt24 & incluso & 1155 & 797,51 & & rt18 & incluso & 527 & 722,65 & & rt7 & incluso & 786 & 759,45 \\
\hline & rt25 & incluso & 1432 & 820,12 & & rt19 & incluso & 616 & 736,64 & & rt8 & incluso & 1117 & 794,09 \\
\hline & rt26 & incluso & 973 & 780,20 & & rt20 & incluso & 654 & 742,18 & & rt9 & incluso & 1365 & 815,02 \\
\hline & rt27 & matriz & 682 & 746,06 & & rt21 & incluso & 694 & 747,60 & & $\mathrm{rt10}$ & incluso/ borda & 1066 & 789,41 \\
\hline & rt28 & matriz & 828 & 764,38 & & rt22 & incluso & 1499 & 825,02 & & rt11 & incluso/borda & 1387 & 816,67 \\
\hline & rt29 & matriz & 967 & 779,65 & & rt23 & incluso & 686 & 746,63 & & rt12 & incluso & 1308 & 810,50 \\
\hline & $r+30$ & matriz & 1145 & 796,69 & & rt24 & incluso & 958 & 778,67 & & $r t 13$ & incluso & 640 & 740,21 \\
\hline & rt31 & matriz & 1129 & 795,25 & & rt25 & incluso & 1026 & 785,55 & & $\mathrm{rt14}$ & incluso/ borda & 552 & 726,80 \\
\hline & rt32 & matriz & 850 & 766,92 & & rt26 & incluso/ borda & 864 & 768,58 & & rt15 & incluso/ borda & 878 & 770,07 \\
\hline & rt33 & incluso/borda & 841 & 765,90 & & rt27 & incluso/ borda & 596 & 733,61 & & rt16 & incluso & 449 & 708,64 \\
\hline & rt34 & incluso/borda & 751 & 755,06 & & rt28 & incluso/ borda & 790 & 759,88 & & rt16 & incluso/ borda & 454 & 709,58 \\
\hline & rt 35 & matriz & 719 & 751,02 & & rt29 & incluso/ borda & 928 & 775,58 & & $\mathrm{rt} 17$ & incluso & 750 & 754,93 \\
\hline & rt36 & matriz & 761 & 756,38 & & rt30 & incluso/ borda & 807 & 761,97 & \multirow{10}{*}{$\begin{array}{l}\widehat{N} \\
\frac{0}{N} \\
N \\
\frac{1}{1} \\
\frac{1}{0} \\
0\end{array}$} & $\mathrm{rt1}$ & incluso & 1182 & 799,92 \\
\hline & rt37 & incluso/borda & 374 & 693,13 & & rt31 & incluso/ borda & 757 & 755,85 & & rt3 & incluso/ borda & 978 & 780,75 \\
\hline & rt38 & matriz & 787 & 759,50 & & rt32 & matriz & 718 & 750,82 & & rt4 & incluso/ borda & 829 & 764,53 \\
\hline & rt39 & matriz & 941 & 776,89 & & rt33 & matriz & 834 & 765,11 & & rt5 & incluso/ borda & 1050 & 787,87 \\
\hline & $\mathrm{rt} 40$ & matriz & 898 & 772,34 & & rt34 & matriz & 919 & 774,56 & & rt6 & incluso/ borda & 756 & 755,68 \\
\hline \multirow{5}{*}{ 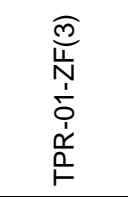 } & $\mathrm{rt1}$ & incluso & 1146 & 796,76 & & rt35 & matriz & 721 & 751,18 & & $\mathrm{rt} 9$ & incluso/ borda & 727 & 752,02 \\
\hline & rt2 & incluso & 1518 & 826,40 & & rt36 & matriz & 737 & 753,33 & & rt10 & incluso/ borda & 967 & 779,62 \\
\hline & rt3 & incluso & 871 & 769,30 & & rt37 & matriz & 770 & 757,42 & & $\mathrm{rt11}$ & incluso/ borda & 435 & 705,78 \\
\hline & rt4 & incluso & 921 & 774,77 & & rt38 & matriz & 582 & 731,52 & & & & & \\
\hline & $r+5$ & incluso & 1448 & 821,29 & & rt39 & matriz & 935 & 776,27 & & & & & \\
\hline
\end{tabular}




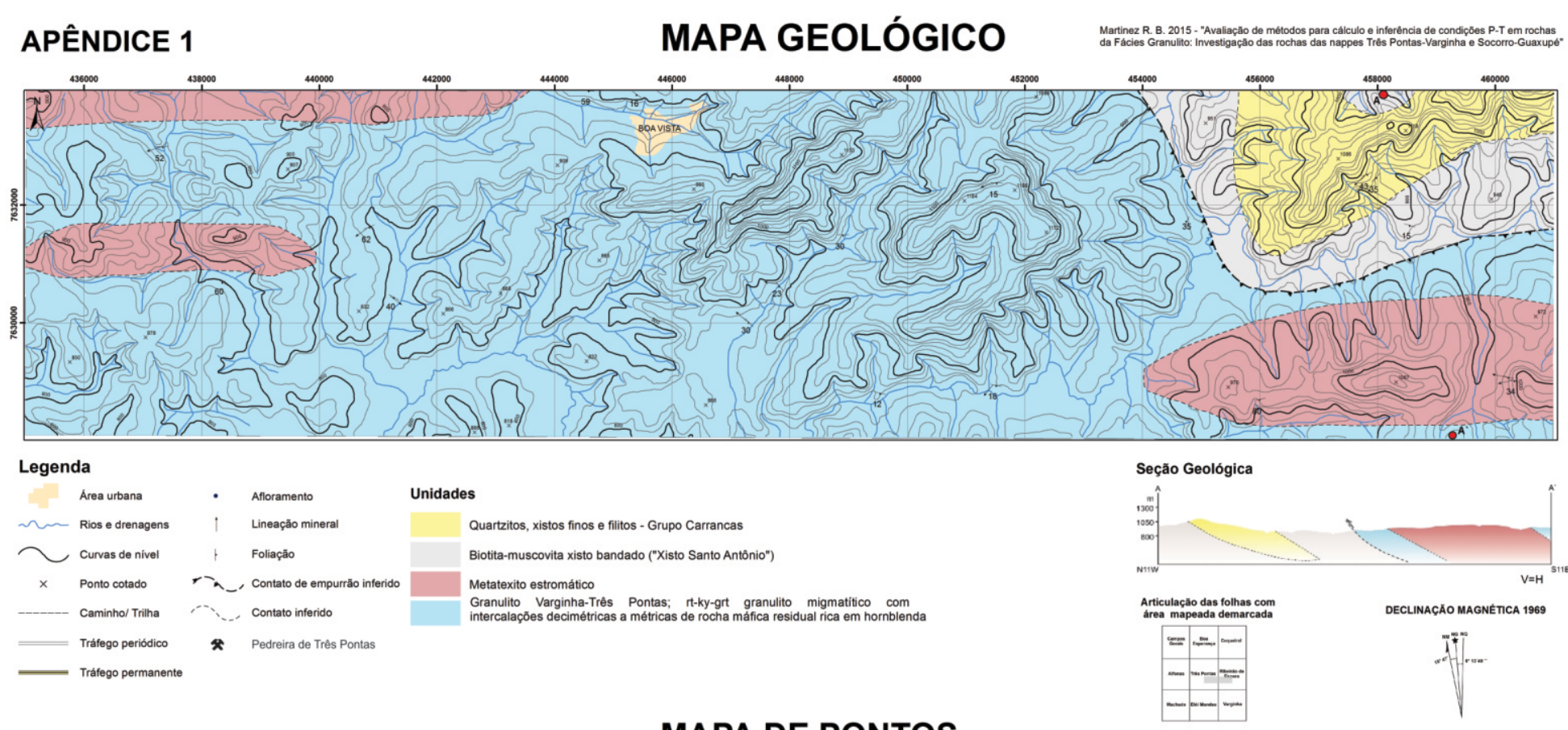

\section{MAPA DE PONTOS}

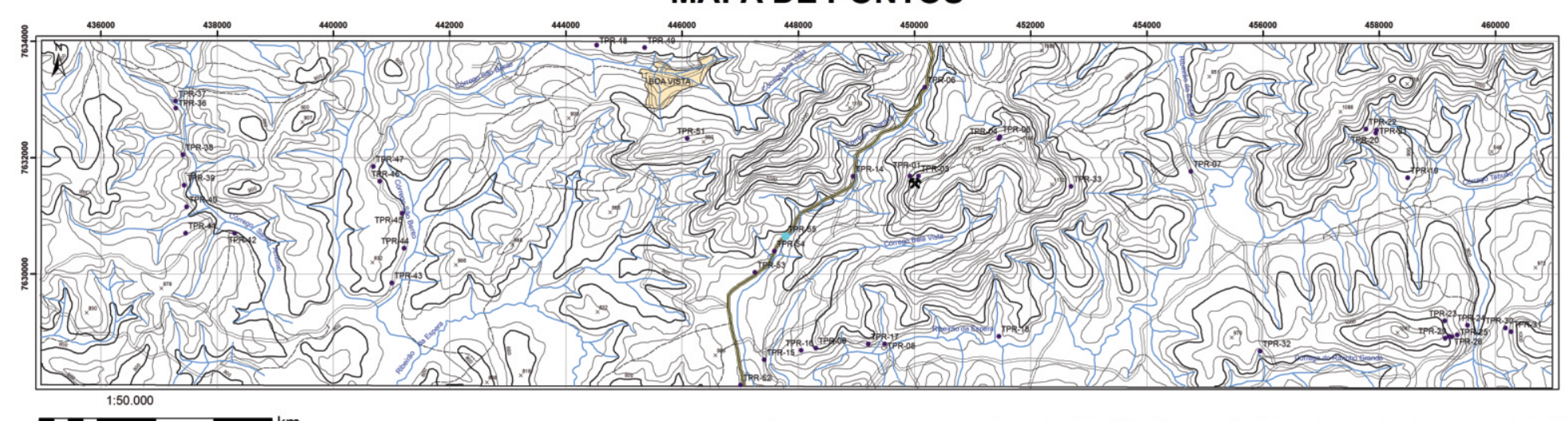

